UNIVERSIDADE DE SÃO PAULO

FACULDADES DE FILOSOFIA, LETRAS E CIÊNCIAS HUMANAS

DEPARTAMENTO DE GEOGRAFIA

PROGRAMA DE PÓS-GRADUAÇÃO EM GEOGRAFIA HUMANA DOUTORADO

ROSANA LIA RAVACHE

MIGRAÇÃO E MODERNIZAÇÃO EM CIDADES MÉDIAS DA AMAZÔNIA LEGAL: ÁREA DE ABRANGÊNCIA DA BR 163

VERSÃO CORRIGIDA

SÃO PAULO

2013 
ROSANA LIA RAVACHE

\title{
MIGRAÇÃO E MODERNIZAÇÃO EM CIDADES MÉDIAS DA AMAZÔNIA LEGAL: ÁREA DE ABRANGÊNCIA DA BR 163
}

\begin{abstract}
Tese apresentada ao Programa de PósGraduação em Geografia Humana, do Departamento de Geografia da Faculdade de Filosofia, Letras e Ciências Humanas da Universidade de São Paulo, para a obtenção do título de Doutora em Geografia sob a orientação da professora Doutora Amália Inês Geraiges de Lemos.
\end{abstract}




\section{UNIVERSIDADE DE SAO PAULO \\ FACULDADE DE FILOSOFIA, LETRAS E CIÊNCIAS HUMANAS PROGRAMA DE PÓS-GRADUAÇÃO EM GEOGRAFIA HUMANA}

\section{CERTIFICADO DE APROVAÇÃO}

Título: MIGRAÇÃO E MODERNIZAÇÃO EM CIDADES MÉDIAS DA AMAZÔNIA LEGAL: ÁREA DE ABRANGÊNCIA DA BR 163.

Autora: Rosana Lia Ravache.

Tese defendida e aprovada em de de 2013, pela comissão julgadora:

Professora Doutora Anna Maria Ribeiro Fernandes Moreira da Costa/ Univag - Centro Universitário

$\overline{\text { Professor Doutor Flavio Gatti/ Univag - Centro Universitário }}$ 
Nenhum de nós pode construir o mundo das significações e sentidos a partir do nada: cada um ingressa num mundo "préfabricado", em que certas coisas são importantes e outras não o são; em que as conveniências estabelecidas trazem certas coisas para a luz e deixam outras na sombra. Acima de tudo, ingressamos num mundo em que uma terrível quantidade de aspectos são óbvios a ponto de já não serem conscientemente notados e não precisarem de nenhum esforço ativo, nem mesmo o de decifrá-los, para estarem invisivelmente, mas tangivelmente, presentes em tudo o que fazemos - dotando desse modo os nossos atos, e as coisas sobre as quais agimos, de uma solidez de "realidade".

BAUMAN (1998: 17). 
Aos meus pais, Erotides e Amandos (in memoriam), aos meus filhos Guilherme e Marcelo, Renata e, especialmente, a Sofia, minha neta. 


\section{AGRADECIMENTOS}

Agradeço ao UNIVAG - Centro Universitário, pela bolsa de estudos oferecida durante o período de pesquisa para o doutorado.

À minha orientadora professora Doutora Amália Ines Geraiges de Lemos, pela confiança e apoio que me deram estímulo para prosseguir pelos intrincados caminhos desta pesquisa.

Ao professor Doutor André Roberto Martin e professor Doutor Francisco Capuano Scarlato pelas profícuas sugestões expressadas durante a qualificação deste trabalho, que deram um novo alento para a pesquisa e ampliaram seu espectro de abrangência.

Ao professor Doutor Flavio Gatti pelo incentivo que me ajudou a chegar até aqui.

À professora Doutora Anna Maria Ribeiro F. M. da Costa, a amiga dos meus momentos de desânimo.

Às alunas do curso de Serviço Social, Eliana Matos Tavares e Reginelda Solange Viana que contribuíram na pesquisa de campo.

Meu agradecimento especial a professora Mariliane Sobrinho que conduziu os trabalhos no município de Sorriso, ao professor Edison Antonio de Souza que orientou os trabalhos no município de Sinop e a Marcelo Paulino, chefe da Assessoria de Comunicação (ASCOM) de Lucas do Rio Verde que contribuiu nos trabalhos no município.

Às pessoas que me concederam as entrevistas, tão importantes para a história oral deste trabalho.

\section{CUIABÁ}

Cibele Madalena Xavier Ribeiro IBAMA (Instituto Brasileiro do Meio Ambiente e dos Recursos Naturais Renováveis), Dilmar Dal'Bosco (Deputado Estadual), Gislaene Moreno (professora de Geografia), Janete Zerwes (Imigrante pioneira), Isis Catarina Martins Brandão (Instituto Memória da Assembleia Legislativa MT), Luiz Antonio E. Garcia (DENIT); Mauro Savi (Deputado Estadual), Onofre Ribeiro (Jornalista), Paulo Pitaluga Costa e Silva (Historiador), Sônia Regina Romancini (professora de Geografia da UFMT), Tereza Cristina Cardoso de Souza Higa 
(Orofessora de Geografia da UFMT), Ten. Cel. Roberto Tailor Souza da Silva (Comandante do $9^{\circ}$ BEC); Wanderlei Oliveira (Superintendente da TV Assembleia).

\section{LUCAS DO RIO VERDE}

Antônio Isaac Fraga Lira (Imigrante pioneiro); Ildo Romancini (Imigrante pioneiro), José Dario Munhak (Historiador e professor), Luciane Bertinatto Copetti (Imigrante pioneira e representante da The Nature Conservancy), Nilfo Wandscheer (Ex-presidente do Sindicato de Trabalhadores Rurais), Williana Mendes (Geógrafa e professora).

\section{SORRISO}

Ary Junior (Consultor de Planejamento da Prefeitura), Avanice Lourenço Zanatta (Secretária de Educação e Cultura), Ednilson de Lima Oliveira (Secretário de Saúde), Emiliano Preima (Secretário de Obras), Idalina Francio (Esposa de Claudino Francio, fundador de Sorriso), Luciene Francio (Diretora Presidente da Colonizadora Feliz e filha de Claudino Francio, fundador de Sorriso), Maria Inêz Ferlin (Contadora da Prefeitura), Marines Perin Smaniotto (Comerciante), Natalicio Ligoski (Socio Gerente da Conectiva Assessoria), Rodrigo de Vargas Hahn (Diretor da Escola São Domingos), Vanice Fronza (Chefe do Depto de Tributação da Prefeitura), Vivyane Maria Cene Bedin (Secretária de Ação Social).

\section{SINOP}

Angela Maria Souza Marquetti (Assessora da Prefeitura de Sinop), Leonildo Bares (Presidente do Sindicato Rural), professor Luíz Erardi F. Santos (Diretor do Museu Histórico de Sinop), José Barbaro Neto (Gerente Comercial da Colonizadora Sinop), Rogério Neves (Secretário de Cultura), Tênisson W. de Souza (Chefe Administrativo da EMBRAPA).

Minha homenagem póstuma ao Ten. Cel. José Meireles, que comandou a construção da BR-163, pelo exemplo de dignidade e amor a Mato Grosso que deixou a todos nós. 


\section{RESUMO}

Esta pesquisa partiu da indagação de como algumas cidades ao norte do estado de Mato Grosso se desenvolvem acima da média nacional, mesmo que na última década venham se desvinculando da dependência econômica exclusiva da produção de commodities. Se entre proprietários individuais e empresas que vivem na área da Amazônia Legal mato-grossense, aproximadamente $2 \%$ são responsáveis pela produção de commodities, em que atividade está inserida $98 \%$ dos habitantes que não atuam diretamente na produção agrícola? Embora existam ainda alguns setores direta ou indiretamente dependentes do agronegócio, o que se percebeu nessas cidades é a ininterrupta chegada de imigrantes e, mesmo assim, o nível de oferta de emprego tem se mantido estável, apesar da exigência, cada vez maior, de mão de obra tecnologicamente qualificada para as diversas atividades desenvolvidas em diferentes setores. Apesar de suas histórias recentes, a economia dessas cidades concentra uma das rendas per capita mais altas do estado, sendo que, paulatinamente, cada uma delas se aproxima mais e mais da ideia que mobilizou seus imigrantes pioneiros, e traça um perfil próprio através de projetos de expansão dos meios de produção calcados em tecnologias de ponta, modernização e políticas voltadas para os interesses econômicos da região.

Palavras-chave: Agronegócio; Amazônia Legal mato-grossense; Cidades de médio porte; Migração; Modernização. 


\section{ABSTRACT}

This research started with the question of how some cities north of the state of Mato Grosso developed above the national average, even though in the last decade will be delinking economic dependency exclusive production of commodities. Between individual homeowners and businesses who live in the area of Amazonia Legal in Mato Grosso approximately $2 \%$ is responsible for the production of commodities, in which activity is $98 \%$ of people who do not work directly in agricultural production? Although there are still some sectors directly or indirectly dependent on agribusiness, which is realized in these cities, is the uninterrupted arrival of immigrants, and even then, the level of jobs has remained stable, despite the requirement, growing, hand technologically skilled labor for various activities in different sectors. Despite their recent histories, the economy of these cities concentrates one of the highest per capita incomes in the state, and, gradually, each approaching more and more the idea that mobilized its pioneering immigrants, and traces their own profile through expansion of the production projects, grounded on cutting edge technologies, modernization and policies aimed at the economic interests of the region.

Keywords: Agribusiness; Amazon Mato Grosso; Midium sized cities; Migration, Modernization. 


\section{RESUMEN}

Esta investigación surgió de la pregunta de cómo algunas ciudades del norte del estado de Mato Grosso se desarrollan por encima de la media nacional, a pesar de que en la última década se tengan desvinculado de la dependencia económica exclusiva de la producción de commodities. Se entre los propietarios individuales y empresas que viven en la zona de Amazonia Legal de Mato Grosso, aproximadamente un $2 \%$ es responsable por la producción de commodities, en que actividad está insertado el $98 \%$ de las personas que no trabajan directamente en la producción agrícola? Aunque todavía hay algunos sectores directa o indirectamente dependientes de la agroindustria, lo que se percibió en estas ciudades es la llegada ininterrumpida de inmigrantes y, aun así, el nivel de oferta de empleo se ha mantenido estable, a pesar de la exigencia, cada vez mayor, de la mano de obra tecnológicamente calificada para diversas actividades en diferentes sectores. A pesar de su historia reciente, la economía de estas ciudades concentra uno de los mayores ingresos per cápita en el estado y, poco a poco, a cada año, cada una de ellas se acerca más a la idea que movilizó a sus inmigrantes pioneros, y traza su propio perfil a través de proyectos de expansión de los medios de producción fundados en tecnologías de vanguardia, modernización y políticas dirigidas a los intereses económicos de la región.

Palabras clave: Agroindustria; Amazonas Mato Grosso, Ciudades medianas, Migración, Modernización. 


\section{LISTA DE FIGURAS}

Figura 01 - Área de influência da BR-163 018

Figura 02 - Manobra de integração nacional proposto por Silva como Esquema 7 032

Figura 03 - Principais estradas do Programa de Integração Nacional/PIN, instituído em 1970 e implantado a partir de 1971 pelo governo federal. 034

Figura 04 - Estados que compõem a área da Amazônia Legal .......................... 036

Figura 05 - Mapeamento das áreas financiadas pela Sudam/ Basa 038

Figura 06 - Municípios envolvidos nos programas de colonização oficial nas modalidades PAR, PAC e PEA, de 1970 a 1980 ............................. 040

Figura 07 - Divisão do Estado de Mato Grosso (1977)..................................... 043

Figura 08 - Distribuição de Projetos Particulares de Colonização - 1970-1980.. 045

Figura 09 - Concentração de municípios ao redor da capital, Cuiabá - 1979 .... 046

Figura 10 - Divisão dos municípios mato-grossenses em 1980 ....................... 047

Figura 11 - Divisão dos municípios mato-grossenses em 1990 ........................ 048

Figura 12 - Municípios mato-grossenses em 2000 ....................................... 050

Figura 13 - Principais Rodovias traçadas entre 1970 e 2000 - Rodovias Longitudinais 059

Figura 14 - Principais Rodovias traçadas entre 1970 e 2000 - Rodovias

Transversais 060

Figura 15 - Principais Rodovias traçadas entre 1970 e 2000 - Rodovias Diagonais 061

Figura 16 - Principais Rodovias traçadas entre 1970 e 2000 - Rodovias Radiais 062

Figura 17 - Desflorestamento da Amazônia Legal ............................................ 064

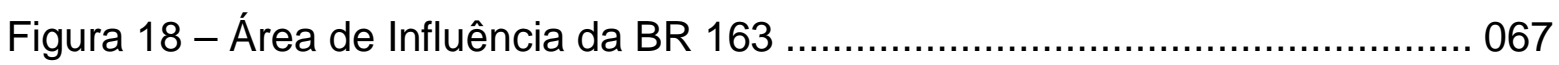

Figura 19 - Principais rodovias que atravessam Mato Grosso .......................... 071

Figura 20 - Localização de Lucas do Rio Verde em Mato Grosso....................... 094

Figura 21 - Instalações da Sadia, 2009 ....................................................... 109

Figura 22 - Hidrelétrica Canoa Quebrada.................................................... 111

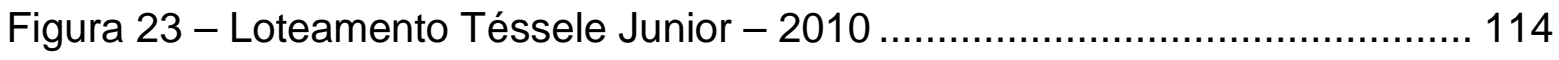

Figura 24 - Loteamento Venturini (2009) .................................................. 115 


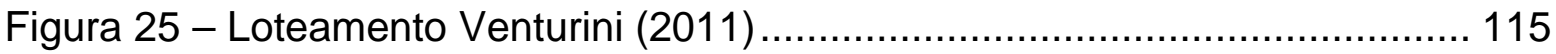

Figura 26 - Loteamento Jaime Seiti Fugii I e II ............................................... 116

Figura 27 - Plano de Saneamento - Implantação da rede de esgoto em

Lucas do Rio Verde.

Figura 28 - Maquete do Centro Cívico: Espaço composto pelo paço municipal existente, praça e proposta de espaço cultural e câmara

Figura 29 - Ponte sobre o lago do parque Ernani José Machado no centro de Lucas do Rio Verde

Figura 30 - Plano Diretor de Lucas do Rio Verde

Figura 31 - Escola Municipal Olavo Bilac em Lucas do Rio Verde 123

Figura 32 - Plano de Tecnologia da Informação: organograma de Educação..... 124

Figura 33 - Plano de Tecnologia da Informação: organograma da Saúde .......... 126

Figura 34 - Av. Rio Grande do Sul em Lucas do Rio Verde, 1970 ..................... 127

Figura 35 - Av. Rio Grande do Sul em Lucas do Rio Verde, 2010 .................... 127

Figura 36 - Localização de Sorriso em Mato Grosso........................................ 132

Figura 37 - Importância da BR-163 para a região central do estado de Mato Grosso. 133

Figura 38 - Núcleo urbano de Sorriso 135

Figura 39 - Traçado da BR-364 entre o Posto Gil a Comodoro e a BR-163. 139

Figura 40 - Detalhe da Planta de Urbanização - Zona Industrial (preto) e Bairro São Domingos (vermelho)

Figura 41 - Planta da urbanização de Sorriso-2012

Figura 42 - Outdoor anunciando a ampliação da área urbana com a criação do novo Centro Comercial e Residencial Universitário e Cultural Rota do Sol em Sorriso

Figura 43 - Pietá: Obra exposta no parque central de Sorriso

Figura 44 - Escultura Lutador de Capoeira, instalada numa das principais avenidas de Sorriso

Figura 45 - Localização de Sinop e municípios de sua área de abrangência como cidade-polo do norte de Mato Grosso

Figura 46 - Itinerário rodoviário de Mato Grosso com a BR-163 com o antigo trajeto via Nova Ubiratã, Vera e Itaúba, rumo ao estado do Pará .... 176

Figura 47 - Vista aérea do Município de Sinop .................................................. 195

Figura 48 - Planta do município de Sinop..................................................... 196 
Figura 49 - Principais rodovias da Amazônia Legal......................................... 209

Figura 50 - Áreas indígenas no Estado de Mato Grosso ................................... 211

Figura 51 - Jardim no centro da cidade de Sorriso .......................................... 234

Figura 52 - Trajeto percorrido pelo grupo de trabalho da colonizadora Sinop para chegar até a Gleba Celeste em 1972 ................................... 237

\section{LISTA DE FOTOS}

Foto 01 - Placa instalada próxima a entrada para o Porto de Santarém, PA ...... 068

Foto 02 - Urbanização do loteamento Téssele Junior (2012) ............................ 114

Foto 03 - Reservatório de Água do Loteamento Venturini (2012) ...................... 116

Foto 04 - Coleta de lixo no Bairro Téssele Junior (2012) …........................... 117

Foto 05 - Avenida que liga o novo paço municipal ao bairro Téssele Junior e o complexo industrial da Sadia........................................................ 120

Foto 06 - Rodovia que liga o Paço Municipal ao centro da cidade ...................... 120

Foto 07 - Entrevistados Nilfo Wandscheer e José Dario Munhak ..................... 130

Foto 08 - Sra. Idalina Francio, esposa do fundador da cidade .......................... 134

Foto 09 - Duplicação da BR-163 - Trecho entre Rosário Oeste e o Posto Gil .... 137

Foto 10 - Entrevista com a Sra. Vivyane Maria Cene Bedin, Secretária Municipal de Ação Social, professora Mariliane Sobrinho e equipe

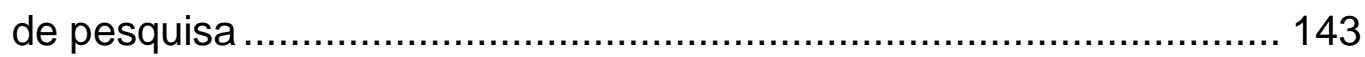

Foto 11 - Crianças saindo da escola no bairro Santo Agostinho Sorriso, 2012... 146

Foto 12 - Uma das ruas estreitas do bairro Santo Agostinho ............................ 151

Foto 13 - Avenida principal do bairro São Domingos ...................................... 152

Foto 14 - Casa construída no Loteamento Rota do Sol..................................... 159

Foto 15 - Casa construída no Loteamento Rota do Sol.................................... 159

Foto 16 - Avenida Central de Sorriso ......................................................... 160

Foto 17 - Outdoor na entrada de Sorriso - 2012 .......................................... 164

Foto 18 - Escultura alusiva à força produtiva de Sorriso, Instalada no jardim

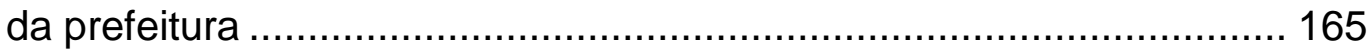

Foto 20 - Correntes utilizadas para desflorestamento na região de Sinop .......... 181

Foto 21 - Madeireira abandonada (Sinop) .................................................... 185

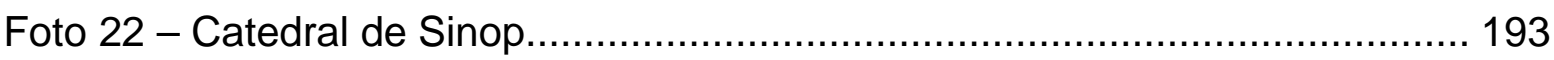


Foto 23 - Futura sede das Promotorias.....

Foto 24 - Nova área residencial próxima ao aeroporto (casas já habitadas)..... 198

Foto 25 - Material para a rede de esgoto dos bairros novos próximos ao aeroporto 201

Foto 26 - Sede da EMBRAPA em Sinop ........................................... 203

Foto 27 - Prédio da Fasipe em Sinop 205

Foto 28 - Professora Mariliane Sobrinho e Sra Luciene Francio (da esquerda para a direita)

Foto 28 - Sr. Ildo Romancini e equipe de pesquisa em Lucas do Rio Verde....... 239

Foto 30 - Sr. Leonildo Bares e equipe de pesquisa em Sinop......................... 242

Foto 31 - Sr. Antonio Isaac Fraga Lira e Rosana Ravache ............................ 244

Foto 32 - Sra. Luciane Bertinatto Copetti em Lucas do Rio Verde ....................252

\section{LISTA DE GRÁFICOS}

Gráfico 01 - Empresas instaladas no município de Lucas do Rio Verde e projeção para 10 anos

Gráfico 02 - Número de empregos disponíveis e previsão para 10 anos 107

Gráfico 03 - População projetada de Lucas do Rio Verde para os próximos 20 anos.

Gráfico 04 - Evolução populacional em 20 anos

Gráfico 05 - Consumo de energia.

Gráfico 06 - Índices FIRJAN de Desenvolvimento Municipal.

Gráfico 07 - Demonstrativo do total de alunos da rede municipal de ensino de

Lucas do Rio Verde

Gráfico 08 - Composição das receitas realizadas até 04/10/2011 em Lucas do

Rio Verde

Gráfico 09 - Crescimento da população mato-grossense urbana e rural de 1940 a 2000 


\section{LISTA DE QUADROS}

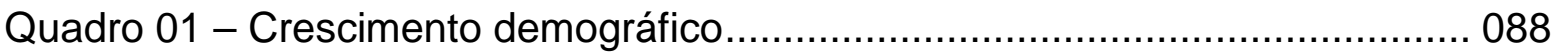

Quadro 02 - Frota de veículos de Sinop ........................................................ 190

Quadro 03 - Geração de Emprego em Sinop ................................................. 191

Quadro 04 - Comparativo da balança comercial de Sinop ............................... 191

Quadro 05 - Comparativo das empresas constituídas em Sinop entre 2000

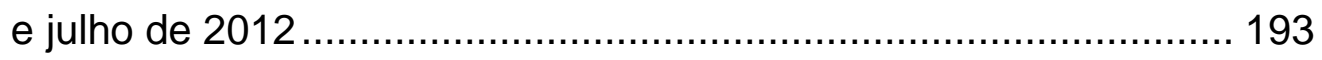

Quadro 06 - Dados demográficos sobre homens e mulheres nos municípios

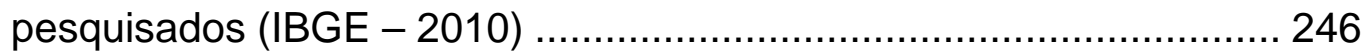

Quadro 07 - Índices demográficos de crianças e jovens (IBGE - 2010) .............. 247

Quadro 88 - Dados demográficos dos municípios pesquisados (IBGE - 2010)... 247 


\section{SUMÁRIO}

INTRODUÇÃO

\section{$1{ }^{\circ}$ CAPÍTULO}

\section{0 - A AMAZÔNIA LEGAL, A BR-163 E A MODERNIZAÇÃO DA REGIÃO} NORTE DE MATO GROSSO

1.1 - AMAZÔNIA PARTILHADA

1.2 - A FORMAÇÃO DE NOVOS MUNICÍPIOS

1.3 - NORTE MATO-GROSSENSE: DIACRONIA SÓCIO POLÍTICA

1.4 - A RODOVIA: VETORA DA ORGANIZAÇÃO DO ESPAÇO REGIONAL....... 058

1.5 - DESENVOLVIMENTO E MODERNIZAÇÃO DO NORTE/NORDESTE DE MATO GROSSO

\section{CAPÍTULO}

2.0 - OS IMIGRANTES PIONEIROS E AS CIDADES DA ÁREA DE ABRANGÊNCIA DA BR-163

2.1 - A TERRA SEM HOMENS PARA HOMENS SEM TERRA …..................... 080

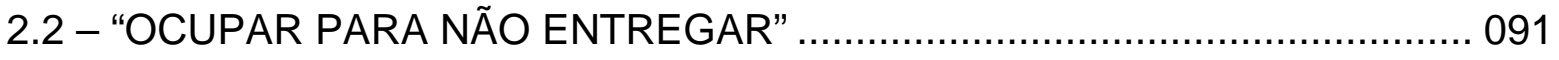

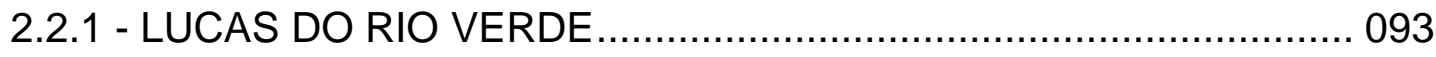

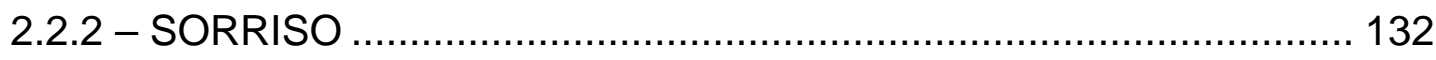

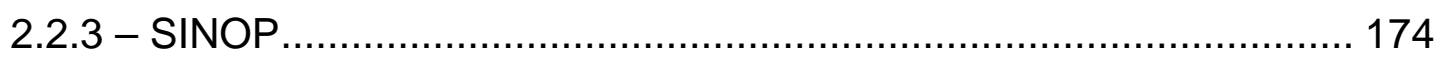

\section{$3^{\circ}$ CAPÍTULO}

\section{0 - AUTÓCTONES E IMIGRANTES PIONEIROS}

3.1 - AMPLIAR FRONTEIRAS: SANGRAR A MATA E AUTÓCTONES ............. 209

3.2 - IMIGRANTES PIONEIROS NA NOVA TERRA ....................................... 218

3.3 - O CRESCIMENTO DEMOGRÁFICO …….......................................... 246

3.4 - "TUDO O QUE PASSAMOS, VALEU A PENA" ....................................... 252

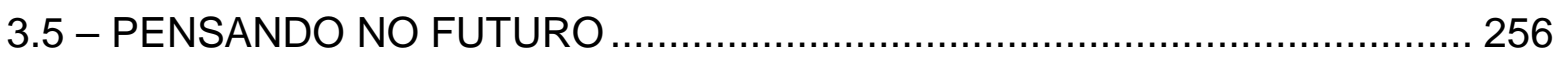

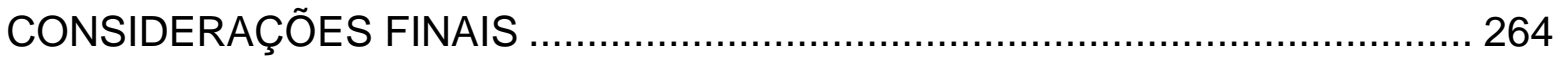

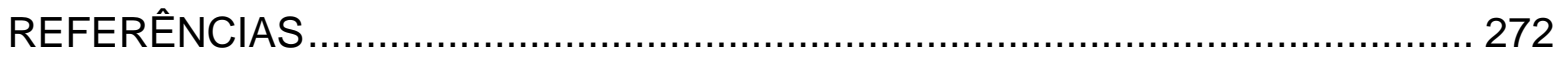




\title{
INTRODUÇÃO
}

\begin{abstract}
O que deve ser guardado para o entendimento da relação entre tecnologia e sociedade é que o papel do Estado, seja interrompendo, seja promovendo, seja liderando a inovação tecnológica, é um fator decisivo no processo geral, à medida que expressa e organiza as forças sociais dominantes em um espaço e numa época determinados. Em grande parte, a tecnologia expressa a habilidade de uma sociedade para impulsionar seu domínio tecnológico por intermédio das instituições sociais, inclusive o Estado. $\mathrm{O}$ processo histórico em que esse desenvolvimento de forças produtivas ocorre assinala as características da tecnologia e seus entrelaçamentos com as relações sociais. (CASTELLS, 2007:49-50).
\end{abstract}

O texto de Castells (2007) dá uma dimensão bastante aproximada do que se pretende discutir neste trabalho. "O que deve ser guardado para o entendimento da relação entre tecnologia e sociedade" na região norte de Mato Grosso, dimensiona não só a relação entre o agronegócio e o Estado, como expõe as contraposições às regras de sustentabilidade propostas para a Amazônia Legal ${ }^{1}$. Isto se torna perceptível em praticamente todo o território amazônico, onde o agronegócio tem organizado as forças sociais dominantes e dominadas e procurado influenciar, através do poder econômico. Qual foi o papel do Estado?

Paralelo a essa dinâmica histórica, surgiram nos últimos quarenta anos, ao norte de Mato Grosso, cidades que se desenvolveram acima da média nacional, sendo que, inicialmente, o progresso, aqui subentendido como desenvolvimento, foi impulsionado apenas pela rede de serviços articulada pelo agronegócio; depois, pela expansão desta rede para as mais diversas áreas do comércio e da indústria de transformação.

Conforme Figura 01, a seguir, a BR-163², em seu trecho Cuiabá - Santarém é a principal via de acesso e, ao mesmo tempo, a rota por onde escoa a produção de toda a região. Atravessa o norte/nordeste mato-grossense, servindo diretamente os municípios de Nova Mutum, Lucas do Rio Verde, Sorriso, Sinop, Colíder e Guarantã do Norte, no Estado de Mato Grosso. Ultrapassada a divisa com o estado do Pará,

\footnotetext{
${ }^{1}$ Em termos administrativos, a Amazônia Legal abrange nove Estados: Acre, Amapá, Amazonas, Pará, Rondônia, Roraima, Mato Grosso, Tocantins e parte do Maranhão. Foi criada pela necessidade do governo de planejar e promover o desenvolvimento da região. Sua superfície de aproximadamente $5.217 .423 \mathrm{~km}^{2}$, corresponde a cerca de $61 \%$ do território brasileiro. Fonte: Unidades de Conservação no Brasil. http://uc.socioambiental.org.br, 2012.

${ }^{2}$ A Lei $n^{\circ}$ 12.131, de 17 de Dezembro de 2009, firmada pelo Vice Presidente da República, José Alencar Gomes da Silva, no exercício do cargo de Presidente da República, denomina o trecho situado entre as cidades de Cuiabá, MT e Santarém, PA da BR-163, como Rodovia Senador Jonas Pinheiro, em homenagem ao senador mato-grossense falecido em fevereiro de 2009. Entretanto, neste trabalho será utilizada apenas a sigla BR-163, por ser popularmente mais conhecida.
} 
passa por Novo Progresso e Rurópolis, onde se encontra com a rodovia BR-230 (Transamazônica), e segue até chegar ao porto de Santarém, por onde escoa boa parte da produção de grãos produzida na região.

Figura 01 - Área de influência da BR-163

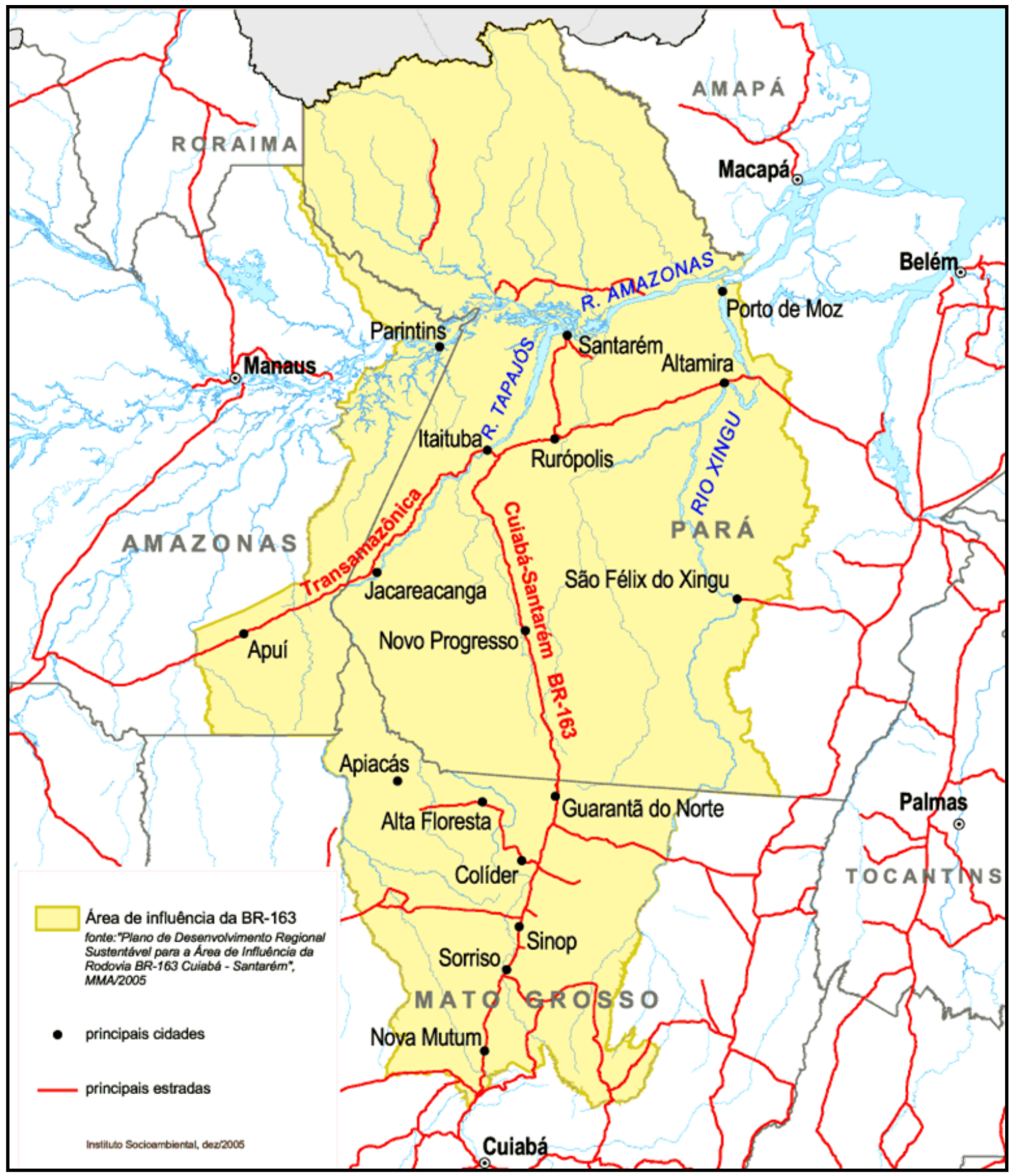

Fonte: Instituto Socioambiental ISA (dez 2006) 
No processo que vem sendo implantado ao longo dos últimos trinta anos, pode-se perceber dois fatores essenciais para este desenvolvimento acima da média:

1) A pesquisa incansável de fazendeiros e técnicos da EMBRAPA (Empresa Brasileira de Pesquisa Agropecuária), até descobrir como "amansar" o Cerrado para o plantio de grãos;

2) A abertura do trecho rodoviário Cuiabá - Santarém da BR-163, que levou o desenvolvimento para o norte do Estado e permitiu o escoamento da produção.

A citada rodovia, aberta pelo $9^{\circ}$ Batalhão de Engenharia e Construção na década de 1970, sob o comando do Coronel Meireles, foi planejada pelo governo Médici como parte do PIN (Programa de Integração Nacional), porém não foi concluída até os dias atuais. Resta ainda asfaltar aproximadamente $500 \mathrm{~km}$ em território paraense, conforme informações do DENIT-MT (Departamento Nacional de Infraestrutura de Transportes - Mato Grosso).

Esta pesquisa pretende enfocar o forte desenvolvimento e consequente modernização de três principais municípios de pequeno e médio porte ${ }^{3}$ distribuídos ao longo da BR-163: Lucas do Rio Verde, Sorriso e Sinop. Como se vê na Figura 01, graças à transversalidade ${ }^{4}$ da tecnologia de ponta no ordenamento do território ${ }^{5}$, ampliou as fronteiras ao norte do Estado de Mato Grosso, analisando a relevância, os limites e a eficácia das políticas públicas aplicadas aos imigrantes pioneiros imbricados nas questões de terras e da geopolítica do Estado.

O principal interesse, portanto, é dar visibilidade à forma como aconteceu o desenvolvimento destas cidades, paralelo à modernização do agronegócio.

\footnotetext{
${ }^{3}$ Para a ONU, qualquer agrupamento com mais de 20 mil pessoas pode ser considerado urbano. $\mathrm{O}$ urbanismo, por sua vez, considera como cidade pequena, aquela que possui menos de 50 mil habitantes; como cidade média-pequena, as cidades com um número entre 50 e 100 mil habintates; como cidade média, aquelas que abrigam entre 100 e 300 mil habitantes; como média-grande, as cidades onde vivem entre 300 e 500 mil habitantes; e as cidades grandes, as que abrigam mais de 500 mil habitantes

${ }^{4}$ Aqui o termo é considerado com as características de transversal, colateral, enquanto modelo de gestão, ou seja, o efeito colateral do agronegócio nas políticas públicas e a performance destes dois fatores no ordenamento do território mato-grossense.

${ }^{5}$ Entenda-se aqui território não como "sendo apenas o resultado da superposição de um conjunto de sistemas naturais e de um conjunto de coisas criadas pelo homem. O território é o chão e mais a população, isto é, uma identidade, o fato, o sentimento de pertencer àquilo que nos pertence. $O$ território é a base do trabalho, da residência, das trocas materiais e espirituais e da vida, sobre os quais ele influi". (SANTOS, 2006:96).
} 
Mesmo tendo o coronelismo atuado ostensivamente na região desde o século XVIII, a pesquisa se atem às ações dos últimos quarenta anos, quando aumentou a distribuição de terras devolutas ${ }^{6}$ doadas ou vendidas a baixo custo a pessoas físicas e jurídicas através de manobras coronelistas que capitanearam inúmeras burlas, em detrimento das populações autóctones e imigrantes.

Estas populações, mesmo tendo aderido aos programas de ocupação espacial, propostos pelo governo federal para a região amazônica entre as décadas de 1970 e 1990, foram praticamente esquecidas, uma vez que estas terras faziam parte das quotas de espaços vazios ${ }^{7}$ disponíveis no território nacional, isto é, áreas devolutas ainda não integradas ao modo capitalista de produção.

Graças ao marketing realizado pelo governo militar, na década de 1970 , as terras ao norte de Mato Grosso, então consideradas anecúmenas pelos projetos federais e estaduais, em pouco tempo se transformaram numa espécie de Novo Eldorado.

Os militares visavam "vender" áreas mato-grossenses principalmente para os agricultores dos Estados do sul do Brasil, com propostas de terra a baixo custo, incluindo moradia, financiamentos com juros módicos e prazos longos para plantio e colheita, além de infraestrutura urbana, serviços de saúde, saneamento básico, escola e estradas para escoar a produção.

Com estas promessas, a política de migração federal visava solucionar dois problemas:

1) Aplacar os ânimos, então bastante exaltados, dos pequenos agricultores no Rio Grande do Sul e em Santa Catarina, que reivindicavam a reforma agrária desde o início da década de 1960;

2) Integrar a Amazônia às regiões centro-oeste e sudeste, sob a proposta de "integrar para não entregar" que embutia a intenção de ampliar fronteiras; acreditavam que, povoando-as, manteriam a imanência amazônica e a proteção do território.

\footnotetext{
${ }^{6}$ Terras devolutas são terrenos públicos, ou em outras palavras, propriedades públicas que nunca pertenceram a um particular mesmo estando ocupadas. O termo 'devolutas' relaciona-se com a decisão de devolução desta terra para o domínio público ou não, dependendo de ações ditas discriminatórias. Historicamente, envolvia a devolução de terras que foram da coroa portuguesa, no período do Brasil Império e que, por serem públicas, nos termos da Constituição da República, não poderiam ser usucapidas. (Fonte: http://lfg.jusbrasil.com.br/noticias/).

${ }^{7}$ A política de integração das áreas periféricas considerava como "espaços vazios" as áreas ainda não integradas ao modo capitalista de produção, mesmo que ocupadas por povos indígenas e camponeses. (ROMANCINI; RODRIGUES, 2007:44)
} 
Desta forma estaria sendo parcialmente solucionada a ampliação de fronteiras como estratégia de proteção para estruturação/ocupação do território amazônico. Isto torna possível afirmar que o processo de produção do espaço em Mato Grosso deu seus primeiros passos utilizando políticas assentadas em características pré-capitalistas, centradas no extrativismo mineral e logo após vegetal, com um desenvolvimento paralelo da agricultura de subsistência e da pecuária extensiva que perdurou até a metade do século $\mathrm{XX}$.

Nesse período, o cotidiano praticamente se restringia a Cuiabá, capital do Estado e principal centro urbano que, embora se expandisse, mantinha os traços básicos do colonialismo ${ }^{8}$, perfil este que prevaleceu mesmo após a ascensão de Getúlio Vargas ao poder na década de 1930.

$\mathrm{Na}$ prática, os imigrantes remanescentes e seus descendentes tiveram de encontrar seus caminhos por conta própria, por falta de bases mais sólidas tanto para a reforma agrária quanto para implantar aquelas políticas consideradas desenvolvimentistas, fomentadas pelos governos federal e estadual, nas décadas entre 1970 a 1990.

Ao mesmo tempo, as interferências do poder público e consequentes alterações na morfologia geográfica mato-grossense ocasionaram um reordenamento territorial que atingiu, mais diretamente, as comunidades autóctones e, em seguida, os imigrantes.

Tudo o que se encontra no entorno do homem é dotado de algum significado e é este significado que se interpõe entre o meio natural e a atividade humana [...] "o estudo da territorialidade se converte assim em uma análise da atividade humana no que diz respeito à semantização do espaço territorial". (GARCIA, 1976:94).

Nesta perspectiva, foi pesquisada a territorialidade produzida em meio a atividade humana nos núcleos urbanos que brotaram na área de abrangência da BR-163, sob a ótica de "uma análise da atividade humana, no que diz respeito à semantização do espaço territorial", como sugere Garcia (op.cit.:94).

Na opinião de Rossetto (2011),

O insucesso dos projetos de colonização deve-se a vários fatores, entre eles a falta do cumprimento das responsabilidades assumidas pelas colonizadoras e as incipientes ações do poder público na gestão do processo, inacessibilidade ao crédito rural, pois as agências financiadoras exigiam o título de propriedade, documento que a maioria dos camponeses

\footnotetext{
${ }^{8}$ Sistema político, econômico e social pelo qual uma potência mantém ou estende seu controle sobre territórios ou povos estranhos. (MICHAELIS, 1998:537)
} 
não tinha. O Programa Especial de Crédito para a Reforma Agrária PROCERA, administrado pelo próprio INCRA (Instituto Nacional de Colonização e Reforma Agrária) não atendia a demanda instalada. Como correlato, muitos camponeses passavam à condição de garimpeiros, trabalhadores assalariados em madeireiras ou nas áreas de agricultura, outros retornaram para suas regiões de origem. (ROSSETTO, 2011:56-57).

Alguns, porém, acreditaram que o futuro não estava necessariamente no garimpo ou no corte de madeira, nem no plantio de grãos ou na pecuária, mas sim nos serviços que pudessem prestar no núcleo urbano, agilizando as demandas que até então o segmento encontrava apenas na capital ou nos grandes centros do país. Passaram a contar com a distância como aliada, para construir seus próprios negócios.

No caso dos municípios da área de abrangência da BR-163, os pioneiros imigrantes transformaram o problema da falta de apoio do poder público e das colonizadoras, em uma nova forma de inserir-se no mercado. Neste entorno, agora intelectualizado que reconstrói e é reconstruído, onde as pessoas aprendem as lições do desconhecido e superam a ignorância a respeito de outra atividade que não fosse a agrícola, aos poucos, transformou pequenos fragmentos de um mundo novo em conhecimento para o exercício de um novo negócio. "O camponês migrante que tenha participado do processo de abertura da fronteira agrícola e mantêm a essência camponesa", como pondera Rossetto (2011:62), se metamorfoseou.

O grande crescimento demográfico e econômico da região tem um débito com as pessoas que resolveram ficar e mudar o rumo de suas vidas. Portanto, é preciso pesquisar sobre o pioneiro imigrante que, sem opções de progredir em sua profissão, percebeu as dificuldades que o Cerrado apresentava e, cada um do seu jeito, procurou uma solução.

A lógica de sobrevivência tem uma matemática muito concisa: na medida em que se apresentam mecanismos de sobrevivência frente à lógica capitalista, manifestada principalmente pela criação e implantação de estratégias, todo um contexto a conduz à proletarização de um lado e à capitalização de outro.

Para escapar desta sina e da lógica que os exclui e reverbera em suas expectativas de vida, os migrantes ou os descendentes de migrantes desta região, hoje apenas conseguem contar muitas histórias. Algumas ouvidas daqueles que seguiram em frente, mais para o norte; outras dos que voltaram para as suas regiões de origem e outras ainda, dos que ficaram para contá-las. 
A dificuldade de conseguir o alimento, por exemplo, motivou alguns pioneiros imigrantes a alugar um ranchinho, conseguir um veículo e, depois de enfrentar as péssimas condições de tráfego da estrada que mais tarde viria a ser a BR-163, conseguiu abastecer sua vendinha com o necessário para atender a clientela durante um mês; em pouco tempo adquiriu um imóvel, um veículo e se transformou em um supermercadista de sucesso. O mesmo aconteceu com o fornecedor de peças, de equipamentos etc. Hoje, a maioria lembra muito pouco dos motivos que a trouxeram à região.

Através dos dados coletados in loco, o que se pretendeu, portanto é remontar a história dentro da própria história, ou seja, além da violência e da falta de escrúpulos de funcionários públicos ou de colonizadoras e de fazendeiros que conquistaram terras pela força, existem outras verdades.

As bases para que a pesquisa seguisse a metodologia adotada na História Oral, foram encontradas em Alberti (2004), Meihi e Holanda (2007), e Merlau-Ponty (1996), visando dar representatividade ao banco de histórias disponíveis entre os remanescentes da migração do "Nortão"9.

Conforme Alberti (2004) História Oral é um método de pesquisa (histórica, antropológica, sociológica etc),

\begin{abstract}
Que privilegia a realização de entrevistas com pessoas que participaram de, ou testemunharam, acontecimentos, conjunturas, visões de mundo, como forma de se aproximar do objeto de estudo. [...] Trata-se de estudar acontecimentos históricos, instituições, grupos sociais, categorias profissionais, movimentos, conjunturas etc, à luz de depoimentos de pessoas que deles participaram ou testemunharam. (ALBERTI, 2004, p.18)
\end{abstract}

Pelos números do censo realizado em 2010 pelo IBGE (Instituto Brasileiro de Geografia e Estatística), as cidades estudadas nesta pesquisa somam 225.176 habitantes. Lucas do Rio Verde, com 45.556; Sinop, com 113.099; Sorriso, com 66.521. Deste total, $194.553(86,4 \%)$ vivem nos núcleos urbanos, ou seja, são munícipes remunerados por atividades que não estão, necessariamente, inseridas no agronegócio.

Nesse mundo urbano e racionalizado, as relações sociais entre os cidadãos assumiram características diferentes daquelas colocadas para o início da colonização local. A força centrípeta protetora, característica das comunidades iniciais, foi substituída pela força centrífuga, característica da economia das sociedades modernas. Passado o primeiro momento de espanto e atordoamento, as pessoas se recompõem, buscam compreender a nova realidade e reorganizar seus planos para o futuro. O entorno, agora

\footnotetext{
${ }^{9}$ É como a região norte de Mato Grosso é popularmente conhecida.
} 
intelectualizado, reconstrói e é reconstruído. As pessoas aprendem as lições do desconhecido e a ignorância, aos poucos, dá lugar a pequenos fragmentos do que virá a ser o conhecimento do meio. Esse processo não ocorre impunemente, mas traz consigo o distanciamento, a individualização, o fim de muitos sonhos assentados naquela proximidade criada pela força da necessidade e da partilha da precariedade de cada um. (JOANONI NETO, 2007:210).

Como estas pessoas se reinventaram? O que estão fazendo para que as portas desta nova classe social que poderia ser reconhecida como nova burguesia ${ }^{10}$ se abram, mesmo sem depender, necessariamente, de suas antigas profissões de agricultores? A curiosidade aumenta quando se leva em conta que a maioria destes imigrantes chegou a Mato Grosso com uma visão poética, semelhante à descrita por Bauman (1998):

Além da curva, existe, deve existir, tem de existir uma terra hospitaleira em que se fixar, mas depois de cada curva surgem novas curvas, com novas frustrações e novas esperanças ainda não destroçadas (BAUMAN, 1998:92).

O projeto em si teve início com a leitura de uma bibliografia diversificada que, além de livros, incluiu artigos de revistas e jornais, pesquisas em documentários e sites. Baseou-se também em entrevistas com autoridades ligadas, direta ou indiretamente, às políticas da região pesquisada, além de professores da Universidade Federal de Mato Grosso que se dedicam à pesquisa da região em foco há alguns anos.

Diante deste contexto e de uma nova perspectiva de descobertas, o livro "Geografia de Mato Grosso: território, sociedade - ambiente" (2005), organizado por Gislaene Moreno e Tereza Higa, ambas da Universidade Federal de Mato Grosso, despertou a curiosidade para o tema da pesquisa e, a seguir, o interesse cresceu com a leitura da obra de Gislaene Moreno, "Terra e poder em Mato Grosso: política e mecanismos de burla 1892-1992" (2007), edição adaptada de sua tese de doutorado na USP (Universidade de São Paulo), Departamento de Geografia, em 1994.

Além destas obras, as de Barrozo (2010), Bernardes (2005, 2007), Joanoni Neto (2007), Maitelli e Zamparoni (2007), Romancini (2007), Rossetto (2011), Zart (1988) e vários autores cujos artigos foram veiculados pela Revista Mato-Grossense

\footnotetext{
${ }^{10}$ Entenda-se o termo burguesia no sentido sociológico que define grupos ou indivíduos cujos interesses se vinculam aos dos possuidores dos meios de produção. (Fonte: MICHAELIS: moderno dicionário da língua portuguesa, 1998).
} 
de Geografia, deram consistência às informações a respeito da migração na região norte de Mato Grosso.

Couto e Silva (1981), Becker (1990, 2004), Costa (2005), Ianni (2004), Silva (2008) e Rangel (2005) estabeleceram as bases para aprofundar os conhecimentos sobre as políticas aplicadas na Amazônia, Amazônia Legal e Reforma Agrária, enquanto Bobbio (1990), Castells (2007, 2008), Condorcet (1993), Elias (1994), Foucault (1996, 2005, 2008), Giddens (1991, 2003, 2007), Gottdiener (2010), Habermas (2007), Harvey (2006), Huntington (2010), Latour (2009), Lefebvre (1974), Löwy (2007), Moore Junior (1983), Nye Junior (2002) e Smith (1983) abriram o campo da política social e sua aplicação nas cidades mais ou menos desenvolvidas.

As informações contidas nas publicações de Antas Junior (2005), Castro (2005), Corrêa (1987, 2003, 2005), Haesbaert (2002, 2011), Lemos (2001, 2005), Lencioni (1999), Santos (1988, 1992, 1994, 1997, 2005, 2006, 2007,2009) e Soja (1993), foram de essencial importância para o direcionamento calibrado da recolha de conteúdos para o relacionamento espaço-tempo nos estudos geográficos.

Também foram muito importantes para as pesquisas de campo, as metodologias de pesquisa-ação estudadas em Barbier (2002) e Dionne (2007) antes aplicadas em um trabalho para a dissertação de mestrado, além das sugestões de Guerra (2006) e Haguette (2007) na pesquisa qualitativa que deram forma aos quarenta questionários aplicados em campo (Sinop, 20 questionários, Sorriso, 8 e Lucas do Rio Verde, 12).

Para identificar melhor a metamorfose que ocorreu nesta região, utilizou-se um assente teórico multidisciplinar visando dar à pesquisa um formato que fosse respaldado na geografia, na geopolítica, nas políticas públicas, na sociologia e no agronegócio porque, tanto quanto se sabia, até então, o sucesso destes municípios não estava preso apenas ao negócio das commodities. O ineditismo subentendeu um aporte geopolítico ao objeto de estudo, uma vez que "a coerência interna da construção teórica depende do grau de representatividade dos elementos analíticos ante o objeto estudado" (SANTOS, 2009:23).

As respostas a este questionamento só poderiam ser encontradas se a linha de pesquisa não só relatasse a saga das mais de duzentas mil pessoas que se instalaram entre as décadas de 1970 e 1990 ao longo da BR-163, como também deveria encontrar um modo de saber o que aconteceu com aqueles que desistiram e foram buscar outro sonho, "além da curva", como disse Bauman (1998). 
A realização de entrevistas, in loco, com imigrantes pioneiros remanescentes, índios, caboclos e moradores dos municípios pesquisados, Lucas do Rio Verde, Sinop e Sorriso, deram importante contribuição para que se conseguisse compreender o processo de desenvolvimento destas comunidades, mesmo porque

Uma participação democrática que se impõe passo a passo cria com o
status da cidadania uma nova dimensão da solidariedade mediada
juridicamente; ao mesmo tempo, ela revela para o Estado uma fonte
secularizada de legitimação. (HABERMAS, 2007:134).

No primeiro capítulo desta tese, "A Amazônia Legal, a BR-163 e a modernização da Região Norte de Mato Grosso", apresenta a formação geopolítica da Amazônia Legal e do Estado de Mato Grosso, bem como da subsequente ocupação do território mato-grossense e urbanização das regiões norte e nordeste, paralelas à elaboração e implantação do projeto de construção da BR-163, como parte de um projeto nacional que fomentaria a povoação do seu entorno e desenvolvimento da região.

O segundo capítulo, "Os imigrantes pioneiros e as cidades da área de abrangência da BR-163", trata do desenvolvimento e da modernização dos três municípios que mais se destacaram na área de abrangência da BR-163, Lucas do Rio Verde, Sinop e Sorriso, bem como das implicações socioeconômicas e espaciais consequentes tanto do processo histórico quanto da omissão deliberada do Estado em algumas circunstâncias.

Finalmente, o terceiro e último capítulo, "Autóctones e imigrantes pioneiros" sedimenta os dados recolhidos em pesquisas e entrevistas quando houve um diálogo com os munícipes a respeito do desenvolvimento e adequação de políticas públicas para estes núcleos urbanos, considerando o amalgamento crescente do espaço rural ao espaço urbano e vice versa. 


\section{CAPÍTULO}

\section{0 - A AMAZÔNIA LEGAL, A BR-163 E A MODERNIZAÇÃO DA REGIÃO NORTE DE MATO GROSSO}

\section{1 - AMAZÔNIA PARTILHADA}

Ao abordar o tema Amazônia Legal, a primeira preocupação é a forma como o poder público vem tratando esta parcela do território brasileiro considerada Patrimônio da Humanidade (UNESCO, 2003), cuja população, vegetal e animal, está entre as mais diversificadas do mundo.

Além de cobrir a maior parte da Bacia Amazônica da América do Sul (dos sete milhões de quilômetros quadrados, cinco milhões e meio são cobertos pela floresta tropical), seu subsolo é formado por rochas com alto potencial de armazenamento e transferência de água potável e o solo guarda grande estoque de carbono, que, liberado na atmosfera, pode alterar o equilíbrio dos gases de efeito estufa.

Conforme Müller (2006),

A grande Amazônia - a América do Sul Setentrional - abrange cerca de 7,8 milhões de $\mathrm{km}^{2}$, aproximadamente $60,05 \%$ da superfície conjunta da Bolívia, Brasil, Colômbia, Equador, Guiana, Peru, Suriname e Venezuela" (MMA, 1997, p. 12). Corresponde a $44,0 \%$ da Superfície da América do Sul, representando $5,05 \%$ da área terrestre do globo. Segundo Ministério de Meio Ambiente, dos Recursos Hídricos e da Amazônia Legal - MMA (op. cit., p. 12), outro fator importante, é que ela contém aproximadamente $20,0 \%$ da água potável do planeta, um terço das florestas latifoliadas, $10 \%$ da biota universal. Sua superfície total atinge a 780,0 milhões de hectares, dos quais cerca de 500,0 milhões no Brasil. A área de floresta virgem alcança algo como 350,0 milhões de hectares. A Amazônia brasileira constitui cerca de $60,0 \%$ dessa grande região. (MÜLLER, 2006:20)

$\mathrm{Na}$ área considerada Amazônia Legal, vivem em torno de 24 milhões de pessoas (IBGE - 2010), distribuídas em 775 municípios, nos estados do Acre, Amapá, Amazonas, Mato Grosso, Pará, Rondônia, Roraima, Tocantins, Maranhão e Goiás.

A ideia de Amazônia Legal nasceu no Estado Novo (1937-1945) ${ }^{11}$ sob o comando do Presidente Getúlio Dorneles Vargas, para expandir a área agricultável

\footnotetext{
${ }^{11}$ A forte concentração de poder no executivo federal, em curso desde fins de 1935, a aliança com a hierarquia militar e com setores das oligarquias, criaram as condições para o golpe político de Getúlio
} 
e, paralelamente, povoar as terras de fronteira. Assim, enquanto o mundo se recupera da "grande depressão" (resultado da quebra da bolsa de valores de Nova Iorque em 1929) e dos desgastes provocados pela Segunda Guerra Mundial, no Brasil nasce o movimento que implanta políticas de centralização políticoadministrativas, acompanhadas por intervenções do Estado na economia, com a intenção de fortalecer o sistema capitalista do país.

Com as políticas de centralização político-administrativas, o governo Vargas visa promover, através do programa Marcha para o Oeste ${ }^{12}$, a ocupação dos "vazios demográficos" por meio de absorção dos excedentes populacionais que fazem pressão no centro-sul do país, encaminhando-os para áreas que produziam matérias-primas e gêneros alimentícios a baixo custo.

Desta forma poderia subsidiar a implantação da industrialização no sudeste, cujo objetivo fundamental era quebrar os desequilíbrios regionais, pela implantação de uma política demográfica que incentivasse a migração, na suposta tentativa de diminuir os desequilíbrios existentes entre as diversas regiões do país.

Para que a política de Getúlio desse certo, é necessária a criação de uma base de apoio nos Estados periféricos, como Goiás, Mato Grosso e Paraná, que ficariam encarregados pela produção de alimentos e de matérias-primas capazes de abastecer o novo pólo industrial do sudeste.

Pelos projetos do Estado Novo, a política de produção e distribuição de alimentos trabalha com a hipótese de abastecer os centros urbanos com produtos a preços mais baixos, promovendo o desenvolvimento industrial e a diversificação da agricultura. Por isto, deu ao campo absoluta prioridade e, ao mesmo tempo, cria uma política territorial de integração dos espaços vazios, na qual Mato Grosso se enquadrou como área ideal para a aplicação do novo estilo de produção agrícola.

É possível afirmar que a ocupação do Centro-Oeste representou um primeiro passo para alicerçar uma etapa preliminar à ocupação da Amazônia uma vez que, a partir daí foram criados alguns órgãos de controle ambiental, como DTC (Diretoria de

\footnotetext{
Vargas em 10 de novembro de 1937, inaugurando um dos períodos mais autoritários da história do país, que viria a ser conhecido como Estado Novo (CORTI, 2009).

${ }^{12}$ Foi um projeto dirigido pelo governo Getúlio Vargas no período do Estado Novo, para ocupar e desenvolver o interior do Brasil. Lançado na véspera de 1938, a Marcha, nas palavras de Vargas, incorporou "o verdadeiro sentido de brasilidade", uma solução para os infortúnios da nação. (Fonte: Emerson Santiago; http://www.infoescola.com/historia-do-brasil/marcha-para-o-oeste).
} 
Terras e Colonização), em 1946, em substituição à Diretoria de Terras e Obras Públicas, foram criados órgãos setoriais.

Os Estados, por sua vez, criaram também órgãos sucedâneos que, teoricamente, funcionariam como extensões destes órgãos federais, atuando como os mentores das políticas de colonização e ordenamento de áreas, visando uma atuação mais direta nas questões locais.

Em Mato Grosso, por exemplo, foi criada em 1947, a CPP (Comissão de Planejamento da Produção). Esta decisão colocava o Código de Terras do Estado, homologado pelo então governador Arnaldo Estevão de Figueiredo, em 1949, como instrumento de sistematização das diretrizes que vinham dando respaldo às decisões sobre as questões de terra em Mato Grosso.

Entre as décadas de 1940 e 1960 foram implantados vários núcleos oficiais de colonização que abrangiam aproximadamente 900 mil hectares de terras públicas, negociadas com empresas particulares e pessoas físicas, entre as quais se incluíram milhares de imigrantes. Apesar dos esforços do governo federal, os resultados ficaram aquém dos objetivos tanto de povoamento quanto de diversificação e expansão da pequena produção ou ampliação do mercado interno.

Com base nos textos de Becker (1990), Joanoni Neto (2007), Moreno (2007) e Silva (2008), é possível afirmar que o fracasso é compreensível uma vez que o poder público realizou muitos contratos com empresas particulares, com base em interesses de grupos econômicos e político-partidários a preços irrisórios ou mesmo como barganhas que serviam de "moeda de troca" com favores políticos que dispensavam concorrências públicas ou garantias de execução. Tanto é que a maior parte dos contratos não foi cumprida, principalmente no que disse a respeito à implantação de infraestrutura física e social, tais como medições e demarcações de terras, abertura de estradas, prestação de serviços educacionais e de saúde etc.

"As alterações feitas no Código de Terras pelo governador Fernando Corrêa da Costa, em 1951, aparentemente ampliaram o espaço para manobras nos negócios com terras devolutas, aumentando expressivamente a venda de títulos das propriedades situadas na região norte (títulos provisórios, 1.269 .573 hectares e títulos definitivos, 715.472 hectares, independente dos 251 títulos vendidos em outras regiões). Em 1953 este volume aumentou para 1.894 títulos expedidos, abrangendo 5.074.611 hectares." (MORENO, 2007:114). 
"Ao final de seu governo haviam sido negociados aproximadamente 45.000.000 de hectares de terra, sem nenhum critério, dispensando-se, inclusive, a concorrência pública e garantias de execução de contratos, ferindo, principalmente, a Constituição Federal de 1948 que vedava a alienação de áreas superiores a 10 mil hectares sem a prévia autorização do Senado Federal. Algumas concessões chegavam a alcançar 200.000 hectares." (MORENO, 2007:113-116).

Em 1966, após muitas denúncias de privilégios, fraudes e corrupção, foi extinto o DTC, órgão responsável pelos programas de colonização da região. A política de colonização só foi retomada na década de 1970 durante o regime militar, apoiada por um aparato jurídico consubstanciado no Estatuto da Terra (Lei $\mathrm{n}^{\circ}$ 4.505/64) e preparada para legitimar as ações de regularização fundiária e de colonização apoiada pelo governo federal nos estados.

No entanto, é preciso levar em consideração que "a política de colonização adotada no Brasil sempre foi baseada na divisão, seja entre colonizadores e indígenas, donatários e degredados, senhores e escravos, seja entre outros segmentos sociais" (TABORELLI e JOANONI NETO, 2008:15). Esta política, por sua vez, tende a acobertar o que Raffestin (1993) identifica como tessituras, nós ou redes de uma sociedade, ratificando a presença constante deste princípio em todas as práticas espaciais.

A tessitura "desejada" é aquela que tenta otimizar o campo operatório do
grupo, enquanto a tessitura "suportada" é aquela que tenta maximizar o
controle do grupo. [...] A tessitura é sempre um enquadramento do poder ou
de um poder. A escala da tessitura determina a escala dos poderes.
(RAFFESTIN, 1993:154)

A tessitura desejada pela ESG (Escola Superior de Guerra) ${ }^{13}$, já na década de 1950, discutia tanto a escala da tessitura "suportada" como a vulnerabilidade das fronteiras a norte e Centro-Oeste do Brasil, habitadas principalmente por índios e

\footnotetext{
${ }^{13}$ A ESG, criada pela Lei no 785/49, é um Instituto de Altos Estudos de Política, Estratégia e Defesa, integrante da estrutura do Ministério da Defesa, e destina-se a desenvolver e consolidar os conhecimentos necessários ao exercício de funções de direção e assessoramento superior para o planejamento da Defesa Nacional, nela incluídos os aspectos fundamentais da Segurança e do Desenvolvimento. A Escola Superior de Guerra funciona como centro de estudos e pesquisas, a ela competindo planejar, coordenar e desenvolver os cursos que forem instituídos pelo Ministro de Estado da Defesa. A Escola não desempenha função de formulação ou execução da Política do País. Seus trabalhos são de natureza exclusivamente acadêmica, sendo um foro democrático e aberto ao livre debate. (Fonte: www.esg.br/a-esg).
} 
alguns caboclos que viviam da agricultura de subsistência ${ }^{14}$, alienados das questões que preocupavam o governo federal como a soberania nacional e a segurança de fronteiras.

Isto se percebe na análise do espaço brasileiro feita pelo General Golbery do Couto e Silva, membro da ESG, em 1952,

O Brasil marginal, inexplorado em sua maior parte, desvitalizado pela falta de gente e de energia criadora, e o qual nos cumpre incorporar realmente à nação, integrando-o na comunidade nacional e valorizando sua grande expressão física hoje ainda quase completamente passiva. Tarefa sem dúvida gigantesca que está a exigir um planejamento cuidadoso e em longo prazo e que consumirá largos anos para sua realização, além de recursos vultosos e de toda a ordem. Mas é preciso que não esqueçamos que o vácuo de poder, como centro de baixas pressões, atrai de todos os quadrantes os ventos desenfreados da cobiça. (SILVA, 1981:43) continua:

E o general já traça a ideia que iria executar vinte anos depois, quando

Portanto, se larga é a empresa e sobremodo difícil, impõe-se pelo menos dispor, sem tardança, na cintura dessa imensa área vazia, postos avançados de nossa civilização, convenientemente equipados para que possam testemunhar a posse indiscutível da terra, à espera dos melhores dias de uma integração e valorização contínuas e totais, e estejam em condições de opor-se a quaisquer veleidades alienígenas de penetração... É preciso tamponar o deserto. Por outro lado, no Brasil centro-oeste, Cuiabá e a região circunvizinha que lhe é tributária, Campo Grande e o sul de Mato Grosso, Goiânia e o sul de Goiás, se integram em vasta área ainda não ecumênica, mas que já se articula ao núcleo central por um istmo bem delimitado, de fraca densidade de circulação. (op.cit. 1981: 45)

Diante do exposto, duas décadas antes da implantação das suas ideias na região amazônica, havia grande preocupação com o espaço, chamado por ele de "deserto" por ter ignorado a população autóctone.

Parafraseando Milton Santos (2007),

Os fatos estão todos aí, objetivos e independentes de nós. Mas cabe a nós fazer com que se tornem históricos, mediante a identificação das relações que os definem, seja pela observação de suas relações de causa e efeito, isto é, sua história, seja pela constatação da ordem segundo a qual se organizam para formar um sistema, um novo sistema temporal, ou melhor, um novo momento do modo de produção novo, ou a transição entre os dois. Sem relações não há fatos. (SANTOS, 2007: 35)

Enquanto muitos discutiam de que forma iria acontecer aquele megaprojeto sugerido pelo regime militar entre as décadas de 1960 e 1970, praticamente todas as etapas já estavam geopoliticamente definidas. Tanto pela observação de suas

\footnotetext{
${ }^{14}$ É aquela que, basicamente, engloba a plantação feita em pequenas propriedades (minifúndios), e a finalidade principal é a sobrevivência do agricultor e de sua família. Em contraposição à agricultura comercial, os produtos excedentes não são para a venda. (Fonte: pt.wikipedia.org/wiki/)
} 
relações de causa e efeito, quanto pela constatação da ordem através da qual se organizou o novo momento de um novo modo de produção, se deduz que as relações do antigo projeto da ESG se identifica, em muitos pontos, com o planejamento feito para a região amazônica "para tamponar o deserto", como citou Silva (1981).

Figura 02 - Manobra de integração nacional proposto por Silva como Esquema 7

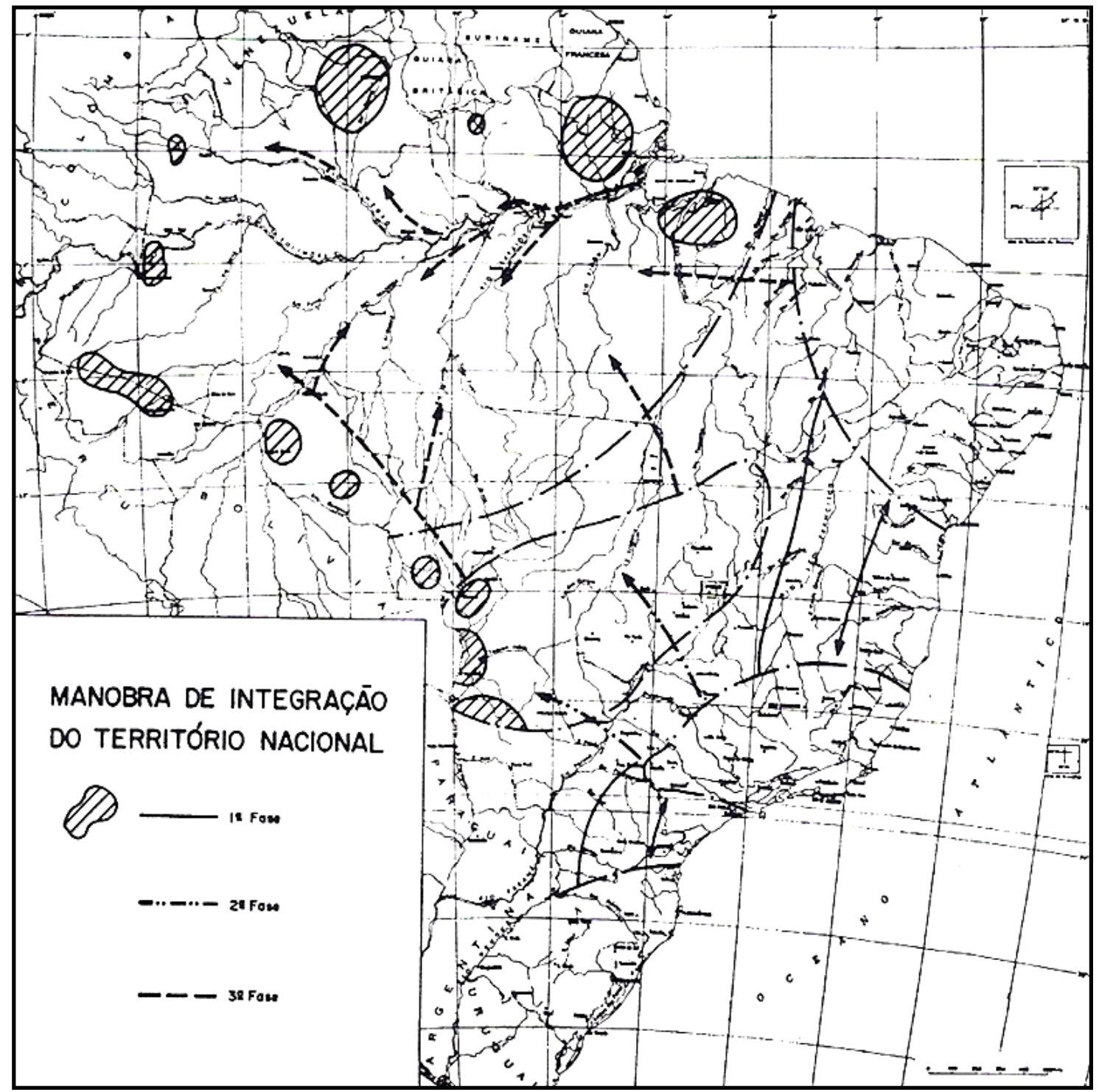

Fonte: Conjuntura Política Nacional - O Poder Executivo \& Geopolítica do Brasil (1981:47)

Conforme a Figura 02, Silva (op.cit.) já delineava em seu trabalho desenvolvido para a ESG, o projeto colocado em prática na década de 1970, como explica no contexto de sua obra:

Resumindo em suas linhas gerais a grande ideia de manobra geopolítica para a integração do território nacional trata-se de (esquema 7): 
$1^{\circ}$ - articular firmemente a base ecumênica de nossa projeção continental, ligando o Nordeste e o Sul ao núcleo central do país; ao mesmo passo que garantir a inviolabilidade da vasta extensão despovoada do interior e tamponamento eficaz das possíveis vias de penetração;

$2^{\circ}$ - impulsionar o avanço para nordeste da onda colonizadora, a partir da plataforma central, de modo a integrar a península centro-oeste no todo ecumênico brasileiro (para o que se combinarão o processo da mancha de azeite, preconizado por Lyautey ${ }^{15}$, e o dos núcleos avançados atuando como pontos de condensação);

$3^{0}$ - inundar de civilização a Hiléia ${ }^{16}$ amazônica, a coberto dos nódulos fronteiriços, partindo de uma base avançada constituída no Centro-Oeste, em ação coordenada com a progressão E.- O. segundo o eixo do grande rio.

Para a realização de tão ingente tarefa, contamos com uma população jovem, de elevado ritmo de crescimento e apreciável grau de homogeneidade. $O$ que precisamos a todo custo quanto antes deter é o êxodo rural desordenado, vinculando o homem à terra do interior pela pequena propriedade, reduzindo o retardo cultural que opõe o sertão à cidade, e diversificando em bases mais sólidas a nossa economia. (SILVA, 1981: 46 e 47)

Nos três itens citados em sua obra e apensados acima estão resumidas as linhas gerais de manobra geopolítica para integrar o território nacional. Neles se lê praticamente o que foi implantado na década de 1970, quando o General Golbery exerceu um papel chave na ditadura militar, principalmente quando esteve à frente da Casa Civil. Esta visão é ratificada mais adiante em seu texto quando afirma que:

O tamponamento efetivo dos caminhos naturais de penetração, que de além-fronteiras conduzem à Amazônia, é medida que se impõe, e se impõe com urgência, para que, como dissemos, possamos levar a cabo, quando oportuno, tranquila e metodicamente, um plano de integração e valorização daquele imenso mundo ainda perdido (SILVA, 1981:55)

O governo militar de 1970 tinha pressa e a ação visou impulsionar o povoamento da Amazônia para alcançar os seus objetivos. Por isto, convocou vários batalhões de engenharia de construção ou transformou alguns grupamentos em batalhões de engenharia para realizar o planejamento estratégico de ocupação e proteção de fronteiras. Assim, a Amazônia, então cognominada pelo regime militar "a terra sem homens para os homens sem terra", passou a ser esquadrinhada por rodovias que partiam de diferentes pontos do espaço mapeado pelo projeto geopolítico estratégico da ditadura militar. Numa comparação entre o Figura

\footnotetext{
${ }^{15}$ Estratégia que o Marechal Lyautey empreendeu no início do século $\mathrm{XX}$, sob o nome de tache d'huil (em francês no original; mancha de óleo), para ganhar o apoio de diversas tribos árabes/berberes do Norte de África, em troca de proteção e serviços sociais - numa expansão lenta e metódica da área sob domínio francês.

${ }^{16}$ Nome proposto por Alexander von Humboldt, geógrafo, naturalista e explorador alemão para designar a floresta equatorial que vai das encostas orientais dos Andes, por todo o vale do Amazonas, até as Guianas (MICHAELIS, 1998)
} 
apresentado em sua obra e o Figura divulgado pelo PIN (Programa de Integração Nacional), na década de 1970, na Figura 03 se percebe a semelhança entre as duas ideias.

Figura 03 - Principais estradas do PIN - Programa de Integração Nacional, instituído em 1970 e implantado a partir de 1971 pelo governo federal.

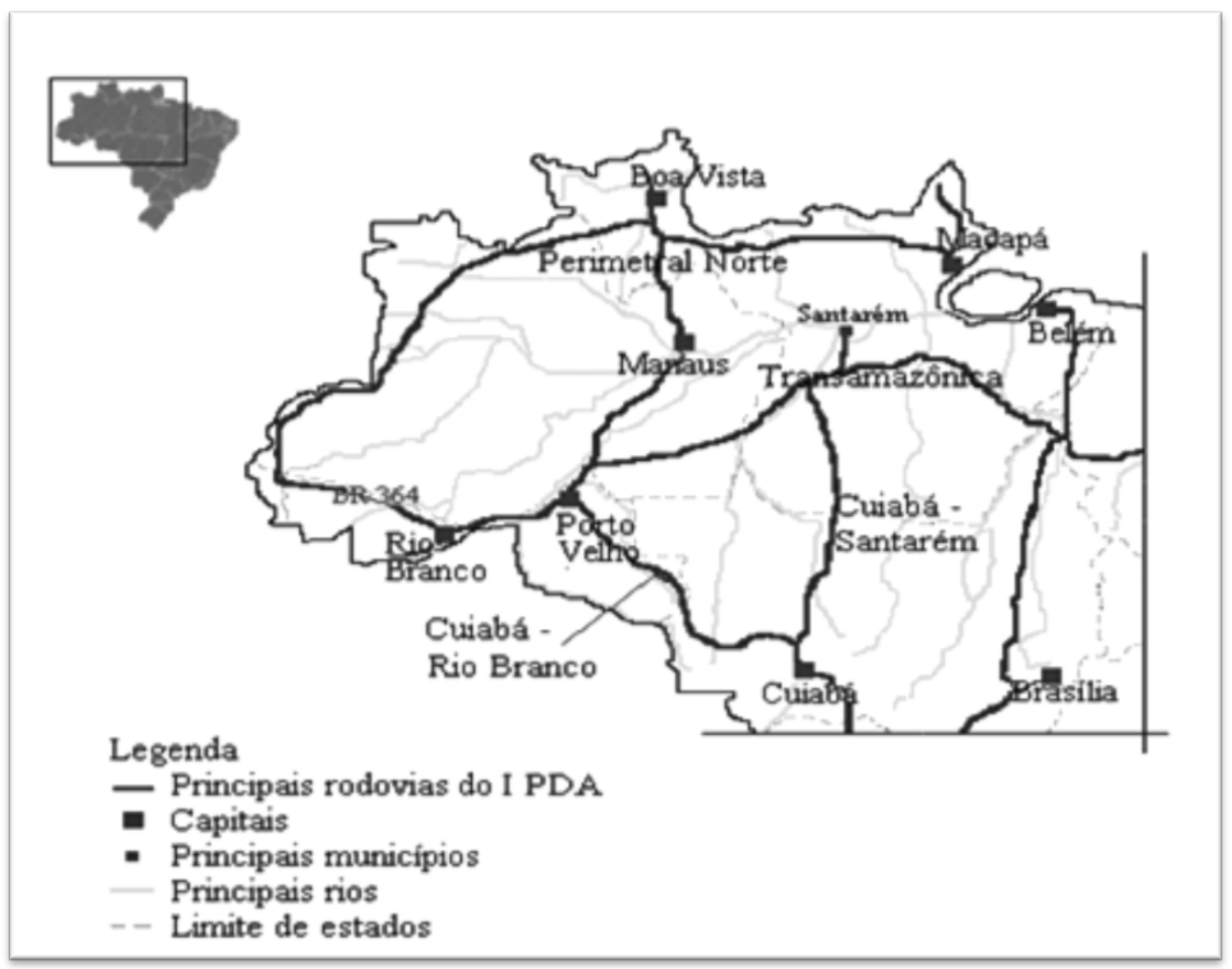

Fonte: Programa de Integração Nacional - PIN (1970)

Para dar conta do projeto foram engajados: o $2^{\circ}$ Grupamento de Engenharia com sede em Manaus (AM); o $6^{\circ}$ Batalhão de Engenharia de Construção, com sede em Boa Vista (RR); o $7^{\circ}$ Batalhão de Engenharia de Construção com sede em Rio Branco (AC); o $8^{\circ}$ Batalhão de Engenharia de Construção com sede em Santarém (PA); o $9^{\circ}$ Batalhão de Engenharia de Construção com sede em Cuiabá (MT); o $11^{\circ}$ Batalhão de Engenharia de Construção, com sede em Porto Velho (RO) e $05^{\circ}$ Batalhão de Engenharia de Construção do Rio de Janeiro (RJ), então cidade sede da Escola Superior de Guerra, que apoiou o projeto desde o início da década de 1970. 
Os batalhões de engenharia do exército assumiram as obras de abertura das estradas transversais, a BR-230 (Transamazônica); diagonais, a BR-364, que inicia em São Paulo, atravessa Minas Gerais, Goiás, Mato Grosso, Rondônia e segue pelo Acre até a fronteira com o Peru; radiais, BR-070 que começa em Brasília, passa por Goiás, Mato Grosso e acaba perto de Cáceres, na divisa com a Bolívia; longitudinais como é o caso das rodovias BR-174, que interliga Amazonas e Roraima à Venezuela, e a BR-163, que inicia no Rio Grande do Sul e, com 3.467 km, atravessa Santa Catariana, Paraná, Mato Grosso do Sul, Mato Grosso e termina em Santarém, no Pará.

No plano estratégico de construção da malha viária havia a intenção subliminar de fomento a novas urbanizações nas áreas de abrangência das rodovias nos Estados do Acre, Amapá, Amazonas, Mato Grosso, Rondônia, Roraima, ampliando assim o índice demográfico das regiões consideradas vulneráveis para a segurança nacional.

A nova conjuntura territorial já esboçava o mapeamento do que viria a ser conhecido como Amazônia Legal ocupando uma superfície de aproximadamente $5.217 .423 \mathrm{~km}^{2}$, correspondente a $61 \%$ do território brasileiro.

É importante anotar que a denominação Amazônia Legal não é recente. Em seu segundo mandato, o presidente Getúlio Vargas assinou a Lei no 1806 em 06.01.1953, que incorporou parte dos Estados do Maranhão, Goiás (atualmente Tocantins) e Mato Grosso como parte deste território e, para atender o crescente interesse na região, foi criada a SPVEA (Superintendência do Plano de Valorização Econômica da Amazônia). Este espaço, que passou a ser conhecido como Amazônia Legal, foi também alvo de atenção especial do governo para planejar e promover o seu desenvolvimento. Mais tarde, com a Lei 5.173, de 27.10.1966, Castelo Branco extinguiu a SPVEA e criou a SUDAM (Superintendência do Desenvolvimento da Amazônia) ${ }^{17}$. A partir daí o conceito de Amazônia Legal foi reelaborado para fins de planejamento e a área ficou como se pode ver no Figura 04, a seguir.

\footnotetext{
${ }^{17}$ A Lei Complementar no 124 institui, na forma do art. 43 da Constituição Federal, a SUDAM Superintendência do Desenvolvimento da Amazônia; estabelece sua composição, natureza jurídica, objetivos, área de competência e instrumentos de ação; dispõe sobre o Fundo de Desenvolvimento da Amazônia - FDA; altera a Medida Provisória nº 2.157-5, de 24 de agosto de 2001; revoga a Lei Complementar n 67, de 13 de junho de 1991.
} 


\section{Figura 04 - Estados que compõem a área da Amazônia Legal}

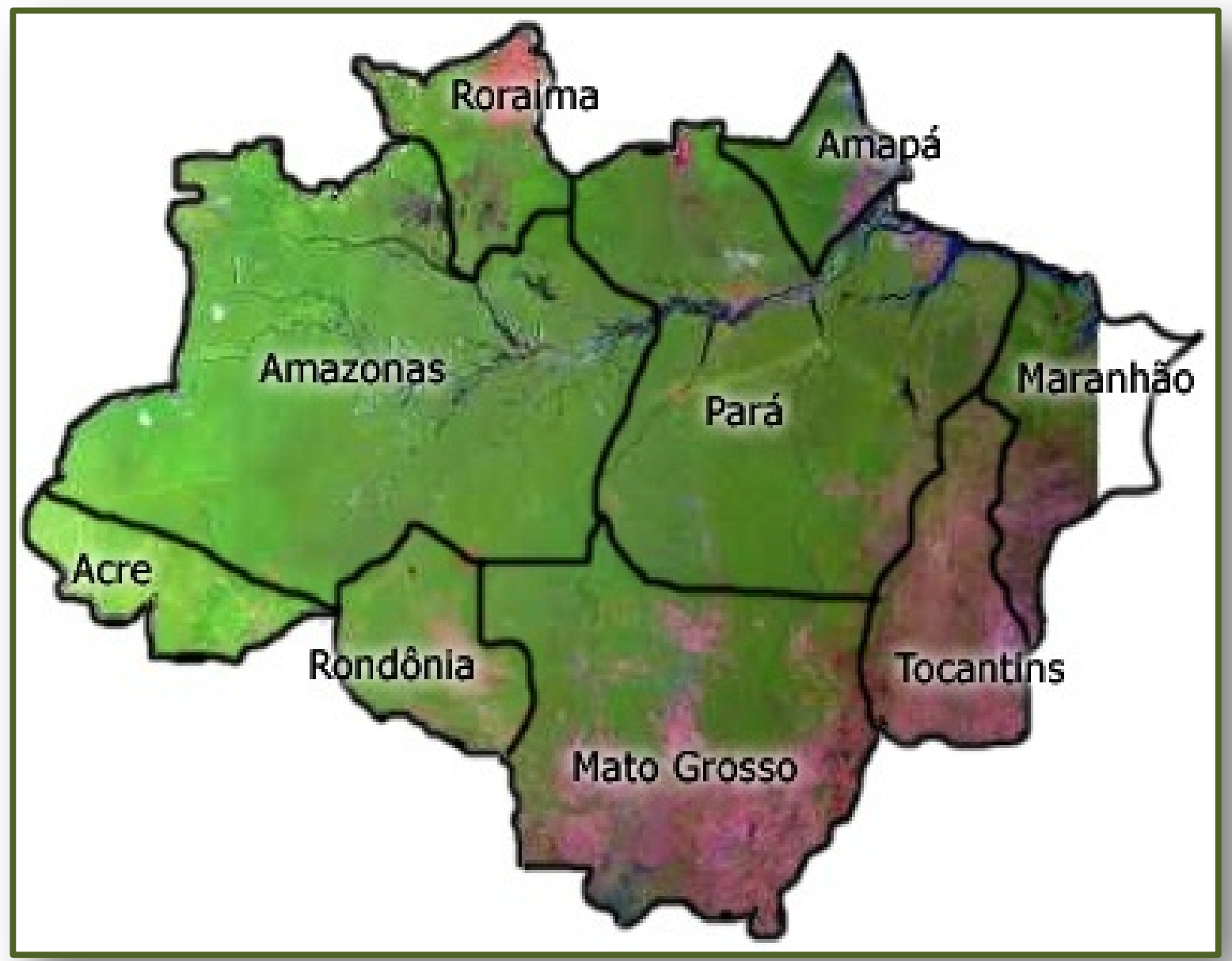

Fonte: Geobrainstorms - Criação: Murilo Cardoso (2005)

A Lei Complementar $n^{\circ}$ 31, de 11.10.1977, estendeu os limites da Amazônia Legal, criando o Estado de Mato Grosso do Sul, pelo desmembramento de área do Estado de Mato Grosso ${ }^{18}$. Em 2001, o presidente Fernando Henrique Cardoso extinguiu a SUDAM e, em 2003, Luis Inácio Lula da Silva a recriou.

\footnotetext{
${ }^{18}$ Nas formas da lei, foi criado pelo Art. $1^{\circ}$ o Estado de Mato Grosso do Sul pelo desmembramento de área do Estado de Mato Grosso; em seu Art. $2^{\circ}$, a área desmembrada para constituir o território de Mato Grosso do Sul, situa-se ao sul da seguinte linha demarcatória: das nascentes mais altas do rio Araguaia, na divisa entre os Estados de Goiás e Mato Grosso, segue, em linha reta, limitando os Municípios de Alto Araguaia, ao norte, e Coxim, ao sul, até às nascentes do córrego das Furnas; continua pelo córrego das Furnas abaixo, limitando, ainda, os Municípios de Alto Araguaia, ao norte, e Coxim, ao sul, até sua foz no rio Taquari; sobe o rio Taquari até a barra do rio do Peixe, seu afluente da margem esquerda, continuando por este até sua nascente mais alta, tendo os Municípios de Alto Araguaia, ao leste, e Pedro Gomes, ao oeste; segue daí, em linha reta, às nascentes do rio Correntes, coincidindo com a linha divisória dos Municípios de Alto Araguaia e Pedro Gomes; desce o rio Correntes até a sua confluência com o rio Piquiri, coincidindo com os limites dos Municípios de Itiquira, ao norte, e Pedro Gomes, ao sul, continua pelo rio Correntes, coincidindo com os limites dos Municípios de Itiquira, ao norte, e Corumbá, ao sul, até sua junção com o rio Itiquira; da junção do rio Correntes com o rio Itiquira, segue coincidente com a divisa dos Municípios de Barão de Melgaço, ao norte, e Corumbá, ao sul, até a foz do rio Itiquira no rio Cuiabá; da foz do rio Itiquira no rio Cuiabá
} 
Assim, o termo Amazônia Legal passou a ser usado efetivamente quando foi recriada a Superintendência de Desenvolvimento da Amazônia, como autarquia federal ratificada pela Lei Complementar $n^{\circ}$ 124, de 03 de setembro de 2007, em substituição à ADA (Agência de Desenvolvimento da Amazônia) que, por sua vez, havia extinguido a SUDAM em 2001. Vinculada ao Ministério da Integração Nacional, teve aprovada pelo Decreto no 6.218, de 04 de outubro de 2007, sua Estrutura Regimental, seu Quadro Demonstrativo dos Cargos em Comissão e suas Funções Gratificadas.

Com esse dispositivo, a Amazônia Brasileira passou a ser chamada de Amazônia Legal, fruto de um conceito político e não de um imperativo geográfico. A necessidade de o governo de planejar e promover o desenvolvimento da região o levou a ordenar nove Estados que, em termos físicos e administrativos representam: Acre, Amapá, Amazonas, Mato Grosso, Pará, Roraima, Rondônia, Tocantins e parte do Maranhão.

Conforme dados fornecidos pelo Instituto de Pesquisa Econômica Aplicada ${ }^{19}$, "a Região Amazônica foi definida, portanto, pela Lei, independentemente se sua área pertenceria ou não à bacia hidrográfica, se seu ecossistema seria de selva úmida tropical ou qualquer outro critério semelhante."

A distribuição dos Projetos Particulares de Colonização, entre 1970 e 1980, iniciou uma verdadeira corrida às áreas que estavam sendo demarcadas pelos governos federal e estadual, como resposta à ação que visava impulsionar o povoamento da Amazônia.

Se por um lado a Amazônia Legal ampliaria as fronteiras do agronegócio, por outro daria condições aos Estados incluídos no território amazônico de receber as concessões de crédito ou as tarifas bancárias especiais para a aquisição de terras devolutas distribuídas em nome do governo federal ou do próprio Estado.

\footnotetext{
segue por este até a sua foz no rio Paraguai, coincidindo com a divisa entre os Municípios de Poconé, ao norte, e Corumbá, ao sul; da confluência dos rios Cuiabá e Paraguai sobe pelo rio Paraguai até o sangradouro da Lagoa Uberaba, coincidindo com os limites dos Municípios de Poconé, ao leste, e Corumbá, ao oeste; da boca do sangradouro da lagoa Uberaba segue sangradouro acima até a lagoa Uberaba, continuando, por sua margem sul, até o marco Sul Uberaba, na divisa do Brasil com Bolívia, coincidindo com os limites dos Municípios de Cáceres, ao norte, e Corumbá, ao sul; em seu Art. $3^{\circ}$, fixa a Cidade de Campo Grande como Capital do Estado e, em seu artigo $4^{\circ}$ estabelece que a Assembleia Constituinte do Estado de Mato Grosso do Sul será eleita no dia 15 de novembro de 1978 e instalar-se-á no dia $1^{\circ}$ de janeiro de 1979, sob a presidência do Presidente do Tribunal Regional Eleitoral do Estado de Mato Grosso.

${ }^{19}$ Fontes: Instituto de Pesquisa Econômica Aplicada - http://wwww.ipea.gov.br; Superintendência de Desenvolvimento da Amazônia - http:/www.ada.gov.br
} 
Tudo estava programado pelo Ministério do Planejamento, responsável, na época, pela coordenação geral de todos os Programas de Governo em andamento, inclusive para a concessão de financiamentos com taxas e prazos especiais que, após a década de 1970, passaram a ser concedidos através da SUDECO (Superintendência de Desenvolvimento do Centro-Oeste) e da SUDAM (Superintendência de Desenvolvimento da Amazônia), BASA (Banco da Amazônia S.A.), BIRD (Banco Internacional para Reconstrução e Desenvolvimento) e Banco Mundial, principais vetores da ocupação do território e do novo fluxo migratório que, além das facilidades financeiras, cedia grandes extensões de terra às firmas colonizadoras.

Figura 05 - Mapeamento das áreas financiadas pela Sudam/Basa

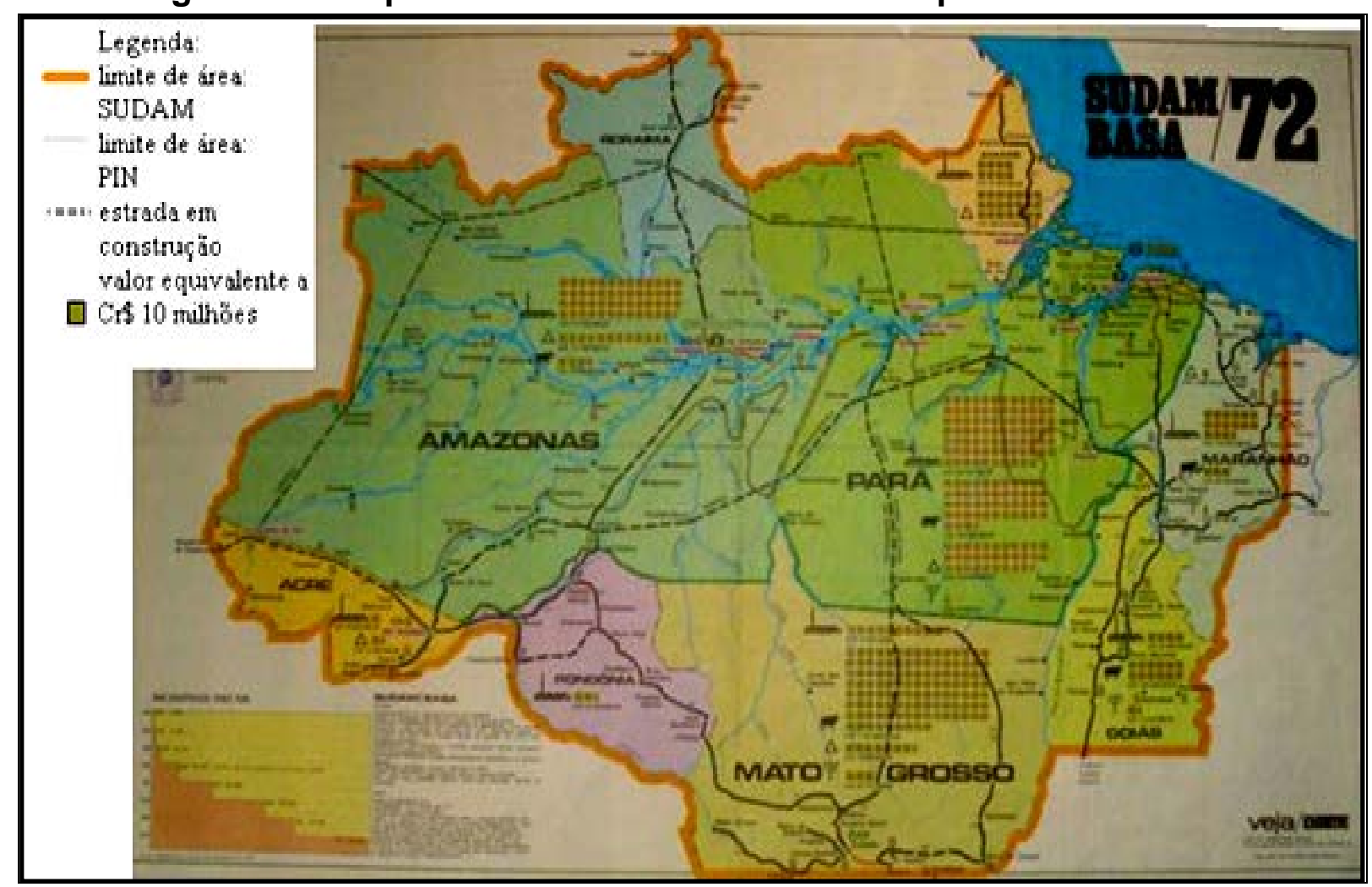

Fonte: Editora Abril. Departamento Cartográfico; Brazil. Superintendência do Desenvolvimento da Amazônia; Banco da Amazônia (1972)

A Figura 05 demonstra que interessava tanto ao poder público quanto à iniciativa privada, fortalecer a estrutura fundiária e criar as condições necessárias ao desenvolvimento do capitalismo no campo mato-grossense. Por isto "a expropriação de terras, indígenas ou as ocupadas por caboclos ou colonos, aconteceram, principalmente, no auge da fronteira econômica em toda a Amazônia Legal". (MORENO, 2007:276). 
Esta realidade também sofreu mutações com o decorrer do tempo, uma vez que os fatos fizeram valer a potencialidade econômica e política da fronteira, conforme o conceito proposto por Becker (1990):

A fronteira hoje não é sinônimo de terras devolutas, cuja apropriação econômica é franqueada a pioneiros e camponeses. É também um espaço social e político, que pode ser definido como um espaço não plenamente estruturado, potencialmente gerador de realidades novas. A fronteira é, pois, para a nação, símbolo e fato político de primeira grandeza, como espaço de projeção para o futuro, potencialmente alternativo. Para o capital, a fronteira tem valor como espaço onde é possível implantar rapidamente novas estruturas e como reserva mundial de energia. A potencialidade econômica e política da fronteira, por sua vez, torna-a uma região estratégica para o Estado, que se empenha em sua própria estruturação e controle. (BECKER, 1990:11).

O conhecimento estratégico citado por Becker logo foi percebido pelas grandes empresas que trataram de "ocupar" de qualquer forma os espaços considerados anecúmenos pelas autoridades interessadas em negociá-los a qualquer preço, desconsiderando as populações que desde muitos anos vivia ali, expulsando-os de suas terras ou simplesmente eliminando-os.

Os projetos federais que tratam do ordenamento do território da Amazônia Legal subentendem uma política pública aplicada ao bloco dos nove Estados, como se fossem partes de um mesmo território, com interesses comuns.

Talvez esteja aí o grande impasse dos estudos até então desenvolvidos para a Amazônia Legal: a forma como têm sido planejados e implantados. O academicismo tem propiciado um mergulho em águas de um charlatanismo inominável, graças às politicagens locais, a ponto de não permitir soluções práticas para os enormes problemas inerentes a cada Estado que compõe este bloco. O tratamento em bloco, sequer toca aqueles problemas considerados típicos de cada Estado e de suas idiossincrasias.

Aparentemente, o tratamento em bloco regional parece nunca ter dado muito certo. O próprio INCRA (Instituto Nacional de Colonização Reforma Agrária), já na década de 1960, com base na no 4.504, de 30 de novembro de 1964, havia criado diferentes modalidades de programas para atender os municípios. No território matogrossense, conforme a Figura 06, a seguir, os municípios envolvidos ficaram assim distribuídos: 
Figura 06 - Municípios envolvidos nos programas de colonização oficial nas modalidades PAR, PAC e PEA, de 1970 a 1980

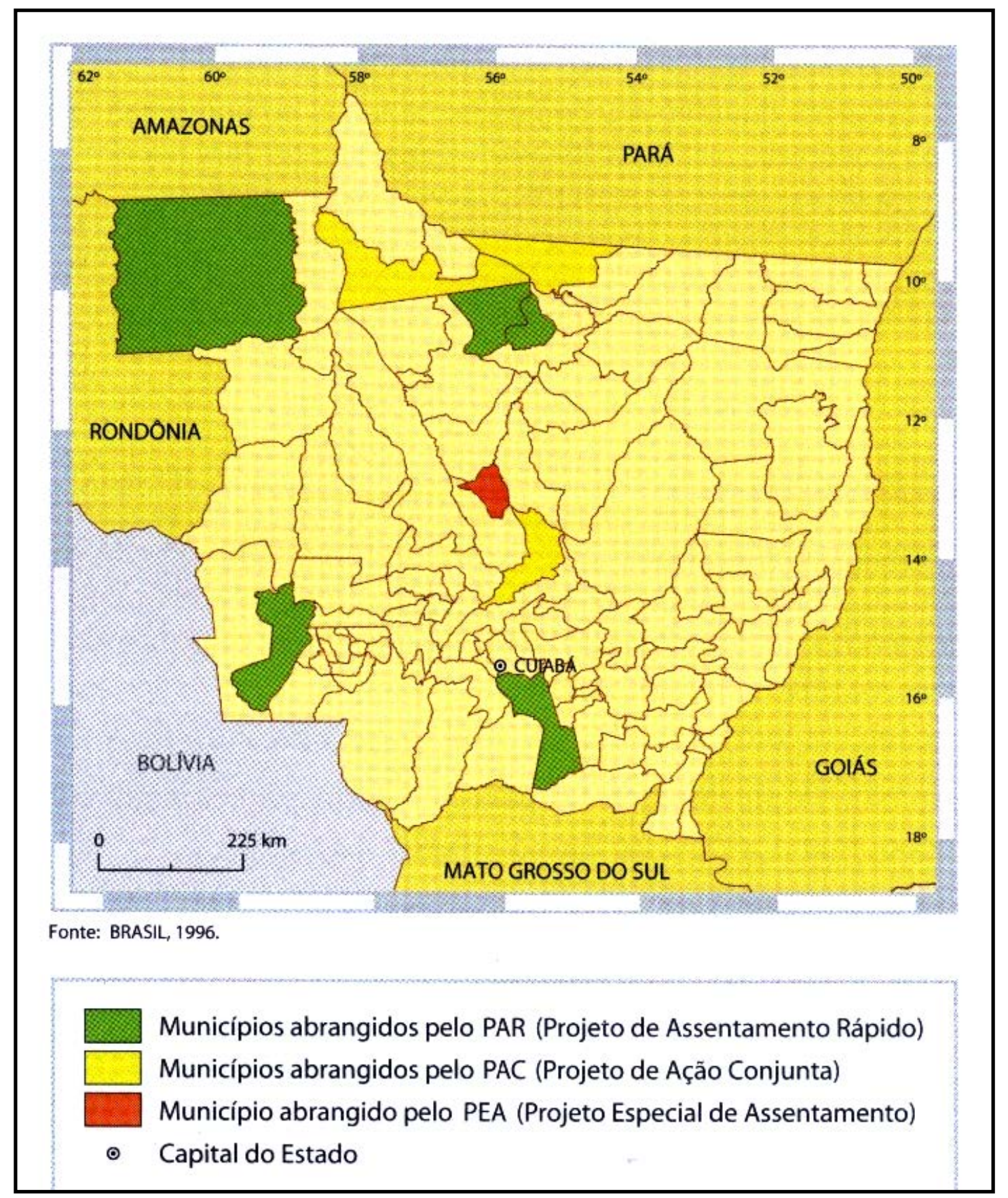

Fonte: Mato Grosso (1996)

Para o PAR (Projeto de Assentamento Rápido) a União criou e titulou terras, visando a regularização de glebas rurais sob seu domínio; embora visasse ainda o aporte de recursos basicamente referentes à demarcação topográfica, não ofereceu o aporte de recursos para implantação de infraestrutura básica.

O PAC (Projeto de Assentamento Conjunto) era direcionado à colonização oficial implantada pelo INCRA, em parceria previamente definida com empresas rurais de grande porte ou cooperativas. 
Já o PEA (Projeto Especial de Assentamento) possuía as mesmas características do PAD (Projeto de Assentamento Dirigido), porém com peculiaridades especiais que tornava prioritária a sua implantação.

A macro-organização espacial que vem sendo aplicada à Amazônia Legal parece manter "esquecida" a geopolítica interregional, assim como praticamente não valoriza o planejamento local para o desenvolvimento regional.

No caso da Amazônia Legal, fazendo uma analogia com o pensamento de Castells (2007), não houve sequer discussão sobre as formas como a sociedade iria se organizar nem como o processo histórico em que esse desenvolvimento das forças produtivas previamente projetadas ocorreria, porque o Estado atropelou o processo geral, em lugar de organizar as forças sociais dominantes.

A tecnologia avançou com seu processo de desenvolvimento e o Estado se retirou estrategicamente para, em conivência com as novas regras estabelecidas pelo mercado, usufruir das melhores oportunidades políticas e de negócios privados para seus representantes, enquanto as comunidades foram sendo acuadas por quem detinha o poder.

Não demorou muito para se instalar o desmando e a violência. E, conforme afirma Foweraker (1982:41), a violência é resultante do Estado capitalista autoritário, ou por ele consentida e advém da circunstância em que "esse Estado, dadas as suas bases sociais, é incapaz de medir as regras da burguesia através de mecanismos de consenso e consentimento."

De fato, a sofismável "incapacidade" do Estado acaba sendo promovida pela burguesia que não é hegemônica por ser economicamente dominante. No entanto, esta mesma burguesia, por temer "cair em desgraça" algum dia, tornando-se proletária, não consegue ser politicamente dirigente, no sentido de formar a sociedade à sua própria imagem, porque existe acima dela a sombra do Estado legitimador comandando o embate entre o mercado e a sociedade. Esta imagem é analisada por Santos (2009) quando diz que:

O território é a arena da oposição entre o mercado - que singulariza - com as técnicas da produção, a "geografia da produção" e a sociedade civil que generaliza - e desse modo envolve, sem distinção, todas as pessoas. Com a presente democracia de Mercado, o território e suporte de redes que transportam as verticalidades, isto é, regras e normas egoísticas e utilitárias (do ponto de vista dos atores hegemônicos), enquanto as horizontalidades levam em conta a totalidade dos atores e das ações. (SANTOS, 2009:259) 
O planejamento estratégico desenhado pela ditadura militar estaria perfeito, não fosse o tamanho original de Mato Grosso e a baixa densidade demográfica do Estado, notadamente ao norte, nas áreas mais próximas da Amazônia. O projeto Marcha para o Oeste, realizado durante o governo de Getúlio Vargas, já havia tentado a ocupação da região norte na década de 1940, incluindo Mato Grosso. Portanto, as autoridades federais sabiam das dificuldades que provavelmente acompanhariam as implantações de qualquer projeto no ambiente amazônico, pois muitos dos componentes que ocupavam altos cargos na ditadura militar haviam tomado parte, direta ou indiretamente, do governo getulista.

Para manter a ideia principal do projeto, evitando os pontos vulneráveis que poderiam provocar outro fracasso, seria necessário encurtar as distâncias, construir estradas e atrair a migração. Havia ainda outro ponto importante: o tamanho do Estado de Mato Grosso, que fazia fronteira com o Paraguai e a Bolívia.

Mesmo assim, nada impedia que o governo militar atendesse a antigas reivindicações mato-grossenses com interesses pontuais de divisão do Estado que já vinham sendo politizadas desde o fim do século XIX pelo Partido Autonomista ${ }^{20}$.

Em 1974, quando o governo federal estabeleceu a legislação básica para a criação de novos estados e territórios, a ideia divisionista de Mato Grosso retomou fôlego e, por decisão do presidente Ernesto Geisel e com o apoio do chefe da Casa Civil, General Golbery do Couto e Silva, se concretizou.

Sob o título de Lei Complementar no 31, veiculada no Diário Oficial em 11 de outubro de 1977, separava-se o território original em dois estados: Mato Grosso, com 38 municípios distribuídos numa área de 903.357,908 km², e Mato Grosso do Sul, com 55 municípios distribuídos numa área de $357.124,962 \mathrm{~km}^{2}$, conforme a Figura 07.

\footnotetext{
\begin{tabular}{c|c|}
\cline { 2 - 3 } & Figura 07 - Divisão-do_Estado-de Mato-Grosso(1977) \\
${ }^{20}$ O período compreendido entre 1935 e 1937 marcou uma fase singular na trajetória política. Com a
\end{tabular} aprovação pela Assembleia Nacional Constituinte de 1934, do projeto encaminhado pela bancada do Partido Aufonomista que previa a autonomia política e administrativa e apresentava um novo quadro político e institucional. Diferentemente da estrutura marcadamente interventiva em vigor pa Primeira República, com os poderes Executivo e Legislativo federais dispondo de diversos instrumentos de interferênc a sobre a dinâmica política local, as cidades passariam a ser administradas por um prefeito não mais nomeado pelo presidente da República e sim eleito, que governaria ao lado de um corpo legislativo municipal também livre das prerrogativas interventivas do Governo Federall. Em Mato Grosso o movimento foi deflagrado pelo fazendeiro e comerciante João Caetano Teixeira Muzzi (MS), que pregaya o divisionismo no sul, por intermédio do Partido Autonomista, em fins do século XIX.
} 


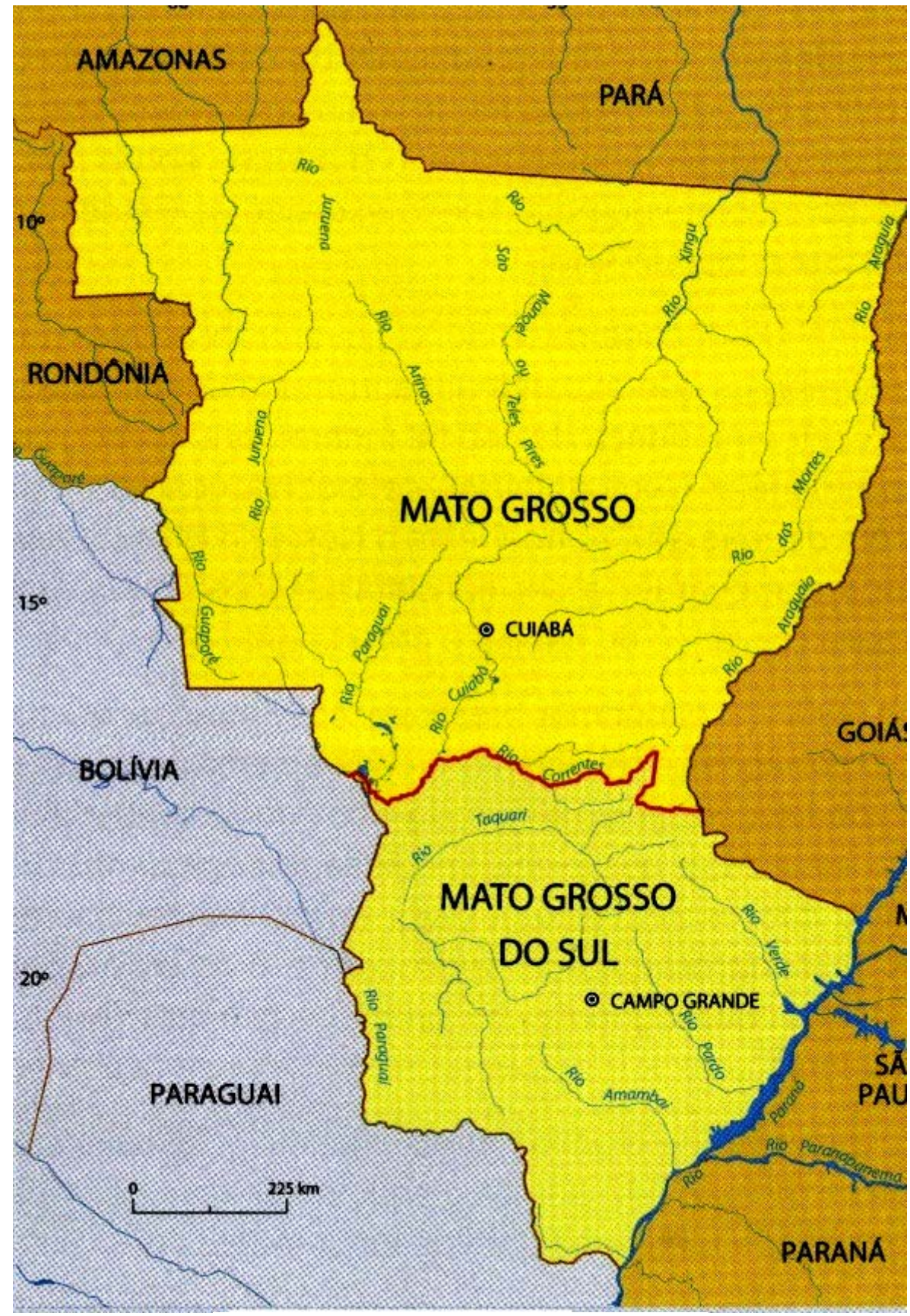

Área de Mato Grosso

Limite Mato Grosso/Mato Grosso do Sul

- Capital

Fonte: Adaptado sobre base cartográfica de 2000; in: Moreno, G. e Higa T.C.S (2005)

Mato Grosso ficou com mais território, porém com um número menor de municípios e com enormes áreas com baixa densidade demográfica, cujas distâncias entre si só seriam vencidas com a construção de uma extensa malha viária que daria sustentabilidade aos projetos de distribuição de terras, crescimento 
populacional, interiorização da economia e consequente urbanização do território. A interiorização, ao lado de outros fatores, sobretudo políticos, foi decisiva para as contínuas divisões territoriais.

Após a consolidação da divisão do Estado, que aconteceu em 1979, caberia então, a Frederico Campos, o primeiro governador pós-divisão, a difícil tarefa de organizar o espaço e atender a demanda dos programas de migração criados pelo governo federal.

\section{2 - A FORMAÇÃO DE NOVOS MUNICÍPIOS ${ }^{21}$}

A região Norte de Mato Grosso se desenvolveu conforme interesses pontuais e foi negociada, tanto em nível público quanto privado, através de sistemas duvidosos de permuta; isto leva a deduzir que havia grande probabilidade de prevalecer uma política especializada em utilizar a falta de planejamento e os desmandos arquitetados para tirar vantagens do "vácuo entre tessituras", como cita Raffestin (1993:s.n) ou mesmo para reforçar a contextura suportável que visava maximizar o controle e o poder do mandonismo local.

O que aqui se chamou de "vácuo entre tessituras", se espelha na distribuição de projetos particulares de colonização, conforme se vê na Figura 8, sob a tutela do INCRA, que passou a ter o domínio sobre $60 \%$ das terras devolutas existentes em Mato Grosso.

Com esta proposta atuou em projetos de assentamento que serviram de vetores do processo de distribuição de terras devolutas do Estado.

Ianni (1986) lembra que:

A colonização representou um processo de contra-reforma agrária, porque a "Amazônia é transformada em uma fronteira de desenvolvimento extensivo do capitalismo [...] [onde] o poder público é levado a desenvolver ou apoiar, projetos de colonização dirigida, oficial e particular, que implicam na prática em uma contra-reforma agrária. [...] Por exemplo, somente cerca de 10 por cento das terras demarcadas em 1977 couberam à colonização dirigida. Isto é, em um total de 627.038 hectares de terras, 65.600 destinaram-se à colonização e 561.438 aos projetos fundiários. Em toda Amazônia tem ocorrido uma acentuada concentração da propriedade fundiária. Se é verdade que alguma terra é distribuída a colonos, ou reservada a grupos indígenas, grande parte das terras da região já foi, ou está sendo, apropriada por grandes proprietários nacionais. (IANNI, 1986:83 e 86)

\footnotetext{
${ }^{21}$ As figuras apresentados neste capítulo apresentam a ordem de emancipação dos municípios entre 1979 e 2000. Os números constantes nas figuras correspondem à localização do município no território mato-grossense, conforme identificação subsequente.
} 
Como afirma lanni (1986), se é verdade que alguma terra é distribuída a colonos ou reservada a grupos indígenas, grande parte das terras da região já foi ou está sendo apropriada por grandes proprietários nacionais.

Figura 08 - Distribuição de Projetos Particulares de Colonização (1970-1980)

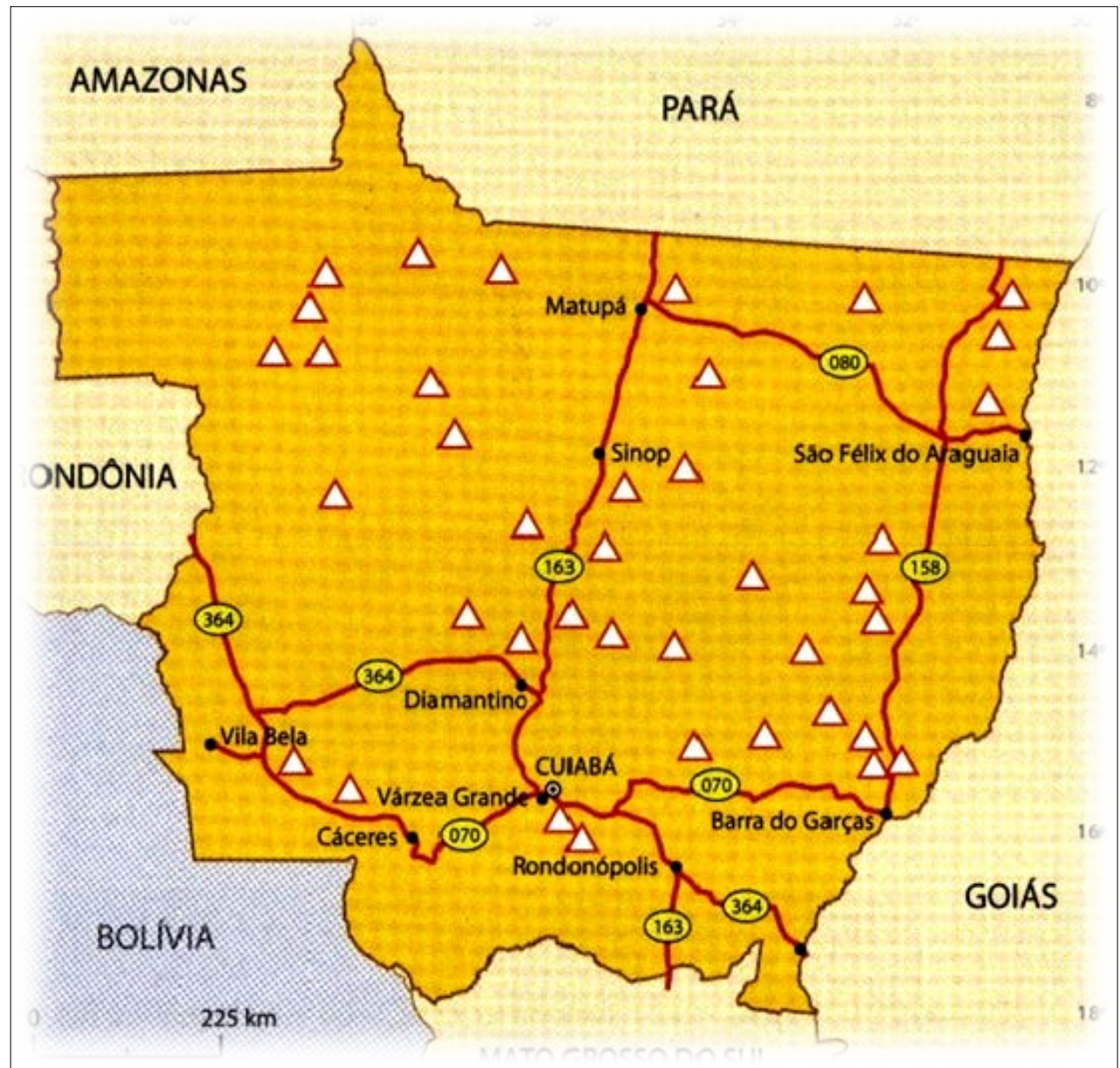

Fonte: Brasil, 1994; in: Moreno, G. e Higa, T.C.S (2005)

O que se verificou após a transformação do estado de Mato Grosso em dois estados foi a urgência em criar estruturas que dessem início à rápida ocupação das áreas distribuídas para projetos particulares de colonização entre as décadas de 1970 e 1980, como se vê na Figura 08.

Paralelamente, havia uma grande concentração de municípios num raio de 300 km da capital, área esta que precisava ser expandida para dar lugar aos projetos de assentamento idealizados pelo governo federal.

Figura 09 - Concentração de municípios ao redor da capital, Cuiabá - 1979 


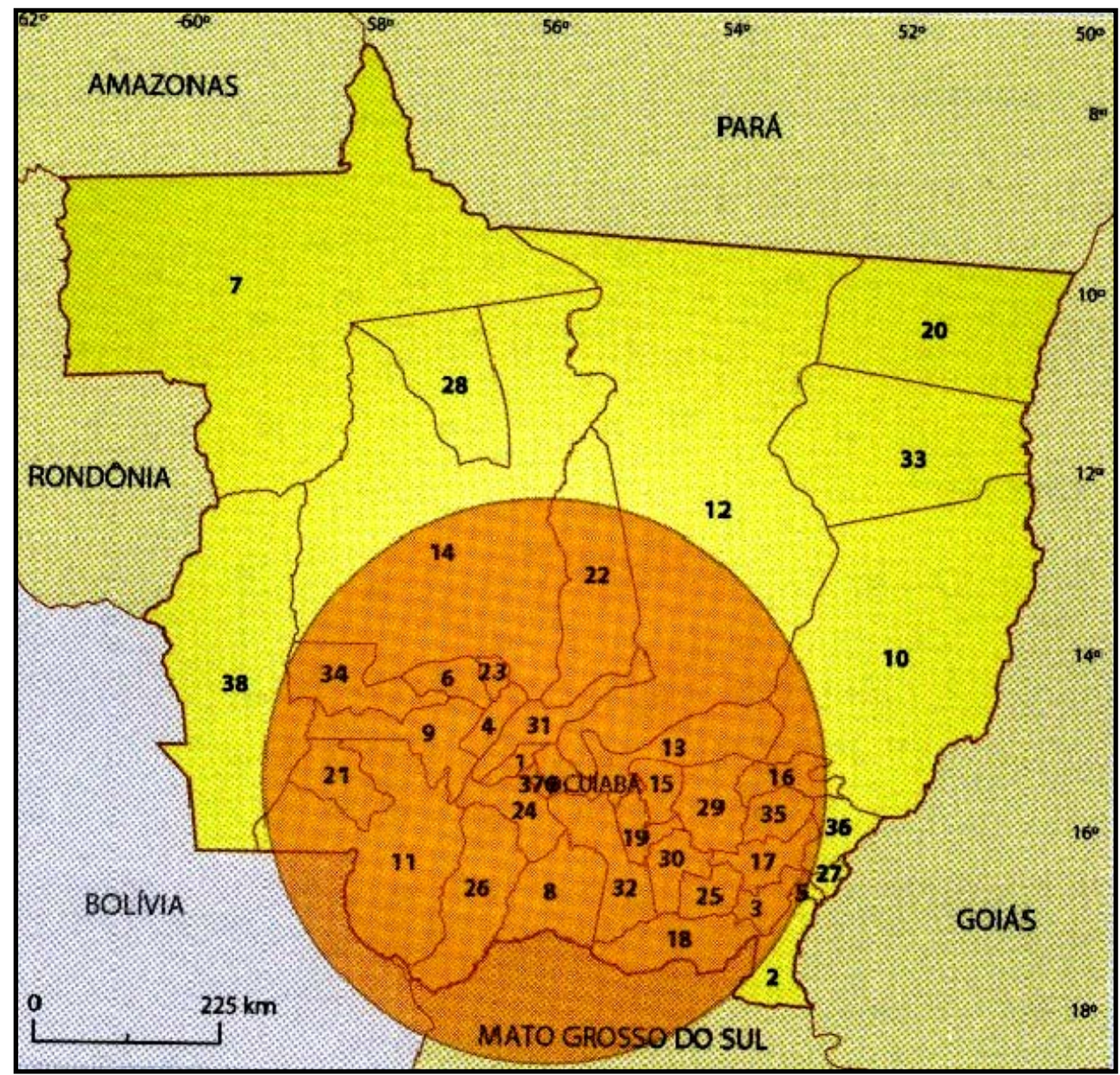

Fonte: Mato Grosso, 1980. In: Moreno, G. e Higa T.C.S. (2005)

Na Figura 09, o círculo representa o raio de $300 \mathrm{~km}$ a partir da capital, Cuiabá. Os municípios enumerados representam: Acorizal (1), Alto Araguaia (2), Alto Garças (3), Alto Paraguai (4), Araguainha (5), Arenápolis (6), Aripuanã (7), Barão de Melgaço (8), Barra do Bugres (9), Barra do Garças (10), Cáceres (11), Chapada dos Guimarães (12), Cuiabá (13, Diamantino (14), Dom Aquino (15), General Carneiro (16), Guiratinga (17), Itiquira (18), Jaciara (19), Luciara (20), Mirassol D'Oeste (21), Nobres (22), Nortelândia (23), Nossa Senhora do Livramento (24), Pedra Preta (25), Poconé (26), Ponte Branca (27), Porto dos Gaúchos (28), Poxoréo (29), Rondonópolis (30), Rosário Oeste (31), Santo Antonio de Leverger (32), São Felix do Araguaia (33), Tangará da Serra (34), Tesouro (35), Torixoréo (36), Várzea Grande (37), Vila Bela da Santíssima Trindade (38).

A partir dos 38 municípios existentes, praticamente todos concentrados ao redor da capital, Cuiabá, o governo do estado passou a emancipar vários distritos de municípios maiores. Chapada dos Guimarães, Diamantino e Nobres foram os 
municípios que mais se subdividiram para dar lugar às novas cidades que passariam a compor a área de abrangência da BR-163, de acordo com a Figura 10.

Figura 10 - Divisão dos municípios mato-grossenses em 1980

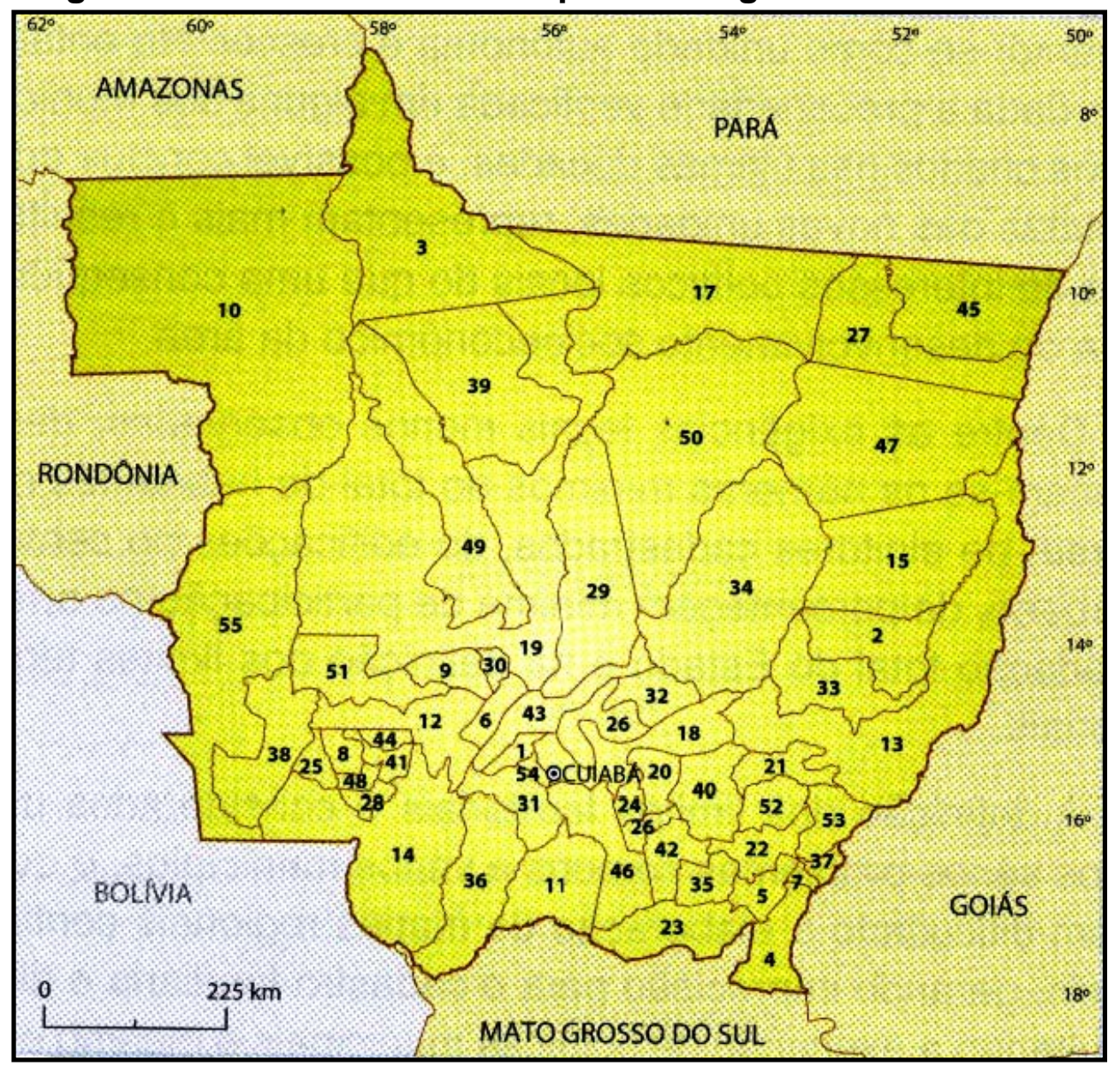

Fonte: Mato Grosso, 1980. In: Moreno, G. e Higa T.C.S. (2005)

Esta ação do governo do estado resultou na criação de mais 17 municípios, em 1980 e a distribuição, conforme a Figura 10, ficou assim: Acorizal (1), Água Boa (2), Alta Floresta (3), Alto Araguaia (4), Alto Garças (5), Alto Paraguai (6), Araguainha (7), Araputanga (8), Arenápolis (9), Aripuanã (10), Barão de Melgaço (11), Barra do Bugres (12), Barra do Garças (13), Cáceres (14), Canarana (15), Chapada dos Guimarães (16), Colíder (17), Cuiabá (18), Diamantino (19), Dom Aquino (20), General Carneiro (21), Guiratinga (22), Itiquira (23), Jaciara (24), Jauru (25), Juscimeira (26), Luciara (27), Mirassol D'Oeste (28), Nobres (29), Nortelândia (30), Nossa Senhora do Livramento (31), Nova Brasilândia (32), Nova Xavantina (33), Paranatinga (34), Pedra Preta (35), Poconé (36), Ponte Branca (37), Pontes e Lacerda (38), Porto dos Gaúchos (39), Poxoréo (40), Rio Branco (41), Rondonópolis (42), Rosário Oeste (43), Salto do Céu (44), Santa Terezinha (45), Santo Antonio de 
Leverger (46), São Felix do Araguaia (47), São José dos Quatro Marcos (48), São José do Rio Claro (49), Sinop (50), Tangará da Serra (51), Tesouro (52), Torixoréo (53), Várzea Grande (54), Vila Bela da Santíssima Trindade (55).

Figura 11 - Divisão dos municípios mato-grossenses em 1990

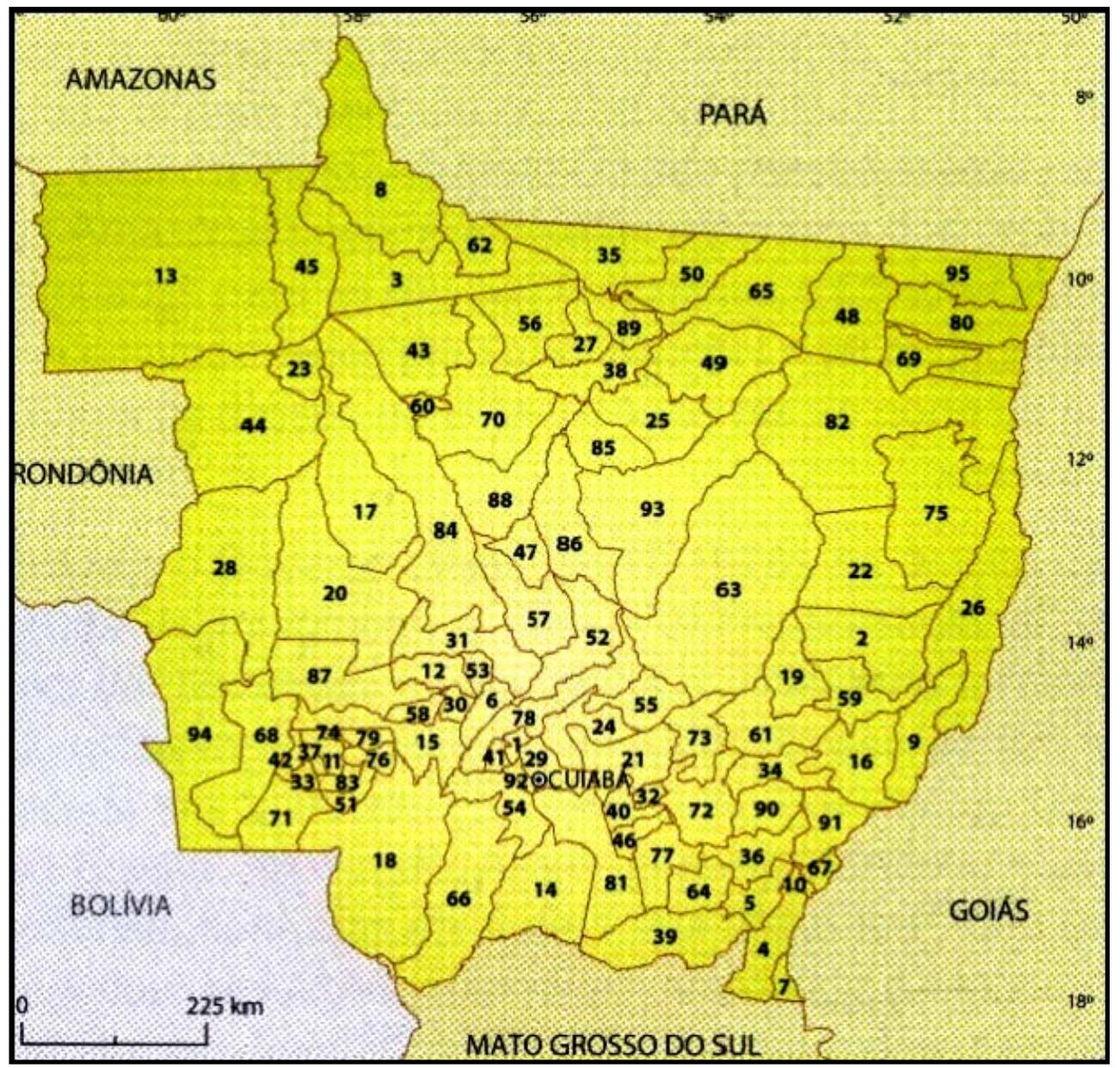

Fonte: Mato Grosso, 1990. In: Moreno, G. e Higa T.C.S., 2005

Os 55 municípios emancipados até 1980 aumentaram para 95, até 1990, conforme constam na Figura 11: Acorizal (1), Água Boa (2), Alta Floresta (3), Alto Araguaia (4), Alto Garças (5), Alto Paraguai (6), Alto Taquari (7), Apiacás (8), Araguaiana (9), Araguaianha (10), Araputanga (11), Arenápolis (12), Aripuanã (13), Barão de Melgaço (14), Barra do Bugres (15), Barra do Garças (16), Brasnorte (17), Cáceres (18), Campinápolis (19), Campo Novo do Parecis (20), Campo Verde (21), Canarana (22), Castanheira (23), Chapada dos Guimarães (24), Cláudia (25), Cocalinho (26), Colider (27), Comodoro (28), Cuiabá (29), Denise (30), Diamantino (31), Dom Aquino (32), Figueirópolis d'Oeste (33), General Carneiro (34), Guarantã do Norte (35), Guiratinga (36), Indiavaí (37), Itaúba (38), Itiquira (39), Jaciara (40), Jangada (41), Jauru (42), Juara (43), Juina (44), Juruena (45), Juscimeira (46), 
Lucas do Rio Verde (47), Luciara (48), Marcelândia (49), Matupá (50), Mirassol D'Oeste (51), Nobres (52), Nortelândia (53), Nossa Senhora do Livramento (54), Nova Brasilândia (55), Nova Canaã do Norte (56), Nova Mutum (57), Nova Olimpia (58), Nova Xavantina (59), Novo Horizonte do Norte (60), Novo São Joaquim (61), Paranaita (62), Paranatinga (63), Pedra Preta (64), Peixoto de Azevedo (65), Poconé (66), Ponte Branca (67), Pontes e Lacerda (68), Porto Alegre do Norte (69), Porto dos Gaúchos (70), Porto Esperidião (71), Poxoréo (72), Primavera do Leste (73), Reserva do Cabaçal (74), Ribeirão Cascalheira (75), Rio Branco (76), Rondonópolis (77), Rosário Oeste (78), Salto do Céu (79), Santa Terezinha (80), Santo Antonio de Leverger (81), São Felix do Araguaia (82), São José dos Quatro Marcos (83), São José do Rio Claro (84), Sinop (85), Sorriso (86), Tangará da Serra (87), Tapurah (88), Terra Nova do Norte (89), Tesouro (90), Torixoréo (91), Várzea Grande (92), Vera (93), Vila Bela da Santíssima Trindade (94), Vila Rica (95)

Uma década após a divisão do Estado, Mato Grosso contava com os 141 municípios que compõem o Estado até hoje, como se vê na Figura 12 a seguir: Acorizal (1), Água Boa (2), Alta Floresta (3), Alto Araguaia (4), Alto Boa Vista (5), Alto Garças (6), Alto Paraguai (7), Alto Taquari (8), Apiacás (9), Araguaiana (10), Araguainha (11) Araputanga (12), Arenápolis (13), Aripuanã (14), Barão de Melgaço (15), Barra do Bugres (16), Barra do Garças (17), Boa Esperança do Norte $(18)^{22}$, Bom Jesus do Araguaia (19), Brasnorte (20), Cáceres (21), Campinápolis (22), Campo Novo do Parecis (23), Campo Verde (24), Campos de Júlio (25), Canabrava do Norte (26), Canarana (27), Carlinda (28), Castanheira (29), Chapada dos Guimarães (30), Cláudia (31), Cocalinho (32), Colider (33), Colniza (34), Comodoro (35), Confresa (36), Conquista d'Oeste (37), Cotriguaçu (38), Cuiabá (39), Curvelândia (40), Denise (41), Diamantino (42), Dom Aquino (43), Feliz Natal (44), Figueirópolis d'Oeste (45), Gaúcha do Norte (46), General Carneiro (47), Gloria d'Oeste (48), Guarantã do Norte (49), Guiratinga (50), Indiavaí (51), Ipiranga do Norte (52), Itanhangá (53), Itaúba (54), Itiquira (55), Jaciara (56), Jangada (57), Jauru (58), Juara (59), Juina (60), Juruena (61), Juscimeira (62), Lambari d'Oeste (63), Lucas do Rio Verde (64), Luciara (65), Marcelândia (66), Matupá (67), Mirassol D'Oeste (68), Nobres (69),

\footnotetext{
${ }^{22}$ O distrito de Boa Esperança do Norte acabou não sendo emancipado conforme o planejamento do Governo do Estado, o que resultou num território dividido em 141 municípios e não em 142 como havia sido previsto.
} 
Figura 12 - Municípios mato-grossenses em 2000

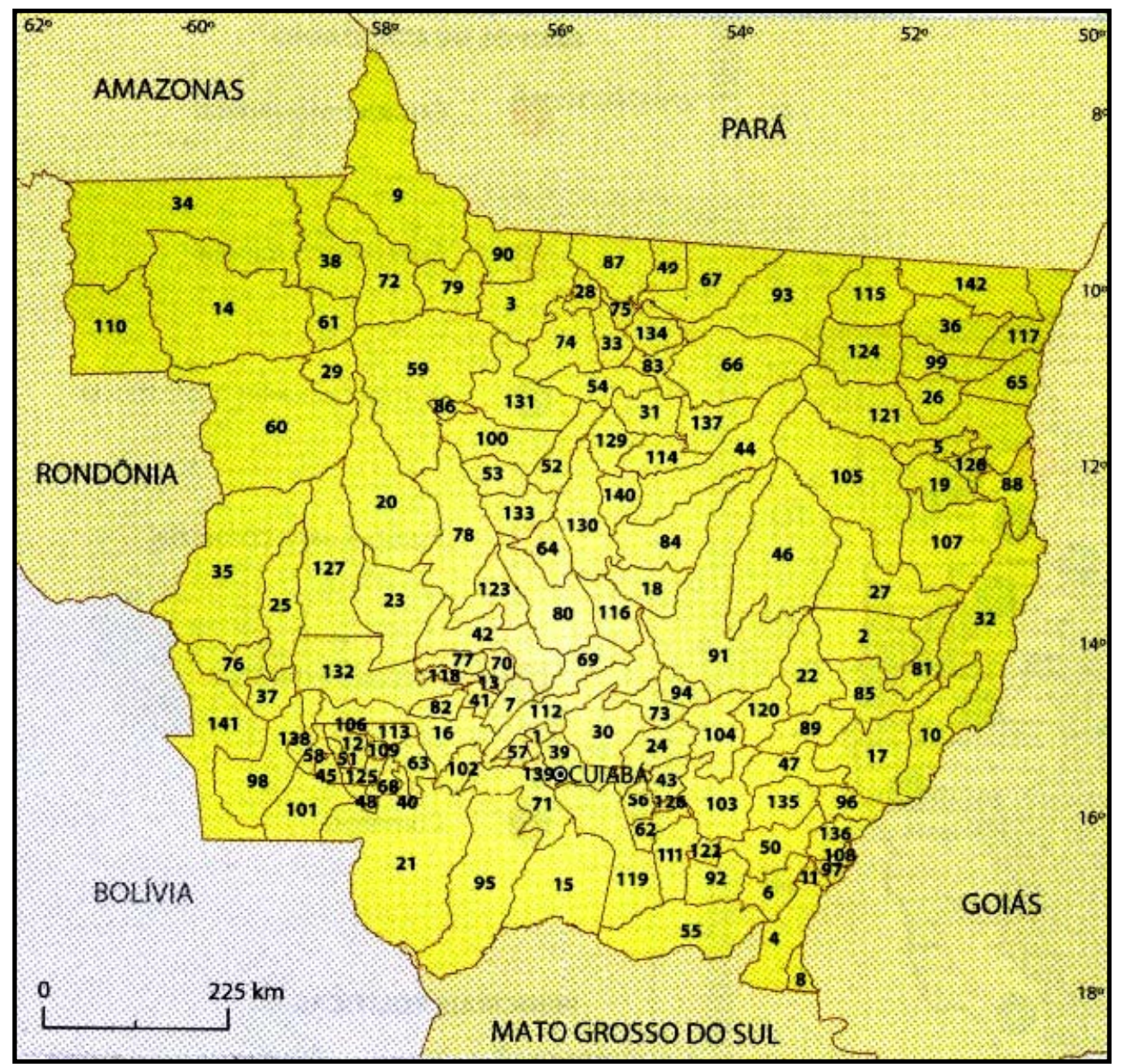

Fonte: Mato Grosso, 2000. In: Moreno, G. e Higa T.C.S., 2005

Nortelândia (70), Nossa Senhora do Livramento (71), Nova Bandeirantes (72), Nova Brasilândia (73), Nova Canaã do Norte (74), Nova Guarita (75), Nova Lacerda (76), Nova Marilândia (77), Nova Maringá (78), Nova Monte Verde (79), Nova Mutum (80), Nova Nazaré (81), Nova Olimpia (82), , Nova Santa Helena (83), Nova Ubiratã (84), Nova Xavantina (85), Novo Horizonte do Norte (86), Novo Mundo (87), Novo Santo Antonio (88), Novo São Joaquim (89), Paranaita (90), Paranatinga (91), Pedra Preta (92), Peixoto de Azevedo (93), Planalto da Serra (94), Poconé (95), Pontal do Araguaia (96), Ponte Branca (97), Pontes e Lacerda, (98), Porto Alegre do Norte (99), Porto dos Gaúchos (100), Porto Esperidião (101), Porto Estrela (102), Poxoréo (103), Primavera do Leste (104), Querência (105), Reserva do Cabaçal (106), Ribeirão Cascalheira (107), Ribeirãozinho (108), Rio Branco (109), Rondolândia (110), Rondonópolis (111), Rosário Oeste (112), Salto do Céu (113), Santa Carmem (114), Santa Cruz do Xingu (115), Santa Rita do Trivelato (116), Santa Terezinha (117), Santo Afonso (118), Santo Antonio de Leverger (119), Santo Antonio do Leste 
(120), São Felix do Araguaia (121), São José do Povo (122), São José do Rio Claro (123), São José do Xingu (124), São José dos Quatro Marcos (125), São Pedro da Cipa (126), Sapezal (127), Serra Nova Dourada (128), Sinop (129), Sorriso (130), Tabaporã (131), Tangará da Serra (132), Tapurah (133), Terra Nova do Norte (134), Tesouro (135), Torixoréo (136), União do Sul (137), Vale de São Domingos (138), Várzea Grande (139), Vera (140), Vila Bela da Santíssima Trindade (141), Vila Rica (142).

\section{3 - NORTE MATO-GROSSENSE: DIACRONIA SÓCIO POLÍTICA}

Mato Grosso é o terceiro Estado brasileiro em dimensão territorial e está na região Centro-Oeste do país. O marco do centro geodésico da América do Sul situase em Cuiabá.

Sua expansão gradativa, até a configuração atual, é resultado da interiorização realizada por exploradores portugueses em busca de produtos para atender o comércio nos séculos XVI, XVII e XVIII.

Entre 1831 e 1840, os presidentes das províncias brasileiras eram nomeados pelas Regências que escolhiam seus representantes entre os membros das elites; fazendeiros, comerciantes e todos os que, de alguma forma, detinham poder político. Em Mato Grosso, não foi diferente. Desde a distribuição seletiva das mercadorias que eram trazidas do Rio de Janeiro para abastecer a região, até a escolha dos 20 deputados para a Assembleia Legislativa de Mato Grosso, que iniciou seus trabalhos em 1835, tudo era controlado por uma elite que também detinha o direito de constituir ou desconstituir representantes e lideranças para exercer a supremacia no poder.

O extrativismo de mate, poaia, látex e cana de açúcar estenderam a hegemonia desta elite, até então mais concentrada em Cuiabá, para o interior do Estado e, com ela, configurou-se uma casta de poder que passou a manipular a política e a distribuição de terras. (ASTRO; BARROZO; COVEZZI; PRETI, 2005)

Conforme Moreno (2007), até a primeira metade do século XX, a terra e o poder nas mãos das oligarquias provocaram uma luta entre as elites, em função da disputa pela hegemonia do poder regional. 
A disputa pela hegemonia do poder regional se revelou, mais tarde, na ideologia separatista, que se firmou no ordenamento diferenciado das forças produtivas do sul em relação ao norte. Os confrontos entre as elites foram inevitáveis, e a violência física e econômica foi a tônica que marcou a prática personalista da política local. Através da política dos governadores, os grupos aliados dominaram o sistema de compromissos característico do período que antecedeu o Estado Novo. A força dos partidos dominantes ainda provinha dos coronéis que comandavam toda a vida econômica e política do Estado. Não raro, os interesses oligárquicos sobrepunham-se às questões partidárias, provocando crises internas e novas acomodações nas composições dos partidos. (MORENO, 2007:56).

Estas acomodações, como cita Moreno, acabavam mudando as políticas públicas e os grupos faziam questão de demonstrar suas forças políticas demarcando ou ampliando seus espaços de domínio.

Nessa época, imperou a prática do "voto de cabresto", pela influência decisiva dos coronéis no processo eleitoral, que através de eficientes "máquinas eleitorais" invariavelmente garantiam a vitória dos candidatos governistas. (MORENO, 2007:56).

Estas práticas, tanto quanto se pôde verificar, se arrastam através da história; já no século XIX houve a ação concreta de coronéis com relação à apropriação de terras devolutas. Osório (2008) ilustra bem a questão do coronelismo, ao relatar a situação do número total de posses em Mato Grosso, em $1897^{23}$.

Ali ficou latente "a incapacidade dos poderes públicos para intervir nas questões de terras" conforme informações do Governador ${ }^{24}$ Antônio Corrêa da Costa. (OSORIO, 2008:291). Desde esta época "as pendências entre particulares eram resolvidas pelos próprios interessados e, naturalmente, vencia o mais forte". (op.cit).

As vitórias políticas conseguiam manter os interesses oligárquicos e a hegemonia do poder político, esta devidamente preservada pelo escambo de

\footnotetext{
${ }^{23}$ No número total de posses registradas no estado era de 3.023 , sendo 1.333 anteriores a 1854 e 1.393 anteriores a 1889, as duas datas-limite para a validade das posses. Outras 297 posses não precisavam a data de ocupação. Das 3.023 posses, apenas 452 haviam sido medidas e demarcadas. As demais ainda não haviam dado entrada, na repartição de terras, a seus processos de medição. Das 3.023 posses registradas, somente 1.941 tinham declarado a superfície ocupada, que perfazia um total de 13.753.011 ha. As restantes 1.082 posses sem superfície declarada, sendo quase todas anteriores a 1854, calculava-se que deveriam ter em média 13.068 ha, o que daria no total uma área de 14.139.576 ha. O total das posses registradas, supondo-se que fossem exatos os dados apresentados no registro, ocupava uma área de aproximadamente 27.892.687 ha. Para fazer uma ideia da área total ocupada pelos particulares no estado seria preciso adicionar a esse subtotal a superfície ocupada pelas propriedades cujos ocupantes possuíam títulos legítimos, mas isso não era possível porque o governo estadual não possuía esta informação. (OSORIO, 2008).

${ }^{24}$ Ligia Osório usou o termo "governador", em vez do título de presidente, tendo em vista que ambos aparecem nos documentos da época e o primeiro se presta a menos confusão. (Fonte: Informação da autora)
} 
nomeações para cargos públicos com privilégios para demover encravos nas questões de terras devolutas ou públicas. Portanto, desde muito antes do século XX, o governo federal vem tentando criar uma legislação que consiga apaziguar estas crises internas e confrontos entre as elites e forças dominantes.

De certa forma, a política local estava pautada no consenso histórico nacional, uma vez que as questões de terras no Brasil sempre privilegiaram as classes dominantes e/ou politicamente bem posicionadas nos poderes instituídos. Cavalcante e Costa (1999:129-130) se referem ao consenso histórico quando citam que "isto ficou mais patente com a criação da Lei das Terras ${ }^{25}$ (1850) que privilegiou quem tinha poder econômico, quem pudesse adquirir a terra através da compra e do registro em cartório".

Diante a invasão de pau rodado ${ }^{26}$, a burguesia mato-grossense, amedrontada com a possibilidade da perda de espaço para politicagem, escolheu se proteger sob siglas de partidos políticos para continuar mantendo o mandonismo sobre as parcas políticas públicas fomentadas pelo governo federal que, no fundo, pretendiam apenas solucionar problemas de reforma agrária nos Estados do sul e distribuir terras entre seus pares a título de negociação de poder.

Assim, os fluxos migratórios destinados à Amazônia Legal, tanto aqueles patrocinados pelo poder público quanto os coordenados por colonizadoras particulares, representavam, para esta burguesia, um processo de expansão da fronteira capitalista do qual poderiam participar, à distância, para auferir ganhos de capital.

Ao analisar a forma como foi organizada a distribuição de terras em Mato Grosso verifica-se que, além de muitas promessas não terem sido cumpridas, ainda houve uma forte influência do estruturalismo mecanicista, cuja diretriz pautou várias ações do regime militar nos seus projetos de migração para a Amazônia Legal, tratando-as como "estruturas estruturadas sem sujeito estruturante". (BOURDIEU, 1996:55).

\footnotetext{
${ }^{25}$ A Lei $n^{0} 601$, de 18 de setembro de 1850 , dispõe sobre as terras devolutas no Império, e acerca das que são possuídas por titulo de sesmaria sem preenchimento das condições legais, bem como por simples titulo de posse mansa e pacifica; e determina que, medidas e demarcadas as primeiras, sejam elas cedidas a titulo oneroso, assim para empresas particulares, como para o estabelecimento de colonias de nacionaes e de extrangeiros, autorizado o Governo a promover a colonisação extrangeira na forma que se declara D. Pedro II, por Graça de Deus e Unanime Acclamação dos Povos, Imperador Constitucional e Defensor Perpetuo do Brasil. (Fonte: www.planalto.gov.br/ccivil).

${ }^{26}$ Alcunha dada aos que vêm de fora e procuram fixar residência (MICHAELIS, 1998).
} 
Esta visão do poder público deu margem a uma série de erros básicos na colonização da Amazônia Legal, principalmente nas áreas que se transformariam em cidades ao longo da BR-163, fração do território amazônico profundamente alterada e amplamente reordenada. A floresta, o Cerrado, a terra, a população autóctone, todo o território acabou sendo seriamente afetado por outros motivos que acabaram sendo mais fortes e deixaram, ao longo de sua curta história, vestígios da falibilidade do espírito humano.

Quando sabemos o que é moralmente correto fazer, até sabemos que não há nenhuma boa razão - epistêmica - para agir de outra maneira. Isso não impede, porém, que outros motivos acabem sendo mais fortes. [...] No sentido validativo das normas morais, ficam vestígios tanto da falibilidade do espírito humano que descobre, quanto da construtividade do espírito humano que projeta. (HABERMAS, 2007: 50 e 51).

Dentre outros motivos, havia os fatores de sobrevivência que acabaram sendo mais fortes e que, epistemicamente, sugeriram boas razões para agir indo de encontro à própria sustentabilidade, que deu origem ao reordenamento do território paralelo ao desflorestamento voraz.

Além da distribuição de terras e consequente "abertura" de fazendas, houve o deslocamento de comunidades indígenas, como é o caso dos índios Panará ${ }^{27}$ que foram levados para o Xingu, onde deveriam conviver com outras etnias culturalmente distintas e até mesmo hostis.

Houve ainda a expulsão dos $\operatorname{caboclos}^{28}$ de seu habitat, promovida por jagunços por ordem de fazendeiros que, na maioria das vezes, usavam truculência para invadir suas terras.

As desavenças, as demandas por uma legislação mais rigorosa que contemplasse os menos favorecidos dentre as comunidades autóctones, teriam evitado muita desordem sociocultural em todo este espaço, pois, como cita Zart (1998:87), "os excluídos não são uma simples massa, mas configuram-se como um

\footnotetext{
${ }^{27}$ Os Panará, também conhecidos como Krenakore, foram oficialmente contatados em 1973, quando a estrada Cuiabá-Santarém estava em construção e cortava seu território tradicional na região do Rio Peixoto Azevedo. A violência do contato ocasionou a morte de $2 / 3$ de sua população, em razão de doenças e massacres. À beira do extermínio, em 1975 foram transferidos pela Funai (Fundação Nacional do Indio) para o Parque indígena do Xingú. Depois de 20 anos exilados, os Panará reconquistaram o que ainda havia de preservado em seu antigo território, onde construíram uma nova aldeia. Além dessa vitória, alcançaram um feito inédito na história dos povos indígenas e do indigenismo brasileiro, quando em 2000 ganharam nos tribunais, contra a União e a Funai, uma ação indenizatória pelos danos materiais e morais causados pelo contato. Tal vitória, se não lhes apaga as tristes marcas de sua história, projetam-Ihes para um futuro mais digno. (ISA Instituto Socioambiental pib@socioambiental.org. Acessado em 14.03.2012).

${ }_{28}$ Indígena brasileiro de cor acobreada. (Fonte: MICHAELIS, 1998)
} 
conjunto de indivíduos que vão se tornando sujeitos da história, influindo em políticas do Estado e do mercado."

Os sistemas e normas adotados pelos poderes constituídos acabaram transformando estas terras e as pessoas que viviam nelas, em moeda de troca, sem o menor escrúpulo. A negociação indiscriminada trouxe muitos desmantelos para a ordem estabelecida para os colonos; abandonados, estavam à mercê da natureza e das doenças, além de precisarem conviver com o medo ante aos despropósitos dos representantes dos órgãos federais que, teoricamente, estava ali para defendê-los. Como cita Castells (2007:41), "cada vez mais, as pessoas organizam seu significado não em torno do que fazem, mas com base no que elas são ou acreditam que são."

Embora houvesse objetivos federais e estaduais colimados às políticas de colonização idealizadas para contribuir com os pequenos produtores rurais, visando a agricultura familiar, gênese da reforma agrária, tanto o INCRA, órgão federal, quanto o DTC, órgão estadual, passaram a dar muito mais atenção aos descaminhos da lei e da ordem, às ações ardilosas como as montagens de croquis que serviam de base para os cadastros de área elaborados em gabinete, ou mesmo a montagem de plantas cadastrais ${ }^{29}$.

As fraudes eram tantas, que deram origem ao que, mais tarde, ficou conhecido como beliches fundiários ${ }^{30}$.

\footnotetext{
${ }^{29}$ As plantas cadastrais eram montadas exclusivamente com base nas informações dos engenheiros agrimensores. Estes, por sua vez, delegavam a execução dos trabalhos de campo a propostos, alguns com conhecimento prático, mas sem nenhum domínio técnico. Depois faziam a montagem dos croquis, que serviam de base para a elaboração "de gabinete" do cadastro da área, pela Secção Técnica. Além do problema cadastral, o Estado sofria com a falta da determinação exata das suas fronteiras com as outras unidades da federação, ocasionando sérios problemas na localização das concessões de terras. Os municípios também careciam de Cartas Geográficas precisas. Tudo isso contribuía para o surgimento de conflitos de jurisdições no momento das plotações (locações de agrimensura) das áreas vendidas. Embora solucionadas mais tarde as questões de fronteira, o Estado chegou à década de 1980 sem ter segurança nas informações cadastrais do seu patrimônio fundiário, dando margem à especulação de toda ordem. Tanto que os proprietários de "Títulos Voadores", isto é, montados sem precisão exata da localização do imóvel, podiam reclamar "suas terras" e terem-nas localizadas onde mais conveniente fosse. [...] A absoluta falta de controle do processo de regularização das terras estaduais serviu ao complicado jogo de interesses, onde objetivos econômicos e partidários comandavam a desenfreada privatização de terras públicas, e as fraudes ocorriam quase sempre com a conivência de funcionários do órgão. [...] $O$ volume de irregularidades e de corrupção atingia níveis extraordinários, tornando a situação insustentável. A determinação do governador Pedro Pedrossian em acabar com as negociatas indiscriminadas de terras e, por fim, às "conveniências da política particularista" no processo de acesso à terra materializou-se no fechamento do DTC. Desta vez por 12 longos anos. (MORENO, 2007:134-135).

30 A expressão "beliches fundiários", utilizada entre os funcionários do antigo DTC, apareceu referenciada pela primeira vez em trabalho acadêmico, na dissertação de mestrado de João Mariano de Oliveira (1983:56); enquanto "terra de dois ou três andares" aparece citada no trabalho de Joe Foweraker (1982:153).
} 
É sabido que "a economia de permanência deveria estar afirmada na perenidade dos recursos, isto é, na habilidade de transformar os elementos do meio ambiente em recursos sem destruir o capital da natureza" (SACHS, 2008: 69-70). Mas, não foi isto que aconteceu nessa parte do território mato-grossense, onde praticamente todas as normas eram burladas com a anuência dos representantes dos órgãos públicos federais e estaduais, cujas representações nos municípios recém-criados obedeciam, principalmente, aos que detinham o poder econômico ou político.

De acordo com Moreno (2007),

Para burlar a constituição no tamanho das áreas, recorriam a um "procurador" que obtinha as procurações de diversas pessoas, para requererem em nome de terceiros os títulos de propriedade das terras devolutas "já ocupadas". Dos órgãos oficiais conseguiam declarações sobre a inexistência de índios ou de posseiros nas terras pleiteadas. (MORENO, 2007:164).

A autora (2007) ainda utiliza uma citação de Oliveira (1987) onde se lê:

Ao INCRA competia apenas sacramentar a ocupação, ou melhor, legalizar a grilagem titulando as terras onde normalmente eram desenvolvidos projetos agropecuários incentivados pelo governo. O mesmo procedimento foi largamente utilizado por diversos governos estaduais na regularização de terras devolutas sob a jurisdição de Mato Grosso, na década de 80 . (MORENO, 2007:164; apud OLIVEIRA, 1987:83-84).

As legalizações ilegais aceleraram o desmatamento do território considerado como Amazônia Legal e também deslocaram mais para norte/nordeste, as fronteiras agrícolas de Mato Grosso, principalmente na área de abrangência da BR-163.

Conforme o Decreto $\mathrm{n}^{0} 1.318$ (Brasil, 1854) ${ }^{31}$ e em conformidade com a Constituição Federal, as terras devolutas eram consideradas inalienáveis, quando reservadas aos indígenas ou julgadas indispensáveis à defesa das fronteiras, fortificações, construções militares e estradas de ferro federais.

Entretanto, nem o Decreto nem a Constituição Federal foram considerados, uma vez que "a articulação entre o poder político local/nacional e o poder econômico permitiu a transformação das terras devolutas sob a jurisdição do Estado em propriedades privadas capitalistas." (MORENO, 2007:275).

\footnotetext{
${ }^{31}$ O Decreto $\mathrm{n}^{\circ} 1.318$, de 30 de janeiro de 1854 , manda executar a Lei $\mathrm{n}^{\circ} 601$, de 18 de Setembro de 1850, que dispõe sobre as terras devolutas no Império, e acerca das que são possuídas por titulo de sesmaria sem preenchimento das condições legais.
} 
Aparentemente predominou o Estado forte e uma cidadania controlada "na sola da bota", como acontece no Brasil agrário desde a independência. Talvez por isto mesmo não tenha havido nenhuma reação do poder público para estancar o terror que se espalhou naquela região, patrocinado tanto pelos funcionários locais de órgãos públicos, quanto por interessados em terras.

A diferença entre o fluxo migratório mato-grossense das décadas de 1970 a 1990 e o que aconteceu entre as décadas de 1940 e 1960 está no fato dos agricultores desta "segunda leva" de imigrantes, não ter esperado o apoio prometido pelo poder público. Eles se equiparam para criar uma agricultura destinada à produção em grande escala que, em pouco tempo, se transformou em tecnologia de ponta do agronegócio.

O preço desta escolha foi conviver em constante disputa com comunidades indígenas e caboclas, porque os projetos de colonização, tanto públicos quanto privados, se apoiaram na ideia de uma região anecúmena, pronta para ser explorada com o apoio do poder público.

Para Joanoni Neto (2007),

O Brasil é, do ponto de vista do estudo das migrações, um imenso organismo vivo com deslocamentos frequentes e multidirecionados. Há um fluxo que denominaremos alternativo, pois escapa à influência mais direta do Estado, e um fluxo direcionado pelos poderes estabelecidos. Nenhum deles pode ser classificado como espontâneo e ambos são resultados das ações do Estado para driblar as pressões sociais e econômicas, que em dado momento se estabelecem em determinadas regiões, rurais ou urbanas, impelindo pessoas a sair em busca de alternativas econômicas, ora procurando colocação profissional, ora fugindo da proletarização que, para o pequeno camponês, é sinônimo de miséria nas periferias das cidades. (JOANONI NETO, 2007:77)

Para manter a ideia de colonização efetiva e escapar do "fluxo alternativo", os colonizadores se dispuseram a incluir infraestruturas e facilidades para os assentados, conforme afirma mais adiante:

[...] Um dos discursos sempre presentes nas empresas de colonização e dos governos foi o fornecimento da infraestrutura nos locais dos projetos de assentamento. Talvez, a parte fundamental dessa infraestrutura fosse as estradas. Elas garantiriam o acesso a outras mercadorias, o trânsito dos migrantes e o escoamento da produção. Tal promessa jamais foi cumprida. (JOANONI NETO, 2007:77)

Concluído o mapeamento do território, articulado pelo INCRA e pelo governo do estado de Mato Grosso, o PIN (Programa de Integração Nacional), com o apoio dos batalhões de engenharia de construção, iniciou a implantação de eixos 
rodoviários para atender às necessidades de locomoção das comunidades e escoamento da produção.

Dentre os principais projetos rodoviários estão a BR-070 (Brasília - Cáceres), a BR-364 (Cuiabá - Porto Velho) e a BR-163 (Cuiabá - Santarém) malha rodoviária idealizada pelo governo militar para integrar a Região Amazônica ao Centro-Oeste e ao Sudeste. Como havia sido programado, à proporção que as estradas iam abrindo a mata, chegavam migrantes de todas as regiões do país interessados em ocupar terras às margens de cada traçado.

\section{4 - A RODOVIA: VETORA DA ORGANIZAÇÃO DO ESPAÇO REGIONAL}

A demarcação dos traçados das rodovias trazia em si a intenção explícita do governo federal de esquadrinhar a região amazônica e assim fomentar 0 povoamento. Em pouco tempo, os batalhões de engenharia do exército se organizaram para a abertura de estradas em diferentes direções.

Entre as principais rodovias longitudinais, destacam-se, conforme Figura 13, a seguir, a rodovia BR-174, que interliga Amazonas e Roraima à Venezuela; a BR163, que inicia no Rio Grande do Sul e, com seus 3.467 km, atravessa Santa Catariana, Paraná, Mato Grosso do Sul, Mato Grosso e termina no Pará e a BR-101 que atravessa doze estados brasileiros: Rio Grande do Norte, Paraíba, Pernambuco, Alagoas, Sergipe, Bahia, Espírito Santo, Rio de Janeiro, São Paulo, Paraná, Santa Catarina e Rio Grande do Sul. Em toda sua extensão é denominada oficialmente Rodovia Governador Mário Covas e margeia a costa atlântica do país. 
Figura 13 - Principais Rodovias traçadas entre 1970 e 2000 - Rodovias Longitudinais

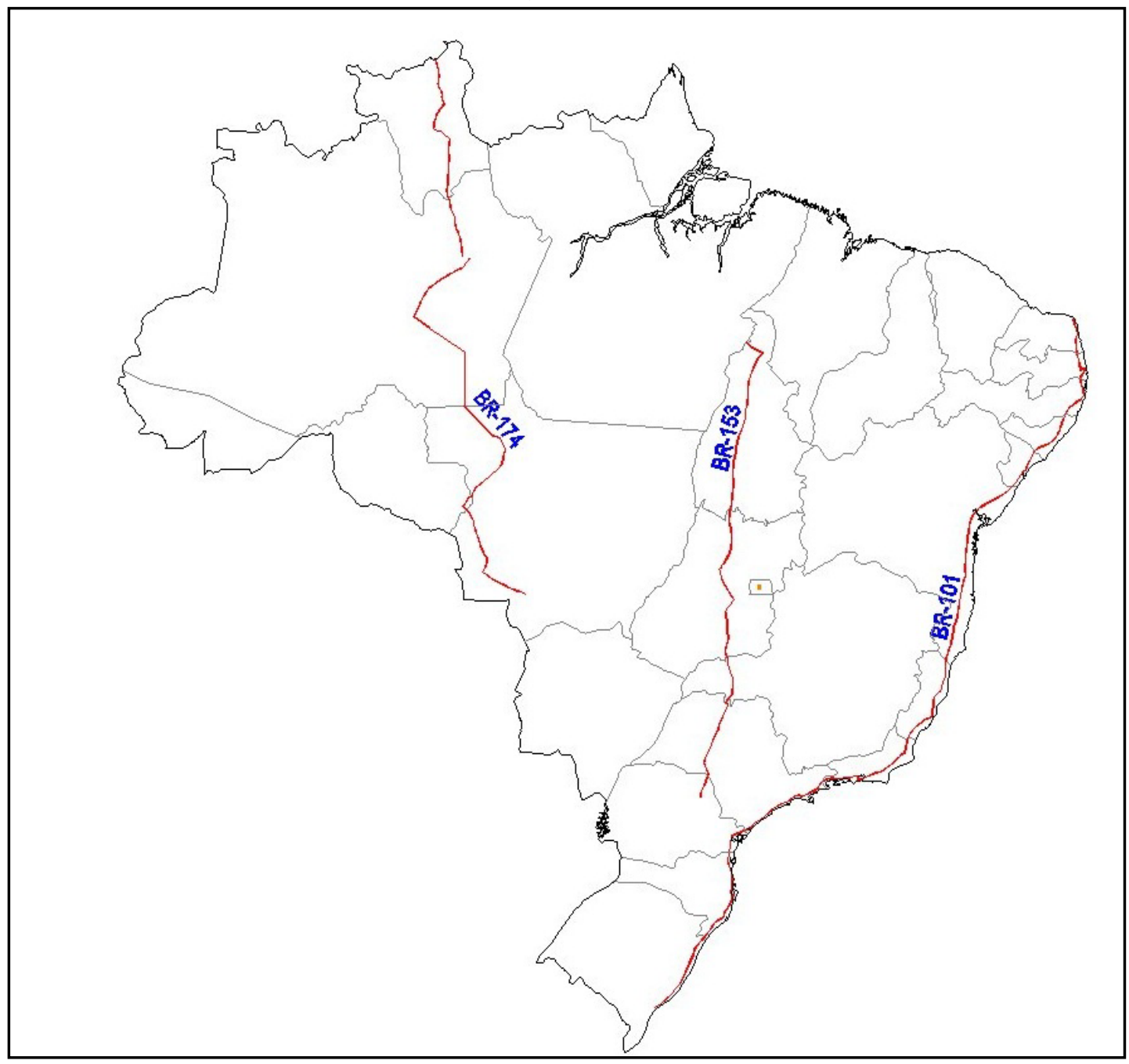

Fonte: Fonte: Departamento Nacional de Infraestrutura de Transportes - DENIT (2012)

Como se vê na Figura 14, a seguir, as rodovias transversais, a exemplo da BR-230 (Transamazônica), tinham a função de entestar a mata, ao mesmo tempo em que promoviam a ligação entre grandes centros e áreas ainda pouco desenvolvidas, como é o caso da BR-262, que começa em Vitória, no estado do Espírito Santo, passa por cidades importantes como Belo Horizonte, Araxá, Uberaba, Três Lagoas e Campo Grande, terminando junto à fronteira com a Bolívia, em Corumbá, no estado em Mato Grosso do Sul. As rodovias transversais também foram projetadas para promover a ligação entre o oceano atlântico e o interior, como é o caso da BR-290. 
Figura 14 - Principais Rodovias traçadas entre 1970 e 2000 - Rodovias Transversais

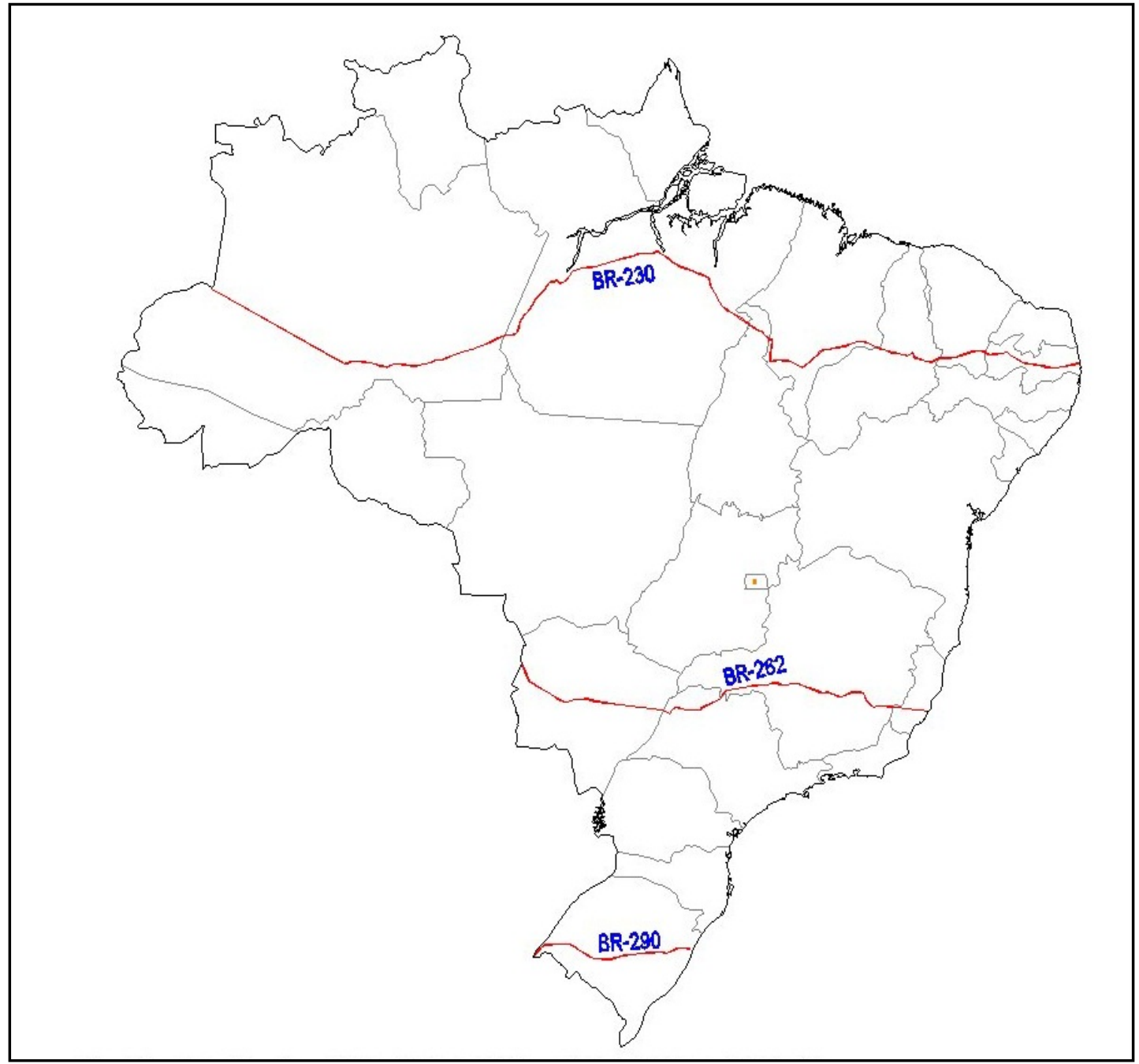

Fonte: Departamento Nacional de Infraestrutura de Transportes - DENIT (2012)

Já as diagonais, apresentadas na Figura 15, a seguir, formam as rotas planejadas para dar tessitura às regiões. A BR-364, por exemplo, inicia em São Paulo, atravessa Minas Gerais, Goiás, Mato Grosso, Rondônia e segue pelo Acre até a fronteira com o Peru; a BR-365, que inicia na BR-364, em Uberlândia, MG, e liga as regiões Nordeste - Centro-Oeste, que dali segue para Mato Grosso e, mais ao norte, cruza com a rodovia radial BR-040.

A BR-381 inicia no entroncamento com a BR-116 (Rodovia Presidente Dutra), em São Paulo, ligando esta capital à capital de Minas Gerais, Belo Horizonte, também conhecida, neste trecho, como rodovia Fernão Dias, para chegar até o Espírito Santo, onde encontra com a rodovia longitudinal BR-101. 
Figura 15 - Principais Rodovias traçadas entre 1970 e 2000 - Rodovias Diagonais

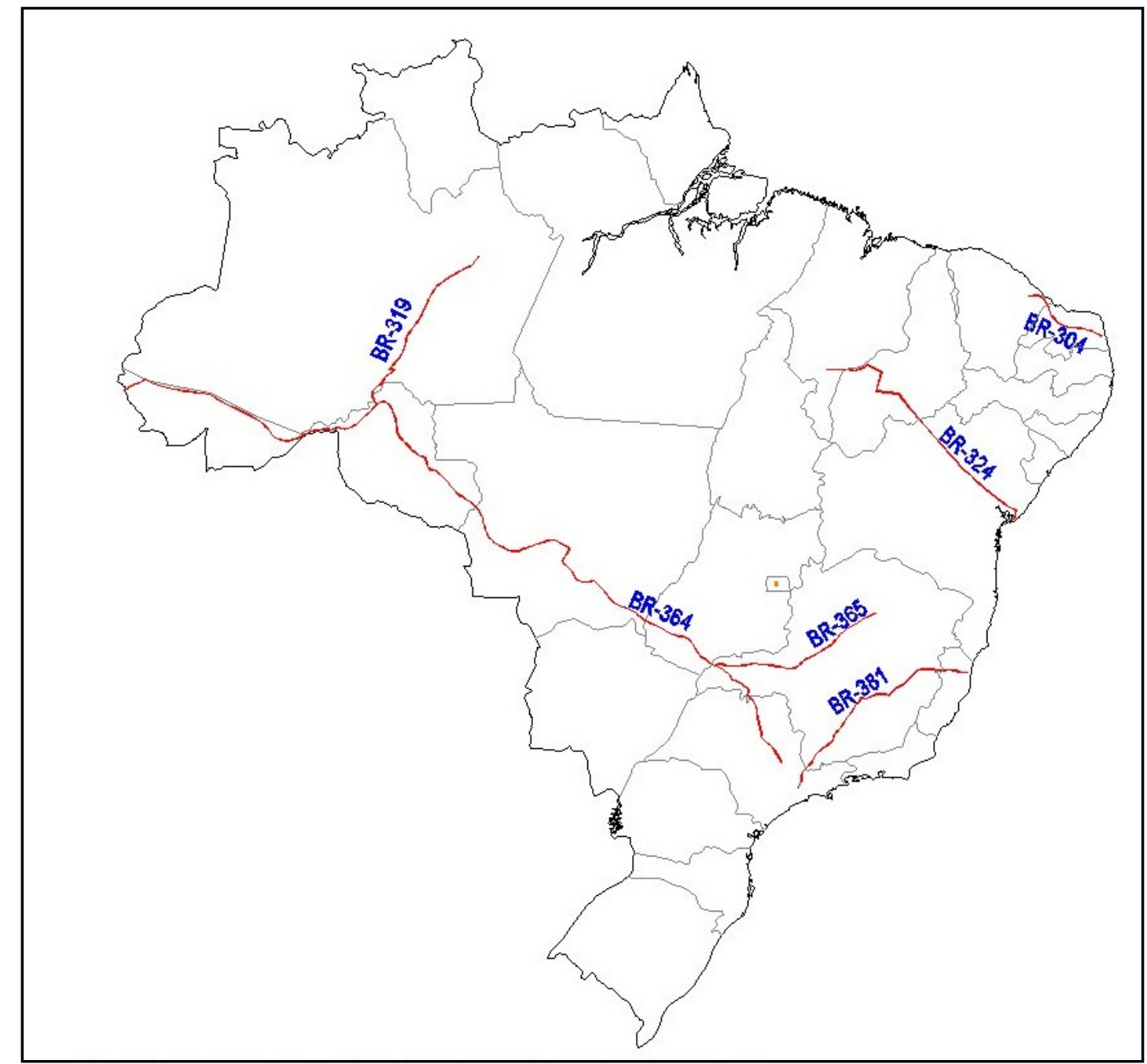

Fonte: Departamento Nacional de Infraestrutura de Transportes - DENIT (2012)

A BR-319 é a única ligação rodoviária entre Manaus (AM) e Porto Velho (RO) e dali, com o resto do país, quando encontra a rodovia longitudinal BR-174. A rodovia BR-304 liga Natal (RN) a Parnamirim (RN), que se encontra com a BR-101, possibilitando a locomoção para todos os estados litorâneos. A BR-324 inicia em Balças (MA) e termina em Salvador (BA). É uma das principais rodovias do estado baiano, por ligar a capital a importantes municípios do interior, como por exemplo, Feira de Santana (BA).

As rodovias radiais, como a BR-070 que começa em Brasília, passa por Goiás, pelos municípios de Barra do Garças e Cuiabá, em Mato Grosso, e acaba perto de Cáceres, na divisa com a Bolívia. Ela promove a interligação das principais 
rodovias transversais e longitudinais, integrando a tessitura formada pelas rodovias diagonais, conforme se constata na Figura 16, abaixo;

Figura 16 - Principais Rodovias traçadas entre 1970 e 2000 - Rodovias Radiais

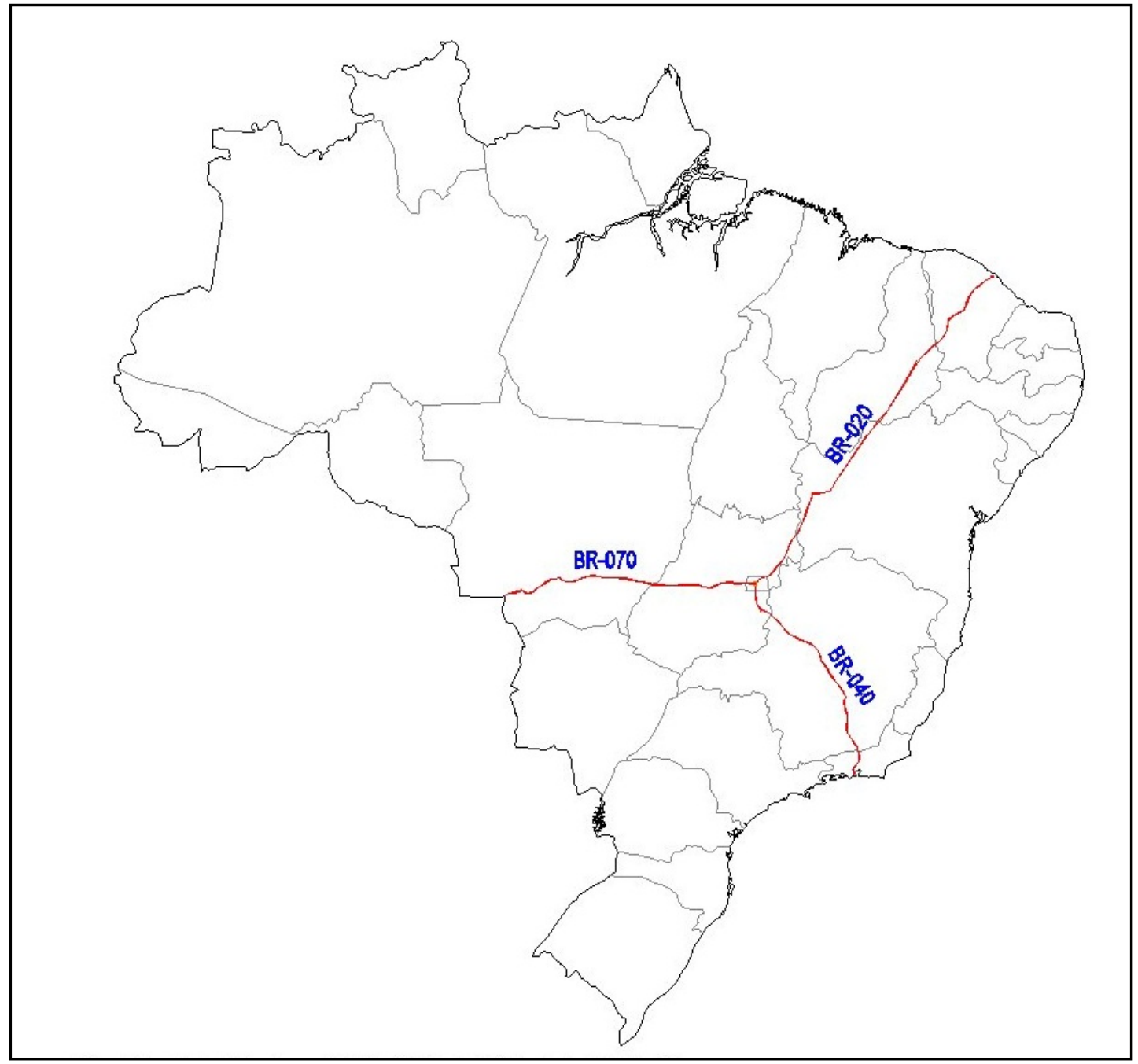

Fonte: Departamento Nacional de Infraestrutura de Transportes - DENIT (2012)

A BR-040, que também inicia em Brasília (DF), e o seu ponto final está na Praça Mauá ou cais do porto do Rio de Janeiro, depois de passar por Goiás, Minas Gerais e boa parte do estado do Rio de Janeiro. Já a BR-020, liga Brasília (DF) e Fortaleza (CE), passando pela Bahia, onde hoje cruza com as rodovias BR-135 e BR-242 e depois de atravessar o estado do Piauí num trecho longo sem asfalto, segue asfaltada até o Ceará.

Esta malha viária tornou-se expressivamente mais importante, com 0 aumento dos interesses econômicos na área da Amazônia Legal e nas áreas de abrangências das rodovias que começaram a ser implantadas na década de 1970. 
A partir daí, os aportes financeiros em Mato Grosso passaram a se concentrar no norte do Estado, mais precisamente na área de abrangência da BR-163, onde iniciou uma produção de commodities cuja meta era ingressar no mercado internacional com preço e qualidade competitivos.

O resultado imediato consistiu na derrubada desordenada de enormes áreas de floresta, para dar lugar a pastagens e à agricultura.

A velocidade do desmatamento na região que se constitui numa grande
preocupação, só será devidamente entendida se contextualizada. Exemplo
disso são as tradições (algumas remontam o período colonial) que
permeiam e constroem o imaginário popular do homem rural no Brasil. A
"Marca do Ferro" é uma delas. A terra pertence a quem nela trabalha e, para
demonstrar concretamente a atividade e, consequentemente, a posse,
apressa-se o desmate, a queima, seus sinais inequívocos. Terra intacta e
mata fechada é terra passível de ocupação. Sem conhecer nuances como
esta, que compõe o imaginário social do nosso camponês e norteiam sua
vida, certas ações desse grupo tornam-se incompreensíveis. (JOANONI
NETO, 2007:89).

A afirmação de Joanoni Neto (2007) se confirma quando se rememora as normas do INCRA que só garantiam o direito da terra aos assentados que derrubassem, pelo menos, $50 \%$ da mata nativa, uma vez que somente a "terra limpa" era considerada como área ocupada ou produtiva.

Apesar de a forte incursão de organizações internacionais com campanhas para a preservação da floresta, o nível de interesse no mercado de commodities predominou, como seria de se esperar, justamente porque

Se, por um lado, nesse nível predominam os interesses visando à proteção e uso sustentável da natureza, por outro lado o mercado estimula a derrubada da floresta, como é hoje o caso da valorização da soja no mercado internacional. (BECKER, 2004:125).

Para entender melhor a estrutura fundiária que se desenvolveu entre as décadas de 1970 e 1990 na área de abrangência da BR-163, são fundamentais as informações de Moreno (2007), quando analisa estes mecanismos na transformação de terras públicas, devolutas e privadas, através de concessões de grandes extensões de terra a colonizadoras e empresas particulares nacionais e estrangeiras. Foi graças a este tipo de concessão que nasceram as grandes propriedades e, consequentemente, os desflorestamentos, como se pode avaliar pela Figura 17, a seguir. 
Figura 17 - Desflorestamento da Amazônia Legal

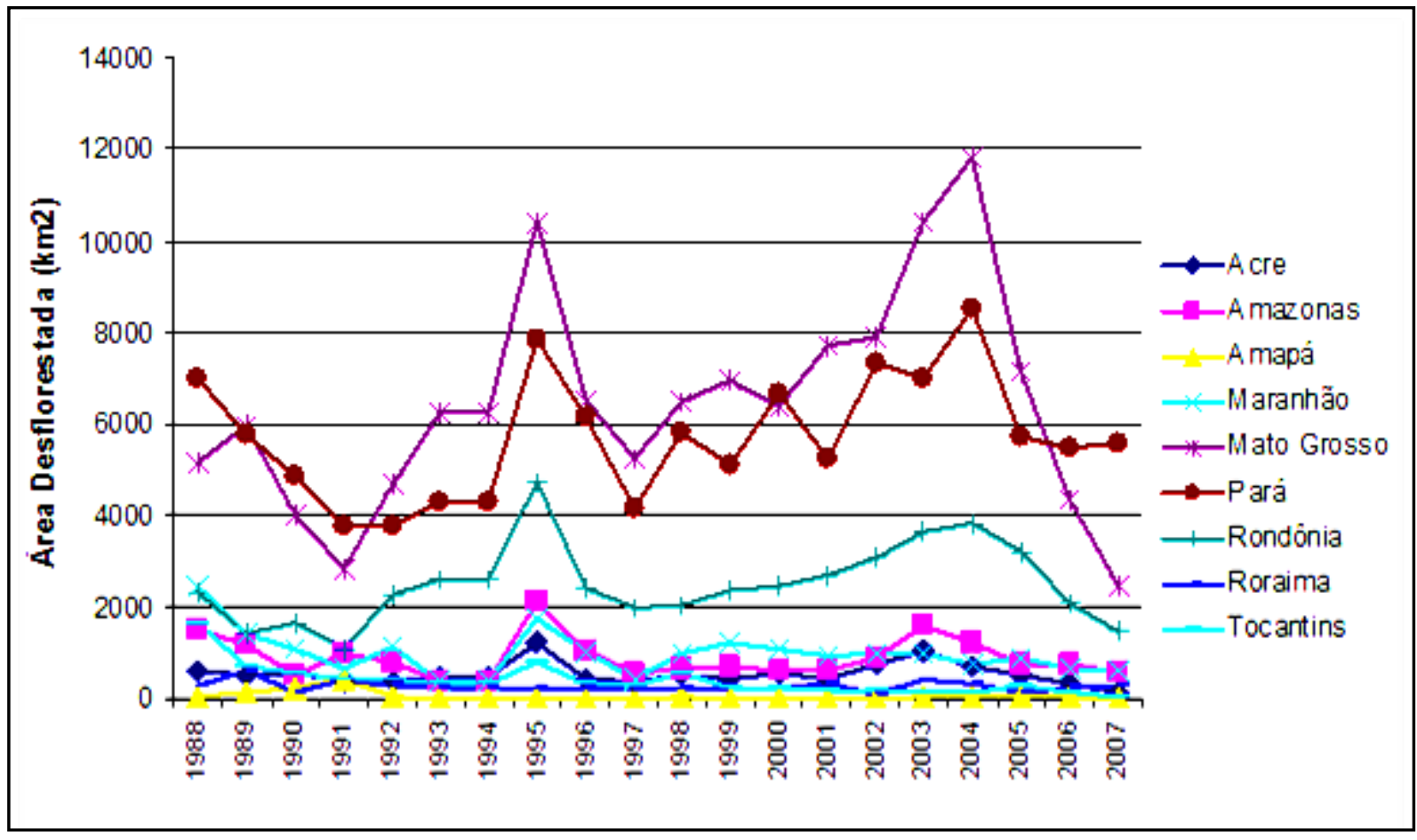

Fonte: Dados INPE - PRODES. Org. Eduardo Paulon Girardi (2007)

Os incentivos para atrair imigrantes com doações de terras devolutas, negociações com colonizadoras e permutas políticas induziu o Estado a promover a desterritorialização da população autóctone, uma vez que os projetos e negociações realizados nesta região jamais consideraram a hipótese de que as terras escolhidas para solucionar os problemas de reforma agrária não fossem anecúmenas.

As campanhas prometiam uma vasta área "vazia", com terras férteis e inabitadas, ou seja, exatamente como acreditava o General Golbery do Couto e Silva, "terra sem homens para homens sem terra"32.

Antagonicamente, o texto de abertura do projeto de ZEE (Zoneamento Ecológico Econômico), diz que:

O Zoneamento Ecológico Econômico de Mato Grosso é um instrumento para racionalização da ocupação de espaços territoriais e redirecionamento de metas e diretrizes; é subsídio para elaboração e execução de planos regionais em busca do desenvolvimento sustentável. Tem a finalidade de dotar o governo de bases técnicas para espacialização de políticas públicas, visando ordenação de territórios (SEPLAN, 2010).

\footnotetext{
${ }^{32}$ O governo brasileiro, tendo à frente o Presidente Médici, instituiu por meio do Decreto-Lei № 1106 , o PIN (Plano de Integração Nacional). Utilizando mão de obra nordestina liberada pelas grandes secas de 1969 e 1970 e com a noção de vazios demográficos amazônicos são cunhados os lemas "integrar para não entregar" e "uma terra sem homens para homens sem terra para incentivar a imigração. (Fonte: http://pt.wikipedia.org/wiki/)
} 
O cotidiano é contraditório a praticamente todo o texto da SEPLAN, uma vez que as cidades da área de abrangência da BR-163 se apropriam do espaço (territórios políticos, econômicos e culturais), em busca de uma dinâmica peculiar a cada grupo de migrantes, combinando seus costumes e culturas com a nova realidade encontrada no Cerrado, já que, historicamente, não houve gestão nem ordenamento possível para aquela parte do território compreendido como Amazônia Legal, cuja fronteira invadia o território de transição, entre o Cerrado e a floresta, construindo seu estilo peculiar de desenvolvimento.

Partindo de um ponto de vista mais pragmático, poderíamos afirmar que questões ligadas ao controle, "ordenamento" e gestão do espaço, onde se inserem também as chamadas questões ambientais, têm sido cada vez mais centrais para alimentar este debate. Elas nos ajudam, de certa forma, a repensar o conceito de território. (HAESBAERT, 2011:76).

Para repensar o conceito de território, Haesbaert (2011) acrescenta que

A implementação das chamadas políticas de ordenamento territorial deixa
mais clara a necessidade de considerar duas características básicas do
território: em primeiro lugar, seu caráter político - no jogo entre os
"macropoderes" políticos institucionalizados e os "micropoderes", muitas
vezes mais simbólicos, produzidos e vividos no cotidiano das populações;
em segundo lugar, seu caráter integrador - o Estado em seu papel gestor-
redistributivo e os indivíduos e grupos sociais em sua vivência concreta
como os "ambientes" capazes de reconhecer e de tratar o espaço social em
todas suas múltiplas dimensões. (op.cit., 2011:76).

No que tange ao ordenamento territorial das cidades situadas na área de abrangência da BR-163, o jogo entre "macropoderes" políticos institucionalizados e "micropoderes" prevaleceu sobre o papel gestor distributivo do Estado, na medida em que praticamente todos os indivíduos que ali se estabeleceram, acabaram sendo obrigados, por diferentes circunstâncias, a transferir suas terras para o poder capitalista, no momento em que já não tinham mais condições de continuar.

A falta de leis para normatizar a ação do homem que já consumiu um quarto da Floresta Amazônica, o próprio estilo de colonização, desordenado, provocou o desmatamento e o desvio de diversos setores para a ilegalidade, como frutos da falta de decisões por parte do poder público e da fraca participação das comunidades nas decisões sociopolíticas. "Isto se dá ao serviço do mercado, e tende a corroer a coesão horizontal que está posta ao serviço da sociedade civil tomada como um todo". (SANTOS, 2009:259). 
A partir do início da construção da BR-163, em 1971, foram surgindo empresas colonizadoras particulares, que adquiriam do Estado ou de colonos combinados, grandes extensões de terras ao longo da rodovia.

Após cinco anos, a estrutura encascalhada da estrada, de Cuiabá a Santarém, estava pronta. Eram 1.777 km, dos quais 1.114 km em território matogrossense onde, paralelamente, foram limitados $10 \mathrm{~km}$ de cada lado da rodovia para a colonização e reforma agrária.

Diante da dificuldade de movimento para a expansão das fronteiras do agronegócio e graças à ineficácia demonstrada pelo Plano de Desenvolvimento Regional Sustentável, a iniciativa privada promoveu um desmatamento desenfreado que, embora tenha diminuído desde 2004, destruiu 17\% da Floresta Amazônica.

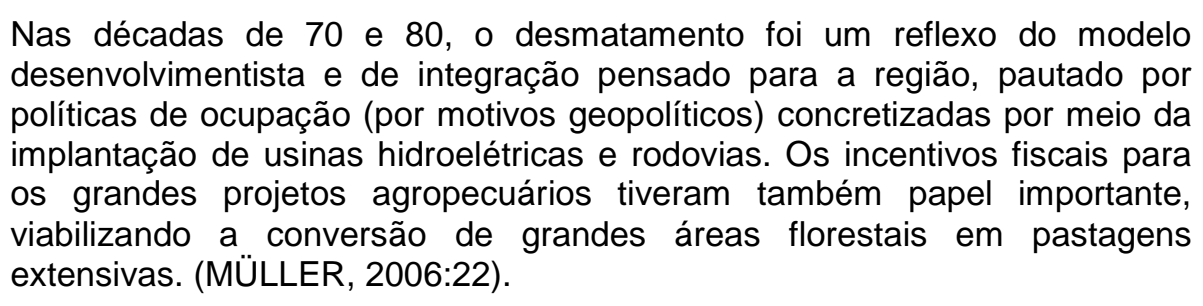

Indiretamente, esta ação tem sido apoiada pelo poder público que conta com o superávit na balança comercial brasileira, graças à produção mato-grossense de commodities. Coincidentemente, a ação dos órgãos de controle municipais, estaduais e federais sempre chega depois da derrubada das árvores e as punições jamais encontram seus principais responsáveis.

No centro da conjuntura metamórfica provocada pelo aumento vertiginoso da produção de commodities está a BR-163, conforme se vê na Figura 17, a seguir, como questão prioritária, para o agronegócio, uma vez que a maior parte desta produção está concentrada na sua área de abrangência.

Em entrevista concedida para a pesquisa em 14.06.2011, o Eng. Luiz Antonio E. Garcia, Superintendente do DENIT-MT (Departamento Nacional de Transportes de Mato Grosso) informou que o trecho mato-grossense, concluído até esta data já teria uma proposta de duplicação entre o município de Rondonópolis e o Posto Gil ${ }^{33}$ em andamento, e a licitação para a obra está prevista para 2012. Isto significa, conforme os prazos atuais para um processo de licitação de estrada e todas as

\footnotetext{
${ }^{33} \mathrm{Um}$ dos primeiros postos de abastecimento de combustível instalados no município de Diamantino, que hoje se transformou num ponto de referência da BR-163, além de ter promovido o desenvolvimento em sua área de abrangência.
} 
licenças ambientais necessárias, uma média de mais quatro anos até a obra iniciar de fato.

Figura 18 - Área de Influência da BR 163

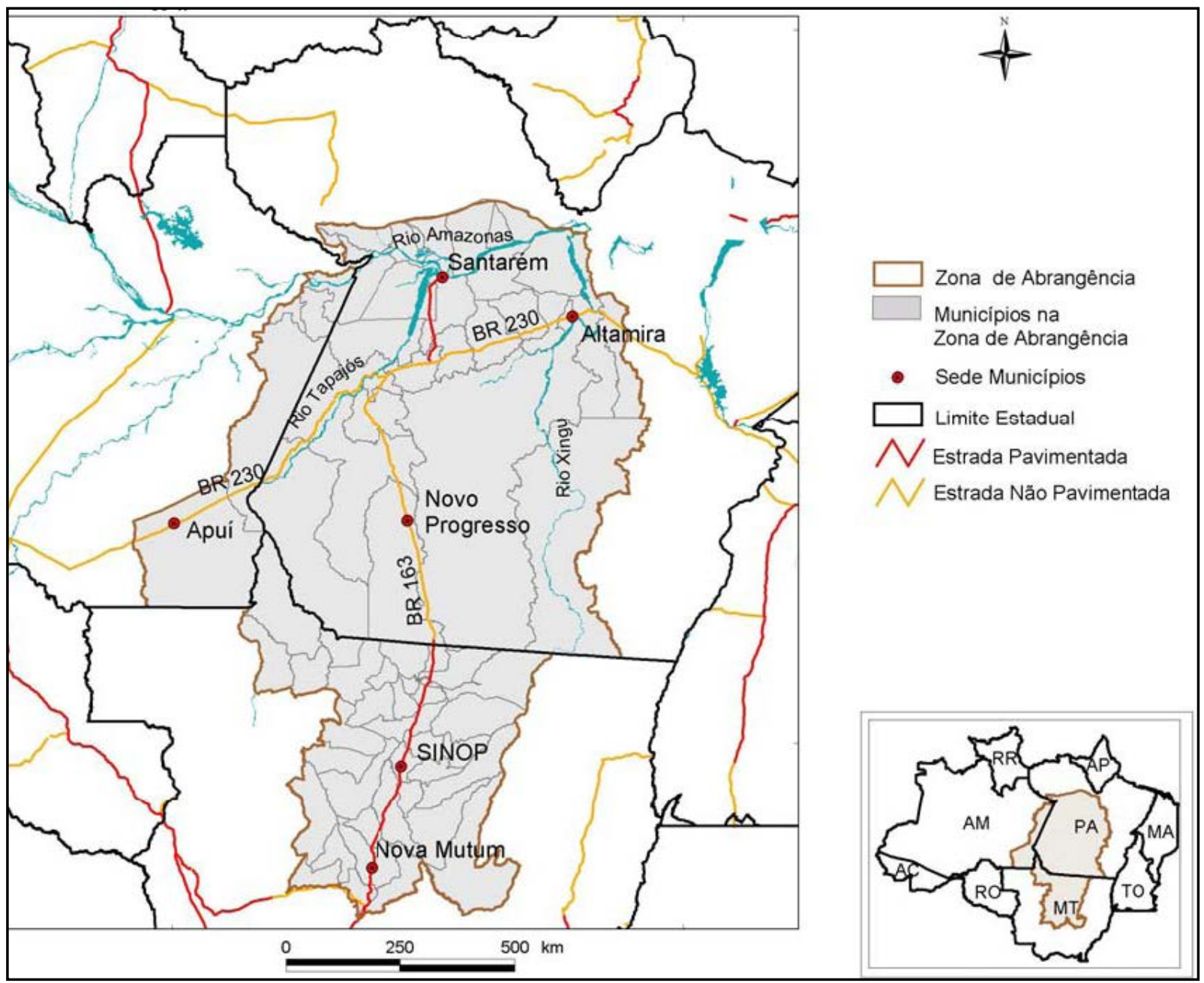

Fonte: Ministério da Integração Social (2004)

Conforme o Eng. Luiz Antonio Garcia, a BR-163 já passou do nível de tráfego suportável e entrou no seu estado limite há muito tempo. Em época de safra, trafegam em média 12 mil veículos/dia, em sua maioria carretas com sete eixos, basicamente no sentido norte-sul, transportando as commodities produzidas na sua área de abrangência.

$\mathrm{O}$ trecho de rodovia asfaltado em território mato-grossense reconfigurou o ordenamento da geografia do território, oportunizando novos estilos de vida influenciados pela tecnologia e moldados no progresso urbano.

As informações fornecidas pela placa da Foto 01, a seguir, localizada nas proximidades da entrada para o Porto de Santarém-PA, por si só justificam a forte pressão exercida pelo setor do agronegócio, através dos membros da FAMATO 
(Federação de Agricultura e Pecuária do Estado de Mato Grosso) sobre o poder público, para que a estrada seja concluída.

\section{Foto 01 - Placa instalada próxima a entrada para o Porto de Santarém, PA}

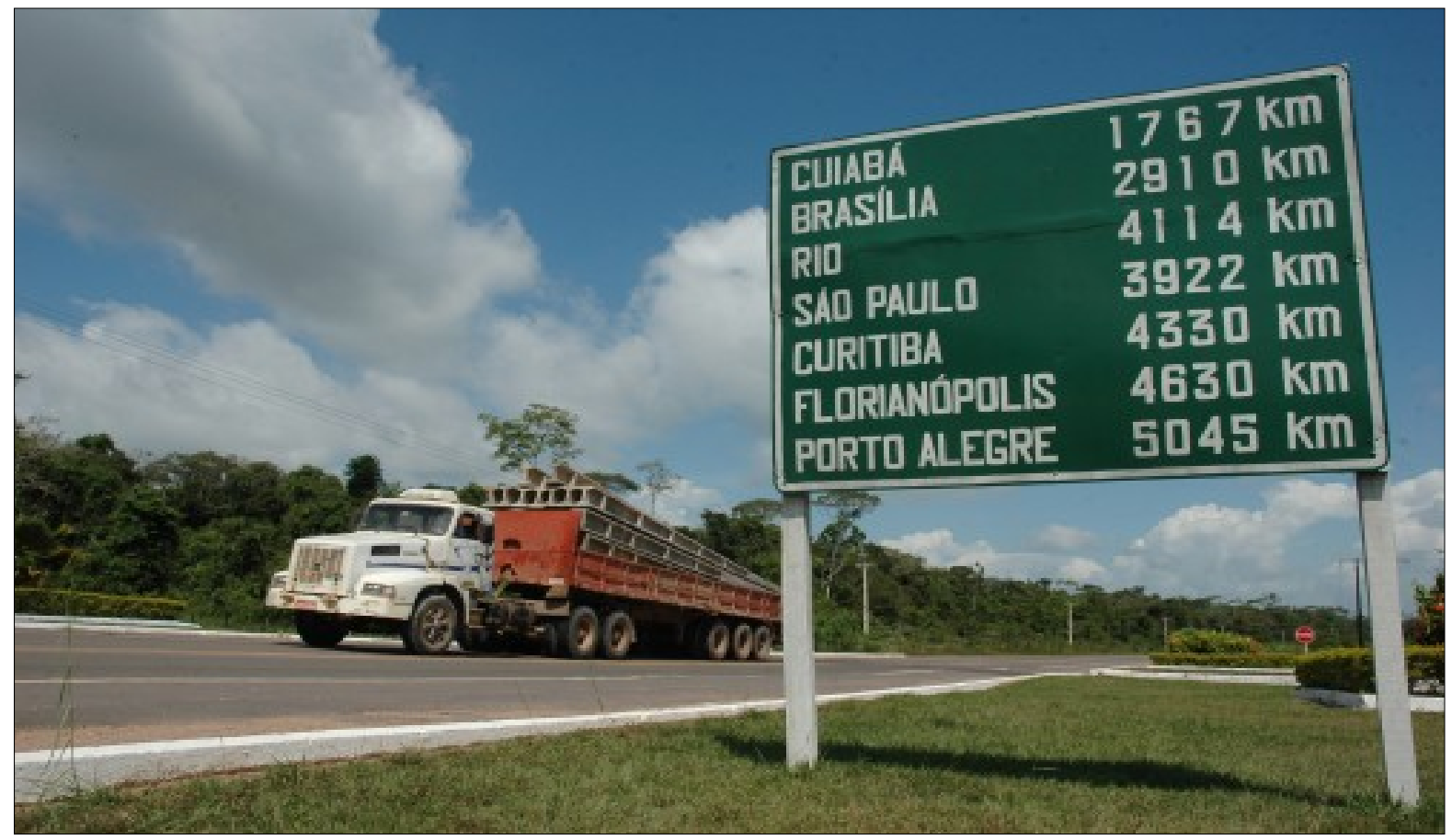

Fonte: Acervo da autora (2005)

Com o asfaltamento de $500 \mathrm{~km}$ ainda não concluídos em solo paraense, o agronegócio economizaria mil quilômetros no trajeto, diminuiria sensivelmente a sobrecarga imposta à rodovia no sentido norte/sul, por onde a produção é escoada rumo aos portos das regiões sudeste e sul do país. Por outro lado, aumentaria o lucro dos produtores, tanto com a abreviação do trajeto, como com a eliminação de boa parte dos prejuízos causados pela perda de produto no transporte, estimado em $30 \%$ do valor da carga. Afinal, "os mercados e as empresas não podem existir sem um poder público para protegê-los" (HIRST e THOMPSON, 2002:291). No negócio de commodities, custo e tempo são os fatores que mais influem nos preços finais dos produtos.

De acordo com Bernardes (2005),

É nesse contexto de reestruturação geral do sistema capitalista e emergência de novos padrões tecnológicos que procuramos compreender o espaço produtivo da nova fronteira do capital, apreender a nova organização da sociedade e as relações emergentes nas áreas de expansão da agricultura moderna nos municípios sob influência da BR-163 mato-grossense, onde vão se instituindo processos que envolvem a abertura de novas áreas, a implantação e articulação de atividades modernas, com destaque da cadeia carne/grãos, impulsionados pela dinâmica de reprodução do capital. (BERNARDES, 2005:13). 
É na instituição de processos que envolvem a abertura de novas áreas, a implantação e articulação de atividades modernas, eu se delineia uma nova organização do espaço e "a nova organização da sociedade e as relações emergentes nas áreas de expansão da agricultura moderna nos municípios sob influência da BR-163" formaram o que Santos e Silveira (2005:119) chamam de "novos fronts, que nascem tecnificados, cientificizados e informacionalizados. Eles encarnam, uma situação: a da difusão de inovações em meio vazio".

Numa análise mais detalhada de textos editados a respeito da região e através de pesquisas realizadas in loco, o que chama a atenção é o fato da mídia tratar com pouca clareza a importância das pessoas que construíram a pujança desfrutada hoje pelos municípios situados na área de abrangência da BR-163, quando se fala sobre Amazônia Legal ou sobre os municípios nela inseridos, principalmente aqueles situados na área de abrangência da rodovia, o tema trata sempre do sucesso das commodities ou do lucro que elas têm aportado para Mato Grosso.

Todo projeto de qualquer sociedade é sempre resultante das vontades e dos interesses dos homens que o concretizam, num determinado espaço e tempo, a sua visão de mundo. Assim, por ser a sociedade caracteristicamente heterogênea na constituição estrutural e organizacional, o projeto dominante suplanta e descaracteriza os projetos-outros que são e que expressam as vontades dos que não controlam o poder e que não encontram espaço institucional para estabelecer e legitimar as relações sociais, organizações políticas e estruturas econômicas. (ZART, 1998:106)

Mais adiante, complementa:

O projeto dominante, para manter-se dominante, necessita apoderar-se do imaginativo da coletividade e fazer acreditar que os seus valores são necessariamente valores universais. Que as definições e os conceitos presentes, nos pareceres, nos decretos e nos atos institucionais do Estado são sempre para a edificação e de uma estrutura socioeconômica que corresponde a todos os membros e a todas as partes do todo. (ZART, 1998:106)

É justamente neste tipo de projeto que está inserida a transversalidade que se deseja analisar; se foram vicissitudes que favoreceram as políticas do agronegócio ou se houve um projeto planejado para a participação efetiva da produção de commodities no mercado internacional, não cabe discutir aqui. A proposta é pesquisar sobre o reordenamento e modernização das cidades, tendo como foco os mais de $98 \%$ da população da região, por considerá-los como principais 
responsáveis pela construção deste fenômeno urbano que não trabalha mais na lavoura, nem participa diretamente do vultoso lucro das commodities da região.

O que se pode chamar de metamorfose espacial decorrente da expansão agrícola desta região, transpira em municípios como Sinop, Sorriso e Lucas do Rio Verde. Conforme o IMEA (Instituto Mato-grossense de Economia Agropecuária), estes municípios são os protagonistas da exportação mato-grossense de soja in natura e suas performances evoluíram muito nos últimos anos.

Mesmo assim é importante notar que os lucros vultosos, concentrados em aproximadamente 1,5\% da população, são produzidos por um número reduzidíssimo de fazendas gigantescas pertencentes a grupos nacionais e estrangeiros, cujos proprietários, em sua maioria, sequer vivem na região.

Esta produção que começou tímida e cheia de dificuldades na "briga com a terra rebelde do Cerrado", saiu de pouco mais de 2.890 milhões de toneladas, em 2000, para 24,1 milhões de toneladas de soja previstas para a safra 2012/2013, sendo que $40 \%$ deste total serão produzidos na área de abrangência da BR-163 (SÓNOTICIAS/IMEA, 2012).

A partir da década de 1970, as estradas foram sendo abertas em todas as direções, para escoar a produção que aumentava ano a ano. Como se verifica na Figura 19, a seguir, embora nem todas as rodovias estejam pavimentadas, hoje o Estado com uma boa malha viária para atender às necessidades do agronegócio e das populações das regiões norte/nordeste do Estado.

Não há mais como racionalizar a ocupação dos espaços territoriais ou redirecionar metas e diretrizes a ordenação do território na BR-163, pois a rodovia, ao mesmo tempo em que trouxe o desenvolvimento a várias cidades do norte de Mato Grosso, carreou com ela sérios problemas de ordem ambiental e social. 
Figura 19 - Principais rodovias que atravessam Mato Grosso

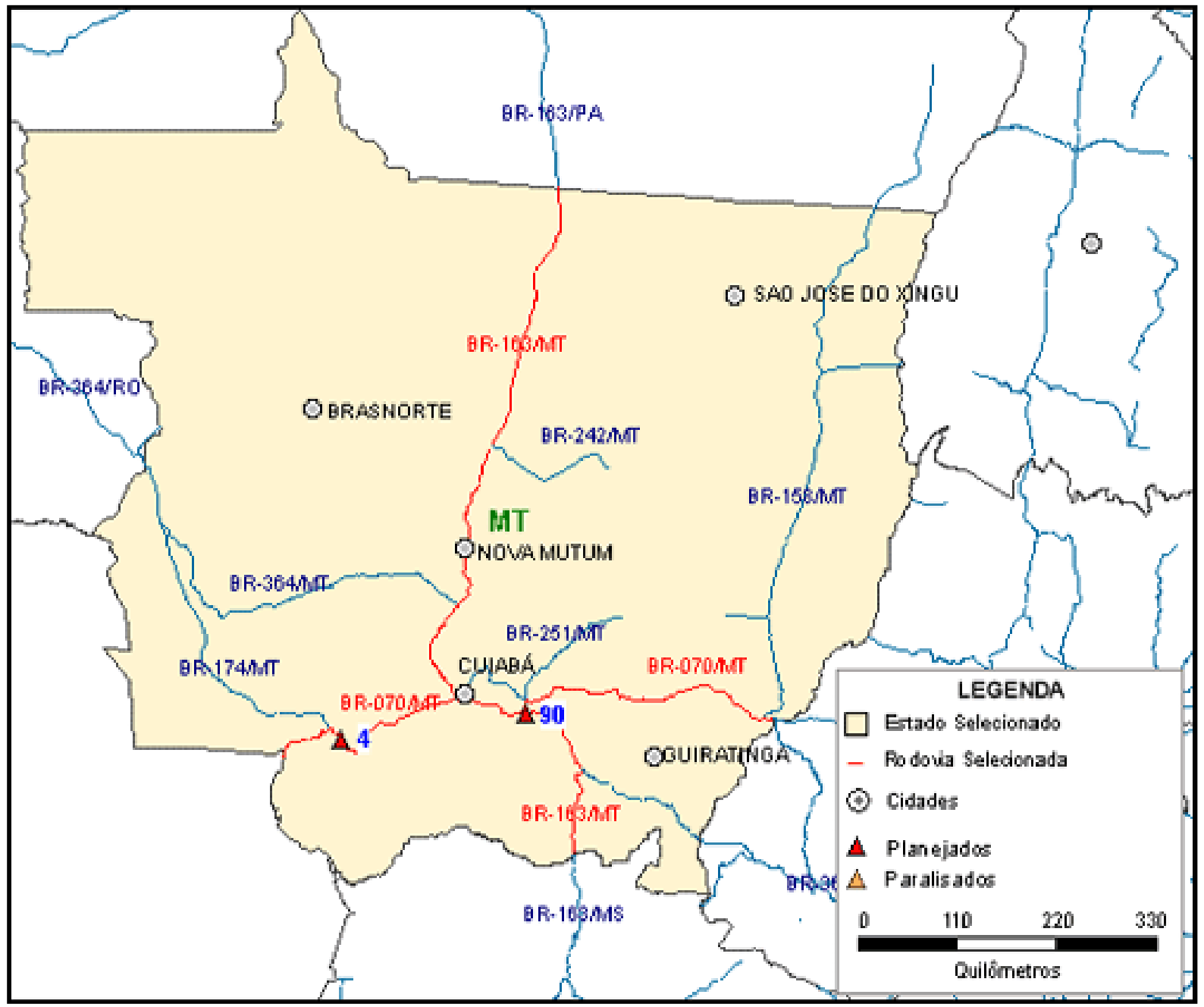

Fonte: Ministério dos Transportes (2012)

Neste ponto, é preciso concordar com Bauman (2001), quando se refere ao jogo do poder público que todos assistem:

O que está ocorrendo não é simplesmente outra renegociação da fronteira notoriamente móvel entre o privado e o público. O que parece estar em jogo é uma redefinição da esfera pública como um palco em que dramas privados são encenados, publicamente, expostos e publicamente assistidos. A definição corrente de "interesse público", promovida pela mídia e amplamente aceita por quase todos os setores da sociedade, é o dever de encenar tais dramas em público e o direito do público de assistir à encenação. (BAUMAN, 2001:83).

Isso porque, a maioria das negociações carreava o interesse nas vantagens proporcionadas pelos programas de incentivos financeiros oferecidos pelo governo federal a título de incentivo à expansão do espaço agrícola, embora tenham alterado significativamente a ordenação do território mato-grossense, uma vez que "na união vertical, os vetores de modernização são entrópicos. Eles trazem desordem às 
regiões onde se instalam, porque a ordem que criam é em seu próprio e exclusivo benefício". (SANTOS, 2009:259).

Uma das formas de negociação consistia na ocupação de terras indígenas, pois,

Os interesses capitalistas prevaleciam aos valores indígenas e estes eram vistos como um empecilho ao "desenvolvimento e ao progresso" e, frente à sua resistência, acabaram por ter de enfrentar a violência dos não-indios. (CAVALCANTE E COSTA, 1999:131),

Por conta da disputa por mais terras para engordar o mercado de commodities ocorreram inúmeros massacres a aldeias indígenas; conforme relatos de sobreviventes foram usados desde "jagunços"34 para coagir e providenciar a "limpeza da área" 35 , até com o artifício de voos rasantes que arremessavam bananas de dinamite sobre as aldeias indígenas, para desocupar a área. Estes aviões, normalmente usados para adubar as plantações passaram a ter esta função extra, até que aquelas áreas de interesse dos latifundiários estivessem "limpas". Além destes capítulos de violência da história recente, outros fatores influenciaram fortemente a morfologia geográfica do território na região norte de Mato Grosso, como, por exemplo, a transversalidade do agronegócio no coronelismo praticado pelas políticas públicas no Estado.

Somente em 2004 foi criado o Consórcio pelo Desenvolvimento Sócioambiental da BR-163 ${ }^{36}$, constituído por 32 entidades que atuam na região. Em 2005, finalizada a versão preliminar do Plano de Desenvolvimento Regional Sustentável ${ }^{37}$

\footnotetext{
${ }^{34}$ Homens liderados por fazendeiros que cometiam crimes de pistolagem e invasão de terras de imigrantes, caboclos ou índios (JOANONI NETO, 2007:162).

${ }^{35}$ Conforme informações de habitantes locais, esta era a expressão usada pelos jagunços, quando a invasão incluía mortes de colonos, caboclos ou índios, para tornar inabitada a área a ser invadida pelo fazendeiro mandante.

${ }^{36} \mathrm{O}$ consórcio era coordenado pelas seguintes organizações sócio-ambientais: Grupo de Trabalho Amazônico (GTA), Federação dos Trabalhadores na Agricultura do Estado do Pará (FETAGRI-PA), Fórum Mato-Grossense de Meio Ambiente e Desenvolvimento (FORMAD), Fundação Viver, Produzir e Preservar (FVPP), Instituto Sócio-ambiental (ISA) e Instituto de Pesquisa Ambiental da Amazônia (IPAM). Foi formado com o objetivo de ser interlocutor do governo federal para viabilizar a implantação de ações prioritárias levantadas pela sociedade em relação ao asfaltamento da estrada. ISA (Instituto Socioambiental) <www.socioambiental.org>. Acessado em: 03/12/2010).

${ }^{37} \mathrm{~A}$ proposta inicial para o Plano de Desenvolvimento Sustentável para a Área de Influência da BR163 foi elaborada por um grupo de trabalho formado por 14 ministérios, Meio Ambiente, Integração Nacional, Planejamento, Orçamento e Gestão, Transportes, Desenvolvimento Agrário, Desenvolvimento, Indústria e Comércio Exterior, Minas e Energia, Cidades, Justiça, Saúde, Educação, Desenvolvimento Social, Trabalho e Emprego e Agricultura, Pecuária e Abastecimento. A seguir, organizou reuniões nos municípios de Altamira (PA), Apuí (AM), Guarantã do Norte (MT), Novo Progresso (PA), Santarém (PA), Sorriso (MT) a fim de colher subsídios para a elaboração do projeto desenvolvido pelo Grupo de Trabalho Interministerial, criado em março de 2004, sob a
} 
para a Área de Influência da BR-163, já havia um projeto de diretrizes estratégicas e ações prioritárias. O Plano dividiu a área de influência da rodovia em três mesorregiões: Norte (calha do Amazonas e rodovia Transamazônica); Central (Médio Xingu e Tapajós); Sul (Norte de Mato Grosso) ${ }^{38}$.

O ordenamento territorial e gestão ambiental estão apensos ao ZEE (Zoneamento Ecológico e Econômico) iniciado na década de 1980. Lamentavelmente, o ZEE ainda não conseguiu ser posto totalmente em prática, apesar de ter recebido o apoio do PRODEAGRO (Projeto de Desenvolvimento Agroambiental do Estado de Mato Grosso).

A situação não mudou, mesmo quando seu gerenciamento passou para a esfera federal, como ZSEE (Zoneamento Socioeconômico e Ecológico) com o respaldo de um financiamento do Banco Mundial ${ }^{39}$ o estudo continua parado.

coordenação da Casa Civil. No final das conversações, foi produzido o texto da carta de Santarém, que inclui demandas relacionadas a Serviços Básicos, Ordenamento Fundiário e Combate à Violência, Estratégias Produtivas e Manejo dos Recursos Naturais, Fortalecimentos Social e Cultural das Populações Locais, Gestão Ambiental, Monitoramento e Áreas Protegidas. Este documento foi assinado pela Associação Terra Indígena Xingu (ATIX), pelo Centro de Estudos, Pesquisa e Formação de Trabalhadores do Baixo Amazonas (CEFTBAM), pelo Fórum dos Movimentos Sociais da Rod. Sen. Jonas Pinheiro, pelo Fórum Mato-Grossense de Meio Ambiente e Desenvolvimento (FORMAD), pela Federação dos Trabalhadores na Agricultura do Estado do Pará (Fetagri), pela Fundação Viver, Produzir e Preservar (FVPP), pelo Grupo de Trabalho Amazônico (GTA), pelo Instituto Centro e Vida (ICV), pelo Instituto de Pesquisa Ambiental da Amazônia (IPAM) e pelo Instituto Socioambiental (ISA). <http://www.socioambiental.org/nsa/ detalhe?id=1778>. Acessado em: 05/07/2010.

${ }^{38}$ Fonte: ISA (Instituto Socioambiental). <http://www.socioambiental.org>. Acessado em: 03/12/2010).

${ }^{39}$. O projeto de Zoneamento Socioeconômico e Ecológico (ZSEE) de Mato Grosso, da forma como foi aprovado pela Assembleia Legislativa do Estado, joga no lixo cerca de US\$30 milhões investidos em 20 anos de estudos e discussões técnicas. De acordo com Roberto Vicentin, diretor de Zoneamento Territorial do Ministério do Meio Ambiente (MMA), foram realizadas 15 audiências públicas - algumas com tamanha participação que utilizaram estádios de futebol e ginásios de esporte. "A equipe técnica do Estado e nós do MMA avaliamos que aquele substitutivo era um ponto de convergência adequado, porque conciliava a base técnica com as aspirações e reivindicações da sociedade", afirmou. Segundo o diretor do MMA, esse texto do relator foi atropelado pelo presidente da Comissão Especial de Zoneamento da Assembleia, Dilceu Dalbosco (DEM). "Ele não ficou satisfeito e elaborou, com técnicos que ele contratou, um substitutivo do substitutivo, submeteu à votação da comissão essa terceira proposta. Não era nem o original do Estado, nem o substitutivo do relator, mas sim uma proposta que, com todas as letras, não tem sustentação técnica". A proposta foi duramente criticada também pelo Grupo de Trabalho de Mobilização Social, formado por representantes de instituições ligadas ao meio ambiente, educadores, indígenas, populações tradicionais e agricultura familiar do estado. (ECOAGÊNCIA, 03/11/2010). Cada substitutivo ao Projeto de Lei original tem progredido num modelo de planejamento territorial forjado para priorizar de maneira exclusiva os interesses do agronegócio, chegando ao seu auge no texto final, modelado segundo a pauta do substitutivo 3 . Além do desrespeito aos diretos territoriais indígenas, devidamente reconhecidos pela União, outras componentes do novo Zoneamento confirmam a unilateralidade da perspectiva ruralista: 1) Aumento de $72,88 \%$ para as Áreas com estrutura produtiva consolidada ou a consolidar (aumento de 72.700 hectares em relação a proposta anterior, totalizando assim mais de 170.000 hectares para o agronegócio); 2) Redução de $41,32 \%$ das áreas para conservação ou recuperação dos recursos hídricos (perda de 61.000 hectares para a proteção das águas do Estado); 3) Redução de 40,24\% das áreas com elevado potencial florestal (perda de 62.000 hectares para a proteção das florestas); 
O objetivo do projeto era identificar potencialidades, vulnerabilidades e definir as formas mais corretas para o uso dos recursos naturais visando atender à realidade econômica e socioambiental da região, bem como viabilizar projetos ambientais que mobilizassem a prosperidade econômica dos agricultores.

O que possibilita o processo civilizador é a singular adaptabilidade e transformabilidade dessas funções auto-reguladoras. Ele é adicionado e mantido em movimento por mudanças específicas no convívio humano, por uma transformação das relações humanas que atua num sentido muito definido, por um movimento autônomo da rede de indivíduos humanos interdependentes. (ELIAS,1994:60).

Portanto, é importante saber o que estão fazendo aquelas pessoas que desistiram do negócio da lavoura, porque se viram penalizadas à miséria, caso não escolhessem outro caminho ou profissão, muitas vezes totalmente diferente da sua condição de "colono". O que aconteceu com os colonos que acabaram se reinventando para sobreviver?

\section{5 - DESENVOLVIMENTO E MODERNIZAÇÃO DO NORTE/NORDESTE DE MATO GROSSO}

Conforme Santos (2006:142), "a história fornece o quadro material e a política molda as condições que permitem a ação"; no "Nortão" é diferente. Frequentemente se vê a realidade histórico-geográfica interferir nos descompassos entre a política ou seus sistemas de ação, e entre a tecnologia ou seus sistemas técnicos. As recentes "marchas e contra-marchas" da ZSEE demonstram que, em lugar das condições permitidas pelo quadro material, a política não tem tido muito coerência para moldar as condições que redundarão em ações.

4) Redução de $82,40 \%$ das unidades de conservação (perda de 52.000 hectares de áreas protegidas no território do Estado). (YIKATUXINGU, 17/12/2101; 27/02/2012). Conforme informações da assessoria do parlamentar deputado Wilson Santos, a Assembleia Legislativa aprovou, em primeira votação, o projeto de Lei Complementar de autoria do deputado Dilceu Dal'Bosco (DEM), estendendo por mais dois anos o Programa Mato-grossense de Regularização Ambiental Rural (MT LEGAL), cujo objetivo é disciplinar as etapas do Processo de Licenciamento Ambiental de Imóveis Rurais. A medida tranquiliza os proprietários com passivos ambientais, que terão mais tempo para o licenciamento e a regularização fundiária, já que o programa regulamentado pelo Decreto n. ${ }^{\circ} 2.238 / 2009$, tem o encerramento previsto para 13 de novembro próximo (2012). Já para o Zoneamento, as alterações na legislação ambiental estadual também são consideradas. Dilceu Dal'Bosco, que preside a Comissão Especial do Zoneamento Socioeconômico Ecológico (ZSEE/MT), afirma que o substitutivo aprovado na Assembleia Legislativa, prevê a consolidação de regiões antropizadas há décadas, alterando a Reserva Legal de $80 \%$ para 50\%. "O Código Florestal poderá dar ao zoneamento de Mato Grosso autonomia de alterar o percentual da Reserva Legal no Cerrado", concluiu. (DIÁRIO DE CUIABÁ, 11/07/2010; 27/2/2012). 
É comum a espacialização do capital que reorganiza a base produtiva e redefine a estrutura socioeconômica, sem amalgamar seus sistemas para proporcionar uma combinação que favoreça grandes e pequenos produtores e comunidades autóctones. Isto implica em

Reconhecer (e enfrentar), também, diante desse quadro de mudanças e dos seus novos desafios, a evidente dissolução e o anacronismo da regionalização oficial vigente no país, um equívoco conceitual e técnico que obstrui a interpretação desses processos em curso e a operacionalização de políticas de ordenamento territorial e de planejamento regional eficientes. (COSTA, 2005: sr).

Cabe ressaltar que, por conta do anacronismo da regionalização oficial vigente no país e, por extensão, nos Estados representados por suas assembleias legislativas, o poder de refação inerente ao movimento sincrônico dos sistemas técnicos e de ação num território, tropeça no que Costa (2005:sr) denomina como "mosaico de desigualdades sócio-espaciais"; ao invés de atuar como vetor entrópico da modernização, com sua enorme capacidade de mutação, atua apenas no desenvolvimento de um agronegócio para médios e grandes proprietários com capacidade para captar subsídios e empréstimos bancários a baixo custo.

Caso ainda seja considerado que este "mosaico" acontece num território onde a tecnologia de ponta é a principal responsável pelas mudanças de perfil no mercado de trabalho, é fácil deduzir que a espacialização do capital trouxe com ela sérios problemas sociais. Também não é preciso muitas pesquisas para deduzir que estes problemas estão prontos para eclodir em forma de conflitos sociais de difícil solução, por falta de políticas públicas.

Perenemente, estas políticas estão apensas às vontades político-partidárias ou sendo retardadas, de uma forma ou de outra, por lobbies e estratégias coronelistas.

O que aqui se chama de estratégia (é) o cálculo (ou a manipulação) das relações de forças que se torna possível a partir do momento em que um sujeito de querer e poder (uma empresa, um exército, uma cidade, uma instituição científica) pode ser isolado. A estratégia postula um lugar suscetível de ser circunscrito como algo próprio e ser a base de onde se podem gerir as relações com uma exterioridade de alvos ou ameaças (os clientes, os concorrentes, os inimigos, o campo em torno da cidade, os objetivos e objetos da pesquisa etc. Como na administração das empresas, toda racionalização "estratégica" procura em primeiro lugar distinguir de um "ambiente" um "próprio", isto é, o lugar do poder e do querer próprios. (CERTEAU, 2007:99) 
Desde as décadas de 1980 e 1990, as comunidades da região têm empreendido esforços na tentativa de estabelecer normas para quantificar as áreas destinadas à "abertura" de florestas para pastagens e plantações. Nem mesmo as várias audiências públicas e visitas de autoridades do poder público conseguiram que as ideias de uma Amazônia Legal hegemônica se organizassem para criar políticas específicas de desenvolvimento sustentável para o território.

É preciso dar razão a Bauman (2000:159), quando diz que "a indiferença e a apatia políticas dos cidadãos e a renúncia do Estado à sua obrigação de promover o bem comum, são filhos desagradáveis, mas legítimos, da sociedade civil."

Tanto é que, por um lado, houve a oportunidade da colonização organizada pelo governo federal e pelas empresas colonizadoras; por outro, os "negociantes" acrescentavam às propriedades adquiridas do Estado ou de particulares, outro tanto de terras griladas ou tomadas de posseiros sem que pudesse haver qualquer controle, pois os próprios representantes locais do poder público se encarregavam de autorizá-las. Para aqueles que não concordavam com as medições e escrituras de terras, dispostas conforme o desejo dos mais poderosos, havia a truculência dos jagunços financiados por fazendeiros interessados em expandir suas posses, que tratavam de "convencê-los".

A truculência das autoridades ou da força policial contra os pequenos
proprietários, trabalhadores rurais sem terra, migrantes, entre outros,
chamou a atenção nessa região, inclusive pela covardia e arbitrariedade
das ações que eram desfechadas contra os pequenos e humildes, no trato
das questões envolvendo os grandes fazendeiros e seus jagunços; as
ações eram cercadas de cuidados, quando não eram simplesmente
ignoradas, como os casos de trabalho análogo ao escravo verificados nesta
região, desde o início de sua ocupação, os crimes de pistolagem, os
atentados contra a vida de políticos e religiosos, os assassinatos de
posseiros, lavradores, trabalhadores rurais sem terra, as denúncias de
irregularidades na extração de madeira, inclusive dentro de áreas indígenas
e de extração mineral. [...] A exacerbação de toda a autoridade e o exercício
pleno do autoritarismo são vistos com naturalidade. O fim, a defesa da
propriedade, justifica o meio, mesmo que isto signifique a degradação do
ser humano, tanto de quem tortura como de quem é torturado. (JOANONI
NETO, 2007:162)

A exacerbação da autoridade, a ocupação de terras, devolutas ou de propriedade dos caboclos, índios ou colonos eram vistas com tal naturalidade, que o coronelismo passou a merecer o respeito das sociedades locais e da capital, onde se realizavam os "ajustes". Tanto é que "o processo de concentração da propriedade privada em Mato Grosso gerou todas as condições necessárias ao desenvolvimento 
de um dos mais arraigados sistemas de mandonismo local, que originou os coronéis modernos." (MORENO, 2007:44).

Por sua vez, os coronéis modernos espalharam suas benesses pelos partidos políticos e "acomodaram" seus apadrinhados nas mais diversas áreas e escalões de órgãos do governo do estado ${ }^{40}$. A intenção era comandar as políticas a serem implantadas nos novos municípios que estavam surgindo ao longo da BR-163, com uma forte tendência a servirem de "forragem" para negociatas com multinacionais e grandes empresas exportadoras de commodities.

O espaço deixou de ser um direito de uso, de acordo com as atividades praticadas anteriormente na região da Amazônia Legal, e passou a compor um título de propriedade privada da terra, coerente com o tipo de atividade econômica em expansão que é a agricultura integrada (mais cedo ou mais tarde) ao sistema nacional de produção capitalista. (CASTRO et al, 1994:18)

Portanto, existe responsabilidade direta, tanto do coronelismo local quanto do governo federal na violência que se instalou na região, uma vez que tanto a burguesia quanto o poder público eram coniventes em todos os atos praticados por jagunços e pela polícia, a pedido dos mais poderosos.

Daí surgem questões tais como: de que modo se adaptou e se transformou esta gente para manter a rede de indivíduos que participa de funções autoreguladoras tais como a falta de políticas para integrar as comunidades autóctones? O que pretende fazer com as políticas para a demarcação racional de áreas indígenas e controle sobre as negociações de ocupação de terras realizada diretamente entre índios e não-indios? De que forma pretende intervir nos diferentes tipos de controle que o poder público não tem tido a capacidade de executar para adequar os planos de manejo ao plantio e desmatamento sustentável? Que políticas públicas imagina, para dar suporte às comunidades indígenas e pequenos agricultores da região, de modo a contribuir com projetos para construção de

\footnotetext{
40 "Era comum ocorrerem demissões em massa a cada ascensão partidária ao governo do Estado para a admissão de correligionários e cabos eleitorais, em funções administrativas diversas. Por conta dessa prática, Fernando Corrêa da Costa, duas vezes governador, tornou-se conhecido como "mão-de-chumbo". Também o aliciamento de bases, pela filiação partidária, e a destinação de "postos de confiança" a parentes ou cabos eleitorais da política partidária, eram práticas comuns no sistema de revezamento do comando do poder estadual. Essa prática estendeu-se ao controle na distribuição das terras devolutas estaduais. Cada governo que assumia, suspendia as concessões, as vendas e a tramitação normal dos processos de regularização, para fazer um balanço das terras alienadas e submeter o órgão de terras a uma devassa. Depois procedia à rápida regularização das terras alienadas de interesse do governo e seus correligionários e à paralisação ou engavetamento dos processos pertencentes a adversários políticos. Além disso, as irregularidades encontradas serviam de plataforma política nas disputas eleitorais subsequentes". (MORENO, 2007:58).
} 
estradas vicinais em condições razoáveis de tráfego viabilizando o ir e vir destas comunidades e facilitando o escoamento da produção legal dos pequenos?

Independente de todas as questões bastante complexas que foram se criando ao longo do desenvolvimento destes municípios, voltamos a pergunta básica: haverá interesse do poder público em contribuir neste processo? Afinal,

O governo não é apenas investido de poder para o exercício de um mandato sem maiores vínculos, por meio de uma eleição entre grupos de liderança concorrentes; ao contrário, ele está comprometido também programaticamente com a execução de determinadas políticas. (HABERMAS, 2007:290).

Em Bernardes (2005:31) se lê que "esse conjunto de interesses e forças interagindo foi desenvolvendo técnicas, criando fluxos, implicando em maior rapidez na circulação do capital e exigindo a reestruturação do território". Esta reestruturação, porém, apesar do desenvolvimento de técnicas, foi ficando aquém do necessário e dificultando a fluidez dos fluxos e a circulação do capital.

As políticas de tecnificação da agricultura que começavam a ser implantadas na região, já sinalizavam que o grande divisor socioeconômico seria a qualificação da mão-de-obra ${ }^{41}$.

Como analisou Santos (2007),

A nova estrutura da acumulação tem um efeito certo sobre a organização do espaço, visto que ela agrava as disparidades tecnológicas e organizacionais entre lugares e acelera o processo de concentração econômica e geográfica. (SANTOS, 2007:23).

Esta talvez tenha sido a forte motivação das famílias que permaneceram na região, mesmo que soubessem das dificuldades, algumas poucas famílias continuariam vivendo da produção agrícola. Entre os que resolveram ficar, a maioria sequer tinha para onde ir; outros nem mesmo tinham condições financeiras para voltar às suas origens ou seguir até outras áreas abertas à migração.

O agricultor que não demonstrou eficiência para acompanhar o trabalhonegócio, foi punido publicamente, ou seja, se por algum motivo deixou de

\footnotetext{
41 "O colono do sul foi transformado em excluído e destituído material e simbolicamente de seu espaço e de seu direito ao espaço ali. Daí a migração não poder ser vista como opção, mas como imposição. Uma vez na área, as condições postas a estas pessoas não lhes permitiu mais do que a reprodução de sua condição de camponês e se a princípio, com um lote maior, bastaram alguns anos para que voltassem à condição original de minifundiários, houve projetos onde essa condição não foi imposta aos colonos, mas a super-exploração veio na condição de um rigoroso direcionamento do que produzir, como e com quem comercializar e a que preço. Mudou-se a forma, o resultado foi o mesmo. [...] Os baixos preços das terras ocultaram a falta de e o verdadeiro caráter dos projetos [...] serviu(ram) para desviar as atenções e aliviar as tensões (econômicas, sociais e políticas), nas áreas que estiveram sob sua influência (dos projetos), além de auferir polpudos lucros a um pequeno grupo de empresários reconhecidos, hoje, em todo o Norte do Estado de Mato Grosso, como "Bandeirantes Modernos", "Desbravadores", ou "Pioneiros"." (JOANONI NETO, 2007:81).
} 
cumprir os contratos firmados com o Banco do Brasil para financiar a safra, os bens sob a jurisdição do banco eram levados a leilão público. Sobrava ao agricultor se sentir aniquilado em seus valores morais e carregar no rosto as marcas do sofrimento e da humilhação. (ZART,1998:75)

Mas, "o espaço se transforma para se adaptar às necessidades da sociedade" (SANTOS, 2007:54) e, por isto, muitos agricultores perceberam que "o crescimento econômico não seria encontrado através de uma procura cega de crescimento por si mesmo, e sim como expansão de forças produtivas da sociedade com o objetivo de alcançar dos direitos plenos de cidadania para toda a população." (FRIEDMANN,1996). Assim, houve necessidade de se criar uma nova estrutura de acumulação, independente da lavoura à qual os agricultores estavam habituados, para poder sobreviver.

Por isto, precisavam criar uma identidade coletiva que espelhasse as individualidades e subjetividades de grupos que haviam deixado suas estruturas para trás; construiriam uma nova vida, sem bases sólidas como: família, Estado e segurança, porque possuíam apenas a si mesmos para continuar numa estrada que sequer sabiam para onde os levaria. Frente a uma situação nova, precisavam se reinventar e como explica Elias (1994:45). "todas essas mudanças se originavam na estrutura da vida conjunta de muitos e não na natureza dos indivíduos isolados. A história é sempre história de uma sociedade, mas sem a menor dúvida, de uma sociedade de indivíduos".

Para entender como desencadeou este processo de nova identidade coletiva, no capítulo seguinte é apresentada a "estrutura da vida conjunta de muitos e não na natureza dos indivíduos isolados", numa região que, hoje, está longe de ser uma "terra sem homens para homens sem terra", como dizia o slogan da ditadura militar. 


\section{CAPÍTULO}

\section{OS IMIGRANTES PIONEIROS E AS CIDADES DA ÁREA DE ABRANGÊNCIA DA BR-163}

\section{1 - "UMA TERRA SEM HOMENS PARA OS HOMENS SEM TERRA"}

Quando a ditadura militar usou o slogan "terra sem homens para homens sem terra", cometeu duas veleidades. Uma foi ignorar a população autóctone porque, apesar da baixa densidade demográfica, ali vivia um número expressivo de índios e caboclos que foram deslocados ou mortos para dar lugar aos colonos ou empresas colonizadoras que "lotearam" boa parte da região amazônica. A outra foi imaginar que resolveria a questão da reforma agrária no Rio Grande do Sul e em Santa Catarina, simplesmente deslocando aquelas pessoas para o meio da selva, em condições precárias de sobrevivência, esperando que elas transformassem e urbanizassem, sem qualquer apoio, as áreas para as quais foram destinadas.

É importante lembrar que, para integrar a região amazônica às regiões centrooeste e sudeste, sob a proposta de "integrar para não entregar" estava embutida a intenção de ampliar fronteiras para, povoando-as, manter a imanência amazônica e a proteção do território. Para tal, seria necessário um aporte mínimo do Estado, algum recurso, durante os dois primeiros anos, de modo que os imigrantes se mantivessem até que a lavoura lhes rendesse algum lucro de subsistência.

\footnotetext{
Toda a colonização traz consigo os mesmos mecanismos estruturais: primeiro, projeta-se os Figuras a fração do território a ser tomado e todos os meios são válidos para justificar a conquista, trazendo nesse processo o conflito entre etnias e/ou classes ou frações de classes que acabam sendo culturalmente domesticadas e dominadas. Essa subordinação estrutura-se por intermédio das empresas de colonização e consolida-se com a sua transformação em municípios. Assim os proprietários das colonizadoras se tornam os novos "coronéis da política local". (OLIVEIRA, 2005:125).
}

No processo de colonização da área de abrangência da BR-163, não só as etnias autóctones foram culturalmente dominadas, como os próprios imigrantes, atraídos dos estados do sul do Brasil, foram enquadrados nos moldes dos novos coronéis da política local.

Este enquadramento, apesar de 0 isolamento e da frustração que acarretaram, deu aos imigrantes forças para superar as vicissitudes e 
metamorfosear suas perspectivas, enquanto grupo social dominado pelas políticas adotadas pelo Estado e pelas colonizadoras.

Os imigrantes transformaram-se, deste modo, em construtores de sua própria ideologia (individual e coletiva) usando esta metamorfose como alavanca para superar o medo, a coação, a manipulação e a omissão do poder público que deveria ter exercido sua função de agente de proteção dos direitos e do exercício da cidadania.

Os homens, para produzirem seus bens de vida e reproduzirem as condições sociais de vida e adquirir sua consciência, não estabelecem relações conforme as suas vontades independentes, mas sim de conformidade com as circunstâncias que legaram para e na história. Não é a consciência dos homens que determina o seu ser; é o seu ser social que, inversamente, determina sua consciência. (MARX, 1986:28); apud ZART, 1998:27.

Conforme comenta Zart (1998:27) a este respeito, "os homens se fazem livres e criativos tendo como ponto de partida a base material e cultural na qual estão condicionados"; por isso se lançam na produção de seus bens de sobrevivência conforme a necessidade de cada um, deixando que as circunstâncias direcionassem os seus atos; nesta trajetória nascerá uma nova consciência social, bem como novos conceitos morais e éticos que se adequarão à nova realidade.

Os imigrantes da área de abrangência da BR-163 só se fizeram livres e criativos tendo como ponto de partida suas bases materiais e culturais, como cita Zart; e o fizeram por uma questão de sobrevivência, pois não foram os colonos que escolheram Mato Grosso, um ponto geográfica e culturalmente tão distante de suas bases; a eles foi proposto um lugar melhor para viver.

O colono é que foi escolhido, buscando a terra e tudo o que ela representava para ele, imaginando um espaço sagrado, onde poderia viver dignamente, produzir e criar seus filhos. (JOANONI NETO, 2007:220).

Concluiu-se, portanto, que esta migração, tão abalada por improbidades administrativas tanto por parte do governo federal quanto do estadual, deveria guardar vários "fatores invisíveis", como coloca Santos (1988:sr), que "formas cada vez mais complexas de realidades, relações sociais e acumulação do capital vão se formando e exigindo uma observação mais aguçada do que se percebe à primeira vista."

Para pesquisar estes "fatores invisíveis" no processo de ordenamento e modernização do território, levou-se em consideração que "como técnicas de 
complexidade crescente, os objetos são solidários estrutural e funcionalmente, pois não trabalham isoladamente" (SILVEIRA, 1997:37). Some-se a estes fatores, a afirmação de lanni, (2004:157) ao lembrar que "muitas famílias reconhecem que ao aceitarem promessa de formar lavouras na Amazônia, estavam ajudando a ditadura a escamotear a questão da reforma agrária".

Porém, a grande maioria não tinha consciência de estar participando de uma trama que resultou perversa para praticamente todos os que acreditaram nas propostas e colonização do governo federal.

\begin{abstract}
Após a construção do território, fundamento concreto do Estado, este passa a produzir um espaço político, o seu próprio espaço, para exercer o controle social, espaço constituído de normas, leis, hierarquias. Para tanto, impõe sobre o território uma malha de duplo controle - técnico e político constituída de todos os tipos de conexões e redes, capaz de controlar fluxos e estoques, e tendo as cidades como base logística para a ação. (LEFEBVRE,1974:279)
\end{abstract}

É nesta construção que talvez as famílias tenham cedido seu próprio espaço à política imbricada nas ações do Estado, permitindo que valores e costumes passassem por mutações radicais, praticamente híbridas para quem estava reconstruindo sua história; um novo perfil que só a própria história da região e suas comunidades são capazes de explicar.

Para identificar o avanço da fronteira agrícola provocado por empresas colonizadoras, posseiros e, posteriormente, por pecuaristas e pelo agronegócio, procurou-se identificar por que as necessidades locais foram fixadas em função de imperativos econômicos que trouxeram com eles um caráter contingente. Como pondera Lefebvre (2004:70-71), a solução premente para instituir o avanço da fronteira agrícola "erigiu-se acima das necessidades, enquanto instituições que as estruturam, e aquém das necessidades, que se configuram em elã, a energia vital, a pulsão ou como se queira chamar".

A pulsão ou elã citados por Lefebvre erigiu-se a partir de um movimento de caráter contingencial, na medida em que as necessidades levaram as comunidades locais a se estruturar para superar-se.

Tanto é que, conforme Müller, de acordo com um texto veiculado em 2006 pela Casa Civil do Governo do Estado de Mato Grosso,

Levantamento realizado pelo Instituto do Homem e Meio Ambiente da Amazônia (IMAZON) revela que há cerca de 24 mil $\mathrm{Km}$ de extensão de estradas endógenas (isto é, construídas pelos agentes econômicos locais 
sem envolvimento de recursos públicos), tendo sido a maioria dessas estradas abertas por madeireiros, de forma ilegal em áreas florestais Amazônicas, causando severos danos ambientais. Muitas dessas estradas foram abertas em terras públicas, o que facilita também a grilagem e a eclosão de conflitos violentos (CASA CIVIL et al., 2004, apud MÜLLER, 2006).

Desde as décadas de 1980 e 1990, as comunidades da região têm empreendido esforços na tentativa de estabelecer normas para quantificar as áreas destinadas à "abertura" de florestas para pastagens e plantações.

O que se sabe, de concreto, é que embora a divulgação sobre a região privilegie as estruturas econômicas do agronegócio, a estratégia do Plano Regional da BR-163 contemplou quatro grandes eixos temáticos que, até então, não avançaram, nem se tem notícia de algum tipo de planejamento público visando a concretização de:

1) Ordenamento territorial e gestão ambiental;

2) Inclusão social e cidadania;

3) Fomento às atividades produtivas;

4) Para o desenvolvimento.

Além de algumas normas de sustentabilidade estabelecidas para 0 agronegócio (raramente cumpridas), não houve ainda nenhum tipo de conciliação para os itens contemplados nos eixos temáticos do Plano Regional da BR-163. Neste ponto, as políticas públicas para a Amazônia Legal não passam de discussões de interesses que colocam, de um lado, o favorecimento de novos investimentos para infraestrutura; de outro as populações locais e a proteção ambiental.

\begin{abstract}
As políticas públicas para a Amazônia passaram a refletir o interesse nacional em seus valores históricos atualizados pela incorporação das demandas da cidadania, e é essa transição que se expressa em duas políticas públicas paralelas desarticuladas e conflitantes. Ambas visam o desenvolvimento numa estratégia territorial seletiva, mas o desenvolvimento previsto por uma e pela outra, mais que diversos, são opostos. Uma baseiase no favorecimento de novos investimentos para infraestrutura e outra está direcionada para as populações locais e a proteção ambiental. (BECKER, 2004:127).
\end{abstract}

A dicotomia de políticas públicas paralelas, desarticuladas e conflitantes sobre a qual Becker (2004) discute, tem atuado como bridão para as ações direcionadas às populações locais e de proteção ambiental. Os interesses capitalistas articulam 
lobbies junto ao poder público e assim forçam o favorecimento das políticas de investimentos em ampliação de fronteiras agrícolas.

Esta questão já é uma prerrogativa de autoridades dos três poderes representadas em Mato Grosso, desde que iniciou a colonização e fundação de cidades, na década de 1960. Com a divisão do Estado, em 1979, o clientelismo parece ter se perenizado nas transações fundiárias. Em entrevista gravada em Cuiabá, MT, em outubro de 2012, com Paulo Pitaluga Costa e Silva, Coordenador Geral do INCRA entre maio de 1979 e maio de 1982, este desabafou:

\begin{abstract}
Hoje o INCRA é uma anarquia, uma vergonha; hoje eu não teria a mínima condição física ou psicológica de aguentar a pressão que eu aguentava. Desde autoridade até grileiro, posseiro, de tudo! A pressão de políticos era mais institucional: "Pô, precisa porque os caras não têm acesso ao crédito", não sei o que, tal coisa. Mas quando eles estavam encima de área da União, a gente dava uma carta de anuência para o Banco do Brasil e resolvia. Mas para receber esta carta de anuência, o cara tinha de ter alguns antecedentes. Tinha de estar encima de terra da União e tinha de ter processo em nome dele no INCRA, para a regularização fundiária do assentamento. Depois trocaram isso pelos termos de ocupação - TO. Então neste termo já estava a anuência para o Banco, não para investimento, mas para a lavoura, sementes, adubo, estas coisas.
\end{abstract}

O mesmo corporativismo continua na discussão sobre o novo Código Florestal que aumenta em 150\% o limite legal para desmatamento nas fazendas da Amazônia e dá anistia aos fazendeiros que já desmataram ilegalmente suas propriedades nos últimos sete anos.

Apesar de os lobbies bem sucedidos de políticos apadrinhados pelo agronegócio, o assunto encontrou uma Nação disposta a discutir sua probidade. Para isto foi criada uma enorme mobilização nacional pela internet que redundou numa análise criteriosa do teor da lei, por parte da presidente Dilma Rousseff, antes de sancioná-la nos termos aprovados na Câmara dos Deputados.

Paralelo à dicotomia discutida por Becker (2004), Giddens (2007:23) lembra que "um Estado sobrecarregado e burocrático não é apenas pouco propenso a prestar bons serviços públicos; é também disfuncional para a prosperidade econômica."

Muitas pessoas da região perceberam que o Estado, sobrecarregado e burocrático, não prestava bons serviços públicos e também era disfuncional. Por isto partiram para a construção de seus patrimônios com muito esforço pessoal para vencer as vicissitudes que se apresentavam tanto com o patrocínio do poder público quanto sob o comando de proprietários de grandes áreas. É provável que tenha 
acontecido com estas pessoas o que Santos e Silveira (2005:47) denominam de "ideologia do consumo, do crescimento econômico e do planejamento",

\begin{abstract}
Que foram os grandes instrumentos políticos e os grandes provedores das ideias que iriam guiar a reconstrução ou a remodelação dos espaços nacionais, juntamente com a da economia, da sociedade e, portanto, da política. Para realizar qualquer desses desígnios impunha-se equipar o território, integrá-lo mediante recursos modernos. O caminho da integração do território e da economia apontado para todos os países era tanto mais facilitado e tanto mais rápido quanto maior o número de opções a atingir, a organizar, como é o caso do Brasil. (SANTOS E SILVEIRA, 2005:47).
\end{abstract}

No entanto, seguindo o processo natural de urbanização e seu caminho da integração do território com a economia, as comunidades destes municípios precisaram produzir e, ao mesmo tempo, controlar seu território porque "como a sociedade sempre se apresenta fragmentada em grupos, classes, castas etc, os graus de controle se afirmam conforme os recursos e as possibilidades dos grupos ou indivíduos para efetivamente exercê-lo." (ANTAS JÚNIOR, 2005:52).

A pesquisa com estas pessoas que se reinventaram está embasada no tipo de transversalidade que imaginam adotar, para reestimular a coesão horizontal e mantê-la a serviço da sociedade civil. Neste momento se percebe um direcionamento de suas ações no sentido de influenciar os mecanismos de prestação de serviços para o ciclo do agronegócio (preparo da terra, plantio e transformação).

Esta influência deve configurar, ao mesmo tempo, políticas de proteção para que as próximas gerações, sobretudo seus descendentes, possam continuar vivendo na e da Floresta Amazônica. A sociedade civil deverá desenvolver argumentos para enfrentar as tantas discussões que, inevitavelmente, irão encontrar tanto na ação irresponsável de alguns madeireiros e agropecuaristas, quanto na falta de comprometimento do Estado com a realização das políticas públicas necessárias para a região.

No caso dos municípios focados nesta pesquisa, a possibilidade que encontraram foi literalmente fragmentar o espaço ocupado pela população, em núcleos divididos por classes sociais, ou seja, a disposição imobiliária dividiu-as em setores pobres e setores ricos, separados pelo traçado da BR-163.

Esta divisão não teria maiores problemas não fosse a discriminação que existe em relação a um dos lados da rodovia, onde vivem as classes menos favorecidas que, em sua maioria, são pessoas que "pararam" na cidade; ou porque o 
trabalho pelo qual buscavam havia deixado de existir em função da entrada do maquinário na produção, ou por não terem encontrado mais vagas na colheita em nenhuma parte da região, como é o caso dos cortadores de cana, dos colhedores de soja, dentre outros.

\begin{abstract}
Pobreza e riqueza são realidades antagônicas, embora complementares, pois uma não pode existir sem a outra. O problema de eliminar a pobreza, isto é, de suprimir as diferenças de renda criadas por um processo produtivo gerador de desigualdades, supõe uma mudança no próprio processo produtivo, o que vale dizer, das relações do homem com a natureza e dos homens entre si. É inútil imaginar que a pobreza poderá ser eliminada sem a modificação da atual estrutura da produção, dos investimentos e do consumo. (SANTOS, 2007: 68)
\end{abstract}

A estrutura da produção dos municípios pesquisados está longe de realizar qualquer tipo de modificação que elimine a pobreza ou provoque um movimento centrípeto em direção aos investimentos para absorver esta mão de obra que acabará acionando a cadeia de consumo e o comércio local.

A impressão que os poderes públicos locais passam, é que em função do grande contingente de imigrantes existente e diante da quantidade que continua chegando à região, apesar das campanhas de estorno, as políticas públicas para lidar com o assunto são fracas diante do grave problema em ebulição silente. Até hoje, só se sabe do trabalho sistemático das Secretarias de Ação Social, no sentido de estornar imediatamente para suas origens os que chegam com condições socioeconômicas precárias.

\footnotetext{
Atualmente parte do grande contingente de migrantes que chega a determinado município, fica sob a responsabilidade da assistência social local, uma vez que essa categoria de trabalhadores é expropriada dos meios de produção e explorada em sua força de trabalho e seus direitos de cidadãos. Cabe, assim, a essa entidade uma mediação entre as classes, com o intuito de amenizar as contradições sociais, pois "a desigualdade é para ser administrada e não superada". (CUTTI,1995:16).
}

No caso destes municípios, não cabe a mediação porque a mão de obra que necessitam precisa ser especializada. Conforme veiculado pelo site da SEPLAN (Secretaria de Planejamento do Estado de Mato Grosso), ela reconhece que:

No Centro-norte estão áreas mais dinâmicas de crescimento econômico e demográfico, com atração migratória, embora em níveis menores que as últimas duas décadas. Destaca-se o eixo da Rodovia BR-163 (Rodovia Senador Jonas Pinheiro), sobretudo os municípios de Lucas do Rio Verde, Sorriso e Sinop. (SEPLAN, 2012). 
Esta realidade constatada pela Secretaria de Planejamento do Estado é de certa forma explicada pelo Assessor de Planejamento do Município de Sorriso, Sr. Ary Junior, quando esclarece em uma entrevista feita em 19.09.2012 na Secretaria de Ação Social da Prefeitura:

Além da Prefeitura, eu dou assessoria a outras empresas privadas também,
para as quais e já tive oportunidade de entrevistar, para seleção, mais de
mil pessoas. E isso me chamou a atenção em várias situações. Sorriso é
uma cidade que cresce e não tem conflito social. Isto me intrigou. Quando
eu cheguei aqui, isto me intrigou, porque é uma minoria que tem um
processo de subserviência permitido.

Neste trecho da entrevista, o Sr. Ary Junior se referia aos migrantes de baixo poder aquisitivo que ainda chegam em grande quantidade do Maranhão e continuou expondo seu ponto de vista:

Para entender esse processo de ocupação antropológica e social, eu fui
acompanhando um mapeamento da cidade para entender porque isto não
gera conflitos quando eu tenho uma minoria que opera num setor de
subserviência porque opera no primeiro setor da indústria que é onde
colheu, esmagou. então este primeiro setor á quase que escravagista,
porque se paga lá seiscentos reais por pessoa que antes ganhava cento e
cinquenta no Maranhão, vem pra cá ganhando seiscentos, compra um
celular... e isso eu fui à noite, de madrugada no São Domingos ${ }^{42}$ porque nós
temos, geograficamente, uma linha que divide isto, que é a BR-163.

Numa outra face do problema estão reivindicações do grande contingente indígena que vive na área de abrangência da BR-163, onde persistem os embates por conta da falta de parâmetros legislativos que ordenem o território indígena e APP (Áreas de Preservação Permanente).

A falta de parâmetros é ratificada pelo índio Marcos Terena numa entrevista transcrita por Edgar Morin:

Nós debatemos muito com as ONGs ecológicas que dizem: não pode. Mas vêm o Banco Mundial e o Banco Interamericano, resolvem fazer uma hidrovia ou uma estrada e aí pode. É o poder que o submisso aceita, o poder do dinheiro. Nós, os índios, estamos procurando encontrar um caminho daquilo que vocês chamam de desenvolvimento sustentável, na linguagem de vocês. Porque se a gente não entender a linguagem de vocês, vamos continuar marginais e apanhando cada vez mais. (EDGAR MORIN, 2008:48-49).

De acordo com informações recebidas durante as pesquisas de campo, existem ONGs trabalhando no sentido de orientar e defender as diferentes etnias indígenas em situação de risco e, ao lado destas, existem outras especializadas em

\footnotetext{
${ }^{42}$ Bairro habitado por pessoas de classes menos favorecidas, praticamente todas originários do Maranhão.
} 
biopirataria e contrabando de biodiversidade amazônica, que aliciam índios, conhecedores da floresta, para lucrar com a contravenção, conforme denúncias dos moradores da região.

Independente deste aspecto, não há planejamento de médio e longo prazos por parte dos governos federal e estadual, muito menos um programa de debates para ouvir as comunidades a respeito das desterritorializações e reterritorializações que vêm ocorrendo em função de obras na região (estradas, hidrelétricas, desvios de rios etc.), em detrimento das comunidades autóctones.

Durante a entrevista realizada em 21.06.2011 com o Deputado Mauro Savi (Partido Republicano), que é de Sorriso, ele desabafou:

\begin{abstract}
Depois de seis anos de muita discussão com o governo (1978/1984), nós descobrimos que nem existia projeto dentro do Denit. [...] Nós fizemos projetos, criamos comitês, fomos atrás de parcerias e não tinha projeto. Foi a coisa mais absurda que eu escutei na minha história como ser humano e como político. Um sonho que estava lá e eu achando que o projeto tinha mais ou menos umas 30 páginas, e não tinha projeto. Nada do que se possa pensar em termos de políticas públicas para o entorno da BR-163, envolvendo assentamentos, índios etc, tem projeto.
\end{abstract}

Estes problemas com as comunidades autóctones acabam refletindo nos núcleos urbanos, uma vez que índios e caboclos vão buscar nas cidades a assistência do poder público, porque suas condições de sobrevivência são cada vez mais precárias, em função do avanço das fronteiras do agronegócio que acaba privando-os da caça e da pesca de subsistência.

Aparentemente não se percebe nenhum esforço extra para agilizar os programas de infraestrutura, incluindo a construção de casas populares, escolas, hospitais etc. O déficit habitacional em função do crescimento natural das populações destes municípios e a contínua chegada de migrantes têm causado enormes problemas não só de moradia como de vários setores da infraestrutura urbana.

Quadro 01 - Crescimento Demográfico

\begin{tabular}{|l|c|c|c|c|c|}
\hline \multicolumn{1}{|c|}{ Municípios } & $\mathbf{2 0 0 0}$ & $\mathbf{2 0 1 0}$ & $\begin{array}{c}\text { Crescimento } \\
\text { Demog. 2000/2010 }\end{array}$ & $\begin{array}{c}\text { População } \\
\text { urbana }\end{array}$ & $\begin{array}{c}\text { \% urbano sobre } \\
\text { o total de 2010 }\end{array}$ \\
\hline Lucas do Rio Verde & 19.316 & 45.556 & $133,66 \%$ & 42.455 & $93,19 \%$ \\
\hline Sinop & 74.831 & 113.099 & $49,19 \%$ & 93.753 & $82,89 \%$ \\
\hline Sorriso & 35.605 & 66.521 & $84,63 \%$ & 58.364 & $87,74 \%$ \\
\hline
\end{tabular}

Fonte: IBGE, Censo Demográfico (2010) 
O crescimento populacional destes três municípios registrou uma média de $89,16 \%$ entre 2000 e 2010, conforme dados do IBGE apresentados no Quadro 02 acima.

O avanço tecnológico que subtrai mão de obra à proporção que incorpora maquinário de ponta no agronegócio, eclode numa outra extremidade com o desemprego e a miséria. Some-se a esta circunstância, a realidade das populações locais que, mais uma vez, precisa se reinventar, distante das commodities produzidas na região, sem poder contar com as facilidades econômico-financeiras que o mercado e os poderes constituídos oferecem aos grandes produtores.

No entender das autoridades locais, as cidades, hoje, têm condições de viver da prestação de serviços, mas tudo depende do sucesso das colheitas, porque o comércio foi criado sobre as necessidades do agronegócio. Talvez por conta destas circunstâncias, acabou ficando num segundo plano a questão da moradia, do emprego ou de como estão vivendo as pessoas que, no fundo, são as principais responsáveis pelo sucesso destes municípios enquanto urbanidades com um nível de crescimento verticalizado.

A verticalização dos municípios da área de abrangência da BR-163, associada à transformação das grandes e médias fazendas em empresas, deu outro perfil a estas urbanidades. Hoje, não existe mais área urbana e rural na região, uma vez que o reordenamento regional e a busca por conforto levou a maioria dos empregados das fazendas a viver nos núcleos urbanos mais próximos dos locais de trabalho.

Por outro lado, existem muitos proprietários que vivem em cidades distantes que administram suas fazendas a partir dos seus escritórios em Cuiabá, São Paulo, Goiânia ou região sul do Brasil. Em função da alta tecnologia e mecanização empregadas nas fazendas os grandes proprietários têm condições de monitorá-las à distância.

\footnotetext{
O fato da cidade hoje é, também, o fato do campo. Ciência, tecnologia e informação fazem parte dos afazeres cotidianos do campo modernizado, através de sementes especializadas, da correção e fertilização do solo, da proteção às plantas pelos inseticidas, da superimposição de um calendário agrícola inteiramente novo, fundado na informação, o que leva às cidades do interior um coeficiente de modernidade. (SANTOS, 1994:45).
}

O coeficiente de modernidade provocado pela ciência, pela tecnologia e pela informação, mesmo que façam parte dos afazeres cotidianos do campo moderno, 
também precisam ser responsabilizados pela relativização das questões de direito e territorialidade. Essas questões têm assumido grandes proporções na área de abrangência da BR-163, uma vez que os grandes grupos corporativos estão participando ativamente da regulação da Amazônia Legal.

A transversalidade da tecnologia de ponta no contexto do ordenamento do território da Amazônia Legal Mato-grossense sugere que, numa ponta existe a política coronelista articulada na capital, vivendo ainda com a letargia nostálgica da manipulação; em outra ponta está o agronegócio vivendo com as articulações do poder econômico que emana do interior do Estado e ganha espaço internacional. Não há como parar o curso da modernização, mas há como ordenar seu fluxo com sustentabilidade, desde que hajam políticas bem estabelecidas para tal.

As questões que ainda ficam sem resposta são: onde se situa o direito do pequeno agricultor, dos povos indígenas, da produção equilibrada com o espaço que dará sustentação ao futuro desta territorialidade que vive em franco descompasso de sistemas técnicos e sistemas de ação?

Partimos então do entendimento de que o espaço geográfico é fonte material e não-formal do direito e de que as decisões sobre as políticas de produção do território implicam a produção de normas que afetam o conjunto da sociedade. As decisões são inequivocamente ações humanas, as políticas territoriais são implementações de objetos e sistemas técnicos. (ANTAS JÚNIOR, 2005:2).

Cabe, portanto, ao Estado, em conjunto com as lideranças representativas dos principais segmentos da comunidade local, influir nas políticas de produção do território; isto implicará na produção de normas que deverão atingir o conjunto desta sociedade. Porém,

Quando o trabalho no campo não pertence mais ao trabalhador rural, a racionalidade se disseminará em trabalho abstrato e, sob a hermenêutica do capital, criará uma competitividade que, por sua vez, provocará a desagregação e a ingovernabillidade. (SANTOS, 1992:s/n)

As chances de ingovernabilidade têm aumentado e ainda aumentarão mais, se as políticas territoriais continuarem a ser formuladas ao sabor de interesses específicos e pontuais, seguindo a hermenêutica do capital, grande responsável pela racionalização que distancia o trabalhador do campo, quando não o prepara para as mudanças que tornam o trabalho abstrato. 
Devolver o trabalho no campo ao trabalhador rural significa adequá-lo às modernizações exigidas pelo agronegócio neste novo perfil de mercado de trabalho, oportunizando-Ihe a participação no processo de ordenamento do território.

$$
\begin{aligned}
& \text { Enquanto imaginarmos que nossos conflitos são questões objetivas, } \\
& \text { estaremos presos na ilusão do desejo mimético. É este desejo, e somente } \\
& \text { ele que investe os objetos com um valor que não possuem. Em si mesmos, } \\
& \text { não contam, não são nada. (LATOUR, 2009:49). }
\end{aligned}
$$

Não há como permitir que os conflitos existenciais se transformem em ilusão do desejo mimético, investindo em valores que não possuem. Esta pode ser uma das faces invisíveis mais relevantes para a discussão sobre o contexto do ordenamento do território mato-grossense. Enquanto parceiro de mais oito estados que compõem a Amazônia Legal, Mato Grosso pode discutir suas idiossincrasias, sem o desejo mimético de políticas improvisadas e pontuais que favoreçam apenas um pequeno grupo.

\section{2 - "OCUPAR PARA NÃO ENTREGAR"}

O mesmo lema que deu asas aos projetos idealizados pelo governo federal nas décadas de 1960 e 1970 transformou-se em mote para os imigrantes pioneiros da região norte de Mato Grosso. O que antes significou uma ameaça à soberania brasileira na área depois conhecida como Amazônia Legal, não demorou muito para representar uma ameaça à soberania dos que acreditaram no sonho prometido aos imigrantes que, mesmo com os sacrifícios causados pela falta de infraestrutura, pretendiam persistir e vencer. Para eles não havia caminho de volta. Era dar certo ou dar certo.

\footnotetext{
O futuro é formado pelo conjunto de possibilidades e de vontades, mas estes, no plano social, dependem do quadro geográfico que facilita ou restringe, autoriza ou proíbe a ação humana. Alcançar inelectualmenteo futuro não é questão estatística, nem simples arranjo de dados empíricos, mas questão de método. (SANTOS, 2005:130).
}

O futuro formado pelo conjunto de possibilidades e de vontades que moveu os imigrantes pioneiros, dependia de um quadro geográfico que mais restringia do que facilitava, mais proibia do que autorizava a ação humana numa região à primeira vista inóspita, por seu clima quente e terras de Cerrado. 
Conforme afirmaram vários imigrantes pioneiros ouvidos nas entrevistas in loco, durante muito tempo o governo do estado simplesmente ignorou todos daquela região. Apesar das inúmeras deputações para conseguir a infraestrutura básica das aglomerações que cresciam rapidamente, ou o asfalto da BR-163, os avanços foram lentos e os progressos para as demandas, quando não eram conquistados pelos próprios imigrantes pioneiros trabalhando em mutirão, só eram alcançados graças à forterepresentação política do agronegócio que aos poucos foi tomando força.

Em pouco tempo a BR-163 rasgou a floresta amazônica e deu passagem aos imigrantes que transformaram o caminho da ocupação em corredor de commodities produzidas para exportação.

Paralelo ao crescimeto do agronegócio, as povoações que nasceram ao longo das rodovias continuaram recebendo imigrantes e se transformaram em prósperos municípios. Assim, em menos de trinta anos, o espaço amazônico foi se transformando numa região cujo espraiamento contrapunha-se a qualquer previsão de crescimento demográfico. "A população urbana das aglomerações com mais de 20 mil habitantes cresce mais depressa que a população total e que a população urbana do país, e o mesmo fenômeno também se verifica em escala regional. (SANTOS, 2005:80)

O crescimento destas cidades aqui identificadas como de pequeno e médio porte $^{43}$, de acordo como os dados da ONU (Organização das Nações Unidas), transformaram a a região num polo de desenvolvimento.

Este conceito de região, de acordo com Santos (1988),

Inclui-se num contexto maior, onde também não podemos mais falar da clássica noção de rede urbana; assim como não podemos mais referir-nos às clássicas noções de relação cidade-campo. Não é que não existam ainda hoje estas relações, mas mudaram de conteúdo e de forma. (SANTOS, 1988:17)

Hoje a rede urbana, a relação cidade-campo, o espaço em si, enquanto arranjo de objetos naturais, geográficos e sociais, embora dê vida à sociedade que nele se movimenta, é comumente manipulado pelos interesses do capital. O espaço,

\footnotetext{
${ }^{43}$ Para a ONU, qualquer agrupamento com mais de 20 mil pessoas pode ser considerado urbano. $\mathrm{O}$ urbanismo, por sua vez, considera como cidade pequena, aquela que possui menos de 50 mil habitantes; como cidade média-pequena, as cidades com um número entre 50 e 100 mil habintates; como cidade média aquelas que abrigam entre 100 e 300 mil habitantes; como média-grande, as cidades onde vivem entre 300 e 500 mil habitantes; e as cidades grandes as que abrigam mais de 500 mil habitantes.
} 
ao ao mesmo tempo em que se desorganiza, também se reorganiza, une e separa pessoas por classes sociais para desterritorializar e reterritorializar conforme 0 dimensionamento espacial desenhado pelas compartimentalizações criadas pelos interesses políticos e econômicos.

No caso dos municípios da área de abrangência da BR-163, Santos (1988) afirma que:

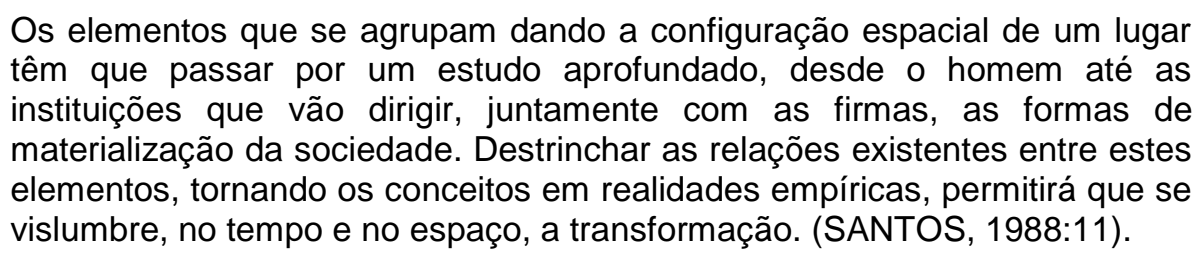

Para estudar a forma, a função, o processo e a estrutura do espaço da área de abrangência da BR-163, foram analisados os seguintes municípios: Lucas do Rio Verde, de pequeno porte, com 45.556 habitantes, Sorriso, médio-pequeno porte, com 66.521 e Sinop, de médio porte, com 113.099. ${ }^{44}$

\subsection{1 - LUCAS DO RIO VERDE}

Situa-se à margem BR-163, a 290 km de Cuiabá, na meso região do médio norte, tem um relevo caracterizado como predominantemente plano, e sua vegetação é constituída por Cerrado, arbóreo denso (cerradão) e matas ciliares.

De acordo com informações cedidas pela Prefeitura, o município está a uma altitude média de $390 \mathrm{~m}$, seu clima é tropical de savana, com duas estações bem definidas: com umidade relativa do ar acima de 86\%, a estação chuvosa (de setembro a abril) e abaixo de $40 \%$, a estação seca (de maio a setembro). Sua área é de $3.645,23 \mathrm{~km}^{2}$.

Como se vê na Figura 19, a seguir, limita-se ao Norte e a Leste com o município de Sorriso, ao Sul com Nova Mutum e a Oeste com Tapurah. Seus habitantes são chamados de luverdenses.

\footnotetext{
${ }^{44}$ Dados estatísticos com base no recenseamento de 2010 (IBGE)
} 


\section{Figura 20 - Localização de Lucas do Rio Verde em Mato Grosso}

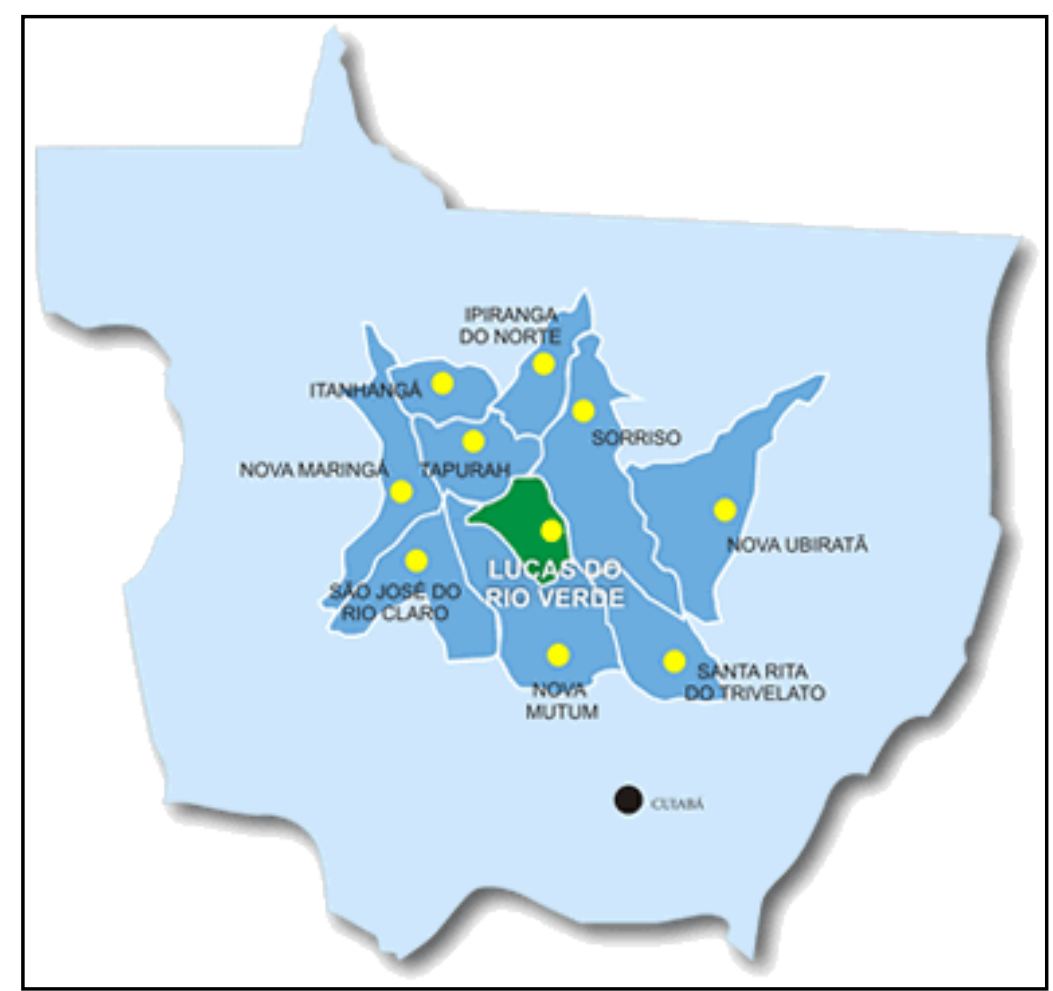

Fonte: ASCOM - Prefeitura de Lucas do Rio Verdel 2012.

O nome foi escolhido em homenagem a Lucas de Figueiredo de Barros, um seringalista, afeito à rudeza da selva, que via na extração do látex sua motivação de vida. Profundo conhecedor da região, teve seu nome perpetuado pela história por uma iniciativa do historiador e então coordenador geral do INCRA para o Estado de Mato Grosso (composto ainda por Mato Grosso e Mato Grosso do Sul), Paulo Pitaluga Costa e Silva. O complemento Rio Verde, anexado ao nome do seringalista, já era utilizado como referência territorial por causa do curso d'água do rio Verde que corta o município, assim chamado por sua cor esverdeada.

Fundado em 14 de setembro de 1974 e emancipado em 17 de dezembro de 1979, Lucas do Rio Verde pode ser considerado como um município de médiopequeno porte, cujo espaço ${ }^{45}$ é ocupado pelo agronegócio sendo que, em paralelo, desenvolve uma indústria de alimentos considerada e se prepara para expandir a indústria de transformação de grãos.

\footnotetext{
${ }^{45}$ Entenda-se aqui espaço conforme Santos (2008:12); "o espaço não pode ser apenas formado pelas coisas, os objetos geográficos, naturais e artificiais, cujo conjunto nos dá a Natureza. O espaço é tudo isso, mais a sociedade: cada fração da natureza abriga uma fração da sociedade atual. [...] contém as demais instâncias. Ele está contido nelas, na medida em que processos específicos incluem o espaço, seja o processo econômico, seja o processo institucional, seja o processo ideológico."
} 
Diferente da maioria dos municípios da área de abrangência de BR-163, Lucas do Rio Verde teve a sua colonização incentivada pelo regime militar que pretendia ocupar os "vazios demográficos" do país. Na opinião de professores locais, até a década de 1970 a região era ocupada por uns poucos índios, provavelmente remanescentes da nação Baikirí e posseiros que avançaram para aquela região muitos anos antes da construção da rodovia.

Existem muitas histórias a respeito do $\mathrm{PEA}^{46}$ Lucas do Rio Verde, instalado, pelo regime militar, junto com outras áreas de outros estados, como alternativa de assentamento para os "Sem Terra" do Rio Grande do Sul e de Santa Catarina.

Em entrevista realizada em 16.10.2012, com o então Coordenador Geral do INCRA-MT, Paulo Pitaluga Costa e Silva, foram esclarecidos alguns pontos que, apesar de o pouco tempo transcorrido entre a instalação do PEA até hoje, já apresentam muitas variantes como:

Sobre o início de Lucas, o coordenador fala que:

Os militares encarregados das obras da BR-163 ou os posseiros, da região de Lucas do Rio Verde, não tiveram confrontos com índios, porque já havia muito poucos naquela área. Aquilo era uma terra devoluta. O que o INCRA fez, foi uma ação discriminatória, porque a área estava cheia de grileiros que haviam deslocado títulos lá para dentro e, na ação discriminatória você vê quem é quem; você discrimina o que é público, devoluto do que já é titulado. Lá não foi encontrado quase nada com titulação séria. Por isso aquela área foi quase toda colocada em nome da União Federal, isto é, aproximadamente 200 mil hectares.

Já sobre a regularização fundiária dos que já estavam na área:

Aí tivemos a necessidade de dar um "chega pra lá" nos grandes posseiros. O sujeito tinha uma pretensão de posse de 50 mil hectares! Ele falava: daquele rio não sei o quê, até aquele morro não sei o quê, é meu. Aí a

\footnotetext{
${ }^{46}$ O PEA (Projeto Especial de Assentamento) consistiu na execução de projetos emergenciais destinados a atender populações removidas compulsoriamente de áreas conflitadas, por decisão do governo federal. A responsabilidade na implantação do projeto era do Incra, desde a organização territorial, a colocação da infraestrutura, até a administração técnico-financeira. Nessa modalidade apenas o PEA-Lucas do Rio Verde, à margem da Rodovia Senador Jonas Pinheiro, no município de Diamantino, serviu como projeto destinado aos sem terra do acampamento Encruzilhada do Natalino, situado em Ronda Alta (RS), como forma de desmobilizar esse movimento de luta pela terra. Em 1981 assentou 252 famílias, cerca de 1000 pessoas, transferidas daquela região, em uma área de 200.000 hectares. Esse projeto ficou famoso no Brasil inteiro pelos escândalos de corrupção ocorridos na sua implantação, com o envolvimento de funcionários do Incra/MT na distribuição de parcelas. Em 1986 restavam apenas 15 famílias assentadas. Muitas retornaram ao Rio Grande do Sul, pelas mudanças ocorridas na política de incentivo agrícola, antes disponíveis para a Amazônia, e também pelos desmandos na condução do projeto. [...] Em 1982, o projeto passou a ser desenvolvido com a participação da Cooperativa de Lucas do Rio Verde (Cooperlucas). Procedeu-se, então, a um redimensionamento da área, ampliando o número de lotes para 972, e um novo "selecionamento" destinado a 972 famílias. Muitos destes lotes já haviam sido "comprados", antes mesmo dos primitivos colonos terem recebido suas Cartas de Anuência, documento provisório de titulação, com cláusulas resolutivas, que limitavam a venda dos lotes cedidos. Assim, com a entrada da Cooperativa, foi regularizada a situação da área, inclusive dos lotes grilados durante a implantação. Em 1985, Lucas do Rio Verde tornou-se município, com forte participação na economia agrícola do Estado. (MORENO, (2007:166-167).
} 
gente perguntava: mas é seu, por que? Ah! porque eu sou posseiro! Aí o INCRA começou a fazer a regularização fundiária daquilo. Tinha uma instrução do INCRA, de como você fazia para dar uma área para o sujeito. Era um cálculo em ASA - Área a Ser Alienada. Era uma coisa aritmética. Via-se quais benfeitorias que o sujeito havia feito e, quanto mais ele tivesse desmatado, mais ele teria direito a área. Por isto teve este desmatamento todo na Amazônia inteira. Quer dizer, um dos responsáveis foi, sim, o INCRA.

\section{Para explicar como se deu a regularização fundiária, Pitaluga explicou:}

Daí nós plotamos no chão as áreas para cada um e aqueles vãos, porque tinham vãos imensos, porque foi muito pouco o que nós conseguimos fazer de regularização fundiária. Daí o sujeito achava que era dono da terra e nós perguntávamos qual era a benfeitoria? Ele respondia: Ah, não, eu só comprei isso há dez anos, etc. Na realidade, não tinha nada que pudesse comprovar. Se tivesse alguma coisa, nós daríamos. Então muita gente ficou revoltada. Aí começaram as ameaças e então o INCRA fez lá o projeto de colonização.

\section{Sobre como nasceu Lucas do Rio Verde:}

Inclusive tem uma coisa interessante. Tem um lugar lá, chamado Piúva, antes de Lucas, você vira à esquerda para a estrada que leva a Tapurah; e lá, com base em fotografia aérea, nós fizemos uma cidade. A cidade teria o nome de Piúva ou Piuval, não recordo bem. Estava tudo lá planejado, quando de repente chega no INCRA um gaúcho, daqueles gaúchos mesmo, todo pilchado ${ }^{47}$. Um bom sujeito, falante, não me lembro mais o nome dele; eu sei que ele era um dos posseiros que teve uma terra regularizada pelo INCRA. Aí ele me falou o seguinte: Dr. Paulo, o senhor conhece aquela área lá onde vocês vão fazer a cidade? Eu respondi: Eu não conheço mas os nossos técnicos foram lá já. Pois é, continuou ele, aquilo, na época das chuvas $^{48}$, inunda. Aquilo é um pantanal. Eu achei que era impossível, mas ele insistiu: é possível sim! Eu perguntei quando estaria voltando para lá, chamei um agrônomo e um técnico agrícola e pedi que fossem lá ver este negócio, constatar isso para ver como é que ficaria. Aí o pessoal foi lá, foi na casa deste gaúcho, que morava a uns 5 ou $10 \mathrm{~km}$ do local, pegaram o gaúcho e foram vistoriar a área. Voltaram e me disseram: Dr. Paulo, o que acontece ali é um dilúvio; não pode ter cidade. Aí eu perguntei ao gaúcho qual seria o melhor lugar para a gente fazer a cidade; e ele respondeu: daqui a uns $5 \mathrm{~km}$ para cima, o senhor já pode fazer em qualquer lugar.

\section{Ainda envolvido com as lembranças de todas estas tratativas, Paulo Pitaluga contou como foi mudada a área onde seria implantado o município e porque seria escolhido o nome Lucas do Rio Verde.}

Me lembrei do local do antigo acampamento do $9^{\circ}$ BEC. Tá bom, vamos fazer lá. Daí, redesenhamos a cidade toda, lá onde hoje é Lucas do Rio Verde. Aí chegou a hora de fazer o PEA - Projeto Especial de Assentamento. Bom, qual vai ser o nome do PEA? Vai ser PEA Rio Verde, por causa do rio. Aí eu sabia da história do Lucas, que é pai do Guilherme Figueiredo de Barros. Liguei para o Guilherme, que sempre teve um escritório de advocacia mais ou menos perto do meu e ele, uma pessoa

\footnotetext{
${ }^{47}$ Vestido com a indumentária gauchesca

${ }^{48}$ Em Mato Grosso, as estações do ano praticamente se resumem em duas: a estação das chuvas e a estação da seca
} 
muito agradável, muito bom, muito interessante para conversar, me contou que esse negócio de Lucas era por causa de Lucas Figueiredo de Barros, que era o nome do pai dele. Que o pai dele era seringalista e lá ele tinha uns armazéns onde o pessoal deixava o látex. Quando dava um determinado tempo, eles iam buscar e voltavam. Ali era só um acampamento do qual um ou dois sujeitos tomavam conta. Era o acampamento do Lucas. Este Lucas morreu uns 10 ou 20 anos antes da fundação de Lucas do Rio Verde. Quando o $9^{\circ}$ BEC foi para lá, uns 30, 40 ou 50 anos depois, sei lá, o lugar ainda era conhecido como o acampamento do Lucas. Aí, como estava esta coisa de Lucas do $9^{\circ}$ BEC e Rio Verde do PEA, eu juntei os dois nomes: Lucas do Rio Verde. Foi o nome que eu escolhi e foi dado o nome para a cidade.

Alguns imigrantes pioneiros de Lucas do Rio Verde chegaram antes do início das obras de abertura da rodovia BR-163, realizada pelo $9^{\circ}$ BEC (Batalhão de Engenharia e Construção), ligando Cuiabá a Santarém (PA), na segunda metade da década de 1970. Outros se deslocaram para a região praticamente junto com a estrada e foram ocupando os espaços à margem do traçado à proporção que este ia avançando.

O Sr. Ildo Romancini em entrevista concedida em Lucas do Rio Verde, em 21.09.2012, descreve o sentimento da maioria das pessoas na década de 1980, quando começou o povoamento:

Eu lembro que o Evangelista, engenheiro civil do INCRA, no fim de 1982, ele estava projetando a cidade. Esta avenida Rio Grande do Sul, avenida Paraná, e tal, e eu cheguei pertinho dele e falei assim: doutor, porque você não muda o projeto da cidade; em vez de ser aqui, joga ela para o lado de cima da BR, ali é no alto, fica bonito. Ele me olhou e disse assim: "a lá vá gautcho bobo", (ele falou com sotaque cuiabano) aqui nunca vai ter cidade. Eu vou fazer isso aqui porque é um projeto de governo e eu tenho que fazer. Mas aqui nunca vai ser cidade. Nem ele acreditava. Imagina se ele olhar hoje, depois de 24 anos de emancipação, a cidade que nós temos. Trinta anos de fundação e 24 de emancipação política. Agora eu sei que ele está lá em Brasília e eu soube que ele veio para Lucas. Eu queria te falado com ele para dizer: Lembra aquela época? Dizem que ele admirou muito, ele acompanhou o prefeito e ficou muito impressionado. Ele não se achou mais.

Quando o PEA foi instalado para receber os "Sem-terra" que vieram pelo projeto, já viviam no local outros 85 posseiros, um grupo de 50 empresários rurais, oriundos da Cooperativa de Imigração e Colonização Holambra ${ }^{49}$ com sede em Paranapanema-SP e 12 pessoas, ditas da própria região e não identificadas, conforme consta na ata de fundação de Lucas do Rio Verde lavrada em 05 de agosto de 1982. Este grupo que acreditou na experiência adquirida nos projetos

\footnotetext{
${ }^{49}$ Também conhecidos como "paulistas", que, conforme o historiador José Dario Munhak, não vinham necessariamente, do estado de São Paulo; por isto, o termo mais exato seria participantes do GICAN.
} 
anteriores e por possuírem uma boa estrutura física e econômica, concordou em criar uma base de extensão cooperativista na "Fronteira Agrícola".

Para flexibilizar o movimento do projeto de expansão da Holambra e agilizar os procedimentos, o grupo de interessados no novo projeto achou por bem criar uma comissão de interlocutores que modelaria a forma como alicerçar novas comunidades rurais e serviria de base para uma nova entidade que se chamaria GICAN (Grupo de Interessados em Colonizar Áreas Novas).

A opção de trazer os "Sem Terra", oriundos da Encruzilhada Natalino, interior do município de Ronda Alta (RS), para o PEA Rio Verde aconteceu no final de julho de 1981, quando o Major Curió ${ }^{50}$, acompanhado por um aparato militar invadiu o acampamento, com intenção de desmobilizar o movimento e pressionou-os até aliciar uma parte deles para o projeto.

A notícia de que o governo federal iria colocar as terras que estavam sendo negociadas pelo GICAN ((Grupo de Interessados em Colonizar Áreas Novas), à disposição dos "Sem Terra" gaúchos, tomou de surpresa a equipe que coordenava a negociação, como relata Huber (2010), então líder do grupo, em sua autobiografia:

Levei um susto! No jornal O Estado de São Paulo do dia 21 de agosto de 1981, a seguinte notícia me chamou a atenção e deveras me surpreendeu. Dizia: "Colonos de Ronda Alta vão para Mato Grosso".[ ...] Fiquei pasmo só podia se referir à área pela qual lutávamos. [...] Os Sem-terra, acampados na encruzilhada de Natalino, em Ronda Alta-RS estiveram lançando crescentes pressões sobre o governo para que ele, com urgência, os assentasse em terras apropriadas para a agricultura. [...] Em conseqüência destas reivindicações, o Incra, por ordem da presidência da República, levou-os a conhecer, entre muitas outras localidades, também a gleba Lucas do Rio Verde que, graças à nossa prévia vigilância, ainda não havia sido invadida ou ocupada de maneira descontrolada e preocupante. Para os gaúchos Sem-terra interessados, apresentava-se, portanto, como área ainda livre, situada em local de condições bem favoráveis. [...] O nosso futuro, muita esperança e o trabalho suado já feito estavam em jogo. [...] mas, naquele momento preocupante, não pude adivinhar que, em breve o

${ }^{50}$ Ex-agente do Serviço Nacional de Informação (SNI) e ex-membro do Conselho de Segurança Nacional (CSN), o major Curió é reconhecido como perseguidor, sequestrador e coordenador de sessões de tortura contra religiosos, lideranças sindicais e ligadas à luta camponesa. Era na verdade o major Sebastião Rodrigues de Moura, o Curió, ferrenho anticomunista que em 1961, como tenente, foi preso por participar da trama que tentou impedir a posse presidencial de João Goulart. No golpe de 1964, ele participou ativamente da conspiração e chegou ao CIEx. Frio e sanguinário, ficou famoso na região por receber de pistoleiros as cabeças, mãos e dedos decepados dos guerrilheiros para os quais pagava de 10 a 50 mil cruzeiros (dependendo da importância política da vítima). Curió foi, possivelmente, a figura que mais encarnou o espírito da "guerra suja", que rasgou todas as leis e princípios que regem os conflitos militares e os direitos básicos do ser humano. Curió ainda iria participar de outras atrocidades praticadas pela ditadura - como a "chacina da Lapa", quando em 1976 a repressão assassinou dirigentes do PCdoB em São Paulo - e se estabelecer na região, onde foi eleito deputado. Dominou o garimpo de Serra Pelada a força e fundou uma cidade em homenagem ao seu nome - Curionópolis. (Fonte: sites www.vermelho.org.br e altamiroborges. blogspot.com.br. Acesso em: 16.5.2012) 
impasse se revelaria de extrema importância para nossos planos. Não iríamos perder nada, ao contrário, uma nova etapa iniciava. (HUBER, 2010:87 e 88)

Isto significava dividir 197.991 hectares de terra sobre as qual deveriam ser assentados posseiros, colonos e empresários, além das 203 famílias que seriam transferidas do Rio Grande do Sul para a região. O Sr. Huber foi chamado a Brasília para ouvir a proposta do governo federal aos agricultores que haviam comprado a terra e que já a ocupavam com plantações de arroz.

Em nome do governo federal, o INCRA propôs que o grupo GICAN compartilhasse a gleba Lucas do Rio Verde com os assentados de Ronda Alta (RS) e, em contrapartida, o projeto governamental arcaria com os custos de medição, levantamentos topográficos além da área, a demarcação individual de cada lote com a implantação e construção de estradas vicinais. Analisados os custos desta empreitada, o GICAN abandonou a ideia de lutar por um projeto privativo, muito embora soubessem que teriam de se sujeitar aos critérios do INCRA, contentandose com o tamanho padrão das áreas, pois sabiam não haver outra opção exequível; estaria fora da competência do grupo assumir uma área em bloco e organizá-la a seu modo, como afirma Huber (2010).

Assim, a entrada dos colonos de Ronda Alta (RS) oportunizou a regularização das terras ocupadas por grileiros, colonos e empresários do grupo, sendo que alguns chegaram a obter até 2.000 ha de terra e, para atender os associados do GICAN, que chegaram em 1982, o projeto precisou ser ampliado para 900 lotes.

O projeto foi elaborado em julho e, de setembro a novembro do mesmo ano, 203 famílias foram assentadas em Lucas do Rio Verde. A execução do assentamento foi realizada pelo INCRA, que fez o transporte e o alojamento dos colonos, assim como implantou e construiu a infraestrutura básica incluindo obras como 96 km de estradas vicinais, três escolas, dois centros de saúde, prédios de administração e um armazém de cereais com 200 m² de área construída.

Os objetivos explicitados no projeto foram os seguintes:

a) Incorporar novas áreas ao processo produtivo;

b) Criar novas unidades agrícolas do tipo propriedade familiar;

c) Facilitar o acesso à terra, possibilitando a elevação da renda familiar;

d) Resolver problemas de tensão social. 
O colono teria direito a crédito para trabalhar a terra, para o plantio, isto é, para desmatamento, destoca, limpeza, gradeação, enleiramento, correção e adubação. O crédito foi condicionado à assistência técnica e à obrigatoriedade de cultivar alimentos básicos durante pelo menos dois anos, reduzindo-se esta exigência ao cultivo de $50 \%$ durante o restante do prazo de financiamento. O custo do lote para o colono era o equivalente ao valor da terra nua, ou seja, $\operatorname{Cr} \$ 360,00$ (trezentos e sessenta cruzeiros) por hectare, na época. Atualizando este valor, de 1981 para 2012, isto representaria aproximadamente $R \$ 0,131$ (US\$ 0,066 ${ }^{51}$ ) por hectare. Este montante deveria ser pago num prazo de 20 anos, com carência de 480 dias. Ao valor da terra nua seriam acrescidos os investimentos em infraestrutura, demarcação, desmatamento e transferência do local de origem para o Projeto. Estes investimentos totalizariam $\mathrm{Cr} \$ 1.041 .810,00$ ou $\mathrm{R} \$ 378,84$, em valores atualizados, ou US $\$ 191,33$, acrescidos de juros que seriam computados conforme o mercado.

No relato sobre a vinda dos gaúchos de Ronda Alta (RS), Paulo Pitaluga Costa e Silva colocou também alguns pontos:

\begin{abstract}
Aí nós trouxemos aqueles gaúchos lá do sul, e foi um verdadeiro desastre. Eles chegavam e, no dia seguinte já tinha gaúcho pedindo carona na estrada para voltar, porque tinha vendido aquilo para o primeiro que aparecesse. O Ferreira me contou que um deles trocou a terra por uma bicicleta, um rádio Philco daqueles de pilha e um dinheiro para a passagem de volta para o Rio Grande do Sul. Uma passagem para o Rio Grande do Sul custa o que hoje? R $\$ 500,00$ ? Mais um rádio, uns $\mathrm{R} \$ 100,00$, mais uma bicicleta, uns $\mathrm{R} \$ 300,00$, quer dizer que ele trocou o lote dele de 40 ou 60 hectares, uma coisa assim, por menos de mil reais. O que desenvolveu Lucas foram aqueles posseiros que já estava lá, alguns já tinha máquinas.
\end{abstract}

O assentamento foi executado e, inicialmente, não havia as infraestruturas física e social previstas. Cada colono recebeu um lote de 200 ha de Cerrado, sem nenhuma perspectiva de levantamento de capital em banco para iniciar o plantio, nem qualquer tecnologia para ser empregada no lote. Como já havia passado o período das chuvas, o resultado da produção foi um fracasso. As famílias passaram a sobreviver com um vale mensal fornecido pelo INCRA para comprar alimentos na COBAL (Companhia Brasileira de Alimentos) e dos serviços prestados nos latifúndios vizinhos ao Projeto.

${ }^{51}$ Calculado sobre a média das cotações do primeiro trimestre de 2013 , ou $\mathrm{R} \$ 1,98$ por US $\$ 1,00$. 
Embora o INCRA tivesse avaliado o solo como "pobre em nutrientes naturais", o mais importante para os imigrantes, foi à conclusão de que naquele solo seria possível cultivar arroz, milho, mandioca e soja, em condições econômicas viáveis, desde que convenientemente tratados com corretivos e adubos.

No segundo ano estes imigrantes pioneiros tiveram acesso ao financiamento do Banco do Brasil, através do PROTERRA (Programa de Redistribuição de Terras e de Estímulo à Agroindústria do Norte e Nordeste) ${ }^{52}$, por intervenção direta do Conselho de Segurança Nacional, que mantinha severa fiscalização sobre os assentados, a fim de impedir que saíssem da área. Com o financiamento, os colonos conseguiram abrir 25 ha para a produção de arroz, mesmo pagando um preço muito alto para utilizar o maquinário dos fazendeiros vizinhos, visto que não tinham condições para financiar máquinas, essenciais para a agricultura no Cerrado, independente da correção do solo que também encareceu muito o custo de produção.

No ato de lançamento da pedra fundamental de Lucas do Rio Verde, em 05 de agosto de 1982 a agrovila, pertencente ao município de Diamantino, recebeu um grande número de autoridades e, durante a solenidade, foi assinada a Ata de Fundação onde constava que,

\begin{abstract}
Através do Projeto Fundiário de Diamantino, está sendo aprovada a regularização fundiária dos pioneiros, os primeiros moradores e agricultores da área, que com seus próprios esforços demonstraram a qualidade e a boa aptidão da terra e transformaram o Cerrado em imensas áreas produtivas; e ainda, em atendimento ao decreto presidencial, foi criada a Cooperativa Agropecuária Mista Lucas do Rio Verde Ltda - COOPERLUCAS, sendo o primeiro presidente o Sr. Anton Huber, cuja finalidade será agregar os colonos e os antigos posseiros, dando-lhes apoio e assistência técnica. (HUBER, 2010:117)
\end{abstract}

\footnotetext{
${ }^{52}$ A partir de 1970, como substitutivos da reforma agrária, o governo federal lançou vários programas especiais de desenvolvimento regional. Entre eles, o Programa de Redistribuição de Terras e de Estímulo à Agroindústria do Norte e Nordeste - PROTERRA (1971). O PIN e o PROTERRA foram os programas que mereceram maior atenção e aos quais foi destinada uma soma significativa de recursos, com o propósito de ocupar uma parte da Amazônia, ao longo da rodovia Transamazônica. O PIN era baseado em projetos de colonização em torno de agrovilas e, segundo a versão da época, buscava integrar "os homens sem terra do Nordeste com as terras sem homens da Amazônia." Na prática, verificou-se que a maior parte das cerca de 5.000 famílias deslocadas para a região eram procedentes do extremo Sul do país, principalmente, dos estados do Rio Grande do Sul e de Santa Catarina, e não do Nordeste. Estudos posteriores demonstraram que os custos do programa foram altos, o número de famílias beneficiadas reduzido e o impacto sobre a região insignificante. $\mathrm{O}$ desempenho do PROTERRA também deixou a desejar: o programa desapropriava áreas escolhidas pelos próprios donos, pagava à vista, em dinheiro, e liberava créditos altamente subsidiados aos fazendeiros. Apenas cerca de 500 famílias foram assentadas depois de quatro anos de criação do programa. Fonte: www.planalto.gov.br/publi_04.
} 
No primeiro ano, a COOPERLUCAS empreendeu muitos esforços e, de acordo com Huber (2010), "conseguiu as primeiras escrituras de terras fossem processadas no Cartório de Registro de Imóveis, com as quais os agricultores poderiam intensificar as negociações com o Banco do Brasil". A partir do ano seguinte, o processo de titulação se tornou cada vez mais difícil e os agricultores encontravam cada vez mais dificuldades na concessão de empréstimos para investir nas áreas destinadas ao plantio de arroz e custeio agrícola.

Como consequência, veio o fracasso na safra agrícola e muitos não conseguiram saldar as dívidas contraídas com financiamentos anteriores. A situação piorou com a mudança na política de incentivos à agricultura, que retirou os subsídios ao crédito rural e os juros passaram de 12 para 35\% ao ano. Esta foi a principal causa da saída maciça dos imigrantes, em agosto de 1983, por não terem outra solução senão vender suas terras a preços inferiores ao do valor real ou simplesmente abandoná-las deixando para trás tudo o que haviam começado.

Os avanços sociopolíticos não foram gratuitos. Os associados da COOPERLUCAS, ao contrário dos sem-terra gaúchos, eram pequenos e médios proprietários de terra que chegaram ao projeto com algum capital. Como o Cerrado exige altos investimentos em mecanização e correção do solo, aproximadamente $50 \%$ destes colonos deixaram o Projeto; alguns por dificuldades de acesso ao financiamento, outros pelas altas taxas de juros.

Da parte do Estado, o projeto ficou praticamente nas mãos do senhor Ferreira, executor do INCRA e personagem que, conforme Zart(1998) remete a péssimas lembranças para a maioria dos colonos e grileiros que viveram ali. Teoricamente, sua função seria a de organizar a região após a saída em massa dos colonos originais, mas utilizou o cargo, para vender indiscriminadamente os lotes rurais a latifundiários do sul do país ou para grandes comerciantes da região, contribuindo para um processo acelerado de concentração dos lotes (ZART,1998:126-136).

Sobre esta questão o então coordenador geral do INCRA-MT, Paulo Pitaluga Costa e Silva, relata durante a entrevista em 16.10.2012 que:

Com relação ao Ferreira, eu tinha amizade com ele. Eu arranjei um emprego para ele no INCRA. Ele era um sujeito despachado, não admitia desaforo; pior ainda: ele tinha sido sargento da Força Pública de Mato Grosso, quando era Força Pública; não era nem Polícia Militar. Aí pediu baixa lá, não sei o que aconteceu, ficou por aí. Eu arranjei este emprego no INCRA, aí nós tivemos um projeto lá em Mato Grosso do Sul que o INCRA 
não acabava nunca. Os caras mantinham todo ano, com orçamento e mandavam... eram os PICs ${ }^{53}$. O PIC Iguatemi Sete Quedas, é a cidade de Mundo Novo hoje. Então eu fiz uma proposta ao presidente do INCRA: para acabar com aquela anarquia, que fossem expedidos o maior número possível de títulos já que, àquela altura estavam sendo expedidos em média 3 títulos por ano. Em seguida, mandei o Bartolomeu e o Ferreira para lá, com plenos poderes para expedir títulos e, em trinta dias ele titulou quase todo mundo. Quer dizer, não titulavam para manter os empregos e as mordomias.

\section{Quanto aos acontecimentos na área onde hoje está Lucas do Rio Verde, ele} relatou:

O que aconteceu foi que no PEA Rio Verde nós tínhamos lá no acampamento uma casinha de madeira e os grileiros cercaram aquilo e meteram bala no pessoal do INCRA. O pessoal do INCRA respondeu, mas eles tinham dois revolveres e acabou que o assunto ficou por isso mesmo. No dia seguinte eles me mandaram um rádio falando sobre o que havia acontecido. Liguei para o presidente do INCRA e ele quis mandar a Polícia Federal, mas achei bobagem porque este tipo de polícia fica 3 ou 4 dias e vai embora. Eu sabia que o assunto não iria acabar assim. Pedi que me autorizasse a compra de armas. Compramos 3 ou 4 revólveres, duas doze, umas quatro Rossi 38, e mandamos os caras para lá armados. Os agressores voltaram dali um mês, só que eles foram recebidos a bala. Mataram um cara. Só que o Ferreira não estava lá ainda; estava em Mato Grosso do Sul. Mas depois que ele chegou lá em Lucas, ele era um cara violento, sargentão, sei que ele andou dando uns tapas em uns caras.

Uma das histórias conhecidas por Pitaluga foi contada por um de seus colaboradores, na época e ele relata:

O Guilherme Müller, responsável pelo Depto de Colonização, assistiu este fato. Na época em que estavam chegando os gaúchos, as casas deles vinham desmontadas encima do caminhão. Uma ou duas casas em cada caminhão. O gaúcho estava reclamando que estava demorando ou coisa parecida, que tinha que levar a nova casa etc. Aí um sujeito lá pediu para o cara: olha, já que você está reclamando, você e seus filhos desçam e ajudem a gente a descarregar este caminhão. O gaúcho respondeu que não era obrigado a descarregar coisa nenhuma. Aí o cara ficou muito brabo com esta história e foi avisar o Ferreira que já chegou no gaúcho mandando: como é? Vai descarregar? E ele de novo respondeu que não iria descarregar coisa nenhuma. O Ferreira deu uma bolacha na cara do gaúcho que caiu e o Ferreira continuou: você vai descarregar, sim. Aí ele e os filhos ajudaram. É isso que sei da violência do Ferreira. Agora, que ele matou gente lá em Lucas, eu nunca soube. Os caras do INCRA mataram um sujeito num caso de intimidação que era uma prática comum aqui em Mato Grosso. Eu não tenho nenhum tipo de informação, além disso.

Mas também conta sobre as "diferenças" entre o Ferreira e o Sr, Huber, da COOPERLUCAS:

Agora, sei que o Ferreira se meteu numas frias por lá com o pessoal da Cooperlucas, porque eles chegaram lá e, quando viram aquela gauchada mais simples, eles acharam que eram o máximo e começaram a fazer e

\footnotetext{
${ }^{53}$ Projeto Integrado de Colonização
} 
desfazer, principalmente o Sr. Anton Huber. Teve um senhor, que eu me esqueci o nome, que foi para lá, obteve um lote e por não aguentar mais o Sr. Anton Huber, veio para cá e falou comigo: Dr. Paulo, o cara é muito arrogante, é muito prepotente, só serve mesmo para meter o pau em brasileiro, mete o pau no INCRA, mete o pau na prefeitura, mete o pau no governo, mete o pau em todo mundo, e ele quer me obrigar a plantar algumas coisas lá e eu não quero; (isso porque ele tinha um esquema de venda de arroz, sei lá). Então eu estou aqui para devolver o meu lote para o INCRA e quando o Sr. Anton soube que eu queria ir embora, ele já está oferecendo o lote lá. Está à venda! Então eu não quero; eu vim entregar para o senhor. Eu ainda sugeri a ele que vendesse o lote, mas ele se recusou, alegando que havia recebido de graça. Pois é, este era um sujeito sério. Aí pedimos a ele que assinasse um documento de desistência e entregamos, de graça, para uma das pessoas que estava na lista de espera para comprar do Sr. Anton, que ficou bastante irritado com a história.

A venda da terra era ilegal, visto que sobre ela incidia uma cláusula resolutiva determinando que as terras dos projetos do INCRA, não poderiam ser negociadas durante cinco anos após a data de registro em Cartório Imobiliário. Tanto quanto se entendeu do texto de Zart (1998), o mesmo aconteceu com as terras na área urbana que fazem parte do projeto original de Lucas do Rio Verde, onde os terrenos foram doados apenas a pessoas que mantinham relações amistosas com o executor ou com os técnicos do INCRA.

Sobre estas alusões, Paulo Pitaluga Costa e Silva relata que:

Que ele (Ferreira) deu uns tapas? Deu; fez algumas arbitrariedades? Fez. ... Eu tinha que trabalhar com gente despachada para a coisa andar. Eles estavam nas frentes de batalha. Era uma linha de frente mesmo. Por isto, durante dois anos fomos os que mais titularam no Brasil; inclusive a Coordenação de Mato Grosso recebeu um prêmio das mãos do Ministro Delfin Neto. Hoje não tem nada mais disso. Só sei que depois a coisa piorou para o Ferreira, porque a legislação do INCRA facultava ao funcionário, quando saia do órgão, receber um lote urbano e um lote rural. Eu não estava mais no INCRA, quando ele me ligou dizendo que lá estava muito ruim. A pessoa que me sucedeu até já havia conversado comigo sobre a pressão que estava sofrendo de todos os lados. Aí, ao concordar com a saída do Ferreira, deu a ele dois lotes urbanos, porque não havia mais lotes rurais, onde ele construiu uma casa. Daí para frente não sei o que aconteceu. Depois o Ferreira mudou de Mato Grosso e só tenho contato com ele quando vem me visitar.

Já Huber (2010) argumenta que:

Depois de o povo já estar cansado de ser intimidado pelas frequentes ameaças e arbitrariedades do executor [Ferreira], afinal seus superiores resolveram destituí-lo do cargo... Como tentativa de manter-se no posto e recuperar a posição que estava perdendo, usou táticas de difamação política e moral contra seus opositores. Ameaçou também seus superiores imediatos, mas não teve o êxito esperado, ao contrário, piorou sua situação de vez. Só retornou ao projeto uma noite, meio às escondidas, para retirar seus pertences. Logo depois desapareceu da região. Ele e seu pai não foram mais vistos, por um bom tempo. (HUBER, 2010:199) 
Em pesquisa realizada recentemente, o historiador José Dario Munhak, que vive em Lucas do Rio Verde, conseguiu localizar 37 famílias de imigrantes pioneiros, sendo que destas, apenas 7 são de assentados de Ronda Alta. Deste total, oito ainda se dedicam ao agronegócio e continuam com a posse de suas terras. $O$ historiador informou ainda que, provavelmente, ainda existem outros remanescentes vivendo no município, mas sentindo-se pressionados pelas inúmeras dificuldades daquele período, ou desistiram de seus sonhos e passaram a se dedicar a outras atividades, ou perderam seus terrenos para a agricultura extensiva que começava a ocupar a vastidão do Cerrado.

Em 17 de março de 1986, o núcleo urbano foi elevado à condição de Distrito do município de Diamantino e no dia 04 de julho de 1988, quando conquistou sua emancipação político-administrativa, já contava com 5.500 habitantes. Neste período, o poder político estava nas mãos da diretoria da COOPERLUCAS que iniciou a luta pela emancipação política do distrito.

A emancipação, para o INCRA, representava a anistia da violência e da corrupção que envolveu a implantação do projeto, ou uma forma de repassar as irregularidades sobre a questão das terras para o futuro município. Já para a COOPERLUCAS e posseiros, a emancipação era o canal para obter a infraestrutura necessária ao desenvolvimento.

Lucas do Rio Verde é um caso concreto de colonização oficial, onde o Estado que aparece como mediador dos interesses de classe, assegura, através de suas instituições, as condições necessárias ao domínio do capital. A partir do momento em que se desmobilizaram os movimentos de luta pela terra para dar acesso aos lotes nos projetos de colonização, sem as condições necessárias à fixação do homem no campo, o Estado expôs, claramente, as contradições inerentes ao seu papel.

Pode-se afirmar que esta foi a contribuição do Estado para o processo de diferenciação social na área rural, uma vez que facilitou a fixação na terra e a capitalização de apenas alguns privilegiados. Ao mesmo tempo, "contribuiu com a ocupação intensiva das áreas de "fronteira agrícola" que incluíam a expansão do capital, sem se importar com as áreas utilizadas, ou mesmo com a violência e a corrupção." (CASTRO et al, 1994:96-100).

Com alta tecnologia e elevados índices de produtividade, a agricultura despontou, rapidamente, como uma das mais eficientes do mundo. Fato 
fundamental para que o município rapidamente se firmasse entre os mais importantes polos do agronegócio. Responsável por 1\% de toda produção brasileira de grãos, embora sua área ocupe apenas 0,04\% do território nacional, Lucas do Rio Verde agora ingressa efetivamente no processo de verticalização de seu perfil econômico que evoluiu, a partir do ano de 2005.

A soja se mantém como principal item da cadeia produtiva local, entre os produtos primários, porém se destacam ainda os cultivos de algodão, arroz e, principalmente, milho de segunda safra, cuja participação, em torno de $10 \%$ no volume da produção nacional, confere Lucas do Rio Verde o título de campeão no setor. Provavelmente esta tenha sido a razão pela qual o município tenha sido o primeiro, dentre todos os municípios brasileiros, a regularizar ambientalmente, conforme o Código Florestal, todas as suas 680 propriedades rurais.

A partir da agricultura, foram surgindo outros investimentos nos setores de serviço e industrial. A alta tecnologia que vinha sendo agregada ao plantio permitiu que os produtores colhessem duas safras ao ano, com elevados índices de produtividade. Com isto o município firmou numa posição confortável de importante polo do agronegócio brasileiro.

Independente dos grandes produtores soja, milho e algodão, houve um grande crescimento da agricultura familiar, conhecida como "agricultura dos chacareiros" que abastecem a cidade com hortaliças, frutas, mel, peixe e outros produtos. Os bons resultados das colheitas são propiciados pelo clima favorável, que suporta duas grandes safras anuais e assegura a comercialização de 1,2 milhões de toneladas de grãos/ano que, sem dúvida, é um forte ingrediente na fórmula de sucesso do padrão de eficiência adotado e embasa o novo ciclo econômico.

Como se constata na Figura 03, a economia de Lucas do Rio Verde tem se expandido para o campo da agroindústria, independente da agropecuária, transformando-se num polo de absorção da mão de obra que, gradativamente, vai sendo preterida pelas máquinas e pela mão de obra especializada necessária para manejá-las.

Mesmo assim, o número de empresas instaladas no município aumentou 309,25\% entre 2005 e 2010 e, a partir de então, este número tem aumentado anualmente numa média de $6 \%$ a $8 \%$. 
Gráfico 01 - Empresas instaladas no município de Lucas do Rio Verde e projeção para 10 anos

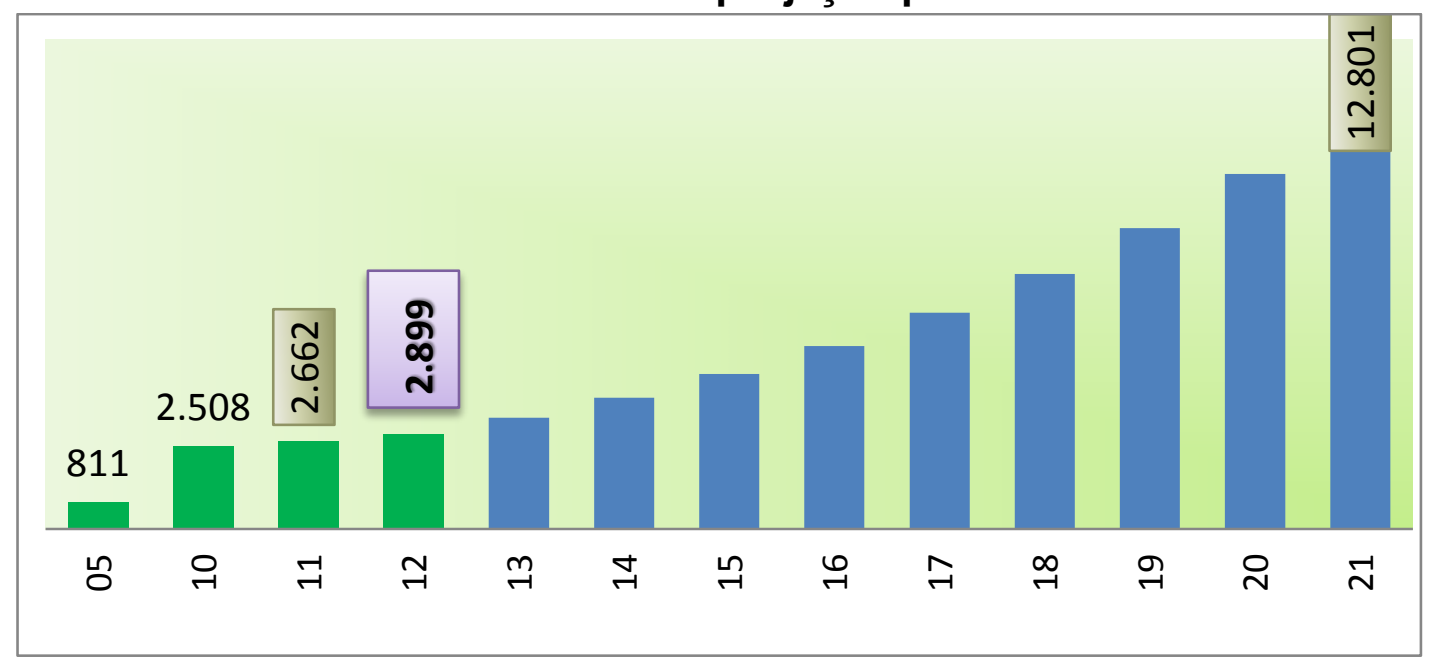

Fonte: ASCOM - Prefeitura de Lucas do Rio Verde (2012)

Os dados de disponibilidade de emprego apontados no quadro a seguir, se baseiam no crescimento da instalação de um número expressivo de empresas de pequeno e médio porte que se instalaram no município a partir de 2005.

A necessidade de mão de obra levou o poder público a criar políticas especialmente desenvolvidas para suportar a demanda de empregos e preparar a cidade para o futuro, estabelecendo para este fim, metas de qualificação em áreas específicas, direcionadas para o mercado de trabalho que vinha se abrindo no município.

Gráfico 02 - Número de empregos disponíveis e previsão para 10 anos

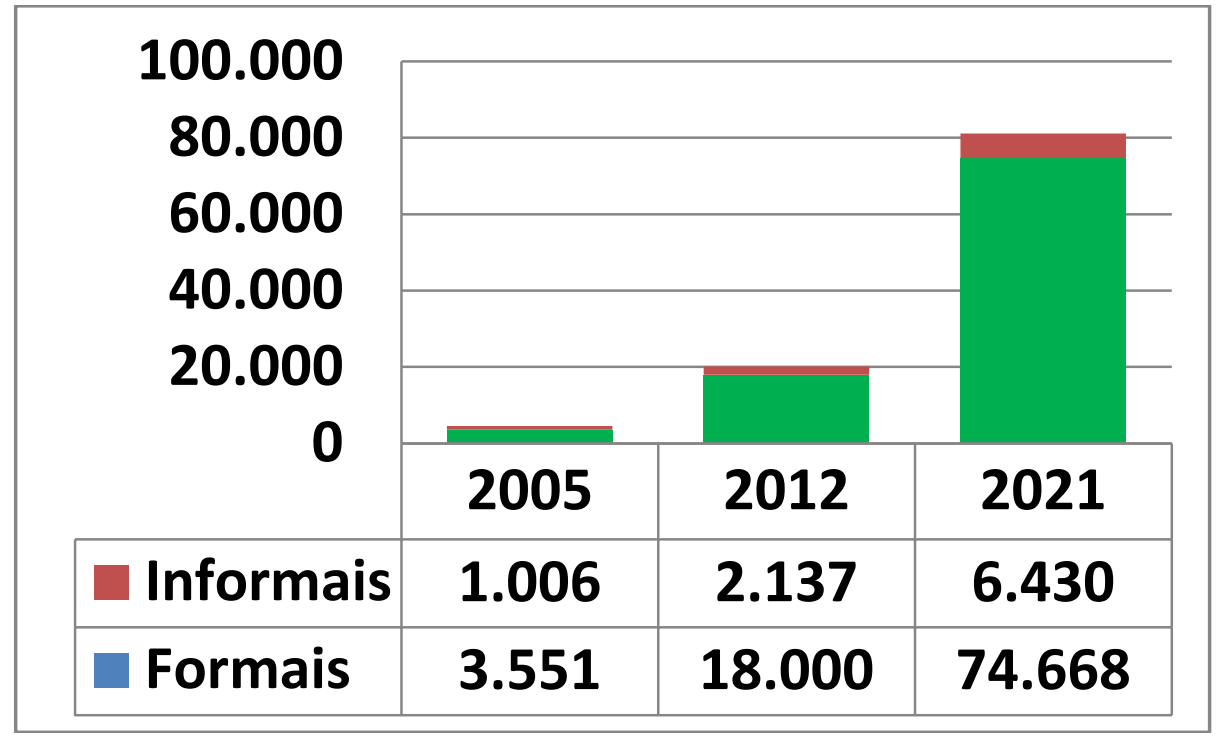

Fonte: ASCOM - Prefeitura de Lucas do Rio Verde (2012) 
A população de 45.556 habitantes (IBGE - 2010) tende a se desenvolver bastante até 2021, como se constata nos dados do Gráfico 02, acima, que tomou por base o grande desenvolvimento ocorrido até o fim da década de 1990, quando o município tinha menos de 7 mil habitantes e ainda não havia colocado em prática a política de incentivo à instalação de empresas.

O crescimento do número de empresas instaladas no município de Lucas do Rio Verde bem como o número de empregos disponíveis indica uma população que, conforme o Gráfico 03, abaixo, deverá aproximar-se dos 80.000 habitantes em 2021.

Gráfico 03 - População projetada de Lucas do Rio Verde para os próximos 20 anos

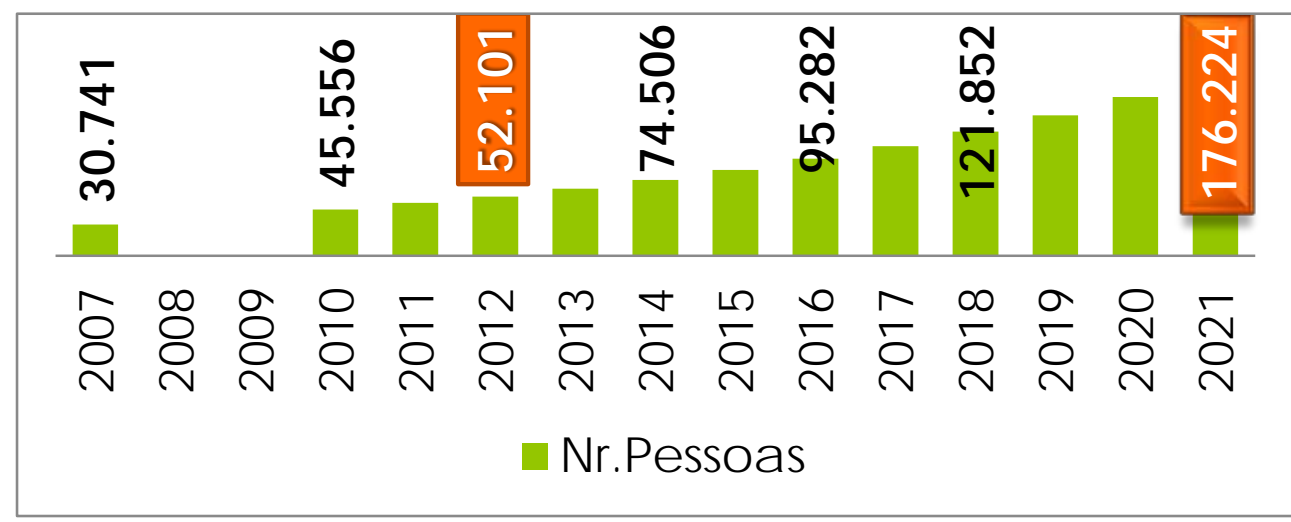

Fonte: ASCOM - Prefeitura de Lucas do Rio Verde (2012)

Como um dos municípios mais dinâmicos no setor produtivo, Lucas do Rio Verde trouxe para o seu território indústrias importantes na produção de alimentos como a Sadia e outras do setor de energia, principalmente as voltadas ao biodiesel.

A Sadia, que iniciou suas instalações a partir de abril de 2008, provocou uma profunda transformação geopolítica não só no município como na região. 
Figura 21 - Instalações da Sadia (2009)

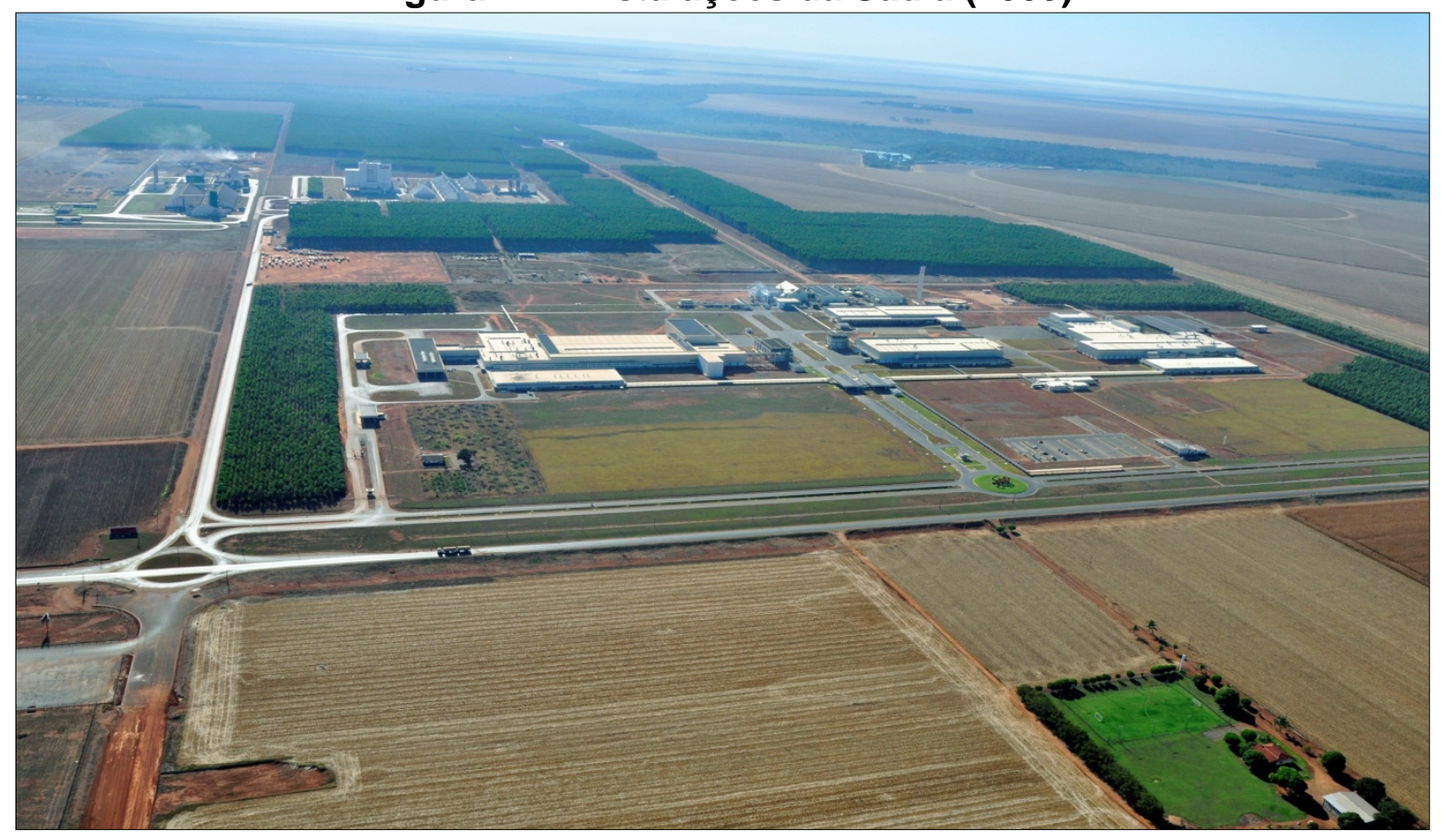

Fonte: ASCOM - Prefeitura de Lucas do Rio Verde (2012)

Como se vê na Figura 21, acima, a Sadia implantou seu complexo industrial em parceria com o poder público, até porque, em paralelo, necessitava não só da logística para sua produção, mas também da infraestrutura socioeconômica para os seus colaboradores. Ambos dependiam do poder público, cuja administração pretendia iniciar uma nova etapa.

A ideia era iniciar a indústria de transformação com base na commodity in natura, para daí expandir, criando uma cadeia produtiva com base num projeto de verticalização da economia criado na década de 1990.

Conforme o projeto, a matéria-prima é produzida pela iniciativa privada e o poder público incentiva os setores industrial e comercial a aproveitar a produção local para, com esta estrutura, ampliar os diferentes tipos de produção e abrir mais vagas no mercado de trabalho dando mais oportunidades e boa qualidade de vida aos munícipes.

Depois do início de suas atividades, a Sadia e outras empresas entre que se instalaram em Lucas do Rio Verde 2003 e 2006 passaram a atrair grande quantidade de pessoas em busca de trabalho. Embora a mão de obra necessária, não exigisse a mesma alta qualificação que a exigida no manejo das máquinas usadas no agronegócio, precisava contar com um conhecimento compatível com a tecnologia de transformação que estas empresas traziam para Mato Grosso. Por 
isto, a contratação de mão de obra local ficou muito aquém das necessidades dos novos empreendimentos que, inicialmente, obrigou-as a abrir as vagas para candidatos de outras localidades.

A consequência imediata desta política expansionista foi o aumento absurdo de habitantes, como está dimensionado no Gráfico 04, abaixo. De 1991 a 2010, conforme dados do IBGE, a população cresceu mais de $680 \%$.

\section{Gráfico 04 - Evolução populacional em 20 anos}

\begin{tabular}{|c|c|c|c|c|}
\hline & \multicolumn{3}{|c|}{ № de pessoas - $14 \%$ nos últimos 2 anos } & 52.101 \\
\hline 6.693 & 12.505 & 19.316 & 30.741 & \\
\hline 1991 & 1996 & 2000 & 2007 & 2012 \\
\hline
\end{tabular}

Fonte: ASCOM - Prefeitura de Lucas do Rio Verde (2012)

Entre 2010 e 2012, a evolução populacional ficou em 14\%, conforme apresenta o Gráfico 04. O poder público, no entanto, já está fazendo os cálculos, com base na média de crescimento desde a década de 1990, para fazer frente à grande evolução demográfica prevista para os próximos vinte anos, quando a população prevista deverá ser de 52.101.

Para dar suporte a este crescimento calcado em ampliação do número de empresas instaladas no município, um dos pontos vulneráveis era o fornecimento de energia elétrica que precisou investir muito para alcançar seus propósitos, como pode se analisado no Gráfico 05.

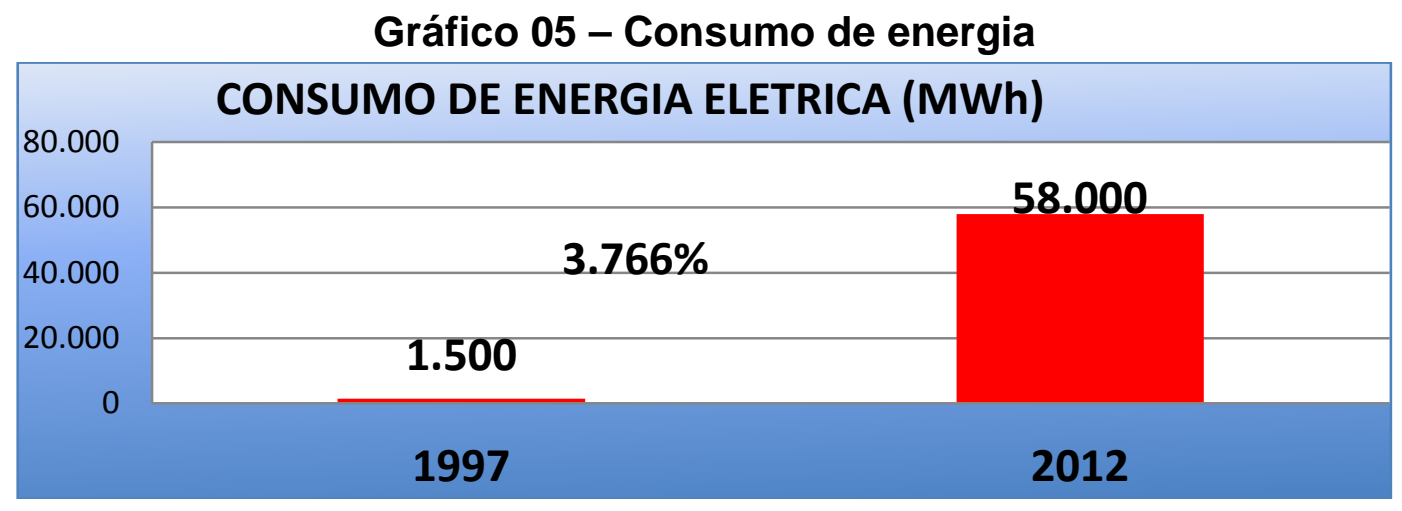

Fonte: ASCOM - Prefeitura de Lucas do Rio Verde (2012) 
Foram investidos $\mathrm{R} \$ 110$ milhões no projeto da Usina de Canoa Quebrada, para gerar $28 \mathrm{MW}$ e assim investir em aproximadamente 500 empregos diretos. Foi necessária uma mudança radical de conceito até atingir estes dados, partindo do abastecimento de energia gerado por motores a óleo até a década de 1990.

A preocupação em participar da globalização da economia através das empresas instaladas no município nos últimos anos, trouxe consigo uma carga de bons resultados e, paralelamente, também trouxe problemas como insuficiência de moradias, escolas, serviços de supermercado e outros serviços do cotidiano, serviços de saúde, saneamento básico, energia e tantos outros.

Uma das primeiras providências foi implantar uma Central de Produção Hidrelétrica que atendesse a demanda dos vários setores instalados e dos que pretendiam se instalar na cidade. Daí o projeto da Hidrelétrica Canoa Quebrada, cuja vista aérea se vê na Figura 22, a seguir.

Figura 22 - Hidrelétrica Canoa Quebrada

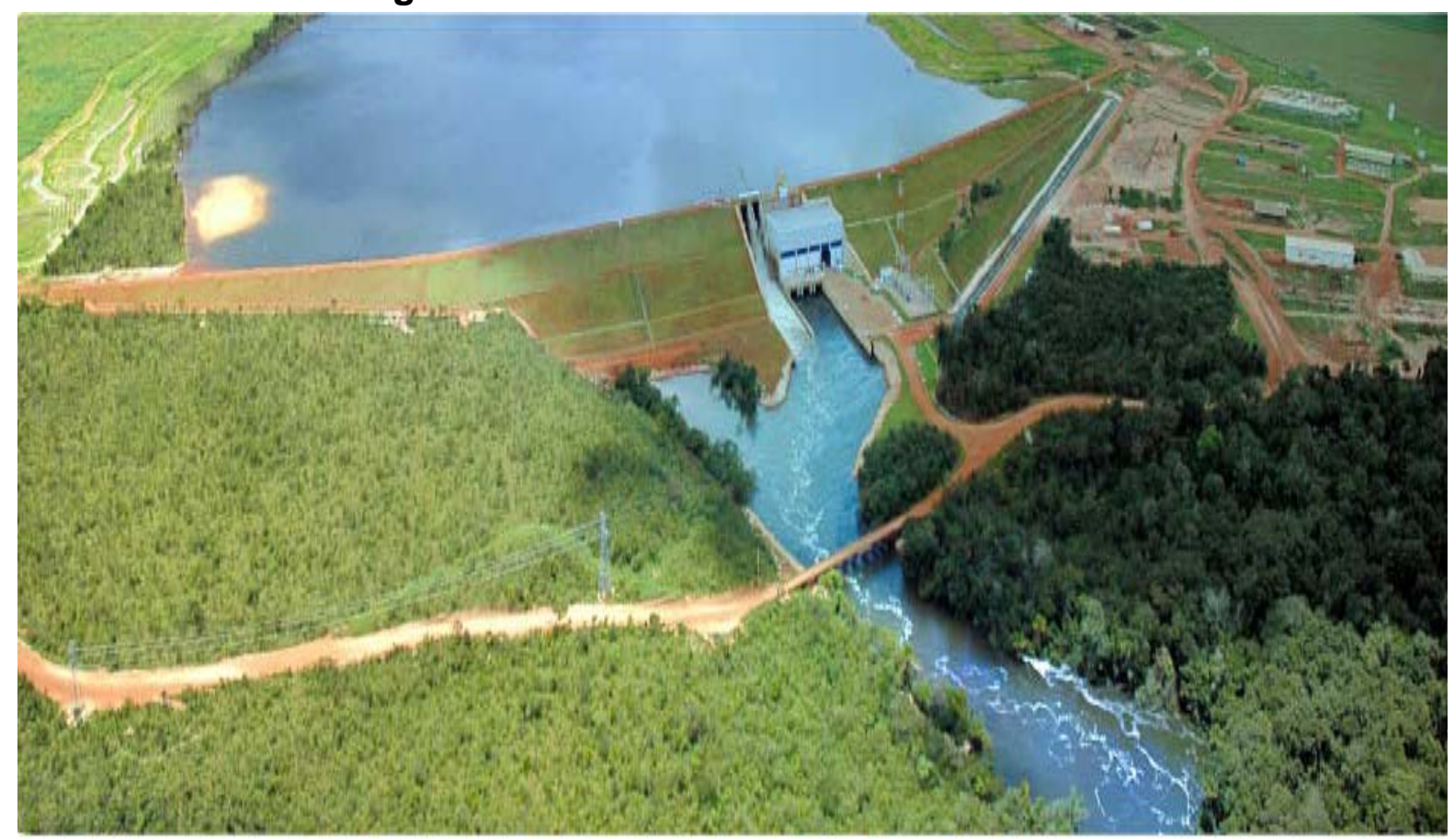

Fonte: ASCOM - Prefeitura de Lucas do Rio Verde, 2012

Independente das questões de energia, havia outro problema a enfrentar, quando eclodiu a questão da falta de moradia, que provocou aumento nos aluguéis, em todos os níveis, até mesmo em diárias de hotéis, pensões e restaurantes.

O nível profissional destes novos habitantes concentra-se nas classes C e D. Estatisticamente, o número de dependentes nas famílias destas classes sociais 
tende a ser maior, demandando uma estrutura urbana bem mais complexa, que exige muito mais escolas e hospitais públicos, mais moradia para uma grande demanda de casas populares, mais supermercados populares, estrategicamente montados, para atender, principalmente, a um público de baixa renda e muito outros detalhes que precisam ser adequados por interferirem direta ou indiretamente na vida dos habitantes.

Disponibilizar esta estrutura, não é uma tarefa simples, nem acontece de um dia para o outro embora exijam urgência na viabilização. O custo de vida, por exemplo, ainda está num patamar bastante elevado, apesar do esforço do poder público para solucionar as questões de infraestrutura.

As famílias dos profissionais contratados chegam, imediatamente após a chegada necessitam de uma casa para morar, escola para os filhos, supermercado, lojas comerciais, atendimento médico, dentário, farmácias e assim por diante.

A consequência imediata de um crescimento acima da média nacional trouxe consigo alguns problemas que, a princípio, pareciam sem solução. Num primeiro momento, estarreceu as autoridades locais; num segundo momento, revestiu a municipalidade de perspicácia para solucionar com agilidade os problemas diários, que não cessavam.

A dinâmica à qual o poder público teve de se adaptar despertou nos munícipes a premência de expandir alguns setores para assegurar 0 desenvolvimento como e aproveitar a mão de obra tipicamente rotativa agora em maior número na cidade. O desenvolvimento acabou por emparelhar-se rapidamente ao crescimento atípico e se destacou a ponto de colocar o município entre os que mais se destacaram em 2009, em dados veiculados pela edição de 2011 do IFDM Índice FIRJAN - Federação das Indústrias do Estado do Rio de Janeiro de Desenvolvimento Municipal, conforme Gráfico 06, a seguir. 


\section{Gráfico 06 - Índices FIRJAN de Desenvolvimento Municipal}

\begin{tabular}{|c|c|c|c|c|c|c|c|}
\hline \multirow{3}{*}{$\begin{array}{l}\text { Ano de } \\
\text { Edição } \\
2008\end{array}$} & \multicolumn{5}{|c|}{ 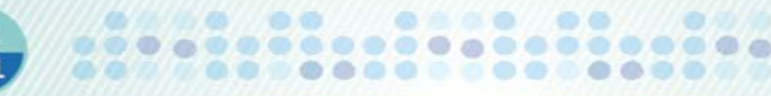 } & \multicolumn{2}{|c|}{$=\mathrm{DN}$} \\
\hline & $\begin{array}{l}\text { Ano } \\
\text { Base }\end{array}$ & $\begin{array}{l}\text { Ranking } \\
\text { Nacional }\end{array}$ & $\begin{array}{l}\text { Rankir } \\
\text { Estadi }\end{array}$ & Média & Renda & Educaçã & Saúde \\
\hline & 2000 & $679^{\circ}$ & $5^{\circ}$ & 0,6742 & 0,5461 & 0,6449 & 0,8317 \\
\hline 2008 & 2005 & $333^{\circ}$ & $1^{\circ}$ & 0,7771 & 0,6087 & 0,8111 & 0,9114 \\
\hline 2009 & 2006 & $262^{\circ}$ & $1^{\circ}$ & 0,7939 & 0,7133 & 0,7368 & 0,9314 \\
\hline 2010 & 2007 & $73^{\circ}$ & $1^{\circ}$ & 0,8538 & 0,8096 & 0,7890 & 0,9628 \\
\hline 2011 & 2008 & $70^{\circ}$ & $1^{\circ}$ & 0,8618 & 0,8108 & 0,8032 & 0,9715 \\
\hline 2011 & 2009 & $8^{\circ}$ & $1^{\circ}$ & 0,9046 & 0,8849 & 0,8650 & 0,9640 \\
\hline
\end{tabular}

Fonte: ASCOM - Prefeitura de Lucas do Rio Verde, 2012

Um dos setores que mais tem se destacado em Lucas do Rio Verde é o da construção civil, por conta da qual têm ocorrido profundas transformações provocadas pela instalação de empresas que alteraram toda a dinâmica espacial, tanto na cidade quanto no campo. A propósito, usando o pensamento de Gottdiener (2010:18), 'palavras como 'urbano' e 'rural', antes empregadas para classificar lugares, perderam seu valor analítico. [...] Os campos da ciência urbana exigem uma re-conceituação, pois os padrões de organização espacial mudaram."

Lucas do Rio Verde é, talvez, um dos melhores exemplos de "transformação do Cerrado para um vergel formado por um caleidoscópio de produções", como diria Santos (2005:40). A exigência de uma re-conceituação configura-se nas relações sócio-espaciais que acontecem nesta esfera, cada vez mais interdependentes, anulando, praticamente, a separação entre campo e cidade.

Como parte deste caleidoscópio de produções e de transformação do Cerrado, o município tem se esforçado para atender à demanda e dar suporte com distribuição de água, coleta de lixo e instalação de saneamento básico em praticamente todos os pontos da cidade inclusive nos novos loteamentos.

De acordo com informações obtidas ${ }^{54}$, os vários loteamentos de casas populares que a prefeitura está implantando, como por exemplo, o Téssele Junior, que se vê na Figura 23 abaixo, ao lado do parque industrial da Sadia, visa atender aos empregados contratados pela empresa em outros municípios.

\footnotetext{
54 Todas as informações e estatísticas a respeito do município de Lucas do Rio Verde foram fornecidas pela Assessoria de Comunicação do Município.
} 
Figura 23 - Loteamento Téssele Junior - 2010

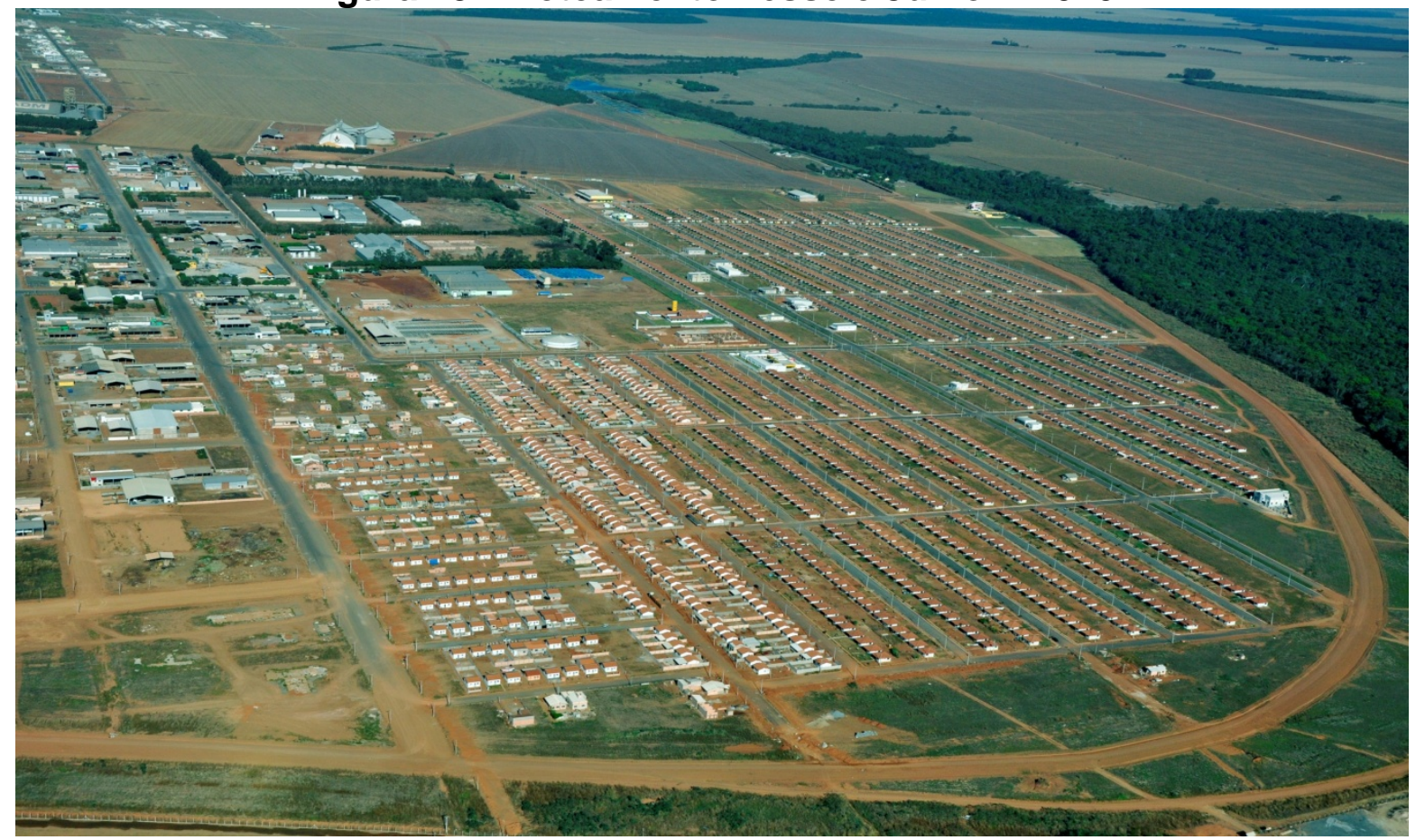

Fonte: ASCOM - Prefeitura de Lucas do Rio Verde (2012)

Este loteamento, com 2000 casas, tem toda a infraestrutura de um bairro como: escola, creche, ginásio de esportes e centro comunitário, conforme o projeto de urbanização do poder público municipal como se vê na Foto 02, a seguir.

\section{Foto 02 - Urbanização do loteamento Téssele Junior (2012)}

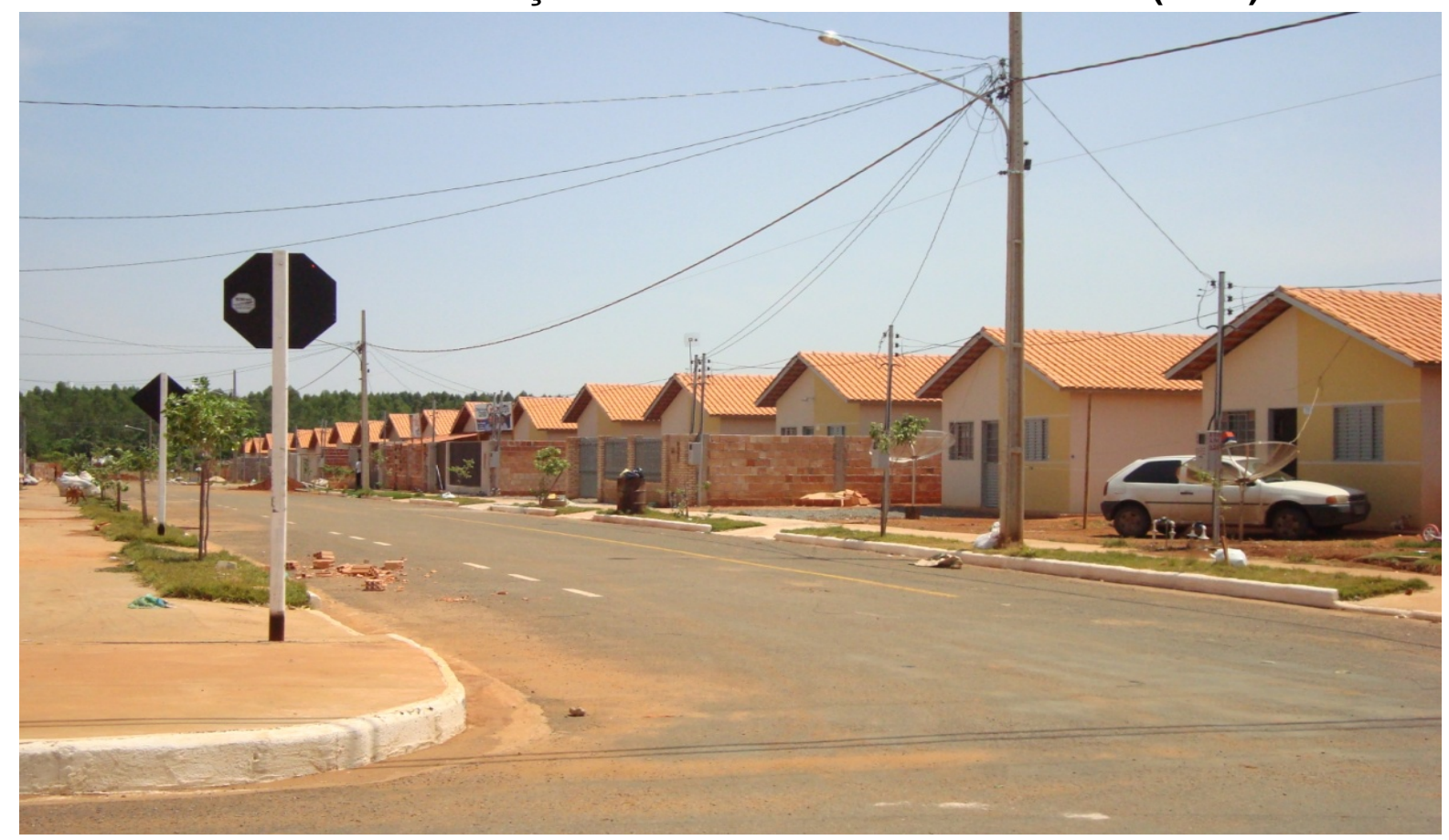

Fonte: Acervo da autora (2012) 
A política habitacional expande a cidade e já implanta as regras de urbanização antes que os moradores tomem posse de suas casas

Estas obras beneficiam um grande número de pessoas que necessita de melhores condições para se deslocar até o Setor Industrial, onde também está o complexo da Sadia, como é o caso do Loteamento Venturini que se vê na Foto 06.

Figura 24 - Loteamento Venturini (2009)

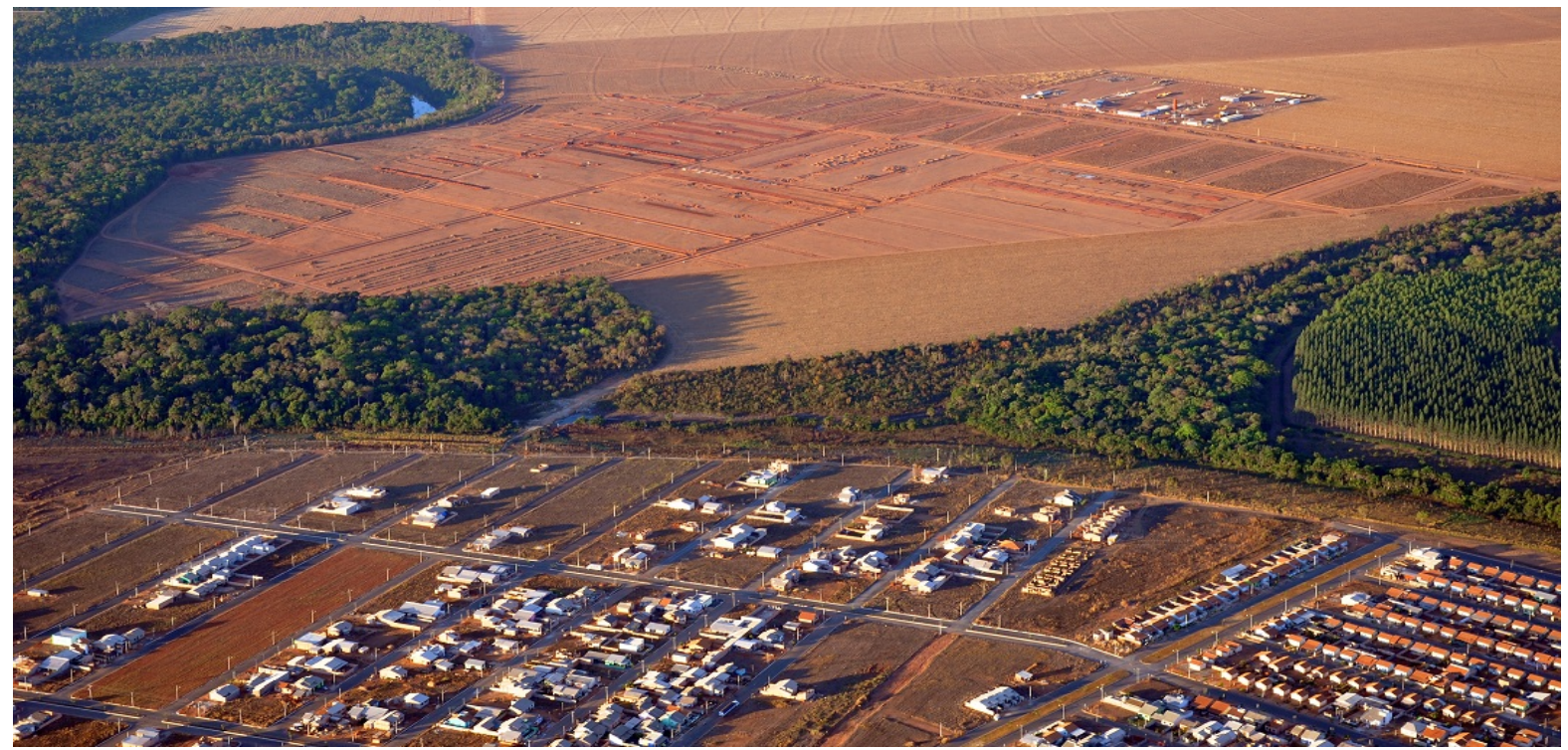

Fonte: ASCOM - Prefeitura de Lucas do Rio Verde (2012)

Como se vê na Figura 25, estas obras seguem em ritmo acelerado para atende à demanda que não para de crescer

\section{Figura 25 - Loteamento Venturini (2011)}

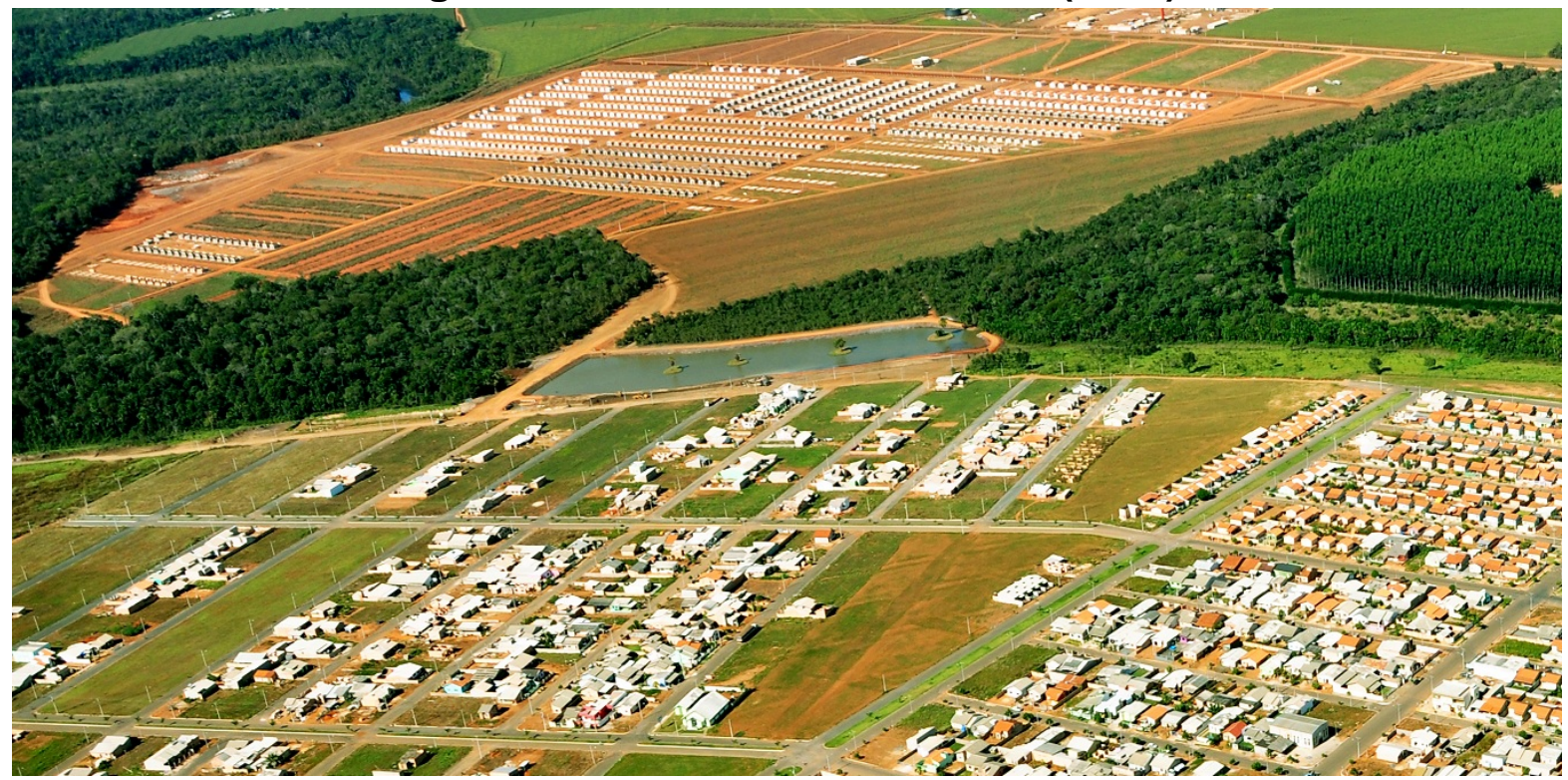

Fonte: ASCOM - Prefeitura de Lucas do Rio Verde (2012) 
Como os futuros moradores acompanham o processo, já que desde o início das obras ele tem ciência de qual será a sua casa, estas providências são controladas por eles. Em caso de descumprimento do acordado por contrato antes do início da obra, estes futuros moradores têm o direito ao ressarcimento que será realizado pela parte descumpridora.

\section{Foto 03 - Reservatório de Água do Loteamento Venturini (2012)}

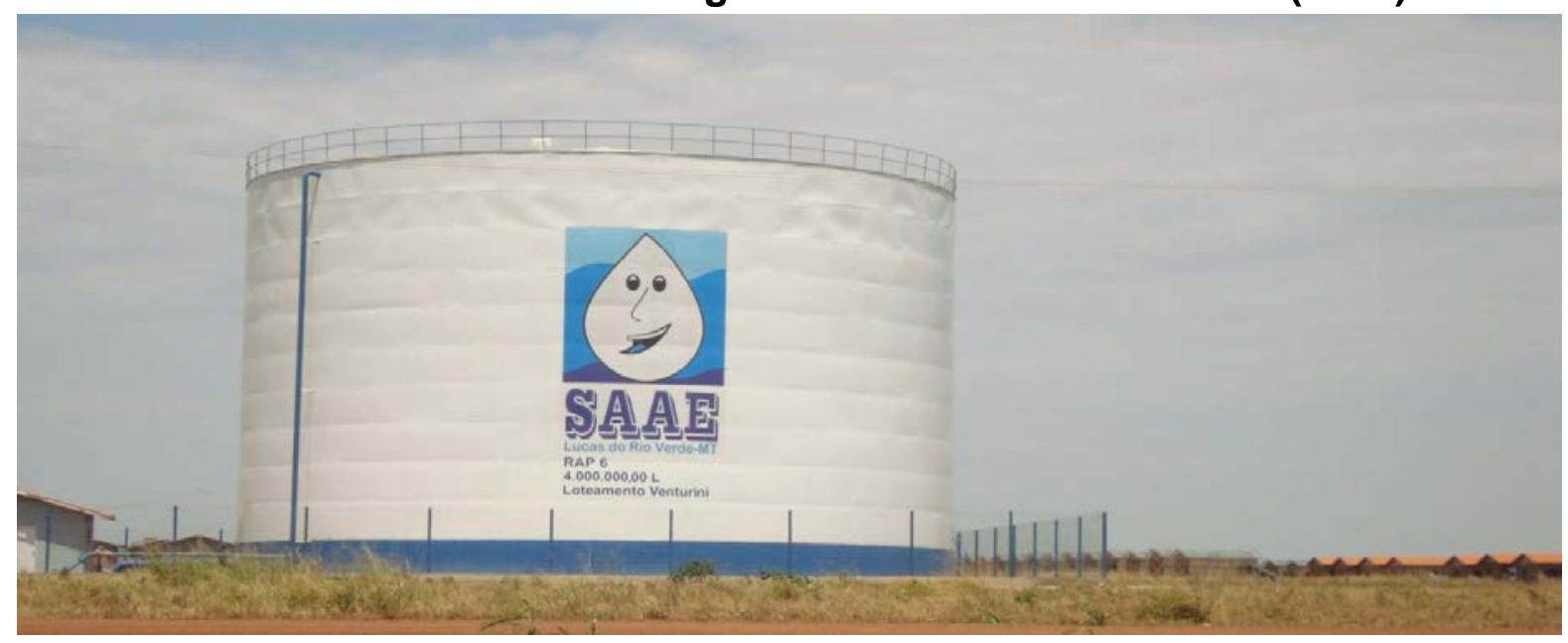

Fonte: Acervo da autora (2012)

A estrutura destes loteamentos, como se vê na Foto 03, é montada com características de um futuro bairro. Embora os projetos sejam vinculados ao programa federal "Minha casa Minha vida", o poder municipal se encarrega de construir a infraestrutura de uso coletivo como: praça de esportes com quadra coberta, escola, posto de atendimento e posto policial, além de cada loteamento estar abastecido com seu próprio sistema de distribuição de água potável.

Figura 26 - Loteamento Jaime Seiti Fugii I e II

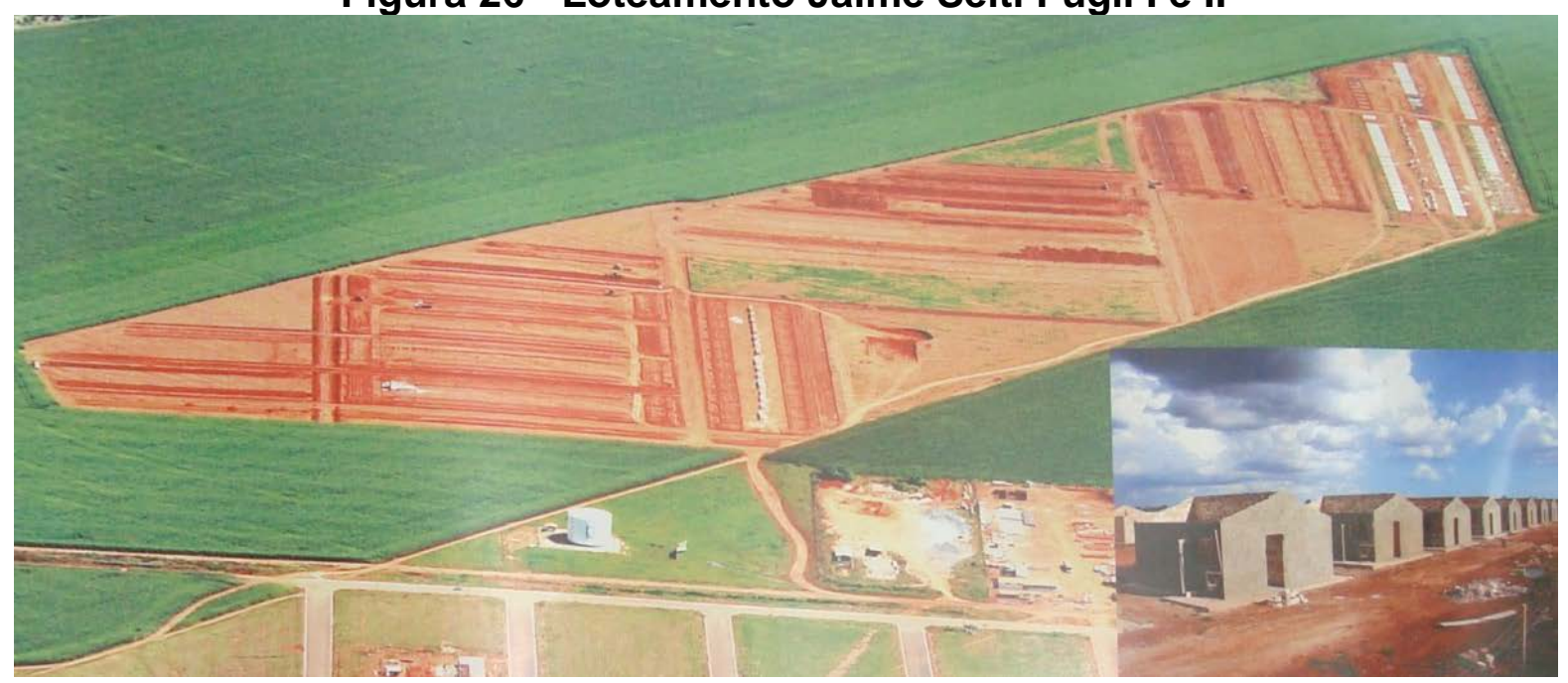

Fonte: Arquivo Prefeitura de Lucas do Rio Verde (2012) 
Entre 2004 e 2012, o município aumentou em 352\% a edificação de casas populares, ou seja, de 1.144 casas existentes em 2004, estava com 5.180 até julho de 2012. A mesma evolução se nota nas ligações da rede hidráulica. Em 1996 contava com 2.565 ligações, entre 1996 e 2005 aumentou 176\% completando 7.084 e, em 2012, este volume cresceu $116 \%$ com 15.349 ligações.

Conforme pode ser constatado na Figura 26, acima, existem ainda outros loteamentos em construção, como é o caso do Jaime Seiti Fugii I e II, que atendem outra área da cidade, onde estão sendo edificadas empresas de menor porte e para onde estão se deslocando as pessoas que trabalham no comércio ou setor de serviços do núcleo urbano.

Outra preocupação do poder público é a rede de esgoto que, em 2005, possuía 346 domicílios ligados a ela e em 2012 está com 4.387. Este número aumentou sensivelmente, depois que a Secretaria de Obras Viação e Serviços Públicos passou a exigir a comprovação da instalação do sistema de esgoto para conceder o "habite-se" a qualquer obra edificada no município.

\section{Foto 04 - Coleta de lixo no Bairro Tessele Junior (2012)}

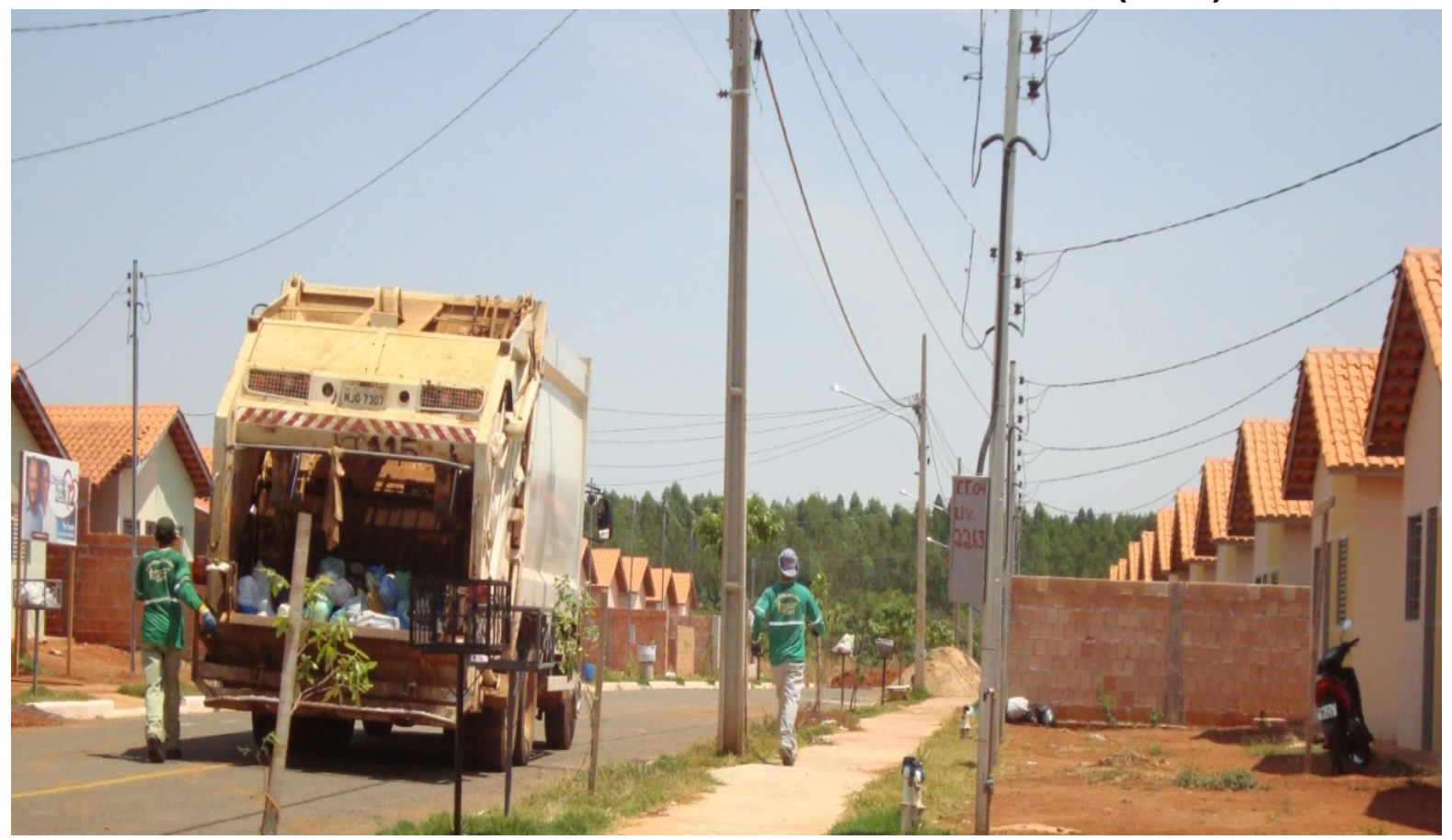

Fonte: Acervo da autora (2012)

A limpeza das vias públicas, terrenos edificados e/ou baldios e habitações particulares ou coletivas estão sob a constante vigilância, considerando não só a possibilidade de formação de cortiços como também pontos que se transformem em criadouros de mosquitos ou insetos que venham a prejudicar a saúde das pessoas. 
Durante a pesquisa in loco se presenciou, conforme Foto 04, acima, uma coleta de lixo no bairro Tessele Junior, loteamento recém terminado onde apenas parte das casas havia sido entregue aos proprietários. A rede de água e esgoto já estava pronta e o caminhão de coleta de lixo já circulava na área ocupada recentemente por moradores.

Estes cuidados levaram o poder público a criar um Plano de Saneamento que está sendo implantado em todo núcleo urbano, independente das exigências estipuladas para os loteamentos novos, onde estas providências já estão inseridas nos projetos para aprovação municipal.

Este plano pretende eliminar as áreas onde ainda não existe o saneamento básico e, aproveitando a planta do município, criar um esquadrinhamento com sistemas de água e esgoto, conforme se vê na Figura 27, abaixo, visando atender toda a população.

\section{Figura 27 - Plano de Saneamento - Implantação da rede de esgoto Lucas do Rio Verde (2012)}

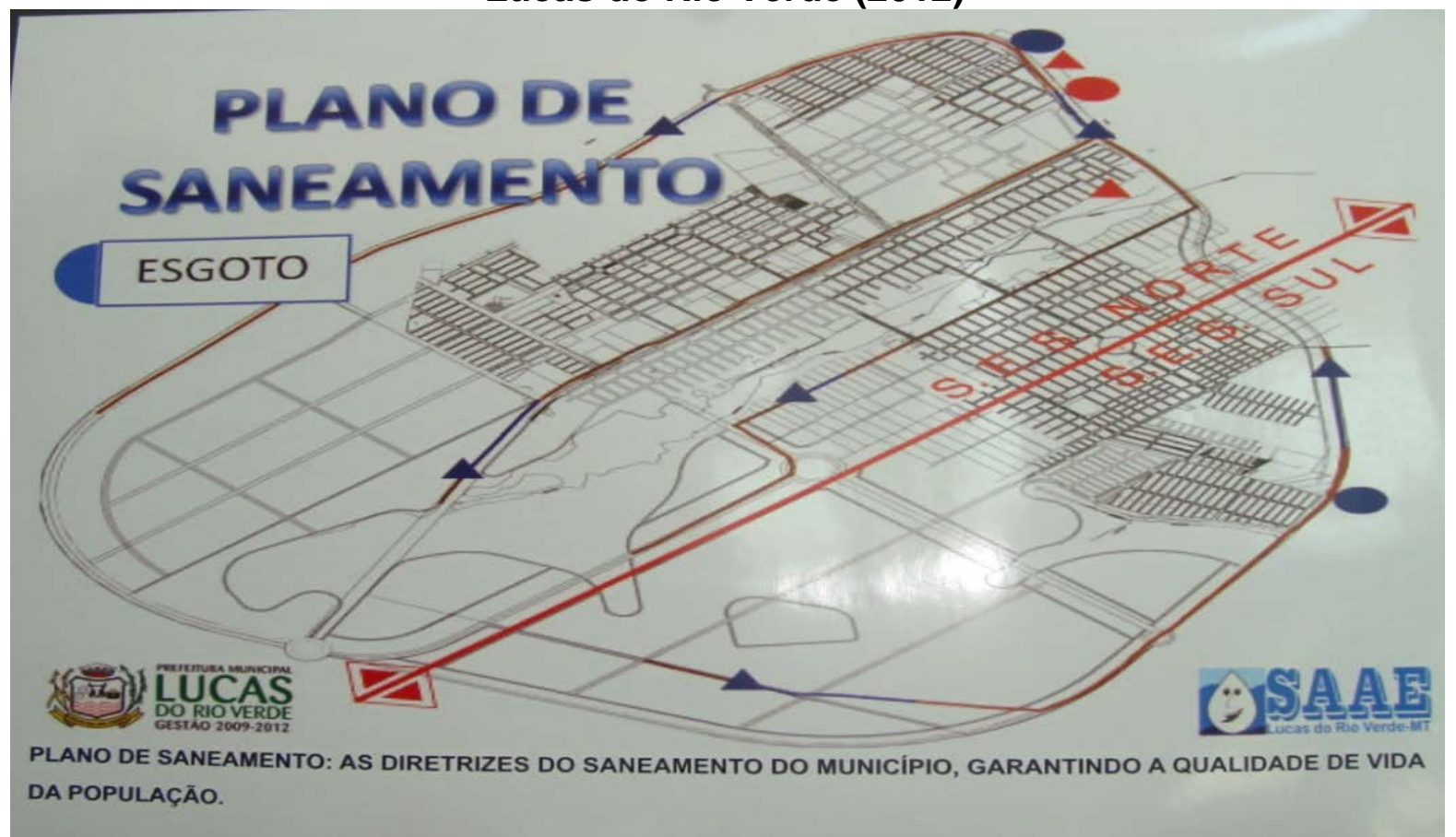

Fonte: ASCOM - Prefeitura de Lucas do Rio Verde, 2012

Para atender a esta prioridade estão sendo tomadas outras providências como mudanças no trânsito e alterações de direcionamento e ruas e o enquadramento paulatino ao Código de Posturas ${ }^{55}$. Isto significa atender exigências que abrangem higiene pública, bem-estar social, costumes, segurança, ordem

${ }^{55}$ Lei Complementar no 002/90, de 10 de outubro de 1990, cuja súmula institui no município de Lucas do Rio Verde penas aos infratores que, por ação ou omissão, infringirem a legislação e os regimentos do Município. 
pública, defesa civil, preservação e conservação do meio ambiente, sinalização viária, numeração de edificações, funcionamento e localização dos estabelecimentos comerciais.

Como cita Maria Encarnação Sposito (2007), em seu artigo "Urbanização difusa e cidades dispersas: perspectivas espaço-temporais contemporâneas",

\begin{abstract}
A combinação de movimentos de (re)centralização das funções associadas ao consumo de bens e serviços, e de desconcentração demográfica, quando se considera o número de habitantes por quilômetro quadrado, em cidades de diferentes portes, parece contraditório, mas faz parte do processo amplo de reestruturação da cidade que se articula, ao de reestruturação urbana. (SPOSITO, 2007: sr).
\end{abstract}

Esta (re)centralização das funções associadas ao consumo de bens e serviços e de desconcentração geográfica, tem sido a tônica de Lucas do Rio Verde, considerando que ainda é grande o número de imigrantes que tem se deslocado para o município em busca de trabalho.

Houve também o deslocamento de toda a administração municipal para uma área afastada do atual núcleo urbano, onde será edificado o Centro Cívico, que será composto pela Prefeitura, Câmara de Vereadores e Espaço Cultural. Até 2012, apenas a Prefeitura funciona na área. Todo o complexo foi criado para centralizar o poder público na convergência das regiões norte, sul, leste e oeste do município, como se vê na Figura 27.

Figura 28 - Maquete do Centro Cívico

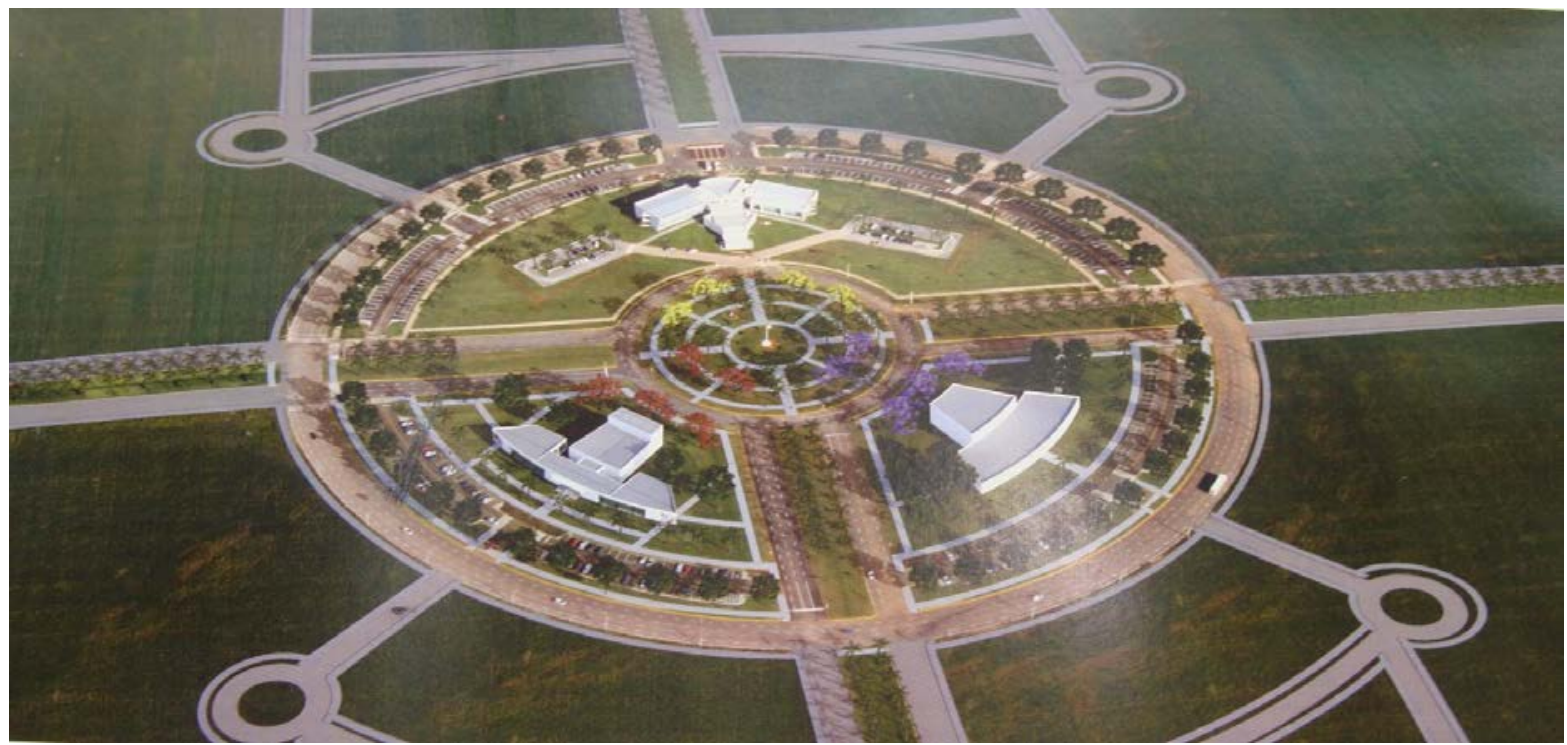

Fonte: Foto do arquivo Prefeitura de Lucas do Rio Verde (2012)

Na Figura 28 é possível avaliar o entorno do Centro Cívico com suas avenidas que levam aos bairros e ao atual núcleo urbano. 
Foto 05 - Avenida que liga o Centro Cívico ao bairro Téssele Junior e ao complexo industrial da Sadia

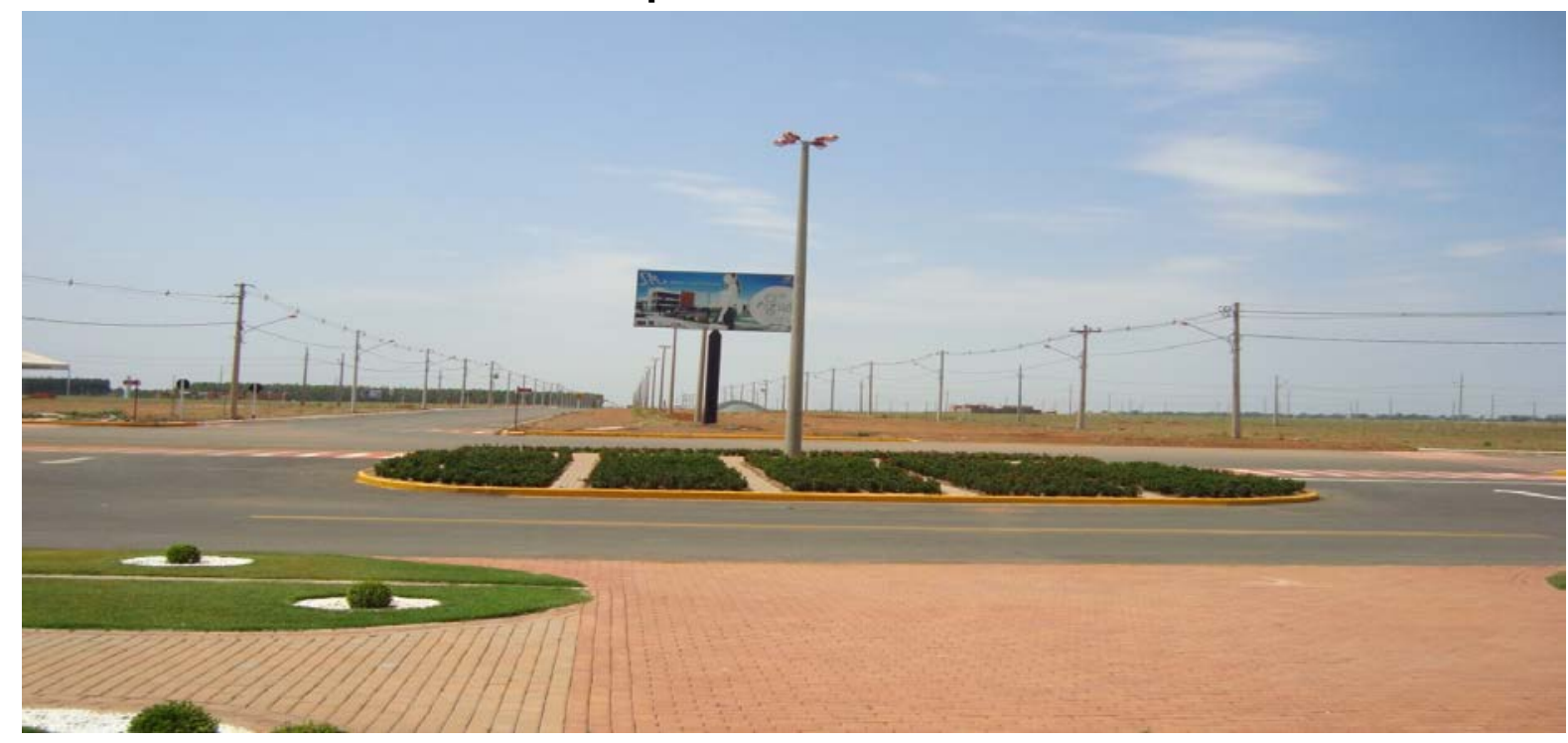

Fonte: Acervo da autora (2012)

Na Foto 05 se vê outra alça da convergência, que liga o Centro Cívico ao atual núcleo urbano para que se tenha uma ideia da reterritorialização que acontece com o deslocamento do poder público que transformará o perímetro urbano da cidade, afastando o núcleo urbano da área de acostamento da BR-163.

Foto 06 - Rodovia que liga o Paço Municipal ao centro da cidade

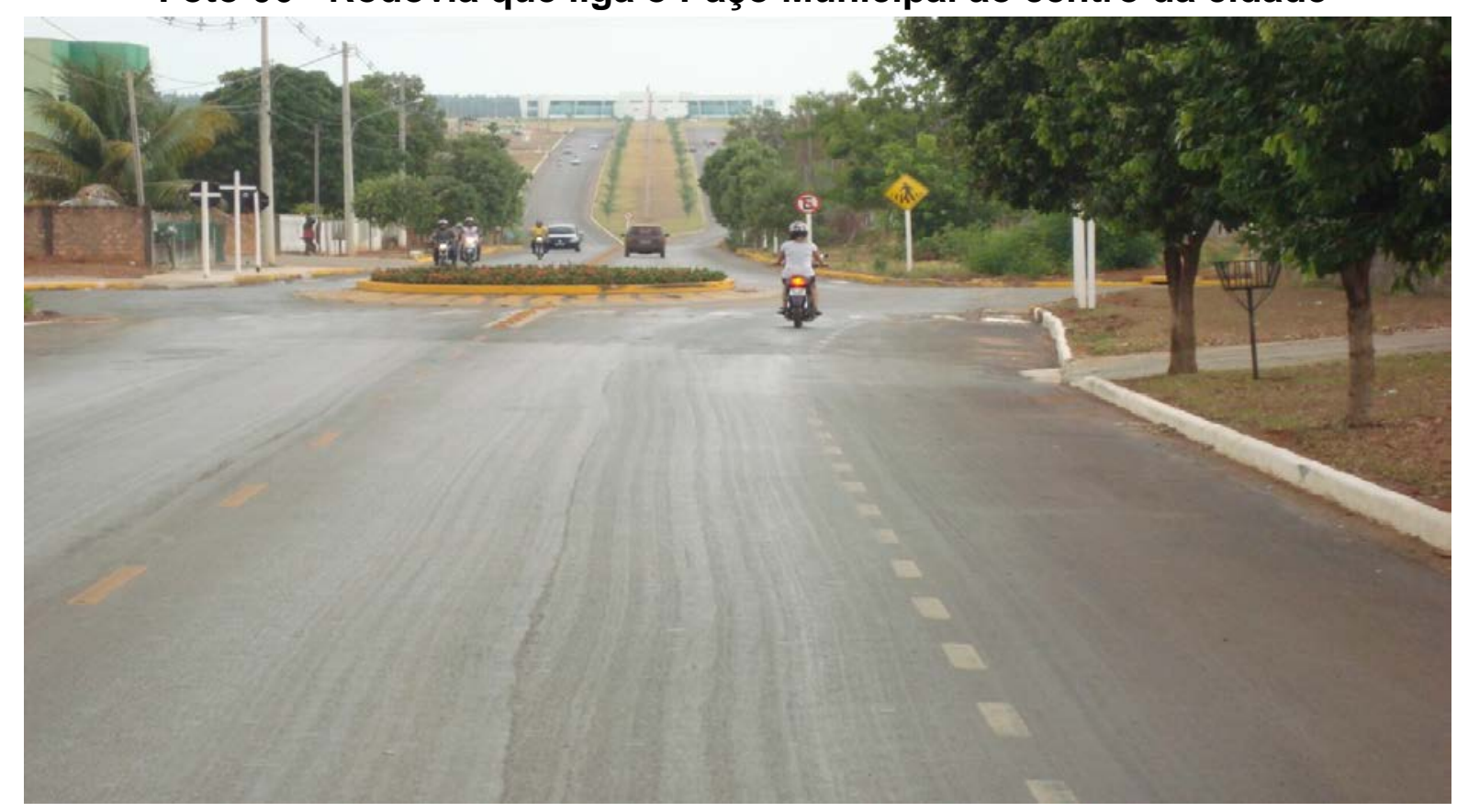

Fonte : Acervo da autora (2012)

Paralelamente, este deslocamento influi positivamente na urbanização que veio se formou ao longo da história do município, que coloca a população menos 
favorecida de um lado da rodovia e as classes mais favorecidas do outro. Com esta reterritorialização, é possível que este divisor de classes representado pela BR-163 perca o sentido.

Estrategicamente construído, localiza-se na bifurcação das avenidas que ligam as principais áreas urbanas às suburbanas do município. A ideia de construir - Centro Cívico numa área afastada do atual núcleo urbano prevê seu o espraiamento, não só para dar lugar à expansão da produção propriamente dita, como também para dar lugar aos processos espaciais, como menciona Santos (2008: 13-14), "aos demais processos que se dão segundo um jogo e fatores que interessa a todas as outras frações do espaço".

O que se percebe em Lucas do Rio Verde é a morfologia espacial contemporânea, "que não é apenas a cidade que se ampliou, mas uma forma qualitativamente nova de espaço de assentamento" (GOTTDIENER, 2010:15).

Além do monitoramento direcional das implantações e novos loteamentos, existe o cuidado permanente de manter no núcleo urbano uma área verde, visando dar mais qualidade de vida aos munícipes e embelezar o centro da cidade.

Assim, a área urbana também tem se reestruturado, principalmente em função do crescimento demográfico, através de projetos e programas que visam à organização espacial da área central.

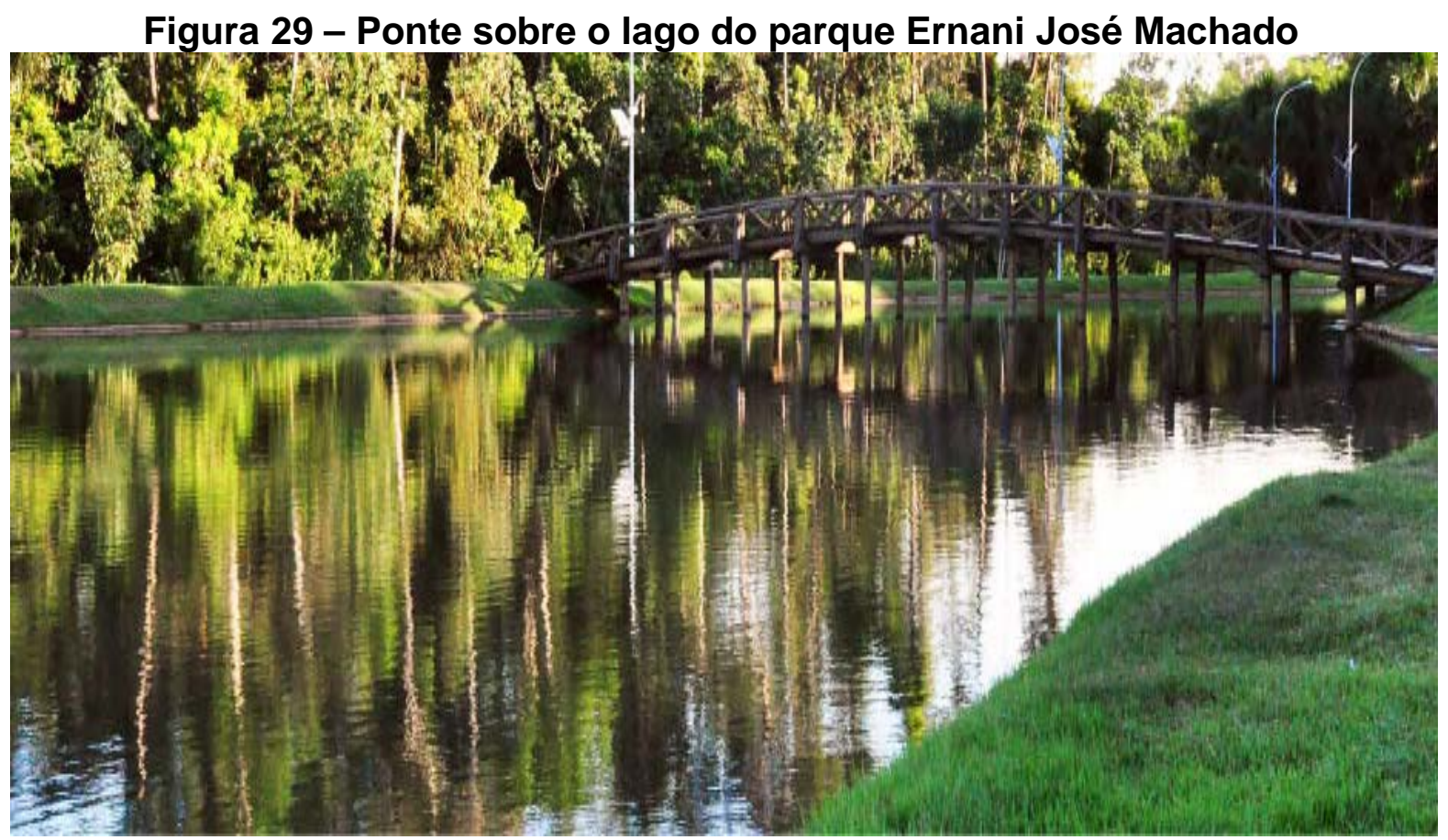

Fonte: Arquivo Prefeitura de Lucas do Rio Verde (2011) 
O Lago Ernani José Machado, na Figura 29, acima, situa-se na área verde do Córrego Lucas, entre as avenidas Mato Grosso e Tocantins, as principais artérias do núcleo urbano, é um exemplo disso. Nele foram construídas trilhas para caminhada, permeadas por calçadões de pedra e uma ponte interligando as duas margens do lago. É um dos cartões postais do município, que atrai inúmeros visitantes e ali também se realizam eventos esportivos, artísticos e culturais.

O Figura 30, a seguir, dá uma ideia de como o município está dividido hoje:

\section{Figura 30 - Plano Diretor de Lucas do Rio Verde}

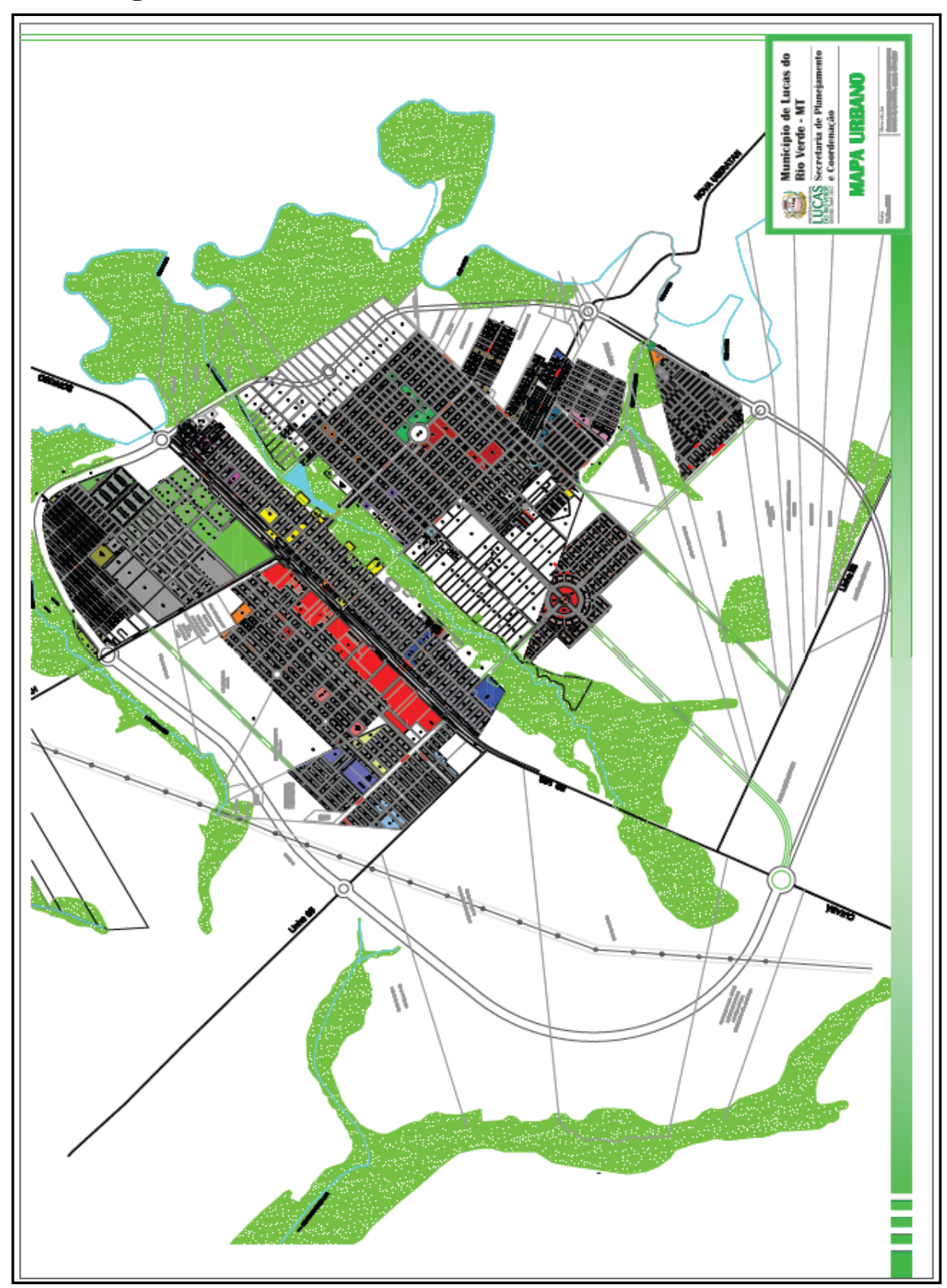

Fonte: ASCOM - Prefeitura de Lucas do Rio Verde (2012) 
Paralelo à agressividade do capitalismo que envolve o agronegócio e a ação econômica e política responsáveis mais diretas pelas transformações desenvolvidas no município, percebe-se um cuidado especial com a educação que atua em estreita parceria com a cultura.

O município optou por construir escolas com boa infraestrutura, sendo que algumas podem ser comparadas a escolas particulares de alto nível, como é o caso da Escola Olavo Bilac, demonstrada na Figura 31, abaixo, que oferece ensino para alunos do ensino fundamental e médio.

\section{Figura 31 - Escola Municipal Olavo Bilac - Lucas do Rio Verde}

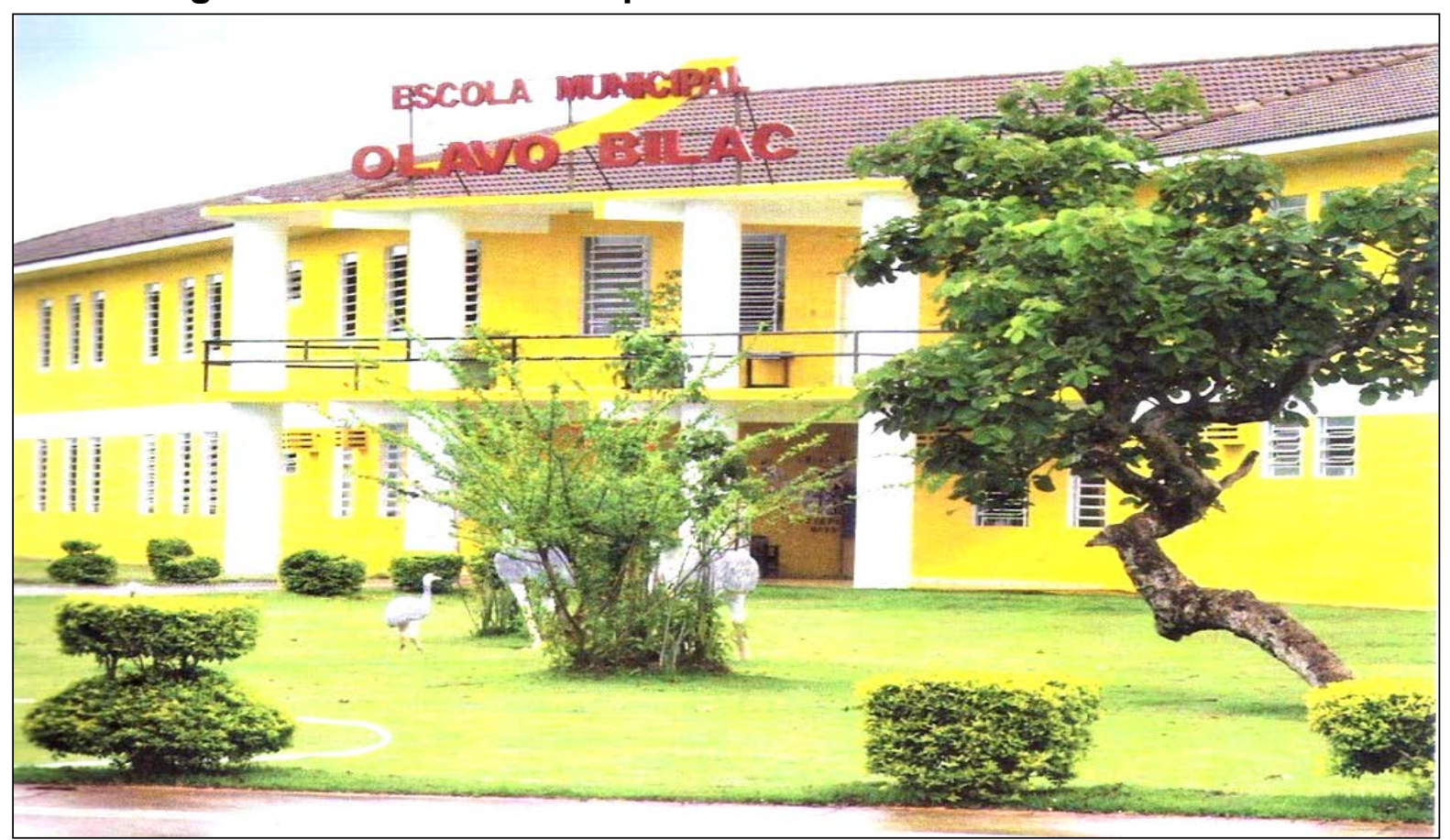

Fonte: ASCOM - Prefeitura de Lucas do Rio Verde (2012)

Um dos projetos que mais chama a atenção é o Plano de Tecnologia da Informação, que atende a todo o município, a partir de uma central instalada na prefeitura, com subcentrais em cada Secretaria.

O sistema consiste na operação de um roteador central instalado na prefeitura que, através de uma antena de banda larga, chega até outra antena instalada num ponto estratégico do município. Dali, o sinal é retransmitido para todos os pontos que possuam links com o sistema.

No caso da Secretaria de Educação, como se pode verificar no Figura 32, o router leva o sinal para as escolas municipais, onde estão instalados computadores que antes atendiam apenas o Projeto de Inclusão Digital e agora estão trabalhando em rede para atender não apenas aos alunos ou a escola, mas também a 
comunidade do entorno que, muitas vezes, não conta com um PSF (Programa Saúde da Família) ou CRESS (Conselho Regional de Serviço Social). Interligados, o sistema faz com que os programas se apoiem e, em rede, deem sustentabilidade aos projetos federais, integrados com os projetos estaduais e municipais.

\section{Figura 32 - Plano de Tecnologia da Informação: organograma de Educação}

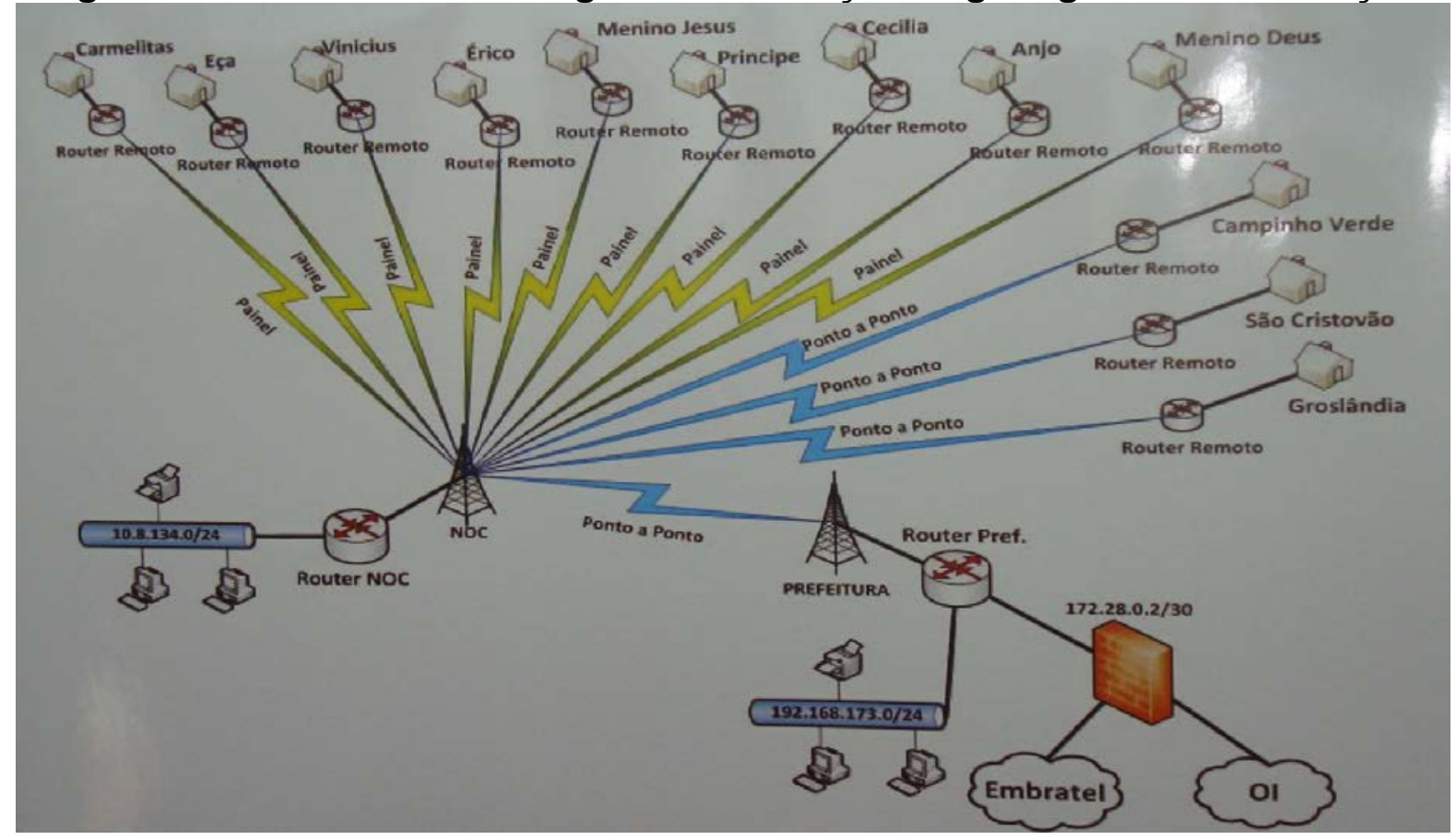

Fonte: ASCOM - Prefeitura de Lucas do Rio Verde (2012)

Este sistema faz parte de um esforço da Administração Municipal para integrar os serviços comunitários, transformando cada escola num ponto de apoio para os munícipes, visando não só um melhor desempenho na área de educação como também fixando na escola um ponto de referência e participação das comunidades em suas áreas de abrangência.

Para dar suporte aos projetos de educação e cultura, existe o programa de acompanhamento da produtividade dos alunos que facilita o ingresso em cursos. Além dos cursos gratuitos de qualificação profissional, direcionados para a demanda do mercado de trabalho local, são disponibilizados gratuitamente cursos de pintura, escultura, tecelagem, teatro e música (instrumental e vocal), paralelamente são promovidos campeonatos de fanfarra e competições esportivas.

Para manter a estrutura dos cursos, as Secretarias de Desenvolvimento Social, Educação e Esportes, Lazer, Cultura e Turismo apoiam os participantes com a doação da maior parte do material necessário para realizá-los. Este apoio se estende a patrocínios, quando os projetos envolvem locomoção de alunos para 
apresentações, concursos, disputas ou outros eventos que possam promover o município e incentivar o público participante dos cursos monitorados pela prefeitura.

A evasão escolar continua sendo o maior problema do município, embora as estatísticas tenham melhorado muito nos últimos sete anos. Conforme dados da Gráfico 07, o índice de alunos concluintes cresceu 52,72\%, o que é um dado bem animador para uma cidade na qual o trabalho precoce é incentivado pelas famílias, fato que traz bastante dificuldade para o poder público no combate ao trabalho infantil.

\section{Gráfico 07 - Demonstrativo do total de alunos da Rede Municipal de Ensino Lucas do Rio Verde}

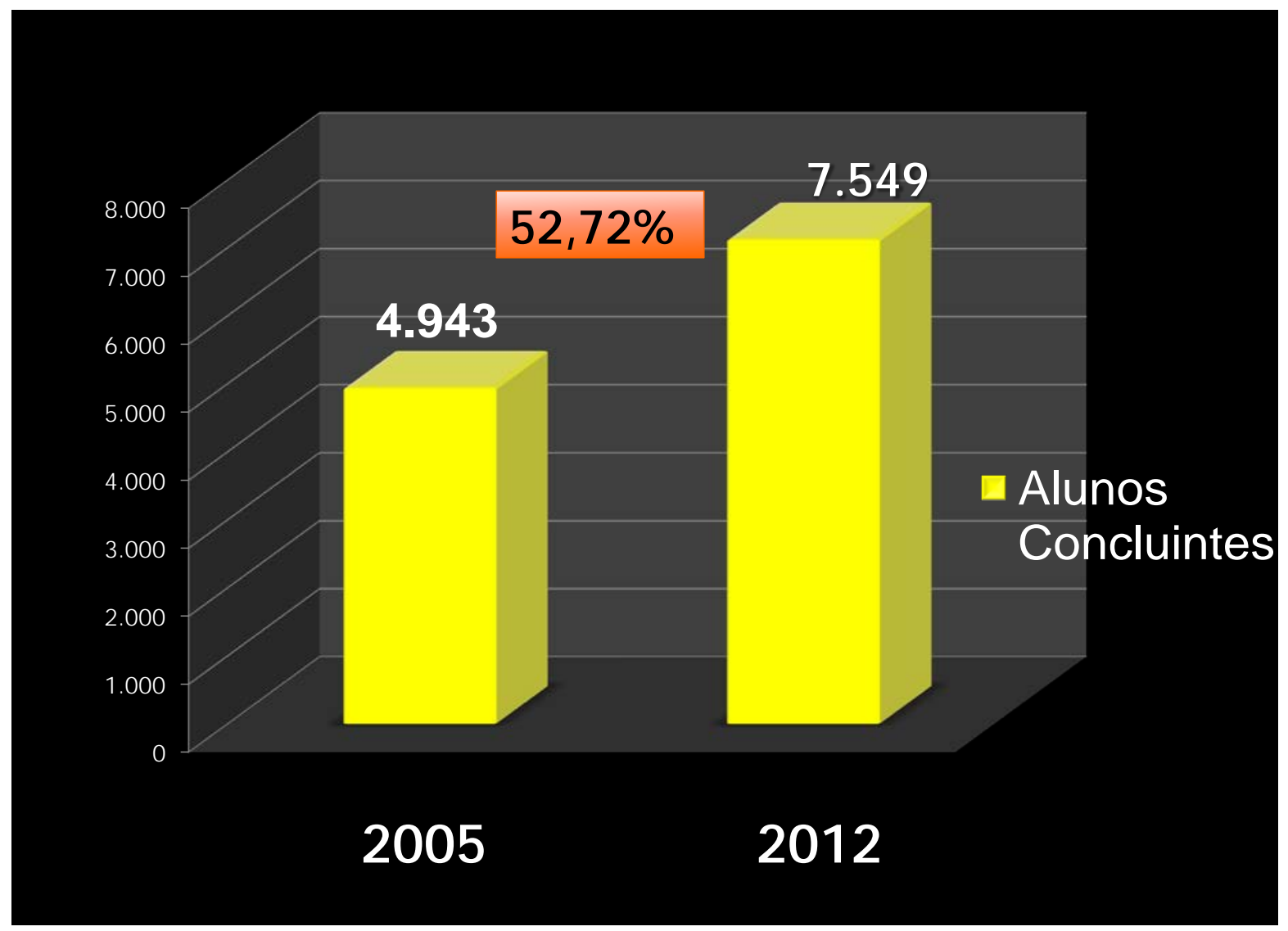

Fonte: ASCOM - Prefeitura de Lucas do Rio Verde (2012)

No caso dos PSF, a estrutura é a mesma da Educação, sendo que, neste caso, o ponto de apoio estabelece a conexão entre a Secretaria Municipal de Saúde e a comunidade onde o router remoto está instalado.

Como pode ser visto na Figura 33, abaixo, o Plano de Tecnologia da Informação para a Secretaria Municipal de Saúde forma uma rede de atendimento que cobre todas as unidades e, conforme informações obtidas na Assessoria de Comunicação da Prefeitura, esta rede trabalha em conjunto com a rede que atende 
a Secretaria Estadual de Educação, O trabalho em equipe tem dado bons resultados no atendimento às comunidades que vivem no entorno das áreas onde estão instaladas.

\section{Figura 33 - Plano de Tecnologia da Informação: organograma da Saúde}

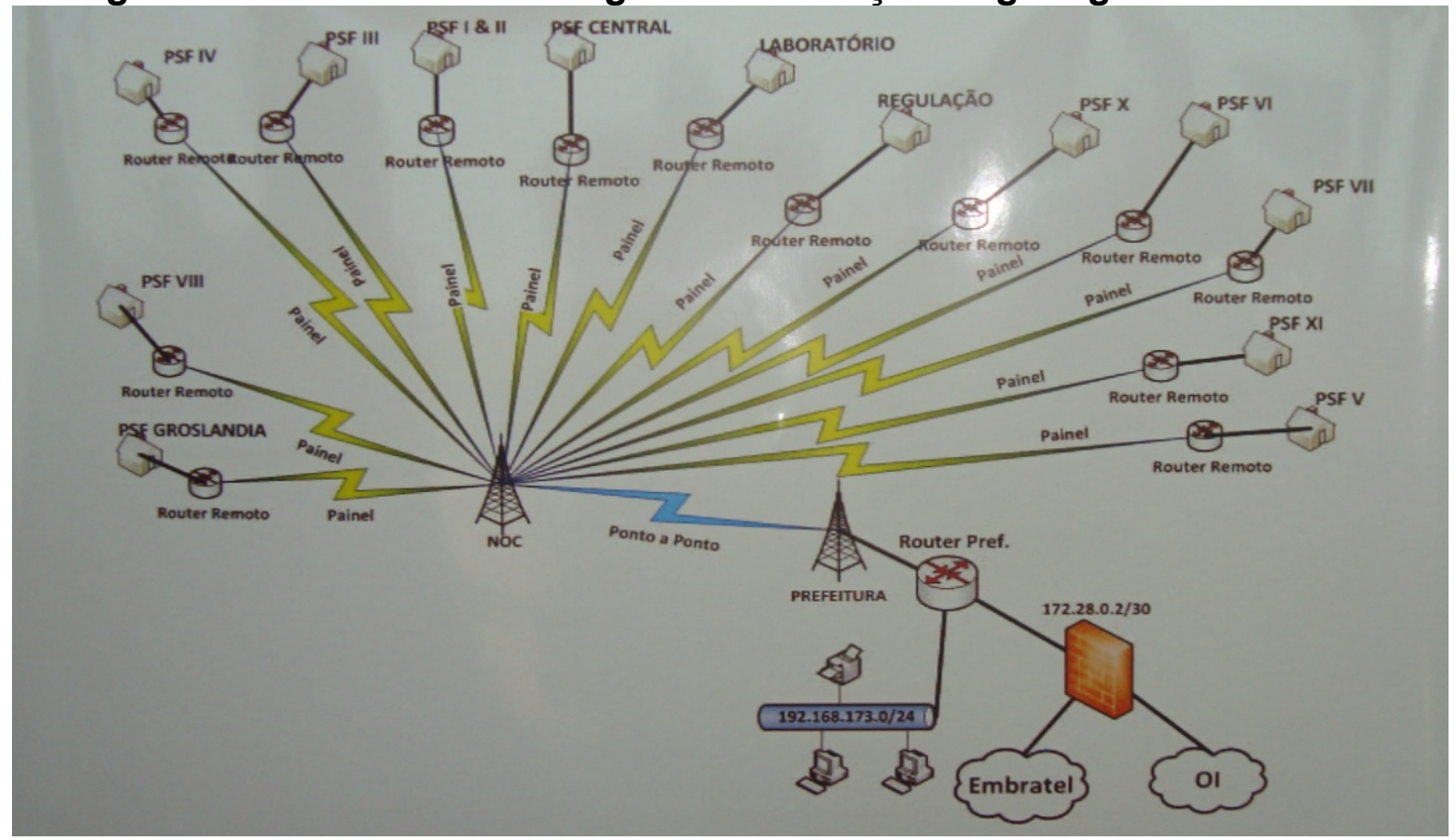

Fonte: ASCOM - Prefeitura de Lucas do Rio Verde (2012)

O crescimento vertical de Lucas do Rio Verde evidenciou a necessidade de empresas de prestação de serviço para dar suporte não só à estrutura do agronegócio como ao próprio comércio lojista que cresceu vertiginosamente. $\mathrm{O}$ comércio local é bastante variado e concorrido, voltado em sua maioria, para as classes $A$ e $B$, que podem pagar seus serviços e também traz para revenda muita mercadoria dos grandes centros.

As lojas de vestuário podem ser consideradas como lojas de alto padrão, sendo que o comércio para as classes menos favorecidas funciona principalmente os bairros onde prevalece a população de menor poder aquisitivo, na periferia do núcleo urbano, ou "no outro lado da BR-163", reservado para as populações menos favorecidas.

A avenida Rio Grande do Sul mostrada a seguir em duas décadas diferentes, é considerada um importante ponto de comércio da cidade: 1970 (Figura 34) e em 2010 (Figura 35). As fotos dão uma demonstração do quanto se desenvolveu a cidade em apenas 30 anos. Já o comércio voltado para as atividades produtivas 
funciona tanto no centro quanto nos bairros, atendendo a um público que varia entre pessoas que vivem no núcleo urbano e pessoas que vivem nas fazendas próximas.

Figura 34 - Av. Rio Grande do Sul - Lucas do Rio Verde, 1970

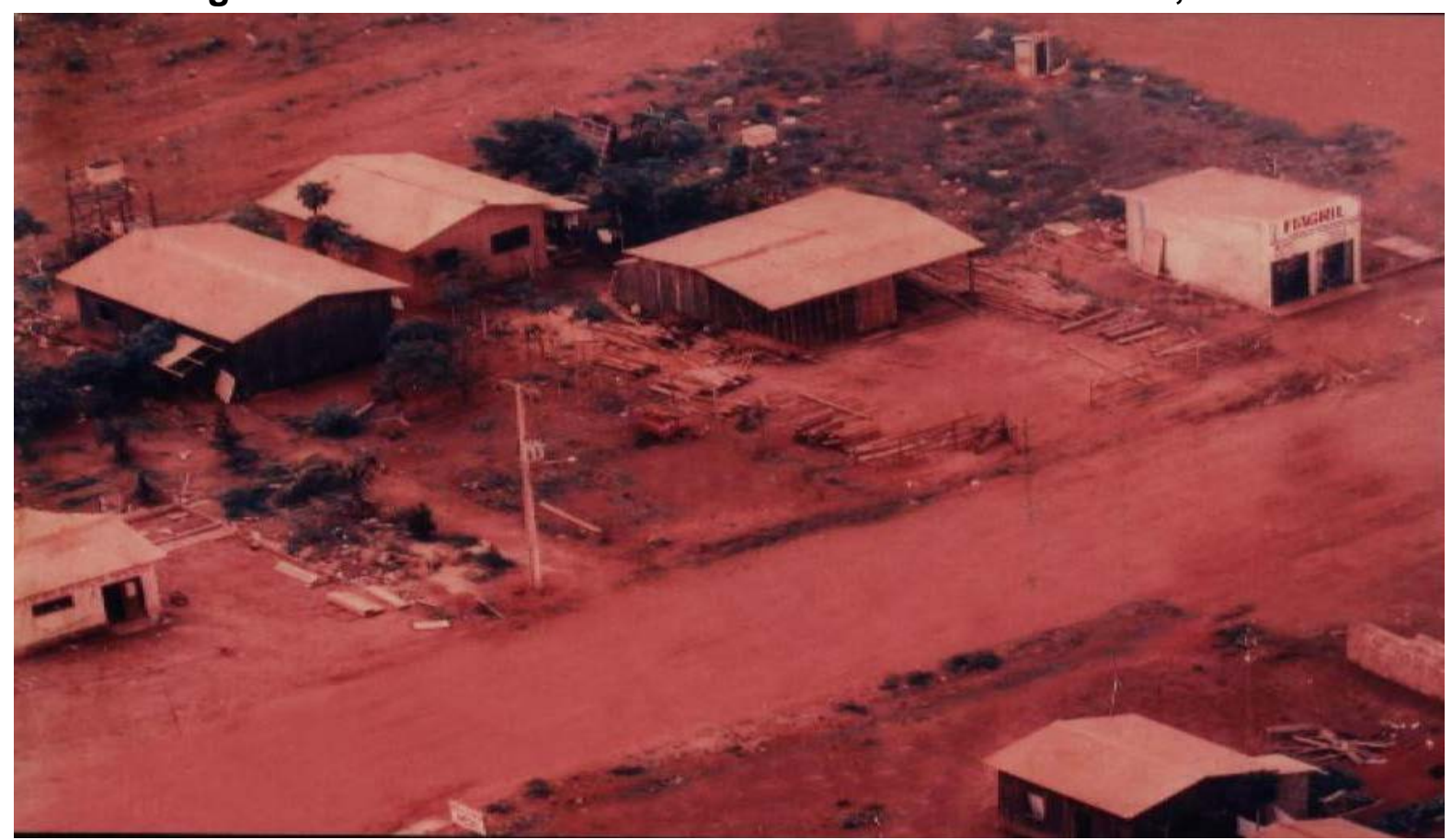

Fonte: ASCOM, Prefeitura de Lucas do Rio Verde (2012)

Figura 35 - Av. Rio Grande do Sul - Lucas do Rio Verde, 2010

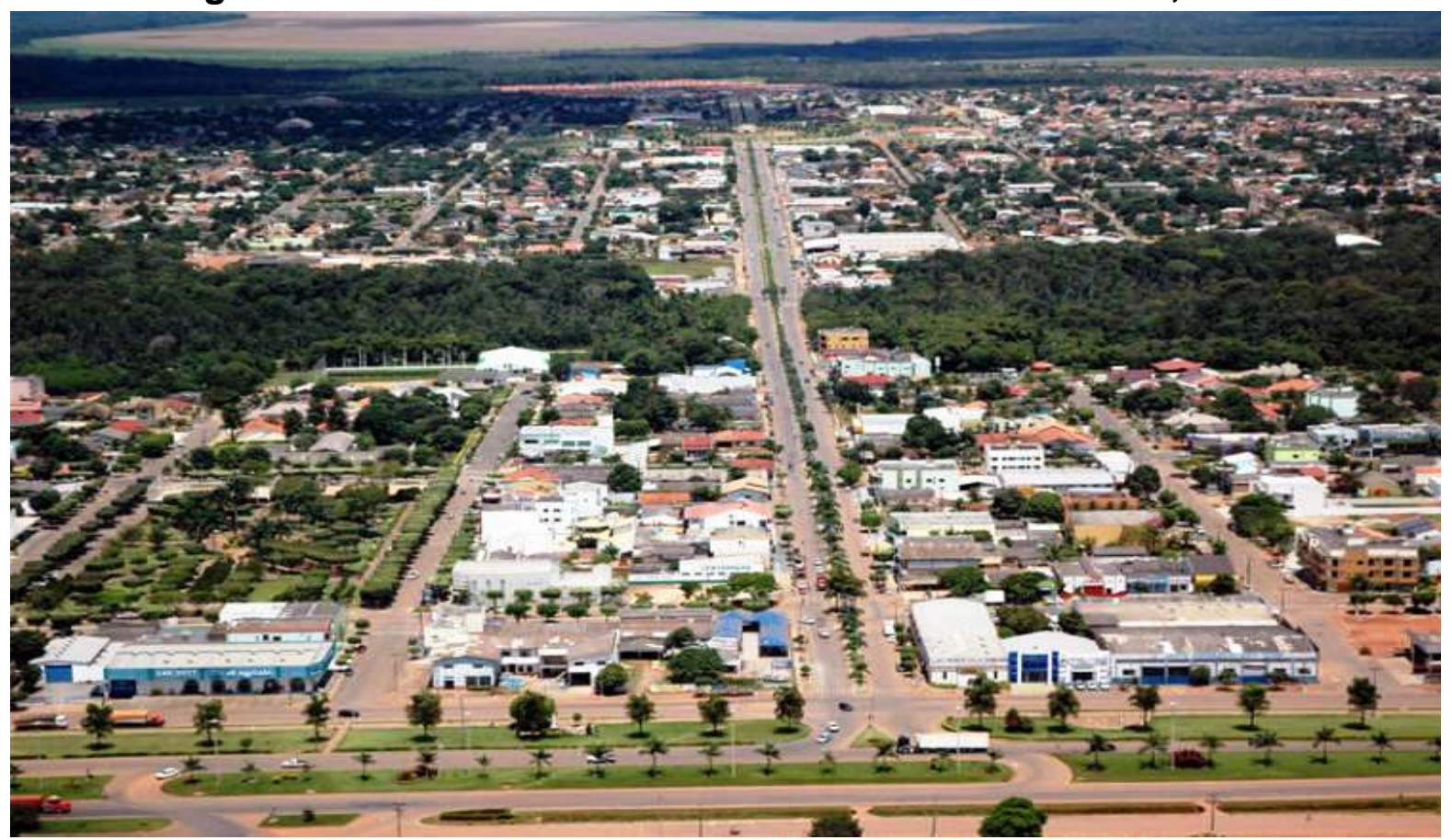

Fonte: ASCOM, Prefeitura de Lucas do Rio Verde (2012)

Um dos pontos fortes do município é uma herança da organização fundiária do INCRA que era aplicada em todos os projetos de colonização, como declarou, 
durante a entrevista concedida em Cuiabá, em 16.10.2012, Paulo Pitaluga Costa e Silva:

\begin{abstract}
Os projetos de colonização tinham três tipos de áreas. A área urbana, os lotes urbanos onde a gente fazia muita praça e tal, aí fazia os lotes pararurais, as chácaras, as chacrinhas de um a três hectares, onde o sujeito plantava verduras e as áreas rurais. Há muito anos atrás, isso não era do meu tempo, eles fizeram uns blocos assim, de área de reserva, mas com o tempo invadiram, acabaram com as áreas de reserva. Então, o que é que nós fazíamos: para-rurais e os lotes urbanos, aqui em Mato Grosso, aquilo num instante virava cidade. Aí, quando virava cidade, a gente titulava tudo. Quando não virava cidade, a gente titulava os lotes como para-rurais e rurais.
\end{abstract}

No caso de Lucas do Rio Verde, esta área para-rural foi efetivamente preservada. Deliberadamente ou não, não se sabe. O que se tem conhecimento é que hoje existe até uma cooperativa de pequenos agricultores produzindo leite, queijos, verduras e legumes para entrega diária na cidade e que está se organizando em sindicato para aumentar a proporção dos produtos consumidos pelos luverdenses.

Este é um dos diferenciais do município em relação aos outros da área de abrangência da BR-163 que recebem praticamente toda a alimentação básica de outros municípios, notadamente dos grandes centros como Cuiabá, Goiânia, de cidades de Minas Gerais ou do Estado de São Paulo, e ainda não se organizaram para mudar esta realidade, embora já existam pequenos grupos caminhando nesta direção.

Conforme relata o presidente do Sindicato dos Pequenos Produtores de Lucas do Rio Verde, Sr. Nilfo Wandscheer, em entrevista concedida em 21.09.2012,

No último levantamento que a gente fez $87 \%$ do alimento do dia-a-dia vem de fora. O folhado é produzido aqui; agora frutas e legumes, de um modo geral, tudo vem de fora. [...] É a questão do espaço, da disputa, do governo, tudo né... Há uns anos atrás, eu fiquei onze anos, como presidente do Sindicato dos Trabalhadores Rurais de Lucas do Rio Verde e aí foi feita muita pesquisa. [...] a base mesmo são poucos chacareiros; o que teve muito foi gente que entrou de sócio porque não tem mais espaço.. pela questão de conseguir um pedaço de terra, de chão, que era o sonho deles, né; em outros municípios a gente assentou 310 famílias, nestes onze anos. Só pelo INC. Em Nova Mutum, Ubiratan, Sinop, Tapurah, enfim, nesta região.

Como se edificou a liderança sindical do Sr. Nilfo, em Lucas do Rio Verde:

Num único projeto eu sempre fiquei, fiquei, porque se eu saísse porque iam ser assentados no outro município, eu tinha de largar o sindicato. Aí toda a fila ainda de sócios não queria e a gente tinha que ficar... e o medo que não iriam conseguir. Então foi que surgiram estes projetos credi-fundiários que eu nunca queria, mas a gente já tinha tudo pronto... são 60 famílias. Então o 
primeiro grupo são 30, que fica logo ali atrás do bairro Venturini, que há 4 anos atrás, ninguém iria imaginar isso aqui... uma a prefeitura aqui...quer dizer, hoje supervalorizou. Quer dizer, o pobre aqui em Lucas do Rio Verde ter um pedaço de chão, quer dizer, o grande (agricultor) não vai desmembrar $5 / 6$ hectares, nem que ele tenha 200/300 hectares, um lote que é daquela área que foi do INCRA.

Os fazendeiros não iriam contribuir muito, mas isto, para o Sr. Nilfo, não significava recuar ou desistir. Ele sabia que seu grupo precisava se organizar, e assim o fez:

Então era a organização em grupos, 30 famílias, cento e cinquenta hectares, 5 hectares para cada uma. Jogamos no crédito fundiário $\mathrm{R} \$ 40$ mil, nós gastamos mais uns $\mathrm{R} \$ 8$ ou $\mathrm{R} \$ 9$ mil... então isso é reverter a visão de que Lucas do Rio Verde é só agronegócio, só grande. Por isso que a cidade, a qualidade de vida e tudo. Tudo bem. Começa a se discutir esta questão; e a questão da segurança alimentar. Se um dia bloquear a BR, o que é que nós vamos comer? Soja, frango da Sadia que é exportado, essas coisas. Então quem que produz mesmo? Então agora, com estas 60 famílias, Com estas questões políticas atuais com a questão das eleições, parece que estão vendo a importância de dar prioridade a políticas públicas para gente. Aí também tem todo um desafio para nós também que é do sindicato, da associação e das cooperativas que é organizar esse pessoal. Porque tem gente que só sabe exigir, criticar e falar do governo municipal, estado, e tudo; querem as coisas, tudo. Mas se organizar em associação, de forma organizada para ter uma assistência técnica e abastecer hoje minimamente uma merenda escolar e as feiras que existem, é um desafio.

Foi no desafio que o Sr. Nilfo traçou o caminho de inimigo para o de líder de movimento social:

Até pouco tempo, nós éramos vistos como inimigos; nossa última questão foi contra os agrotóxicos em 2006, que só foi resolvida depois de 5 dias de discussão. O cara, porque tem dinheiro passa de avião e joga veneno nas nossas cabeças e nem prefeito nem ninguém toma providência! Então a gente serviu como exemplo. Movimento social tem que ser assim! Então nós criamos vários movimentos sociais para conseguir isso. Hoje isto mudou porque foram criadas diversas políticas públicas voltadas para estas situações. A verticalização da economia, da qual tanto se fala, transformar o grão, fazer com que a produção seja mais diversificada, a gente pegou esta carona colocando: então, nessa verticalização não é importante dizer que está também aí inserida a agricultura familiar, que vai abastecer o mercado que está vindo de fora as coisas. Que tem um potencial na geração de emprego e renda e alimentos saudáveis e, principalmente, mais barato porque não há o custo do transporte dos outros estados para cá. Agora, a sociedade como um todo e o próprio poder público fazem com que a gente seja visto com outros olhos.

Como tudo mudou e hoje Lucas do Rio Verde não depende mais só da soja, havia necessidade de dar mai um passo à frente:

Aí entra a questão da confiabilidade. Este é um ponto importante, porque Lucas do Rio Verde hoje tem 205 chacareiros. Aí é importante saber do poder público se para Lucas do Rio Verde isto é importante ou não, porque não tem só soja, mas tem espaço para criar o alimento que vem de fora e pode ser produzido aqui também. [...] Nós partimos do resultado dessa 
experiência daqui do sindicato de trabalhar em capacitação, formação de lideranças, de apoio às organizações nos assentamentos da região do eixo da BR-163, pelo Plano BR-163 Sustentável que a gente entrou e ocupou espaço, mostrando que este projeto é de inclusão social e não de exclusão, e fortalecemos os assentamentos a gente criou uma referência de busca de recursos no governo federal e conseguimos estruturar as associações. Isso gerou uma cooperativa regional. Eu saí do sindicato e já era o presidente da COOPERREDE BR-163 que inclui 11 municípios.

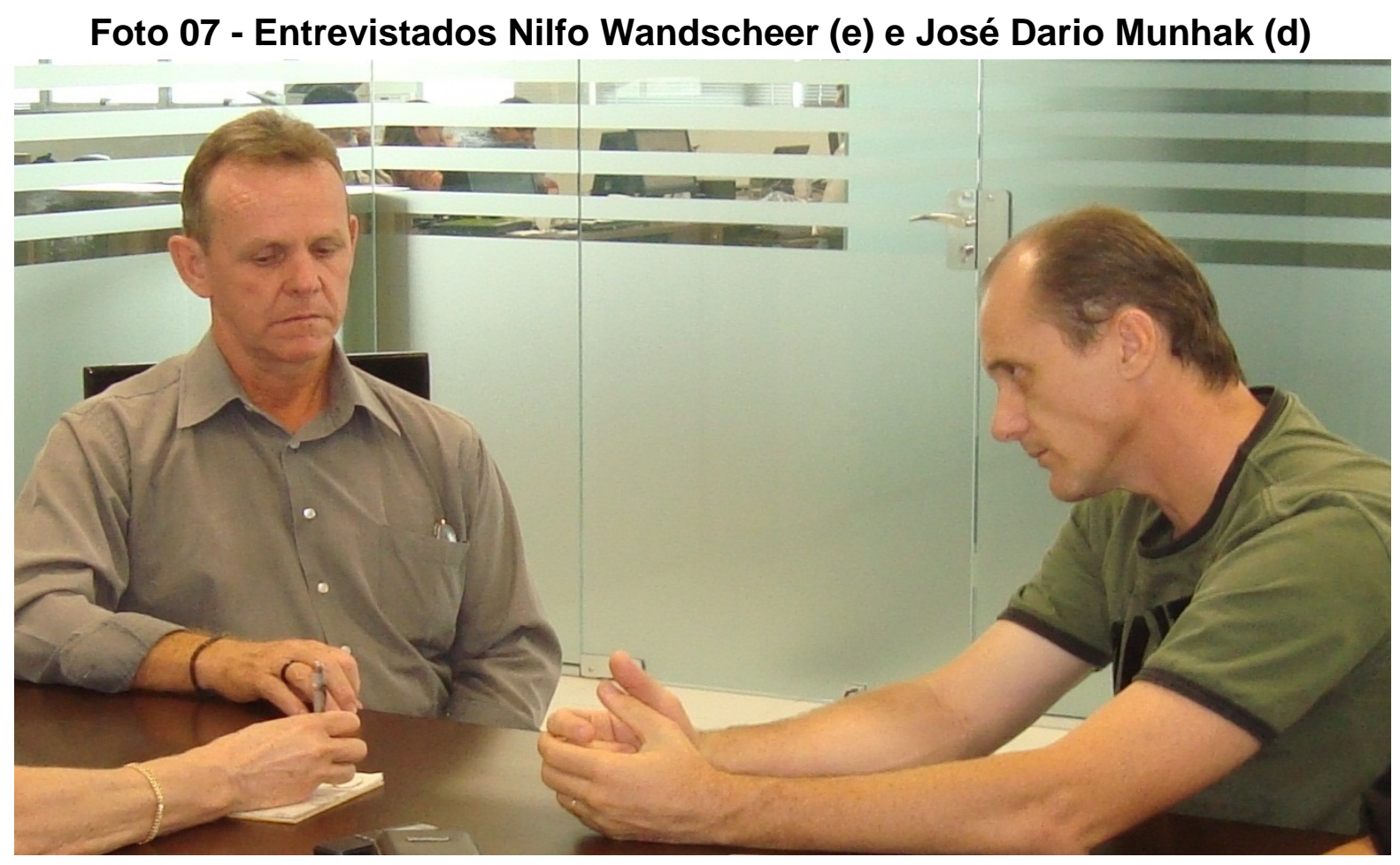

Fonte: Acervo da autora (2012)

Durante a entrevista (Foto 07), o Sr. Nilfo fez uma análise desta nova cidade e dos projetos futuros para os cooperados da COOPERREDE BR-163:

Então o que é que acontece hoje: se eu como chacareiro mais quatro companheiros de chácaras, nós colocamos as vaquinhas juntas, compra do Programa Nacional de Fortalecimento da Agricultura Familiar (PRONAF), primeiro crédito, uma vaca de cada um, três anos para cada já são vinte. Nós vamos construir agora, com o "Mais Alimentos" que é um programa de créditos, minha data é até $\mathrm{R} \$ 130$ mil. Dez anos; três anos de carência e $2 \%$ de juro ao ano. É o investimento de uma miniusina de laticínio, de leite. Nós queremos, a partir de fevereiro, quando voltar das férias e começar as aulas municipais, nós queremos ver se chegamos, não no ano que vem ainda, logo, mas nós queremos produzir os doze mil litros de leite da merenda escolar do município. E aí uma indústria que compra por $\mathrm{R} \$ 0,58$ ou $\mathrm{R} \$ 0,60$ o litro e aqui a merenda escolar paga, sabe-se que a prefeitura está comprando a $R \$ 1,65$. Se nós vendermos a $R \$ 1,50$, estamos ganhando muito dinheiro. E o custo para a merenda, como cai! Ai é que é importante, porque este modelo de produção alternativa, próximo da cidade, faz com que o governo compre para a merenda no mínimo $30 \%$ do que é produzido pela agricultura familiar. 
Pelo relato do Sr. Nilfo, se percebe uma organização de, pelo menos, vinte anos, para que o município pudesse preservar a sua área para-rural, de modo que esta pudesse atender à comunidade local e garantisse trabalho para a agricultura familiar que sobrevive harmoniosamente com as grandes fazendas produtoras de commodities.

O Índice de Desenvolvimento Humano (IDH) de Lucas do Rio Verde coloca seus munícipes numa situação muito confortável, quando comparado aos índices de outras cidades brasileiras, fato que tornou o município mais conhecido após a divulgação dos resultados no relatório da Organização das Nações Unidas (ONU). No seu âmago, entretanto, tem sérios problemas contra os quais se percebe uma verdadeira disputa do poder público contra o tempo, para suprir as necessidades de uma população que cresce cada vez mais rápido, por conta de uma política expansionista empreendida pelo próprio poder público, para dar sustentabilidade ao município.

\section{Gráfico 08 - Composição das receitas realizadas até 04.10.2011 em Lucas do Rio Verde}

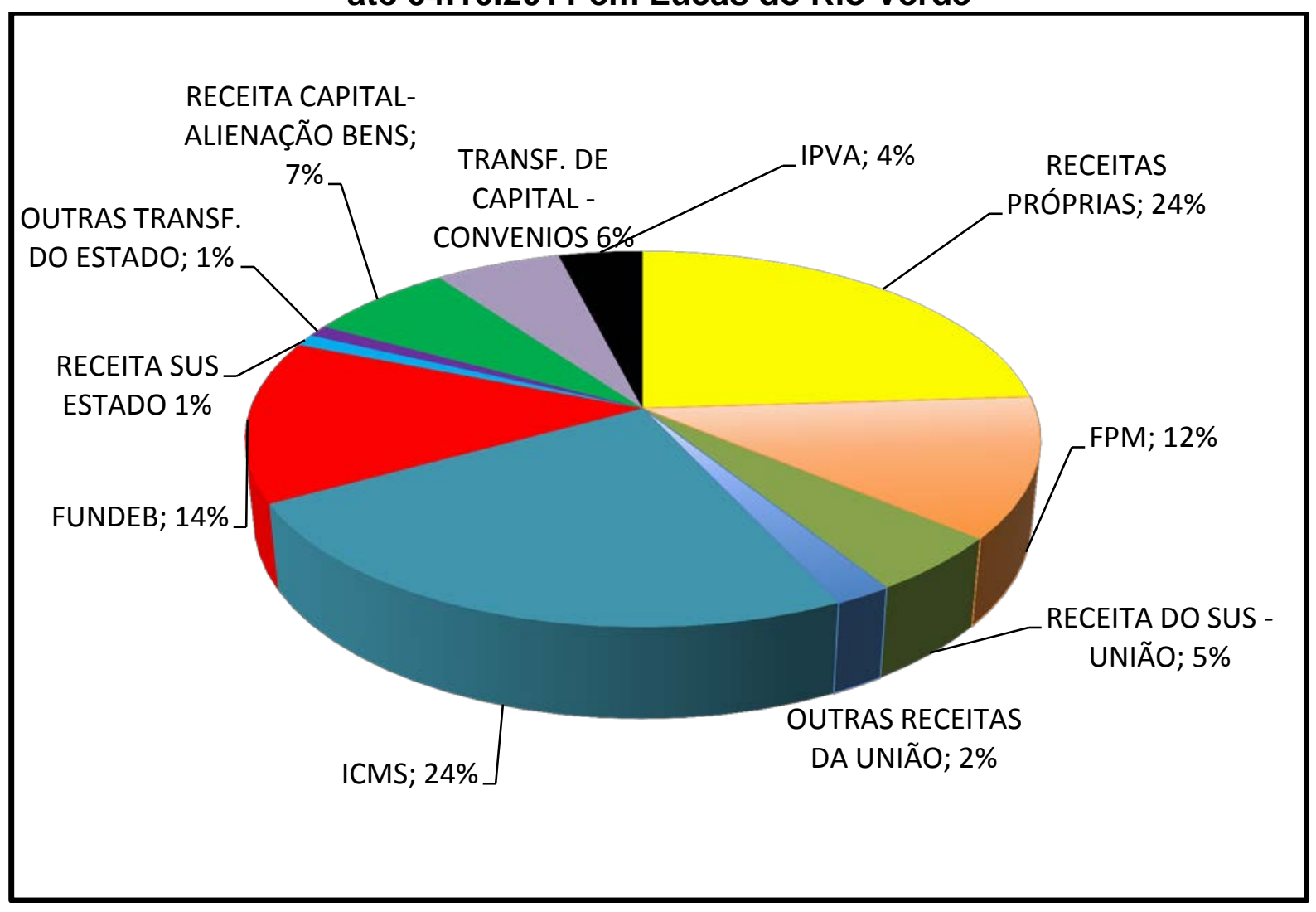

Fonte: ASCOM - Prefeitura de Lucas do Rio Verde (2012)

Como se constata no quadro de composição de receita cedido pela Assessoria de Comunicação da Prefeitura exposto no Gráfico 08, o município 
arrecada $48 \%$ da verba disponível, entre receitas próprias e arrecadação do ICMS. Daí se conclui que a base da verba despendida para a maioria dos projetos municipais origina-se no próprio município, incluindo parte das receitas aplicadas em construção de moradias, cuja parceria como governo federal tem contribuído para solucionar, em parte a demanda dos últimos cinco anos.

A análise da projeção de espaço sobre o tempo que aconteceu em Lucas do Rio Verde, aqui identificada em sua própria trajetória, a partir de seu tumultuado início em 1974, pode ser resumida em uma frase de Bauman (1998):

\begin{abstract}
A projeção de espaço sobre o tempo forneceu ao tempo traços que só o espaço possui "naturalmente": a época moderna teve direção, exatamente como qualquer outro itinerário no espaço. O tempo progrediu do obsoleto para o atualizado, e o atualizado foi desde o início a obsolescência futura. $\mathrm{O}$ tempo tinha sua "frente" e seu "atrás": uma pessoa era incitada e empurrada a andar "para frente com o tempo". (BAUMAN, 1998: 110).
\end{abstract}

\title{
2.2.2 - SORRISO
}

Conforme dados da Associação Mato-grossense dos Municípios, Sorriso pertence a mesorregião geográfica Norte Mato-grossense e microrregião do Alto Teles Pires, a 412 km da capital, Cuiabá, Sorriso está a uma altitude de 365 metros e tem uma extensão territorial de $9.345,755 \mathrm{~km}^{2}$.

Figura 36 - Localização de Sorriso em Mato Grosso

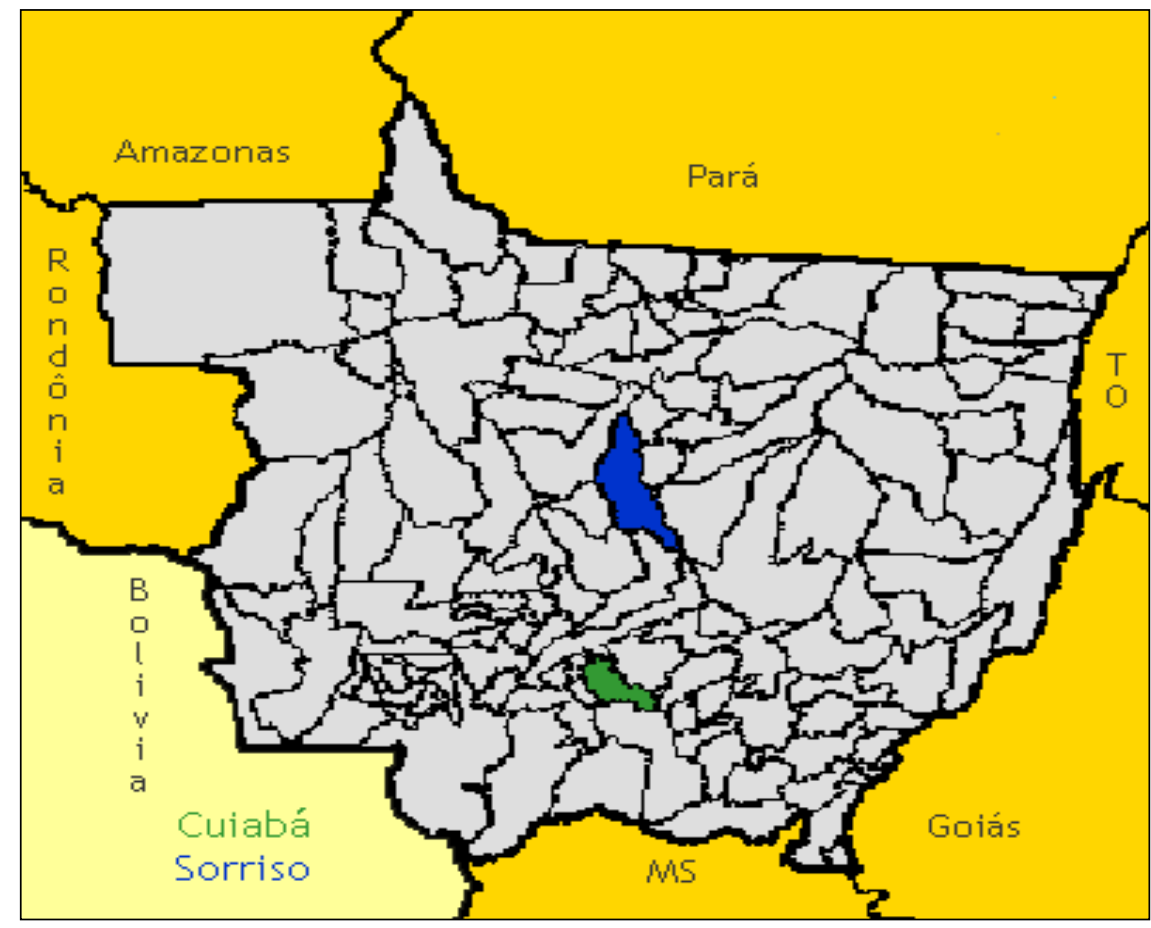

Fonte: Google Imagens (2012) 
Como se pode observar no Figura 36, Sorriso se localiza praticamente no centro do estado de Mato Grosso e a BR-163 é a principal ligação entre o município, Sinop e Lucas do Rio Verde.

Limita-se ao norte com os municípios Sinop e Vera; ao sul, com o município de Lucas do Rio Verde; a sudeste com o município de Santa Rita do Trivelato; ao leste com os municípios de Vera e Nova Ubiratã e a oeste com os municípios de Tapurah e Ipiranga do Norte.

Sorriso nasceu em 1970, também como fruto da expansão brasileira direcionada à ocupação e colonização da Amazônia Legal. O projeto de loteamento que deu origem ao plano piloto da cidade de Sorriso fazia parte de uma grande quantidade de terras pertencente a um grupo norte-americano, às margens da BR163, como se vê no Figura 37, no médio norte mato-grossense.

Figura 37 - Importância da BR-163 para a região central do Estado de Mato Grosso

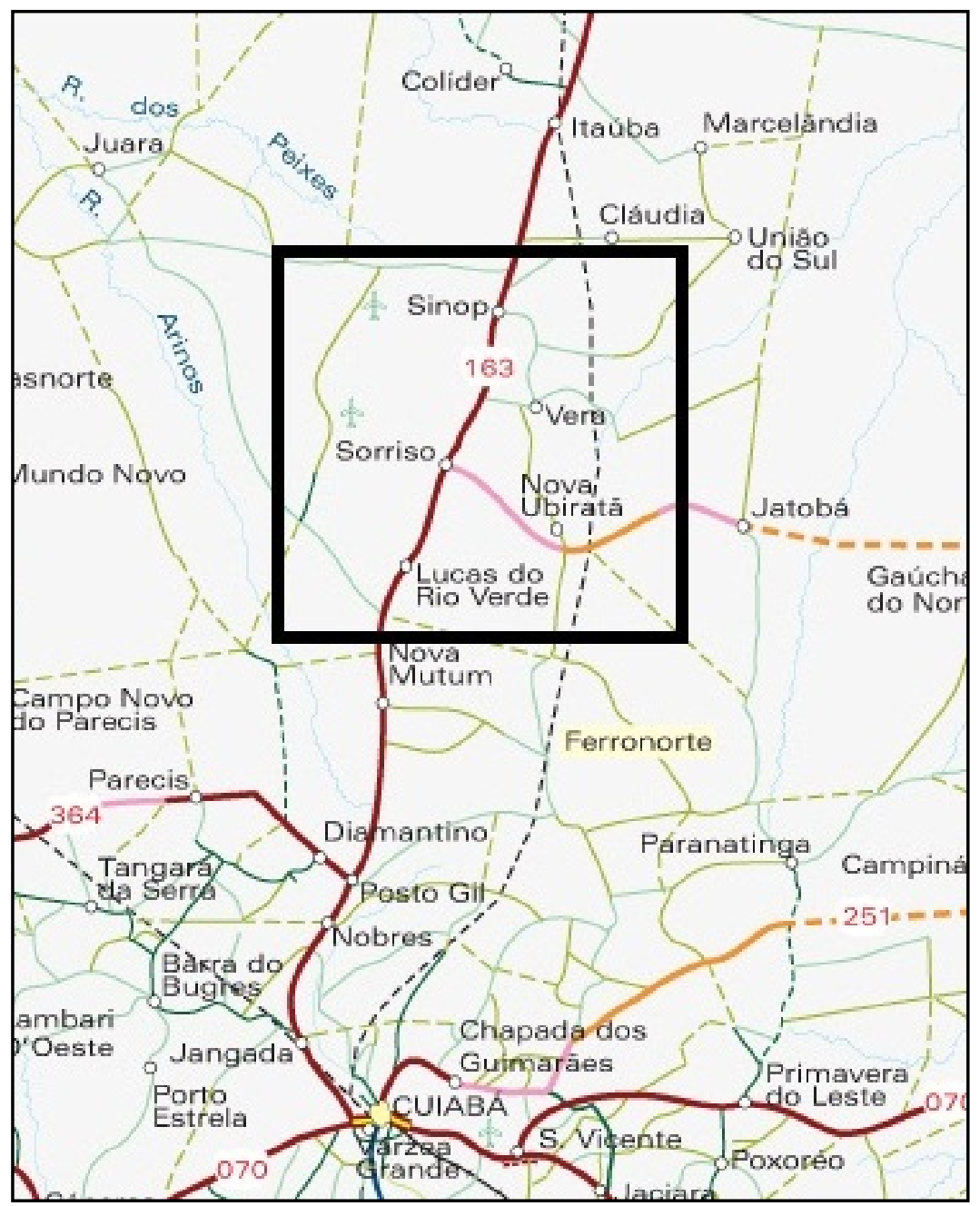

Fonte: Secretaria de Infraestrutura do Estado de Mato Grosso (2010) 
Claudino Frâncio, sabendo do desinteresse dos norte americanos em continuar com as terras, comprou boa parte delas e comercializou para eles outra parte, estabelecendo-se no município ainda na década de 1970.

Conforme narrou Sra. Idalina Francio, viúva do pioneiro e fundador da cidade, Claudino Francio, em entrevista concedida em 20.09.2012 em sua casa, a vinda dele para Mato Grosso se deve a um período de dificuldades financeiras pelo qual passavam no sul, onde subsistiam graças a produção de uma malharia da família.

\section{Foto 08 - Sra. Idalina Francio, esposa do fundador da cidade Claudino Francio}

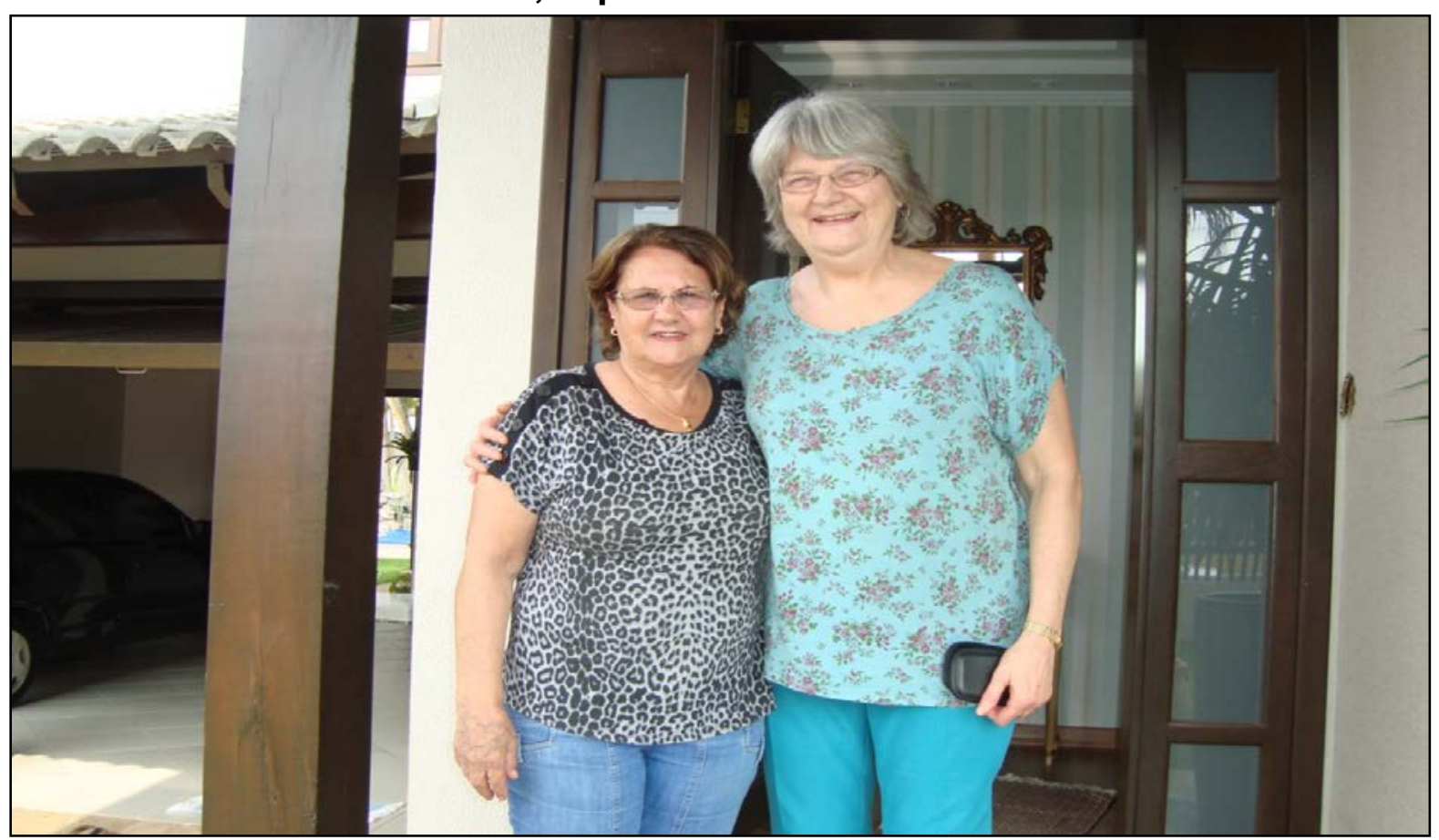

Fonte: Acervo da autora (2012)

A fábrica, conta a Sra. Idalina, que está na Foto 08, acima, era bem equipada, mas as vendas andavam baixas.

Daí ele veio pra cá, onde se encontrou com um senhor em Cuiabá e, pelas tantas, a conversa enveredou para as questões de terras. Foi quando o homem convidou para que dessem uma volta pelo Estado e eles chegaram às áreas onde hoje é Sorriso. Mas aqui não tinha nada; era só mato... nem mato não era, era Cerrado na verdade; mato nem tinha. Daí ele gostou daqui e quando chegou de volta comentou comigo: olha, eu acho que daqui uns tempos nós vamos morar em Mato Grosso. Daí eu dei risada, e perguntei o que é que nós iríamos fazer lá. Ele só respondeu: Não, eu gostei e a gente tem que dar um jeito de ir pra lá. $E$ aí começou aquela influência de vir pra cá, de mexer pra vir pra cá, aí eles vieram e aí ele ficou uns dois anos para cá porque aí ele tinha um irmão que ficou morando em Cuiabá e outro irmão que ficou por aqui. Quando começou a vender, viram que precisava construir uma casinha, depois de muito tempo debaixo da lona. Eles tinham que mostrar as coisas para as pessoas que vinham do sul, para comprar. Daí ele fez um tipo de um restaurante, porque aqui não tinha nem luz, nem água, nem nada, ele tinha que ter uma casa e um restaurante para as pessoas terem onde dormir e comer. A gente ficou dois anos, minha 
cunhada e eu, sem porta e sem janela onde a gente estava morando. Aí foi indo e hoje está Sorriso como se vê aqui.

A procura de terras se deu na década de 1970, quando o Sr. Claudino resolveu convencer outros gaúchos e catarinenses a comprar terras naquele "fim de mundo", como diziam eles. Ainda como vendedor da malharia, saiu de Passo Fundo, RS, divulgando as maravilhas daquela cidade que ele adotaria como sua "filha mais nova". Não falou em outra coisa, até vir na frente da família para "preparar o terreno". Como conta a Sra. Idalina Francio em entrevista concedida em sua casa, dia 20.09.2012,

Depois que ele abriu a Colonizadora Feliz, os fins de semana eram no meio do mato, procurando locais que depois seriam negociados porque, no início, ele vendia uma terra para pegar outra e assim ia.

Em 26 de dezembro de 1980 a pequena agrovila encravada em pleno Cerrado mato-grossense foi elevada à categoria de Distrito, pertencente ao Município de Nobres. A Assembleia Legislativa do Estado do Mato Grosso aprovou em 13 de maio de 1986 e o governador Júlio Campos sancionou pela Lei 5.002/86, a elevação do então distrito de Sorriso à categoria de município.

Como se constata na Foto 20, nas últimas quase três décadas, o município cresceu muito e se transformou numa das cidades de pequeno-médio porte mais importantes para a economia do país.

Figura 38 - Núcleo urbano de Sorriso

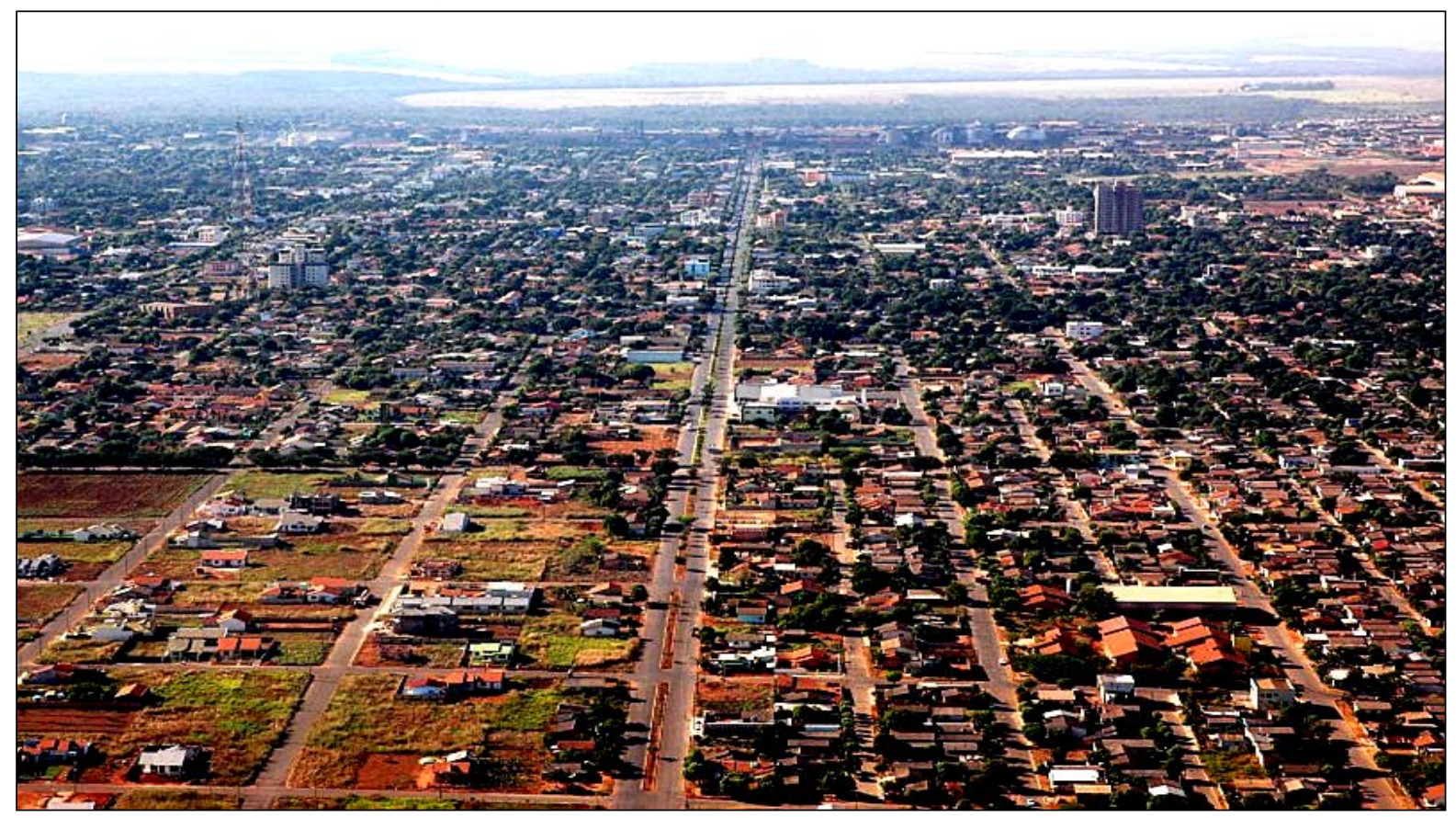

Fonte: Acervo Prefeitura Municipal (2004) 
Em entrevista concedida dia 19.09.2012, Natalício Ligoski, primeiro tesoureiro e primeiro Secretário de Fazenda do município conta que:

\begin{abstract}
Até 1984, o único plantio do qual se falava era arroz. A soja começou a surgir em 1984, talvez em 1983, numa fase experimental, daí foi aumentando e, à medida que o tempo foi passando $0^{56}$ soja tomou o espaço do arroz e do plantio de milho e aí começou o desenvolvimento. Em 1986 Sorriso emancipou e eu fui convidado para fazer parte da primeira administração. Daí eu saí do Banco Nacional, onde eu tinha trabalhado praticamente desde quando eu cheguei aqui, e fui trabalhar como tesoureiro. Eu me recordo muito bem que nos três quatro primeiros meses a única receita que tinha era uma tarifa de conta de água que o município recebia. Tanto que a gente nem teve salário nos primeiros meses, porque não tinha receita. A medida que as coisas foram se regularizando [...] nós concentramos as contas em Sinop e passamos a receber o ICM, e outras tarifas estaduais e federais.
\end{abstract}

A pavimentação asfáltica da BR-163, no início da década de 1980, permitiu a evolução do potencial agrícola, pois facilitou o escoamento de grãos da região. A correção do solo, inicialmente não receptivo ao plantio, somada a pavimentação, se mostrou decisiva para que a região se transformasse num dos principais pólos de produtividade do mundo.

Maria Inêz Ferlin, a atual contadora da prefeitura de Sorriso, entrevistada em 20.09.2012, expressa sua experiência de vida dizendo que:

Em Sorriso não falta nada. Em 26 anos de emancipação política, nós temos tudo o que tem na capital e mais ainda, uma qualidade de vida. Só não temos mais qualidade de vida porque quando nós viemos para cá, nós tínhamos um único objetivo: trabalhar. Quando eu vim pra cá, há vinte e nove anos atrás, só tinha asfalto até Jangada. Nós levamos quatorze horas e meia pra chegar até aqui de ônibus. Não tinha água, não tinha luz, não tinha telefone, não tinha comida. O leite do meu sobrinho vinha de São Paulo. O Rafael aprendeu a falar com um ano e seis meses, ele falava tudo corretamente porque como a mãe e o pai dele e eu não tínhamos amigos, então a gente falava com ele.

Assim como o Rafael, hoje um médico pediatra bem sucedido, moveu a vontade da tia e dos pais, a cidade, também uma criança, estimulou-os a deputar por infraestrutura, como continua Maria Inêz:

Nós fizemos campanha para ter telefone, fez campanha para ter televisão, fez campanha para ter energia, fez campanha para ter asfalto, para ter 0 linhão ${ }^{57}$, Por tudo. Foi muito sofrido, mas gratificante. Como se vê o progresso chegou aqui galopando, correndo. Em dois anos, nós tivemos

\footnotetext{
${ }^{56}$ É interessante perceber que todas as pessoas da região onde prevalece o plantio de soja, a planta é tratada no masculino, aludindo o grão e não a planta, como no resto do Brasil.

57 Nome popular pelo qual são conhecidas as linhas de energia que partem de Cuiabá, desde a estação da Eletronorte, localizada no bairro Alto da Glória, até as cidades do interior do estado de Mato Grosso.
} 
asfalto de Cuiabá a Sinop; coisa que não acontece; $400 \mathrm{~km}$ em dois anos. A gente vendo a duplicação da BR do Posto Gil até Rosário Oeste que há mais de ano está assim, imagina! O trabalho é o mesmo, até mais porque a estrada não era por ali. Era uma estrada que vinha por trás do morro e ia sair em Vera. Mas, acho que foi a melhor experiência que eu tive na vida. Eu jamais voltaria para Caçador, cidade de onde eu vim, no Oeste de Santa Catarina.

O trecho de duplicação da BR-163, sobre o qual a Sra. Maria Inez se refere e aqui se vê na Foto 09, são 40 km entre o município de Rosário Oeste e o Posto Gil, que está sendo construído pelo DENIT como parte de um projeto que fará a ligação da BR-163 com a BR-364.

\section{Foto 09: Duplicação da BR-163 - Trecho entre Rosário Oeste e o Posto Gil}

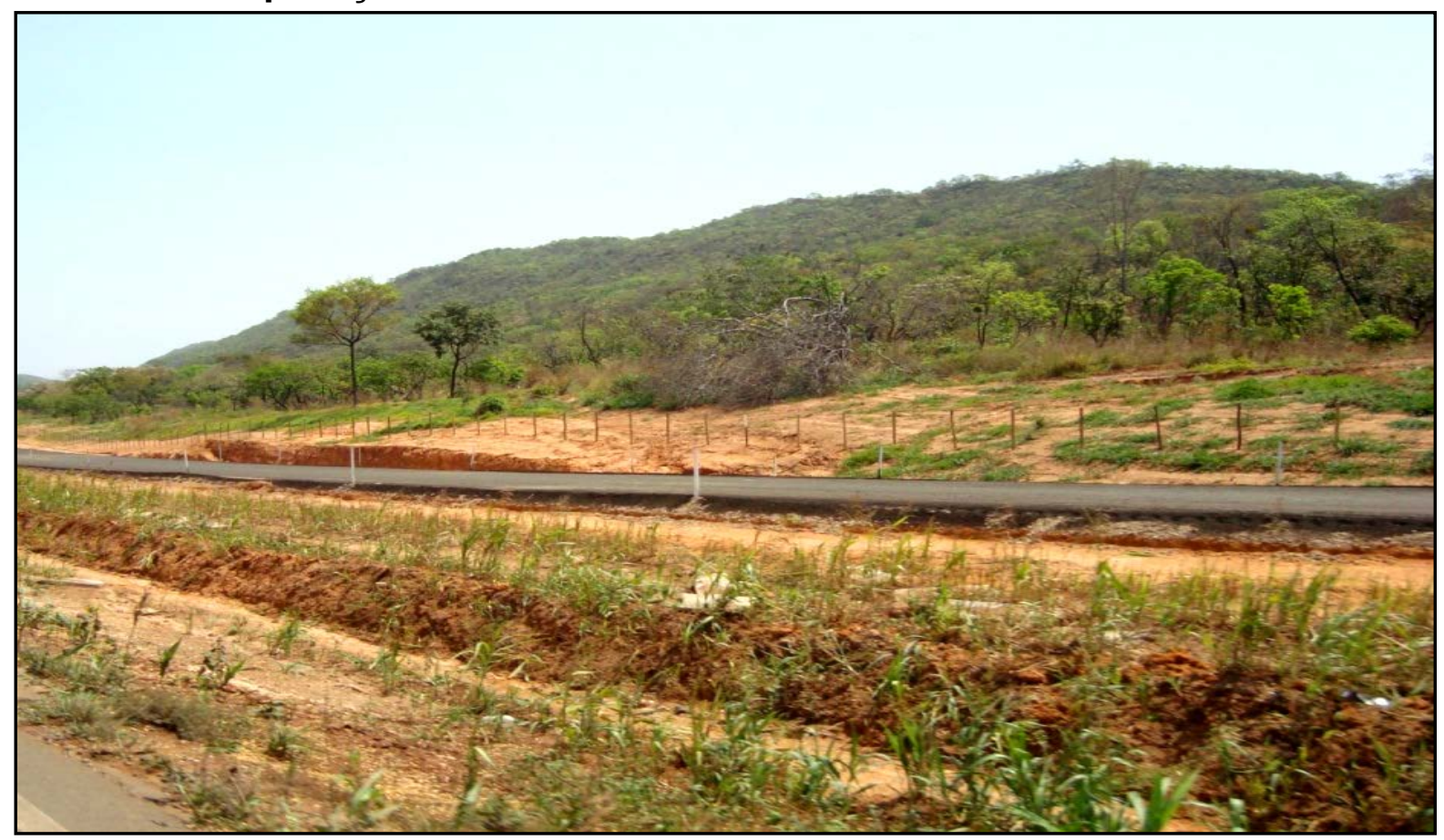

Fonte: Acervo da autora (2012)

A BR-364 inicia no Posto Gil e liga os municípios de Diamantino, Tangará da Serra, Itanorte, Campo Novo do Parecis, Sapezal, Campos de Julio e Comodoro, já na divisa com Rondônia. Trata-se de uma ligação muito importante pelos altos índices de produção agrícola daquela região e esta duplicação facilitará o transporte de commodities para as regiões sudeste e sul, rumo aos portos de embarque.

Para o Sr. Emiliano Preima, Secretário Municipal de Obras e Serviços Urbanos, entrevistado em 19.09.2012, por quatro mandatos, que vive em Sorriso desde 1984, por ter exercido funções administrativas em vários mandatos 
municipais, pode avaliar como a cidade foi vencendo dificuldades e se desenvolvendo:

Em 1977, a gente comprou uma área de terra aqui. Aí meu irmão veio morar pra cá, acreditando no Eldorado. Só que se sofreu muito aqui até 1988. [...] Ninguém da minha família tinha trabalhado como agricultor antes. Aí agente acabou se envolvendo com agricultura aqui em Mato Grosso. Meu irmão chegou aqui e não sabia diferenciar um pé de soja de um pé de milho. $\mathrm{E}$ a terra era horrível, péssima. E nós ainda tivemos um agravante maior. Nós compramos uma terra que era terra dos americanos. Então nós compramos uma área de terra deste cidadão na São Luiz Gonzaga, a uns 75 km daqui, no sentido Ubiratan. Nós, mais um monte de proprietários, compramos uma área em litígio, mas nós não sabíamos. Nós compramos em 1977, pagamos esta área parcelada e em 1980 começou o litígio do americano com a Colonizadora que é dos Francio. Em 1980, quando nós fomos fazer um financiamento no Banco do Brasil pelo FCO que era a grande deixa do momento, que era o que alavancava o produtor rural, quando a gente foi passar a escritura, não passou porque já estava em litígio. Então nós já não conseguimos mais fazer e a gente dependia do Banco do Brasil de Rosário e de Nobres.

Não se pode dizer que este início tenha sido fácil para a família do Sr. Preima. Mas, como todos os imigrantes pioneiros, seguiu em frente e conta sobre as primeiras mudanças que ocorreram no município, ainda na década de 1980.

De 1988 para cá eu vejo assim que houve uma mudança para a população em si. Começou a se pensar no cidadão. Até então não se pensava muito no cidadão. Todo mundo estava preocupado com o que iria fazer, então ninguém se preocupou com o cidadão. Até porque o município se criou em 1986, a primeira administração foi $1987 / 1988$, e nesse período aí era subprefeitura de Nobres que estava a $300 \mathrm{~km}$ daqui, então o Distrito de Sorriso praticamente não existia para o município de Nobres. Era um distrito longe.

O seu comentário sobre o "abandono" é algo que se repetiu em várias entrevistas com imigrantes pioneiros. Pelos relatos se pode verificar que o mesmo poder público que os trouxe, os esqueceu em pleno Cerrado, em terras que, em princípio não sabiam o que fazer com elas, por desconhecerem o clima e a forma de produzir alguma coisa nelas. Até mesmo o caminho para chegar até Sorriso como continua narrando o Sr. Preima, era mais longo, como ele conta:

Então nesse período de 1980, começou assim a ter um pouco mais de gente na vila, já tinha a estrada, por causa de Sinop. Só que não era por aqui era lá por Boa Esperança. A estrada subia lá na serra e vinha por dentro, por perto de Trivelato, passava perto de Ubiratan, perto de Vera que só existe porque esta estrada antiga fazia este traçado para chegar a Sinop, município que foi criado em 1974 e aí o governo Figueiredo depois criou o aeroporto porque era mais fronteira e nós não existíamos ainda. 
A BR-163, construída em outro traçado, alterou substancialmente a economia das cidades que haviam sido planejadas com perspectivas de desenvolvimento ao longo da BR-364, como é o caso de Vera e Nova Ubiratan e Claudia.

É fácil perceber na Figura 39 que as cidades que ficaram fora da área de abrangência de BR-163, não se desenvolveram tanto quanto aquelas que passaram a integrar a área de entorno da estrada.

Figura 39: Traçado da BR-163 e BR-364 entre o Posto Gil e Comodoro

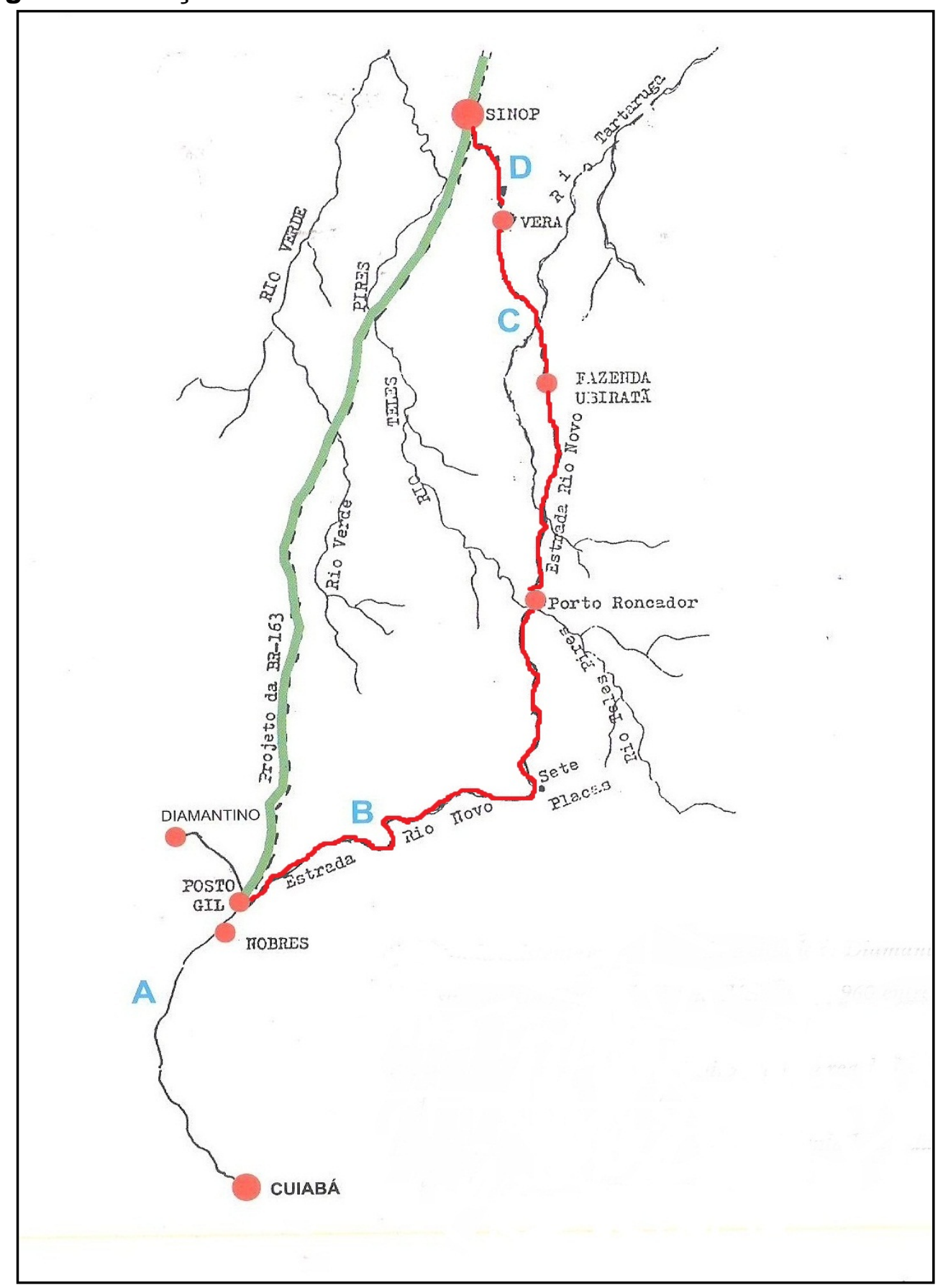

Fonte: Secretaria de Infraestrutura do Estado de Mato Grosso (2010) 
O Sr. Preima relata ainda com detalhes as consequências desta mudança nos planos das estradas traçadas para esta região.

Então de 1980 para cá começaram a chegar famílias em Sorriso e aí núcleo era só lá embaixo, onde tinham alguns moradores e na prefeitura não tinha muito o que fazer. Tinha só um caminhãozinho d'água e mais nada. Então ali começou a expandir naquela área. Tinha a farmácia da Jurema, a Farmácia Bom Jesus, o hospital onde tinha o Dr. Carlos ${ }^{58}$ e o Dr. Teles ${ }^{59}$ que vieram e são pioneiros, médicos, eles tinham um barquinho ali no lado de cá do córrego onde é o hospital e mais nada para o lado de cá. Depois, em 1982, veio mais aqui para cima onde é a praça, mas a vila expandiu ali, com a dificuldade de não ter correio, a água tinha um motor, na área verde ali embaixo que era dragada do próprio córrego, porque tinha uma nascente ali e vinha num encanamento de água bem caótico que distribuía água para as casas. Aí tinha alguns motores a óleo diesel que forneciam energia elétrica das seis às dez da manhã e depois das quatro da tarde até as dez da noite. Fora este período não tinha energia elétrica. Então as geladeiras eram difíceis, não tinha como guardar alimento nenhum, conservar na geladeira. A não ser aquelas pessoas que já tinham uma condiçãozinha de ter um gerador na sua casa. Alguns tinham; poucos.

O empenho em conseguir a infraestrutura necessária para o município, como continua o Sr. Preima, moveu praticamente todos os habitantes, que se organizaram em comissões, tanto para se fazerem representar junto às autoridades estaduais e federais como para realizar mutirões de mão de obra, para agilizar a construção de igrejas, escolas e outros edifícios de uso coletivo.

O telefone, foi 1984/1985, foi feita uma comissão, tudo era comissão, que
veio substituir a centralzinha telefônica que tinha aqui, que era via bateria
solar, só que pra você falar, tinha uma antena ali e juntava todo mundo da
vila, que dava uns 40 a 50 e todo mundo escutava a conversa de todo
mundo porque tinha que falar alto. Era uma cabinezinha com uma
telefonista do lado e ficava todo mundo em volta e o cara chorando pra
mãe, pra namorada, pra esposa, pro pai. Era uma farra de se ouvir. Às
vezes ficava 4 a 5 horas pra conseguir falar um pouquinho no telefone neste
período. Aí mais tarde foi feita uma comissão que trouxe a estrutura do
telefone para cá e para se viabilizar foram necessários 600 terminais. Então
alguns compraram dois, outros compraram três, os mais ricos compraram
seis, para poder viabilizar o telefone. Aí compraram instalaram, quer dizer,
deram as condições e a rede telefônica só veio e inaugurou. Tudo foi feito
pela população local. Quem investiu no telefone foi a população. E até
$1985 / 1986$ a parte de motor, tudo, ainda era bem caótico.

Algumas reivindicações foram mais complicadas, mas a população não esmoreceu, como conta o Sr. Preima em sua entrevista de 19.09.2012:

\footnotetext{
${ }^{58}$ Dr. Carlos Gilberto Frison, enfrentou todas as adversidades e fundou o primeiro hospital, quando haviam apenas algumas casas e alguns pioneiros que também acreditavam que Sorriso.

${ }^{59}$ Dr. Edmar Washington Oliveira Telles, chamado com muito carinho por Dr. Telles, que com o mais alto respeito a vida humana juntou-se ao $\mathrm{Dr}$. Carlos, suportando as imensas dificuldades e deixando a vida mais digna de todos aqueles que para continuar investindo nos seus ideais precisavam de apoio na saúde.
} 
Em 1987, quando o Sr. Manfroi ${ }^{60}$ assumiu a primeira administração, aí já conseguiu mais um ou dois motores, até 1988, depois o José Domingos conseguiu mais alguns motores foi melhorando, assim os motores, mas era desolador! Porque os motores quebravam, fundiam... Então, a população sofria muito com isto. Comida? Comprar uma alface ou um tomate aqui era... Primeiro que os caminhões não eram térmicos. Chegava tudo murcho. Até certo tempo não tinha o asfalto ainda. Só em 1985. Até hoje se produz muito pouco aqui, por causa da praga. Então se produz muito folha; alface, repolho, almeirão. Minha cunhada veio em 1978, minha outra cunhada veio em 1980 e eu vim com a minha família em 1984.

Em 2000, a população de Sorriso já era formada por 35.605 habitantes e, de acordo com o censo do IBGE (2010), cresceu para 66.506 habitantes, ou 7,13 hab/ $/ \mathrm{km}^{2}$. As estimativas municipais, no entanto, apontam uma população superior a 75.000 habitantes em 2012, porque o município cresce muito acima da média brasileira.

Tanto o consultor de planejamento da prefeitura, Sr. Ary Junior, como o diretor da Escola São Domingos, Rodrigo de Vargas Hahn, têm consciência de que a cidade continua recebendo um número expressivo de pessoas e que o poder público não pode parar, nem um dia, de produzir novas frentes de trabalho e ampliar a infraestrutura para o cotidiano dos munícipes; caso contrário, o poder público corre o sério risco de "perder o trem da história".

Na entrevista concedida pelo Sr. Ary Junior em 19.09.2012, ele salienta que:

Sorriso tem 25 anos de idade cresce a 6,5\% ao ano isso dá uma média de 8 mil pessoas chegando, são 200 ônibus que chegam do Maranhão e estas pessoas chegam aqui e encontram solo fértil para desenvolver os seus sonhos.

Mesmo com as ações de planejamento estratégico para ampliar o mercado de trabalho, o município recebe constantemente novos moradores que nem sempre têm a qualificação desejada pelo mercado que vem se instalando ali. Até a década de 1990 era relativamente fácil chegar à cidade, se instalar e conseguir um trabalho, mesmo não tendo nenhuma especialização. A Secretaria Municipal de Ação Social, se organizou para realizar duas tarefas básicas. Num primeiro momento, se propôs a financiar a viagem de retorno para as cidades de origem, àqueles que chegam ao município sem vínculo empregatício ou moradia.

De acordo com um funcionário da Prefeitura, a decisão de estornar os pretensos novos migrantes sem vínculo empregatício ou perspectiva de moradia, baseava-se no fato do município não estar estruturado para receber tantas pessoas,

${ }^{60}$ Alcino Manfroi que exerceu um mandato tampão de 01/01/1987 a 31/12/1988. 
como vinha acontecendo, nos últimos anos. Esta preocupação podia ser considerada verdadeira, por não haver lugar para a mão de obra desqualificada num mercado que demanda alta qualificação profissional e que deseja equiparar-se ao mercado da agroindústria estrangeira.

Num segundo momento, quando novos imigrantes estavam instalados, porém sem condições de sustento, a Secretaria de Ação Social os incluía no programa Bolsa Família. Sobre este projeto, a Secretária de Ação Social, Vivyane Maria Cene Bedin colocou na entrevista concedida em 19.09.2012 que:

\begin{abstract}
A lei de ação social do município foi sancionada pela presidente em julho do ano passado. Quando nós entramos aqui, nós tínhamos uma distribuição de cestas básicas de 1.500 no mês de janeiro de 2009. Isso era uma herança da administração anterior. Então a gente começou a implantar uma nova política, através de um projeto de qualificação profissional, capacitação e inclusão social pelo trabalho. No início, nós tínhamos a maior dificuldade em fazer com que as pessoas aguardassem os cursos. Tínhamos parceria com o Serviço Nacional de Aprendizagem Rural (SENAR), com o Serviço Nacional da Indústria (SENAI). Então sempre tinha alunos sobrando e cursos faltando. Hoje já não mais. Este ano, por exemplo, eu cheguei a questionar a ausência de alunos causando até dificuldade para fechar turmas destes cursos. Cursos nas mais diversas áreas; desde ceramista, construção civil, armador de ferro; passando aí pelo administrativo, todas as partes do administrativo, por pequenas indústrias, panificação, confeitaria, artesanato, manicure, cabeleireiro, então em todas as áreas. As pessoas que tinham estes cursos e a gente tentando fazer estes cursos. Este ano aconteceu que nós não conseguimos alunos. Então nós ligamos para os alunos, usando nosso banco de dados das pessoas que são mais vulneráveis economicamente, de zero a três salários, que são a nossa clientela, e aí constatamos que estas pessoas estavam sem condições de fazer o curso, porque estavam ocupadas, trabalhando.
\end{abstract}

Sobre os resultados conseguidos pela Secretaria, a Sra. Vivyane Maria Cene Bedin que está ao centro da Foto 10, a seguir esclarece, que foram muito bons, pois o número de requisitantes da Bolsa Família diminuiu substancialmente, por conta do projeto paralelo de qualificação de mão de obra.

Então o que eu posso dizer é que nós não temos hoje um número significativo de pessoas que estejam sem ter o que fazer. Hoje nós fechamos o mês de agosto (2012) com a entrega de 146 cestas básicas, e as pessoas não têm procurado pela Secretaria. Mesmo a gente fazendo levantamentos sócio-assistenciais ela leva técnicos ela faz entrevistas, mas não se detecta mais aquele nível de quase mendicância que existia. No meu entender a Bolsa Família é emergencial; ela tem um tempo. Por isto nós fazemos uma análise técnica dos casos. Ela verifica dois meses, três meses, até seis meses e, neste tempo a gente busca auxiliar esta pessoa, abrindo espaço no mercado de trabalho. Em menos de quatro anos, nós qualificamos 1.600 pessoas; não digo que sejam 1.600 famílias. Devem ser aproximadamente mil famílias que hoje têm uma formação; seja artesanato, seja manicure, que agora tem uma renda de meio salário mínimo. Para quem tinha uma renda entre $R \$ 70,00$ e $R \$ 100,00$ mensais, já é muita coisa. 


\section{Foto 10 - Da direita para a esquerda, Reginelda Solange Viana, Rosana Ravache, Sra. Vivyane Maria Cene Bedin, professora Mariliane Sobrinho e Eliana Matos Tavares}

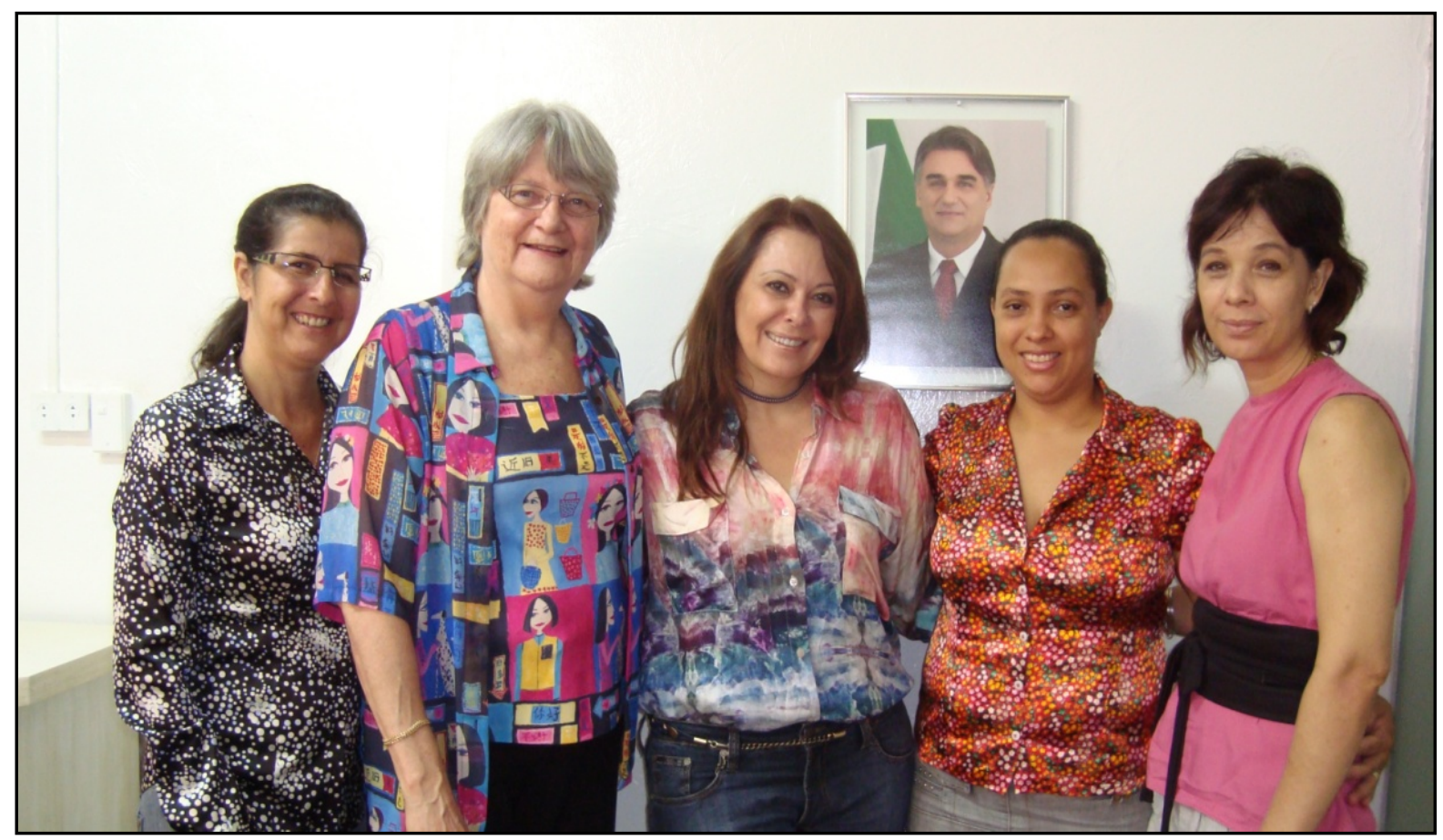

Fonte: Acervo da autora (2012)

A mudança de estratégia para lidar com o mesmo problema transformou um processo de exclusão em processo de inclusão e, paralelamente, tem contribuído com um mercado de trabalho que funciona paralelo ao agronegócio, mas é básico para o cotidiano de qualquer cidade.

É compreensível a preocupação do poder público municipal porque, como pondera Castells:

A capacidade tecnológica, infraestrutura tecnológica, acesso aos conhecimentos e recursos humanos qualificadíssimos tornam-se fontes essenciais de competitividade na nova divisão internacional da mão de obra. (CASTELLS, 2007:150):

O número de migrantes das classes menos favorecidas, além de ser bem mais alto, tende a se tornar mais um problema social tanto nas áreas de habitação como nas de saúde e segurança, haja vista a estatística crescente da criminalidade, cujos índices chegam a ultrapassar a média brasileira.

Apesar de Sorriso nunca ter tido grandes problemas com violência no campo, desde que iniciou com o Sr. Claudino Francio, aparentemente a violência urbana está se estendendo ao campo, onde recentemente se repetiu o desmando por parte do INCRA, conforme relata o Sr. Emiliano Preima em sua entrevista de 19.09.2012. 
Por exemplo, a fazenda que era de uns paulistas aqui, a Fazenda da Poranga, foi uma invasão de 1997. De 1997 para trás, não teve nada assim de áreas invadidas. Essa já foi invasão dos Sem-terra. Tem ainda o Piratininga e o Santa Rosa 1 e 2. O Piratininga, pra lá de Boa Esperança, uns 50 ou $40 \mathrm{~km}$, lá foi um assentamento já criado e o Santa Rosa 1 e 2 também. Só que quem, como eu, conheceu aquilo lá na época, eu acho que se fazer isso com a população é um crime desgraçado. Lá é capim, algumas nascentes do rio Teles Pires, areia... hoje as áreas melhoraram... as pessoas compraram e melhoraram com tecnologia. Para uma família lá! Lá tinha borrachudo e pernilongo, que as vezes que eu fui lá, as pessoas ficavam numa área com foguinho, fumaça e dentro para os bichos não... Eu fiquei meia hora, a minha cabeça começou a queimar de tanto que me picaram no rosto, nas orelhas no cabelo, que eu disse: olha estou indo embora, porque era impossível ficar lá. E aquelas famílias com criança. Então realmente a única invasão que eu conheço em Sorriso, é a Poranga. As outras foram assentamentos já pré-determinados.

\section{O Sr. Preima continua seu relato, esclarecendo que, nos dias de hoje, ainda existem disputas de posse, cujas soluções nem sempre são muito claras.}

Esse da Piratininga o INCRA já veio na Santa Rosa, houve um despejo lá, mas foi criminoso, o que se fez lá é crime, porque o INCRA autorizou as pessoas a entrarem lá treze anos atrás. Loteou as áreas, botou a população lá. Quando essas pessoas, na maioria, desmataram, levaram e plantaram e que a área que valia 10 sacos por hectare, passou a valer 300 sacos por hectare, apareceram uns donos, arrumaram um despejo e tiraram as famílias e derrubaram casas com máquinas. Então isso é crime. Quem estava envolvido nisso, quem autorizou as pessoas a entrar foi o INCRA. O INCRA foi lá. Só que lá dá tempo ainda, porque hoje envolveu deputado e coisas, então está se segurando um pouco lá ainda. Mas os grandes proprietários moram na cidade, aqui em Sorriso, pessoa que tem 60 mil hectares de área não planta um pé de couve e que colhe... hoje 60 mil hectares de área a dez sacos por hectare, dá 600 mil sacos de soja ${ }^{61}$, no mínimo, e é um dos proprietários dessa área adquirida pós INCRA instalar este povo lá dentro, há treze anos atrás. Estas áreas foram adquiridas a quatro ou cinco anos atrás. No meu entendimento, o INCRA usou as pessoas para valorizar a área e agora e agora ajuda a pessoas a saírem de lá. No nosso estado hoje, às vezes eu fico revoltado com isso, porque eu vejo que nós mudamos o coronelismo, mas continua o mesmo batidão.

\section{O Secretário informa ainda, como a prefeitura apoia aquelas comunidades}

que se sustentam com o fornecimento e alguns tipos de hortaliças e legumes para o município.

Então essas pessoas que estão hoje nesses assentamentos, salvo os daqui do Poranga que estão muito bem assistidos, e hoje nós assistimos bem os da Santa Rosa, nós temos equipe de máquinas lá, a prefeitura ajuda eles com adubo. Hoje, $70 \%$ da Poranga é de pessoas que estão voltadas para a agricultura. Tem aquele programa da mais leite, da horta viva, e estão sobrevivendo. E 30\% são pessoas que estão lá para lazer, pescaria. Infelizmente essa foi a forma que se colocou e está aí. Só que assim mesmo, apesar de todos os problemas, desse caso, aquela fazenda que pertencia ao proprietário de São Paulo que não planta um pé de couve aqui,

\footnotetext{
${ }^{61}$ Uma das coisas interessantes no linguajar das pessoas que vivem na área de abrangência da BR163, é que a moeda de cálculo para valorizar a maioria dos bens é o saco de soja. Conforme o valor de mercado é estabelecido o valor do bem (desde maquinário até propriedades de maior porte).
} 
aqui, tem duzentas e poucas famílias que vivem lá. De certa forma, bem ou mal vive. Senão teria caído na mão do vizinho que é um grande proprietário e tem 3/4 das famílias lá (número de pessoas trabalhando para ele). Então se a gente for falar em termos de comunidade, a gente vai entrar em outro caminho aí... A gente viveu aquilo lá. Quando loteou aquelas terras, eu abri cada estrada daquela lá. A gente abriu, cascalhou... Foi assim.

Em Sorriso, cuidar dos migrantes não qualificados e sem endereço identificado, vem sendo uma das prioridades do município que, ao mesmo tempo, procura acelerar o processo de melhoria do IDH, ampliando o mercado de trabalho para absorver mais mão de obra local. Paralelo a esta iniciativa, o poder público criou meios de incentivo fiscal para atrair a implantação de novas empresas no município.

Existem bairros onde se concentra um grande número de nordestinos, principalmente maranhenses que, embora sejam enquadrados numa situação econômica menos favorecida, encontram em Sorriso melhores condições de vida que aquelas deixadas para trás, quando percebiam salários em média inferiores a $\mathrm{R} \$ 200,00$ mensais. A dignidade adquirida com um salário mínimo de $\mathrm{R} \$ 622,00$ mensais é, sem dúvida, um valor agregado ao esforço de se adequarem a uma nova vida.

Conforme relatou numa entrevista realizada em 20.09.2012, o professor Rodrigo de Vargas Hahn, diretor da Escola Santo Agostinho, a principal do bairro com o mesmo nome, habitado principalmente por maranhenses de baixa renda, seu cotidiano, tem se tornado dia a dia mais complicado.

Para exemplificar o que eu estou falando, eu trabalho nesta escola há oito anos. Eu enfrento um problema na minha escola hoje que é a falta da família, da estrutura familiar. Nós, pes, fizemos uma pesquisa aqui, há uns 3 ou 4 anos atrás, e tinha mais ou menos $70 \%$ dos alunos que não tinham pai no registro de nascimento. Isso era uma realidade. Hoje eu não sei o dado, mas hoje eu tenho aqui mais ou menos 50 documentos com suspensão, advertência, encaminhamento para conselho tutelar e tem até BO, só do mês de agosto. Eu assumi a direção aqui em março. A outra diretora aqui nunca havia dado este número de advertências em dois anos. Não é porque eu seja ruim e ela boazinha; é que a realidade hoje é outra. O pai não vem na escola, você manda para o Conselho, o Conselho não consegue, manda para a Promotoria, a Promotoria não faz nada, porque a família está desregrada. Porque está tão desregrada? Outro dia mesmo eu fui levar um menino com febre em casa e chegando lá eu não sabia se deixava o menino em casa ou se trazia de volta para a escola, mesmo queimando de febre. Três horas da tarde de uma quinta feira, eu levo o aluno pra casa porque ligava e a mãe não atendia, chegando na casa dele, seis mulheres na casa, com mais uns 5 ou 6 homens, som lá em cima e tomando cerveja. Ou seja, uma realidade que hoje a gente vive muito. 
O professor Rodrigo tem muito claro as questões que afetam a comunidade do bairro São Domingos, cuja realidade confronta com outra muito diferente daquela do núcleo urbano.

\begin{abstract}
Eu chego aqui na escola quinze para as sete, quando eu passo ali na esquina que tem um bar já tem uns quinze ali bebendo cachaça. Então é assim: vem muita gente, vem sem qualificação, emprego aqui em Sorriso tem, só que não tem para quem não tem essa qualificação hoje e muitos não estão nem interessados em se qualificar. Hoje a droga aqui no bairro, não é só aqui, mas é muito preocupante, porque o índice de violência aumenta por causa da droga, eu estou tendo que erguer os muros da escola porque os traficantes passavam naquela lateral onde tem a grade e jogavam balinha para as crianças dentro da sala de aula. Imagina $4^{\circ}, 5^{\circ}$ e $6^{\circ}$ ano, acabava com uma aula. Chuva de balinha. Eu estou tendo de adequar a escola por causa da sociedade de fora. Eu não tenho mais espaço. Sala de aula a gente até vai dando um jeito, mas eu não tenho espaço para eles brincarem no recreio, serem crianças. Tem uma quadra que não é anexa a escola, para ir até a quadra o aluno precisa ir para a rua e atravessar a rua, isso já é um problema, por isso eu tenho uma preocupação muito grande ainda que a realidade que nós estamos vivendo, pelo que eu conheço, nós estamos ainda bem tranquilos.
\end{abstract}

Na Foto 11, abaixo, se vê a saída das crianças da escola, entorno este que traz tanta preocupação ao professor Rodrigo.

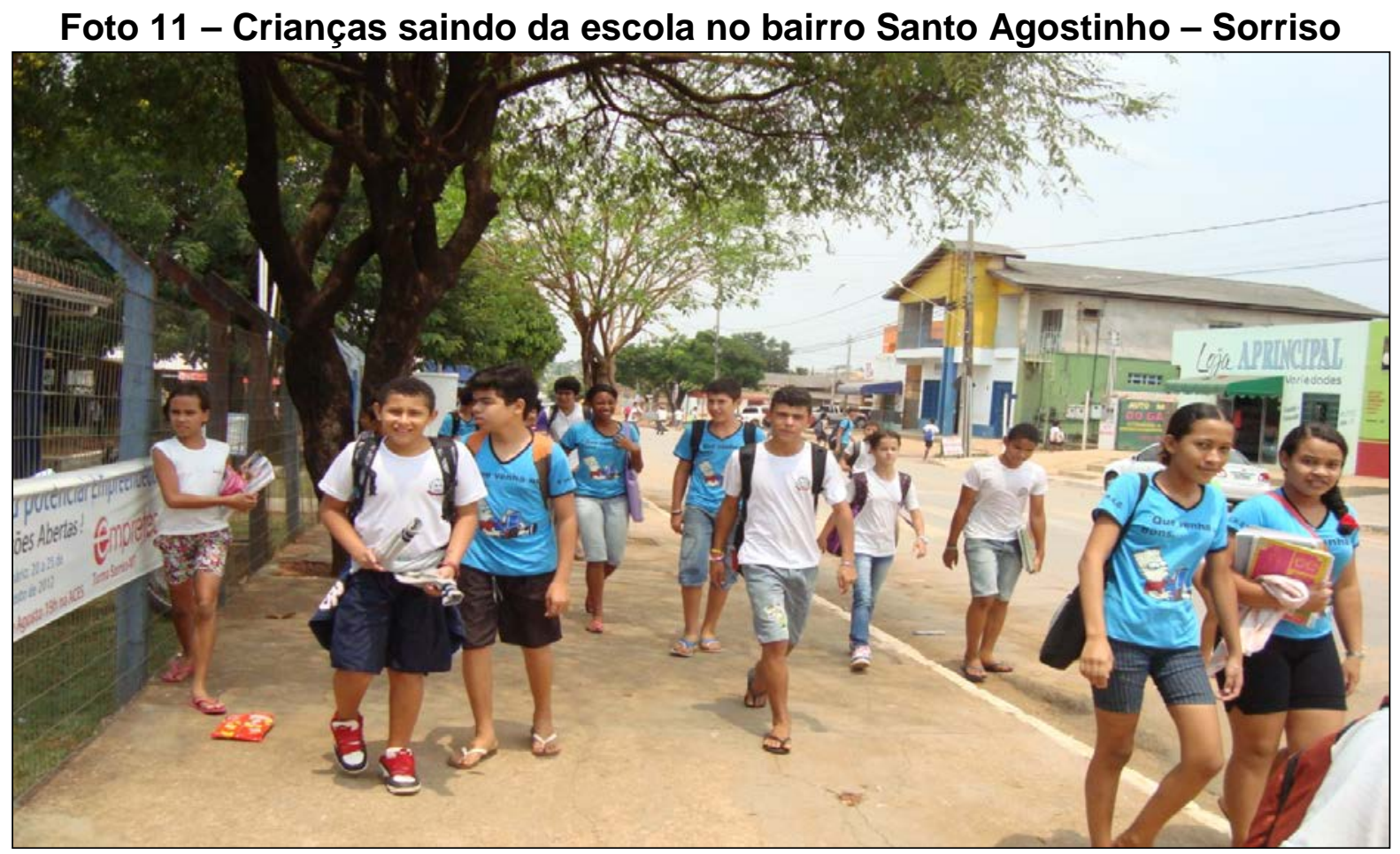

Fonte: Acervo da autora (2012)

Mas, a preocupação do professor vai mais longe, na medida em que a violência só vem aumentando e muitas vezes ele se sente impotente para enfrentar esta realidade, apesar de ter relativo apoio do poder judiciário. 
Mas o que me preocupa é que a cada ano que passa vai piorando e eu não consigo ver uma perspectiva de melhora neste quadro social. A única coisa que eu acredito que possa melhorar isso, é o que eu disse ao promotor de justiça: eu só leio cumpra-se, cumpra-se. O cara é marginal, mas a lei diz que ele tem de ser matriculado na escola mais próxima do lugar onde ele reside; ele vai cair aqui e eu tenho que colocar o cara aqui porque é a lei. Eu tive quatro alunos deste jeito aqui e dos quatro, nenhum está na escola mais. Aí tem o artigo 22 dizendo que a educação incumbe aos pais, é obrigação do pai; foi o que eu falei para o promotor numa reunião que a gente teve: Doutor, não precisa de lei, vamos responsabilizar a família. Do jeito que um pai, quando não paga a pensão alimentícia vai preso, quando a escola chama a mãe, manda um SOS para a mãe, e ela não aparece na escola, vamos á atrás dela. Vamos responsabilizar, é lei. Agora os pais não estão nem aí, e os que vêm não ajudam.

Lidar com a realidade de seu dia a dia não tem sido uma tarefa fácil para o professor Rodrigo de Vargas Hahn. Apesar de contar com o carinho e com o respeito da comunidade, em certas ocasiões tem se sentido acuado apoio do poder público.

[...] O índice de violência está muito grave. Ontem até saiu uma reportagem sobre o índice destas violências que acontecem fora da escola que eles gravam, que vai para a internet. Aqui eu já tive três casos muito graves, com brigas fora da escola. A minha festa junina sempre foi uma festa aberta. Este ano eu tive que fazer fechada e deu tanto problema como se fosse aberta. Ano passado a gente fez festa aberta e mesa voava aqui pela festa. Aí este ano eu resolvi fazer uma festa fechada o pessoal de fora, de outras escolas vinham pra cá e pulavam o muro para dentro e aí tinha que botar para fora. Eu passei três dias trabalhando com este pessoal, marginais de outras escolas, sentados na calçada do outro lado da rua me ameaçando. É uma realidade que a gente vive hoje. Por que? Falta apoio à escola, falta ação do poder público. Um destes alunos que me ameaçou de morte foi encaminhado para Cuiabá, ficou lá 42 dias e volta para a mesma família. Não adianta levar só ele para Cuiabá; tem que levar a família. A família tem de ser responsabilizada, tem que ser tratada, se precisar de tratamento, porque nós, sozinhos não vamos controlar isso.

Nota-se no professor Rodrigo de Vargas Hahn a persistência dos imigrantes pioneiros, agora com outro tipo de desafio.

Diante de toda esta problemática, nós ainda temos uma escola muito bacana hoje. Um IDEB muito bom, professores muito dedicados, uma estrutura boa, claro que tem muita coisa para se fazer estruturalmente na escola, mas ainda tem uma estrutura boa perto de outras realidades, uma merenda boa... temos um problema grave que é a falta de espaço físico que, acredito, só seria resolvido se conseguisse negociar esta casa aqui ao lado. Só que nós já tentamos ir conversar in off para ver se conseguia agilizar isso, mas eles na arredam o pé. Pedem fortunas num terreno que vale... Porque sabem que se for para fazer, eles vão acabar ganhando indenização e aí não tem jeito. Mas esta seria a única saída para aumentar o espaço físico. O poder público não se organizou nem previu o crescimento. Se bem que o bairro também começou e cresceu sem o menor planejamento. 
Para o professor Rodrigo de Vargas Hahn, poderia ser feito muito mais, uma vez que a municipalidade sabe dos problemas e do aumento constante da demanda, especialmente neste bairro onde a escola funciona.

[...] Apoio para as escolas sempre tem. Não falta dinheiro. O governo federal com os projetos libera dinheiro para a gente. Este laboratório, por exemplo, é todo Prolnfo ${ }^{62}$. A gente fez o projeto no ano passado e deu para montar tudo. Não foi a prefeitura que deu. Então aqui está tudo com a internet funcionando, só que hoje a gente não tem monitor de laboratório para utilizar o laboratório. O monitor que estava aqui passou num concurso público, assumiu na secretaria e a prefeitura não encaminhou ninguém ainda para assumir aqui. Então o laboratório hoje está fechado como laboratório. Só que este espaço hoje virou uma videoteca. Eu já licitei com o dinheiro do PDDE este ano [...] A nossa biblioteca é muito precária e falta dinheiro para comprar livros. [...]

O professor Rodrigo de Vargas Hahn acredita no futuro e, mesmo convivendo com as dificuldades de uma escola de bairro pobre, sabe que precisa prestar atenção nestas crianças e adolescente que não para de chegar, demandando mais espaço a cada semestre.

A grande maioria dos alunos daqui está vindo de fora. Não são de Sorriso. Como eu disse a gente tem que estar sempre se adaptando, começando por baixo e ir melhorando o nível do aluno. Gera uma preocupação para a gente porque agora e gente tem que manter esta meta e não é fácil. Está chegando muita gente de fora. Hoje a defasagem de sala de aula para nós é muito grande. Eu tenho turmas da quinta série que estão acima dos níveis tolerados, isto é, 35 alunos, todas as minhas turmas de quinta série têm alunos com algum tipo de deficiência. Não vejo isto como um problema, a não ser um problema de estrutura física. Além disso, a sala de aula não comporta 35 alunos. O professor não tem espaço físico para trabalhar. Estamos quase no final do terceiro bimestre e eu recebo pedidos de 4 a 5 pais de alunos todos os dias.

A opinião do professor Rodrigo de Vargas Hahn, por um lado, analisa o que pode ser feito com esta comunidade que está muito aquém do que a produção do espaço de Sorriso necessita. Por outro lado, o consultor de Planejamento da Prefeitura, Ary Junior, referindo-se à mesma comunidade, sem citar o nome do bairro, faz uma analogia com a Caverna de Platão ${ }^{63}$, para explicar este fenômeno social recente:

Depois de passar alguns relatórios para o Antonio Marins Filho, pra gente entender este processo de miscigenação (de Sorriso). Aí ele me colocou que isso aí é um case, porque normalmente essa minoria que se submete a esse trabalho mais braçal por um valor pequeno e não gera conflitos sociais,

\footnotetext{
${ }^{62}$ Programa Nacional de Tecnologia Educacional (Prolnfo).

${ }^{63}$ O mito da Caverna, é uma metáfora desenvolvida por Platão em sua obra "A República". Trata da forma como podemos nos libertar da condição de escuridão que nos aprisiona, escolhendo da luz da verdade. Discute sobre teoria do conhecimento, linguagem e educação na formação do Estado ideal.
} 
nós temos um fenômeno aí. E passou um tempo, eu pensei até que não iríamos falar sobre isso, [...] E aí ele passou para mim uma tese que eu achei interessante, vale a pena debruçar encima dela. O Maranhão é feito de pessoas que têm dono. Então estas pessoas que vem do interior do Maranhão, notadamente as que estão vivendo em cidades que têm quinhentos habitantes (o grande centro delas porque elas estavam na roça), elas entram num ônibus e vão para Sorriso. Sorriso é como se fosse um oásis.

É preciso esclarecer que o Sr. Ary está tomando por base aquelas pessoas que chegam nos ônibus fretados que, há alguns anos, traziam mão de obra para a "destocagem"64. Depois, um bom número deles seguia em frente ou voltava para o Maranhão e alguns ficavam em Sorriso. Estes foram formando o bairro São Domingos, área doada pelo então vereador José Domingos, que também foi prefeito e hoje é deputado estadual.

Por isto, coloca a situação atual assim:

Quando elas chegam aqui, isto é, conforme a visão de ocupação ou visão antropológica delas, elas estavam na caverna, na caverna delas, Sorriso virou a boca da caverna. Quando elas chegam na boca da caverna, até elas desfrutarem da beleza da boca da caverna e perceberem que estão em outra caverna, elas percebem o mundo como elas percebiam antes. Quando elas chegam aqui, a primeira coisa que elas querem é um dono. E quando elas encontram este dono que dá para elas uma cesta básica, que dá a elas um mínimo de condição de sobrevivência que é no mínimo dez vezes mais do que elas tinham lá, elas começam a desfrutar desta boca da caverna. Então, nos próximos cinquenta anos, nós vamos ter conflitos sociais em Sorriso." E ele disse isto, baseado no que eu relatei a ele, porque ele nunca esteve em Sorriso, mas ele se interessou pelo caso e eu tenho colaborado neste sentido, porque nós só vamos perceber que estamos em outra caverna quando começarmos a nos ambientar e dar o salto para perceber que precisa de uma nova opção. Então, quando eles perceberem que estão numa outra caverna, vão começar todos os conflitos sociais.

Pelas constatações da pesquisa in loco, existem bairros na cidade que foram "montados" através da politização da moradia. Há alguns anos, havia o hábito de trazer pessoas do Maranhão para a "destocagem". Com a evolução do maquinário, até mesmo esta tarefa foi sendo realizada mecanicamente, como relata o Secretário de Obras e Serviços Urbanos, Emiliano Preima:

As colheitas em Sorriso sempre foram mecanizadas; aqui nunca teve colheita manual. Mas os primeiros nordestinos que vieram para cá, em 1995, vieram para catar raiz. O trator fazia a primeira derrubada e arada e aí passava uma grade, mas ficavam aqueles tocos, aqueles pedaços que tinha de ser feito manual. Hoje já não tem mais isso e ainda tem algumas máquinas que catam bem. O final ainda é feito à mão. Então muita gente veio para catação de raiz. Eles vinham, ficavam um período aqui depois iam embora. O caminhão do fazendeiro trazia, no início da safra, e quando

\footnotetext{
${ }^{64}$ Arrancar manualmente os tocos de árvores remanescentes no solo das lavouras, tarefa que não era possível realizar com máquinas.
} 
começava o plantio, as pessoas iam embora. Alguns também trabalhavam no ensacamento do arroz. Quem trouxe muita gente que não veio do nordeste, veio do Paraná, foi o falecido Bia, que foi vereador em Sorriso. Veio gente ali daquela região de Rolândia, do interior do Paraná que eram braçais lá e acabou vindo com ele. Ele trouxe, e o bairro Fraternidade, ele criou e botou as pessoas em barracas de lona lá. Esse bairro nasceu assim em 1989/1990, mas em 1981/1982/1983, esse bairro nasceu por aí, dessa forma.

O Sr. Preima acompanhou todo o crescimento de Sorriso, sempre perto da administração municipal, por isso pode falar do se desenvolvimento da cidade com muita propriedade.

[...] Desde aquela época já fazia este tipo de serviço. Depois em 1996 para 1997 houve um problema sério nos garimpos de Peixoto, nessa região aqui do norte, aí houve uma grande migração do pessoal de Peixoto e aí contam que foi o Zé Domingos ${ }^{65}$ que trouxe o povo, mas na verdade faltava mão de obra. Como as pessoas sempre ouviam falar muito bem de Sorriso, diziam: nós vamos para esta terra aí. Então hoje no bairro Boa Esperança 1 e 2, ali ao lado do bairro Fraternidade e no bairro São Mateus que foi uma criação, um prolongamento ali daquele bairro onde os terrenos eram de $20 \mathrm{~m}$ por $100 \mathrm{~m}$ para a indústria, aí, o que é que a Colonizadora (Feliz): ela criou neste lote de 20X100 alguma coisa assim: eu comprava o terreno e vendia para mais sete. Criou pequenos condomínios para poder vender as terras. Então oito pessoas pagavam mas não eram proprietárias, porque o município não permitia que se loteasse aquela área ou subdividisse porque era um bairro industrial. Aí ficou sem passagem porque num lote de 20X100, as pessoas dividiam em oito, como é que vão viver aí dentro. Aí em cada lote deste, no outro lá eles abriam uma ruazinha. Então testa pra cá testa pra lá, dividiram ao meio e ficou assim. Ficou um bairro cheio de becos. Tem lugar que eu não consigo entrar com o caminhão para coletar lixo.

O que se percebe pelo relato do Secretário, é que há 13 ou 14 anos atrás, esta área dita "industrial", era relativamente distante do núcleo urbano.

De acordo com informações locais, a contrapartida aos políticos seria o voto para eleger a si mesmo ou seus agregados e, no caso da Colonizadora Feliz, olhou a questão de modo a realizar um negócio, sem se preocupar muito com a urbanização da área que traria consequências graves no futuro, porque as pessoas foram se acomodando como podiam, transformando este aglomerado num dos maiores bairros de Sorriso; o bairro São Domingos.

Como se vê na Figura 40, a seguir, a área demarcada em preto, era a área denominada industrial. A área demarcada em vermelho, o bairro São Domingos, hoje, ambos incorporados ao núcleo urbano.

${ }^{65}$ José Domingos Fraga Filho, prefeito de Sorriso de 1989 a 1992, de 1997 a 2000 e de 2001 a 2004 
Figura 40 - Detalhe da Planta de Urbanização; Zona Industrial (preto) e bairro São Domingos (vermelho)

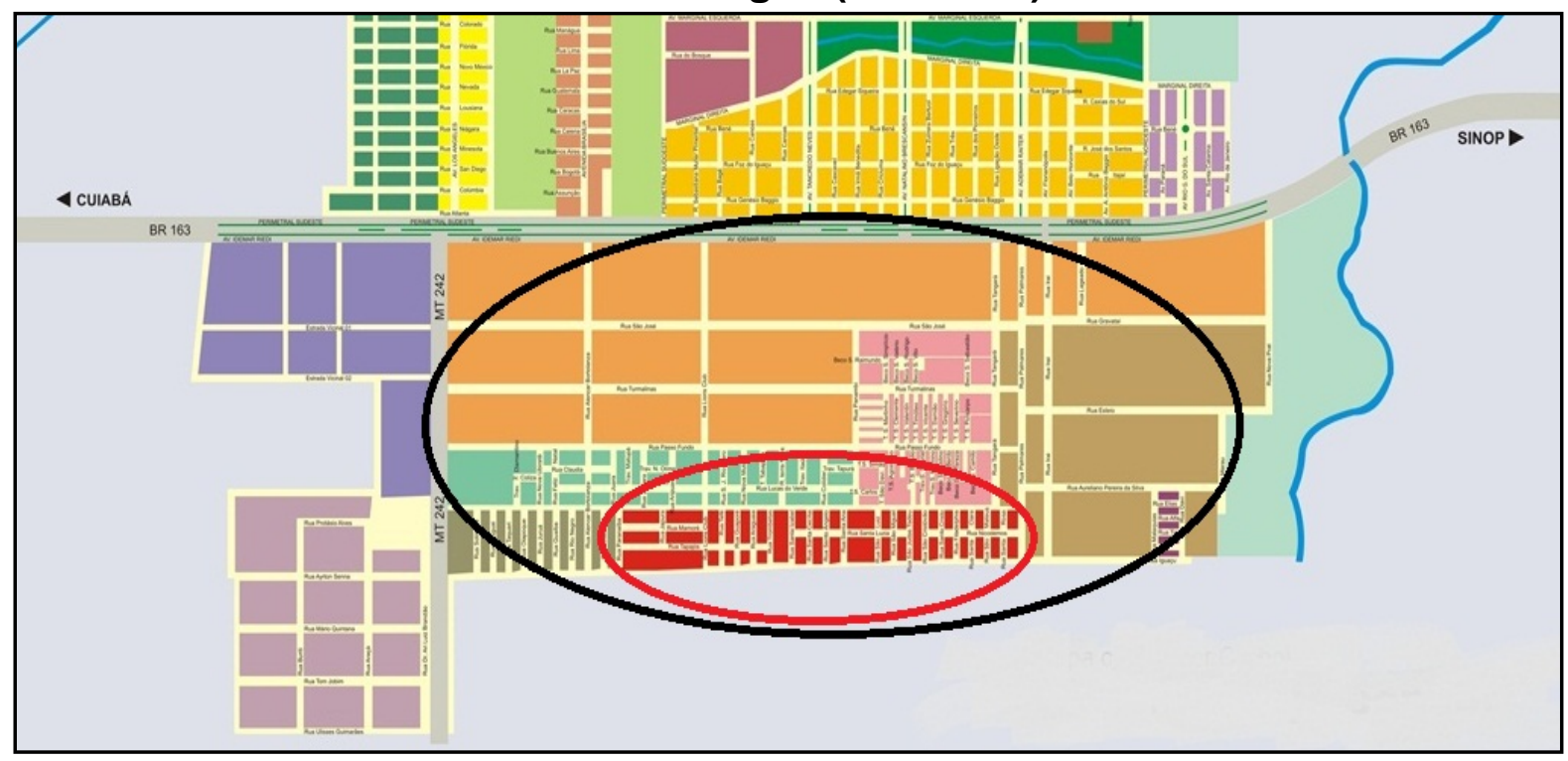

Fonte: Site Clic Hoje (2012)

Como não poderia deixar de ser, um bairro que nasce e cresce sem um planejamento prévio, se transforma rapidamente em transtorno, tanto para quem vive nele como para o poder público. No início não havia água, nem saneamento básico ou luz elétrica. As pessoas viviam em barracas e "se viravam como podiam" porque tinham poucas condições de encontrar trabalho na cidade

Foto 12 - Uma das ruas estreitas do bairro Santo Agostinho

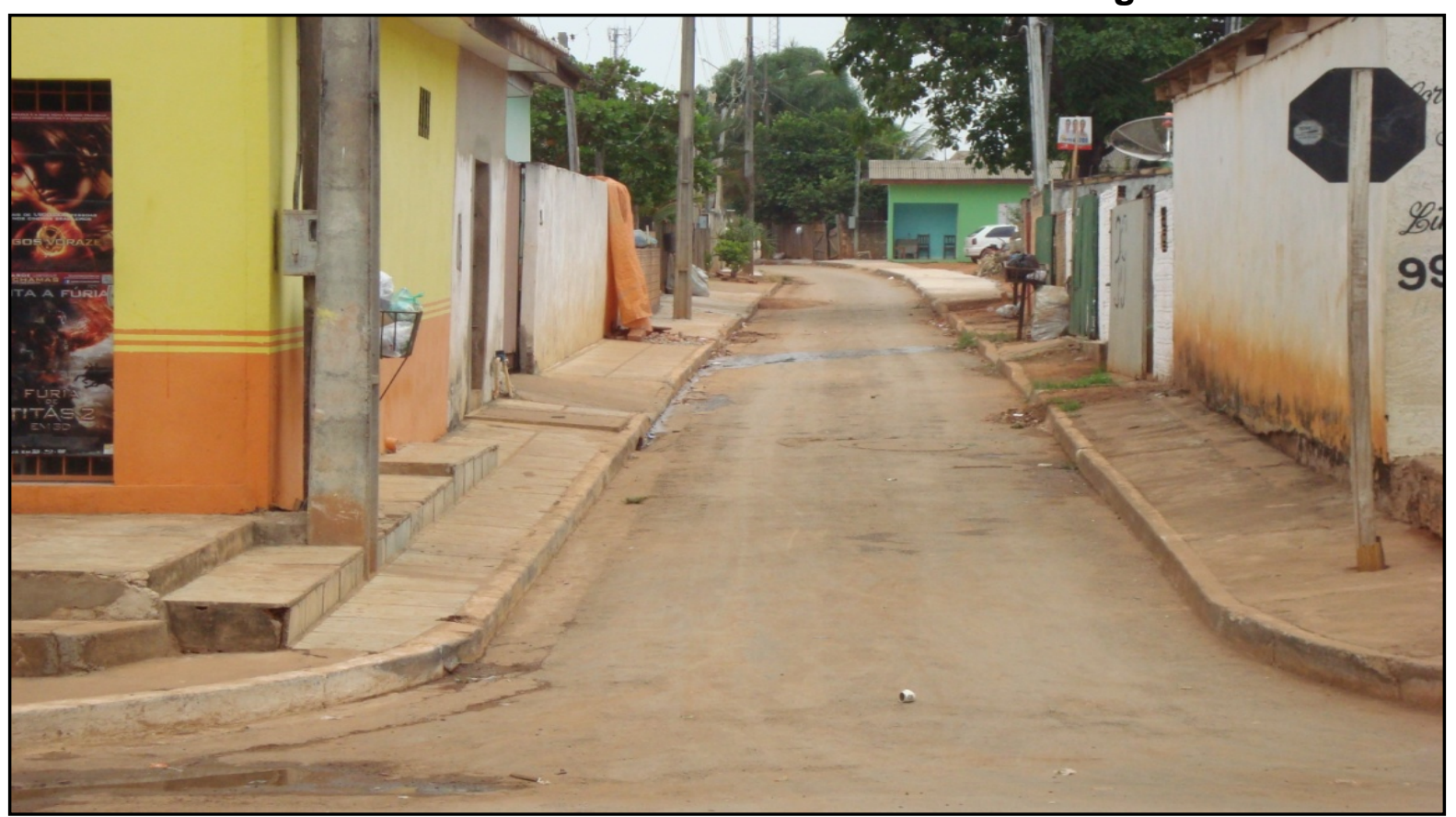

Fonte: Acervo da autora (2012) 
Independente das carências sanadas paulatinamente, as casas iam sendo construídas sem obedecer a nenhum critério. Isto provocou sérios problemas viários no interior do bairro, pois as ruas ficaram estreitas e, em alguns casos, ficaram sem saída, como se vê na Foto 12, acima.

Estes problemas, conforme nos relata o Sr. Emiliano Preima, acabaram em demandas judiciais:

Isso foi em 1998/2000, aí teve até uma reunião com o Ministério Público para poder regularizar a situação desse pessoal lá, porque a Colonizadora (Feliz) vendeu, me desculpe, mas de má fé, porque ela sabia que o proprietário era o João, entre aspas, mas eram oito pessoas que iriam ocupar este terreno. Aí o Ministério Público e a prefeitura, porque eles queriam água, luz e coleta de lixo. Como é que eu vou entrar no bairro. Eu não tinha como fazer. A gente coletava nas testadas das ruas. Aí entrou o Ministério Público junto, foram feitas reuniões, e ficou um bairro horrível, no meio da cidade, cheio de becos, ruas estreitas, tem lugares que o caminhão do lixo para passar se alguém estiver no meio fio não passa. Foi uma situação criada pela Colonizadora Feliz.

A Foto 13 , a seguir, dá uma ideia da estrutura reformulada da rua principal do bairro, que ficou mais larga e serve de ponto de apoio para a comunidade que vive ali:

\section{Foto 13 - Avenida principal do bairro São Domingos}

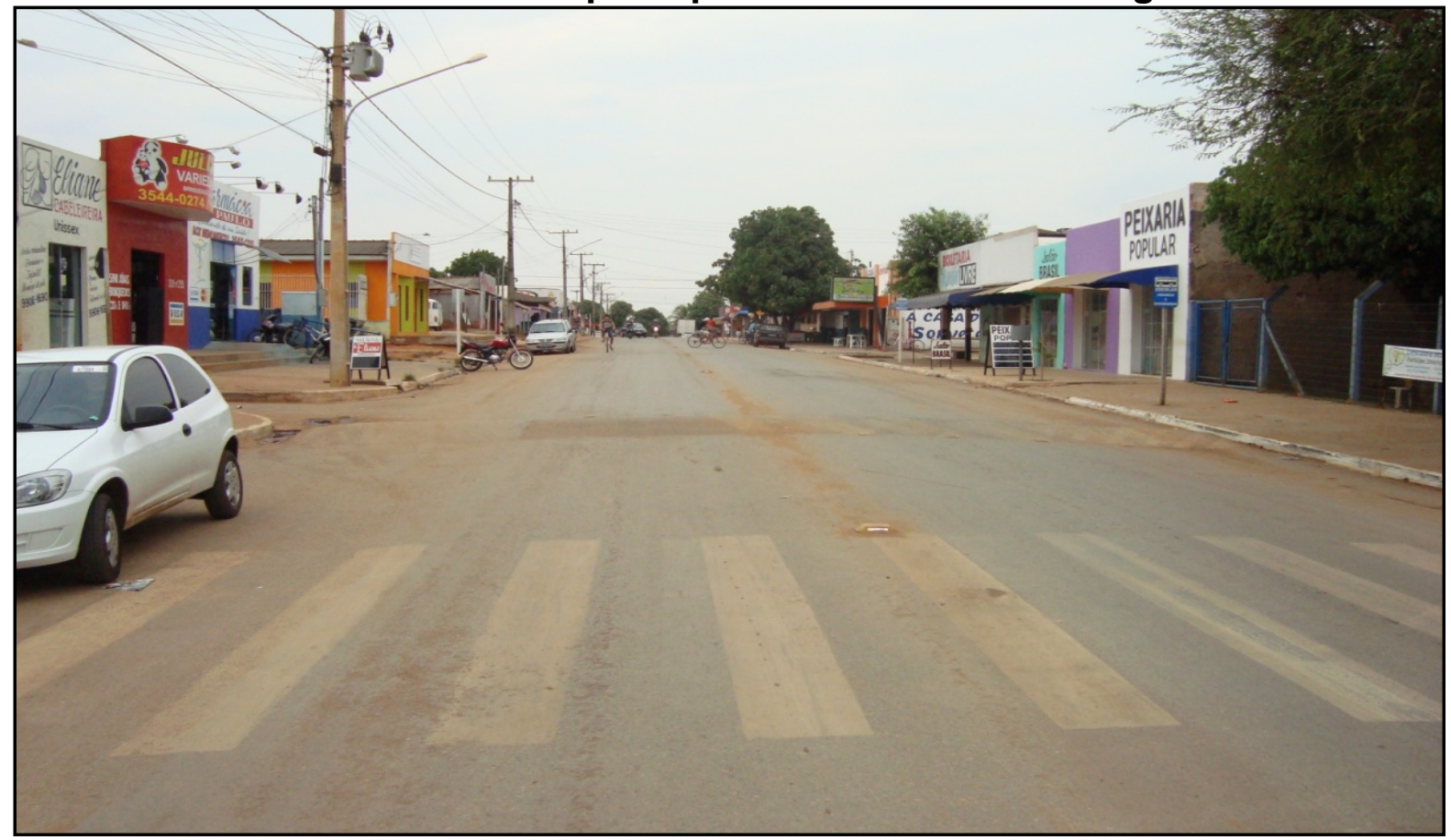

Fonte: Acervo da autora (2012)

Conforme pesquisa realizada no bairro São Domingos, cuja população é predominantemente maranhense, ninguém demonstrou interesse em voltar para as suas origens, mesmo amargando seus problemas. Dentre as oito pessoas 
entrevistadas (desta, três crianças) o sentimento de pertença em relação a Sorriso é latente em todos.

O próprio Rodrigo de Vargas Hahn, diretor da escola do bairro confessa que o esforço tem valido à pena:

O nível da escola é muito bom, a começar pelos professores, praticamente todos pós-graduados, infelizmente todos precisam trabalhar com as dificuldades dos alunos e se adaptar à realidade deles. Apesar das dificuldades de adaptação ao nível elevado de ensino na fase inicial, a escola ainda mantém um IDEB ${ }^{66} 18 \%$ acima da média nacional nos anos iniciais e $28 \%$ acima da média nacional nos anos finais.

Este comentário fez com que a professora Mariliane Sobrinho lembrasse do tempo em que deu aula naquela mesma escola e relatou um fato bastante curioso:

Nós pagávamos $\mathrm{R} \$ 1,00$ por semana aos pais dos alunos, para cada pai se sentisse participante da manutenção da apostila. Era como se a apostila custasse $\mathrm{R} \$ 4,00$ e o pagamento em prestações. Este projeto, com um custo de médio de $\mathrm{R} \$ 4,00 /$ mês por aluno, na realidade pretendia evitar que os pais destruíssem o material escolar, pois descobrimos que eles usavam as folhas da apostila para fazer cigarro. Pois é; do tempo que eu dei aula aqui, para hoje, melhorou muito.

Estes resultados nem sempre garantem vagas no mercado de trabalho, mas contribuem muito para que estes alunos saiam do segundo grau, relativamente bem preparados para encarar a competição profissional. Com a abertura constante de empresas, o mercado tem aberto muitas vagas em diversos setores, favorecendo não só os profissionais altamente qualificados como aqueles que estejam se preparados para assumir vagas no comércio ou na indústria.

Este bairro não é o único problema de Sorriso. O município, assim como Lucas do Rio Verde e Sinop, tem sérios problemas de habitação por conta não só do crescimento demográfico natural nestas cidades, mas porque continuam chegando muitos imigrantes, notadamente dos grandes centros do país e até do exterior. A Prefeitura tem procurado atenuá-lo com projetos diferenciados. Uns dirigidos às classes A e B; outros do tipo "Minha casa, minha vida" para atender as classes C e $D$, em parceria com os governos do Estado e Federal, visando construir casas

\footnotetext{
${ }^{66}$ O Ideb - Índice de Desenvolvimento da Educação Básica foi criado pelo Inep - Instituto Nacional de Estudos e Pesquisas Educacionais Anisio Teixeira em 2007, em uma escala de zero a dez. Sintetiza dois conceitos igualmente importantes para a qualidade da educação: aprovação e média de desempenho dos estudantes em língua portuguesa e matemática. O indicador é calculado a partir dos dados sobre aprovação escolar obtidos no Censo Escolar e médias de desempenho nas avaliações do Inep, o Saeb e a Prova Brasil. Nos anos iniciais (primeiro ao quinto), o Ideb nacional alcançou 5,0. Nos anos finais (sexto ao nono) do ensino fundamental, o Ideb nacional atingiu 4,1. Fonte: MEC - Ministério da Educação, www.mec.gov.br
} 
populares em áreas consideradas "periféricas" da cidade, onde vive a população de baixa renda.

O processo para a obtenção destes imóveis na planta se inicia com a inscrição do interessado que atenda às exigências estipuladas. Aprovado o cadastro completo, o contemplado acompanhará a construção e, durante todo o processo, terá o apoio de uma comissão composta por moradores que fiscaliza as obras do empreendimento, desde o alicerce. Conforme alguns moradores da periferia, estes projetos, embora atendam a uma parcela da comunidade, excluem os menos favorecidos.

Como comenta Arruzzo,

Mesmo quando estes trabalhadores excluídos procuram as periferias das cidades no intuito de se territorializar, já está em grande parte ocupada com a produção de soja, que chega aos limites do urbano. (ARRUZZO, 2005:101),

Por outro lado, os condomínios construídos para uma clientela de poder aquisitivo mais elevado, tendem a crescer em número e status, uma vez que o espaço urbano torna-se cada vez mais escasso e mais caro.

$\mathrm{Na}$ ótica do poder público, não precisa haver grandes projetos públicos para aqueles migrantes com capacidade tecnológica, citados por Castells, porque eles encontram os meios resolver as questões de moradia, escola para os filhos etc. até porque em Sorriso, esta dificuldade de territorialização já é uma realidade, a partir do momento em que até mesmo a classe média tem sido obrigada a adquirir terrenos um pouco mais afastados do núcleo urbano, por conta dos preços exorbitantes do metro quadrado nas áreas mais centrais.

Para que se tenha uma ideia, o metro quadrado de imóveis populares está na faixa de $\mathrm{R} \$ 400,00$; para os imóveis de classe média, o valor sobe para $\mathrm{R} \$ 1.000,00$ e para os imóveis de luxo, o metro quadrado sobe para $\mathrm{R} \$ 1.300,00$. Mesmo assim, a construção civil tem aumentado entre 10\% e 15\% nos dois últimos anos.

Em contrapartida ao sucesso no agronegócio, os munícipes sentem a premência de solucionar problemas como moradia, segurança e ação social que vieram no rastro da mecanização e melhoria do IDH que dão a Sorriso características muito peculiares.

Sua evolução é, conforme Santos,

Uma evolução diacrônica, no decorrer da qual cada variável conhece uma mudança relativa de valor a cada mutação. Essa mudança de valor é 
relativa, já que só pode ser entendida em sua relação com o todo." (SANTOS, 2007:57).

A diacronia citada por Santos (2007) se revela principalmente no seu modo de vida diferenciado. Ao contrário de Sinop e Lucas do Rio Verde, os grandes proprietários de terras sorrisenses optaram por morar na cidade. Isto faz com que o dinheiro arrecadado por eles seja aplicado, em grande parte, no município. É comum, por exemplo, ver fazendeiros engajados em causas coletivas que, muitas vezes, dão celeridade a ações de bem estar social, postergadas pelo Estado.

Estas ações podem variar entre a construção, pavimentação e manutenção de estradas vicinais para facilitar o escoamento das commodities do grupo que tem fazendas na região em questão, até a construção, instalação e manutenção de uma Casa de Apoio para pessoas que chegam do interior e não têm onde ficar enquanto aguardam a recuperação de seus familiares no hospital da cidade.

Em 2005 a prefeitura contratou a equipe do urbanista Jaime Lerner, exgovernador do Paraná, para criar o plano diretor que norteará o crescimento da cidade até 2020, quando o índice demográfico aponta para uma probabilidade de 200.000 habitantes. O estudo realizado pela equipe pode ser considerado uma segunda etapa do código de obras e posturas do município ${ }^{67}$. É este código que dá origem ao plano de estruturação urbana, incluindo as áreas a serem ocupadas no perímetro urbano.

O estudo sugere algumas alterações no código municipal como, por exemplo, a verticalização das edificações numa das principais avenidas. Aqui foi importante ouvir a opinião do Sr. Preima durante a sua entrevista em 19.9.2012:

O Plano Diretor de Sorriso, quem fez foi a Jaime Lerner, que é um grande arquiteto, só que ele veio sonhar no lugar errado. Ele pegou a cidade de Sorriso, pegou a Blumenau que é paralela a esta aqui e verticalizou a Blumenau. $\mathrm{E}$ todas as avenidas perpendiculares a ela, como a Tancredo Neves, Brescancin e a Brasil não se permite construir edifícios. Manhattan concentrou edifícios, não é só porque é caro. É porque para a prefeitura é interessante coletar lixo numa maior concentração possível de pessoas, porque você tem menos deslocamento, o custo é mais barato, e a rede de água de esgoto, você concentra e barateia tudo.

Ele explica a sua ideia com exemplos locais:

Então se eu faço um edifício de 20 andares com 40 apartamentos ou 80, eu tenho coleta de 80 casas localizada, ao invés de eu ter que me deslocar em bairros com casas como aqui que tem quatro casas por quadra. Para o

\footnotetext{
${ }^{67}$ Lei $\mathrm{n}^{\circ} 249$ de 07 de julho de 1992 de Sorriso, institui o código de obras do município de Sorriso e dá outras providências.
} 
município, para o serviço público quanto mais verticalizar, mais barato fica. Como não houve um interesse e aí sim eu acho que a Colonizadora (Feliz) foi muito tendenciosa junto com o Jaime Lerner, e acredito que nem podia ser diferente, porque qual é o interesse das colonizadoras? A expansão horizontal, porque ela vende terrenos. Se verticalizar, as pessoas já têm os terrenos comprados. Os terrenos já não existem mais o centro. Então para ela, quanto mais horizontalizar, melhor. Porque ela vai estar vendendo sonhos de condomínios fechados, ao passo que se você verticaliza, melhora para todo mundo, inclusive para a segurança pública. Nós temos um edifício de 17 andares aqui, na Blumenau, para conseguir passar eu estou passando este processo no CNLU, que é o Conselho de Engenharia, depois para o CONDESC que é o Conselho de Desenvolvimento formado por prefeito, juiz, conselho do Rotary, enfim, para poder ir para a Câmara para poder autorizar um edifício de 17 andares. Eu acho isso o fim! Cara isso é uma coisa técnica! Tudo bem que nós temos de ter alguns bairros só com residências, mas ali é uma avenida ampla.

Para quem conhece tão bem a cidade e a estrutura que foi se incorporando aos projetos de ampliação do núcleo urbano e urbanização o Sr, Preima detalha um pouco mais:

O problema nosso agora foi a intervenção de colonizadoras e imobiliárias
junto ao projeto. Só posso entender dessa forma porque a cidade, no plano
do Jaime Lerner, não consta bairros como São Domingos, Nova Aliança,
Novos Campos que são extremamente populosos, tem mais de 20 mil
pessoas morando do lado de lá; não consta no Plano Diretor. Que Plano
Diretor é esse? Vendeu-se talvez uma idéia para ele, de uma Sorriso
diferente. Ele foi lá, pegou um lápis, fez uns rabiscos e entregou dizendo:
isso aí é de vocês. Ele criou um corredor de bicicleta e não tem bicicleta
aqui. Criou uma pista para ciclista na Blumenau e não tem ciclista nesse
sentido (Nordeste X Sudoeste). Tem ciclista nesse sentido (Noroeste BR-
163). Dos bairros, para o bairro industrial. As ciclovias que eu preciso, estão
nesse sentido. Só lá do lado da BR-163 que eu preciso ter no sentido
paralelo.

A proposta de Plano Diretor ratifica a afirmação de Santos (2005:11) de que "o campo brasileiro moderno repele os pobres e os trabalhadores da agricultura capitalizada vivem cada vez mais nos espaços urbanos".

Como Sinop e Lucas do Rio Verde, em Sorriso não há, praticamente, uma divisa entre as áreas rural e urbana. Some-se a este fato, a tendência da agricultura capitalizada de Sorriso preferir viver na cidade e atuar no agronegócio numa periferia de aproximadamente 200 quilômetros, distância esta que não altera os hábitos de trabalhar no campo e voltar diariamente para a cidade.

De um modo geral, patrões e empregados vão cedo trabalhar nas fazendas e retornam para suas casas no fim da tarde. Esta modalidade cresceu muito, principalmente depois do asfaltamento das estradas vicinais e com a transformação dos sistemas de operação das fazendas para operações empresariais; inclusive muitas operam seus negócios de escritórios montados no centro da cidade. 
Figura 41 - Planta da urbanização de Sorriso ${ }^{68}$

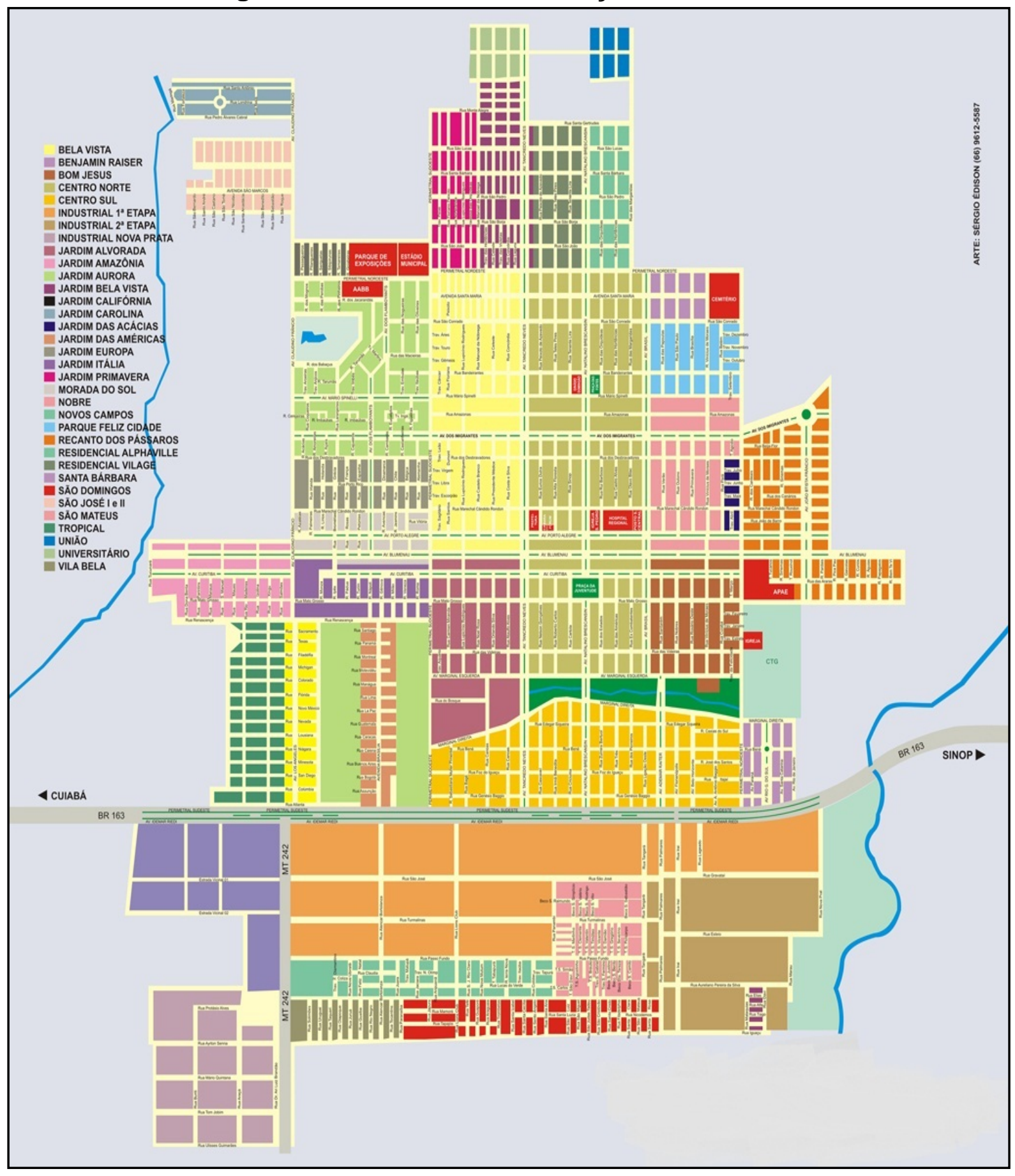

Fonte: Site Clic Hoje (2012)

Daí o interesse em colocar em prática a execução da urbanização e da modernização do município $\mathrm{cm}$ base em um plano diretor, como se vê na Figura 41,

${ }^{68}$ Os bairros de Sorriso anotados acima, à esquerda da planta de urbanização são: Bela Vista, Benjamin Raiser, Bom Jesus, Centro Norte, Centro Sul, Industrial $1^{\mathrm{a}}$ Etapa, Industrial $2^{\mathrm{a}}$ Etapa, Industrial Nova Prata, Jardim Alvorada, Jardim Amazônia, Jardim Aurora, Jardim Bela Vista, Jardim Califórnia, Jardim Carolina, Jardim das Acácias, Jardim das Américas, Jardim Europa, Jardim Itália, Jardim Primavera, Morada do Sol, Nobre, Novos Campos, Parque Feliz Cidade, Recanto dos Pássaros, Residencial Alphaville, Residencial Vilage, Santa Bárbara, São Domingos, São José I e II, São Mateus, Tropical, União, Universitário e Vila Bela 
acima, para dar melhor mobilidade e atender a demanda crescente de moradas pelos mais diversos tipos de público que hoje chegam à cidade.

Esta possibilidade tem atraído técnicos e profissionais liberais do país e do mundo, que se instalam no município em busca de uma oportunidade de trabalho especializado. Daí o elevado nível profissional que tende a se sofisticar cada vez mais. Uma comprovação desta realidade é o número crescente de construtoras e profissionais ligados ao ramo da construção civil que vem ocorrendo.

O ritmo empreendido pelas imobiliárias acompanha a urgência da população em todo tipo de moradia. O outdoor abaixo, fotografado em 2008, dá uma ideia de como os empreendimentos acontecem em Sorriso.

A proposta inicial era de investir num terreno afastado do núcleo urbano, onde começava a Rota do Sol e seria criado um novo Centro Comercial e Residencial Universitário e Cultural. A propaganda imobiliária ressaltava que a região tinha uma das melhores vistas para a cidade, pois estava em lugar elevado, de onde se via a maior parte do perímetro urbano da cidade de Sorriso. Com os terrenos quase todos vendidos, a população que continua crescendo vislumbrou também a quase certa super valorização da região num prazo de tempo muito curto.

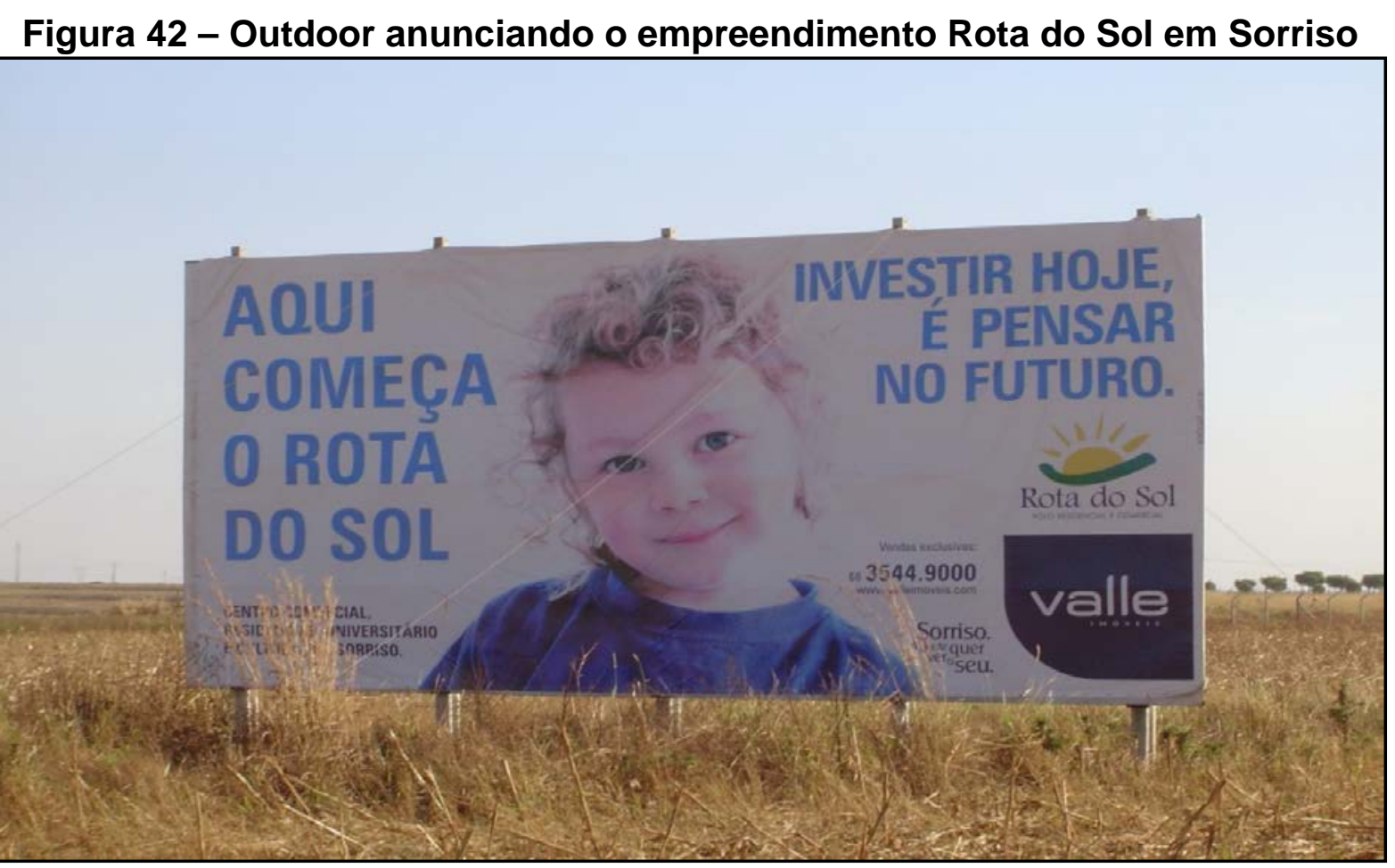

Fonte: Acervo da autora (2008) 
Pelo outdoor que se vê acima na Figura 42, anunciando a ampliação da área urbana com a criação do novo Centro Comercial e Residencial Universitário numa área que se chamará Rota do Sol.

Ao comparar a mesma área fotografada em 2008, com a a mesma área fotografada em 2012, Fotos 14 e 15, se tem uma ideia do ritmo de crescimento de Sorriso.

\section{Foto 14 - Casa no Loteamento Rota do Sol}

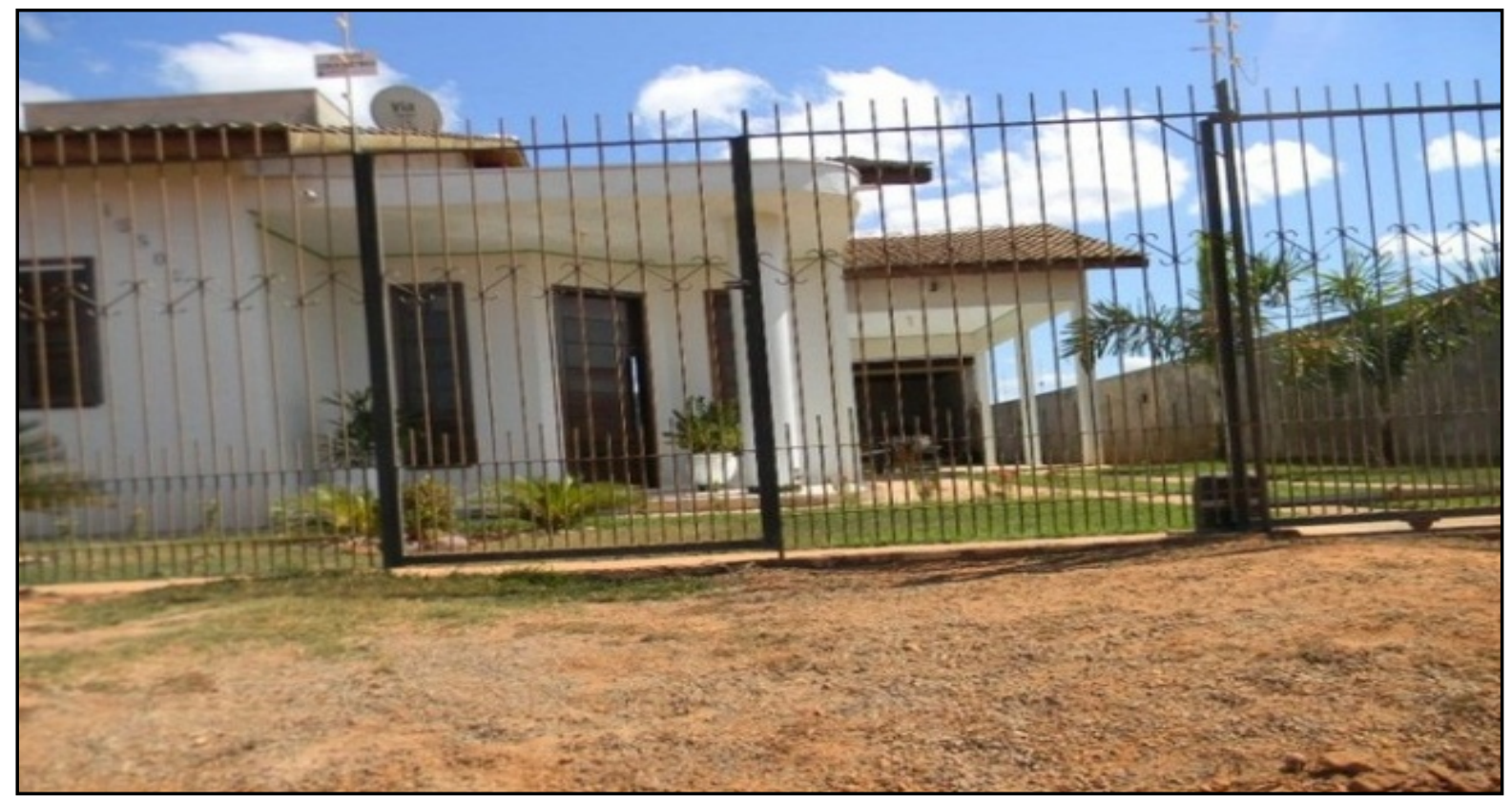

Fonte: Grupo Agroverde, proprietário do empreendimento (2011)

\section{Foto 15 - Casa no Loteamento Rota do Sol}

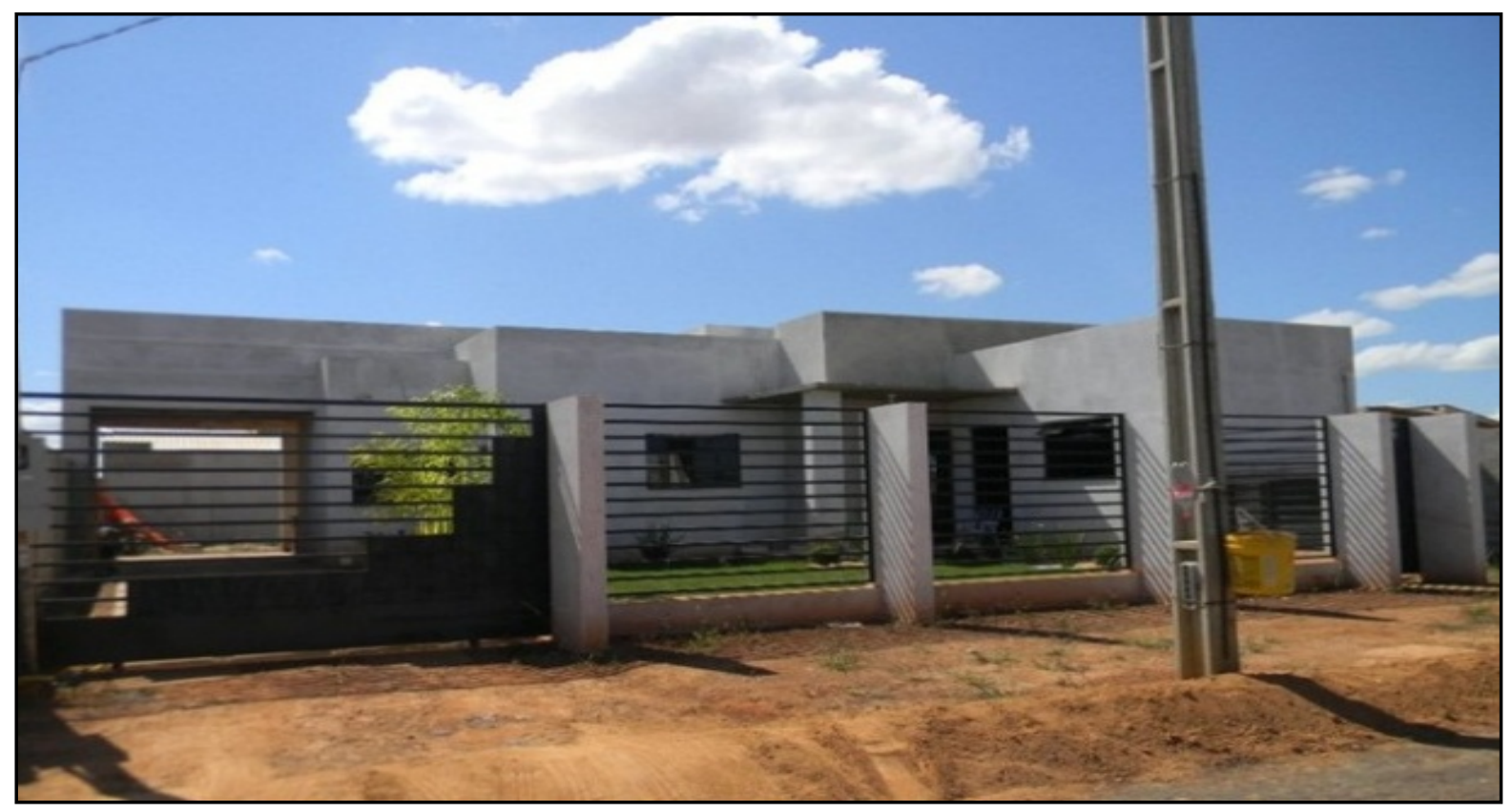

Fonte: Grupo Agroverde, proprietário do empreendimento (2011) 
A supervalorização acabou virando verdade e hoje, como detalha o Sr. Emiliano Preima em sua entrevista de 19.10.2012, a realidade do bairro é outra.

\begin{abstract}
Hoje tem alguns loteamentos como por exemplo o Rota do Sol. Há uma briga ali com a Colonizadora (Feliz). Nós autorizamos um loteamento ao lado do Rota do Sol, que as pessoas mais elitizadas e a própria Colonizadora (Feliz), a Câmara, não queria que loteasse porque ela já entendia que o Rota do Sol não podia vender para pessoas que construíssem casas de $45 \mathrm{~m}^{2}$. Até se você passar lá, você vai ver bem certo, que a quadra da avenida não tem nenhuma habitação. As habitações estão na segunda rua, apesar de que geralmente ali é tomado mais como uma área comercial, mas não era para fazer daquela forma como está lá. Então há este direcionamento; é tentar jogar os pobres para a periferia.
\end{abstract}

Dentre os quase seis mil estabelecimentos instalados no município, existem 7 agências bancárias, além de outras instituições financeiras e seguradoras, mais de 100 pontos de comércio lojista; mais de 50 empresas que trabalham direta ou indiretamente com a construção civil e administração de obras, mais de 50 lojas de material de construção e mais de 200 profissionais liberais especializados trabalhando neste segmento, além de engenheiros e arquitetos; são 26 lojas de móveis e eletroeletrônicos, mais de 20 supermercados, mercearias, armazéns e lojas de hortifrutigranjeiros, mais de 30 lojas de material para informática, 51 hotéis e motéis e mais de 100 bares, lanchonetes e restaurantes. Estes números, por si só, demonstram o forte comércio no qual gira a principal renda per capita do Estado de Mato Grosso.

\title{
Foto 16 - Avenida Central de Sorriso
}

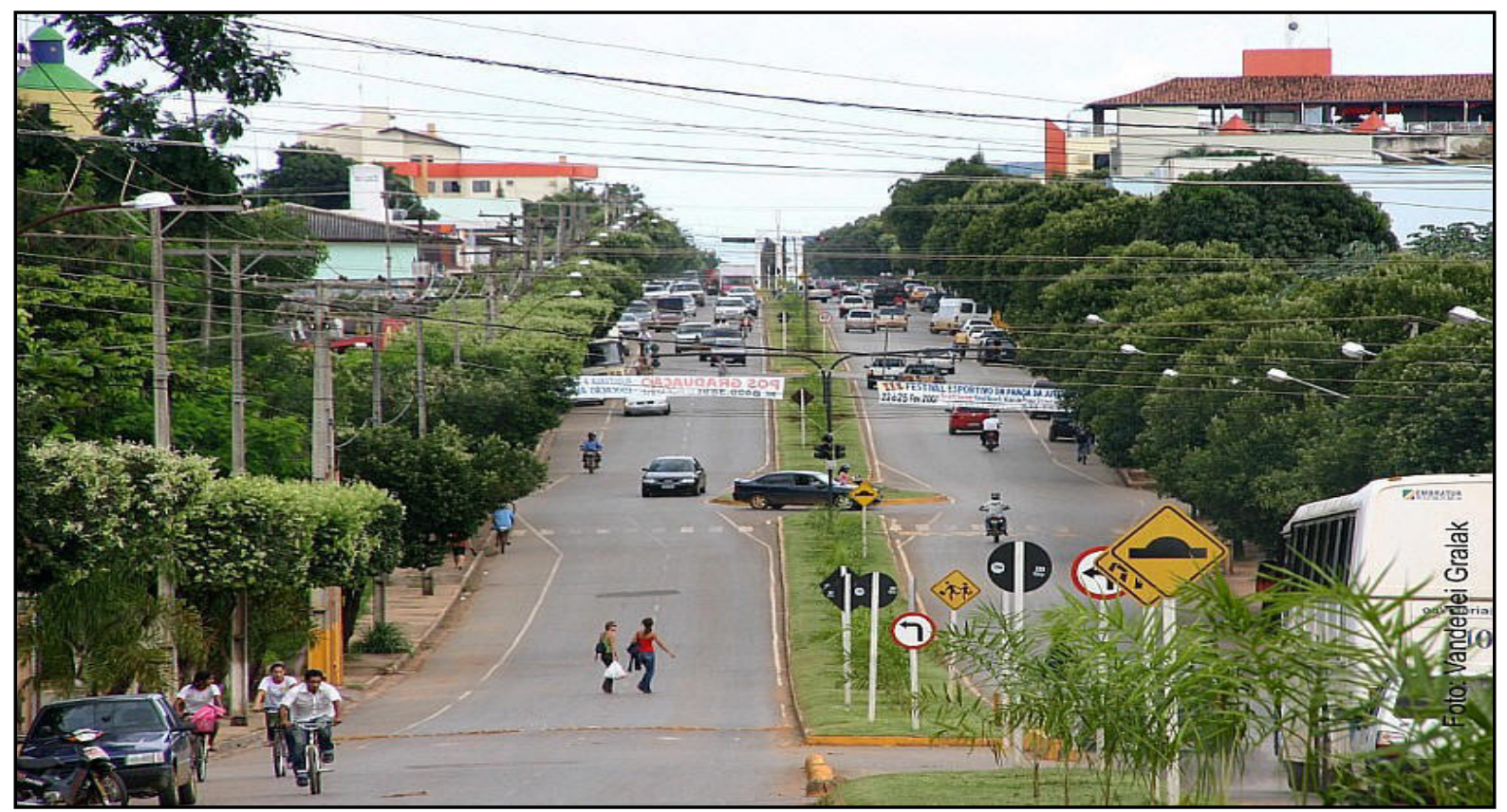

Fonte: Arquivo Prefeitura de Sorriso (2010) 
Como se vê na Foto 16, acima, Sorriso é uma cidade com avenidas amplas e bem sinalizadas, com mais de $60 \%$ das ruas pavimentadas. Suas praças, jardins e áreas verdes são distribuídos em toda a extensão da zona central. É uma dos 200 municípios com melhor qualidade de vida do Brasil e ocupa o primeiro lugar entre os municípios de Mato Grosso. As boas condições de vida permitem construções de alto padrão que refletem um desenvolvimento constante na área urbana.

Para Vanice Fronza, do Departamento de Tributação da Prefeitura, entrevistada em 19.09.2012, a percepção do crescimento de Sorriso se evidencia através do número de empresas novas que se instala anualmente numa escala que varia entre $10 \%$ e $15 \%$ ao ano e do crescimento da população que também fica mais ou menos entre $10 \%$ e $12 \%$ ao ano. Conforme Vanice,

No ano passado, nós fechamos o ano com quase mil construções novas e
este ano já estamos em torno de oitocentas, o que significa que fecharemos
2012 com mais de mil. Pela construção civil, você já tem uma noção de
quanto cresce esta cidade. Quando eu cheguei aqui em 1985, a gente
conheçia todo mundo. Hoje a gente não conhece mais ninguém. O que a
gente nota é que tem vindo muita gente das classes B e C, que vêem como
uma perspectiva de uma vida nova, emprego... Como o comércio cresce,
aparecem sempre oportunidades de emprego. Uma coisa leva a outra. O
que a gente vê são filhos de Sorriso que estão voltando depois de
formados, principalmente na área de engenharia civil, arquitetura e
agronomia. Lógico que também tem outras profissões como médicos,
dentistas, nutricionistas que estão voltando depois de formados. Isso é
diferente de tudo, porque de um modo geral os jovens que se formam não
voltam para o interior de onde saíram.

A pujança do município transparece no alto padrão de IDH (Índice de Desenvolvimento Humano) do município, que alcança 0,824 , e se espelha no comércio variado e de alto luxo. Uma das características da cidade é a aplicação de riquezas em seu próprio território. No comércio, por exemplo, é comum as esposas de fazendeiros abastados montarem lojas de alto luxo, no estilo das encontradas no bairro Jardins, em São Paulo, para desenvolverem seu próprio negócio. O comércio local encontra-se distribuído nas principais ruas da área central da cidade e em seu entorno. Para Marines Perin Smaniotto, proprietária de uma das lojas de alto luxo de Sorriso, entrevistada em 20.09.2012, o caminho para chegar até onde está não foi muito simples.

Meu pai veio em 1985, para vender produtos para a agricultura. Eu vinha visitá-lo todos os anos e trazia uma malinha de roupa, porque a minha sogra já tinha uma loja no Paraná, como lá era inverno eu vinha para vender roupas de verão. Eu vendia muito bem para as vizinhas e amigas da minha mãe. E aí foram vários anos, até que meu esposo sugeriu que era hora de nós montarmos uma loja. Aí nós viemos em 1991. Meu pai arrumou uma 
sala e nós começamos na Avenida Mato Grosso, mas nós pensamos mais numa loja para pessoas que trabalhassem em fazendas, uma loja mais popular. Só que não deu certo. Logo que eu cheguei, meu irmão já me disse: com este tipo de roupa você não vai muito longe, porque aqui as pessoas gostam de coisas boas, gostam de se vestir bem e de roupas modernas. Aí o que é que eu fiz: corri para São Paulo e mudei totalmente a cara da loja, escondi aquelas roupas que eu tinha trazido e troquei tudo. Aí o meu irmão comentou: agora sim. As pessoas gostam de moda, gostam de estar bem arrumadinhas porque o poder aquisitivo aqui é maior e por ser muito distante o acesso. Eles gostavam de moda, mas devido ao difícil acesso, tinham de comprar aqui. Foi assim que eu comecei a loja.

Dizer que o começo foi fácil para a Sra. Marines, certamente não foi; mas ela teve a sorte de encontrar na família o apoio para seguir em frente e vencer.

Ai foi melhorando, porque quando eu cheguei não tinha luz e a água era muito pouca, aí veio o linhão, com a energia que para nós foi tudo e aí veio a água encanada direta, e as pessoas foram vindo de vários lugares do país [...] muita gente com vários estilos e precisava adequar a moda para as pessoas. [...] Hoje já tem lojas mais populares mas eu, depois que comecei com as etiquetas e grifes, não consegui mudar. Daí depois de um tempo precisou mudar o estilo da loja também. Precisava uma loja bonita. A maioria das pessoas que compra na minha loja ainda é do sul. Sul que eu digo, é Paraná, Santa Catarina e Rio Grande do Sul, que ainda é a maioria.

O que ela pensa a respeito do futuro:

Se eu pensar em futuro, eu acredito que a cidade precisa de mais indústria, porque se ficar só na soja, fica num grupo muito pequeno e o comércio precisa de mais gente. Não pode acontecer o que aconteceu com a minha cidade no Paraná, que de 25 mil habitantes hoje não tem nem 10 mil, porque não expandiu a indústria. Hoje é que estão abrindo um frigorífico de frango, mas agora a maioria já foi embora porque não tinha do que viver lá. Por isto o que nós precisamos urgente é de um aeroporto, porque os empresários hoje não têm muito tempo a perder.

Outra característica do estilo de vida do sorrisense é a aplicação de capital no próprio município ou em municípios vizinhos. É comum entre os fazendeiros, a aquisição de terras na mesorregião, como forma de concentrar a produção e assim, de acordo com eles, concentrar o negócio das commodities.

Esta é a grande diferença entre Sorriso e outras cidades da área de abrangência da BR-163: os grandes produtores moram no município e expandem seus negócios na região.

Reconhecida nacionalmente como capital da soja, hoje Sorriso conta com 15.889 contribuintes e a arrecadação mensal do município é algo ao redor de $\mathrm{R} \$ 14$ milhões. Conforme informações obtidas na prefeitura, isto dá ao município condições de arcar com muitas despesas que deveriam ser financiadas pelos governos estadual e federal que, na ausência das verbas estaduais ou federais, têm sido financiadas pelo município, para não correr o risco de parar projetos. No caso de 
Sorriso, parar projetos significa andar para trás devido ao grande número de pessoas que continua chegando à cidade em busca de oportunidade para melhorar a qualidade de vida.

$\mathrm{Na}$ opinião técnica de profissionais da prefeitura, entre os novos projetos estão enquadradas a implantação e ampliação de novos plantéis nos setores de avicultura, suinocultura e piscicultura, inclusive o desenvolvimento de projetos em parceria com a Friboi ${ }^{69}$, através de uma de suas unidades instaladas no município. É perceptível a busca de alternativas factíveis, considerando as características de clima, solo, produtividade e vocação agrícola do município, para ampliar a oferta de emprego e agregar valores às commodities ali produzidas.

A meta dos empreendedores é diversificar a produção e implantar novas atividades com seus respectivos processos de industrialização. Gradativamente, vão sendo criados projetos de industrialização para soja, milho e algodão, com base em estudos patrocinados pelo segmento empresarial que visa, inclusive, desenvolver uma área para o plantio de cana de açúcar, concomitante à implantação da indústria do álcool. Os investimentos e pesquisas para aumentar a produtividade são propícios, uma vez que Sorriso já possui importante know-how adquirido através da vivência como um dos maiores produtores mundiais de grãos.

Natalício Ligoski, primeiro Secretário de Fazenda de Sorriso entrevistados em 19.09.2012,

\begin{abstract}
A peça chave de Sorriso sempre foi agricultura que hoje ocupa uma área ao redor de 600 mil hectares de lavoura produtiva, porque o que era para desmatar, já foi desmatado, são todas áreas agricultáveis, acredito que não existam mais áreas por abrir e assim a economia foi crescendo e chegou à $4^{\mathrm{a}}$ posição no estado em ICMS, me lembro muito bem que na década de 1990 ela subia 9,5 a 10\% ao ano, na época em que eu fui secretário, então estas são mais ou menos as informações que a gente tem a respeito do desenvolvimento
\end{abstract}

No que tange o setor de alimentos, um dos campos mais visados é o da transformação das commodities em produto acabado. De certa forma, o setor pretende andar na contramão do comércio atual que vende produtos in natura para comprá-los acabados por valores que variam entre cinco e dez vezes mais que o

\footnotetext{
${ }^{69}$ Empresa do grupo JBS, $3^{\text {a }}$ maior empresa de alimentos do mundo que nasceu em Anápolis (GO). Atua nas áreas de alimentos, couro, biodiesel, colágeno e latas. Está presente em todos os continentes, com plataformas de produção e escritórios no Brasil, Argentina, Itália, Austrália, EUA, Uruguai, Paraguai, México, China, Rússia, entre outros países.
} 
preço pelo qual vem sendo comercializado. A proposta inclui não só a agregação de valor ao produto, como também abre um grande espaço no mercado de trabalho.

Em entrevista concedida em 20.09.2012, Luciene Francio, filha do fundador da cidade e diretora da Colonizadora Feliz, responsável por boa parte do mercado imobiliário da região e também participante do grupo de fazendeiros que decide sobre as prioridades socioeconômicas do município, esclarece que

A prioridade dos fazendeiros é alcançar mais produção em menos espaço e com um volume sempre menor de defensivos agrícolas. Daí a evolução para os defensivos já nas sementes e até mesmo na produção de transgênicos.

A cidade, considerada capital do agronegócio no país, como anuncia o outdoor da Foto 17, produz, isolada, 3\% da produção nacional e tem um PIB (Produto Interno Bruto) de $\mathrm{R}$ \$ 2,5 bilhões e a produção de soja na cidade chega a 2 milhões de toneladas por safra, com 690 mil hectares plantados produzindo uma média de 62 sacas por hectare.

Foto 17 - Outdoor na entrada de Sorriso - 2012

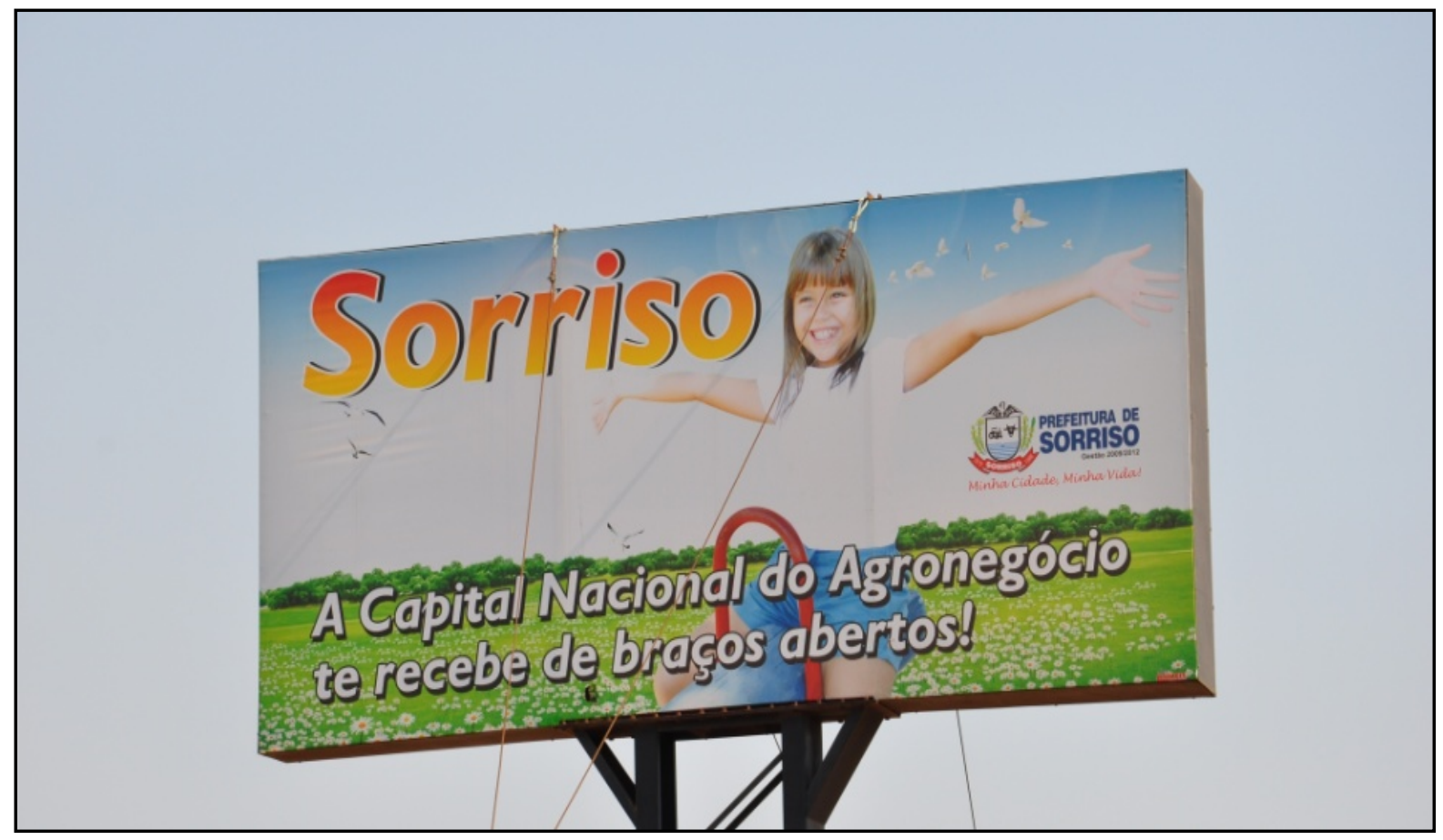

Fonte: Acervo da autora (2012)

Paralelamente, os produtores locais também investem em outras culturas, como milho, feijão, arroz e algodão, bem como na produção de bovinos, suínos e aves. Este fator tem favorecido a instalação de frigoríficos na cidade, atualmente em franca expansão. 
Para acompanhar de perto esta produção, a BM\&F (Bolsa de Mercadorias e Futuros) ${ }^{70}$, a maior bolsa brasileira, se instalou no município. Ali são negociados os contratos de mercadorias, principalmente commodities e derivados, tanto à vista, quanto programados para pagamento futuro. Trata-se de uma sociedade mercantil criada para negociar a produção regional, cujas operações se realizam com base nas taxas diárias de câmbio e juros equivalentes aos aplicados nos mercados nacional e internacional, para produtos como café, açúcar, soja, gado bovino, milho e ouro.

A Capital da Soja, como é conhecida, conta com uma infraestrutura agropecuária das mais sofisticadas do mercado de trabalho internacional, posição esta que exige, cada vez mais, um alto índice de qualificação profissional para atingir os recordes na produção de commodities aos quais se propõe.

\section{Foto 18 - Escultura alusiva à força produtiva de Sorriso,}

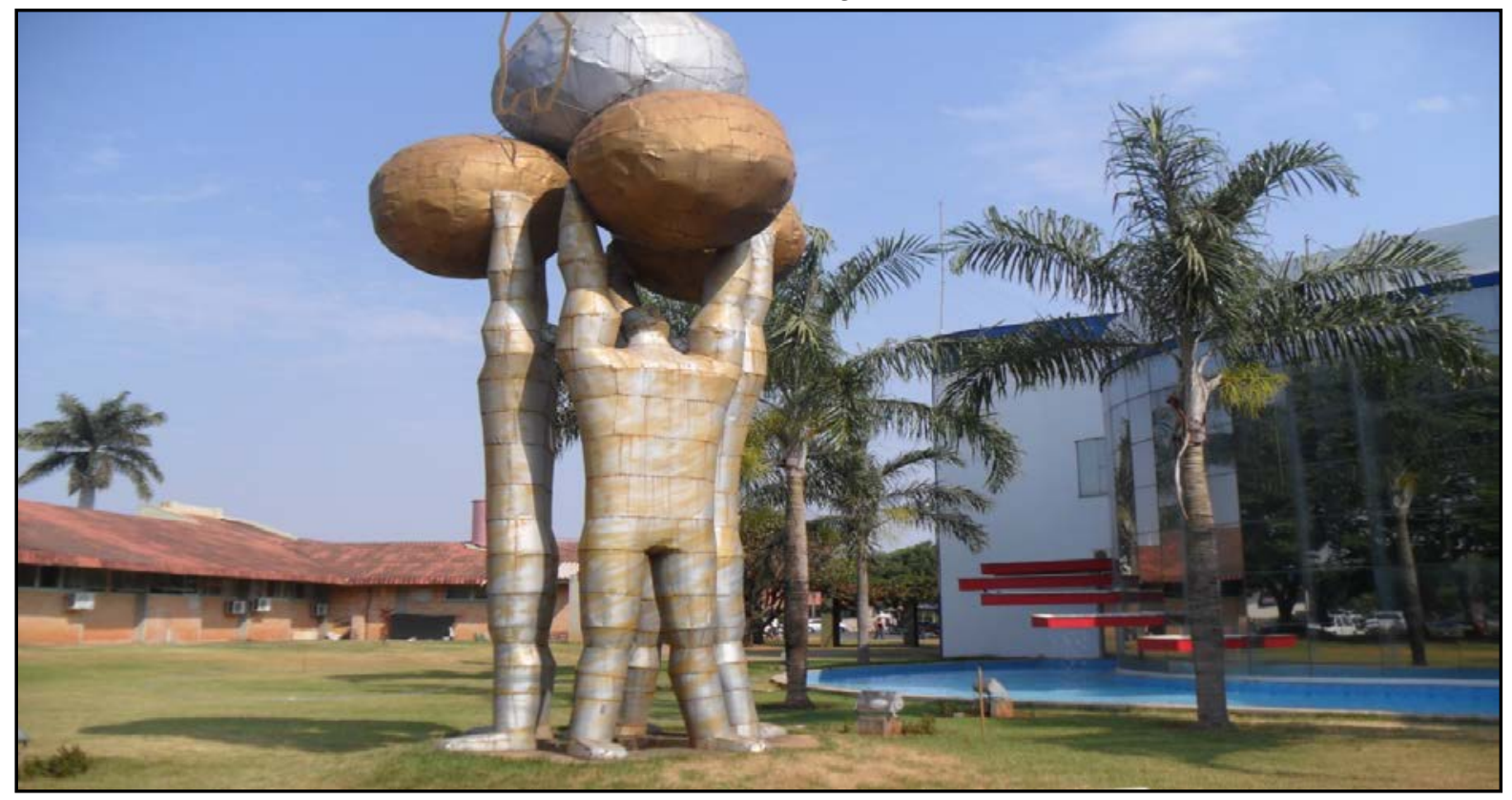

Fonte: Acervo da autora (2012)

${ }^{70}$ Desde outubro de 2006, o município de Sorriso foi escolhido para abrigar a nova sede da (BM\&F) Bolsa de Mercadorias e Futuros do Brasil. A BM\&F foi criada para desenvolver, organizar e operacionalizar mercados livres e transparentes para negociação de títulos e contratos que possuam como referência ativos financeiros, índices, indicadores, taxas, mercadorias e moedas, nas modalidades a vista e de liquidação futura. Para tanto, efetua o registro, a compensação e a liquidação, física e financeira, das operações com tais títulos, ou contratos, realizadas em pregão de viva voz ou em sistema eletrônico. É uma associação sem finalidade lucrativa, que organiza, regulamenta e fiscaliza mercados de liquidação futura, tendo como principal função fornecer condições físicas e organizacionais à realização de negócios entre clientes representados pelas Corretoras de Mercadorias associadas à Bolsa. A BM\&F é uma associação de caráter privado, cujos títulos patrimoniais pertencem a corretoras associadas, sendo os mercados por ela administrados regulamentados e fiscalizados pelo Banco Central do Brasil e pela Comissão de Valores Mobiliários. (Fonte: Agência de Notícias dos Municípios/ Assessoria da Prefeitura). 
O que indica a escultura alusiva à força produtiva do município que está instalada no jardim da Prefeitura, Foto 18, é que além de sustentar o título de maior produtor individual de soja do Brasil, a intenção do município é evoluir a produção por hectare e ampliar sua capacidade de armazenagem e transformação industrial, para ser um polo agroindustrial no setor de alimentos.

A condição de "município de sucesso" atrai não só grandes investidores como também pessoas que acreditam poder desfrutar de uma fatia deste mercado. Nem sempre alcançam suas intenções, até porque as melhores posições parecem já ter sido ocupadas nos últimos vinte anos. Esta realidade traz em seu bojo um nível de frustração elevado. Durante a entrevista realizada em 19.09.2012, o Sr. Ednilson de Lima Oliveira, Secretário Municipal de Saúde relatou que:

$\mathrm{Na}$ realidade a gente tem um estudo aí em relação a quantidade de fluxetina ${ }^{71}$ que a gente entrega no município. A fluxetina é um medicamento antidepressivo, ansiolítico... e em função de que? As pessoas chegam aqui e querem ganhar dinheiro. Então a gente tem, de todos os lugares do Brasil, você encontra em Sorriso. Várias culturas diferentes, com a ideia de vir para cá, enricar, comprar uma caminhonete e voltar e mostrar para os parentes que conseguiu comprar esta caminhonete, porque se deu bem na vida. Muitos conseguiram, outros estão empacados. Não consegue crescer, vê o colega crescendo e vê o outro crescendo, e isso gera muita depressão, que é o problema do ansiolítico que é onde ele entra no estado depressivo. A gente gasta uma quantidade enorme de antidepressivo no município por causa dessa situação. Quase ninguém é filho daqui. Tem poucas crianças 25/26 anos então tem poucos filhos daqui. A grande maioria da mão de obra qualificada daqui veio de fora. Eles vieram com esta ideia de crescimento, crescimento, crescimento. E aí gerou um problema! O câncer veio por causa da angústia, a depressão por causa da angústia, a busca pela droga é por causa dessa angústia, Então, o grande mal de Sorriso, é a depressão.

Uma das principais preocupações do Secretário é o aumento do consumo de drogas ilícitas em todas as faixas etárias.

As pessoas buscam droga por que o pai e a mãe estão o tempo inteiro na rua trabalhando e esquecendo da família; aí o amigo é o traficante. Às vezes a gente tem aqui pessoas com 36, 40 anos viciado em droga, porque, como eles dizem, não conseguiu trabalho, mas na verdade trabalho tem. $\mathrm{Na}$ verdade ele não conseguiu melhorar de vida. Não se qualificou e veio pra cá com a condição de enricar. Sem qualificação, não consegue porque não tem espaço. Para atender estas pessoas, a gente tem o CAPS $^{72}$ que atende bem estas pessoas, hoje a gente está trabalhando com programas de saúde nas escolas que envolver álcool, drogas, obesidade infantil.

Outra preocupação é com a obesidade infantil:

\footnotetext{
${ }^{71}$ Medicamento antidepressivo da classe dos inibidores seletivos da recaptação da serotonina. Suas principais indicações são para uso em depressão (de moderada a grave), transtorno obsessivocompulsivo (TOC), transtorno alimentar, transtorno do pânico e de ansiedade. É utilizado na forma de cloridrato de fluoxetina, como cápsulas ou em solução oral.

${ }^{72}$ Centro de Atenção Psicossocial
} 
A gente tem o NASF (Núcleo de Apoio à Saúde da Família). Esse Núcleo está indo para as escolas trabalhar com palestras, nós fizemos um levantamento em todas as crianças do município para ver quem estava com obesidade, quem estava dentro do peso e agora a gente está disponibilizando para aquelas crianças obesas, natação, hidroginástica, para que a gente consiga tirar a criança desta obesidade. E dentro disso, trabalha-se a conscientização sobre o uso de álcool e drogas. Para isso, a gente tem uma parceria, a única do Brasil com a AABB (Associação Atlética do Banco do Brasil). Então a gente manda para a AABB. Tínhamos com a FACEM (Faculdade Centro-matogrossense), que é a faculdade, que agora cortou por problemas que estavam na piscina e estamos mandando para a AABB. Neste programa tem professor de natação, fisioterapeuta, nutricionista, psicólogo e os resultados têm sido excelentes.

\title{
O problema com a recuperação de adictos ainda depende da verba do poder
} público estadual ou federal para ampliar dar melhores condições de atendimento aos dependentes.

\begin{abstract}
A gente não tem um centro de tratamento para adictos, a não ser o CAPS (Centro de Atenção Psicossocial) que é a porta de entrada. Nós trabalhamos junto com a Assistência Social e Unidades Básicas de Saúde. Os UBSs detectam o problema e encaminham para o CAPS. Se o paciente quer se tratar, ele vai ao CAPS porque é de livre e espontânea vontade. Não quer se tratar, ele vai continuar usando, porque a gente não tem um local definido ainda para tratamento. O CAPS é optativo, acompanha. É o papel do mero encaminhador entre aspas, porque tem psicólogo, tem médico; Não deu conta, encaminha para o Paulo de Tarso em Rondonópolis. Esse é o caminho do CAPS. A gente tem um outro caminho, outra porta de entrada que é a justiça. Quando o CAPS não deu jeito, agente não tem esse local de tratamento, as pessoas buscam a Promotoria ou a Defensoria Pública e aí o juiz determina a internação; ou na clínica Renascer, que tem aqui em Sorriso ou na Ambaru em Chapada dos Guimarães, que são clínicas particulares e os tratamentos são financiados pelo município. Estamos gastando uma média de $\mathrm{R} \$ 50$ mil por mês.
\end{abstract}

\section{A área médica de Sorriso pode ser considerada como privilegiada, se} comparada a outros municípios mato-grossenses.

Em relação a muitos municípios do Brasil a gente tem um diferencial, porque a arrecadação de Sorriso é muito grande. A gente abraça a alta e a média complexidade. A obrigação municipal é dar Unidade Básica de Saúde e um pouco da média complexidade. A média e alta complexidade é obrigação do estado. Por isto a gente faz uma pactuação com o Estado chama PPI que é um recurso que viria direto do Ministério da Saúde para as contas do município e fica no Estado. Então o Estado se obriga a fazer esta média e alta complexidade, mas ele não tem feito e a gente está com um problema sério, que não é mais sério porque a gente ainda consegue fazer. Eu compro muito no particular. Então tomografia, ressonância, endoscopia, tudo o que seria do Estado, a gente faz. Cirurgias, mesmo, eu estou acabando com a fila de 2010. Coisa que nos outros municípios tem fila de 2004, 2005. Tem muito paciente aí que está capengando para conseguir alguma coisa. Mas em função deste recurso financeiro que a gente consegue, a gente tem feito. Comparando com os outros municípios, a gente está muito bem. 
O Secretário reconhece que o apoio do prefeito é muito importante para o sucesso que a Secretaria alcança:

[...] Se o prefeito me desse só os $15 \%$ que ele tem obrigação de investir na saúde, eu peço demissão. Ou ele gasta os $30 \%$ ou eu estou fora. A gente gasta $30 \%$ da arrecadação do município em saúde. É muito. Por isso que eu falo. A gente está numa situação privilegiada que ainda consegue fazer isso. Mas vai ter uma hora que a gente não vai aguentar mais. A sorte é que a nossa Secretaria de Assistência Social não está trabalhando hoje com assistencialismo; está fazendo realmente assistência social. Dar 140 cestas básicas num município deste tamanho porque? Porque a gente tem emprego. A sociedade é pujante. Quando você tem emprego, não tem gente passando fome, não tem problemas.

\section{Sobre os planos de saúde:}

Infelizmente não pagam planos de saúde aqui, porque se você for hoje no hospital privado fazer uma consulta, você vai se demorar, com plano de saúde; se você for na UPA agora, você vai ser atendido na hora. Aqui é ao contrário do resto do Brasil. O SUS é que dá respaldo para as urgências aqui. Não é particular, é o SUS. Tanto que pacientes da UTI do particular, precisa usar esse respaldo. A transferência do particular para o SUS é porque o particular não tem. Aqui é totalmente ao contrário. Aqui, se a gente for lá na UPA, vai ver caminhonete chegando com uma pessoa para ser consultada. Diferente de Cuiabá. Em Cuiabá o cidadão não vai lá porque lá ele está concorrendo com cinquenta. E outra, a oferta do serviço em Cuiabá no particular é bem maior do que Sorriso.

\section{Explica ainda que a realidade da saúde em Sorriso é bem diferente da grande}

maioria dos municípios brasileiros, embora ele também tenha alguns problemas:

Sorriso tem um único hospital com estrutura bem simples e o profissional que está atendendo lá é o mesmo que atende no SUS. Então para o particular não importa. Porque ele vai pagar se ali tem o mesmo serviço e não paga nada e ainda vai ser mais rápido? E ainda sai dali, passa na farmácia e leva uma sacola com medicamentos. Enquanto os municípios brasileiros estão dando 109, nós estamos dando 244 tipos diferentes de medicamentos. Enquanto os municípios brasileiros dão 39 exames de baixa complexidade, a gente dá 89. Então, ainda estamos numa situação boa. [...] Meus principais problemas aqui, hoje, é tratamento renal, ortopedia, psiquiatria e traumatologia. E para resolver o problema, nós entramos no tal custo x benefício. Não dá para trazer uma clínica de tratamento renal, para fazer hemodiálise e tudo, com a quantidade de pacientes que a gente tem. Então fica inviável trazer esta clínica para cá. Porque o custo dela é muito maior do que o que irão render dez pacientes só. A região hoje está pactuada com Sinop. Então teria de rever a quantidade de pacientes que tem, para tirar a pactuação com Sinop e trazer para Sorriso. Isso se tiver alguma clínica que viria para cá, para fazer esta pactuação, porque não seria o município que pagaria. Seria o governo do Estado com a alta complexidade. Teria que tentar, mas hoje não funciona. Tem que levar estes pacientes para Sinop.

Com os casos de traumatologia, oncologia e outros que necessitam de exames como a ressonância magnética, por exemplo, não é muito diferente: 
A questão do trauma, porque a gente tem acidentes de trânsito todos os dias, a quantidade de ortopedistas que tem no município é pequena. No hospital regional, no hospital privado não tem recurso. Então é humanamente impossível fazer cirurgias. Então a gente tem bastante gente aí sequelada por causa da falta de profissionais e da válvula de escape; mandar estes pacientes para fazer em outro lugar. A gente ainda manda uma média de 20 pacientes por dia para Cuiabá. Isso dá uns 400 a 500 pacientes por mês. Estes pacientes são basicamente da oncologia, ou para especialidades que a gente não tem as ressonâncias magnéticas, que agora abriu uma empresa aqui, mais vale a pena comprar aqui, pelo custo $x$ beneficio, porque eles me fazem uma ressonância a $R \$ 450,00$. Se eu mandar o paciente para Cuiabá, vai o paciente mais um acompanhante; é $\mathrm{R} \$ 150,00, \mathrm{R} \$ 300,00$, mais casa de apoio mais a alimentação, já deu os $\mathrm{R} \$ 450,00$. Então, vou comprar aqui, porque é mais fácil comprar aqui porque o paciente faz e vai para casa. Não precisa este transtorno todo de ir para Cuiabá, além do risco que corre na estrada.

O Sr. Ednilson de Lima Oliveira é um economista que ocupa pela segunda vez a Secretaria de Saúde do Município. Conforme explicou,

Ser economista ajuda porque tem a visão do todo. O médico tem a visão da medicina, só aquilo. Na maioria das vezes eles não sabem trabalhar com números. Eu não sei se dá certo porque eu iniciei fazendo medicina, eu gosto da área, aí não tive dinheiro para pagar, aí eu fui fazer economia para entender porque eu não tinha dinheiro para pagar. Eu gostei e também gosto da área da saúde.

Ao melhorar a área de saúde, ampliar o agronegócio para outros setores, bem como o mercado de trabalho no comércio e na indústria, Sorriso avançou muito também nos campos social e cultural. É um dos municípios mato-grossenses que mais incentiva seus artistas, alguns internacionalmente conhecidos, e que mais patrocina eventos culturais para a população. Uma demonstração disto é a praça principal da cidade, uma verdadeira exposição ao ar livre, com esculturas de artistas locais.

Neste contexto, a educação tem um importante destaque e a Secretária Municipal de Educação e Cultura, Sra. Avanice Lourenço Zanatta, em entrevista concedida em 19.09.2012 relata que:

Hoje, nós temos 31 unidades escolares. São 11 centros de educação infantil e 20 escolas, que atendem em média 13 mil alunos. Este ano nós estamos vivendo, na verdade, uma situação atípica. A gente sabe que tem um crescimento durante o ano. Só que nós estamos trabalhando no sentido de que o número de alunos não aumente muito mais, porque a rede municipal está atendendo um porcentual maior, porque ela está atendendo também o que não é da competência dela que é da rede estadual. Então nós estamos fazendo um trabalho com o estado, para que o estado construa escolas, para possam atender numa escala de 50\%, 50\%, que é o ideal. Nós estamos com 75\%. Então nós estamos trabalhando assim. A nossa ideia é não aumentar o número de alunos. Mas quando você olha para frente, você tem que pensar bem isso. Não é aumentar o número de alunos. Este talvez tenha sido o pecado: vamos trazer a responsabilidade para o município e 
hoje a gente está nesta situação bastante difícil. Porque o custo subiu e a responsabilidade do município é a educação infantil e as séries iniciais. As séries finais, é do Estado. E nós estamos atendendo uma grande parcela que é de responsabilidade do estado. Nós estamos neste trabalho há quase quatro anos trabalhando nesse sentido. Não aumentar o número de alunos, porque a gente tem que fazer o remanejamento das séries finais para o Estado, para que a gente possa atender aquela parcela ainda das séries iniciais que a gente não está atendendo e que é da nossa responsabilidade.

Durante a entrevista, a Secretária permite que se observe seu conceito de responsabilidade, que não se atém apenas as questões da educação formal, mas se estende ao campo da cultura, da preservação do patrimônio cultural exposto nas praças e ruas do núcleo urbano como a obra Pietá, vista na Figura 43, a seguir.

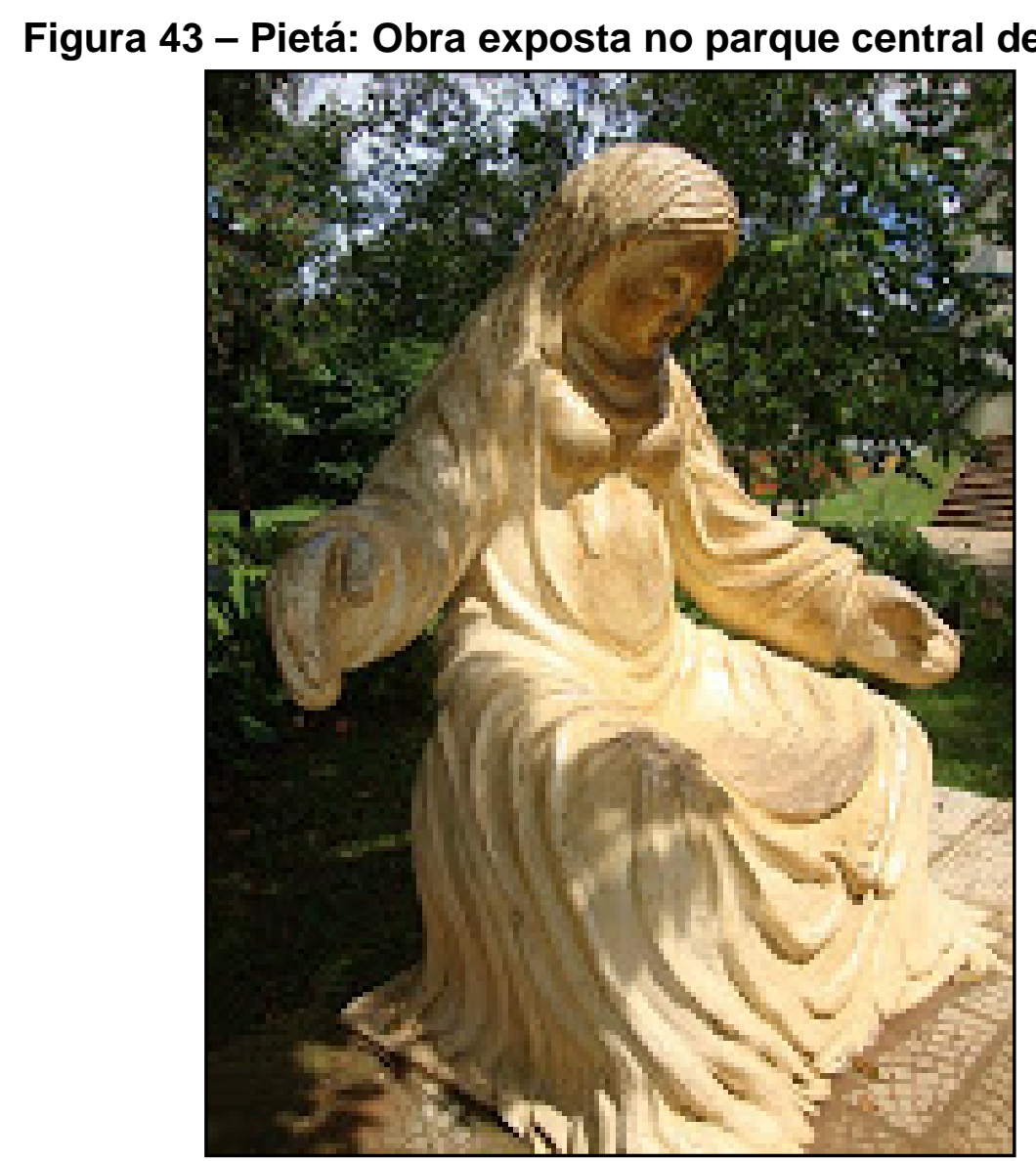

Fonte: Arquivo da Secretaria de Educação e Cultura (2011)

A Secretária está com o olhar no presente, mas precisa ir plantando o futuro, porque o crescimento demográfico é uma realidade diária para o qual ela precisa apresentar soluções, mesmo antes que os problemas se agravem. E, em sua entrevista, pontuou:

Então, olhando para frente, nós temos que trabalhar com este objetivo. Este ano, a gente teve um aumento no número de alunos assim, no meio do ano, que superou tudo. Daí, no meio do ano, nós tivemos que aumentar o 
número de alunos por sala de aula. Aumentar o número de transporte escolar... também tudo isso nos pegou assim... todo o planejamento que nós tínhamos feito, aumenta assim 10\% no meio do ano, não sei as outras escolas. Nas escolas estaduais, eu sei que eles tiveram este aumento também. Bastante significativo. E nas escolas particulares eu não posso dizer mas já me falaram que elas também estão recebendo bastante alunos. Mas a gente tem procurado fazer as adequações dentro da estrutura que a gente já tem. Nós inauguramos uma escola este ano e agente achava que, tranquilamente, nós não iríamos ter problemas.

\section{Quanto ao estudo da nova forma de administrar escolas, que pretende colocar em cada escola pública um psicólogo e um assistente social, a Secretária} informou que:

De certa forma nós já praticamos isto aqui na Secretaria. Eu, particularmente, sou psicóloga e trabalho na Secretaria de Educação desde que eu cheguei aqui em Sorriso. E quando eu cheguei aqui, há 19 anos atrás, a minha proposta era esta, de trabalhar com a rede pública mesmo, porque eu acho que é importante o fato de eu ser psicóloga. Então nós temos o apoio de três psicólogas na Secretaria de Educação, que dão apoio a todas as escolas da rede municipal. A nossa proposta, também era ter uma assistentes social que a gente conseguiu só agora viabilizar via concurso, não conseguimos fazer diretamente por que não podia, mas nós vamos pegar de uma outra Secretaria para que a gente possa atuar. Eu acho importante. Entre as psicólogas, uma trabalha especificamente com a educação especial e as outras duas trabalham na rede, o que a gente já sabe não ser o suficiente. Na realidade, no nosso planejamento era dividir um número xis de escolas para cada psicólogo, para que ela possa dar este suporte e também a assistente social para trabalhar com a família. A gente sabe da importância da família na questão escolar. Eu não consigo ver como não estar diretamente ligada.

\section{O fato de ser psicóloga contribui com a importância que dá ao trabalho dos}

psicólogos junto aos alunos e suas famílias:

Pelo fato de eu estar trabalhando há mais tempo com os pes sobre este assunto, eu percebo que o professor, muitas vezes pensa que a intervenção do psicólogo é aquela que ele vai atender a criança e vai resolver o problema. Não é este o papel do psicólogo na rede escolar. Ele vai estar lá, vai até fazer uma avaliação, se for algo clínico, ele vai ter que examinar para um tratamento clínico, mas ele vai trabalhar com toda a rede que cerca este aluno. A família, professores, escola, este gancho que o psicólogo tem que estar fazendo. Nossa ideia é o assistente social e o psicólogo trabalharem neste sentido. Muitos professores ainda acham assim: o que é que adianta, ele foi lá no psicólogo mas quando voltou, no outro dia, está o mesmo na sala de aula. Às vezes eles querem a resposta imediata. E quando você vai fazer uma sondagem familiar, você vê o quanto influi. Eu sempre falo para os professores, quando você vai conhecer a história de um aluno, normalmente aquele aluno que dá mais trabalho na escola, aquele Joãozinho. A quando ele não vai você diz: que benção, a escola está tranquila. Não é assim que eles dizem? Pois é, mas é aquele Joãozinho que precisa da nossa atenção. É para ele que nós estamos aqui para trabalhar. Aquele que vai, ele vai! É só dar um suporte, porque ele deslancha e vai para a vida! Tem o suporte da família; agora o Joãozinho, precisa da gente; precisa do professor, do diretor, do coordenador, da merendeira, da 
zeladora, do psicólogo, de toda esta gente, e esta rede toda tem de estar preparada para tem para isso. Não é fácil.

Pelo que explicou a professora Avanice Lourenço Zanatta, este trabalho com os professores está sendo feito há algum tempo, contribuindo para a compreensão dos professores quanto ao papel do psicólogo na escola como atividade de apoio ao ensino.

\begin{abstract}
Eu acho que os nossos professores já têm uma leitura, porque não é de hoje; eu já venho há muitos anos trabalhando com eles. Alguns já conseguem fazer esta leitura melhor. O trabalho com a família, que eu acho muito importante, reuniões com as famílias, é isso que vai fazer a diferença, que vai somar. Quando eu atuava como psicóloga, teve uma situação que eu nunca me esqueço. Teve o relato de uma mãe, porque eu sempre fazia reuniões, e eu falava: às vezes está lá lavando a ouça ou assistindo uma novela ali, e o seu filho lá longe largado! Aí um dia chegou uma mãe e fez o relato que a filha chegou e foi mostrar um desenho para ela. $\mathrm{E}$ o desenho era só um rabisco; ela já ia dizer: ah! Não tenho tempo! Mas na hora ela parou e pensou nas reuniões e foi lá dar atenção e a filha foi explicar o que era aquele rabisco para ela. Daí a mãe percebeu que aquele pouquinho faz a diferença. Essa reflexão a gente tem que estar fazendo no dia a dia. $O$ prefeito que sempre apoiou o nosso trabalho nos dá autonomia, até porque ele dá muita importância para este trabalho com as famílias. Tanto é que nós já estamos pensando em aumentar o numero de psicólogos e ele me diz brincando que eu estou legislando em causa própria. Mas este trabalho com a família, a gente sabe da importância. Ter psicólogo e assistente social é fazer com que toda a engrenagem da escola funcione. Não adianta o psicólogo sair daqui ir lá fazer o trabalho se no outro dia ele vai chegar na escola, o professor não vai estar pronto para receber.
\end{abstract}

Dentre as instituições de nível superior, Sorriso conta com a UNEMAT (Universidade Estadual de Mato Grosso), onde são ministrados os cursos de Letras e Administração; FACEM (Faculdade Centro Mato-Grossense), com os cursos de Agronomia, Educação Física e Tecnológico em Estética e Cosmética; FAIS (Faculdade de Sorriso) com os cursos de Administração, Agronegócio, Análise e desenvolvimento de Sistemas, Ciências Contábeis, Direito, Enfermagem, Farmácia, Gestão Financeira, Letras e Pedagogia.

Como parte deste mesmo contexto educacional, está o incentivo à arte, patrocinado pela Secretaria Municipal de Educação e Cultura. Não há como não perceber a quantidade de esculturas artísticas espalhadas pela cidade, dando um ar de galeria às ruas arborizadas do núcleo urbano que circunda o enorme parque central. Os trabalhos de artistas locais de renome e dos que ainda não são tão conhecidos, estão numa exposição permanente de esculturas artísticas expressando a diversidade cultural do município. 
A preservação destas obras de arte a céu aberto conta com um trabalho constante da Secretaria de Educação e Cultura junto ao grande público que, mesmo com campanhas constantes nas escolas e faculdades, ainda luta com práticas de vandalismo, falta de sensibilidade e respeito.

A conscientização da importância das obras para a beleza da cidade tem sido o mote para o incentivo à prática dos bons costumes com a arte e com a comunidade sorrisense para quem esta "galeria de arte a céu aberto" foi dedicada. Como se vê na Figura 44, o poder público tem consciência de que o patrocínio do material de alta qualidade utilizado para esculpir estas obras tem um custo elevado, assim como a preservação e restauração, nos casos de vandalismo.

\section{Figura 44 - Escultura Lutador de Capoeira instalada numa da principais avenidas de Sorriso}

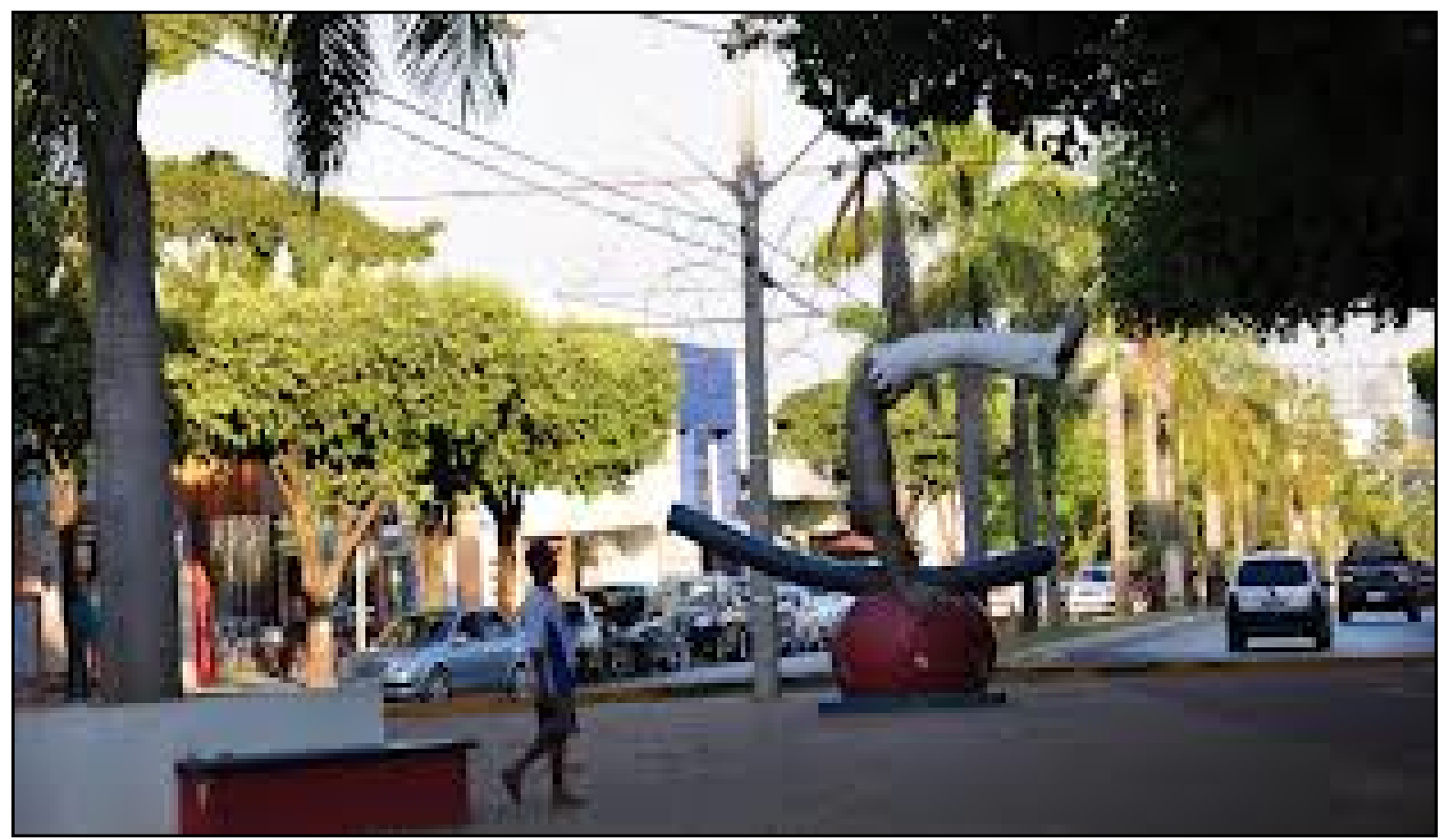

Fonte: Secretaria de Educação e Cultura de Sorriso (2011)

A Secretária de Educação e Cultura, Avanice Lourenço Zanatta, acredita não ter preço o talento e dedicação daqueles que se empenharam na confecção destas obras que retratam um sentimento, uma exaltação à coragem de todos aqueles que fazem o bem, porque sentem orgulho de serem chamados de cidadãos sorrisenses.

No parque central da cidade, em cada uma das alamedas rodeadas de vegetação nativa há recantos onde os visitantes podem sentar para apreciar a 
natureza, sempre guardadas pelas esculturas artisticamente distribuídas pelos jardins.

A paixão declarada do Sr. Claudino Francio por Sorriso parece ter ficado impregnada no ar da cidade, pois os jovens saem para estudar em outras cidades e voltam para exercer suas profissões. Os fazendeiros que "enricaram", todos moram em Sorriso e reaplicam seu capital na região.

Na palestra proferida em 1998 junto ao Programa de Pós-Graduação em Geografia da Universidade de Uberlândia sob o tema "Repensando cidades médias brasileiras no contexto da globalização", Beatriz Ribeiro Soares coloca que:

As cidades médias também devem ser definidas pelo lugar que ocupam na rede urbana, no sistema econômico global, ou seja, suas relações são feitas tanto em nível local como em escala nacional ou internacional, tendo em vista as modernidades tecnológicas presentes nesses territórios.

Considerado este ponto de vista, Sorriso foi entendida como cidade médiapequena neste trabalho, principalmente pela sua importância no contexto econômico global e pela liderança na implantação de modernidades tecnológicas em vários setores do agronegócio.

\subsection{3 - SINOP}

O mesmo ponto de vista que pautou o entendimento de Sorriso como uma cidade média-pequena, coloca Sinop como município de médio porte, considerando não só sua importância no contexto econômico global e no contexto Amazônico, como principal polo do norte mato-grossense e do sul do Pará, independente de ter registrado no censo IBGE de 2010 uma população de 113.099 habitantes.

Situado a norte de Mato Grosso, o município é considerado como um dos principais da Amazônia Mato-grossense, por estar estrategicamente localizado no eixo de divisão entre o Cerrado e a maior floresta do mundo. O núcleo urbano situase na Bacia Hidrográfica do Amazonas e tem o Rio Teles Pires, importante afluente do Rio Tapajós, como sua fonte de abastecimento.

O processo de ocupação da área onde hoje está localizada a cidade de Sinop fazia parte de um dos projetos de colonização implantados pelo governo federal que iniciou com terras adquiridas pela Colonizadora SINOP (Sociedade Imobiliária Noroeste do Paraná S/A), com sede em Maringá (PR). 
A 500 km de Cuiabá, capital do estado, o município ocupa, conforme dados do IBGE, uma área de $3.942 .231 \mathrm{~km}^{2}$. O clima predominante é tropical e sua altitude é de $384 \mathrm{~m}$, que favorece uma variação de temperatura entre $40^{\circ}$ (máxima) e $12^{\circ}$ (mínima).

Limita-se com os municípios de Sorriso, Vera, Santa Carmem, Itaúba, Cláudia e Ipiranga do Norte, sendo considerada a capital do "Nortão". Sua hidrografia é composta pelos rios Teles Pires, São Manoel, cujos afluentes são os ribeirões Roquete, Gurupi, Piraquetinha, Preto, Azul, Kaiaby e outros córregos menores.

Figura 45 - Localização de Sinop e municípios de sua área de abrangência como cidade-polo do norte de Mato Grosso

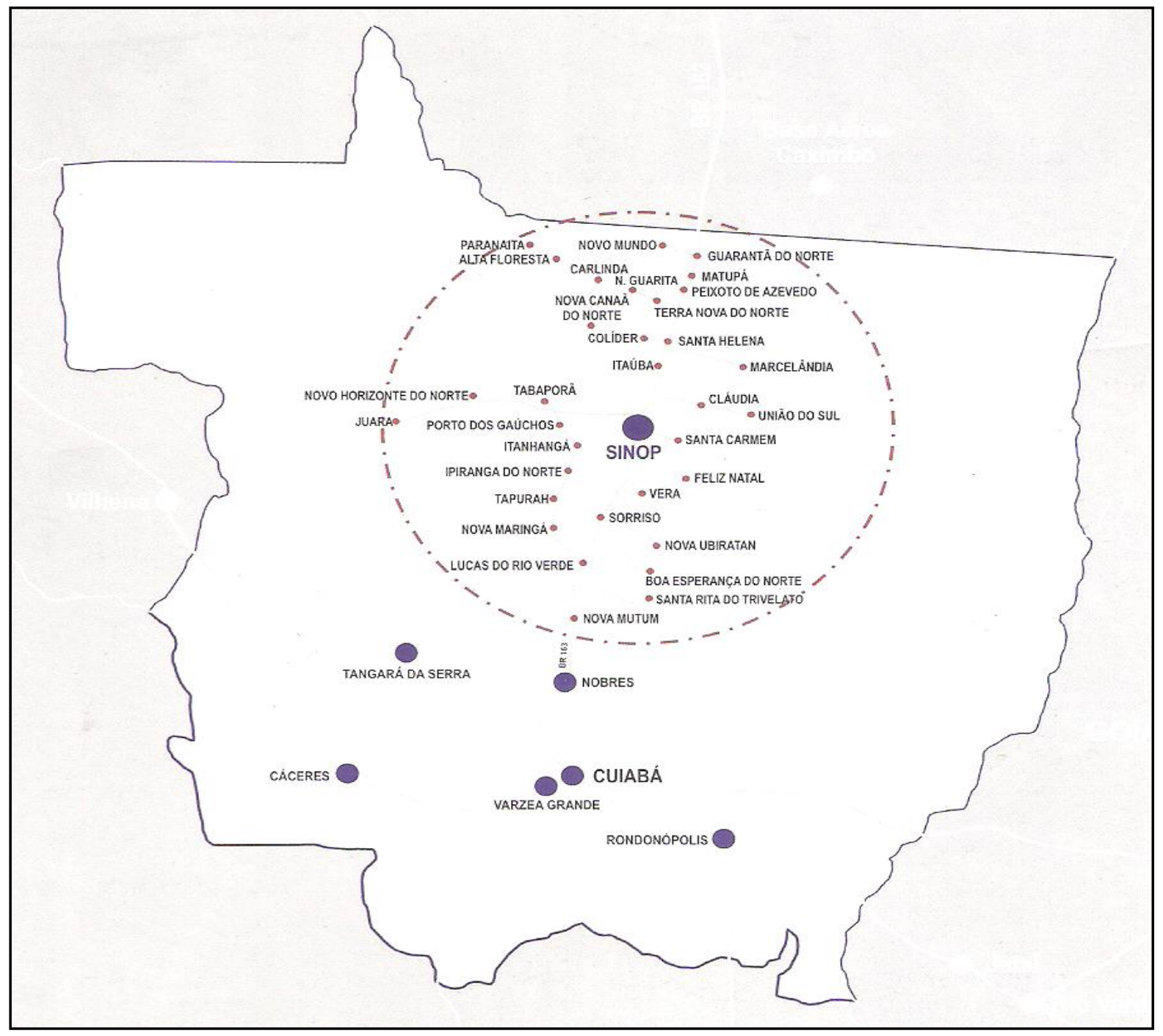

Fonte: Colonizadora Sinop (2010)

Como se vê na Figura 45, a área de abrangência deste polo que está se formando, se localiza praticamente no centro da Amazônia Legal. Esta localização despertou o interesse de várias empresas de grande porte, como Lojas Americanas, 
Blindex (fábrica), Hyundai, Citroën, Honda, Toyota e tantas outras que pretendem atender à demanda da área aqui apresentada e atingir também o sul do Estado do Pará e parte do Estado de Tocantins.

O nome do município origina-se da Colonizadora SINOP (Sociedade Imobiliária Noroeste do Paraná S/A) e seus habitantes são denominados sinopenses. Fundado por Ênio Pepino, então presidente da Colonizadora Sinop, em 14 de setembro de 1974, o município foi elevado a distrito em 29 de junho de 1976 e emancipado em 17 de dezembro de 1979.

$\mathrm{Na}$ implantação e execução do projeto, mais de 300 homens atravessaram o Rio Verde e, utilizando maquinário pesado, abriram as primeiras picadas na selva, originando quatro cidades: Sinop, Vera, Santa Carmem e Cláudia.

A princípio a Colonizadora Sinop havia se organizado para transformar o município de Vera como núcleo da região, porque a estrada de terra que dava acesso às outras aglomerações de imigrantes passava por ali.

Figura 46 - Figura rodoviário de Mato Grosso com a BR-163 e o antigo trajeto via Nova Ubiratã, Vera e Itaúba, rumo ao estado do Pará

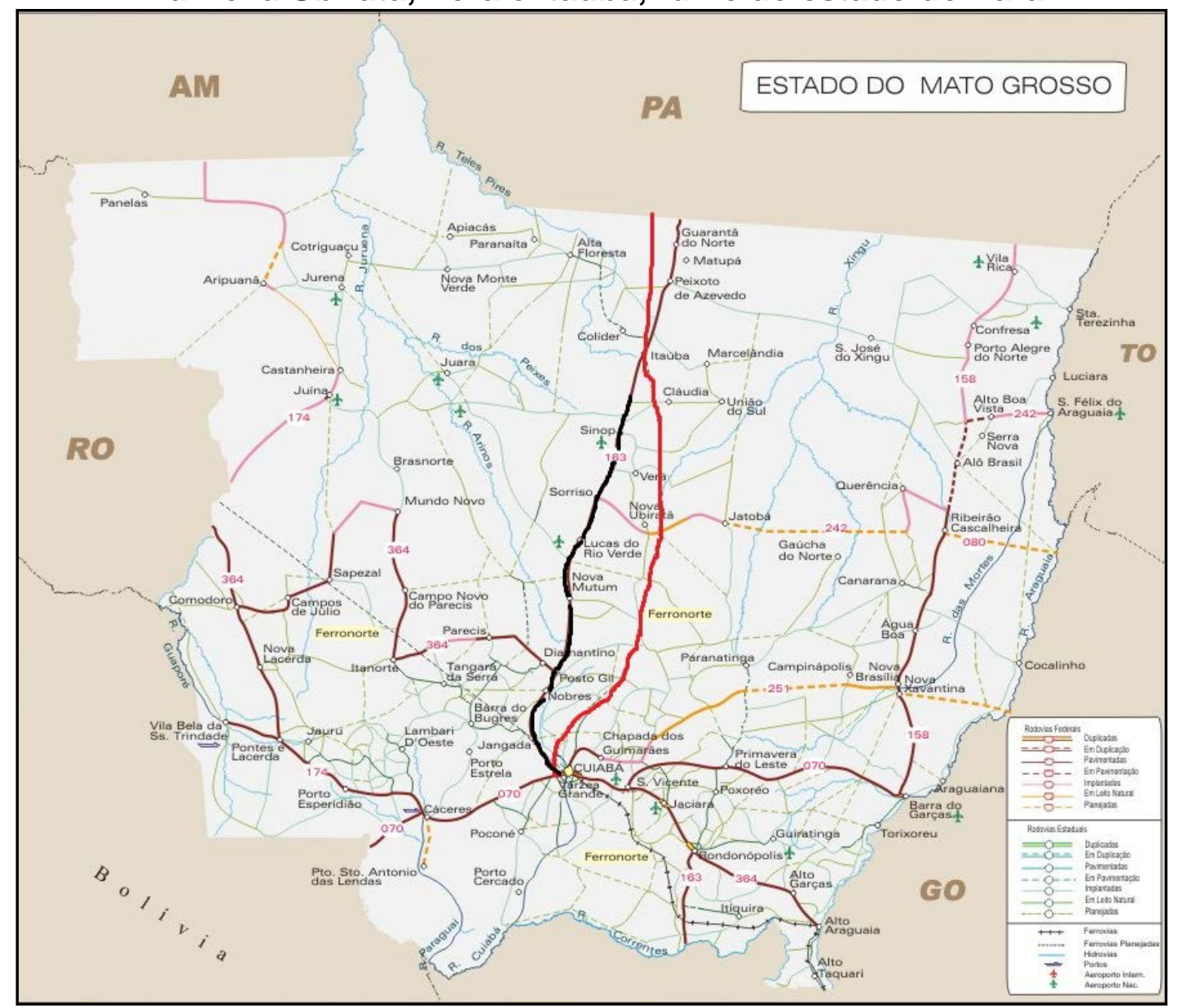

Fonte: Secretaria de Infraestrutura do Estado de Mato Grosso (2010) 
Com a mudança do trajeto da estrada, Sinop passou a ocupar esta posição, porque a BR-163 praticamente atravessaria todo o seu núcleo central.

Efetivamente, a mudança de percurso da estrada, trouxe muitas vantagens para Sinop, que passou a ser desenvolvida à margem da rodovia como se vê na Figura 46, acima.

$\mathrm{Na}$ Gleba Celeste ${ }^{73}$, a empreitada de abrir espaço na floresta amazônica "abriu" $1.400 \mathrm{~km}$ de estradas vicinais, campos experimentais, centros comunitários, escolas e infraestrutura de apoio. Toda esta movimentação visava alocar imigrantes brasileiros que chegassem de diversas regiões do país, proposta que provocou um fenômeno de explosão populacional e transformou o núcleo urbano num dos principais desafios da ocupação da Pré-Amazônia Mato-grossense ${ }^{74}$.

Conforme o relato, em 17.09.2012, de Luiz Erardi F. Santos, professor e historiador que reside em Sinop desde a década de 1980,

A maioria das pessoas que iniciou a cidade veio do sul: Paraná, Santa Catarina e Rio Grande do Sul. Em 1982 eu vim conhecer Sinop, influenciado por um professor, meu colega no Paraná. Eu já tinha uma cunhada que morava aqui desde 1976. Eu fiquei por aqui, mais ou menos com a mesma ideia das famílias que vierem para cá - se a cidade crescer a gente cresce junto. Assim como eu, cada família pioneira que está aqui tem sua história. Elas vieram atraídas para cá por uma divulgação muito forte que a Colonizadora fez naquela época em toda aquela região em todos os meios de comunicação, aí vê toda esta questão: vamos para Mato Grosso, lá não

${ }^{73}$ Gleba Celeste era uma área de 645 mil hectares que iniciou a uma colonização na altura do $\mathrm{Km}$ 500 da Rodovia Senador Jonas Pinheiro, com uma Gleba dividida em sítios, fazendas, chácaras e implantando as cidades de Vera, Sinop, Santa Carmem e Claudia, atraindo milhares de brasileiros, principalmente do sul do Brasil. Posteriormente reuniram-se em Assembléia Geral e Extraordinária para deliberar entre outras coisas a aquisição de terras, com o objetivo de Colonização de cidades no Norte do Estado de Mato Grosso, ou seja: Gleba Celeste ( $1^{\mathrm{a}}$ e $2^{\mathrm{a}}$ parte): o primeiro ponto de penetração na mata densa da Amazônia foi povoado de Vera e de Santa Carmem; Gleba Celeste ( $3^{a}$ e $4^{a}$ parte): implantação de Sinop Sede e Comarca; Gleba Celeste (5a parte): implantação de Claudia. A Gleba Celeste fazia parte de um projeto implantado pela Sinop Terras LTDA, de propriedade dos senhores João Pedro Moreira de Carvalho e Ênio Pipino Em cada uma dessas glebas foram criados Núcleos Rurais, com os respectivos cinturões verdes, denominados de "chácaras", com lotes cortados, demarcados e com estradas vicinais, transitáveis o ano todo. Adquiriram as áreas de terras necessárias e deram início aos seus trabalhos de colonização. (Dados Históricos da Prefeitura de Sinop)

${ }^{74}$ De acordo com o relatório de pesquisa organizado por Maitelli e Zamparoni(2006), a Pré-Amazônia brasileira corresponde à zona de transição que margeia a grande floresta pluvial, definida - do ponto de vista ecológico, por ecótonos (áreas de contato entre dois biomas) entre a massa florestal da Amazônia e os Cerrados do Brasil Central e as caatingas do Nordeste Semiárido. Enquanto categoria territorial, a Pré-Amazônia está também presente na Bolívia, Peru, Colômbia e Venezuela, marcada não apenas pela vegetação peculiar, mas também por uma população autóctone, cujos gêneros de vida são influenciados pelo habitat que entremeia floresta densa com áreas de vegetação aberta. A criação da Amazônia Legal prolongou as fronteiras políticas da floresta muito além de seus limites naturais, transformando-a em bandeira de luta, tanto dos movimentos ambientais, como os que buscavam incentivos fiscais e privilégios financeiros. Para o presente estudo optou-se pela denominação Amazônia Mato-Grossense (ROMANCINI e RODRIGUES, 2007:43). 
tem geada ${ }^{75}$, aí mostravam aquelas fotos lindas, e lá dá café, e tiravam fotos dos cafezais de lá mesmo, do Paraná, quer dizer, até certo ponto foi uma informação meio enganosa, para atrair estas pessoas, principalmente os que vieram para cá, que eram todos agricultores. Aí foram chegando

O professor conta como foram chegando as famílias e como foram encontrando trabalho para sobreviver:

A primeira família que chegou aqui foi do Pissinati Guerra, que era agricultor numa cidadezinha lá do Paraná. Então, eles foram atraídos. Viram aqui uma chance de se tornar dono, porque alguns lá eram empregados, não tinham nem propriedade. Outros tinham uma pequena propriedade lá, e já passavam uma situação meia complicada, porque naquele período já estava na concentração de rendas lá no sul.. de terras. Então o pequeno já não conseguia mais subsistir com o pequeno lote que ele tinha lá, a chacrinha. Aí ele vislumbrou, eu tenho aqui três alqueires, lá você vai ter 50; se tem 8 alqueires, lá você vai ter 100. Aqui a família está crescendo e eu não estou conseguindo sobreviver, então eu indo para lá, não é possível, não é? A própria Colonizadora facilitou na venda destas terras; todas estas primeiras famílias que vieram para cá, eles doaram terrenos onde hoje é a área central da cidade. $\mathrm{Na}$ avenida principal, ali, a maioria dos terrenos foram doados para estas famílias que vieram. Mesmos os professores, a minha cunhada mesmo foi uma que ganhou um terreno. A Colonizadora doava um terreno aqui na cidade, para quem se arriscava vir para cá. $\mathrm{E}$ essas famílias todas tinham em mente que como se plantava e colhia café no sul, aqui seria a mesma coisa, porque eles não faziam ideia da diferença climática que havia, nem que aqui existem períodos definidos; seca é inverno, só calor não se fala em frio e o problema também das chuvas que lá são mais constantes, aqui período seco, período de chuva. Além da propaganda, entra o próprio governo que incentivou muito nessa época.

\section{Para o professor Luiz Erardi F. Santos, o incentivo do governo federal foi} muito importante na criação e desenvolvimento de Sinop.

Aí o governo entra com grandes financiamentos e incentivos fiscais, SUDAM (Superintendência do Desenvolvimento da Amazônia), SUDECO, (Superintendência do Desenvolvimento da Centro-Oeste) com todo incentivo atraindo; eu lembro aqui na BR aquelas enormes placas do governo federal com aquelas faixas verde e amarela atravessadas e 0 brasão da República onde dizia: obra financiada pela SUDAM; para as madeireiras... Quer dizer, os próprios madeireiros quando vieram para cá, eles vieram a chamado mesmo. Ele vinha, montava a serraria e tal com dinheiro do governo e ainda sobrava dinheiro e tudo para pagar a perder de vista. Quer dizer o próprio governo contribuiu, complementando com a abertura da BR-163. É lógico que num primeiro momento, eles vieram achando que tudo seria bem mais fácil do que foi e que o que tinha sido colocado para eles lá no sul iria de fato acontecer aqui. É lógico que isso não iria acontecer nunca. Mas isto eles só perceberam depois de chegar aqui. Eles caíram na realidade. Pior que muitos vieram, alguns ficaram e outros voltaram. Num relato do Pissinati Guerra ${ }^{76}$ teve gente que chegou aqui e, dali uma semana, quinze dias, um mês, o cara dava para ela a

\footnotetext{
${ }^{75}$ Formação de uma camada de cristais de gelo na superfície ou folhagem ao ar livre provocada pela queda de temperatura.

${ }^{76}$ Pioneiro Olímpio João Pissinati Guerra que instalou a primeira máquina de arroz, nas margens da BR-163, onde hoje está a rua Salvador, esquina com a rua São Paulo
} 
chácara e o sitio, para ele levar num caminhãozinho que ele tinha, a mudança de volta para o sul. Tiveram vários casos. Uns porque a família não se adaptou, viram que a coisa era diferente etc.

Pelo relato do professor Erardi, as pessoas foram chegando e, na medida em que não encontraram o que haviam imaginado, foram criando novas atividades, úteis para a população que se aglomerava na pequena vila.

Outros por problemas de doença. Não tinha nada aqui na área de saúde, então ficaram com medo porque tinham filhos pequenos e tal. Quer dizer houve os que chegaram aqui, viram a situação e concluíram que aqui não dava para eles e resolveram votar. E esses que ficaram aqui, embora tenham vindo para ser agricultores, acabaram mais ou menos com esse plano. E quando eles não podiam o seu Braz mesmo, a primeira casa que foi feita aqui na cidade foi a casa dele. Como não tinha condições de abrir o sitio dele, que tinha o nome de Porta do Céu. Aí ele foi trabalhar de carpinteiro, porque a Colonizadora estava construindo os barracões, os acampamentos e aí já chegou um e mais outro e começou a levantar sua casa, madeira tinha aí à vontade. Quer dizer, ele veio como agricultor, mas foi trabalhar de carpinteiro. A esposa dele, Dona Geraldina, fazia estes pães caseiros, eu até tenho uma forma que está guardada no museu histórico, e para se sustentar, ela vendia os pães para os peões da Colonizadora que estavam abrindo as ruas e as avenidas, então a tardezinha eles iam pegar o pão da Dona Geraldina. Então eles fizeram o que tinha para fazer, porque não tinham condições de abrir a propriedade. O Osvaldo Paula é um dos que chegou aqui primeiro, ele conseguiu abrir a chácara dele, é lá na entrada de Sinop, no bairro São Cristovão, mas ele jamais iria sobreviver daquilo lá. Então ele montou um comercinho, o Armazém Santa Paula. Como ele tinha um fusquinha ele era o taxista. Ele mesmo comenta: eu fui taxista, fui comerciante pra muito depois eu ir mexer com a minha propriedade. O Plinio Calegaro acabou montando um bar, depois uma churrascaria e assim foi. Isto tudo aconteceu em 1973. A primeira família chegou em 1972 e estes aí em 1973.

A abertura das primeiras ruas, conforme o relato do professor Erardi, iniciou em maio de 1972 e logo as primeiras famílias de migrantes chegaram à cidade, que só foi tomar impulso mesmo com o asfaltamento da BR-163, até a confluência com a rodovia MT-320 (Colíder - Alta Floresta), em 1984.

O asfalto "passando por ali" era um sonho de todos, mas este sonho não estava incluído entre as obrigações da colonizadora, embora contasse com o apoio do presidente da Colonizadora, do Sr. Enio Pipino, para reivindicar junto as autoridades estaduais e federais, para manter a cidade como ponto de interesse de investidores e assim atrair moradores. O município foi planejado observando critérios urbanísticos modernos, com traçado regular e quadras interligadas, com praças e, principalmente, reservas naturais. 
Recuperar estas reservas naturais não foi muito fácil, considerando que a devastação foi muito grande até a década de 1990, como afirma em sua entrevista de 17.09.2013, o professor Erardi:

\begin{abstract}
No meu ponto de vista, houve muita crítica aos madeireiros daqui, e de fato tinham alguns bandidos, mas se existe um grande culpado da devastação da Amazônia, este chama-se governo brasileiro, porque ele fechou os olhos para muita coisa, ajudou a criar muito problema, incentivaram a derrubada de árvores através do INCRA [...] $\mathrm{O}$ antigo IBDF $^{77}$ cobrava uma taxa dos madeireiros que exploravam madeira aí, por cada árvore que era derrubada. Conforme eles diziam era para o reflorestamento, que nunca aconteceu por aqui. Essa taxa era para fazer uma nota que legalizava a madeira, mesmo porque para mandar para o exterior tinha que ter esta guia. E os madeireiros começaram a se incomodar com a história do dinheiro da taxa só ir para Brasília e aqui não ficava nada nem eram replantadas as árvores que eles prometiam. Aí o SINDUSMAD (Sindicato Rural), em 1986 ou 1987, fez um documento e mandou para Brasília, pedindo ao IBDF que ele assumisse o papel de fiscalizador e que esta taxa que era cobrada para reflorestamento, que não estava acontecendo, que ficasse no SINDUSMAD, órgão organizado por eles, e o sindicato assumiria o papel de executor, ou seja, a cada árvore derrubada deveriam ser plantadas 3 ou 4 árvores. E caberia ao IBDF, fiscalizar. Pergunta se o IBDF aceitou? Claro que não. Resultado: até hoje, nem IBDF nem IBAMA (Instituto Brasileiro do Meio Ambiente e dos Recursos Naturais Renováveis) plantaram uma árvore. Pelo contrário; os próprios funcionários, em várias situações entraram em acordo e ajudaram a derrubar madeira também. Forneceram guias falsas e coisas do gênero. Portanto, a devastação aqui na região tem vários culpados e o maior deles é o governo até porque no momento em que ele deveria agir, nunca agiu. Eu digo o governo como um todo, com seus devidos órgãos.
\end{abstract}

Como meio de incentivar a preservação do meio ambiente a população sinopense vive o verde e respira o ar puro de mais de 10 reservas ambientais espalhadas no perímetro urbano. Conforme legislação municipal, cada bairro deve ter uma área de preservação ambiental, para que o conjunto possibilite a melhoria da qualidade do ar do município. Entre elas está o Parque Florestal de Sinop que possui cerca de 100 hectares, sendo uma área de preservação e conservação, onde coabitam espécies vegetais e animais nativos da região. Neste parque existe ainda a nascente de um lago, de grande importância para a qualidade do ar do núcleo urbano.

77 O Instituto Brasileiro de Desenvolvimento Florestal foi criado pelo decreto lei $n^{\circ} 289$, de 28 de fevereiro de 1967. Era uma autarquia federal do governo brasileiro vinculada ao Ministério da Agricultura encarregado dos assuntos pertinentes e relativos a florestas e afins. Foi extinto por meio da Lei $N^{0}$ 7.732, de 14 de fevereiro de 1989 e transferiram-se seu patrimônio, os recursos orçamentários, extra-orçamentários e financeiros, a competência, as atribuições, o pessoal, inclusive inativos e pensionistas, os cargos, funções e empregos para a Secretaria Especial do Meio Ambiente - SEMA (criada em 1973 e extinta em 1989) e, posteriormente, para o Instituto Brasileiro do Meio Ambiente e dos Recursos Naturais Renováveis - IBAMA, de acordo com a Lei № 7.735, de 22 de fevereiro de 1989. Fonte: pt.wikipedia.org 
Esta devastação, de certa forma incentivada pelo governo federal, exigia que a mata fosse retirada rapidamente, para dar lugar a pastagens ou simplesmente porque o agricultor desistia de pagar impostos muito mais altos por terras cobertas por vegetação. Houve muita gente que persistiu em deixar boa parte de suas terras com floresta, mas foi demovida pelo alto custo dos impostos a retirá-la.

Conforme afirmou o professor Erardi, em pouco tempo o projeto original da cidade, que previa um círculo verde permanente, deu lugar a bairros programados para classes menos favorecidas e os chacareiros que ainda desejavam preservar a mata de transição ali existente, acabaram por utilizar o método da corrente amarrada a dois tratores para remover mais rapidamente a vegetação que cobria estas áreas mais próximas da cidade.

Este método consistia em prender as pontas de uma corrente muito pesada, como a que está na Foto 19, em dois tratores que a arrastavam bem esticada derrubando com o impacto toda uma área de floresta. Para que as pessoas não esquecessem de um dos principais instrumentos de devastação da Amazônia, a EMBRAPA utilizou uma das correntes apreendidas há pouco tempo e colocou como peça de decoração na entrada de suas instalações em Sinop.

\section{Foto 19 - Correntes utilizadas para desflorestamento na região de Sinop}

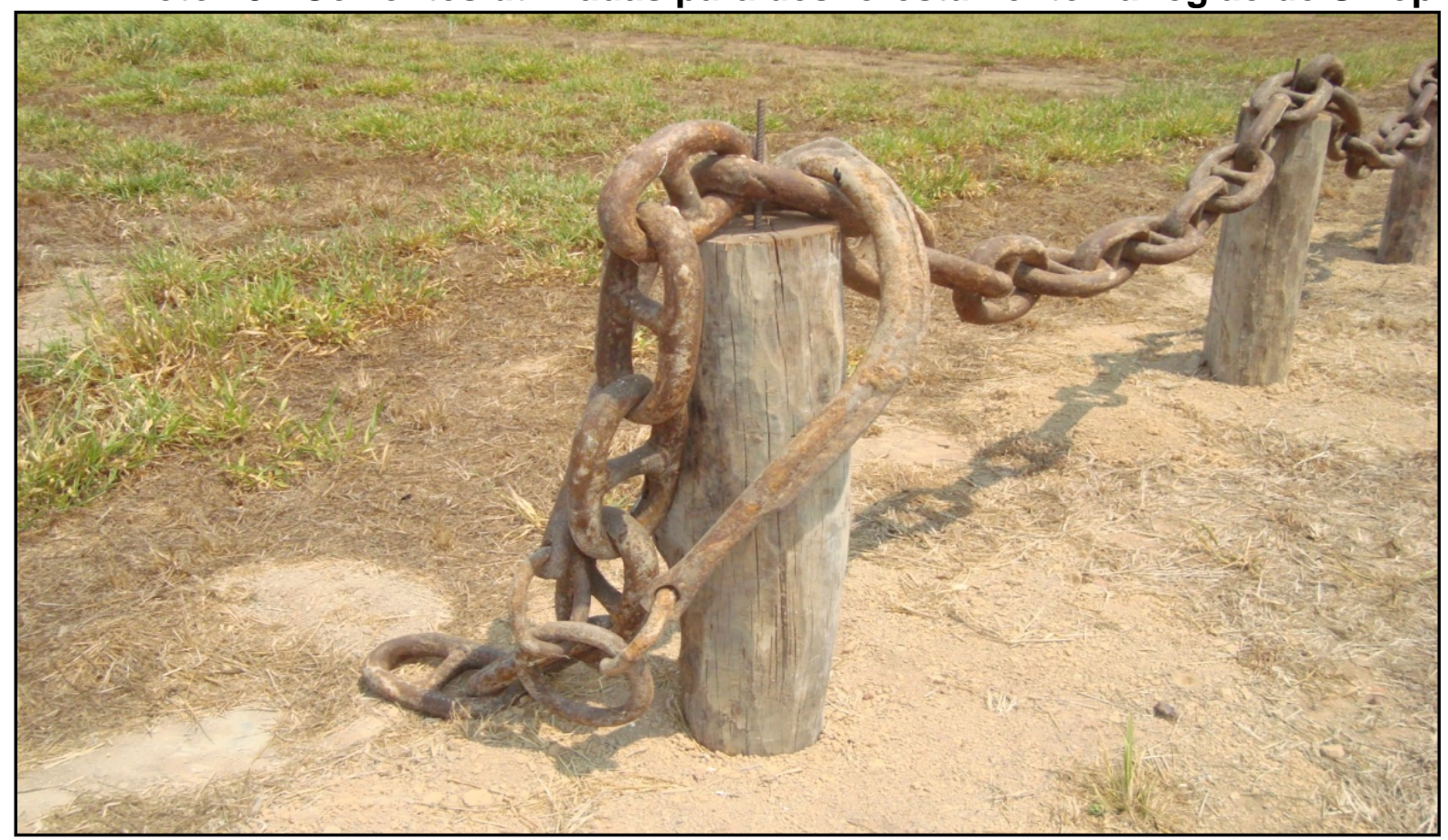

Fonte: Acervo da autora (2012)

Da colonização à emancipação, foi tudo muito rápido. Em quatro anos, no dia 24 de julho de 1976, o então governador José Garcia Neto assinou uma lei que 
elevou a vila a distrito do município de Chapada dos Guimarães e, em 17 de dezembro de 1979, o governador Frederico Campos assinou a Lei 4.156/79 que elevou o distrito à categoria de município.

A este respeito, o professor Luiz Erardi F. Santos conta que:

A Colonizadora tinha um trânsito muito grande no governo federal e o Enio Pipino era uma presença constante no governo, porque ele tinha interesse neste todo aqui que era a Gleba Celeste. Nessa Gleba ele colocou Sinop, Santa Carmem, Vera e Claudia. Esse interesse era para venda também; para comercializar as áreas que ele tinha aí. Por meio deste transito que ele tinha com o governo federal, ele foi conseguindo atrair. O presidente era 0 Figueiredo; antes o Geisel. Tanto é que quando foi fundada Sinop, em 14 de setembro de 1974, o presidente era o Geisel que não pode vir e veio o Ministro do Interior, Rangel Reis. Com o transito que o Sr. Pepino tinha ele foi conseguindo as coisas! Aí com o Figueiredo ele conseguiu certas melhorias aqui que mais de cem anos de Mato Grosso não tinham conseguido que foi a instalação do telefone para falar com todo o mundo, a primeira TV nacional e a rádio Nacional que era de Brasília e tal, e foi conseguindo. Conseguiu até trazer o presidente aqui. Ele veio em 1980 e em 81 instalou o telefone com DDD (Discagem Direta a Distância) já, a primeira rádio e a primeira televisão.

Consolidou-se em pouco tempo como polo industrial em diversificação e polo comercial e de serviços, embora a energia elétrica, até 1993, ainda fosse gerada a óleo diesel e mantida por geradores ligados em horários diversificados.

Pelo relato do professor Luiz Erardi F. Santos em sua entrevista de 17.09.2012, a chegada da energia elétrica foi muito importante para o desenvolvimento do município:

Principalmente nos anos 1994, 1995, quando foi melhorada a energia, porque até 1994 a energia de Sinop era um caos. Era o motor da Cemat que funcionava, não funcionava, quebrava, faltava óleo, aquilo ali atravancava o desenvolvimento da cidade. Aí em 1994, com a inauguração do linhão famoso linhão de Cuiabá a Sinop, com estas torres aí, foi quando veio o Itamar aqui. Ele veio inaugurar o Fórum. Com a chegada da energia suficiente para a demanda da cidade, ela não parou mais não.

A população de Sinop saltou de pouco mais de 54 mil em 1996 para 116.099 habitantes (IBGE - 2010), distribuídos em 3.942.231km²; Destes habitantes, 93.753 concentram-se nos $17 \mathrm{~km}^{2}$ de área urbana. Hoje, o PIB municipal monta em 1.813.363 bilhões ( $4^{\circ}$ em Mato Grosso) e a renda per capita é de $\mathrm{R} \$ 1.324,96 / \mathrm{mês}$ e R\$15.899,58/ano, que colocam o município com um IDH de 0,897 (IBGE - 2010).

A realidade atual, nem sempre foi assim. Sinop teve seus altos e baixos e, porque não dizer, situações bastante difíceis para manter-se como município importante ao norte de Mato Grosso. De acordo com as informações transmitidas 


\section{pelo professor Luiz Erardi F. Santos em sua entrevista de 17.09.2012, a busca pelo} sucesso econômico perpassou por alguns percalços, alguns bastante graves:

Se você olhar a bandeira de Sinop, tem uns ramos de café e do arroz. Era o que os pioneiros esperavam plantar aqui; café a arroz. Tanto é que onde hoje está o ginásio olímpico numa quadra inteira ali, era um viveiro de mudas de café, mas o café não vingou porque o clima não permite. Eles plantaram café, depois de 4 a 5 anos dava a florada e conforme o ano vingava, ou não chegava nem a frutificar, por isso em pouco tempo eles foram desistindo do café e aí a cultura maciça era o arroz até por causa da alimentação. A terra é muito ácida aqui. Apesar de que em 1975 reuniu os agricultores aqui e lançou o projeto do calcário aqui; mesmo assim, a Colonizadora criou aqui a COMICEL (Cooperativa Mista de Celeste). Através da cooperativa eles conseguiam comprar o calcário para ir corrigindo a terra, diminuindo a acidez. Mas em Sinop, desde o começo, nunca a agricultura foi o forte, como é em outras cidades aí. Aí o que aconteceu? Sinop veio bem antes das outras cidades e também tem que levar em consideração o contexto da região. Como hoje Sinop cresce muito em função de Lucas e Sorriso, como lá está crescendo acaba sobrando para cá, tranquilamente; na época, também a gente não pode esquecer, que estava estourando o garimpo aí para cima. E o pessoal que vinha para o garimpo em Peixoto de Azevedo, Alta Floresta, Paranaita, Guarantã do Norte e outros lugares, a passagem é aqui. Então muitos chegaram até aqui e outros seguiram mais para cima. E muitos que estavam aqui, também investiram lá no garimpo, tiraram algum proveito lá e trouxeram para cá. Então nesse começo aí, o que ajudou Sinop um pouco, foi a exploração dos garimpos.

\section{Como o historiador continua narrando, nem tudo foi sempre estabilidade}

\section{socioeconômica em Sinop:}

A cidade teve vários altos e baixos. A cidade vinha crescendo devagar e o Sr. Enio Pipino sempre trabalhando para isso. Quando chegou em 1979, ele criou aquele mega-plano da Agro Química ${ }^{78}$ algo inédito aqui no Brasil. Na época o pró-álcool estava bombando; tanto é que ele conseguiu financiamento do governo federaagroquiml para essa Agro Química, só que o pró-álcool no Brasil estava bombando com a cana de açúcar. Mas o Enio Pipino fez uma coisa diferente. Foi buscar tecnologia alemã e fazer o álcool da mandioca. Tanto é que na época no Brasil, no Jornal Nacional, na Bandeirantes, ele saiu lá. A questão da Agro Química de Sinop. A maior indústria que seria a primeira indústria do Brasil a extrair o álcool da mandioca em grande escala. Tanto é que a Shell a Atlantic, as grandes empresas de combustível, instalaram na frente da indústria os seus reservatórios. Pelo projeto a indústria teria uma ligação direta com os tanques das distribuidoras. Com este projeto, ele atraiu gente, técnicos, empregados para a Agro Química, mas ao mesmo tempo, também aqueles agricultores que já estavam aqui, viram a grande possibilidade e seguindo aquele mote do João Figueiredo "plante que o João garante", aqui eles copiaram e colocaram "plante que a Agro Química garante". Então plante a mandioca que você vai resolver seu problema de agricultor. E aí foi só plantar mandioca, mas eles não haviam feito uma análise maior. Se plantar um dois pés de mandioca é uma coisa. Neste volume, é outra. Vem o problema da praga, vem uma série de coisas. E a Agro Química bombando. Construindo, era uma coisa de louco! Eram carretas e mais carretas com

\footnotetext{
${ }^{78}$ Agro Química Industrial, maior indústria instalada no município, destinada a produzir álcool para o PROALCOOL (Programa Nacional do Álcool) para substituir a gasolina como combustível.
} 
material. E isso aí acabou atraindo mais gente. Quem não vinha para trabalhar na Agro Química nem estava plantando mandioca, veio para trabalhar no comércio que começou a aumentar. Isso foi 1979.

A cidade que tinha tudo para decolar com a Agro Química viu seus sonhos, aos poucos ir se esvaindo.

Ai em 1980 veio o Figueiredo. Quando ele veio, a cidade estava naquela ebulição. Foi quando ele concluiu que a cidade merecia o telefone, a rádio a TV e dali, quando eu vim pra cá em 1983, a Agro Química estava começando a funcionar. Funcionou pouquinho tempo. Em 1985, ela arriou. Começou com mandioca, aí começaram a surgir os problemas. Começou a produzir o álcool, mas ainda tinha problemas de estrada que ainda não era asfaltada, o governo federal começou a encolher as rédeas do pró-álcool, os financiamentos que deveriam continuar saindo acabaram não saindo mais, e naquela época ainda não tinha o carro flex, quem quisesse colocar álcool tinha de colocar outro motor no carro. Nesse período a Agro Química entra em colapso, tentaram fazer álcool de sorgo não deu certo, até batata doce foi plantada aqui para ver se dava certo. O sorgo dá um álcool mais fino para laboratório. Enfim, a Agro Química acabou falindo. O último ano foi 1986, se não me engano. [...] Aí, a partir de 1987, a cidade passou a entrar em descrédito.

Apesar das criações do Sr. Enio Pipino para manter a economia de Sinop em alta para atrair pessoas e investidores, a cidade mantinha-se, como narra o professor Luiz Erardi F. Santos praticamente de boom em boom, dependendo sempre de ações político-econômicas que a mantivessem como "capital do Nortão".

Alta Floresta estava bombando com o garimpo. Tanto é que o pessoal que parava aqui, antes de continuar dizia: aqui é passagem. Lugar de futuro é Alta Floresta. Realmente, na época, Alta Floresta era considerada muito mais importante que Sinop. Tem que lembrar que lá corria muito ouro. [...] Só que em 1990, entra a era Collor que decepou o garimpo. Quer dizer, prejudicou Peixoto, Alta Floresta, mas para Sinop, até certo ponto, favoreceu, porque gente de Sinop tinha explorado lá também e investiu aqui. A indústria madeireira não sofreu nada nesta época. Aí houve um certo esvaziamento da região lá e as populações de Alta Floresta mais uma cidadezinha por aí, Paranaíta, Apiacás e outras, acabaram vindo para cá. Aí Sinop viveu um período bom. Depois, em 1992, mudou a administração. Então depois que passou esta fase ruim que ela teve entre 1985, com o fechamento da Agro Química, até 1989, depois, praticamente ela não parou mais. Ela explodiu.

\section{O progresso registrado na cidade foi tanto que nasceu a proposta de uma} nova divisão do Estado de Mato Grosso, para formar o Estado do Araguaia:

Foi por volta de 1984, 1985, que chegou muito forte aquela campanha que fizeram para a separação do estado. Então era Mato Grosso do Norte, Estado do Araguaia, Estado de Tocantins e todas as vezes que falava em separação, a capital seria Sinop. Então foi mais ou menos uns dois anos dessa campanha e essa propaganda de Sinop ser a capital, também ajudou muito. Porque muita gente pensou assim: opa, lá vai ser a capital, vou investir lá. Por isto, neste período aí, Sinop deu outro boom de 
desenvolvimento, por estar aparecendo a mídia e na boca dos políticos que seria a futura capital do novo Estado, que seria a subdivisão da divisão já feita em 1979. E aí, no caso, apareceram alguns Figuras doidos aí. Uns pegando só o norte aqui, de Mutum para cima, só até a divisa. Outros pegando de Mutum para cima até Novo Progresso, que é o sul do Pará. Um pegava aqui só esse meio norte. Foi quando apareceu a história do Estado do Araguaia que pegaria o norte inteiro de Mato Grosso. Como Sinop em todos estes contextos era a cidade maior e aparecia em todos os Figuras, isto acabou favorecendo Sinop em termos de investimento, de crédito. As pessoas diziam: vou investir na futura capital.

Até 2005, a principal atividade econômica do município era a agropecuária e o setor madeireiro. Atualmente o comércio desempenha um papel relevante no setor de prestação de serviços especializados, na área de comércio atacadista e varejista; foi a saída da comunidade para enfrentar a crise do setor madeireiro, no início de 2005, uma vez que desde a década de 1970, até esta data, o município vivia praticamente em função do corte e produção de madeira para os mais diversos fins.

\section{Foto 20 - Madeireira abandonada (Sinop)}

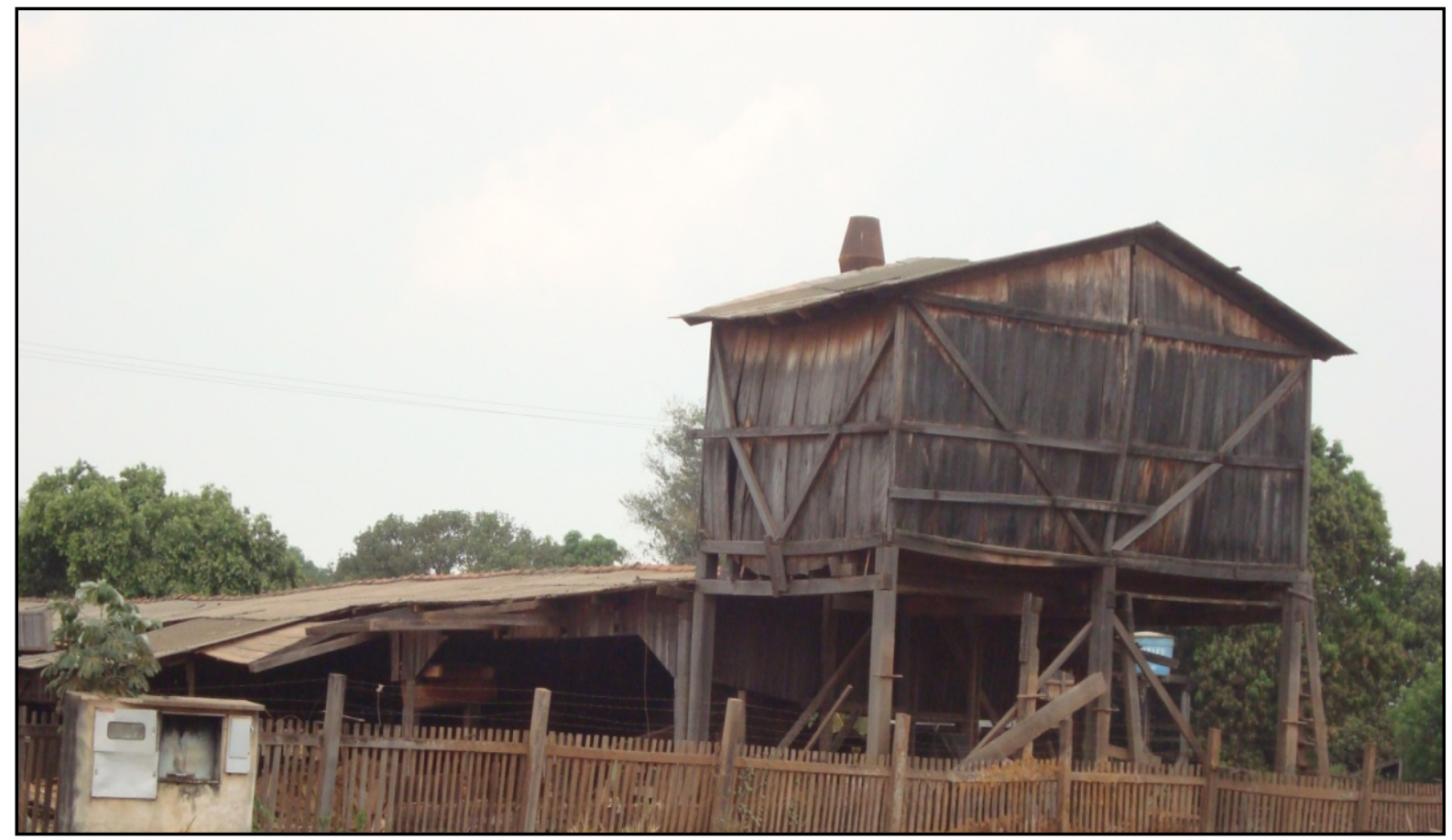

Fonte: Acervo da autora (2012)

O declínio da indústria madeireira, como se pode ver na Foto 20, representou uma queda expressiva na economia que encontrou uma saída no setor de prestação de serviço que voltou a alavancar a economia do município, embora a atividade madeireira continuasse em menor escala, com boa parte da produção sendo pautada pelas regras dos órgãos de controle ambiental.

Como relata o professor Erardi, 
Na década de 1990 a indústria madeireira foi gradativamente entrando em declínio, não total, foi aos poucos, Sinop foi aos poucos fortalecendo outras áreas. A agricultura começou a tomar novo impulso, com o plantio de soja, algodão, milho, veio a tecnologia, o calcário para corrigir a terra e uma série de outras coisas que possibilitam. Outros fatores muito importantes foram a evolução da área comercial e a área da saúde. Sinop acabou se transformando numa cidade prestadora de serviços. E aí a gente, mais uma vez, tem que olhar o contexto da região. Enquanto Peixoto de Azevedo entrou em declínio, Matupá, Alta Floresta e outras daqui da região, principalmente as que estão aqui em volta, as pessoas foram escolhendo Sinop para fazer tudo o que tinham necessidade. Agora, o que ajudou muito, foi a ascensão de Sorriso e Lucas do Rio Verde. O crescimento das duas ali, tranquilamente influi muito no nosso crescimento de Sinop. Lá o objetivo deles é o agronegócio, é plantar.

As serrarias abandonadas acabaram dando lugar a bairros populares, mas 0 aspecto da área que antes abrigava mais de mil madeireiras ficou desolador.

Gradativamente, o espaço sociopolítico ocupado pelas madeireiras foi dando

lugar à prestação de serviços e ao agronegócio. Como observa o professor Edison

Antonio de Souza, entrevistado em 16.09.2012.

O agronegócio, em termos diretos, quem se beneficie talvez não chegue a $10 \%$. Talvez Sorriso chegue um pouco mais, mas esse agronegócio ele gira uma questão indireta. Por ser uma região, aqui tem várias máquinas, concessionárias, tem oficinas, tem fertilizantes, tem toda aquela cadeia que o grande agronegócio precisa e que gera emprego aqui na cidade. Agora, no interior não. No interior é muito pouco porque a tecnologia do campo é muito avançada, é muito grande. Então há uma concentração de terra, de poder e de riqueza. Essas pessoas que moram nas cidades, mas trabalham no campo, que é o grande campo, mas que por outro lado você vê que cada cidade tem a sua identidade. A sua identidade cultural a sua identidade financeira a sua identidade, por exemplo, aqui, nos últimos dez anos nós vemos a presença do agronegócio da agropecuária. Mas quem são estes proprietários. É aí a pergunta interessante. Quem são as pessoas que estão produzindo soja, arroz em Sinop? São poucos de Sinop mesmo, porque muitos madeireiros, que tinham a terra, que faliram, eles venderam ou arrendaram para empresários de Sorriso, de Lucas do Rio Verde ou de outras regiões do sul do Brasil. E nos últimos tempos, estão vendendo para empresários argentinos e americanos. Isso até Sorriso. Aqui eles estão arrendando e tem os laranjas, porque devido a questão ambiental os americanos não compram terra por enquanto aqui nesta região.

A identidade dos habitantes desta região é diferenciada, conforme continua o professor Edison Antonio. Desde o modo de avaliar os objetos, até a forma como organizam suas vidas, sua cidade e seu futuro.

Quem são estas pessoas que estão comprando? O que eu acompanhei, por exemplo, em Feliz Natal. Madeireiro que tinha área que quebrou, ele vendeu e o fazendeiro grande de Sorriso comprou. Eles estão comprando próximo daqui, próximo do aeroporto. Então este fazendeiro capitalista que tem este poder de compra, e agora eles estão nadando de braçada, porque está chegando a $\mathrm{R} \$ 80,00$ a saca da soja. Pensa, mil sacos de soja, como dizem os gaúchos daqui, ele compra uma S-10 nova. Apesar de que o jogo é outro, mas veja bem, isso é muito pesado. É esta a questão, do lado do grande. E o outro lado? Você tendo esta visão, esta leitura, você passa a 
observar esta questão e a mudança na paisagem. E aí é pouco gente, é 10 anos; 10 ou 15 anos atrás, você vê uma mudança nesta paisagem. Mudança no sentido do que era, desde a questão urbana. Se você pegar a entrada da cidade de Sinop, para que vem de Cuiabá há 5 anos atrás. O que era em termos de madeireiras, e hoje quantas você conta. Cinco anos! $\mathrm{O}$ que aconteceu ali? Onde tinha madeireiras, hoje tem bairro ou tem empresas que prestam serviços. Os barracões foram vendidos, porque as pessoas por uma razão ou outra, principalmente por endividamento, acabaram vendendo para este setor imobiliário ou para empresas se instalarem.

O movimento desta região de fronteira, movido pelos altos e baixos pelos quais passou Sinop nos últimos 30 anos, como explica o professor Edison Antonio de Souza, teve razões geopolíticas bastante claras:

A atividade madeireira teve um declínio porque $90 \%$ era ilegal, esta região tinha uma economia paralela, tinha um estado paralelo e principalmente de desobediência civil em relação às leis, então com a decadência da atividade madeireira, pela questão da ausência de matéria prima, pela questão dos crimes ambientais pela devastação, pela falta de matéria prima e pelo desrespeito às leis ambientais e trabalhistas. Ou seja, foram vários fatores; se você for lá eles não vão dizer isto. Essa decadência da atividade madeireira, tá, mas e daí? Para onde foram estas pessoas?

\section{O professor Edison Antonio explicou a mobilidade dos trabalhadores menos}

qualificados em função da demanda de mão de obra:

Pra onde eles foram com o impacto aqui? Muitos foram para o sul do Pará; muitos. Muitos trabalhadores das atividades madeireiras eu acompanhei, por exemplo, os casos de Claudia e Feliz Natal. Esses trabalhadores foram para o sul do Pará. Estava inchando! Com a morte da freira ${ }^{79}$, e com a interferência do Estado, do exército, das forças armadas, teve este impacto dessas pessoas que se diluíram. Pra onde grande parte deles foi? Trabalhar na mão de obra da construção civil em Sinop, mas, principalmente, quem mais recebeu foi Lucas do Rio Verde, por causa da Sadia. Então você vai encontrar hoje bairros em Lucas do Rio Verde, o que você encontrava a 5 ou 10 anos em Sorriso, bairros só de nordestinos, como o bairro São Domingos, só de nordestinos praticamente, e bairro escondido, ou seja, porque existe este apartheid social, então você vai encontrar em Lucas do Rio Verde agora essas pessoas. Desse movimento migratório e de muitos que voltaram para o nordeste, porque existe uma rede de ônibus que sai de Peixoto de Azevedo e vai até o Maranhão e muitos que foram para outras regiões do Brasil, que foram inclusive que foram para trabalhar nas obras da Copa em Cuiabá, que foram para Rondônia, que voltaram para o sul do Brasil, só que agora não é tanto, e que nesse movimento migratório, e inclusive alguns estão trabalhando no garimpo, porque no garimpo foi retomado nesta região de fronteira.

\section{O movimento migratório do qual fala o professor Edison Antonio de Souza} acontece não só no sentido de levar mão de obra com baixo índice de qualificação

\footnotetext{
79 Missionária Dorothy Stang, assassinada no Pará em 12.2.2005. Sua atividade pastoral e missionária buscava a geração de emprego e renda com projetos de reflorestamento em áreas degradadas, junto aos trabalhadores rurais da área da rodovia Transamazônica. Seu trabalho focavase também na minimização dos conflitos fundiários na região.
} 
para as diferentes áreas e novas oportunidades profissionais da região, como também acabou criando uma espécie de retroalimentação econômica entre os municípios da área de abrangência da BR-163.

\author{
Para muita gente, a operação Curupira ${ }^{80}$ foi a grande derrocada da atividade
} madeireira em Sinop, quando a cidade precisou se reinventar, diversificando suas atividades econômicas. Pelo que já se viu nos relatos do professor Erardi, a questão da madeira sempre foi um ponto forte na política econômica de Sinop, porém a derrocada do setor não se deu com a Operação Curupira:

\begin{abstract}
Um fator muito importante, é que a cidade diversificou suas atividades, porque a indústria madeireira aqui foi o suporte econômico da cidade aqui, em toda a década de 1980 e na década de 1990, começou a cair já. Não foi só por causa da Operação Curupira. Para quem viu esta BR desde o bairro São Cristovão até mais ou menos $15 \mathrm{~km}$ margeando a BR com madeireiras, pequenas, médias, grande, "pica-pau" ${ }^{81}$, laminadoras, na década de 1990, praticamente $40 \%$ a $50 \%$ desta estrutura aí de madeireiras já tinha acabado. Uma boa parte partiu para outra atividade, como o comércio, mas várias desmontaram aqui e foram para o sul do Pará. Muitos destes proprietários de madeireiras acabaram investindo aqui em outras áreas, outras atividades econômicas, principalmente na pecuária, alguns na
\end{abstract}

\footnotetext{
${ }^{80} \mathrm{~A}$ Operação Curupira, conforme artigo veiculado pela revista Veja, edição 1908 de 8 de junho de 2005, em reportagem de Marcelo Carneiro, prendeu 102 pessoas, entre madeireiros, fiscais do IBAMA e outros funcionários públicos, acusados de colocar abaixo quase 2 milhões de metros cúbicos de árvores em troca de propinas e lucro fácil, só nos últimos dois anos, para engordar o caixa da campanha petista. No comando do roubo da floresta, conforme a Polícia Federal, estava o funcionário número um do IBAMA em Mato Grosso, Hugo Werle, que coordenou a derrubada ilegal e comercialização da madeira, executada nos dois últimos anos. De acordo com a PF, daria para carregar 66.000 caminhões; enfileirados, eles ocupariam uma extensão equivalente à distância entre o Rio de Janeiro e Natal. Um dos expedientes usados pela quadrilha para assaltar as florestas, passava por uma ATPF (Autorização para o Transporte de Produtos Florestais), concedido em duas vias aos madeireiros pelo IBAMA, onde é descrito o tipo de madeira e a quantidade que cada caminhão está autorizado a transportar. No caso da quadrilha de Mato Grosso, o madeireiro preenchia a primeira via do documento (aquela que acompanha o caminhão com o carregamento de madeira) de uma forma e a segunda (que seguia para o IBAMA), de outra. Obviamente, colocava na primeira uma quantidade de madeira sempre superior à permitida. Em um determinado momento, as duas vias tinham de se encontrar no IBAMA para conferência. Nessa hora, os funcionários corruptos entravam em ação: simplesmente não conferiam nada e sumiam com a via adulterada. A segunda modalidade de fraude é a com ATPFs (Autorizações de Transporte de Produtos Florestais) têm era mais simples. Funcionários do IBAMA se limitavam a vendê-las em branco para os madeireiros, a R\$ $2.000,00$ a folha e estes a preenchiam com a quantidade de carga e tipo de madeira que desejassem, inclusive madeiras nobres cujas árvores demoram de 130 a 200 anos para se regenerar. A Polícia Federal descobriu ainda a existência de mais de 450 madeireiras-fantasma, criadas exclusivamente para ampliar a cota de árvores derrubadas permitida aos empresários. Para atestar a existência de uma empresa inexistente, funcionários do IBAMA recebiam de $R \$ 3.000,00$ a $R \$ 5.000,00$. Outro ótimo negócio descoberto pela quadrilha consistia em abrir uma empresa de recomposição florestal para compor um esquema triangular de corrupção. Por lei, a madeireira que esgota sua cota de derrubada de árvores pode conseguir autorização do IBAMA para cortar mais madeira, desde que contrate uma empresa de reflorestamento para aumentar o plantio de árvores em seu terreno. No esquema da quadrilha, a madeireira fingia contratar uma empresa de reflorestamento, esta fingia plantar árvores no terreno da empresa e o IBAMA fingia que estava tudo certo e, no final, todo mundo levava seu quinhão. Tudo isto fazia parte de uma praga muito mais devastadora para as florestas: a corrupção.

${ }^{81} \mathrm{O}$ termo é usado para identificar as madeireiras muito pequenas.
} 
agricultura. Algumas madeireiras doaram aos empregados as casas ou maquinários no acerto de contas. Muitos desmontaram as casas onde moravam, em fazendas mais afastadas, e montaram aqui na cidade. Foi aí que começaram a abrir alguns bairros mais simples, que favoreciam na compra do lote, que era um trabalho bem forte das imobiliárias que recebiam os acertos de contas nas madeireiras para a quitação dos lotes na periferia. Tanto é que o projeto original de Sinop extrapolou; onde hoje temos a maioria dos bairros era tudo chácara no projeto original.

Sinop é uma cidade que apesar de suas deficiências, por seu grande desenvolvimento, conseguiu se destacar na área da saúde. Hoje o município é considerado um polo regional de saúde, sendo referência nas regiões norte de Mato Grosso e sul do Pará. A formação deste polo é resultado do trabalho conjunto da iniciativa privada com o poder público que se solidificou através da qualificação de mão de obra e consequente aumento da qualidade dos produtos e serviços incluindo tratamentos que abrangem desde a atenção básica até os exames de alta complexidade. Estes fatores foram os principais vetores do interesse de empreendedores da área de saúde que passaram investir mais capital em novos serviços e capacitação de pessoal a para lidar com tecnologias de ponta do setor.

Capacitar pessoas é outra questão preocupante para o município, uma vez que como "capital do Nortão", Sinop suporta os atendimentos médicos de praticamente toda a região. O sério problema poderá ser mitigado com a instalação da faculdade de medicina, recentemente aprovada pelo MEC, no campus já existente da UFMT (Universidade Federal de Mato Grosso), com início das aulas previsto para 2013. Por outro lado, o número de leitos disponíveis está muito aquém da necessidade e, por isto, o governo federal deve transformar o Hospital Santo Antônio na maior estrutura de saúde de Mato Grosso, especialmente nas áreas de neurologia e oncologia. Se transformará numa estrutura de $35.000 \mathrm{~m}^{2}$, com 241 leitos, 24 UTI (Unidades de Tratamento Intensivo) e uma capacidade de 400 internações/mês.

Conforme Wellington Randal, diretor administrativo Fundação Santo Antônio, o segredo destas vitórias é a grande parceria que a instituição sempre teve com as empresas e organizações do município. Só a área doada pela Colonizadora Sinop para esta expansão, está avaliada em $R \$ 3.000 .000,00$ e esta não é a primeira doação da empresa que, há 21 anos, doou $18.900 \mathrm{~m}^{2}$ para a implantação do hospital e em 2006 repassou para a Fundação mais 4.200 m²$^{2}$.

O dinheiro do governo federal ampliará a área de oncologia que já existe na unidade. Além da quimioterapia, oferecida hoje, o hospital vai dispor dos tratamentos 
de radioterapia e braquiterapia e, com estes novos equipamentos, passará a ser referência nacional no tratamento do câncer. Independente da verba concedida pelo governo federal, o projeto Santo Antônio prevê um investimento de $R$ \$ 4 milhões com recursos próprios que custearão a abertura de 50 leitos de internação pelo SUS, ampliação de 12 leitos de UTI adulto e instalação de outra UTI pediátrica e uma cardiológica.

Como pode ser visto no Quadro 02, abaixo, o grande desenvolvimento da cidade tem movimentado o comércio de veículos e o número de unidades tem aumentado significativamente. Somente em 2012, o município emplacou, até julho, 3.354 novos veículos, o que significa uma média de 18,5 veículos por dia. O aumento do consumo e o perfil dos consumidores têm atraído concessionárias que hoje somam 22 lojas instaladas.

Quadro 02 - Frota de veículos de Sinop

\begin{tabular}{|c|c|c|}
\hline ANO & No VEICULOS $^{\text {OBSERVAÇÕES }}$ \\
\hline 2008 & 49.925 & $\begin{array}{c}\text { de 08 a 09 } \\
(+12 \%)\end{array}$ \\
\hline 2009 & 56.125 & $\begin{array}{c}\text { de 09 a } 10 \\
(+11 \%)\end{array}$ \\
\hline 2010 & 62.314 & $\begin{array}{c}\text { de } 10 \text { a } 11(+ \\
11,8 \%)\end{array}$ \\
\hline 2012 (jan/jul) & 73.819 & $\begin{array}{c}\text { de } 11 \text { a } 12(+ \\
5,9 \%)\end{array}$ \\
\hline
\end{tabular}

Fonte: Prefeitura de Sinop (2012)

Um dos fatores importantes foi a tecnificação da agricultura, na opinião do professor Edison Antonio que detalhou o assunto durante a entrevista concedida em 16.09.2012:

Estão vindo muitas pessoas de outras regiões do Brasil, e aí é aquilo que o Souza Martins fala da frente de expansão, primeiro vai a frente pioneira abrindo o caminho bruto, pesado, e depois vem o capitalista que investe e o investimento dele requer uma certa segurança, esse capitalista que vem, já em terras praticamente abertas, com condições de produzir e isso está acontecendo com pessoas de outros estados. Estas pessoas estão morando em Sinop e atuando num raio de até $200 \mathrm{~km}$. Por exemplo, eu tenho vizinhos aí que vieram de Cascavel (PR), por exemplo, meu vizinho lá, comprou uma fazenda em Claudia. A família dele está aqui, porque aqui tem escola, tem mais segurança, aqui tem condição. Ele vai na segunda e volta na sexta. Aqui no Jardim Maringá, em bairros mais nobres da cidade tem vários casos assim. Pessoas que vieram do interior de São Paulo... 
Dando seguimento ao seu raciocínio, explicou o professor como este procedimento altera o social da cidade e, ao mesmo tempo vem impulsionando vários mercados:

\begin{abstract}
Mas quem trabalha com a soja, não é de São Paulo. É do sul do Brasil mesmo ou daqui do próprio estado como é o caso de Lucas, de Sorriso. Estas pessoas estão comprando. Os que vêm morar aqui, por exemplo eu estou acompanhando pessoas do Rio Grande do Sul, que venderam suas áreas lá e vieram morar aqui e eles têm áreas aqui a 150 até $200 \mathrm{~km}$. A família fica aqui e ele trabalha nessa fazenda. Então isso é interessante. Isso faz com que a cidade tenha esse giro, esse polo, essa referência. Então aqui tem as áreas de saúde, hospitais, educação, do nível primário até as universidades, a questão do comércio, a questão do aeroporto, e essa questão da logística é importante, os dois voos diários, os voos das duas empresas estão lotados sempre. Eu tenho acompanhado pessoa de cidades vizinhas que não investem, por exemplo, R\$ 200.000,00 lá em Claudia, mas investem aqui, compram um apartamento aqui. Veja como a questão da segurança financeira como é interessante.
\end{abstract}

Pelo seu destaque no setor terciário, a economia da cidade tem aumentado muito sua oferta de emprego nos últimos anos, como se confere no Quadro 03, a seguir;

Quadro 03 - Geração de emprego em Sinop

\begin{tabular}{|l|c|c|}
\hline ANO & PERÍODO & $\begin{array}{c}\text { EMPREGOS } \\
\text { GERADOS }\end{array}$ \\
\hline 2008 & JANEIRO A DEZEMBRO & 832 \\
\hline 2009 & JANEIRO A DEZEMBRO & 429 \\
\hline 2010 & JANEIRO A DEZEMBRO & 1483 \\
\hline 2011 & JANEIRO A DEZEMBRO & 1952 \\
\hline 2012 & JANEIRO A JULHO & 1427 \\
\hline
\end{tabular}

Fonte: Prefeitura de Sinop (2012)

Para ter uma ideia das mudanças que tiveram de ser administradas, tanto pela população quanto pelo poder público municipal, a balança comercial de Sinop tem evoluído conforme os dados apresentados no Quadro 04, abaixo:

Quadro 04 - Comparativo da Balança Comercial de Sinop

\begin{tabular}{|c|c|c|c|c|}
\hline PERÍODO & EXPORTAÇÃO & IMPORTAÇÃO & SALDO & OBSERVAÇÕES \\
\hline JAN A DEZ 2008 & 81.630 .234 & 1.017 .544 & 80.612 .690 & \\
\hline JAN A DEZ 2009 & 127.641 .413 & 739.423 & 126.901 .990 & De $08 \mathrm{p} / 099+57,43 \%)$ \\
\hline JAN A DEZ 2010 & 102.363 .608 & 708.432 & 101.090 .725 & De $09 \mathrm{p} / 10(-20,30 \%)$ \\
\hline JAN A DEZ 2011 & 193.261 .753 & 1.174 .868 & 190.225 .459 & De $10 \mathrm{p} / 11(-88,17)$ \\
\hline JAN A JUL 2012 & 137.889 .402 & 2.168 .929 & 135.720 .473 & De $11 \mathrm{p} / 12(-45,63 \%)$ \\
\hline
\end{tabular}

Fonte: Prefeitura de Sinop (2012) 
O potencial de crescimento equivalente a três vezes a média nacional, estimulou uma pesquisa especializada em consultoria que identificou alguns pontos bastante curiosos. Dos 113.099 habitantes (IBGE - 2010) de Sinop, 81,5\% tem menos de 40 anos. A maior fatia é formada por crianças entre 0 e 9 anos, que compõem $23,3 \%$ da população. Os adolescentes entre 10 e 19 anos são responsáveis por 20,6\% do total, seguidos dos jovens entre 20 e 29 anos, com $20 \%$.

A pouca idade da população contrasta com o poder aquisitivo. A pesquisa identificou que apenas $12,4 \%$ dos munícipes são das classes D e E, ou seja, com renda familiar igual ou inferior a $\mathrm{R} \$ 880,00$ mensais. A maior parte da população ou, aproximadamente $65 \%$, ganha acima de $R \$ 2.200,00$ mensais. A classe $A 1$, com renda média de $R \$ 23.000,00$, representa $1 \%$ da população enquanto quase $4 \%$ da população pertence a classe $A 2$, com renda mensal na faixa de $R \$ 9.800,00$.

A classe $B$, com renda mensal na faixa de $R \$ 6.200,00$, concentra $24,7 \%$ da população enquanto a maioria da população, $35,8 \%$, está na classe $C 1$, onde estão pessoas com salários mensais de até $\mathrm{R} \$ 3.000,00$. Apesar de o alto custo de vida, a média salarial se mantém elevada, na faixa de $R \$ 3.276,00$, devido a pujança econômica do município.

Isto significa uma renda média 19\% maior que a média de Mato Grosso e duas vezes maior que a média do brasileiro, que é de $R \$ 1.600,00$. Somando as rendas de todas as classes sociais, circulam por Sinop, mensalmente, uma média de $\mathrm{R} \$ 337.000 .000,00$, sendo que $\mathrm{R} \$ 91.000 .000,00$ do montante geral estão nas mãos da classe $\mathrm{C} 1$.

O crescimento vertiginoso de Sinop tem levado o poder público a reorganizar seu espaço urbano e suburbano para suprir a demanda de espaço para empresas de médio e pequeno porte, com baixo e médio teor de poluição. Para este fim, o poder público criou o Loteamento Industrial, Comercial e de Prestadores de Serviços Norte de Sinop (LIC), com 27 hectares, no qual investe $\mathrm{R} \$ 6.000 .000,00$ em obras de drenagem de águas pluviais, rede de distribuição de energia elétrica, pavimentação, implantação de água tratada e terrenos. Da área total do LIC com cerca de 15 hectares foram mantidos para preservação florestal, com uma atenção especial para a nascente do Córrego Janaína. 
Quadro 05 - Comparativo das empresas constituídas em Sinop entre 2000 e julho de 2012

\begin{tabular}{|c|c|c|c|c|c|c|c|c|c|c|c|c|c|c|}
\hline & $\begin{array}{c}\text { ATÉ } \\
2000\end{array}$ & $\mathbf{2 0 0 1}$ & $\mathbf{2 0 0 1}$ & $\mathbf{2 0 0 3}$ & $\mathbf{2 0 0 4}$ & $\mathbf{2 0 0 5}$ & $\mathbf{2 0 0 6}$ & $\mathbf{2 0 0 7}$ & $\mathbf{2 0 0 8}$ & $\mathbf{2 0 0 9}$ & $\mathbf{2 0 1 0}$ & $\mathbf{2 0 1 1}$ & $\mathbf{2 0 1 2}$ & TOTAL \\
\hline INDÚSTRIAS & 843 & 83 & 93 & 74 & 96 & 60 & 45 & 55 & 45 & 63 & 113 & 150 & 136 & 1.856 \\
\hline COMÉRCIO & 1.685 & 215 & 267 & 232 & 296 & 236 & 169 & 221 & 238 & 244 & 376 & 438 & 363 & 4.980 \\
\hline SERVIÇOS & 2.299 & 347 & 382 & 429 & 451 & 331 & 302 & 321 & 312 & 317 & 431 & 589 & 405 & 6.916 \\
\hline TOTAL & 4.827 & 645 & 742 & 735 & 843 & 627 & 516 & 597 & 595 & 624 & 920 & 1.177 & 904 & 13.752 \\
\hline
\end{tabular}

Fonte: Material de Divulgação - Prefeitura de Sinop (2012)

O Quadro 05, com os dados comparativos de empresas constituídas entre 2001 e 2012, demonstra substancial diferença no crescimento de empresas instaladas no município. Por isto foram disponibilizados 196 lotes que receberão incentivos fiscais da prefeitura em forma de redução do IPTU e do Alvará de Funcionamento. Entre as empresas já inscritas estão se instalando fábricas de confecção, de barcos, de embalagens plásticas, de temperos e condimentos, de tintas e argamassa, de móveis e de estruturas metálicas, dentre outras. Outros 356 terrenos serão destinados à ampliação do LIC.

Sinop é uma cidade planejada que observa critérios urbanísticos modernos, com traçado regular e quadras interligadas por mais de $480 \mathrm{~km}$ de ruas e avenidas.

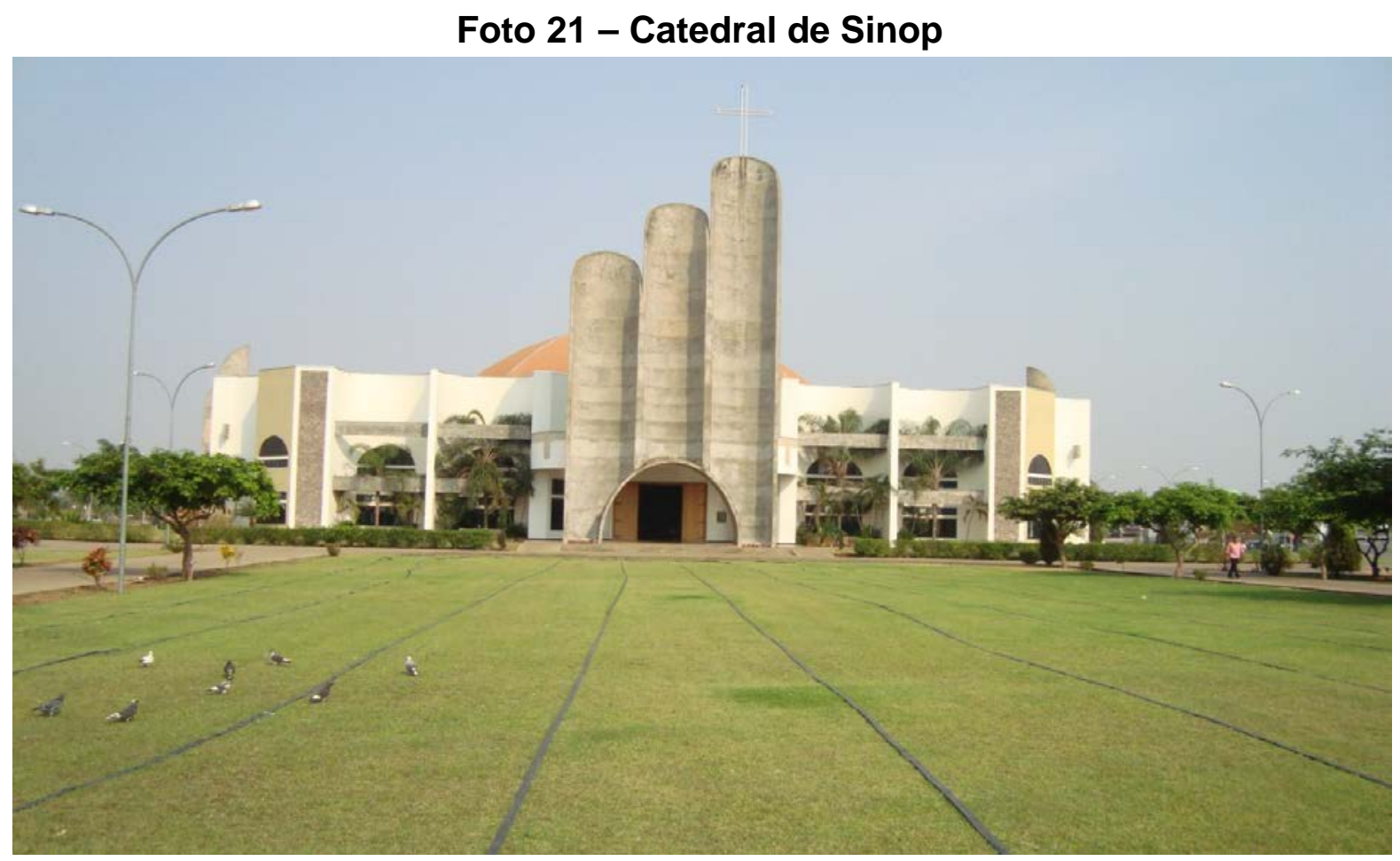

Fonte: Acervo da autora (2012) 
A melhor visão disto é o jardim da catedral, Foto 21, acima, na praça central de Sinop, que atualmente tem recebido outras construções como o Fórum e, mais recentemente, a futura sede das Promotorias, na Foto 22, abaixo.

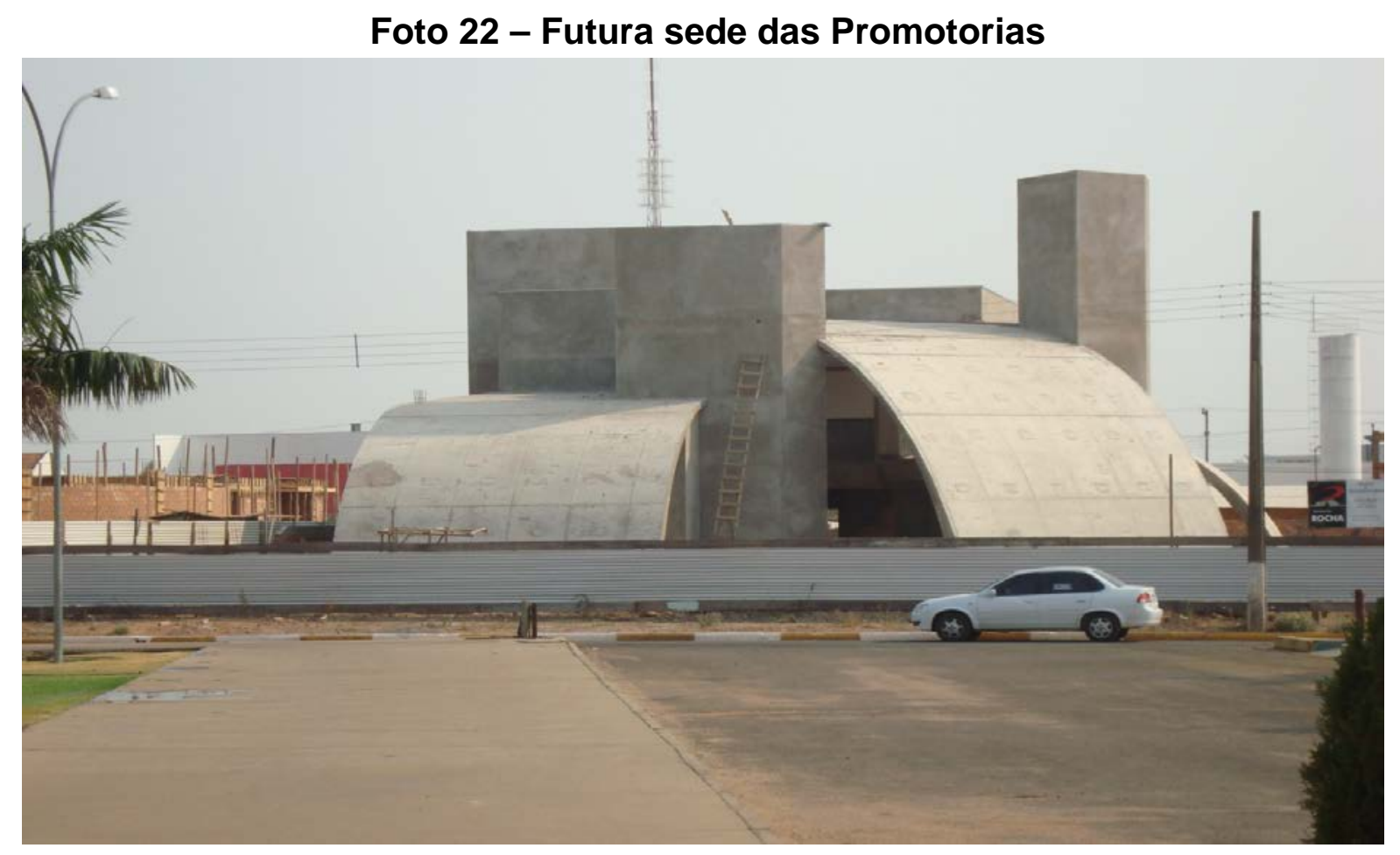

Fonte: Acervo da autora (2012)

As áreas residenciais são limitadas por avenidas com até $50 \mathrm{~m}$ e calçadas com até $7 \mathrm{~m}$ de largura. As ruas centrais têm $20 \mathrm{~m}$, com calçadas de $5 \mathrm{~m}$ de largura, que atendem à grande demanda provocada pelo aumento da frota no município que entre 2008 e julho de 2012 cresceu quase 68\%.

A administração pública de Sinop, tem uma visão de futuro muito nítida e, por isto, a importância ao conjunto de edificações públicas do núcleo urbano.

O espaço deve ser considerado com um conjunto indissociável de que
participem, de um lado, certo arranjo de objetos geográficos, objetos
naturais e objetos sociais, e, de outro, a vida que os preenche e os anima,
seja a sociedade em movimento. (SANTOS, 1988: 15).

A maioria das avenidas e ruas que levam a várias praças, reservas naturais e áreas de lazer com nomes de árvores e flores. A proposta de reurbanização para enfrentar um crescimento populacional médio de 5,07\% ao ano, a prefeitura tem incentivado empresas de maior porte, supermercados, prestadoras de serviços especializados entre outras, a deslocarem-se para áreas periféricas, não só como meio de 'desafogar' o centro, como também para abrir novas áreas para habitação. 
Esta iniciativa procura ampliar também a área de abrangência da BR-163 que atravessa o perímetro urbano por mais de 40 km e levar os projetos imobiliários para a região do aeroporto.

Como se vê na Figura 47, estão sendo implantadas dezenas de desafios urbanos em diferentes áreas, embora o que impressione, a princípio, é o interesse dos munícipes em trabalhar, ganhar dinheiro e consumir. Com esta visão de mundo, a população aceita, aparentemente, a ausência de livrarias e museus, por exemplo, além da falta de eventos como opção de lazer popular, mesmo contando com uma grande área verde em seu perímetro urbano, com reservas florestais, um parque com lago e praia artificial, além de rica fauna e flora nativa.

Figura 47 - Vista aérea do Município de Sinop

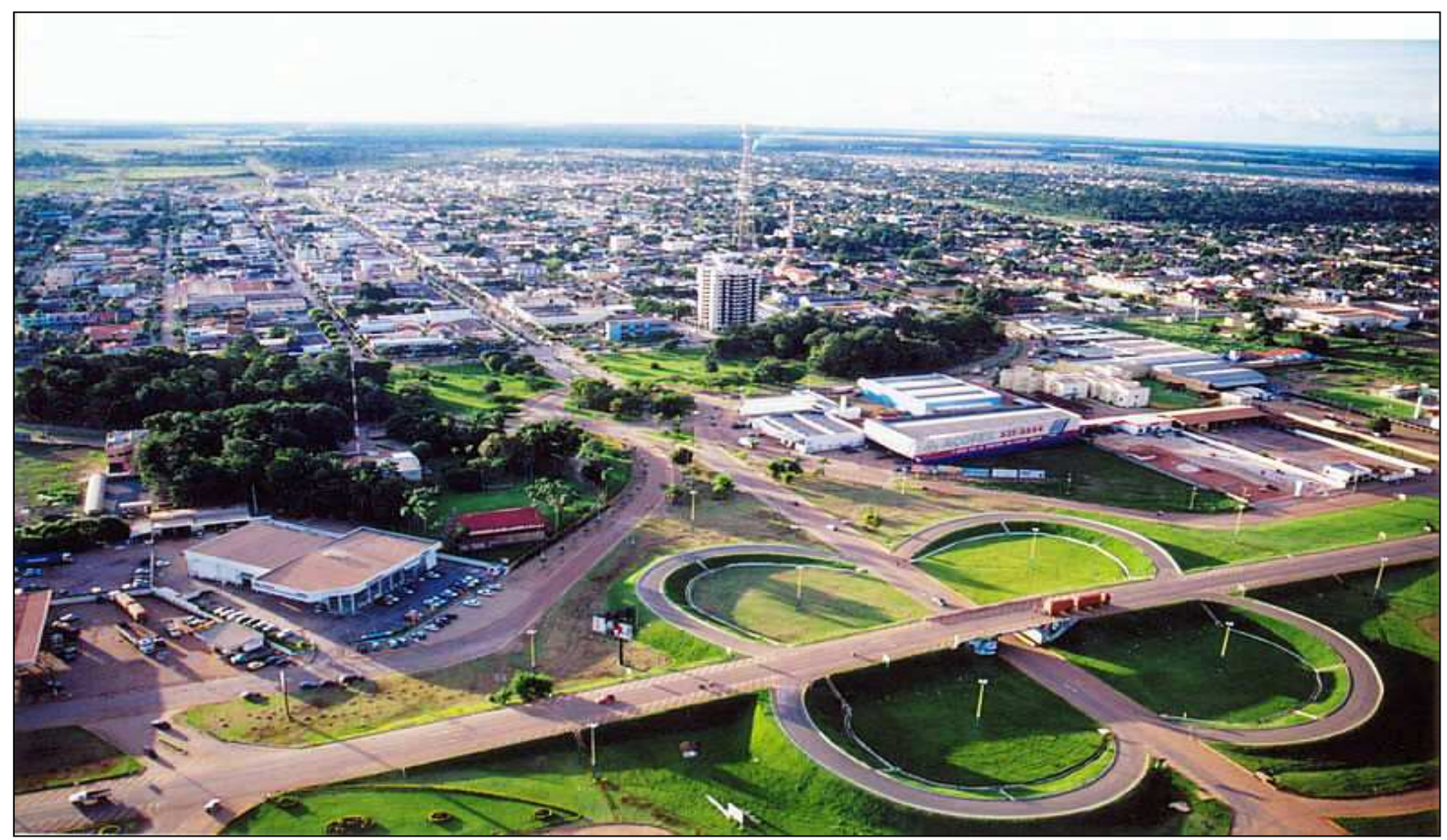

Foto: Secretaria de Comunicação Social de Sinop (2007)

Após um crescimento vertiginoso, o mercado imobiliário esfriou na região como consequência da crise do agronegócio que aconteceu entre os anos de 2005 e 2006. A partir de 2007 tornou a se aquecer e hoje os preços dos imóveis, para qualquer tipo de cliente, estão em ascensão.

Como se pode ver na planta montada pela Colonizadora Sinop, no Figura 48, a cidade acompanha o formato de uma asa delta desde sua fundação; a ampliação do espaço urbano vem mantendo a ideia inicial. 
Figura 48 - Planta do município de Sinop

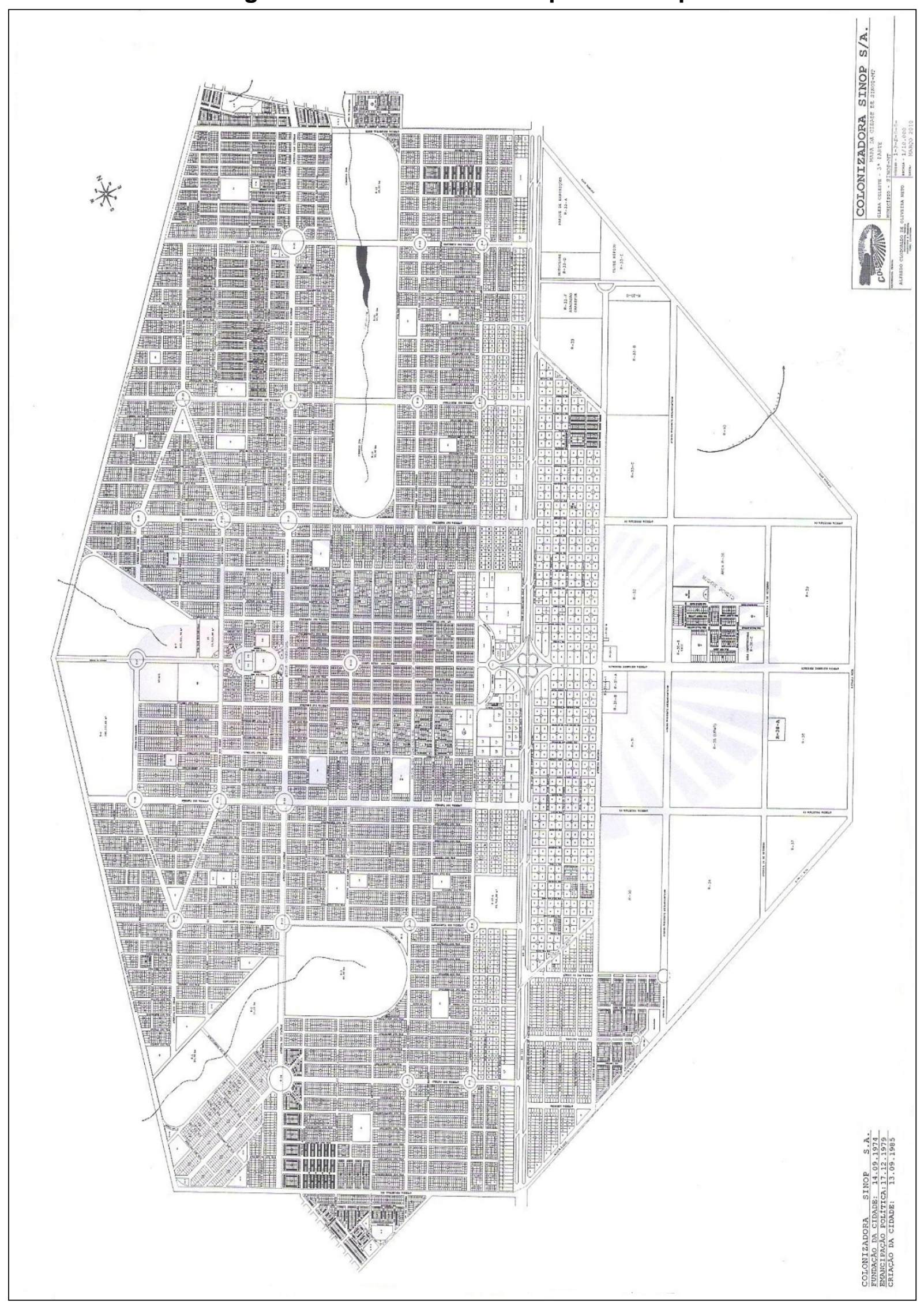

Fonte: Colonizadora Sinop (2012) 
Na opinião do professor Edison Antonio, este aquecimento se deve a alguns fatores políticos que têm alavancado a construção civil em Sinop:

Nos últimos anos está tendo aqui um investimento muito grande do governo
federal naquilo que se chama de construção civil. Se você percorrer bairros
que quando você entra na cidade você não vê, estão afastados, estão para
dentro, você vai ver loteamentos de quatro anos para cá, com milhares de
pessoas. E aí abre-se uma janela para algo muito interessante nestas
regiões aqui, que inclusive a Sonia trabalha isto em Cuiabá, que é a
questão imobiliária. A questão imobiliária aqui é muito séria. Ela tem um
poder de fogo, ela tem um poder político e ela tem um poder de influência, a
começar pela Colonizadora (Sinop). Qual é os termos deles? Que
desvalorize os bens, a questão imobiliária. Então, só estas imobiliárias, não
dão conta e aí entra a questão do PAC - Programa de Aceleração do
Crescimento, do dinheiro federal. Grande parte hoje do desenvolvimento
deste setor da construção, dos loteamentos, oficiais podemos dizer, são
verbas federais. Milhões investidos de verbas federais. E isso faz com que,
em parte, acalme ou os conflitos sejam levados para estas pessoas
morarem, mas também comprarem. Eles se endividam. Qual é o maior
sonho do habitante da fronteira? É ter a casa própria. E aí é uma questão
histórica. A gente que estuda a migração, a colonização, a gente sabe, ou
seja, porque as pessoas saem de onde saem e porque vem. Qual é o
sonho? O sonho, principalmente é da terra e essa terra que antes podia ser
a grande área, agora é a pequena área. É o sonho da ter a para ficar, mas
ter o seu terreno.

De acordo com a Prodeurbs (Projetos de Desenvolvimento Urbano de Sinop), em 2012, estão em andamento quinze projetos para novos loteamentos no município, que correspondem a uma área de aproximadamente $5.000 .000 \mathrm{~m}^{2} \mathrm{ou}$, quase um terço da área urbana. Destes, seis já tiveram ou foram oficializados e os terrenos já estão comercializados, dentro do que estabelece a lei 004/2001 que todos os loteamentos nascem, obrigatoriamente, com asfalto, redes de água, esgoto e energia elétrica (baixa tensão). O loteador tem dezoito meses para concluir a infraestrutura de cada etapa e tem até dois anos, sem isenção de IPTU sobre os imóveis que ainda não foram vendidos.

As empresas também precisam disponibilizar 10\% do loteamento para área verde e 7\% para as áreas institucionais que serão doadas para a prefeitura instalar escolas, creches e postos de saúde. Outros $20 \%$ da área total são destinados para arruamento e calçadas. Com os descontos o volume de lotes deve corresponder a $3.100 .000 \mathrm{~m}^{2}$.

De acordo com o Plano Diretor do município e com base na lei de parcelamento do solo, nenhum dos novos lotes pode ter menos de $300 \mathrm{~m}^{2}$, devendo respeitar o limite mínimo de $10 \mathrm{~m}$ de frente. Se tomada por base a medida mínima, serão aproximadamente 10.000 terrenos novos prestes a serem abertos à moradia. 
Acredita-se que a conta deva ser muito menor, na medida em que entre os projetos em andamento, pelo menos oito estão em áreas privilegiadas, consideradas nobres.

\section{Foto 23 - Nova área residencial próxima ao aeroportol Casas já habitadas (Sinop )}

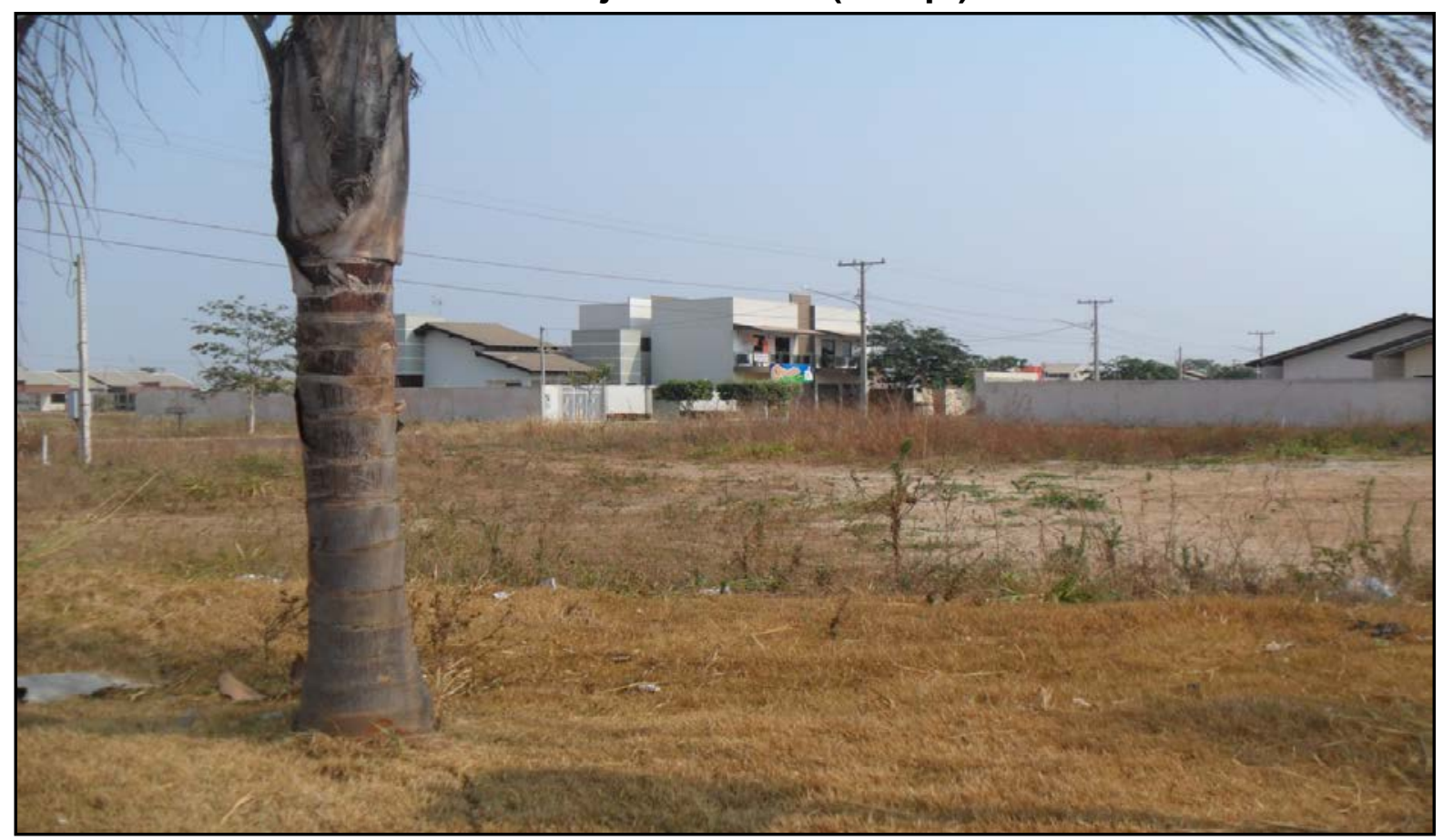

Fonte: Acervo da autora (2012)

A Foto 23, acima, demonstra que a avenida principal continua sem edificações, até que se resolvam algumas questões entre a imobiliária e a prefeitura.

Já outros quatro empreendimentos são mais populares, incluindo dois direcionados a projetos habitacionais apoiados pelo programa federal Minha Casa Minha Vida ${ }^{82}$.

Ao contrário do início da ocupação, quando a cidade crescia às margens da BR-163, agora a expansão é no sentido do aeroporto, mais para oeste. A nova centralidade está em torno da Estrada Bruno Martini, recentemente transformada em avenida para dar suporte a alguns projetos e esta também é a avenida que leva à sede da EMBRAPA a $5 \mathrm{~km}$ dali, conforme pode ser constatado na Figura 47, apresentada anteriormente.

\footnotetext{
${ }^{82}$ É um programa do governo federal que concede a baixo custo a casa própria para populações de baixa renda. É realizado em parceria com estados, municípios, empresas e entidades sem fins lucrativos. Na primeira fase foram contratadas mais de 1 milhão de moradias e o programa pretende . construir 2 milhões de casas e apartamentos até 2014. (Fonte: http://www.caixa.gov.br/habitacao.
} 
Informações obtidas junto a funcionários da prefeitura de Sinop esclarecem que o problema com a construção de casas populares foi solucionado em 2008, depois que o prefeito enfrentou uma batalha judicial, durante a qual teve de provar que a área onde a cidade foi implantada não era originária de grilagem de terra. Até então, a extensão territorial do município esteve sub judice e só a partir da comprovação, pôde ser implantado um Programa Habitacional. Em conversa com alguns munícipes que vivem na periferia, reservada para as classes menos favorecidas financeiramente, percebe-se que, na realidade, não há uma prioridade para a construção de casas populares.

O que existe, conforme o professor Edison Antonio de Souza, é um grande negócio que se respalda na baixa renda para manter a construção civil em movimento e, ao mesmo tempo, ampliar as áreas que haviam sido reservadas para dar qualidade de vida aos munícipes:

Nesta complexidade da economia política, é interessante a gente observar
isso: que aquele projeto inicial do Enio Pipino de criar um cinturão verde,
aquilo não se realizou porque o investimento imobiliário foi muito mais
lucrativo. Ou seja, nós comemos tomate, batatinha aqui que vem de
Curitiba, de São Paulo, porque não se planta aqui. Este cinturão verde virou
um cinturão imobiliário. Ele transformou as chácaras, e aí o poder, por isso
que o poder é importante, são faces praticamente da mesma moeda do
público e do privado. Então você vai observar que, nesse sentido, não
existe a favela naquele termo clássico do IBGE e assim por diante e de
outros estudiosos, mas existe uma classe social que está esparramada,
distribuída por interesses políticos e imobiliários e isto é uma questão que
só isto dá um belo estudo, que é esta questão imobiliária, do interesse de
vender as áreas mas com o dinheiro público, o dinheiro do PAC ${ }^{33}$, o dinheiro
federal muito grande que é investido aqui no município.

Com base nos dados de renda do município, somando os conjuntos habitacionais e projetos individuais aprovados pela prefeitura, conclui-se que até o fim de 2012, uma média de 3.500 novas residências serão ocupadas, aumentando em 15\% o número atual de domicílios. Se for tomado por base um imóvel de dois quartos, incluindo móveis e eletrodomésticos básicos e de modelos populares, uma família irá gastar, em média, $\mathrm{R} \$ 8.000,00$.

Por outro lado, existirão aquelas famílias que levarão os móveis e eletrodomésticos antigos e só comprarão uma parte do mobiliário. Este pressuposto aponta para uma média de $\mathrm{R} \$ 6.000,00$ por família, o que significa uma cifra de $\mathrm{R} \$$ 21 milhões, cuja maior parte será injetada no comércio lojista.

\footnotetext{
${ }^{83}$ Programa de Aceleração do Crescimento
} 
Apesar de 63\% das moradias serem ocupadas pelos seus proprietários, é relevante citar que a Colonizadora Sinop, hoje uma imobiliária com alguns privilégios, trata apenas de assuntos que dizem respeito aos proprietários de imóveis com alto poder aquisitivo.

Os programas de construção da casa própria, para os cidadãos de baixa renda, como meio de compensar os altos valores cobrados pelos aluguéis, ainda são precários, como se viu pela distribuição de loteamentos apresentada anteriormente, e excluem um grande número de famílias que necessitam de moradia. Como referência a esta discriminação velada que acontece na maioria das cidades capitaneadas pelo agronegócio em Mato Grosso, é admissível lembrar que:

Numa sociedade pressionada principalmente pela necessidade material não (há) opção entre "eliminar" a miséria e interpretá-la como inexistente. Em nossa sociedade, mais assombrada pelo risco que pela necessidade material, a opção existe - e é feita diariamente. (BAUMAN, 2001: 241).

Sinop procura eliminar as causas da miséria que tem se agravado com o crescimento do núcleo urbano e com reestruturações básicas, porém nem sempre aquelas que os moradores mais carentes acreditam ser mais urgentes. $O$ asfalto, por exemplo, significa prioridade para a população, mas a lógica urbana aponta como obra prioritária a rede de esgoto que atende prioritariamente à prevenção contra doenças entre os habitantes de classes menos favorecidas.

Ainda não existem redes de captação de esgoto na cidade de Sinop, embora o projeto de implantação para a área urbana já esteja em estudos. Atualmente o sistema de esgoto utilizado é o individualizado, construído com fossas e sumidouros.

Como afirma o professor Edison Antonio de Souza em sua entrevista, isto traz consequências bastante sérias para o núcleo urbano:

São vários os fatores que dão esta dinâmica capitalista para a cidade que por um lado, materialmente, ela cresce, mas tem problemas sérios de qualidade de vida. Por exemplo, Sinop não tem um palmo de esgoto. Como dizia um rapaz outro dia, Sinop está em cima de uma grande fossa. Nós temos problemas de água. Água tratada, tudo bem, mas nós temos problemas de contaminação. Então Sinop está passando aquilo que a professora Gilda Tomazini já estudou há uns 10 anos atrás aqui, da ilha de calor. Aqui já se formou uma ilha de calor em relação ao centro e alguns bairros, ou seja, aumentou a temperatura, pela questão da construção, do asfalto e assim por diante. Os desafios da cidade, na minha opinião, são de ordem de mentalidade. 
O crescimento vertical da população da cidade e a falta da rede de captação de esgoto e água servida causam um acentuado índice de contaminação do lençol freático, fato este que traz sérios riscos para a saúde da população.

\section{Foto 24 - Material para a rede de esgoto dos bairros próximos ao aeroporto}

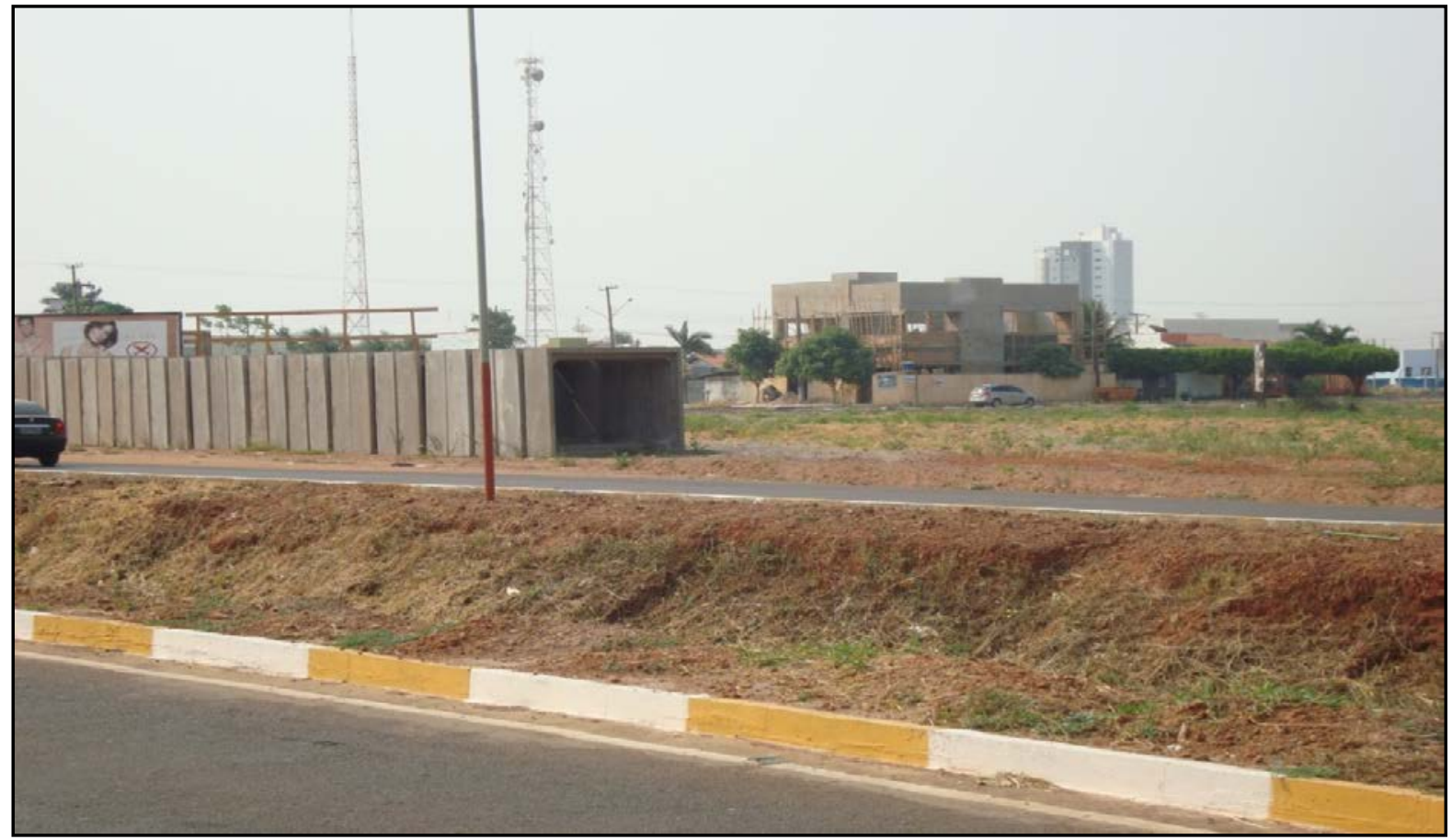

Fonte: Acervo da autora (2012)

Nos novos bairros um dos requisitos básicos para a comercialização dos empreendimentos é a instalação dos sistemas de água e esgoto. A Foto 24 mostra o material que será instalado nos condomínios que estão sendo comercializados na área próxima ao aeroporto.

Comparada a outras cidades do mesmo porte no Estado, a rede elétrica municipal já se tornou precária, mesmo estando integrada ao sistema nacional de energia elétrica através do "linhão". Esta é uma das preocupações recentes do poder público, para fazer frente ao consumo das empresas que estão se instalando no município, como nos relata o professor Luiz Erardi F. Santos em sua entrevista de 17.09.2012:

Agora está se transformando numa área industrial, não a indústria que é a proposta de Sorriso, que é a indústria de transformação de alimentos, é mais a indústria do tipo, por exemplo, a Blindex está instalando uma indústria dela aqui. Por que em Sinop? Porque aqui ela desfruta da infraestrutura da cidade a pode atender todo o norte, incluindo Sorriso, Lucas e Mutum que antes comprava tudo em Cuiabá. Outra empresa que se instalou aqui e está atendendo todo o norte de Mato Grosso, até o sul do Pará, é o Atacadão. [...] Virou uma espécie de entreposto para toda a região. Vamos pegar uma outra loja que se instalou: Lojas Americanas; se 
instalou aqui, mas com o olhar para toda a região também. Estas são algumas entre muitas que se instalaram não só aqui em Sinop como em outras cidades da região.

Recentemente, a cidade tem tomado mais impulso ainda, por conta da instalação de empresas de tecnologia de ponta, que colocam Sinop no rol das empresas de pesquisa internacionais e dão, de certo modo, novo alento aos cientistas que trabalham nos programas de preservação da Amazônia, procurando conciliá-los com a pesquisa tecnológica do agronegócio. Na opinião do professor Erardi, este também é um dos fatores que contribuem com a cidade:

O último lance de Sinop foi a EMBRAPA (Empresa Brasileira de Pesquisa Agropecuária), que foi uma perda para Sorriso, porque estava tudo previsto para ser em Sorriso. [...] É certo que tem muito a ver com o fator político, mas também tem a questão de ser mais dentro da Amazônia, de ter aqui as universidades, de também estar instalado aqui o projeto SIVAM (Sistema de Vigilância da Amazônia), além do aeroporto que é o único da região que tem voos comerciais.

De acordo com Tênisson W. de Souza, Chefe Administrativo da EMBRAPA, além destes fatores, a implantação da EMBRAPA (Empresa Brasileira de pesquisa Agropecuária) em Sinop, se deve, principalmente a sua situação geográfica e, principalmente, porque as condições são favoráveis à realização de pesquisas cujo foco principal é como será mantida a biologia do solo viva, quando a condição de aproveitamento está estreitamente ligada ao fato da necessidade de insumo que pode chegar a níveis tão altos que inviabilize a produção. Com comenta o Sr. Tênisson W. de Souza,

Quando a gente montou este centro, a gente teve uma palavra chave nessa história: integração. Você vê um prédio que ele parece que abre e fecha, mas ele é um só. Então o complexo de pesquisa é uno. Você anda nele sem sair dele. Isto é para que as pessoas mantenham uma correlação, não importa a área de pesquisa que esteja desenvolvendo. As pessoas têm a oportunidade de fazer a prática interdisciplinar, para que não fique só na teoria. Então aqui o conhecimento é feito por blocos e não mais por áreas isoladas. Dentro de um bloco só você vai ter toda a parte de sanidade animal e vegetal junto; na outra parte você vai ter toda a parte de energia e tudo perto um do outro. Você não sai de um bloco, atravessa um corredor e entra num grupo de pesquisa. Você topa com todos os grupos de pesquisa o tempo todo, porque o físico também tem que forçar. Não é só a vontade, porque o meio tem que dar condições para que isso ocorra, senão não vai ocorrer nunca. Quando nós fizemos isto aqui, nós fizemos uma série de indagações: isto vai funcionar, isso não vai?

Também era importante saber qual o conceito adotado pela EMBRAPA, uma vez que nesta região já havia muita pesquisa aplicada ao plantio de grãos? Para tomar esta decisão, foram somados a ela os conhecimentos anteriores, adquiridos 
pelos seus técnicos, além do avanço da tecnologia para resolver alguns problemas renitentes.

\begin{abstract}
O conceito que se adotou aqui foi o da unidade de Rub; todos penduram dentro de uma célula mãe. Todas as partes do conhecimento estão penduradas dentro de uma célula mãe. Aqui nós já temos 12 unidades de pesquisa. Principalmente nas pesquisas daqui, a EMBRAPA tem uma relação muito grande com o INPE (Instituto de Pesquisas Espaciais) que é na realidade o principal órgão de levantamentos dos dados da Amazônia, junto com o exército. Um dos centros da EMBRAPA, o Centro de Monitoramento Ambiental, funciona dentro do exército em Campinas. Aqui a gente vai ter uma relação muito forte com isso. Tanto é que tem um setor específico de sensoreamento remoto, para que junto com o exército e aí tem a intenção de trazer o IBAMA (Instituto Brasileiro do Meio Ambiente e dos Recursos Naturais Renováveis), não mais no sentido de polícia, mas no sentido de geração de conhecimento pró-ativo. Ao invés de sair multando, se trabalharia antes das coisas acontecerem. Mas isso é para longo prazo. Assim como a pesquisa, isto não se dá de um dia para o outro e é uma coisa cara. Pesquisa não é uma coisa barata como as pessoas pensam. Agora, o ganho com o conhecimento apropriado, é uma coisa estúpida. Se você for mensurar o que já se gerou dentro das universidades em benefício de uma sociedade, o que mudou o comportamento dela para melhor! Enquanto os países de primeiro mundo investem milhões na geração de conhecimento o Brasil investe muito pouco. Isso a gente vê que o eixo começa a mudar. A gente vê hoje tanto o privado como o poder público começar a mexer.
\end{abstract}

O Centro de Pesquisa da EMBRAPA Agrossivipastoril, que se vê na Foto 25, tem $8.500 \mathrm{~m}^{2}$ de área construída. A estrutura conta com 24 laboratórios multiusuários nas áreas de sanidade animal e vegetal, fitoquímica, biologia molecular, solo, água, biomassa, sementes e mudas.

\title{
Foto 25 - Sede da EMBRAPA em Sinop
}

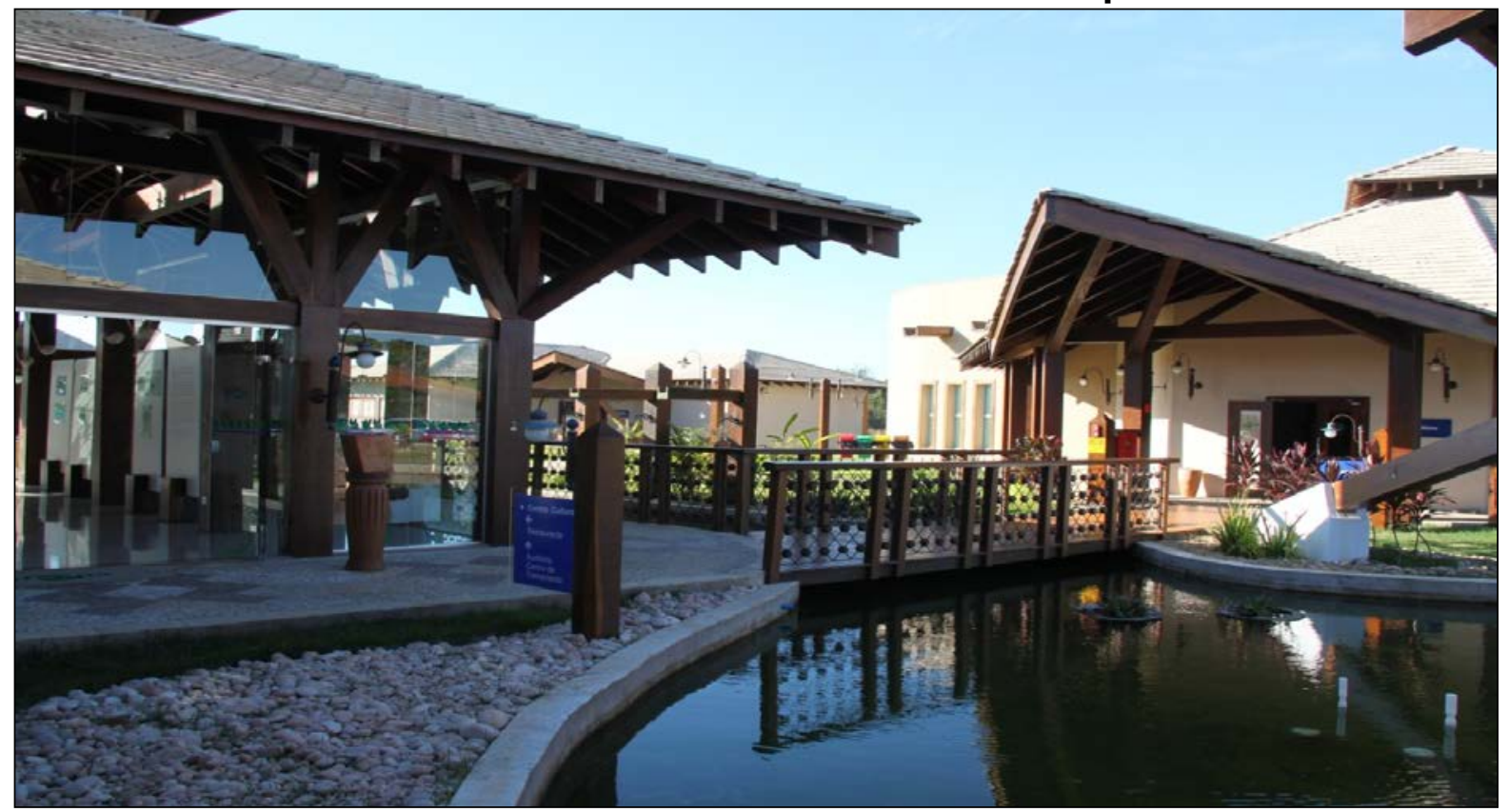

Fonte: Acervo da autora (2012) 
As salas de trabalho foram construídas de modo a alocar as equipes de pesquisa e suporte à pesquisa, sempre em duplas e com a mesma estrutura de mobiliário. Há ainda salas de reuniões, salas de estagiários e bolsistas e espaços para pesquisadores visitantes e parceiros institucionais.

A unidade tem ainda um auditório com 120 lugares, centro de treinamento, restaurante, espaço cultural e biblioteca. O setor de serviços é formado por galpões, garagem, oficina, posto de combustível, central de tratamento de resíduos de laboratório e de campo, casa de força e casas de vegetação.

Ainda conforme o Sr. Tenisson,

O meio de pesquisa que está se adotando aqui e que já vinha andando há algum tempo, é um modelo totalmente novo. Ele não é americano, não é alemão, não é australiano, ele não é nada. Ele é brasileiro. Quando a gente fala em integração de lavoura, pecuária e floresta, ou leite ou fruticultura e aí vem o sistema integrado, é brasileiro. E é uma coisa complicada porque você não está mexendo com uma ou outra variável, igual se fazia antigamente. Quando você se intera de que isto aí está mexendo com 70 a 90 variáveis cruzadas e hoje nós estamos começando a levantar os dados.

Um dos aspectos interessantes das instalações da EMBRAPA Sinop, é a sua distribuição no espaço físico.

[...] Aqui o espaço físico tem a ver com o espaço humano. Tem umas coisas interessantes aqui na área social; do menos, do operário rural, ao pesquisador, a mesa é a mesma a sala é a mesma e a cadeira é a mesma. Não tem diferença estrutural. Todos podem gerar conhecimento; desde o operário do campo, o menorzinho, desde que sejam dadas as condições a ele. É uma coisa interessantíssima você ver o conhecimento chegar porque você oportunizou ao pequenininho a chance dele mostrar sua criatividade.

Para ele, um dos pontos importantes na tarefa da EMBRAPA-Sinop é a sustentabilidade,

[...] Muito se fala em sustentabilidade, mas o que é que é isso? Nada mais nada menos que o equilíbrio das coisas. Uma das nossas missões aqui é esta: como identificar e descrever estes indicadores.

Também está instalado em Sinop o radar do Sivam - Sistema de Vigilância da Amazônia, que monitora de Sinop toda a área da Amazônia Legal. Além deste orgão federal, a EMBRAPA (Empresa Brasileira de Pesquisa Agropecuária), também instalou ali sua sede, a única do Estado de Mato Grosso.

Considerada como cidade da indústria educacional, Sinop recebe, semestralmente, um grande número de jovens que desejam frequentar um curso superior. O campus avançado da UFMT (Universidade Federal de Mato Grosso), frequentado por aproximadamente 2.400 acadêmicos, desenvolve projetos 
específicos para a região nas áreas de medicina veterinária, zootecnia, agronomia, engenharia florestal, enfermagem e ciências naturais. Já a UNEMAT (Universidade do Estado de Mato Grosso) atende 2.150 acadêmicos nos cursos de ciências contábeis, engenharia civil, administração de empresas, matemática, economia pedagogia e letras. Este também é um dos fatores que contribui para o desenvolvimento da cidade, como bem coloca o professor Erardi:

O que acabou transformando Sinop de fato foi a área educacional. Hoje a cidade é o maior polo educacional do interior de Mato Grosso; só perde para a capital. Tem as duas universidades aqui: a federal e a estadual. Tem a UNIC (Universidade de Cuiabá) que é privada; tem a FASIPE (Faculdade de Sinop), que é particular; tem a UNIC, que tem dois campus. A Federal (Universidade Federal de Mato Grosso) atraiu muito estudante de fora. Já tem medicina veterinária, em 2014 vai entrar medicina ${ }^{84}$.

O número de alunos que frequentam as faculdades em Sinop tem aumentado muito nos últimos anos e hoje o município atende estudantes de todo o Brasil e principalmente os que chegam do sul do Pará e de todas a região norte de Mato Grosso.

\section{Foto 26 - Prédio da FASIPE em Sinop}

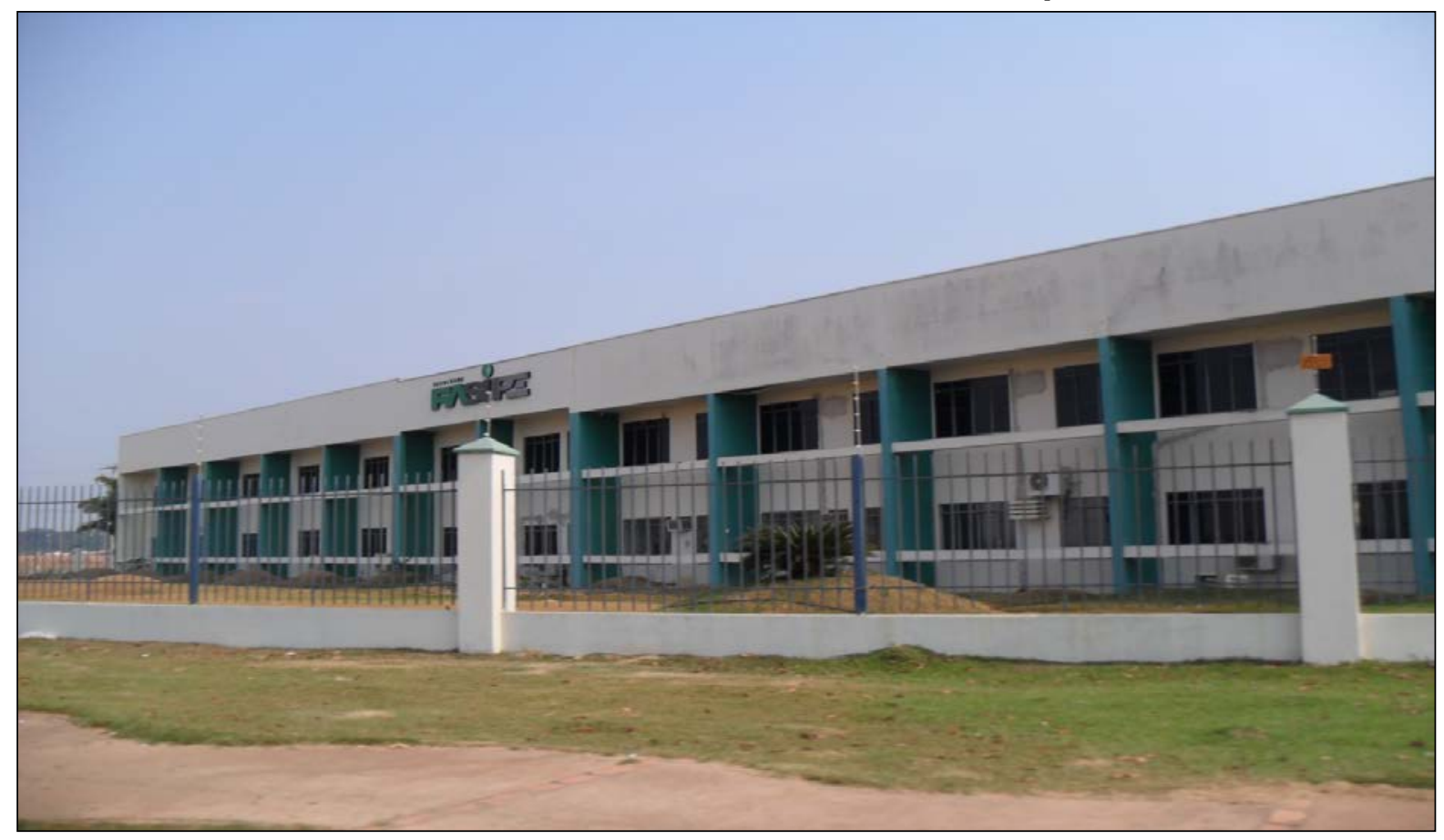

Fonte: Acervo da autora (2012)

O número aproximado de estudantes está assim distribuído: FASIPE) (Faculdade de Sinop) na Foto 26, com 1.216 alunos; UNIC (Universidade de

\footnotetext{
${ }^{84}$ A Faculdade de Medicina da Universidade Federal de Mato Grosso recebeu a licença do Ministério da Educação para abrir 60 vagas em Sinop a partir do segundo semestre de 2013.
} 
Cuiabá), com 1.450 alunos; FACENOP (Faculdade de Jornalismo de Sinop), com 30 alunos; REGINA PACIS/UNINTER, com 450 alunos; CEPI/EADECON/UNITINS, com 250 alunos e Faculdade Cenecista - CNEC 9Campanha Nacional de Escolas da Comunidade de Sinop), que oferecem vários cursos, permitindo à cidade ampliar sua área de influência sobre outras cidades da região.

$\mathrm{Na}$ opinião do professor Edison Antonio de Souza, o discurso que evoca Sinop como cidade da indústria educacional e da pesquisa faz parte de um contexto político que começa a se delinear:

\begin{abstract}
Existe um discurso do progresso, uma ideologia do progresso e existe toda uma engenharia para mostrar isto. O que acontece: a elite, a classe dirigente eu não diria a classe dominante, porque a classe dirigente domina pelo consenso, esta classe dirigente que controla os que têm os grandes meios de comunicação e a mídia, tem um grande discurso. Se você acompanhar o programa eleitoral daqui agora, você vê isso. Sinop, que era capital do Nortão agora vai se tornar capital do conhecimento, ou seja, eles apropriam algo, porque tem as universidades, porque tem a EMBRAPA, só que eles não falam que a EMBRAPA vai levar de 5 a 10 anos para ter resultado de pesquisa. Só que eles não falam que a UFMT, por exemplo está em greve há 4 meses e para arrumar isso ainda vai mais uns dois anos e olhe lá. Ou seja, esta questão é muito mais complexa.
\end{abstract}

Além do urbano, indiferente a cada peculiaridade que ele contém o que se pretendeu, até aqui, foi reunir as diferenças para mostrar na força do pioneirismo a questão do invisível, colocada tanto por Santos (2006) como por Smith (1983), e que na área da abrangência da BR-163 é assunto tabu, mas de grande relevância. Conforme continua a explicar o professor Edison Antonio de Souza durante sua entrevista concedida em Sinop,

A cultura é muito conservadora, muito reacionária, um povo em grande parte bastante frio, existe um certo neo-fascismo aqui e distinção social, existe isso, mas a questão fundamental da distinção social aqui é o dinheiro. É o ter. E isso você vai encontrar muito mais sério e mais claro em Sorriso. Isso em Sorriso é muito mais forte. Se você chega a pé numa loja para comprar uma bolsa, dependendo do lugar onde você for não sei se você vai ser recebida. Eu falo isto porque aconteceu lá com uma conhecida minha. A questão mais interessante para você observar é a violência, a agressividade no trânsito.

$\mathrm{Na}$ concepção do professor Edison Antonio de Souza muito dos sentimentos dos habitantes da região amazônica, é pautado pelas questões de fronteira.

E aí, não sei se você vai tratar da questão da fronteira, esses tempos da fronteira. O que é a fronteira? Aí vai encontrar trezentos conceitos, de Turner a Souza Martins e outros, mas o que é esta fronteira matogrossense? $\mathrm{O}$ que ela diferencia esses tempos sociais essas pessoas que vieram do sul do Brasil e vieram para cá. Por exemplo, eu estou estudando a questão da presença dos gaúchos em Mato Grosso. O que identifica este gaúcho que está em Mato Grosso? Esse rio-grandense. Como ele se 
relaciona? E é interessante, os meus estudos têm encontrado isso, ou seja, o rio-grandense que veio para Mato Grosso é principalmente descendente de italiano e alemão. E aí eu fui estudar; eu tenho colegas que estão estudando esta questão no Rio Grande do Sul, em Passo Fundo, ou seja, quem são estas pessoas e como elas se relacionam aqui. Por que esse cara que lá no Rio Grande do Sul não usava bombacha, aqui ele usa? Por que aqui ele frequenta o CTG - Centro de Tradições Gaúchas e lá isso só acontece de vez em quando, com uma diferença: aqui ele só frequenta o CTG se ele tiver dinheiro. Aí é que está o diferencial. Qual é a questão? É o dinheiro, é o capital. Então, ele vai frequentar o CTG, ele vai usar bota e bombacha, morrendo de calor que nem eu vi aqui.

Esta chancela pode ser percebida pelo professor Edison Antonio de Souza até mesmo em sua vizinhança:

E aqui é interessante, eu tenho um vizinho que mora logo aqui atrás que é
empresário, tem loja, tem duas fazendas, etc e eu o conheci lá no sul e
agora aqui; nunca o vi de bombacha e de bota. Só que agora, aqui ele está
agora com 5 milhões de capital, ele sai pilchado, suando, mas ele vai para o
CTG. Mas então, esse gaucho que vai para o CTG aqui, em Ipiranga do
Norte, Tapurah, Sorriso, é o gaúcho que tem dinheiro. Senão ele não vai,
por duas razões: uma porque se ele for de fusca ou qualquer outro carro,
ele vai ser rechaçado com o olhar. É o que Foucault já disse: ele será
controlado pelo olhar. Se ele for com uma caminhonete, ele será bem
recebido e bem aceito. É nesse CTG que serão discutidos os rumos
políticos da cidade e da região. Esse gaúcho, na concepção dele, ele traz o
ideal de civilização e modernidade da fronteira.

As cidades atraíram para si inúmeros fracassos e sucessos que o tempo foi transmutando em pujança, a ponto de suas populações não estão mais inermes aos ataques psicológicos, morais ou físicos. Hoje, todos têm consciência de que "o que é direito, lei ou obrigação, se olharmos a coisa do lado do poder, o novo discurso mostrará como abuso, como violência, como extorsão, se colocarmos do outro lado." (FOUCAULT, 2005:81).

Ao olhar estas coisas da lei ou obrigação, mesmo do lado do poder, como é o caso da visão do Sr. Leonildo Bares, presidente do Sindicato Rural de Sinop, mostrará uma visão intermediária a de Foucault, uma vez que apesar da violência e da extorsão sobre a qual todos os imigrantes pioneiros têm a própria opinião formada, persistiu a ideia de Bauman (1998) de que "além da curva, existe, deve existir, tem de existir uma terra hospitaleira em que se fixar" quando ele diz:

Por que é que nós tornamos Mato Grosso tão grande quanto é? Eu me perguntei isso muitos anos e um dia eu achei a resposta. Porque entre vir para o Mato Grosso e voltar para o sul ficar aqui ainda era melhor, por ruim que fosse. Foi por isso que Mato Grosso deu certo. Porque os que vieram com dinheiro foram embora, porque era melhor voltar. Mas os que estavam aqui, como a minha sogra, era melhor matar o papagaio, porque no Paraná não tinha nem o papagaio para matar. Primeiro porque tinham vendido tudo o que tinham lá, se é que tinham; depois a vergonha de chegar e falar para 
a família: chegamos sem nada e aí trabalhar de empregado no próprio sítio que você vendeu. $O$ orgulho humano falava. $O$ ego não permitia que as pessoas voltassem. Então, já que tinha que ficar, tinha que lutar. (BAUMAN, 1998:92)

Pode-se dizer que a visão de infraestrutura dos municípios escolhidos para esta pesquisa está alinhada no contexto discutido por Lefebvre (2004):

A cidade atrai para si tudo o que nasce da natureza e do trabalho, noutros lugares: frutos e objetos, produtos e produtores, obras e criações, atividades e situações. O que ela cria? Nada. Ela centraliza as criações. E, no entanto, ela cria tudo. Nada existe sem troca, sem aproximação, sem proximidade, isto é, sem relações. Ela cria uma situação, a situação urbana, onde as coisas diferentes advêm umas das outras e não existem separadamente, mas segundo as diferenças. O urbano, indiferente a cada diferença que ele contém, é considerado frequentemente como indiferença que se confunde com a da Natureza, com uma crueldade que Ihe seria própria. Contudo, o urbano não é indiferente a todas as diferenças, pois ele precisamente as reúne. (LEFEBVRE 2004:111).

O aprofundamento deste conceito é o que se procura encontrar nas outras histórias pessoais contadas por eles no próximo capítulo, e que darão a visão de como cada pioneiro percebeu que, como afirma Lefebvre (2004), "o urbano não é indiferente a todas as diferenças, pois ele precisamente as reúne". 


\section{$3^{\circ}$ CAPÍTULO}

\section{3 - AUTÓCTONES E IMIGRANTES}

\section{1 - AMPLIAR FRONTEIRAS: SANGRAR FLORESTAS E AUTÓCTONES}

A nova divisão territorial imposta à região norte de Mato Grosso encontrou dificuldades por causa da indefinição por parte do governo federal quanto ao modus vivendi com as comunidades autóctones, principalmente com os povos indígenas que, em determinado momento, estavam atrapalhando a realização do projeto traçado para avançar as fronteiras através da BR-163 até se encontrar com a Transamazônica, BR-230 como se vê na Figura 49, abaixo;

\section{Figura 49 - Principais rodovias da Amazônia Legal}

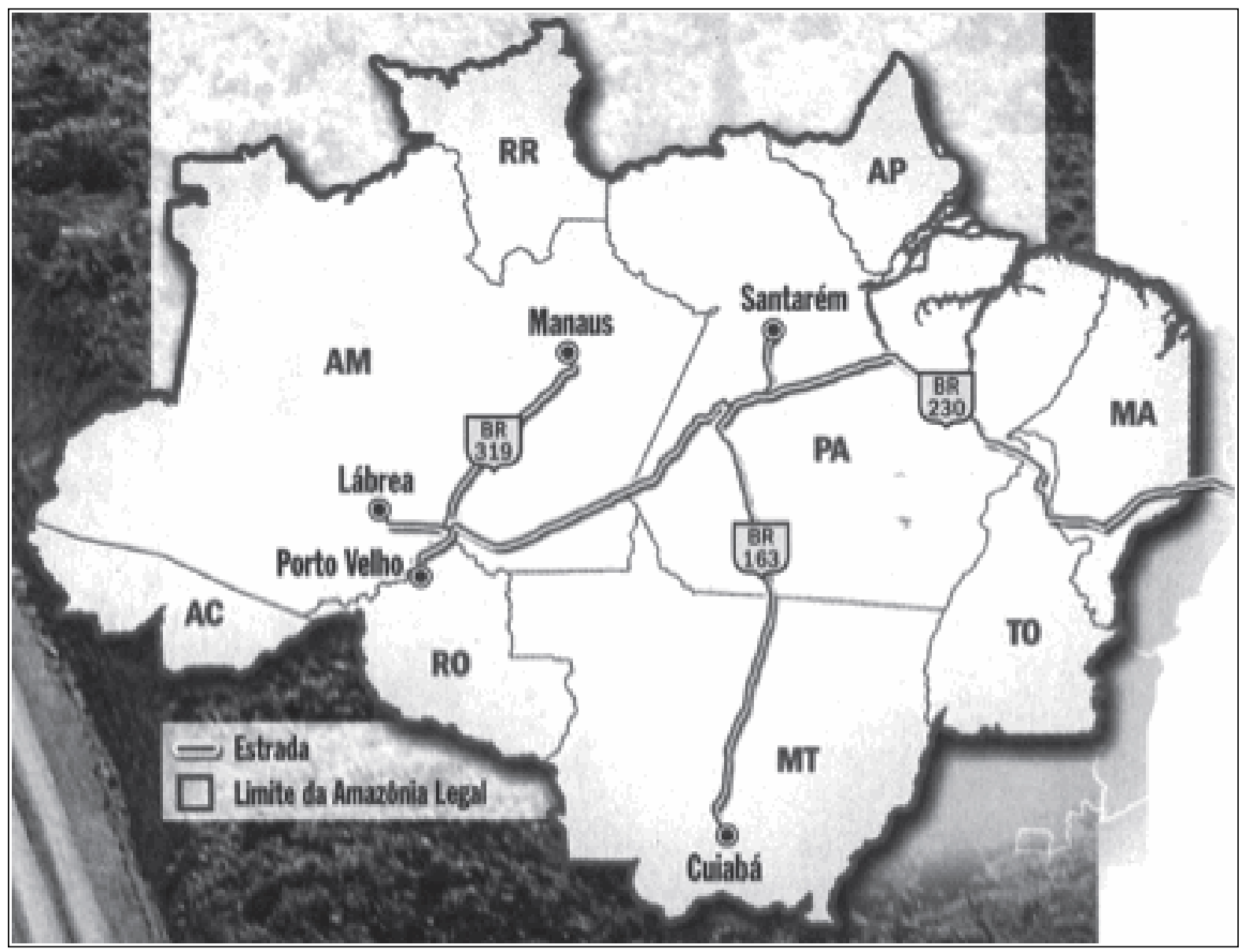

Fonte: Site Geografia para todos (2012)

Sem leis inclusivas que determinassem com clareza quais eram as áreas de proteção permanente para o povo indígena ou quais as terras seriam destinadas à sua agricultura de subsistência, eles permaneceram na condição de parcialmente 
capazes e, neste caso, ainda com a animosidade dos não-índios por conta da acusação de estorvarem o avanço do progresso e da fronteira agrícola brasileira.

Para Rossetto (2011:51), "com o avanço da fronteira agrícola brasileira, diversas etnias indígenas foram dizimadas ou transferidas para o Parque Indígena do Xingu, criado em 1961", como foi o caso dos Panará que viviam na região da Serra do Cachimbo/ MT, próximo à divisa com o estado do Pará.

O avanço da fronteira agrícola brasileira ao qual se refere Rossetto (2011) se deve à reinvenção do conceito de Amazônia Legal para fins de planejamento que, como fruto de uma ideia política e não de um imperativo geográfico, trazia em seu bojo a intenção do governo federal de colocar a Funai (Fundação Nacional do Índio) em contato com os índios que habitavam a região da Serra do Cachimbo para convencê-los a facilitar a passagem da BR-163. Para o governo federal, a melhor forma de solucionar o impasse seria agrupar todo o contingente indígena naquele momento representava um entrave ao avanço do capitalismo, no Xingu.

Coube aos irmãos Villas Boas levar estes índios para o Parque Nacional do Xingu, mesmo sabendo que todo tipo de relocação indígena tinha todas as probabilidades de não dar certo, principalmente neste caso, porque estes índios pertenciam a etnias tão diferentes que se consideravam praticamente inimigas umas das outras. De qualquer forma, o traslado das aldeias foi realizado e, como se previa, o que se constata hoje é o retorno da maioria dos índios às regiões de onde foram retirados.

Alguns índios conseguiram se readaptar em áreas próximas às antigas terras de onde haviam saído, mesmo com a natureza já transformada e com vários dos seus sítios sagrados tomados pelos não-índios. Outros povos indígenas, devido à falta de condições de sobrevivência na natureza, por conta do desmatamento e suas consequências no equilíbrio ecológico, passaram a procurar outros meios de sustento e moradia nos núcleos urbanos. Como seria previsível, passaram fazer parte de uma população de baixa renda, por dificuldade em se adaptarem à vida na cidade.

Embora existam figuras das áreas indígenas no estado de Mato Grosso, assim como a Figura 50, a seguir, ainda não existe uma demarcação definida para as áreas de preservação, nem condições socioeconômicas de sobrevivência devido ao definhamento de seus espaços, a vida da população autóctone passou a ser mais difícil. Por um lado, não haviam recebido uma educação que os tivesse 
preparado para sobreviver entre os não-índios, muito menos para serem inseridos num mercado de trabalho que exigia dia a dia mais qualificação e conhecimento de novas tecnologias; por outro, o que se percebe hoje nos municípios próximos às aldeias indígenas, é que esta população se viu cada vez mais dependente das prefeituras, por falta de opções no mercado de trabalho e por terem certas dificuldades para se adaptarem ao modo de vida dos não-índios.

Daí não ser raro colocarem entraves na organização social dos não-índios, utilizando expedientes como bloqueios de estradas ou importantes avenidas nos núcleos urbanos mais próximos, para reivindicar soluções de impasses pontuais que ocorrem em suas aldeias.

Figura 50 - Áreas indígenas no Estado de Mato Grosso

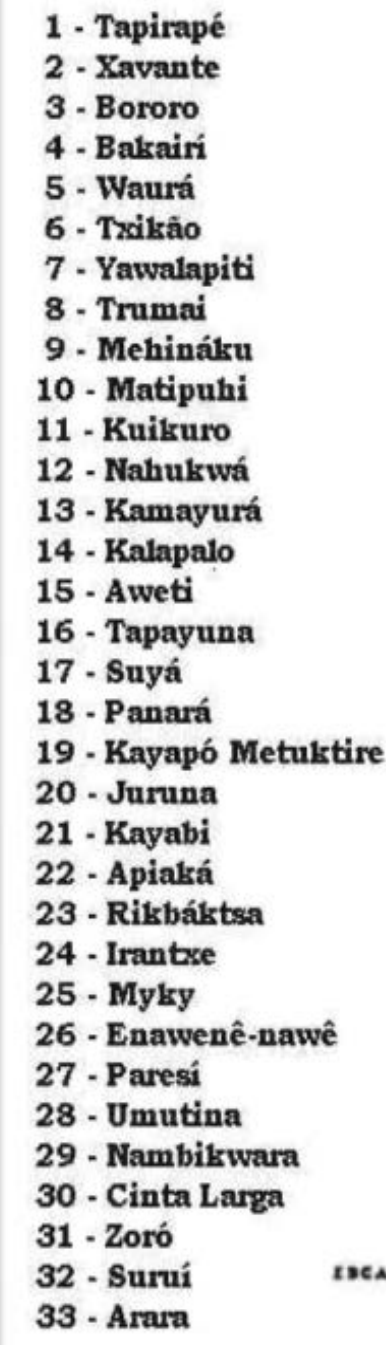

1. Tapirapé

9. Mehináku

10- Matipuhi

11 - Kuikuro

12 - Nahukwá

13 - Kamayur

- Kalapa

19. Kayapó Metuktire

20 - Juruna

21 - Kayabi

22 - Apiaká

23 - Rikbáktsa

24 - Irantse

25 - Myky

26 - Enawenê-nawê

27 - Paresí

28 - Umutina

29 - Nambikwara

30 - Cinta Larga

33 - Arara

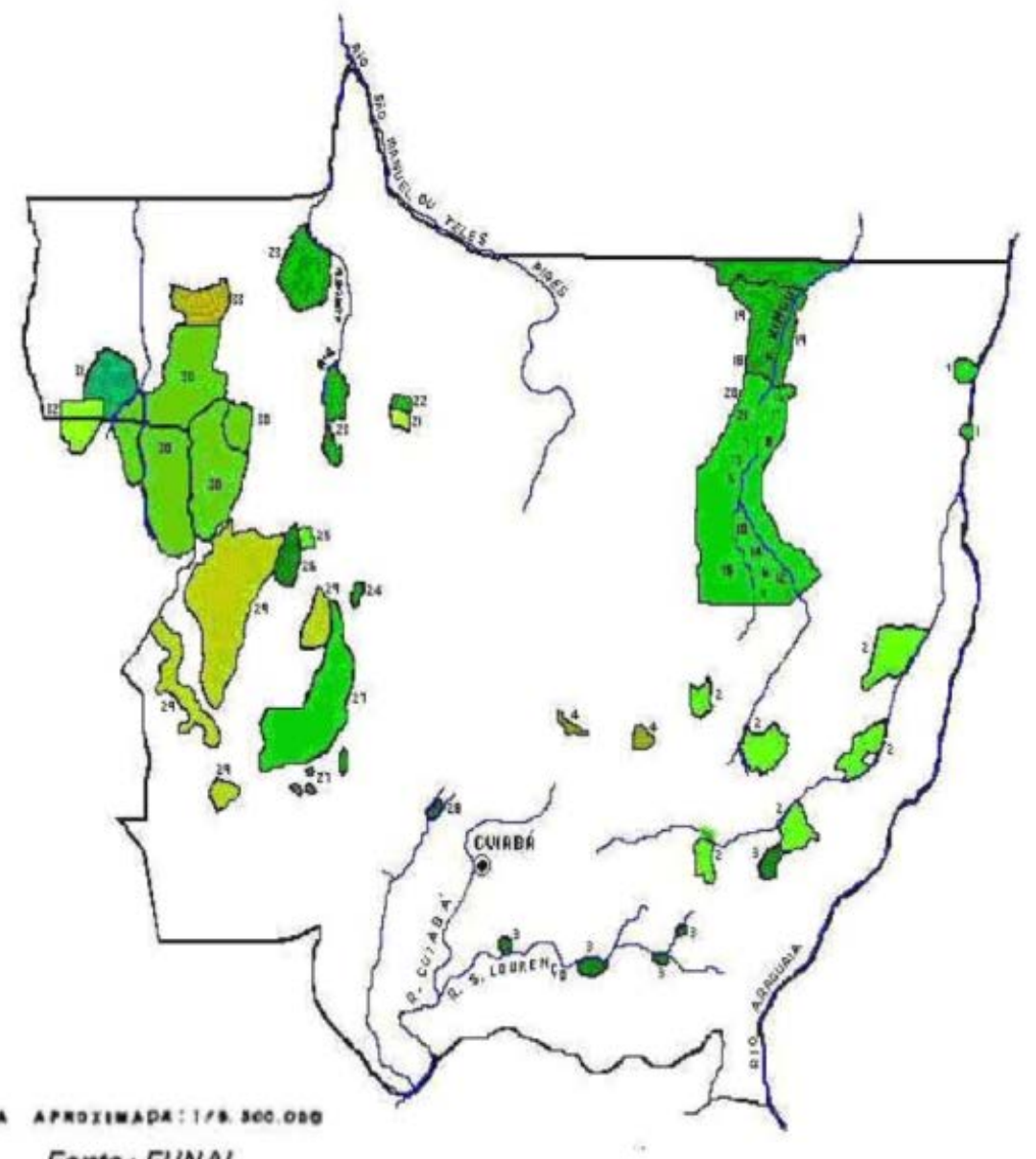

Fonte: FUNAI

Fonte: FUNAI (2011) 
Nesse sentido, é importante o pensamento de Lévi-Strauss (1962:353) quando afirma que "o indígena é um capitalizador lógico, (porque) ele refaz, sem cessar, os laços, redobra incansavelmente sobre si mesmo todos os aspectos do real, sejam eles físicos, sociais ou mentais". Isto significa que os municípios matogrossenses que têm mais proximidades com as populações indígenas precisam criar políticas públicas mais adequadas para manter uma relação menos conflitante entre índios e não-índios para, inclusive, atenuar o preconceito vigente nestes núcleos urbanos.

Para alguns dos imigrantes pioneiros, à região à medida que as obras da BR163 avançavam para o norte, a presença indígena não afetou em nada a proposta de expansão agrícola. Para outros, no entanto, configurou-se na oportunidade de aproveitar a falta de estrutura do Estado e impor o próprio arbítrio; foi quando praticaram todo tipo de desmando e atrocidade, até atingirem seus objetivos e praticamente dizimarem os índios desta região, provavelmente da etnia Bakairí, entre as décadas de 1960 e 1970. Ainda existe um número muito reduzido de remanescentes vivendo na área hoje ocupada pelos municípios de Nobres, Diamantino e Sorriso (ver área maior em verde no alto à direita da Figura 33)

Huber (2010) relata em seu livro o que ouviu de José Armando Ribeiro, um mateiro que conhecia muito bem a região:

Um pouco mais ao sul, na região do rio Verde ${ }^{85}$, por conta da intensiva exploração de látex, os indígenas já haviam se evadido porque os seringueiros invadiram suas terras. Em 1972, ainda restavam alguns índios da tribo Beiço-de-Pau rodando pelas margens do rio Arinos, que acabaram sendo convencidos a se transferirem para o Xingú, para encontrar com seus familiares anteriormente expatriados. Contava ainda o mateiro que outros viram como os seringalistas e seus capatazes misturavam arsênico nas sacas de açúcar e farinhas destinadas aos silvícolas, em seus depósitos de abastecimento de mantimentos. Sabiam que os índios iriam se servir ou se apossar delas porque, por tradição, consideravam todos os bens como de todos. Os agressores sinalizavam as sacas que continham produtos envenenados com uma cruz vermelha, para alertar seus próprios peões e companheiros, poupando-os do envenenamento. Os índios, com fortes cólicas e, impelidos por insaciável sede, iam beber água no rio e ali mesmo caiam desfalecidos. Em consequência disto, os colonizadores viam um grande número de corpos boiando rio abaixo. Outra tática perversa era reunir roupas sujas dos leitos de moribundos vitimados por doenças contagiosas no hospital de Diamantino e presenteá-las aos índios, pois sabiam que eles tinham baixa imunidade e não resistiriam muito tempo. Contou ainda que os capatazes dos donos de fazendas, empresários poderosos de cidades brasileiras e estrangeiras, simplesmente passavam com seus tratores de esteira sobre as malocas, destruindo tudo. [...]

\footnotetext{
${ }^{85}$ Área menor na cor verde mais escura do Figura 33.
} 
Conforme André, outro mateiro, os problemas com os indígenas surgiam à medida que a derrubada das matas progredia. (HUBER, 2010:19 a 21).

A principal pergunta seria: por que tanta atrocidade? Simplesmente para avançar a fronteira agrícola apoderando-se de terras que, teoricamente, estariam em área indígena? Entre os índios se percebe total desinteresse em falar a respeito; o que passou, passou, desconversou um índio. Mas, a maioria das informações ainda reverbera na memória coletiva. A prova cabal disto é que até pouco tempo, nenhum índio aceitava qualquer tipo de comida, sem que o doador não-índio a comesse primeiro, na sua frente.

A releitura da história oral que poderia ser feita através do diálogo com alguns remanescentes, se cala em suas almas, para dar lugar a uma forte vontade de mudar o rumo de suas histórias. O que mais desejam é enterrar, no passado, as vicissitudes, privações e violações de direitos, para começar vida nova.

Caberia aqui resumir o pensamento de Condorcet (1993:196), expresso na primeira metade do século XVIII, quando se referiu ao aviltamento aos direitos humanos: "o costume pode familiarizar os homens com a violação dos seus direitos naturais a ponto de entre aqueles que os perderam ninguém sonhar em reclamá-los nem crer que tenha sofrido injustiça".

Apesar deste tipo de sentimento aplicar-se a um número expressivo de autóctones, é importante saber o que efetivamente aconteceu com eles e o que pensam os imigrantes pioneiros e a geração que já nasceu na região, ou esteja chegando recentemente à área de abrangência da BR-163.

De que forma estes grupos sociais imaginam políticas públicas para ampliar o mercado de trabalho nos núcleos urbanos, ou de que forma acreditam que o poder público possa mitigar as disputas pela terra, até hoje ainda tão controversas. Quais serão os vetores deste futuro promissor, depois de implantada a indústria de transformação que atrairá um número expressivo de novos habitantes, provocando uma nova demanda de moradia, educação e saúde?

O raciocínio do mercado empregador, neste momento, os vetores têm caminhos bem delineados que apontam um futuro mais industrializado, como explica Luciene Francio, Diretora Presidente da Colonizadora Feliz e filha de Claudino Francio, fundador de Sorriso:

A cidade está cada vez maior independente da produção de soja e esta é uma das coisas que a gente busca, porque a soja não consegue acomodar muita gente. A tendência é acomodar cada vez menos pessoas; a gente 
reconhece isso e sabe disso porque para aumentar a produtividade e diminuir custos é a máquina, não adianta. Nossa preocupação é transformar a produção, o processo de transformação, com linhas de industrialização desse produto que produzimos e transformar isso em carne. Não estamos conseguindo achar o equilíbrio econômico desse processo porque o grão está subindo demais e a carne não acompanha. Então é assim: suinocultura em crise, o boi com preço baixo, e não estamos conseguindo o equilíbrio econômico, mas a gente sabe que este é o caminho; pegar este grão, seja milho, seja soja, seja o que for, e transformar em alimento através do processo que transforma em carne e transforma em alimento. Isso a gente sabe. E também tudo o que for derivado; mas aí é a indústria, a industrialização do processo; trazer para cá o processo industrial e não vender mais nada in natura. Este é o nosso sonho.

Com a atenção voltada entre o presente e o futuro, a Sra. Luciene Francio tem bem clara a proposta de ampliação do processo de produção de grãos, que inclui a transformação da soja, por exemplo, em produto acabado.

Agregar valor e reduzir custo, porque você não está levando grão, está
levando para um processo industrializado, e para o Brasil cria divisas; é o
cúmulo a gente mandar a soja in natura e depois compra os derivados. É
aquele velho dilema do Brasil: manda in natura depois compra
industrializado. Então a gente sabe que o caminho a percorrer é este,
trabalhando com todos os pontos críticos: absorver mão de obra, capacitar
esta mão de obra para a indústria, porque quem absorver tem que
capacitar. Por isso a nossa renda per capita é alta. É em função da alta
capacitação dos técnicos da produção. Eles ganham muito bem, você tem
que pagar bem porque não vai colocar uma máquina de quase 1 milhão de
reais na mão de um funcionário qualquer. Tem que pagar bem para ter um
bom funcionário. Só que realmente está diminuindo a oferta de mão de obra
nas fazendas. A migração que acontece em Sorriso, assim como em Lucas e Sinop, trata principalmente de maranhenses que não têm condições de voltar porque a vida no Maranhão de onde vieram, nas áreas de garimpo mais ao norte de Mato Grosso ou no Pará, por onde já haviam tentado a sorte, oferecia ainda menos oportunidades. A questão migratória é histórica e, no caso destas cidades da área de abrangência da BR-163, é movida pela busca por melhores condições de vida, como explica o professor Edison Antonio de Souza:

Tem todo um trâmite histórico desde a colonização dos que quebraram, voltaram que foram para o sul, foram fazer parte do MST, quer dizer, o fenômeno migratório brasileiro existe desde que os portugueses chegaram aqui, porque é uma questão de exclusão social. Como o Souza Martins fala, é expropriação. É uma questão de luta pela terra, mas também é uma questão de sobrevivência. É a reterritorialização que você vai encontrar mais claro em Lucas, entre nordestinos que vieram para Mato Grosso para trabalhar na atividade madeireira (Sinop), que foram para o sul do Pará (garimpo), que voltaram de lá, porque existe uma teoria que diz existirem fatores atraem e que fatores expulsam. Que fatores os expulsaram de Vera, de Marcelândia e de Sinop? O fator econômico causado pela crise da atividade madeireira. $\mathrm{O}$ que os atraiu para Lucas? A agroindústria. 
A grande dúvida, para o professor Edison Antonio de Souza, é a forma como está sendo tratado este trabalhador que circula de um lado para o outro, de um Estado para o outro em busca de trabalho.

Mas qual a condição de trabalho desse povo? Onde eles estão vivendo? Quanto eles estão ganhando? Quanto eles estão pagando de aluguel? Quanto eles estão pagando pelo custo de vida? No caso de Sorriso, que é um divisor de águas, no bairro São Domingos, que fica escondido atrás dos silos, do outro lado da cidade, você vê, em termos materiais, o crescimento da cidade. Você vê bairros surgindo, loteamentos fechados, inclusive foi lançado um há poucos dias e aqui também foi lançado um loteamento para uma classe média nesses níveis regionais. Lá dentro deste loteamento você vai ter tudo! Vai ter de igreja para baixo. Vai ter academia, vai ter mercado, vai ter segurança, vai ter piscina, vai ter toda uma condição de vida para quem pode pagar. Por que? Porque essa classe média quer proteção, ordem e segurança. Quem é essa classe média da fronteira? Quem são os novos ricos da fronteira? Como eles se formaram e como eles atuam. Quem são essas pessoas. Quem são os intelectuais orgânicos e como eles articulam e como fazem esta relação com o Estado?

Esta fase de preocupação com o destino do grande número de jovens que nasceram entre as décadas de 1980 e 2000, era bem outra entre as décadas de 1960 e 1980, conforme relata o Sr. Leonildo Bares, na presidência do Sindicato Rural de Sinop, em entrevista concedida dia 17.09.2012:

\begin{abstract}
Eu tenho 32 anos de Mato Grosso e faço parte da história que construiu e da que destruiu o Estado. Fiz parte [da equipe] dos motoristas que puxaram terra. Eu trabalhei trinta dias repondo um motorista que tinha ficado doente, para construir a BR-163. Em 1979 eu vim para Mato Grosso, para São José do Rio Claro. Viajando no túnel do tempo, até porque eu faço parte da história [...]. Quando na era de 1960, que o governo brasileiro começou a emitir títulos e vender para cidadãos do Brasil inteiro terras em Mato Grosso, ele esqueceu que Mato Grosso tinha um " $x$ " de terra e vendeu dois " $x$ " de escritura. Então nós já começamos assim: o governo vendia títulos para arrecadar dinheiro para manter o país em pé. Tanto é que se colocar uma escritura ao lado da outra, nós vamos ter que invadir Rondônia, invadir o Pará, Tocantins, tudo, e ainda vai faltar terra. São problemas fundiários que nós temos até hoje que o governo nunca quis resolver. Então, a princípio foi isso.
\end{abstract}

Entre as muitas histórias que o Sr. Bares tem para contar, estão aquelas em que as terras prometidas pelo governo federal ainda estavam vinculadas ao município de Chapada dos Guimarães e praticamente ninguém tinha noção do que acontecia na região do Centro-Oeste do Brasil. O presidente do Sindicato continua:

Num segundo ponto, o governo vendeu os títulos e o governo precisaria trazer gente para cá, porque o exército não tinha condições de vir fazer uma soberania brasileira, com medo de intervenções do mundo para invadir a Amazônia. Então o governo pegou este cidadão e jogou ele para cá. E a história se deu assim: quando estes cidadãos vieram para cá, eu era garotinho ainda, mas me lembro que meu avô, em 1968, adquiriu uma terra que, supostamente, ela estaria em São José do Xingu. E ele disse assim: lá é município de Chapada dos Guimarães. Chapada dos Guimarães tinha o 
titulo de maior município do mundo até então. O que acabou acontecendo: as pessoas vieram para cá atrás de um sonho de vender 5 a 10 alqueires no Paraná e comprar aqui 40,50, 80 alqueires. Ainda se pensava muito pequeno naquela época; poderiam ter comprado metade de Mato Grosso com aquele dinheiro, já que nada valia nada mesmo.

\section{Para Sr. Bares, houve um logro, o governo brasileiro enganou as pessoas.}

Eles foram logrados pelo governo brasileiro, pelas corretoras e pelas imobiliárias. Eu me lembro de algumas situações que eles pegavam um sítio de 10 alqueires, se fosse para comprar pelos valores de Mato Grosso, daria para comprar mil alqueires; e deram 84 alqueires de terra para o cara, porque cortava 21, 42 e 84, que são: 50 hectares, 100 hectares e 200 hectares, com as parcelas cortadas ${ }^{86}$. Quando eles colonizaram desta forma, jogaram as pessoas aqui para dentro e o governo militar estava cruzando a Transamazônica com a BR-163 e começou a mostrar que iria cortar o Brasil de norte a sul, de leste a oeste. E prometeu que iria dar respaldo para as pessoas, assim como fizeram os americanos, quando colonizaram o oeste; levou a ferrovia depois levou o povo. Aqui não; levaram o povo, prometendo que iriam levar rodovia e estas coisas e isso acabou não acontecendo.

Estas inversões de demanda, bem como as promessas que não foram cumpridas, levaram os imigrantes pioneiros de Lucas do Rio Verde a criar meios de sobrevivência iniciando do nada. E, como relata o imigrante pioneiro Antonio Isaak Fraga Lira, numa entrevista concedida dia 21.09.2012, em sua casa no centro de Lucas do Rio Verde,

A vila foi crescendo e aí como a gente não tinha espaço dentro do município, já existiam o distrito de Tapurah e Nova Mutum, mas Lucas não existia. Então eu tive de criar um espaço entre Lucas e Mutum para nós colocarmos o nosso distrito que era Lucas do Rio Verde. Isso foi bastante complicado porque nenhum dos dois queria ceder espaço para nós. Todo mundo já estava pensando que onde ficasse as divisas ia ser a divisa dos municípios, como de fato foi. Então foi somente em 1986 que eu consegui oficializar a criação do distrito de Lucas do Rio Verde, e a partir daí já começamos a trabalhar a criação do município. Daí foi mais rápido. Já em 1988 conseguimos oficializar o município; em julho de 1988 o governador sancionou a lei criando o município, juntamente com Tapurah e Nova Mutum, sendo que os três municípios saíram de Diamantino. Foi uma luta muito grande. Quando precisava de uma votação pesada na câmara e convocavam as lideranças o pessoal pegava seus carros e iam; é difícil porque daqui a Diamantino são $200 \mathrm{~km}$ e na época nem asfalto tinha. Era complicado. Eu ia uma vez ou duas por semana para Diamantino, para Cuiabá, no governo do estado, tentando buscar as coisas e isso tudo sem diária, sem gasolina, sem nada; era tudo do nosso bolso. Eu morava na fazenda, deixava a família em casa, com criança pequena, ficava às vezes até uma semana fora, e era assim a luta. Foi uma luta árdua.

\footnotetext{
${ }^{86}$ Parcelas doadas ou vendidas com a intermediação de órgãos do governo ou colonizadoras.
} 
Como continua narrando o Sr. Lira, o tempo passou e tudo na cidade foi mudando, a ponto de hoje todos sentirem muito orgulho da terra que ajudaram a construir.

\begin{abstract}
É muito bonito as pessoas chegarem de fora e verem esta maravilha que é hoje, nem imagina o que os primeiros passaram para construir tudo isso. Tem gente hoje que fica criticando ainda e nunca ajudou a levantar uma palha para isso aqui e ainda acha alguma coisa para criticar. O nosso sentimento, como pioneiro, é o de um orgulho muito grande de ter feito parte de tudo isso, de ver a cidade como uma criança que a gente viu nascer ajudou a fazer este parto, e ver esta cidade que cresceu que hoje está dando frutos, que está maravilhosa. Nós somos a oitava cidade do Brasil em qualidade de vida; isso causa muito orgulho na gente, por ter feito parte disso tudo. Mesmo hoje, a gente estando fora da administração, mas sempre junto, do lado das pessoas, ajudando no que é possível e fazendo parte dessa história. Desde o início, direta ou indiretamente, a gente sempre esteve junto da administração da cidade. O meu compromisso sempre foi com o município. Enquanto eu fui vereador durante seis anos em Diamantino, na minha gestão eu criei distrito, porque nem distrito não era aqui, quando eu comecei aqui nem a vila existia ainda.
\end{abstract}

Para Onofre Ribeiro, jornalista que acompanhou de perto o processo de abertura da BR-163,

O objetivo fundamental do Regime Militar era abrir a estrada; povoar a Amazônia. Em nenhum momento os militares falaram em asfaltar a BR-163 além de Cuiabá, porque eles achavam que ninguém tinha uma leitura de como seria aquela ocupação da Amazônia, principalmente porque 0 conceito ainda era aquele implantado por Ferreira de Castro, em seu livro A Selva, de que a Amazônia era um Inferno Verde. Na época não tinha preocupação ambiental, nem se pensou um futuro para a região. A idéia era abrir a rodovia, que o resto acontecia. [...] A filosofia dos colonizadores não importava muito ao governo naquele momento; a meta era ocupar a Amazônia. Aí foi aquele estrago todo que fez aquela coisa da madeira... até porque o sistema agrícola demorou muito a dar certo porque não se tinha tecnologia. Quando acabou o Regime Militar, tinha Sinop, que se emancipou em 1979, um polo que surgia e... Sorriso vem depois.

Para ele, o significado das coisas mudou muito e torna-se complicado criticar,

hoje, as atitudes que eram normais há alguns anos.

De lá para cá veio a percepção ambiental como política de sustentabilidade e aí nós ficamos com uma região ocupada que nunca teve uma filosofia a não ser a dos colonizadores. Chega-se então ao século XXI, com uma rodovia ocupada aleatoriamente, com cidades que têm projetos econômicos, mas começam a perceber que precisam ter um projeto mais sustentável. É correr atrás do prejuízo. [...] A rodovia está pronta, atingiu seus objetivos: pôs gente. Aconteceu o que aconteceu, o que está lá, está. Já que a Amazônia tem hoje uma importância territorial de soberania, além de uma importância de biodiversidade, que pode gerar um outro tipo de economia, seria o caso do governo federal criar um novo plano de ocupação, uma nova caminhada para a Amazônia do século XXI, que estabelecesse uma filosofia, não aquela exploratória, mas uma conservatória com mais consciência e garantias de sustentabilidade à região amazônica. Antigamente, derrubar uma árvore era economicamente correto. Esta árvore tinha um significado transcendente, quer queiramos ou 
não. Hoje se discute o aproveitamento de quanto vale esta árvore de pé. Ela vale para sempre. Caída ela vale por um tempo curto. [...] A UFMT (Universidade Federal de Mato Grosso) que foi instalada aqui com o fim de tratar dos assuntos amazônicos, poderia encabeçar esta discussão.

Para o jornalista, a acuidade perceptiva para detectar as grandes mudanças no pensamento econômico das pessoas que atuam no agronegócio, principalmente em relação à natureza, é fundamental.

\begin{abstract}
Não podemos ignorar a ação econômica da soja e da carne em Mato Grosso, que abre uma vertente ao norte. Mas, tudo isto pode ser disciplinado, desde que haja um propósito econômico. A rodovia poderia servir para isto [...] dentro de uma nova política, com uma filosofia de século XXI; uma Amazônia com percepção ambiental, sustentabilidade e economia, um novo momento civilizatório, não ignorando nada; só disciplina que agregue valor, não necessariamente valor de industrialização, mas valor de conhecimento. Agora já se construiu uma consciência de que a Amazônia é um patrimônio valiosíssimo, uma moeda muito nova que a qualquer minuto começa a valer: o sequestro de carbono. Mas alguém tem que disciplinar isso. Isso cabe ao governo federal; depois delega aos estados responsabilidades regionais. A EMBRAPA, mesmo, que sempre foi pioneira e tem um banco de dados científicos muito alto, está desenvolvendo uma ideia de agricultura de baixo carbono, que integra todos os componentes; uma agricultura altamente sustentável, moderna, que está sendo reconhecida 'um agricultor para uma nova agricultura e uma nova agricultura para um novo agricultor'.
\end{abstract}

\title{
3.2 - IMIGRANTES PIONEIROS NA NOVA TERRA
}

Com base nas pesquisas realizadas em Lucas do Rio Verde, Sinop e Sorriso, procurou-se traçar um perfil de cada cidade, com base principalmente nas entrevistas que revelaram a força cunhada por seus imigrantes pioneiros ao espelharam seus perfis em cada uma delas.

Embora os processos sociais das colonizações tenham sido distintos, em função da complexidade dos interesses de cada colonizadora ou projeto de colonização, cada comunidade tinha seus projetos de vida específicos. Foi com eles que construíram suas histórias à revelia do poder público que, enquanto a região representava muito pouco em termos de arrecadação para o erário, ficou praticamente abandonada pelos governos estadual e federal.

Em relação ao município de Sorriso, a Sra Luciene Francio conta que:

A história mais ou menos da colonização de Sorriso, e que não é muito diferente do resto, de Lucas e Mutum é assim: eram famílias grandes numerosas no sul do país, com vocação agrícola. Era um pessoal acostumado a plantar lá milho, arroz, soja, o que pudesse, em pequenas áreas lá no sul do país, Rio Grande, Paraná e Santa Catariana. Eram famílias numerosas. Então tinha o pai e tinha lá dez filhos. Não tinha mais 
espaço de ocupação no sul do país para a atividade agrícola. Eles não tinham mais como colocar estes filhos lá. E aí o Cerrado mato-grossense, quer dizer desponta como uma fronteira agrícola. Eles não sabiam muito bem o que iria dar, mas sabiam que era possível porque tinha condições climáticas, topografia adequada e terras muito baratas. Então este pai comprava terra aqui para colocar os filhos. Bem no início foi isso. A gente está falando de 1975/1976 até 1980. Esse pessoal veio pra cá sem saber o que iria plantar. E na época a Colonizadora [Sorriso] que nem era Colonizadora ainda, mas era minha família, fez convênio com a EMBRAPA para fazer um campo experimental aqui e plantar várias coisas: guaraná, banana, café, arroz, menos soja, porque nem se falava de soja, para ver o que poderia ser plantado aqui e produzir. Fizeram um monte de experimentos. O que melhor se adaptou na época, foi o arroz. Então eles começaram a plantar arroz.

Como a Sra. Francio colocou, estes imigrantes pioneiros sequer sabiam o que iriam fazer com uma terra que não conheciam, nem como iriam viver em um clima quente ao qual não estavam acostumados.

Esse pessoal que chegou, só sabia que tinha de trabalhar na agricultura, mas estes filhos tinham ainda de resolver o que plantar. Depois começou o processo de vender aqui e comprar lá, porque o arroz estava dando certo, então vamos vender 10 hectares para comprar cem no Mato Grosso, ou 10 compra mil no Mato Grosso. Aí que começou. Mas eu falo assim, a soja não é causa, é consequência. Se não fosse soja, iria plantar guaraná, iria criar porco, criar gado, minha família veio para cá para produzir gado, pecuária. Meu pai, que era também ligado a agricultura, a família dele foi da área agrícola a vida inteira, mas em pequenas propriedades em Santa Catarina, ele veio para cá e comentou que 'aquilo lá' para uma pecuária era uma maravilha. Aí ele juntou os irmãos para comprar terra aqui. Ele comprou só que a terra era muito grande e eles não davam conta de pagar sozinhos. Aí meu pai resolveu vender uma parte disso para dar conta: 'a gente fica com uma parte e vende uma parte'. Como ele era representante comercial, porque minha família tinha 'negocinho' agrícola, mas também tinha um pé na indústria de confecções, ele andava muito e conhecia muita gente do interior do Paraná e do Rio Grande do Sul. Aí ele foi conversar com o pessoal lá, isso na década de 1970/1980.

\section{O Sr. Leonildo Bares, que chegou a São José do Rio Claro com 17 anos}

quase na década de 1980, conta um pouco do que aconteceu na sua história em Mato Grosso, antes de viver em Sinop onde hoje, além de presidente Sindicato Rural, também é fazendeiro:

Como naquela época os produtores plantavam o arroz aqui e produziam muito, como produz até hoje, chegava na hora de ceifar o seu arroz, tinha de ser tudo manual. A família produzia o arroz e na hora de vender era mais caro o frete para levar onde tinha comércio, do que o próprio arroz. Então deu inviabilidade agrícola naquele momento; alguns ficaram com um pouco de gado leiteiro para fazer um queijo ou ter um leite e outros colocaram seus filhos nos garimpos. Muitas mães choraram lágrimas de sangue ao ver seus filhos mortos encima de uma mesa, dentro de um garimpo. Mas o garimpo era a única coisa que dava para se sustentar. Depois do garimpo, já mais avançado, aí a madeira começou a ter um escoamento, porque com a madeira acontece o seguinte: quando tem muita madeira, ela não tem preço. Como não tinha preço, ela tinha de ser ilegal, porque se fosse pagar 
as taxas do governo corretamente, como deve ser paga a madeira também se tornava que nem o arroz; era mais caro o frete que o material. Então nasceu a madeira clandestina em Mato Grosso, como meio de sobrevivência, para continuar ali.

A madeira, o garimpo e a agricultura, durante muito tempo permaneceram na ilegalidade em Mato Grosso, não porque as pessoas desejassem assim, mas elas passaram a atuar desta forma, por ser a única viável numa terra onde cada um tinha de sobreviver da melhor forma, como continua relatando o Sr. Leonildo Bares.

\begin{abstract}
E a malária pegando pesado e aí a SUCAM (Superintendência de Campanhas de Saúde Pública) ${ }^{87}$ veio para cá, e eu posso falar com conhecimento de causa, como se fosse hoje, eu tinha 17 anos de idade eu peguei uma malária em São José do Rio Claro, e eu fui na SUCAM, e o pessoal que fez um atendimento cinco estrelas. É bom que se frise isto: o Mato Grosso foi palco de muita safadeza do governo, mas teve coisa que o governo colocou aqui dentro, que teve eficiência; uma delas se chama SUCAM. E aí um cidadão que tinha lá, era até um baita de um morenão, foi num saco que parecia estes sacos de ração para cachorro, cheio de comprimidos; ele enfiou uma xícara grande lá dentro, encheu, passou a régua na boca e me disse: olha isto aqui são oito semanas de tratamento. Ele não contou comprimido; só enfiou num envelopinho e me disse: aqui dentro tem mais ou menos tantos comprimidos; você toma 4 cada vez, uma vez por semana. Me passou um regime e um remédio para o fígado, eu agradeci a ele a agradeço até hoje, que Deus abençoe aquele cidadão onde ele estiver, porque ele me salvou e até hoje eu não tenho problema de fígado. Esse era o tratamento que tinha. Quer dizer, foi com este Mato Grosso que nós convivemos.
\end{abstract}

Como o Sr. Bares relata, até os anos 1970 não havia a menor condição de sobrevivência segura em nenhuma cidade do interior mato-grossense. Por isto, muita gente que estava em outras regiões do Estado se deslocou para as povoações que nasciam ao longo da área de abrangência da BR-163, para tentar novas oportunidades.

Quando foi em 1983, dia 10 de março, eu vim para Lucas do Rio Verde. Depois de ter andado por vários lugares. Eu já tinha morado em Primavera do Leste, Campo Novo do Parecis, na Guia [atual Distrito de Nossa Senhora da Guia], perto de Cuiabá, já tinha ido para Tangará da Serra, já estive em São José do Rio Claro, aí então eu vim para Lucas do Rio Verde. Nós fomos o terceiro plantador de soja em Lucas do Rio Verde. Nós plantávamos arroz e foi aí que começou a entrar a soja.

\footnotetext{
87 Órgão que resultou da fusão do DENERu (Departamento Nacional de Endemias Rurais), da CEM (Campanha de Erradicação da Malária) e da CEV (Campanha de Erradicação da Varíola). A experiência e conhecimento acumulados, ao longo de várias décadas, das atividades de combate às endemias de transmissão vetorial, a transformaram no órgão de maior penetração rural no país. Sua estrutura operacional estava presente em todos os Estados brasileiros. A SUCAM (Superintendência de Campanhas de Saúde Pública) foi legítima herdeira de um dos mais antigos modelos de organização de ações de saúde pública do Brasil, denominado sanitarismo campanhista. Esse modelo teve como premissa a revolução pasteuriana (alusão ao cientista francês Louis Pasteur) e foi implementado pelo médico-sanitarista Oswaldo Cruz, na primeira década do século XX. Dela nasceu a FUNASA (Fundação Nacional de Saúde) Fonte: www.funasa.gov.br
} 
Em Lucas do Rio Verde, a história dos imigrantes pioneiros que chegaram antes da decisão do INCRA de assentar os colonos do Rio Grande do Sul na região, não foi muito diferente. Conforme esclarece o Sr. Antonio Isaak Fraga Lira, que chegou a Lucas do Rio Verde em 1976,

\begin{abstract}
No início era plantio de arroz, soja não saia e aí somente em 1982 nós começamos a plantar as lavouras de soja. Também em 1982, nós lançamos a pedra fundamental da cidade também e ali começou a nossa luta. Eu fui o primeiro vereador em Diamantino, o primeiro político que foi o representante do povoado e entre 1983 e 1988 eu criei distrito e município de Lucas. Depois de seis anos da pedra fundamental, nós entregamos a cidade emancipada. É muito pouco tempo, não é? Quando o governo federal criou o assentamento aqui, para trazer o pessoal do sul, em 1981, eu e mais 84 famílias já morávamos aqui. Desde 1976/1977/1978, nós já estávamos aqui, mas no interior; não tinha vila não tinha nada. Todo mundo nas suas fazendas; não tínhamos documentos de terra, não tinha nada. À partir do assentamento, em 1982, foi quando a gente começou a mexer politicamente. Nós nos reunimos e resolvemos lançar um candidato a vereador, porque nós vimos que o caminho era político, aí eu, como tinha domicilio eleitoral em Diamantino, tinha uma certa liderança na comunidade, então me lançaram candidato a vereador. Foi quando eu comecei a trabalhar politicamente, em 1983. A vila começou a existir, as pessoas começaram a construir suas casinhas, o INCRA que fez o projeto da agrovila na época, traçando as ruas e assim foi começando. E aí a gente começou a correr atrás das coisas; atrás da energia, dos primeiros postes, do primeiro motor, a partir de 1983. E foi devagarzinho que a gente foi começando a fazer tudo isso.
\end{abstract}

Cada cidade recebeu também uma forte influência dos seus colonizadores e conviveu de modo diferente com seus percalços, até atingirem a condição de município. Para entender esta trajetória, é preciso saber um pouco da história das pessoas e as estruturas com a qual contam até hoje, depois de criarem uma economia baseada no comércio e na prestação de serviços que, direta ou indiretamente, se apoia a produção do agronegócio.

Onofre Ribeiro, em seu artigo "Mato Grosso e o século 20 - migrações", veiculado no jornal A Gazeta em 27 de dezembro 2000, resume esta visão:

Colonos gaúchos oriundos das imigrações europeias [...] que ganharam do governo brasileiro 25 hectares de terras iniciais, já se espalhavam por Santa Catarina e pelo Paraná. Os que ficaram já não cabiam na terra e tornaramse um problema social, acampados debaixo de lonas nos arredores de Porto Alegre no começo da década de 70 [...] O norte do Paraná sofreu fortíssimas geadas que acabaram com os cafezais que formavam a rica economia regional. No mesmo momento, o governo militar brasileiro desenvolvia o projeto estratégico de ocupar a Amazônia com temor de sua internacionalização. [...] Daí nasceu a proposta: "Amazônia - Integrar para não entregar".

O jornalista, que acompanhou a história de perto, conta que: 
Decidiu-se que a ofensiva se faria a partir de Mato Grosso, que já estava ocupado. Daí o nome "Portal da Amazônia". Era preciso separar o sul do estado, porque não fazia parte da geopolítica da ocupação amazônica. Por isso criou-se Mato Grosso do Sul. Programas federais criaram condições de financiamento da terra, da ocupação, da produção, da pesquisa, e de meios para atrair gente de todas as regiões do Brasil, para Mato Grosso, na busca da nova frente que se chamava "Novo Eldorado" [...] Vieram primeiro os gaúchos trazidos por Norberto Schwantes [...] Por outros caminhos chegavam os paranaenses do café, catarinenses e gaúchos para projetos de colonização privados que resultaram em cidades [...] A década de 80 começa com 1.139 mil habitantes e encerra com 2.027 mil [...] Finalmente, em 1991 a população já mostra sinais de estabilização, com apenas 2.235 mil e 2000 fecha com 2.498 mil. De 1970 a 2000, tivemos um crescimento de $417 \%$. (RIBEIRO, 2000)

Destes 417\%, muitos colonos não permaneceram nas áreas a eles designadas para colonização; aqueles que ainda tinham meios voltaram para suas origens; outros seguiram mais para o norte e outros partiram em busca de terras em outras áreas da Amazônia Legal.

\section{Gráfico 13 - Crescimento da população mato-grossense urbana e rural de 1940 a 2000}

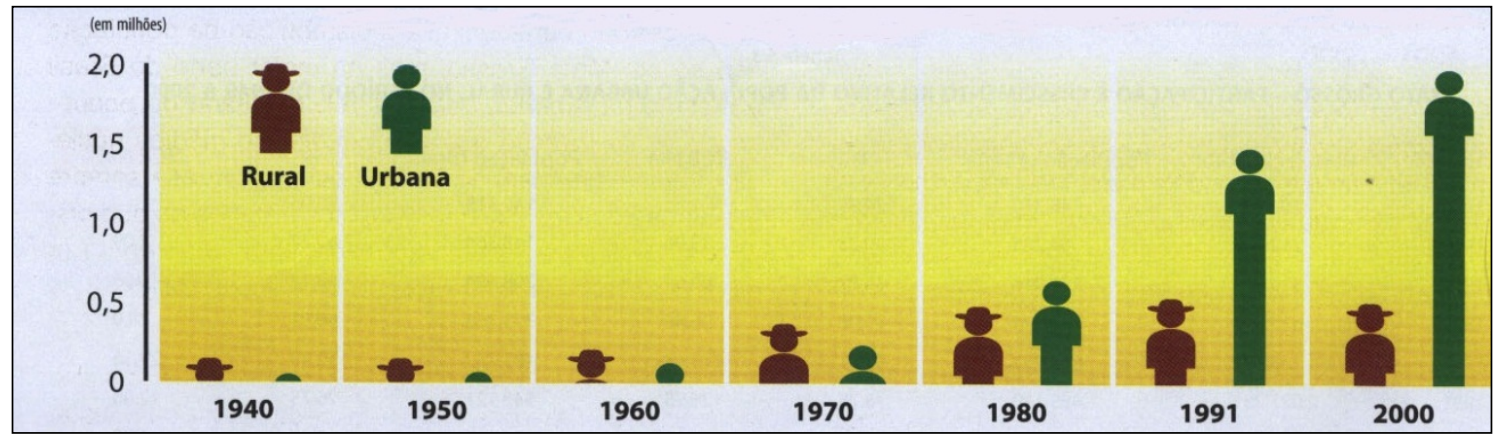

Fonte: IBGE 1952, 1956, 1967, 1971, 2000

Obs. Os dados anteriores à divisão do Estado, ocorrida em 1977, se restringem ao atual território mato-grossense

O enorme crescimento populacional mato-grossense até o ano 2000, conforme apresenta o Gráfico 13, se deve, principalmente, ao fato da propaganda ter omitido que o acesso ao "Novo Eldorado" dependia de "picadeiros ${ }^{88 "}$ para chegar ao lote adquirido; as moradias, quando existiam, não passavam de casebres de madeira com aproximadamente $12 \mathrm{~m}^{2}$ em média; os financiamentos foram rapidamente esquecidos e a infraestrutura urbana precisava ser criada pelos próprios imigrantes. Em outras palavras, a grande maioria dos imigrantes que

\footnotetext{
${ }^{88}$ Homens que se embrenhavam na mata por caminhos que praticamente só eles conheciam para mostrar a terra aos interessados ou futuros proprietários.
} 
chegou ao norte mato-grossense na primeira metade da década de 1970, ficou entregue à própria sorte, sem ter sequer para onde voltar ou seguir.

$\mathrm{Na}$ obra "A Colonização Oficial de Mato Grosso: a nata e a borra da sociedade", Castro afirma que:

\begin{abstract}
A colonização surgiu como uma opção por parte do governo federal no sentido de fazer uma ampla distribuição de terras na fronteira, evitando-se assim uma redistribuição de terras já apropriadas no resto do país. O mais importante a ser ressaltado é que essa política, que começou como uma alternativa à reforma agrária, modificou todas as outras alternativas antes existentes. [...] Ao promover a penetração de agricultores numa área de fronteira brasileira, o governo federal preparou, na realidade, a estrutura de posse legal da terra de maneira que permitiu a sua apropriação pelos novos agentes econômicos que chegaram à região. [...] o governo federal acabou por ser o grande responsável pelos conflitos notórios e a violência presentes nestas áreas de fronteira. O espaço deixou de ser um direito de uso de acordo com as atividades praticadas anteriormente na região da Amazônia Legal e passou a compor um título de propriedade privada da terra, coerente com o tipo de atividades econômicas em expansão que é a agricultura integrada (mais cedo ou mais tarde) ao sistema nacional de produção capitalista. (CASTRO et al., 1994:17-18).
\end{abstract}

Na vasta literatura a respeito da colonização mato-grossense, os autores são unânimes em afirmar que a flagrante falta de programação e desmandos nos processos migratórios no Estado já haviam sido vivenciados por imigrantes dos programas incentivados pelo governo de Getúlio Vargas.

A intenção de se trabalhar com estas comunidades que vivem na área de abrangência da BR-163 que, aparentemente, diferem tanto entre si, mas que ao mesmo tempo dependem das mesmas políticas públicas, trouxeram em seu bojo a necessidade da pesquisa in loco. É preciso ouvir a relato destas pessoas para elucidar vários pontos omissos a respeito dos imigrantes que ficaram na região e que, por conta do sucesso do agronegócio, parecem ter se familiarizado com a violação de seus direitos. Conforme colocou llan Pappe (2012), historiador e professor israelense que hoje vive e leciona em Londres, no documentário "Mitos e propaganda israelenses",

Em qualquer situação nova, os vitoriosos, os que ficaram com as vantagens, ficam com os documentos, com os arquivos. Aos perdedores, aos que foram expulsos ou afastados para dar lugar à nova situação, Ihes resta apenas uma memória coletiva, a história oral a respeito das evidências que foram deixadas para trás na mão dos "expulsadores". (ILAN PAPPE, 2012)

Que tipo de significado se pode encontrar hoje nestas comunidades que, apesar de alguns terem superado as enormes dificuldades encontradas no processo migratório, conseguiram adaptar-se e criar um meio de vida, dando outro significado 
para o que se interpunha entre o natural e a atividade humana que precisava ser desenvolvida? Como cita Müller (1989:98, apud Zart, 1998:85), "ao mesmo tempo em que o sistema estrutural e organizacional modernizado nega o camponês e o pequeno produtor rural, este nega o sistema, mesmo quando reivindica a sua inclusão".

Mais adiante, Müller completa:

Os marginalizados formam um exército de homens que, pela sua posição social, representam uma constante ameaça aos setores tecnificados e incorporados ao sistema e ao próprio Estado, pois, pela falta de perspectiva, colocam-se à marcha, reivindicam e protestam. (MÜLLER, 1989:98, apud ZART, 1998:85)

No caso das comunidades dos municípios que se desenvolveram ao longo da BR-163, muitos dos seus membros foram marginalizados de diferentes formas, como já se viu anteriormente. Mas, os que permaneceram, criaram um novo mercado, paralelo àquele que os afastou. Este caminho, à primeira vista, parecia não representar uma ameaça aos setores tecnificados e incorporados ao sistema ou ao próprio Estado, uma vez que todo tipo de coação e violência já havia sido praticada em nível mais do que suficiente.

Motivados pela lei da sobrevivência, os imigrantes pioneiros passaram a se unir cada vez mais, trabalhando ainda com mais afinco, para atingir as metas às quais se propuseram quando resolveram ficar.

Como lembra o Sr. Ildo Romancini:

Para a gente tomar água fresquinha eu comprei um balde de alumínio em Diamantino, tudo a gente comprava em Diamantino, de 15 ou 18 litros, não me lembro, nós enchíamos de água de noite e deixávamos ao lado do poço, no sereno; amanhecia era aquela água fresquinha! Depois eu arrumei uma térmica com uma torneirinha, enchia aquela térmica com a água fresquinha que era só para tomar durante o dia.

Portanto, não sobrava tempo para reivindicar e protestar, embora tenham se articulado politicamente para alcançar seus objetivos, no momento em que perceberam que o futuro dependia exclusivamente deles, já que as promessas haviam se perdido com o fim do regime militar e, como elas, a própria BR-163 foi abandonada.

A Sra. Luciene Francio lembra que

Foi o espírito comunitário. De certa forma, o abandono do governo nos fez grandes e fortes. Nós tínhamos um lema: se o governo não nos atrapalhar já está bom, porque a gente dá conta de fazer. Tanto é que quando as pessoas chegavam na cidade, até elas se acomodarem ficavam na minha casa. Eu vivi isso, porque quando meu pai resolveu implantar Sorriso, eu 
tinha 5 anos. Foi em 1975. Eu cresci junto com Sorriso; ele tinha duas filhas: eu e a cidade e não sei por qual ele tinha mais amor porque eu cresci junto com a cidade e eu tenho estas memórias. Eu vim para cá quando não tinha nenhuma casa. Aí eu vi quando tinha uma, aí eu vi quando tinham três, quando tinham cinco, quando tinham dez, enfim, eu acompanhei o crescimento. E o sentimento que eu vejo, era assim: o pessoal que vinha do sul rompia a ponte de volta. Não tinha aquilo de "eu vou tentar lá no Mato Grosso, mas se não der certo eu volto para trás". Não tinha isso. Eles vendiam o que eles tinham lá e não tinha volta, tinha que dar certo; tinha que dar certo. E aí o espírito é outro. Você entra de corpo e alma.

Coube a cada colonizadora, ou mais diretamente aos responsáveis por cada uma delas, organizar o futuro e a distribuição de responsabilidades: construir estradas vicinais, estabelecer contatos políticos na capital, criar escolas, atrair comerciantes, fomentar a vinda de mais famílias e incentivar a construção de casas nos núcleos urbanos. Como lembra Isnard (1975: 6), "a grande aventura humana sobre a terra foi a de ter reformulado, em definitivo, o espaço a partir de modelos diferentes dos ecossistemas originais, substituindo a necessidade pela intencionalidade".

A intencionalidade dos migrantes que aportaram no Nortão, não só reformulou definitivamente o espaço como consolidou o sucesso tanto da produção como da urbanização, desenvolvidas ao mesmo tempo, na medida em que foram sendo descobertas novas fórmulas de enriquecer o solo do Cerrado, antes avaliado como produtivo só para o plantio do arroz de baixa qualidade.

O diretor comercial da Colonizadora Sinop, Sr. José Barbaro Neto, lembrou que numa palestra sobre sustentabilidade, um técnico da EMBRAPA disse que o solo de Mato Grosso era considerado o mais inóspito do mundo e, com pesquisa, conseguiram fazer esse solo, além de produtivo, bater recordes mundiais de produção.

Os membros das sociedades da região que não se dedicaram ao agronegócio desenvolveram suas forças produtivas para atender subprodutos diretos ou indiretos deste segmento que hoje chega ao ponto de ter suas ações controladas pelos interesses dos controladores do poder tecnológico.

Assim como o Estado teve muito pouca incursão nas decisões de implantar novas tecnologias e mecanização, hoje raramente este mesmo Estado toma qualquer atitude que não esteja sintonizada com as forças dominantes do agronegócio. 
Na concepção de Santos (2007), citando Bertrand Russel (1996, p.231), o espaço e o tempo participam desta objetivação que molda a realização social:

O passado passou, e só o presente é real, mas a atualidade do espaço tem isso de singular; ela é formada de momentos que foram, estando agora cristalizados como objetos geográficos atuais; essas formas-objetos, tempo passado, são igualmente tempo presente enquanto formas que abrigam uma essência, dada pelo fracionamento da sociedade total. Por isso, o momento passado está morto como tempo, não porém como espaço; o momento passado já não é, nem voltará a ser, mas sua objetivação não equivale totalmente ao passado, uma vez que está sempre aqui e participa da vida atual como forma indispensável à realização social. (SANTOS, 2007:14)

Assim como Santos (2007:14), escreve que "o passado agora está cristalizado como objetos geográficos atuais, como tempo presente enquanto forma que abrigam uma essência". Os sistemas técnicos implantados na região, tal como demiurgos apátridas, têm ratificado, sem ab-rogações, as decisões socioeconômicas que usualmente atendem, em primeira instância, aos privilegiados que contam com um perfil tecnológico adequado à realidade presente.

As comunidades da região têm consciência disto; sabem que "o momento passado já não é, nem voltará a ser, mas sua objetivação não equivale totalmente ao passado, uma vez que está sempre aqui e participa da vida atual como forma indispensável à realização social" (Santos 2007:14). Sabem até mesmo que, se a mão de obra recrutada para expandir rumo à produção internacional de bens e serviços tem sido recrutada em outros estados, é por conta do custo e do tempo necessários para a formação de profissionais que operem globalmente; estes dois itens fazem parte das "formas-objetos, tempo passado, são igualmente tempo presente enquanto formas que abrigam uma essência", à qual se referiu Santos (2007) anteriormente.

O Sr. Leonildo Bares exemplifica estas formas-objetos:

Quando começou o soja, nós plantávamos uma variedade que produzia entre 25 e 30 sacos por hectare. Era a produção que nós tínhamos. O adubo custava US\$164,00 a tonelada. Bom, nós começamos a plantar estas lavouras ali, e nós não sabíamos o que era acidez de solo. Então falaram para nós que calcário era bom. O Banco do Brasil que financiava para nós era em Rosário Oeste. O patrão ia lá em Rosário Oeste! Na praça de Rosário Oeste tem uma árvore grande, uma figueira, era o palco do assombro dos agricultores. Muitos pousaram ali esperando o banco abrir no outro dia, porque era tudo muito enrolado e demorado para sair uma migalhinha de dinheiro. Enfim, era o único jeito que tinha... e o cartório que 
registrava era em Diamantino ${ }^{89}$. Era totalmente uma correria, mas o produtor podia fazer o seu trabalho.

Mas nada esmoreceu a vontade férrea destes imigrantes pioneiros que, aos poucos foram montando as cidades que hoje compõem uma das áreas mais prósperas do país.

Em seguida, em Lucas do Rio Verde nasceu a COOPERLUCAS. Fui sócio e fiz parte dela. A COOPERLUCAS tinha como destino viabillizar o plantio de soja. Então a COOPERLUCAS começou num processo como Sr. Neri Artmann e mais uma meia dúzia de produtores que eram ali do Itambiquara, povoadinho vizinho de Lucas do Rio Verde, e ela foi criando um corpo e uma dimensão que chegou ao ponto de vir agrônomos da Itália, da Espanha, da França, Estados Unidos e até do Japão. A fazenda palco de tudo isso era do Sr. Minifuno Matzubara, na saída de Lucas, no sentido para Sorriso, quando atravessa a ponte, do lado esquerdo, sentido Sinop, tem 600 hectares que o Sr. Muni doou, que era o campo experimental da COOPERLUCAS. E o resto da fazenda do Sr. Muni servia como palco de experimentos. Ali foi ampliando. Então os produtores que tinham saído do garimpo, saído da madeira, entravam na soja. Isso em 1981/1982.

A marca dos imigrantes pioneiros está no perfil da gente que hoje empreende num ritmo acima da média nacional as cidades da área de abrangências da BR-163.

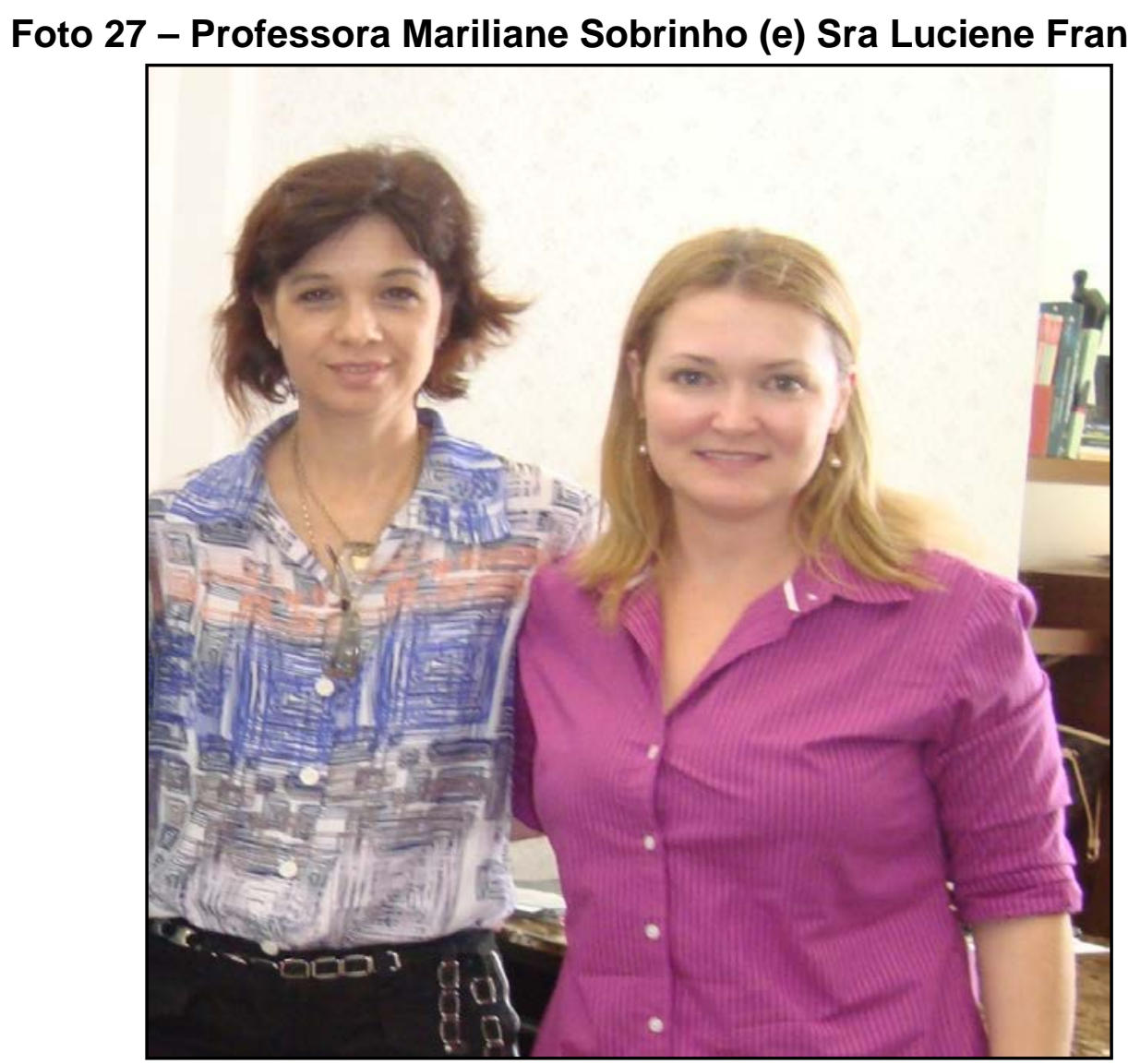

Fonte: Acervo da autora (2012)

\footnotetext{
${ }^{89}$ Uma distância de aproximadamente 200 km.
} 
Como explica a Sra. Luciene Francio, na Foto 27 com a professora Mariliane Sobrinho, parece fazer parte do espírito que move estas comunidades:

Acho que tem um pouco a ver com a forma como foi colonizado o sul do país. Os imigrantes alemães, italianos também vieram da mesma forma. Acho que é uma continuidade dessa cultura porque, se a gente for ver, é uma reprise. Da mesma forma que o pessoal saiu da Itália, fechou as portas e para lá não volto; tem que dar certo. E este espírito que a gente encontra nas histórias de lá, a gente encontra aqui. Este negócio de acolhida, das comunidades se desenvolverem por sua conta... do sul veio esse espírito, eu acho, de ter que fazer acontecer e que é um pouco das raízes mesmo. Eles devem ter visto os avós fazerem isso lá no sul, e eles se acostumaram... e também fica no DNA.

O melhor empregador no Estado de Mato Grosso ainda é o poder público. Esta realidade não foge totalmente à regra nos municípios da região norte, embora estes saibam da importância da ampliação do mercado de trabalho, por conta do enorme crescimento demográfico dos últimos 30 anos. Se por um lado, a mecanização do agronegócio diminuiu consideravelmente a utilização de mão de obra não qualificada, por outro lado o Estado negligenciou com a capacitação adequada de pessoal local, para ocupar as novas funções oferecidas pelo novo mercado de trabalho.

Apesar de o preconceito da população mato-grossense com os imigrantes, estes reconhecem que Mato Grosso só conheceu o sucesso financeiro para além do pequeno grupo que comandava o Estado, depois da chegada dos "paus rodados", que ampliaram não só o mercado de trabalho como as oportunidades para todos os que desejassem acompanhar o ritmo acelerado e competitivo do mercado internacional.

Até a chegada dos imigrantes, o mercado de trabalho se restringia praticamente ao comércio e ao funcionalismo público. Daí a dificuldade das empresas que estão se instalando ou desejam se instalar no Estado, com a contratação de mão de obra especializada da região.

Paralelo a estes dados, é preciso levar em conta que:

Assim como na manufatura, o aumento do comércio de serviços expressa, de fato, a expansão da produção internacional de bens e serviços, já que as multinacionais e suas subsidiárias precisam da infra-estrutura dos serviços, necessária para funcionar globalmente. (CASTELLS, 2007:161).

O capital pode se instalar onde operam as vantagens do mercado, mas cabe às políticas nacionais e locais criar mecanismos que deem condições às comunidades de participar do processo de espacialização do capital. 
Como coloca Castells (2007:161), já que "as multinacionais e suas subsidiárias precisam da infraestrutura dos serviços, necessária para funcionar globalmente", é fundamental a participação da comunidade nesta terceira fase do processo de produção do espaço. Esta infraestrutura é ainda mais importante, quando está se implantando uma indústria de transformação, como é o cão de Sorriso. Dará às forças de trabalho os meios para que possam se adaptar com certa agilidade às expectativas geopolíticas que enfrentarão pressionadas pela competitividade internacional.

A obliteração da agricultura familiar trazida pelos imigrantes e a ausência de indigenização apontam, aparentemente, para um êxodo rural. Afinal, a simples posse da terra não basta; é necessário menos discursos e mais incentivos para plantar e colher.

Em conversa com alguns imigrantes pioneiros ficou evidenciado que, entre as décadas de 1980 e 1990, a iniciativa privada foi responsável pela construção de tudo; o governo só ia para o interior inaugurar as estradas e pontes construídas pelos agricultores, os verdadeiros responsáveis pela formação agrícola do Estado. Conforme alguns imigrantes pioneiros, as estradas pagas pelos agricultores, que custavam em média 1/3 do orçado para as estradas construídas pelo governo, eram concluídas em menos da metade do tempo.

Foi sob este espírito que em 2003 agricultores resolveram propor uma parceria ao governo estadual para asfaltar as estradas vicinais que davam suporte à colheita e à movimentação do interior do Estado. Como conta o Sr. Ildo Romancini, agricultor de Lucas do Rio Verde, em entrevista concedida em 21.09.2012:

Até 2003, Mato Grosso não tinha um palmo de asfalto no interior deste Estado. A Sra. sabe como iniciou isto? Onde foi o início desta história de agricultor fazer parceria com o governo do estado? Foi em Lucas do Rio Verde, na MT- $449^{90}$ que está aqui. Sabe de quem foi a ideia? De Otaviano Pivetta. Eu falo porque participei junto e até hoje faço parte da diretoria da primeira Associação, a APRM - Administradora de Pedágio Rodovia da Mudança. Primeiro fui secretário, depois fui presidente e até hoje sou presidente e sou diretor do pedágio hoje. [...] Numa conversa entre o Otaviano Pivetta e Blairo Maggi, os dois chegaram à conclusão que poderiam envolver os agricultores para construir estradas no interior. $O$ governo entraria com $50 \%$ e os agricultores com $50 \%$. Se esse povo assumir junto, vamos fazer este povo assumir.

\footnotetext{
${ }^{90}$ MT é a sigla que identifica as rodovias estaduais
} 
Assim iniciou, como detalha o Sr. Romancini, um dos maiores projetos implantados no interior do Estado, para dar vazão à produção de commodities que aumentava a cada ano.

Logo depois veio o Pagot ${ }^{91}$ que era o secretário da SINFRA (Secretaria de Infraestrutura). Ele veio aqui, fizemos uma reunião onde estavam umas 350 pessoas entre agricultores, comerciantes e pessoas interessadas nessa reunião, e ali mesmo foi escolhida a dedo a diretoria e se resolveram fazer para depois ver os papéis. Um dos contra, que é contra até hoje, sugeriu fazer primeiro um estatuto, e recebeu como resposta que era mais importante trabalhar. Portanto, a MT-449 que liga Lucas, Eldorado, Tapurah, Ana Terra, voltando um pedaço da MT-484, que liga Ipiranga. [...] Eu como secretário do município, visitei todos os fazendeiros, o proprietários de terra pequenos, médios, grandes, todos. Eu já via na prefeitura a área que cada um tinha e chegava lá dizendo, por exemplo: você tem 200 hectares, o seu valor vai ser tantas sacas de soja. Tudo proporcional ao tamanho da terra de cada um. Tinha alguns que eram 10. Aceitavam na hora. Outros não pagaram até hoje. [...] Muitos companheiros que são agricultores pequenos como eu, que não podiam, nós pegamos dinheiro do banco para cada um pagar a sua parte do asfalto.

Este movimento acabou se estendendo à toda a área de abrangência da BR-

163 e a construção de estradas vicinais resolveu grande parte das dificuldades da logística do agronegócio, como explica ainda em sua entrevista a Sra. Luciene Francio, empresária e fazendeira de Sorriso:

A gente tem que trabalhar nas cidades e é via industrialização, até porque a infraestrutura viária das fazendas para a cidade foi montada com recursos da comunidade; a gente tem que dar a mão a palmatória que quem alavancou isso foi o governo Blairo Maggi. Porque era feito dessa forma: vai o FETHAB (Fundo Estadual de Transporte e Habitação) aí ele volta e aí o $50 \%$, nem era $50 \%$, mas que seja $50 \%$ em FETHAB e $50 \%$ em recursos dos fazendeiros. Isto é, era nosso mesmo. E nem vinha 100\%. O Estado não mandava os $50 \%$ vinha menos. Então a gente recebia parte do imposto de FETHAB, que era gente mesmo que tinha pago, que voltou um pouco e o resto era complemento que o agricultor pagava. Isto foi para todas as estradas que nós temos, inclusive as vicinais. Na minha fazenda, por exemplo, é uma MT que passa; foi feita com recursos nossos. A gente bancou integral e condicionou algumas coisas, mesmo porque nós não temos nenhum centavo de desconto em impostos; muito pelo contrário, o FETHAB está aumentando. Então, na época de fazer as estradas vicinais, a gente condicionou que se formassem consórcios municipais para a administração dos recursos. A gente não quis isso administrado por empreiteiras do governo. Então, por exemplo, pega a linha do Barreiro, onde está minha fazenda; a gente montou um consórcio lá de agricultores. Nós montamos o consórcio e aí este consórcio administrava a aplicação do recurso. E o governo, porque não podia, mandava o recurso através de óleo diesel, massa asfáltica, quer dizer, ele licitava e daí mandava o produto. Era a contribuição do governo que para nós estava bom. E a nossa parte dos recursos, a gente é que aplicava.

${ }^{91}$ Luiz Antonio Pagot, então Secretário de Infraestrutura do Governo de Mato Grosso (2003-2007), que assumiu posteriormente a diretoria do DENIT - Departamento Nacional de Transportes (2007.2011). 
A infraestrutura necessária para a construção, também foi administrada pelo consórcio formado pelos agricultores, como explica a Sra. Luciene Francio:

O consórcio que contratou a empreiteira e foi tudo feito pelo consórcio. Agora, a gente criou o pedágio, nas estradas que a gente fez, nós pagamos para nós mesmos para manter. O que adianta você gastar para fazer e sucatear daqui a pouco. Mas funciona! $\mathrm{Na}$ cidade foi do mesmo jeito! $\mathrm{Na}$ verdade na cidade foi assim: de uns 12 anos para cá, foi aprovada uma lei municipal que todo loteamento novo tem que ter total infraestrutura. Asfalto, esgoto, água, luz, tudo. Então de lá para cá, eu como empreendedora, loteamento é o meu negócio, a gente já faz tudo completamente urbanizado. Então resolveu o problema; a gente colocou um divisor de águas. Daqui para frente as coisas vão acontecer todas certinhas e daqui para trás o poder público tem que resolver. Mas daí, de que forma o poder público resolvia? Da mesma forma repassando para o empreendedor imobiliário. $O$ dono do terreno paga a metade e a prefeitura entra com alguma coisa. Os primeiros asfaltos foram feitos pelos moradores daqui mesmo. Nestas cidades aqui, tudo foi feito pela iniciativa privada. A gente está falando da década de oitenta, não é?

É possível notar certo resentimento da empresária com o tratamento dispensado aos agricultores no período em que ainda estavam preparando o sucesso que hoje é tão importante para a balança comercial brasileira.

O governo do Estado nem sabia, porque aqui não estava produzindo ainda. A produtividade da região era muito pequena. Eles nem olhavam para essa banda. Os recursos eram aplicados todos na baixada cuiabana e aí a gente tinha que se virar. Se queria telefone tinha que trazer, se queria televisão tinha que trazer, se queria fazer uma igreja tinha que fazer, a comunidade que fez tudo. Aí depois, como foi crescendo a arrecadação, aí os governos começaram a olhar e os recursos começaram a voltar. Hoje volta. A gente recebe. Não é o que a gente paga, mas recebe. Mas por muito tempo a comunidade que fazia tudo. E continua, porque o governo não dá conta de suprir; então a comunidade se organiza e acaba fazendo através de entidades sem fins lucrativos que tem por aí, continua fazendo.

Nesta conjuntura, embora as áreas rurais da BR-163 estejam cada vez mais próximas dos núcleos urbanos, o estímulo para o plantio vai se redirecionando lentamente para os empregos nas áreas urbanas, porque o agricultor sente seus direitos boicotados e seus sonhos vão se desfazendo nas dificuldades do cotidiano.

O pequeno agricultor permanece refém dos juros bancários exorbitantes, das estradas intransitáveis que impossibilitariam o transporte da produção até 0 consumidor final, para evitar a figura do atravessador. Este círculo vicioso capitaneado pelo trabalho morto depende do processo produtivo, ou seja,

A produção em cada lugar é o motor do processo, porque transforma as relações do todo e cria novas vinculações entre as áreas. Distribuído no território ao sabor do trabalho morto, isto é, dos lugares já organizados para uma dada produção, o trabalho vivo organiza-se sob novas formas de produção e circulação, e desse modo uma nova divisão territorial do trabalho se impõe. (SANTOS e SILVEIRA, 2005, p. 30). 
Ao organizar-se "sob novas formas de produção e circulação" como mencionam os autores houve, efetivamente, uma divisão territorial do trabalho, com base nos destinos que cada um dos municípios traçou para si. Isto aconteceu a partir da forma como cada um foi acionando o seu processo produtivo e estabelecendo princípios que passariam a pautar as ideias das colonizadoras e dos imigrantes pioneiros em cada uma das cidades.

O pensamento individual destes líderes parece ter servido de nota de rodapé para as ações que foram tomadas a partir da abertura das Glebas. Luciene Francio explica este processo, descrevendo o trajeto das tomadas de decisão dos imigrantes pioneiros:

\begin{abstract}
Aí esse pessoal veio, e eu falo: se não desse soja, ia dar pecuária, não sei eles iriam desenvolver alguma coisa para dar. Porque o que pegava muito era o empreendedorismo desse pessoal. Mas deu sorte porque eles acertaram no arroz e o que eles não sabiam é que o solo era muito ácido e precisava calcarear, mas na época não tinha esse domínio dessa tecnologia. Aí descobriram isso e em Rondonópolis começaram a calcarear as áreas e começou a produzir soja, porque até então não produzia; eles tentaram, mas não produzia. Um dos primeiros que plantou soja aqui foi o José Vigolo, porque calcarearam as terras e começou a produzir melhor aí eles começaram a trazer para cá o soja e calcarando as terras começaram a contornar este problema. Quando dominaram a tecnologia, migrou do arroz para o soja. Aí plantava arroz no primeiro ano, que era o ano de abertura da terra, e migrava para o soja. Daí foi embora. Porque daí o soja, que é uma atividade mais perene, economicamente mais estável, porque mexe com o mercado internacional o pessoal ficou no soja. Esse foi o processo inicial de escolher qual cultura plantar na região.
\end{abstract}

Os parâmetros diferenciados de cada uma destas urbanidades, independente da produção de commodities ou da pujança socioeconômica que cada uma conquistou para si, ocorreram num ritmo e direções diferenciadas, embora praticamente todas tenham tido como maior apelo o agronegócio.

Porém, o que se deseja focar é a importância histórica da metamorfose destes imigrantes que se reinventaram como prestadores de serviços:

Uma análise sobre migração deve levar em conta grupos sociais e as causas estruturais e subjetivas que impulsionam o seu deslocamento de um lugar para outro, bem como os fatores de expulsão e atração da população, definidores do fluxo ou da corrente migratória, em determinadas condições de espaço e de tempo. Nesse sentido, como processo social, a colonização será sempre um fenômeno complexo, onde forças antagônicas de diferentes agentes sociais se confrontam na esperança de realização de seus interesses e projetos de vida específicos. (SINGER, 1973:74).

É provável que o processo social "onde forças antagônicas de diferentes agentes sociais se confrontam na esperança de realizar seus interesses e projetos 
de vida específicos", referido por Singer, tenha sido o fator decisivo na construção de um perfil próprio que cada grupo colonizador tenha moldado nas principais cidades da área de abrangência da BR-163.

O pensamento inicial que trouxe o sucesso para algumas aglomerações enquanto destinou estagnações para outras desta mesma área ao longo dos anos 1970 e 1980, deixa bem claro a importância do fenômeno complexo que é o processo social. Algumas comunidades souberam se articular mais rápido e escolheram caminhos sólidos, como é o caso de Sorriso que se desenvolveu a partir da Colonizadora Feliz.

Comandada por Claudino Francio que gerenciou as vendas de grande quantidade de terras pertencentes a um grupo norte-americano e que, quando percebeu o desinteresse destes em continuar naquela região. A partir do momento em que teve condições de negociá-las por conta própria, reverberou seu entusiasmo entre os amigos que havia deixado em Passo Fundo - RS e redondezas, e cercou-se da ajuda do bom amigo cuiabano que além de tê-lo orientado para procurar terras naquela região, depois se tornou seu sócio na Colonizadora Feliz.

Foi assim que transformaram o núcleo da vila num ponto de encontro de pessoas que, a princípio, vinham da mesma região, pensavam de forma semelhante e se apoiavam mutuamente. De certa forma, estes fatos facilitaram o crescimento e a expansão do agronegócio, pois, como conta Sra. Idalina Francio, esposa do Sr. Claudino, entrevistada em sua casa, em Sorriso, dia 20.09.2012 "para cada fazenda vendida, vinha como doação um terreno na cidade; e tudo tinha de ser muito ligeiro, porque o dinheiro da venda de uma fazenda ia pagar aquela que tinha comprado". Embora trabalhasse muito, na filosofia dele, a família ficaria mais segura na cidade, enquanto o fazendeiro "amansava" a terra. Com este pensamento, fez crescer rapidamente o núcleo urbano.

De alguma forma, este tipo de colonização fez com que a agricultura sorrisense já tenha nascido praticamente mecanizada; os migrantes que optaram comprar terras do Sr. Claudino já traziam em mente "a presença dos interesses da agricultura de exportação que desde os primeiros momentos da constituição do Estado Nacional é indiscutível" (SILVA, 2008:366). Este talvez seja um dos motivos que faz os fazendeiros que possuem terras no perímetro do município optar por viver na cidade, diferente dos proprietários de fazendas em outros municípios. 
Mas nem só de fazendeiros vive a cidade de Sorriso. O pensamento do Sr. Claudino parece ter influenciado, inclusive, as primeiras mulheres que chegaram ao povoado, em 1975. As primeiras imigrantes foram as principais responsáveis pelo incentivo as mulheres que iam chegando. Mesmo com todo tipo de dificuldade, faziam verdadeiras festas de recepção para as recém-chegadas, como forma de animá-las a ficar. A falta de fogão para fazer comida, por exemplo, não as intimidava. A comida era preparada em uma panela pendurada numa forquilha; a falta do forno para assar pão ou carne, inspirou-as a cavar um cupinzeiro, transformando-o em forno onde preparavam o jantar e os doces para as festas de recepção.

Parece que elas também trouxeram na bagagem, o costume de cultivar jardins, comum nas casas do sul do Brasil, e acabaram influenciando até mesmo a urbanização da cidade, como se vê na Figura 51, abaixo.

\section{Figura 51 - Jardim no centro da cidade de Sorriso}

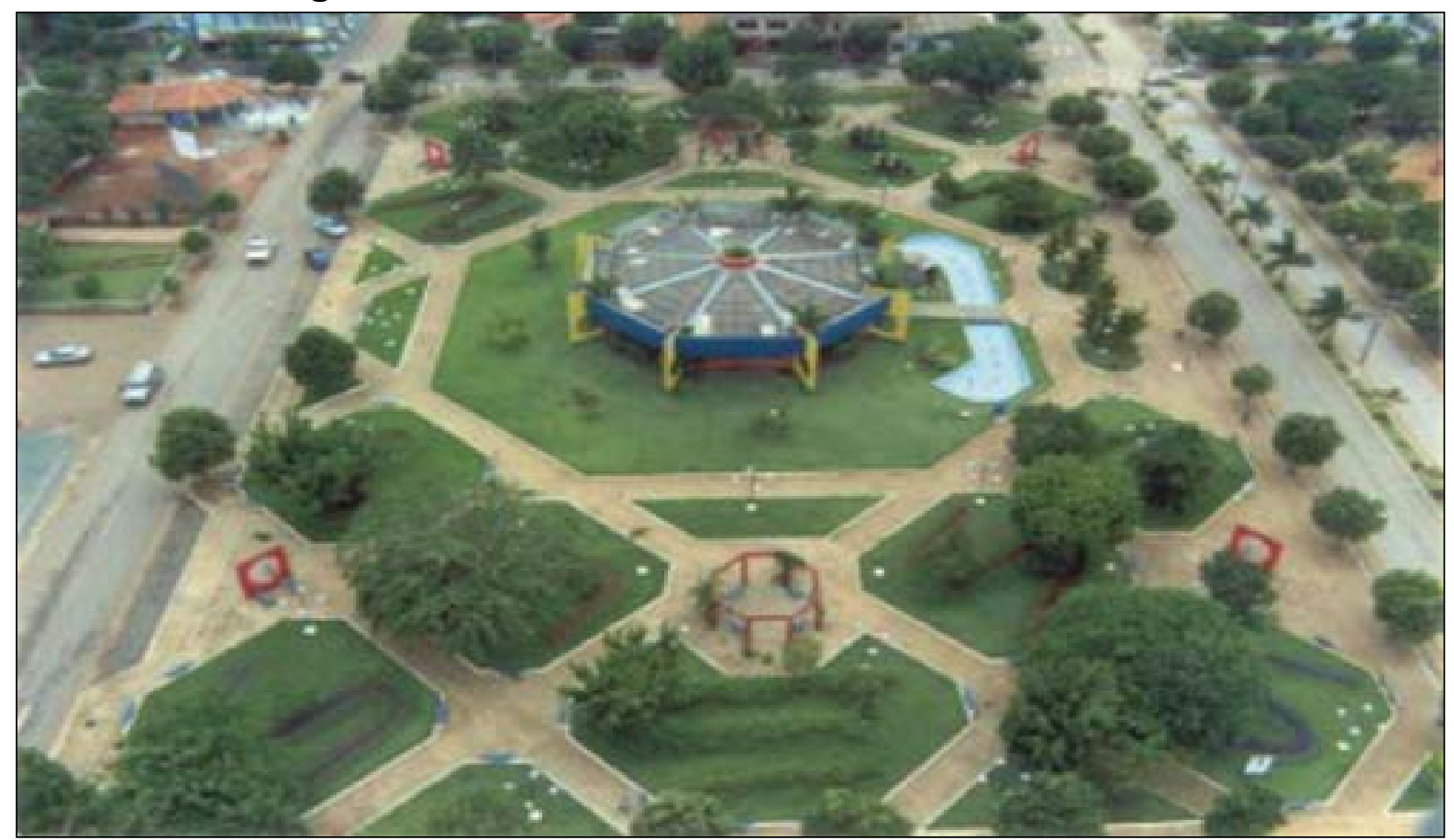

Fonte: Prefeitura de Sorriso (2010)

A Sra. Luciene Francio relata que neste início de colonização, o apoio mútuo foi a principal arma para vencer o desânimo e a falta de recursos:

Então as pessoas que vieram para cá elas apostavam tudo naquilo e trabalhavam para a coisa acontecer. Então elas eram receptivas com quem chegava, elas queriam ter gente. Era muito bonito e tinha um espírito assim muito legal, porque era muito precário. Praticamente não tinha água, não tinha hospital, as escolas eram precárias, o poeirão era dessa altura, mas o 
espírito e o otimismo assim, era impressionante. Aí quando chegava o pessoal do sul, as mulheres davam atenção. Os homens se encantavam porque para eles o que valia era a terra e oportunidades de crescimento econômico; a mulher é que se deparava com as dificuldades: os filhos, comida; se meu filho ficar doente o que é que eu vou fazer? Então a mulher é que se desesperava. Aí as mulheres que já estavam aqui se reuniam para acolher esta mulher que chegava. E acolhiam; aí tinha isso: o pessoal que chegava não tinha onde ficar, ficava na casa de alguém. Minha mãe recebeu muita gente. Minha mãe ficava aqui, o pessoal chegava, encostava o caminhão de mudança, e agora. Vem pra cá, fica aqui em casa que amanhã a gente acha um jeito. Em dois, três dias construía uma casa e daí tá, beleza! Era assim, mas a comunidade que já estava aqui acolhia muito.

\section{E não era só a mãe da Sra Luciene Francio que agia desta forma:}

Eu sempre falo que meu pai, Dona Helena que sempre conta esta história, esposa do Sr. Merival Brandão, um empresária que tem aqui, e o meu pai dizia assim: Dona Helena é minha sócia no projeto de colonização, porque quando vinha o casal do sul, meu pai levava o cara para vender fazendas, para ver as terras, e ele largava a mulher com a Dona Helena lá na loja. Ela tinha uma lojinha bem pequenininha e era muito otimista, levava na casa de uma outra para tomar chimarrão e ela era do sul também, daí já conhecia fulano, sicrano, daí de noite já se reunia todo mundo para uma janta, pescavam, era assim o espírito. A comunidade acolhia muito quem chegava e aí a pessoa devagar ia se acostumando com a realidade, coisa e tal, e aí na próxima vinda fazia a mesma coisa. Se acostumando ou se conformando, não voltava para trás, porque não era lugar para gente fraca. Era gente que tinha vontade de arregaçar as mangas e trabalhar. Eles eram muito trabalhadores. Quando hoje as pessoas falam: ah! Porque anda num carrão, coisa e tal! Gente este pessoal trabalhou muito! Ralou! De catar raiz, porque no começo não tinha quem fizesse. De uns tempos para cá é que veio a mão de obra. Na época em que isso aqui começou, quem catava eram os donos da terra, a mulher é que fazia a comida para os funcionários, como não tinha estrada, não podia trazer muito trator, nem tinha funcionário... era um grande desafio. O pessoal não tinha medo de trabalho!

\section{É perceptível a influência das mulheres até no comércio local, conforme}

relata o Sr. Emiliano Preima, Secretário de Obras de Sorriso, em sua entrevista concedida em 19.09.2012:

O centro da cidade cresceu meio que por obrigação. Mas o comércio, eu vejo assim, são pessoas da própria área da agricultura que gostavam mais de comércio. Até eu tinha uma lojinha aqui até 1995. Aí minha filha acabou indo embora e eu acabei desistindo da loja. Mas eu acho que deveria ter ficado no comércio. Nós ainda não temos a pujança do comércio de Sinop, porque em Sinop o comércio é dez vezes melhor que o nosso em todos os aspectos, nós ainda temos um comércio muito elitizado no centro da cidade. Nós temos lojas aqui que nem cidades com mais de 150 anos tem. Temos algumas grifes, se é que é assim que se chama, que compra lá roupa no Bom Retiro, em São Paulo, que eu conheço bem também, porque eu já fui lá comprar para mim, e que vende por grife aqui. Mas nós temos um comércio central muito caro para a população de Sorriso. E temos também algumas lojas que se desenvolveram mais para a periferia, que melhoraram o comércio local. Por exemplo, aquela loja de calçados ali em cima... é uma loja que veio para um comércio mais barato, para a população mais simples, mais popular, que vende o mesmo artigo que vende numa outra loja qualquer onde uma sandalhinha para mulher custa $R \$ 300,00$ e ela vende 
$\mathrm{R} \$ 50,00$, da mesma marca, inclusive. Se é ponta de estoque que pega lá em Franca, eu não sei, mas é a mesma marca. O comércio é bem elitizado.

Para o Sr. Preima não resta a menor dúvida que boa parte do comércio atende à elite sorrisense que, mesmo comprando muito nos grandes centros e até no exterior, exige lojas sofisticadas para suas compras. Esta realidade, no entanto, vem mudando, até porque o número de pessoas com menor poder aquisitivo vem crescendo nos últimos anos.

Melhorou bastante, depois entraram algumas lojas populares que também deram uma melhorada no comércio da linha branca, e algumas lojas na área de material de construção. Outras pessoas criaram comércios menores e cresceram até porque a cidade expandiu muito. Por exemplo hoje não tem cimento na cidade. Se eu precisar de cimento hoje, vou ter dificuldade para concretar algumas calçadas, porque eu não tenho cimento. Os mercados melhoraram muito à partir da instalação de alguns mercados mais populares, entre 1998 e 2000. Eles melhoraram a alimentação e nivelaram os preços para baixo. Porque até esta época os preços eram um absurdo. Hoje você compra o arroz, o feijão ou a carne aqui, mais barato que em qualquer lugar. Mesmo os preços de ave. O peixe que é ainda um pouco caro. Mas a comida em si e o próprio material de limpeza, se nivelou com cidades do sul. Antes eu trazia café do sul, porque eu gosto muito de café, leite em lata. Nós tínhamos gado já, mas tem criança que não se adapta com leite de vaca; então a gente trazia muita coisa do sul.

Até mesmo para as questões de alimentação, na opinião do Sr. Preima, a oferta cresceu bastante e tudo ficou bem mais fácil.

Hoje você tem tudo. Com a vinda destes mercados, melhorou; nivelou para melhor. Não para cima; nivelou para baixo. Um dos mercados está construindo um "atacarejo" aí, que deve melhorar ainda mais. Então, a parte de alimentação melhorou muito, mas a parte de vestuário ainda está muito elitizada. Até no comércio de carro hoje, continua muito elitizado. Você só vê carro caro aqui; tudo com preços de $\mathrm{R} \$ 150$ mil, $\mathrm{R} \$ 200$ mil. Os donos de lojas, de um modo geral, são mulheres de proprietários de fazendas que tinham uma vocação para o comércio e quis fazer alguma coisa diferenciada e fez; só que fez para a elite. O comércio mais popular é de gente de fora que veio para cá. É por isto que o comércio de Sinop é melhor que o nosso. Lá se pensa em vender mais, para mais gente e aqui eles preferem vender menos para pouca gente.

Já o desenvolvimento e a modernização de Sinop, devem muito à persistência do colonizador Sr. Ênio Pipino e ao seu sócio João Pedro Moreira de Carvalho. Ambos eram daqueles brasileiros para os quais a palavra não é apenas um estímulo para seguir em frente. Eles não desistiam, embora a realidade de Sinop fosse muito diferente dos outros municípios pesquisados porque, além da proximidade da floresta, condição que fomenta muito mais o interesse de madeireiras que de agropecuárias, havia a distância para os principais centros do país, sua principal adversária. 
Quando a colonizadora iniciou, por via aérea e fluvial, o reconhecimento da área a ser demarcada para elaborar o projeto de colonização precisou de uma equipe altamente especializada que delimitasse as terras pertencentes à Gleba Celeste.

Figura 52 - Trajeto percorrido pelo grupo de trabalho da colonizadora Sinop para chegar até a Gleba Celeste em 1972

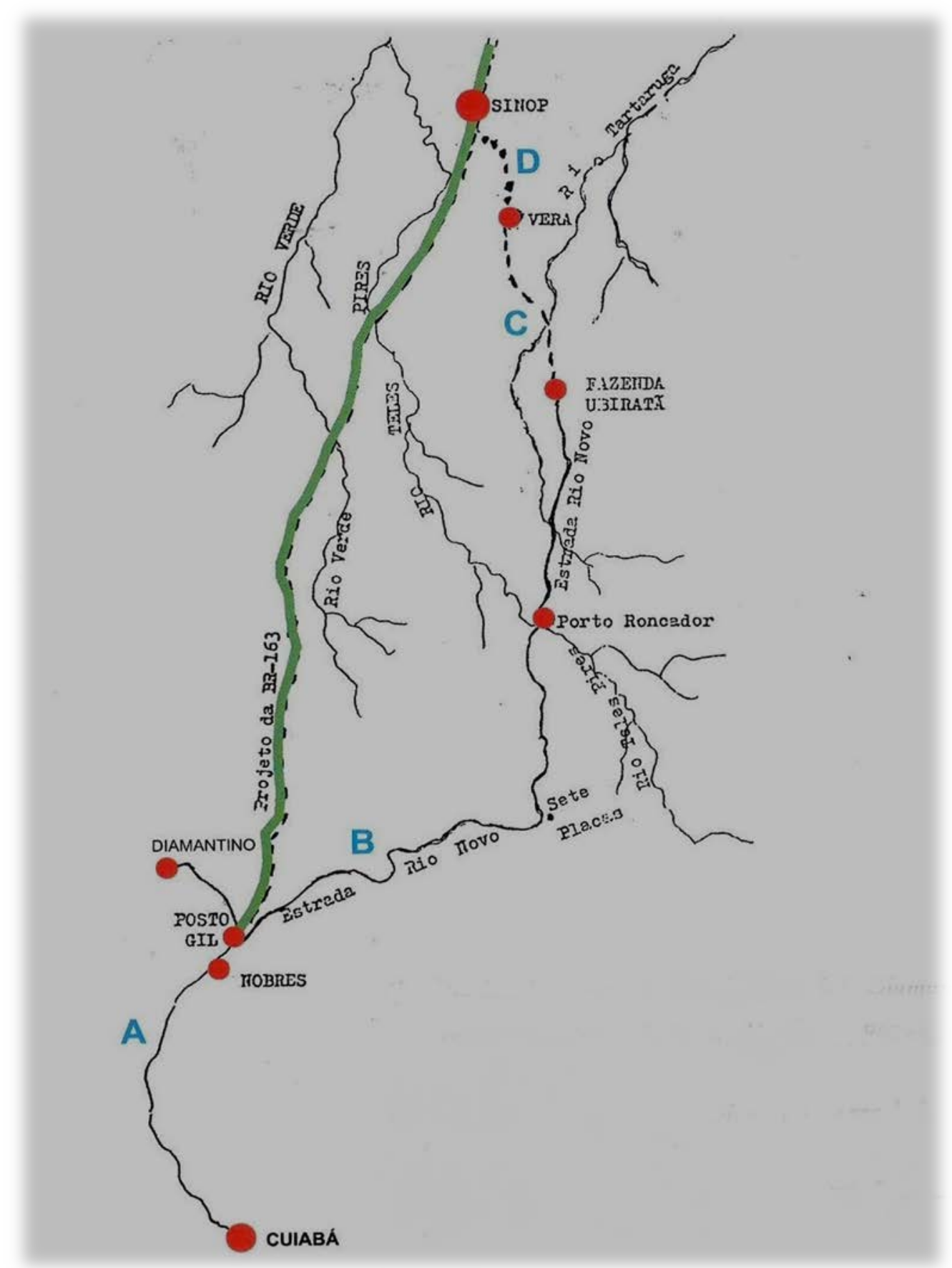

Fonte: Livro Raízes da história de Sinop (2011:32) do Prof. Luiz Erardi F. Santos 
A Figura 52, acima, permite localizar os traçados das duas estradas, aqui demarcadas com as letras A, B, C, e D. Onde A - é a estrada existente entre Cuiabá e a cidade de Diamantino, mais precisamente o Posto Gil, ponto de referência desta região desde a década de 1960; B - é a estrada Rio Novo, aberta na década de 1960, entre o Posto Gil e a Fazenda Ubiratã; C - é a picada aberta da Fazenda Ubiratã até a área da Gleba Celeste, onde foi fundada a cidade de Vera; D - é a picada aberta entre o local de implantação da cidade de Vera e a área onde foi fundada a cidade de Sinop.

O trajeto percorrido pela equipe da colonizadora para chegar até a Gleba Celeste, em 1972, abriu a estrada que serviu de apoio a todo o Nortão até a conclusão da BR-163, que iniciou suas obras neste mesmo ano.

Conforme Santos (2011:31-32), a equipe partiu de Cuiabá em direção ao Posto Gil e dali se deslocou rumo ao norte do estado pela estrada Rio Novo que ia até a Fazenda Ubiratã, nas proximidades do rio Tartaruga. Este trajeto tomou dois dias do grupo para percorrer $340 \mathrm{~km}$.

Em abril de 1972, o grupo abriu outra picada em direção à área onde hoje está o município que recebeu como nome a sigla da colonizadora, Sinop Sociedade Imobiliária Noroeste do Paraná.

A partir da fazenda Ubiratã, a equipe continuou avançando para o norte, agora já em plena floresta amazônica. Foram abertos $52 \mathrm{~km}$ até o local da Gleba Celeste, onde foi implantada a cidade hoje conhecida como Vera; no local passaria a BR-163, em seu projeto original, mas interesses econômicos e influência política desviaram seu traçado.

Com o desvio da BR-163, Sinop transformou-se em área de maior interesse e o que estava apenas num projeto secundário se transformou em primeira etapa de colonização da Gleba. Vera, Carmem e Cláudia, que haviam sido projetadas para crescer graças à estrada aberta pela equipe da Colonizadora Sinop, acabaram ficando num plano secundário, embora também tenham atraído muitos imigrantes.

Durante a pesquisa ficou entendido que, quando se fala da pujança da região, da importância que as commodities têm para a economia nacional, é comum esquecer que estas cifras são produzidas por aproximadamente $0,2 \%$ da população da região; a maioria dos grandes latifundiários sequer vive na Amazônia Legal, à exceção de Sorriso, onde vive grande parte dos fazendeiros do município, inclusive 
os que estão adquirindo terras nos municípios de Colíder e Vera, mais ao norte do Estado.

Lucas do Rio Verde demorou um pouco mais a encontrar sua vocação, na medida em que a implantação do povoado já começou tumultuada, sob o controle do INCRA. Sem os títulos definitivos das terras, os posseiros que chegaram a Lucas antes mesmo da decisão do INCRA de implantar ali o PEA Lucas do Rio Verde, os imigrantes pioneiros passaram por histórias que marcaram suas vidas.

O Sr. Ildo Romancini, contou um pouco de suas experiências numa entrevista concedida em 21.09.2012:

Saímos de Diamantino, depois de três dias lá no balcãozinho do banco para conseguir um financiamento, porque agente ainda não tinha o título da terra, cansados, viemos embora de carona, tudo estrada de chão, não tinha asfalto de Cuiabá para cá; chegamos no Posto Gil, vinha um Mercedes, me lembro até a cor, era azul trucado com uma carga de mercadoria toda enlonadinha, com as corda etc, e eu ergui a mão por erguer, imaginando que o cara não iria parar. E o cara parou e nós estávamos em cinco, mas dentro da cabine estava ele a mulher e uma criança de uns 5 anos. Ele estava indo para Alta Floresta, levar uma carga de mercadoria de um supermercado. Toda aquela carga alta ali, não é. Aí nós conversamos e ele nos disse que se nós tivéssemos coragem de sentar encima da carga, na lona. não teria problema. A gente olhou um para o outro e resolvemos "encarar". O sol já estava meio baixo quando nós subimos e sentamos um atrás do outro bem no meio da carga e metemos a mão por baixo da corda para segurar, porque se cai lá de cima, dá uns dois metros e meio para cima da carroceria, e viemos embora. Quando foi uma três e meia da manhã, nós estávamos no Posto São Genaro, a uns 35 a $40 \mathrm{~km}$ para trás aqui, quebrou a carcaça do caminhão e caiu ali. Escuro ainda, descemos do caminhão, o que fazer? Esperar outra carona? Mas também passava pouco carro, o jeito era esperar até poder ir embora. Quando nós olhamos para dentro do cerradinho, tinha uma luz. Tem coisa ali, vamos lá. Fomos nós cinco; o motorista, a esposa e a criança ficaram no caminhão.

Apesar do medo, eles sabiam que alguma coisa deveria ser feita. E saíram em busca da luz para ver o que iriam encontrar.

Chegamos lá era um "botequinho", um cara junto de uma mesa de snooker jogando e um caboclo atrás do balcão com cara de quem estava tchuco, já cansado, e eu perguntei para ele: escuta, não tem talvez umas camas aí para gente dormir? Ele me deu uma olhada e disse assim: cama tem aí, mais se ocêis qué durmi, espera aqueles que tá durmindo levantá pra ocêis ir. E o cara não deu muita moral e nós não conhecíamos ninguém, nem nada. Não, tudo bem. Saímos e fomos sentar na beira da estrada para esperar raiar o dia, contar "causos", rir, não sei o que, então tudo era uma festa.

O tempo passou e para o Sr. Ildo Romancini, na Foto 28, abaixo, estes casos e outros não passam de boas lembranças dos tempos em que Lucas do Rio Verde era um ponto perdido no meio da estrada para o Nortão. 
Foto 28 - Sr. Ildo Romancini e equipe de pesquisa

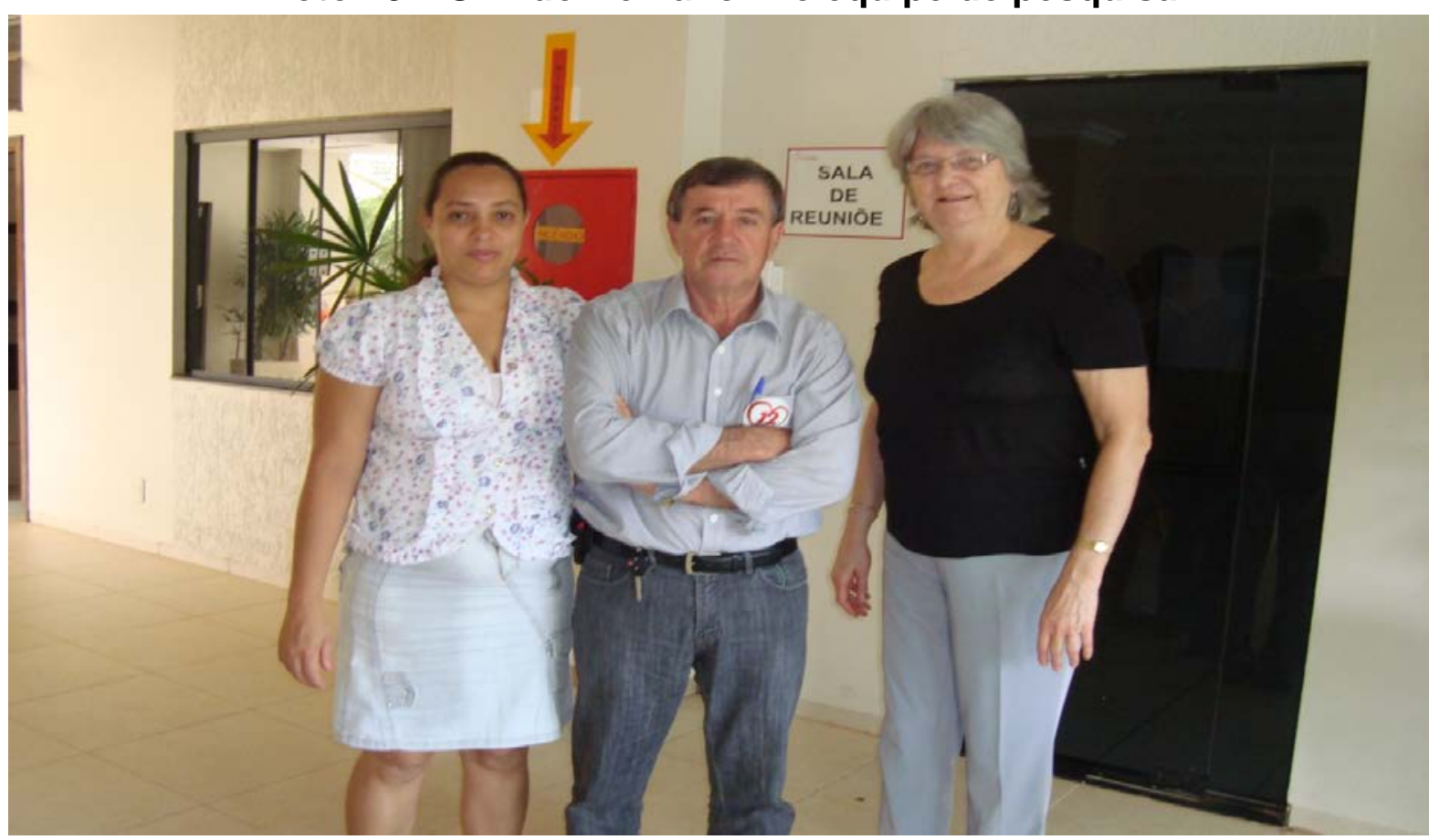

Fonte: Acervo da autora (2012)

Havia ficado uma pergunta que precisava ser respondida: conseguiram o empréstimo? "Nesta viagem, não. Porém, com intermediações de posseiros, assentados e membros do GICAN, conseguimos depois".

O suíço Anton Huber, um dos líderes do GICAN, projeto precursor da COOPERLUCAS, relata em seu livro de memórias que:

\begin{abstract}
O levantamento efetuado pelo INCRA, antes de 1978, registrava que na gleba o Verde, menos de 10 áreas estavam ocupadas, porém existia uma planta geométrica de lotes demarcados e numerados de 1 a 56, além de 11 áreas adjacentes à gleba, algo maiores, das quais duas nela se incluíam. Esta planta já estava invalidada pelo ato discriminatório em processo pelo INCRA. Pouco tempo depois, por volta de 1980, um novo levantamento indicou mais de 20 possessões territoriais reclamadas. (HUBER, 2010:57).
\end{abstract}

Uma das batalhas vencida aconteceu em 24 de agosto de 1981, quando foram entregues os documentos da regularização fundiária aos 85 colonos que conseguiram provar a posse da terra e que, por isto, foram reconhecidos pelo INCRA. Outra batalha que corria paralela, era a organização e fundação da COOPERLUCAS - Cooperativa Agropecuária Mista Lucas do Rio Verde Ltda, da qual fariam parte todos os associados do GICAN (Grupo de Interessados em Colonizar Áreas Novas), em sua maioria ainda em São Paulo aguardando as decisões do INCRA, isto é, os processos de titulação das terras, para que tivessem a garantia de receber o crédito de investimentos para financiar a infraestrutura e 0 
custeio do plantio das lavouras. Portanto, o processo de registro da COOPERLUCAS teria prioridade, pela importância do seu papel no processo de fundação do Distrito. Finalmente, em 22 de dezembro de 1981 foi fundada a COOPERLUCAS. Com os documentos legais, pode assumir a responsabilidade da parte que cabia aos imigrantes pioneiros no Acordo de Ação Conjunta firmado com o INCRA, que destinava 3 mil hectares à cooperativa, para a implantação de infraestrutura administrativa industrial e comunitária e instalações de campos experimentais agrícolas e florestais. (HUBER, 2010:99-100).

O Sr. Bares conta que o próprio desenvolvimento das commodities deve muito do seu sucesso à COOPERLUCAS:

Tudo era muito difícil, era muito longe, tudo era estrada na poeira ou na lama, nós tínhamos que fazer uma briga eterna para resolver um probleminha. Aí em seguida, nós começamos, nessa época que a COOPERLUCAS começou a avançar e descobrir que poderiam vir novas variedades de soja e de arroz. Até então nós plantávamos um arroz chamado 25 que era um de ciclo curto e um 47 que era arroz de ciclo longo que produzia mais. Ai foi quando o Sr. Minifumo Matsubara com uma equipe de franceses trouxeram para o Brasil o arroz do tipo Cirad. Através de uma parceria com os franceses, o Sr. Minifumo Matsubara começou a produzir sementes ali no campo dele e aí também foram entrando outras variedades de soja, como as do tipo IAC106, o 108, depois entrou o 110, e foram entrando outras variedades, mas nós nunca passávamos de 33/35 de produção por hectare. Até mesmo porque não tínhamos tecnologia de plantadeira, nós plantávamos com semeadeira... até tem uma história interessante [...] e aí nós tínhamos o problema da logística que nós estamos convivendo com ele até hoje. Nós tínhamos uma produção de soja, poucos compradores, mas era a única alternativa de você continuar trabalhando. E aí nós entramos numa paranoia que produzir 30 sacos de soja por hectare não era um bom negócio. Nós tínhamos que produzir mais. Por isso nós tínhamos que nos associar à COOPERLUCAS e buscar o desenvolvimento tecnológico, que se deu na nossa região através da COOPERLUCAS.

Paralelo às produtivas havia também questões políticas de demarcação de terras para aprovar a criação do distrito, houve ocasiões em que tudo parecia estar andando para trás, conforme nos conta o Sr. Leonildo Bares:

Mas nós tínhamos outro problema; nossas terras não valiam nada. Eu me lembro que em 1986 meu sogro vendeu metade da fazenda que começava na frente do Morocó e chegava até no rio Verde, foi vendida por 17 sacos de soja por hectare para pagar em quatro anos. Para derrubar aquela área custava 25 sacos. Era mais cara a derrubada do que o valor da terra. Muitos produtores que tinham áreas grandes começaram a vender uma parte para tentar a outra produtiva. Até então meu sogro, que tinha uma fazenda de 1.200 hectares trabalhava de carpinteiro e pedreiro por dia para poder sustentar a família. Aí ele viu a oportunidade de vender uma parte de fazenda e preparar ali uns 100/150 hectares para tentar plantando para tentar viver de agricultura que era o grande sonho dele e que tinha ficado para trás porque ele vendeu no sul como agricultor, veio para cá como produtor e teve de trabalhar como pedreiro porque como produtor ele não 
podia sustentar a família, no ano seguinte ou dois anos depois ele quebrou a fazenda dele e teve que arrendar a terrinha que ele tinha na frente de 160 hectares e ele arrendou para os cunhados e voltou a trabalhar de pedreiro e vivendo da rendinha da terra e de pedreiro. Em 1988, ele conseguiu voltar a plantar; ele e muitos outros. Uns quebravam saiam e outro entrava.

Para ele, algumas situações permaneceram inexplicáveis.

O mais interessante é que os que vieram de fora com dinheiro de fora, não aguentaram, voltaram, foram embora. Os que estavam aqui sem dinheiro, acostumados a passar fome, diga-se de passagem, seguravam porque sabiam que um dias as coisas iriam acontecer. Eu não tenho vergonha de dizer que eu ouvi minha sogra contar esta história e a minha mulher conta também, que muitas vezes minha sogra saia com uma espingarda na mão, porque ela era uma boa caçadora e matou papagaio, por falta de outra coisa para comer. Elas dizem que cozinhar um papagaio toma duas horas de fogo, para fazer uma mistura junto com o arroz e o feijãozinho que produzia na fazenda. Era a sobrevivência deles.

A diferença de Lucas do Rio Verde em relação aos outros municípios é que a cidade não teve uma colonizadora para nortear seu destino, como as outras.

Foto 29 - Sr. Leonildo Bares e equipe de pesquisa - Sinop

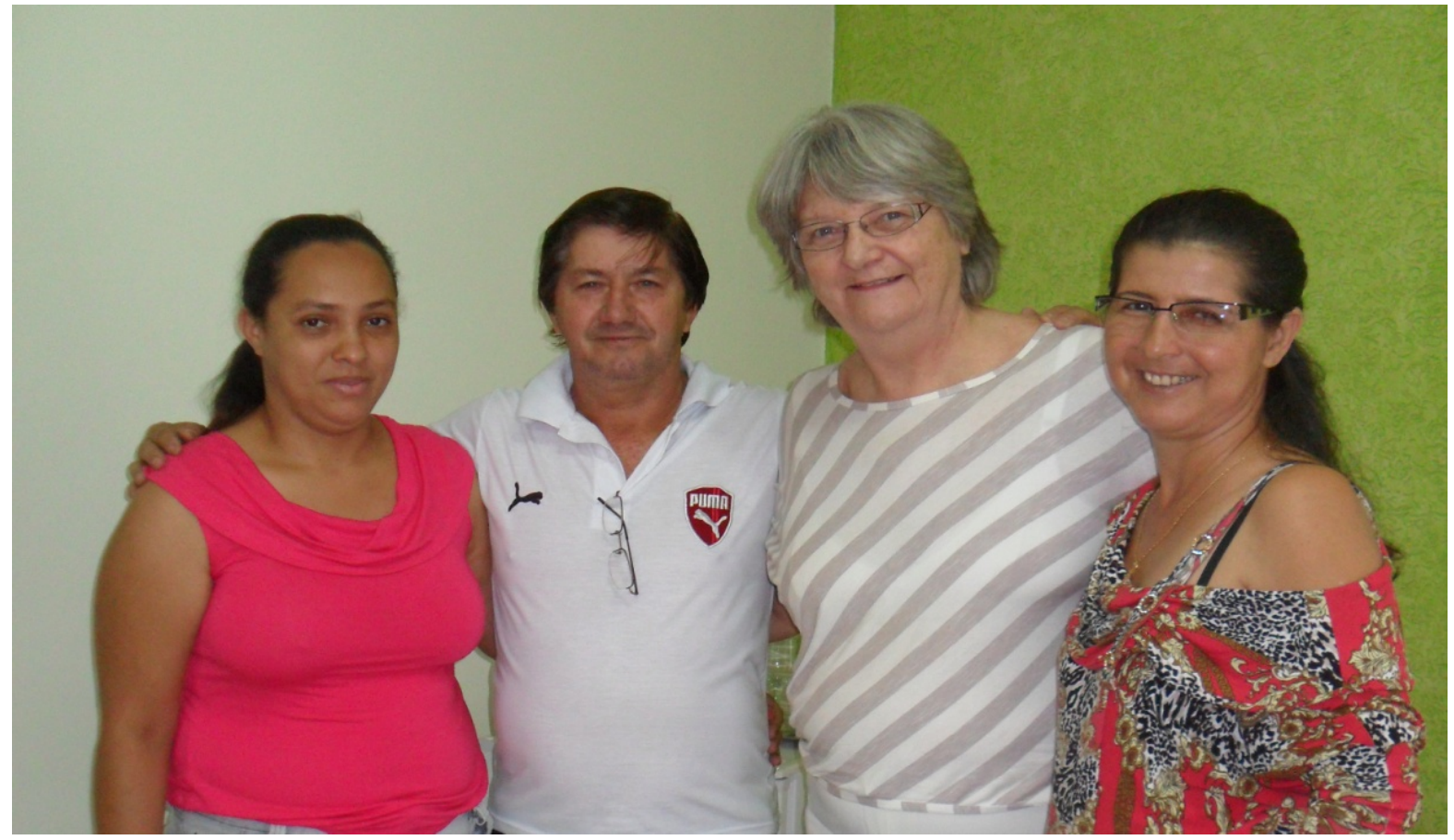

Fonte: Acervo da autora (2012)

O Sr. Leonildo Bares, na Foto 29 com a equipe de pesquisa, conta que o desenvolvimento de Lucas se deve, principalmente, aos agricultores que já estavam aqui, antes da intervenção do governo federal para, através do INCRA, assentar as 203 famílias que chegaram do Rio Grande do Sul. O crescimento e a modernização foram sendo amalgamados pelos imigrantes pioneiros e pela COOPERLUCAS. 
$\mathrm{Na}$ versão dele, a questão dos assentados é bem diferente do que se lê a respeito e se aproxima muito do que foi narrado por Paulo Pitaluga Costa e Silva, Coordenador Geral do INCRA em Mato Grosso, à época.

Por volta de 1981/1982, o INCRA colonizou Lucas do Rio Verde, entrando em Lucas, no sentido Cuiabá para cá, do lado esquerdo, foi colonizado pelo INCRA tudo em lotes de 200 hectares, que era uma colônia gaucha que se criou ali. Então o INCRA vinha, dava 200 hectares para o cara, derrubava 10 hectares, plantava o arroz e... para cima da ponte do rio Verde, daqui para lá, no sentido Lucas, logo para cima tem um arco grande ali escrito quilometragem e tal. Você passa por baixo dele. Do lado esquerdo dele, uns 100 metros para cima, tinha a COBAL (Companhia Brasileira de Alimentos), um armazém do governo para vender os produtos para os produtores. Então eles davam aqueles 200 hectares, derrubava 10 hectares e dava plantado o arroz, o governo pagava um salário durante um ano para os gaúchos e eles faziam compra na COBAL (Companhia Brasileira de Alimentos). Daqueles gaúchos ali deve ter uns quatro que ficaram assentados até hoje; os demais desistiram. Venderam ou trocaram a troco de uma passagem para o Rio Grande do Sul, a troco de um fusca ou alguma coisa, venderam e foram embora. Ficou em Mato Grosso quem já estava aqui e tinha condições de ir mexendo com a terra. O que foi acontecendo: a região foi entrando na etapa do arroz mecanizado e soja.

Quando o professor Edison Antonio de Souza discorre sobre a questão da migração, da expropriação trata da questão da sobrevivência que provoca reterritorialização fato que se vê melhor em Lucas. Aqueles nordestinos que vieram para trabalhar na atividade madeireira em Sinop e que foram para o sul do Pará, voltaram de lá, porque viram uma nova oportunidade na indústria alimentícia em Lucas. Este é o jogo do capitalismo, que nesta região é acelerado e a qualquer custo.

O Sr. Antonio Isaak Fraga Lira, na Foto 30, a seguir, imigrante pioneiro de Lucas do Rio Verde, descreve numa entrevista concedida em sua casa, em Lucas do Rio Verde, dia 21.09.2012, o que foi para a cidade o forte fluxo migratório provocado pela instalação da Sadia:

Nós somos uma cidade de imigrantes; aqui tem poucas pessoas matogrossenses. Depois da instalação da Sadia aqui, veio muita gente de fora, principalmente nordestino e quando vem muita gente de fora, muito imigrante, sempre tem problema social porque assim como vem as pessoas boas vem as ruins. Nós tivemos bastantes problemas de assalto de casas, de residências. Mas assim mesmo, tudo e válido porque se você quer progresso, você tem que trazer indústrias e como veio, vem pessoas que vem trabalhar, procurar serviço, principalmente porque Lucas é uma cidade que está muito na mídia nacional. Então as pessoas ouvem, veem e tem muito aventureiro também que vem com as malas para aventurar. Muitos se dão bem outros não se dão, mas tudo é válido. Eu acho assim que Lucas, principalmente a administração pública conseguiu conter esta invasão de pessoas, com saúde, com educação, mesmo com esta avalanche de pessoas de fora vindo, nossa administração conseguiu dar a volta por cima. 
Não faltou moradia para ninguém, não faltou escola para nenhuma criança, não faltou posto de saúde para as pessoas, isso é muito importante.

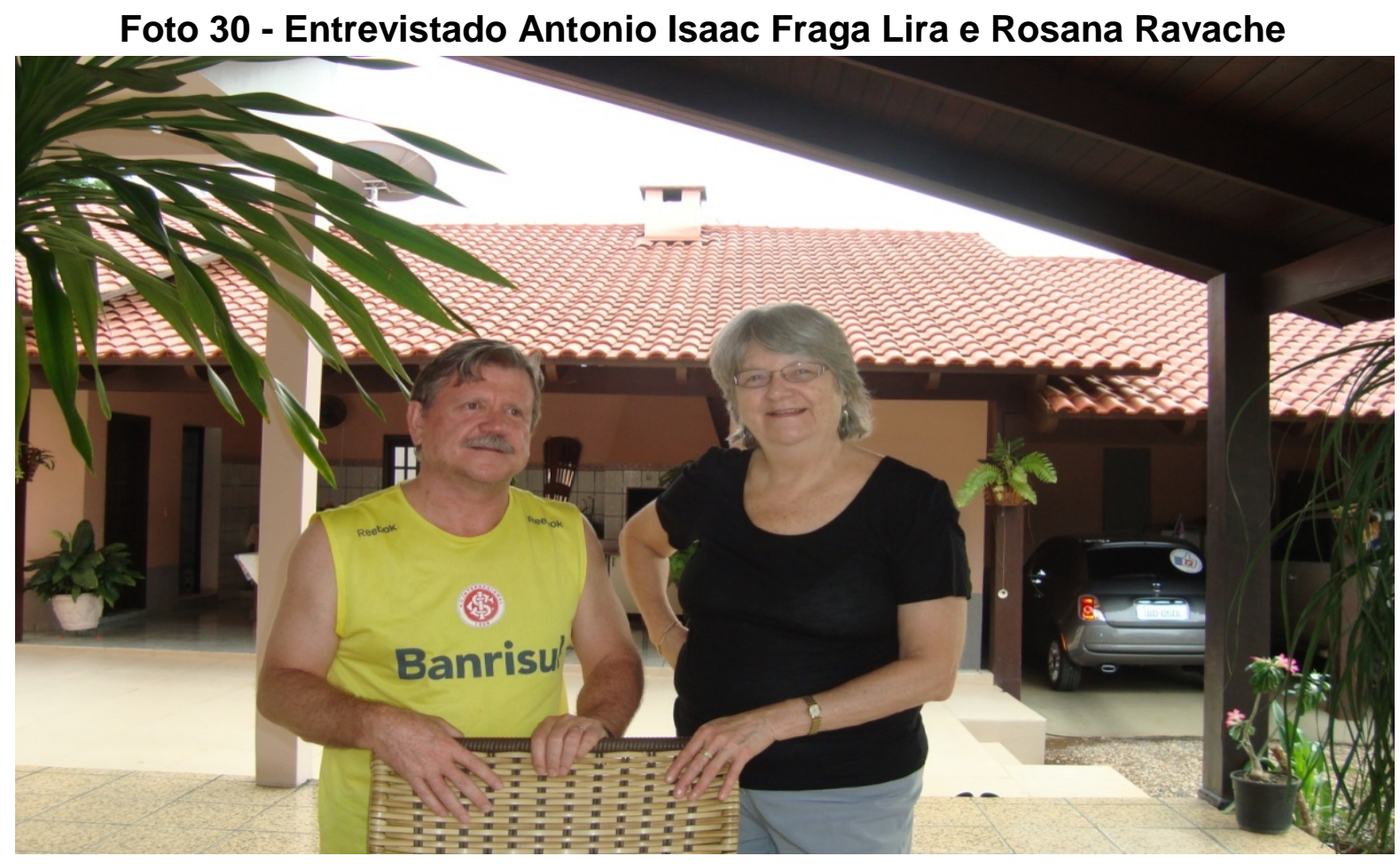

Fonte: Acervo da autora (2012)

Muitas dificuldades foram superadas em toda a região, como relata o Sr. Lira, mas ainda subsistem resquícios de preconceito, apesar dos esforços do poder público, como é o caso da Secretaria de Educação e Cultura de Sorriso.

Para Avanice Lourenço Zanatta, Secretária de Educação e Cultura de Sorriso, a questão do preconceito precisa ser combatida na base da educação pública:

E eu sempre falo, na educação, nas escolas, a gente tem que saber trabalhar com toda esta diversidade, para que não ocorra nenhum preconceito, porque hoje, quem constrói a nossa cidade, somos todos nós. Todos nós temos que fazer a diferença. A soja tem um papel importante? Tem. Mas não é só isso. Nós temos empresas chegando, temos trabalhadores que estão vindo, com as suas famílias, com as suas histórias e com as suas raízes e que estão presentes aqui e que a gente tem que saber: além de respeitar, valorizar e fazer disso parte da nossa sociedade, eu acho. Não tem como você dizer que isso não é parte da sociedade sorrisense. Ele (o maranhense) está ali e tem que saber como lidar com ele. Às vezes eu vejo que ainda tem muito resquício desta diferença. Não dá para a gente ser hipócrita e dizer que não existe. Eu acho que existe também ainda muito presente. Mas eu acho que a educação tem um papel fundamental, principalmente nós, em escolas públicas, temos que trabalhar isso. Nós das escolas da rede pública, nós temos escolas que são frequentadas por alunos de diversas classes. Nós temos alunos de poder aquisitivo alto que frequentam as escolas da rede municipal. Nos centros de educação infantil, eu até coloquei isto semana passada para o promotor que estava dizendo que nós temos uma grande cultura de pessoas de classe alta, e eu falei que isto tem um ponto positivo porque significa que o ensino da rede municipal é de qualidade, senão o pai que tem um poder aquisitivo 
melhor iria procurar uma rede particular e não iria procurar uma rede pública. Então, toda esta miscigenação é no convívio.

Não bastam os novos saberes da empregada maranhense, como explicou a Sra. Maria Inez Ferlin - contadora da Prefeitura de Sorriso, em entrevista concedida dia 20.09.2012, que no decorrer de nove anos ensinou-a o modo de viver sulista; muito menos a crítica ao preconceito social percebido nos frequentadores dos bares, relatado por Rogerio Neves, Secretário de Cultura de Sinop, em entrevista feita dia 17.09.2012, ao ser questionado sobre a razão dos jovens ficarem nos fins de tarde de domingos na Avenida Rio Grande do Sul. Conforme o Secretário é principalmente a questão do preconceito nos bares que leva estes jovens a ficar até tarde aos domingos na rua principal da cidade, sentados nas carrocerias das caminhonetes ou encostados nos carros, ouvindo sertanejo universitário, bebendo, sorvendo tererê ${ }^{92}$ e conversando, enquanto outros carros desfilam pela avenida, como se fosse um corso carnavalesco.

Para responder ao comportamento diferente o secretário argumentou que, possivelmente, está associado a outro problema comumente vivenciado na cidade:

\begin{abstract}
Em Sinop existem os bares só que seus donos determinam quem pode e quem não pode entrar. Na frente do bar tem sempre um garçom, então se eu não chegar adequado ao modo como eles estão pensando, na hora eles já pedem para se retirar. Eles não usam a frase: "você não pode entrar"; eles dizem: "a casa está cheia". Aqui tem bastante lugares.
\end{abstract}

Estes fatores demonstram claramente que as questões socioeconômicas imbricadas no comportamento das pessoas que vivem nestas cidades médias da Amazônia Legal, onde a maior parte dos imigrantes é compelida pela célere modernização à quimera de serem protagonistas deste fenômeno, quando na realidade, hoje, muitos precisam disfarçar suas verdadeiras histórias diante do crescimento demográfico e suas consequências, analisados a seguir.

\title{
3.3 - O CRESCIMENTO DEMOGRÁFICO
}

Se for levado em consideração que o estado de Mato Grosso cresceu 417\% entre 1970 e 2000, como informa Ribeiro (2000), é fácil deduzir que este crescimento está refletindo na população atual, com uma média entre 20 anos e 40

\footnotetext{
${ }^{92}$ Bebida feita de mate verde que ao invés de ser quente, como o chimarrão, é gelado. É sorvida com uma bomba de uma cuia, da mesma forma que o chimarrão.
} 
anos de idade ${ }^{93}$. Isto significa um aumento proporcional no número de pessoas em busca de mais conhecimento, de postos no mercado de trabalho, de alimento e de saúde, assim como significa um aumento expressivo na necessidade dos serviços públicos para atender a essa demanda.

Chegou-se a este cálculo aproximado, deduzindo que, apesar de muitos dos imigrantes terem se deslocado para outras regiões, um grande em número continua a chegar às três cidades incluídas na pesquisa. Além disso, é prudente incluir neste cálculo, que a faixa etária com maior índice na população mato-grossense está entre os 10 e 29 anos (IBGE - 2010).

Os dados demográficos dos municípios pesquisados pelo IBGE (2010) e demonstrados no Quadro 06, abaixo estão assim divididos:

Quadro 06 - Dados demográficos sobre homens e mulheres nos
municípios pesquisados (IBGE-2010)
\begin{tabular}{|l|r|r|r|r|r|r|}
\hline \multicolumn{7}{|c|}{ HOMENS } \\
\hline CIDADES & $\begin{array}{r}\text { C/MENOS } \\
\text { DE 1 ANO }\end{array}$ & $\begin{array}{r}\text { DE 1 A } \\
\text { 4 ANOS }\end{array}$ & $\begin{array}{r}\text { DE 5 A } \\
\text { 9 ANOS }\end{array}$ & $\begin{array}{r}\text { DE 10 A } \\
\text { 14 ANOS }\end{array}$ & $\begin{array}{r}\text { DE 15 A } \\
\text { 19 ANOS }\end{array}$ & $\begin{array}{r}\text { DE 20 A } \\
\mathbf{2 4} \text { ANOS }\end{array}$ \\
\hline LUCAS & 460 & 1.525 & 1.919 & 5.399 & 2.067 & 3.149 \\
\hline SINOP & 943 & 3.844 & 4.825 & 5.581 & 5.399 & 5.565 \\
\hline SORRISO & 596 & 2.259 & 2.976 & 3.306 & 3.150 & 3.369 \\
\hline TOT.REG. & 1.999 & 7.628 & 9.720 & 14.286 & 10.616 & 12.174 \\
\hline & \multicolumn{7}{|c|}{ MULHERES } \\
\hline CIDADES & C/MENOS & DE 1 A & DE 5 A & DE 10 A & DE 15 A & DE 20 A \\
& DE 1 ANO & $\mathbf{4 ~ A N O S ~}$ & $\mathbf{9}$ ANOS & $\mathbf{1 4 ~ A N O S}$ & $\mathbf{1 9}$ ANOS & $\mathbf{2 4}$ ANOS \\
\hline LUCAS & 437 & 1.521 & 1.807 & 1.887 & 2.041 & 2.624 \\
\hline SINOP & 905 & 3.565 & 4.738 & 5.418 & 5.447 & 5.650 \\
\hline SORRISO & 587 & 2.231 & 2.918 & 2.992 & 3.122 & 3.304 \\
\hline TOT.REG. & 1.929 & 7.317 & 9.463 & 10.297 & 10.610 & 11.578 \\
\hline
\end{tabular}

Fonte: Censo Demográfico IBGE (2010)

A divisão do grupo de jovens por sexo e local onde vivem demonstram que a área urbana concentra a maioria maciça de jovens das cidades mais habitadas ao longo da BR-163.

Entre seus 3.035.122 habitantes (IBGE - 2010) os jovens, em Mato Grosso, representam quase 8\% deste total, como se vê no Quadro 07:

\footnotetext{
${ }^{93}$ Se for levado em consideração que Lucas do Rio Verde foi fundada em 1981; Sorriso, em 1980 e Sinop, em 1974.
} 


\section{Quadro 07 - Índices demográficos de crianças e jovens}

\begin{tabular}{|l|c|}
\hline \multicolumn{1}{|c|}{ Faixa etária } & Quantidade \\
\hline De 0 a 5 anos & 48.910 \\
\hline De 6 a 15 anos & 87.349 \\
\hline De 16 a 19 anos & 39.248 \\
\hline De 20 a 24 anos & 55.651 \\
\hline & 231.158 \\
\hline
\end{tabular}

Fonte: Censo Demográfico IBGE (2010)

Mesmo considerando que muitos dos imigrantes que chegaram à área de abrangência da BR-163 entre as décadas de 1970 e 1990 tenham deixado Mato Grosso, dos 225.176 habitantes aferidos pelo censo do IBGE (2010) nas três cidades aqui enfocadas, $20,24 \%$ das pessoas recenseadas na região estão na faixa etária entre 15 e 24 anos. Isto significa uma demanda média projetada de 45.576 postos de trabalho em 2013, conforme demonstra o Quadro 08, a seguir.

Quadro 08 - Dados demográficos dos municípios pesquisados (IBGE-2010)

\begin{tabular}{|c|c|c|c|c|c|c|c|c|c|}
\hline \multirow{2}{*}{ CIDADES } & \multicolumn{3}{|c|}{ HOMENS } & \multicolumn{3}{c|}{ MULHERES } & \multicolumn{2}{c|}{ TOTAL } & \multicolumn{2}{c|}{ JOVENS ENTRE } \\
\cline { 2 - 11 } & TOTAL & URBANA & RURAL & TOTAL & URBANA & RURAL & HABIT. & 15 E 24 ANOS \\
\hline LUCAS & 24.016 & 22.254 & 1.762 & 21.540 & 20.201 & 1.339 & 45.556 & 9.881 & $21,69 \%$ \\
\hline SINOP & 57.565 & 47.139 & 10426 & 55.534 & 46.614 & 9.920 & 113.099 & 22.152 & $19,58 \%$ \\
\hline SORRISO & 34.267 & 29.886 & 4381 & 32.254 & 28.478 & 3.776 & 66.521 & 12.945 & $19,46 \%$ \\
\hline
\end{tabular}

Fonte: Censo Demográfico IBGE (2010)

Portanto, a realidade socioeconômica da região é totalmente diferente da realidade do Estado, que reúne apenas quase $8 \%$ de crianças e jovens. Ao levar-se em conta que a média do crescimento demográfico entre 2000 e 2010 para estes três municípios foi de $89,16 \%$ e se somar a este dado o fato de que a população urbana média para os três municípios atingiu $87,94 \%$ em 2010, tudo indica que as oportunidades para os jovens ficam cada vez mais difíceis.

Com este mesmo raciocínio, deduz-se que as causas da forte antropização do Nortão nas três últimas décadas do Século $X X$, não pode ser atribuída exclusivamente ao cultivo da soja, cultura que só veio a ter sucesso após a segunda metade da década de 1980, quando pesquisas e estudos do solo, em RondonópolisMT foi encontrada a solução para corrigir tanto a acidez do solo do Cerrado com calcário quanto o equilíbrio adequado dos fertilizantes para combater as pragas. Acredita-se que o estímulo ao plantio de soja tenha influenciado bastante no início 
do século XXI, entre 2000 e 2010, quando a população mato-grossense cresceu 21,15\%. (IBGE - 2010).

Por outro lado, como admitir um crescimento da população neste patamar, quando o agronegócio, no mesmo período, passou a dispensar mão de obra em função da mecanização que rapidamente invadiu a maioria das fazendas de médio e grande porte? Se a mecanização aumentava dispensando o trabalho humano, por que a população continuava crescendo num ritmo atípico para os parâmetros demográficos nacionais?

Parecia cada vez mais evidente que o número de pessoas envolvidas diretamente com a soja era cada vez menor e que estas cidades, na trajetória de urbanização e modernização, haviam criado outras fontes de renda, independente do agronegócio ou, pelo menos, parcialmente independente dele.

Para reunir dados mais palpáveis destas características diferenciadas percebidas em visitas anteriores, a pesquisa in loco se pautou em algumas características dos três municípios e procurou informações com:

a) Imigrantes pioneiros ou seus descendentes que permaneceram na área da pesquisa;

b) Realização de um levantamento de profissões praticadas hoje por colonos que assumiram profissões voltadas para a prestação de serviços ou qualquer outro ramo, sem que esteja diretamente ligado à produção agrícola.

Dentro deste contexto, se procurou focar a falta de sistematização por parte do poder público para:

a) A capacitação de mão de obra destinada à mecanização do campo e à indústria de transformação que vem sendo implantada;

b) A carência de monitoramento e normatização do espaço urbano onde as comunidades locais convivem, em regime seletivo;

c) As justificativas plausíveis para os retardamentos sistemáticos da aprovação definitiva do Zoneamento Socioeconômico Ecológico, cuja proposta poderia restabelecer a relação de espaço amorfa, partilhada por índios, pequenos agricultores e grandes empreendedores da região.

Tangenciar este tipo de análise é permear o texto de Costa (2005) onde se lê que: 
O tema do ordenamento territorial inspira uma reflexão sobre a relevância, os limites e a eficácia das políticas públicas formuladas e operadas a partir de estratégias e objetivos especificamente nacionais. (COSTA, 2005:1)

São várias perguntas cujas respostas vão se formando de acordo com o perfil de cada uma das cidades à medida que elas vão criando seus próprios parâmetros para solucionar questões do seu dia a dia.

Nas entrevistas se pode avaliar que alguns fatores preponderantes se fizeram presentes no decorrer do processo civilizador destes núcleos urbanos; dentre eles se destacam a adaptabilidade e a capacidade de transmigração destas
comunidades. Como explica o Sr. Leonildo Bares, durante a entrevista concedida na
presidência do Sindicato Rural de Sinop em 17.09.2012:

Aí veio a década de 1990 , veio a crise e da crise veio uma securitização ${ }^{94}$. Enterrado em dívida o produtor não tinha mais o que fazer. Vender a fazenda não pagava a dívida. Então saiu a securitização e aí eles começaram. A COOPERLUCAS já tinha evoluído um pouco mais em cima de tecnologia, já estava plantando soja que produzia 42 a 45 (sacas por hectare) e a coisa começava... Mas interessante que quando nós falamos de produto hoje, depois de ter feito gestão empresarial e tudo, eu não estou aqui de presidente do sindicato à toa não, a APROSOJA (Associação dos Produtores de Soja e Milho do Estado de Mato Grosso) preparou a gente para isso. Eu fiz academia de liderança três anos, fizemos um ano de gestão política, fizemos um ano de gestão empresarial, fizemos uns três meses de mídia, para falar em televisão e tudo para transparecer aquilo da forma que a gente precisa, então nós fizemos alguns trabalhos através da APROSOJA porque ela teve este cuidado de nos preparar para ser líder.

O Sr. Bares aprendeu que em lugar do Brasil importar comida, como fez durante muitos anos, poderia exportá-la e ainda ganhar muito com isto. E continuou explicando que:

Então hoje estudando um pouco sobre a história da agricultura do mundo, porque eu leio muito sobre o passado e, pegando o passado e conectando com a situação que nós vivemos, e trazendo o presente prevendo o futuro, a gente começa a encontrar os caminhos por onde as coisas vão acontecer. Aí que você vai entender como foi o passo. Conversando depois com o Sr.

\footnotetext{
${ }^{94}$ Têrmo do inglês securitization, indica uma prática financeira que consiste em agrupar vários tipos de passivos financeiros (notadamente títulos de crédito tais como faturas emitidas e ainda não pagas, dívidas referentes a empréstimos e outros), convertendo-os em títulos padronizados negociáveis no mercado de capitais. Assim, a dívida é transferida, vendida, na forma de títulos, para vários investidores. Assim, securitização é a conversão de uma dívida (duplicatas, cheques, notas promissórias) em título lastreável e negociável entre instituições financeiras. Estes títulos podem ser adquiridos diretamente por Bancos, Distribuidoras de Valores ou Fundos de Investimento como forma de rentabilizar o capital investido. Caberá também ao comprador do título securitizado a cobrança individual de todas as dívidas que compõe o título, isentando a Securitizadora e qualquer intermediário, de qualquer ônus. Esses títulos são, portanto, caracterizados por um compromisso de pagamento futuro, de principal e juros, a partir de um fluxo de caixa proveniente da carteira de ativos selecionados.
} 
Alysson Paulinelli ${ }^{95}$, o ex-ministro da época dos militares, eu pude entender melhor. Ele mostrou para nós um número assim: na década de 1950, o Brasil, importava leite da Holanda, leite em pó este que já estava indo para ração porque estava lá 3 a 4 anos armazenado, ia para ração animal, então eles vendiam para o Brasil. O Brasil estava importando feijão do Chile e da Flórida nos Estados Unidos que plantava para vender para o Brasil porque era um bom negócio, e nós importávamos arroz do Japão, da Indonésia, da Malásia e alguns outros países. O Brasil era um grande importador. Importava carne da Austrália, que eu tive oportunidade de ir lá agora, passei 22 dias na Austrália e Nova Zelândia fomos num grupo de presidentes de sindicato através da FAMATO (Federação da Agricultura e Pecuária do Estado de Mato Grosso). Fomos lá fazer uma visita, fizemos um bom trabalho de intercâmbio com eles e conheci a história. O Brasil importava comida. Basta analisar que o Brasil importando alimento nesta época, 54\% do salário de um brasileiro custava para comprar comida. Sobravam $46 \%$ do salário do brasileiro para as demais necessidades. Aí nós entendemos porque um pai não tinha condições de por um filho na escola, porque a Conga, o Bamba e o chinelo Havaiana fez tanto sucesso na época. Eu estou falando de uma época que muito jovem não sabe, mas a única pasta de dentes que existia era Kolynos. Para se ter uma ideia, nós estamos falando de um Brasil super atrasado, mas as coisas aconteceram muito rápido no Brasil.

\section{Com dados desta mesma época, o Sr. Emiliano Preima, Secretário de Obras}

de Sorriso relata na entrevista concedida em 19.09.2012:

O produtor rural que sobreviveu e está aí hoje, foi com muita luta. Claro que alguns tiveram situação diferenciada, os privilegiados pelo próprio banco. Por exemplo, nas negociações das dívidas do governo Sarney, 1991, entre o governo Collor e Sarney, para algumas pessoas os funcionários do banco criaram facilidades. Mas isso era problema de funcionário; não foi o governo, em si. Isso aconteceu muito por aqui e até hoje o produtor pequeno em Mato Grosso ainda sofre. Então o que é que acontecia. $O$ grande produtor, aqui, tinha as facilidades oferecidas pelo funcionário; gerente, diretores. Não era propriamente do banco. Era aquele negócio: você leva esse daí você me dá esse. Para renegociar dívidas, por exemplo, eu renegociei dívida no Banco do Brasil nesse período de 1990/1991, só que o banco não financiou mais para mim. Aí como é que a gente paga? Vendi casa, vendi tudo e arrumei uma briga com o Banco do Brasil que até hoje não está resolvida e vou morrer assim. Quer dizer, o produtor rural hoje, o médio, os pequenos... não sei... mas os grandes, não sei se pagaram, porque eles negociaram e renegociaram. Mas o que é que o grande fez: os maiores, aqueles que tinham aquelas condições especiais dentro do banco, colhia, vamos supor, dez mil sacos de soja, ou vinte ou cinquenta e levava para um outro armazém e no armazém que ele tinha que entregar, ele não entregava. Aí ele ia ao banco e dizia: não colhi. Pegava mais dinheiro, comprava outra fazenda, colocava no nome de outra pessoa, financiava outra lavoura.

Conforme o Sr. Preima relata, houve muita negociação lícita e ilícita para manter as fazendas produzindo, embora tivesse havido uma mudança radical na postura do governo federal quanto ao incentivo aos produtores da região.

\footnotetext{
${ }^{95}$ Foi ministro da Agricultura no governo Ernesto Geisel, de 15 de março de 1974 a 15 de março de 1979. Presidiu a Confederação Nacional da Agricultura. Foi filiado ao PSD, Arena, PDS e PFL. Por este último elegeu-se deputado federal por Minas Gerais nas eleições de 1986, fazendo parte da Assembleia Nacional Constituinte de 1987-1988.
} 
Depois começou a entrar os pacotes agrícolas através de algumas empresas e deu no que deu. Os que tinham, ficaram mais ricos e os que não tinham perderam tudo. Em função dessa desgraça da corrupção em todos os setores, INCRA, estes movimentos de Sem Terra como o MST (Movimento dos Trabalhadores Sem Terra), SUDAM (Superintendência do Desenvolvimento da Amazônia), FCO (Fundo Constitucional de Financiamento do Centro-Oeste) que era um plano excelente, a ideia do governo foi fantástica na teoria, mais do que na prática! O Sr. Ferronato, que já faleceu, a fazenda dele foi tudo FCO. Depois ele pagou tudo, mas ele estruturou a fazenda dele com FCO. No nosso caso, se nós tivéssemos estruturado com FCO, naquela época era 4 tratores, 4 casas, armazém, fósforo, potássio, calcário e colheitadeira, tudo o que é necessário para a fazenda. E você pagava no longo prazo, sem correção monetária, com um juro nem me lembro quantos porcento ao ano ${ }^{96}$. Então a ideia do governo federal era transformar esta região numa grande produtora de grãos e que hoje sustenta boa parte do Brasil na exportação. Esta foi uma grande sacada do governo militar, mas foi uma forma que fez o país evoluir, assim como a própria Itaipú e outras coisas que evoluíram, por conta dos militares. Tem muitos erros? Tem, mas a gente não pode negar que fizeram muita coisa boa. Então a gente teve estas dificuldades nos refinanciamentos das dívidas.

Outro fator importante é a força dos propósitos dos colonizadores e imigrantes pioneiros, que amalgamaram o perfil de cada cidade e de seus habitantes, ao modelo idealizado por eles. Para identificar este perfil e o percurso socioeconômico destas comunidades, optou-se pela entrevista qualificativa como meio de reviver a história da região.

\section{4 - "TUDO O QUE PASSAMOS, VALEU A PENA"}

Numa carta veiculada por Oliveira (2011), Maria Terezinha Trierweiller, viúva de Lindolfo Trierweiller, imigrante pioneiro da indústria madeireira que chegou à Gleba Celeste (Sinop) em 1972, conta o que passou a sua família no decorrer destes anos e expressa o sentimento comum a praticamente todos que chegaram ao Nortão misturando suas próprias histórias, com o desenvolvimento destas cidades que ajudaram a construir:

Os anos se passaram, as dificuldades foram superadas, os objetivos alcançados. Hoje com o peito cheio de orgulho podemos dizer aos nossos filhos e netos e a quem agora chega, que tudo o que passamos valeu a pena, pois não existe recompensa maior do que poder dizer: eu ajudei a construir a história desta cidade que faz parte da minha história. (OLIVEIRA, 2011:38)

Nas quase trinta horas de entrevistas gravadas com imigrantes pioneiros, autoridades municipais e estaduais, professores, jornalistas, historiadores, líderes do

\footnotetext{
${ }^{96}$ À época, dependendo do volume do financiamento, o juro oscilava ente 5\% e 8,5\% ao ano.
} 
agronegócio e líderes sindicais, diretores de empresas e imobiliárias, levou-se em conta, principalmente, os grupos sociais, bem como as causas estruturais e subjetivas que impulsionaram os agricultores imigrantes pioneiros para a área de abrangência da BR-163 e que trouxeram consigo um mesmo propósito apontando sempre para "uma nova esperança ainda não destroçada, além da curva". (BAUMAN,1998:92).

Como citou a Sra Maria Teresinha Trierweiller, "a história desta cidade que faz parte da minha história" traduz o que praticamente todos os imigrantes pioneiros repetiram. Foram somadas aos dados fornecidos por estes entrevistados os dados históricos e bibliográficos com os quais se pôde "reconstruir" a trajetória destes municípios, ao longo dos últimos quarenta anos, rumo à urbanização e modernização da região.

Já na versão de Luciane Bertinatto Copetti, na Foto 31, abaixo, no início foi difícil de aceitar.

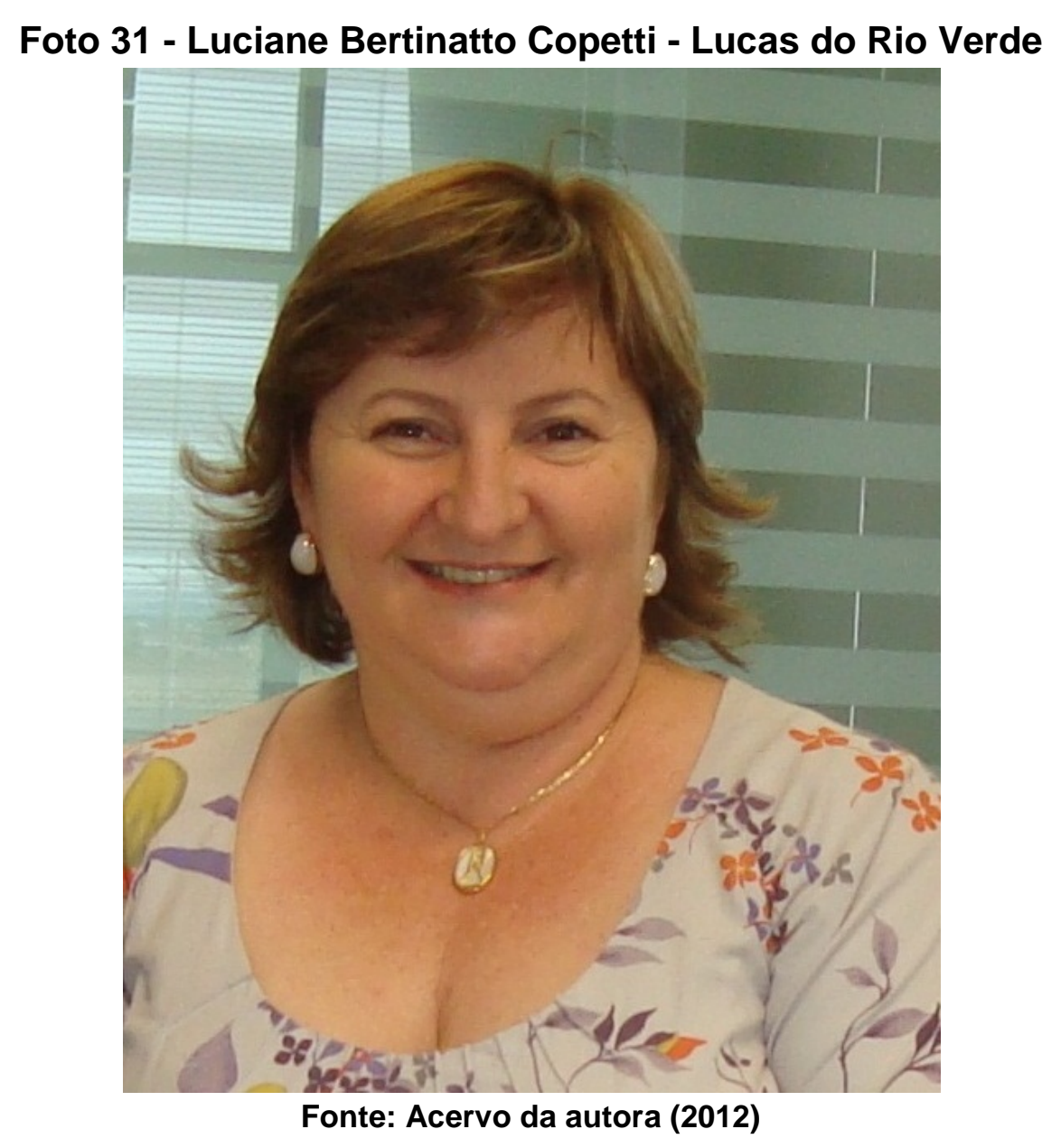

Como relatou em sua entrevista concedida em 21.09.2012: 
Eu estou aqui há 20 anos e quando eu vim pra cá, em 1993, eu nunca esqueço quando eu cheguei lá na fazenda era um matão e o meu primeiro vizinho era a nove quilômetros. De noite, do lado de fora da casa, a gente escutava a onça passar assim bem pertinho. Eu chorava e dizia: o que é que eu vim fazer neste Mato Grosso? Mas hoje a gente não arrepende de nada disso. Nunca esqueço, a primeira vaca de leite que eu tive, deu cria e começou a dar leite eu fiquei feliz porque poderia fazer um queijinho, eu fazia isso lá no sul. Dez dias de cria, morreu a vaca com a picada de uma cobra. Cadê o leite para o meu filho? Tinha que comprar leite.[...]

Muitos dos que chegaram um pouco depois, sequer imaginavam o que os imigrantes pioneiros haviam passado, logo no início, como continua contando a Sra. Luciane:

\begin{abstract}
Eu me lembro que eu chorava e tinha uma senhora que morava perto da minha casa, dona Izabela, ela dizia assim: Luciane, pensa no seguinte, eu estou aqui dez anos antes de você. Eu não tinha o carro que você tem hoje. Nós tínhamos uma F 4000 na época. Você hoje vai ali no Eldorado, vai no telefone e liga para o seu pai ou para a sua mãe uma vez por semana. Nós escrevíamos uma carta e não sabíamos noticia de ninguém. Hoje você precisa de um botijão de gás, você vai em Sorriso; nós íamos em Diamantino. Então hoje já está muito melhor. Não desanima! Não vai ser fácil, mas vai dar certo! Eu nunca vou esquecer o aniversário do meu filho mais velho que chegou aqui com 5 anos. Quando ele fez 6 aninhos, eu fiz o bolo, cortei no meio, recheei, fiz um quadradinho assim e não tinha como bater o merengue. Aí eu fiz um creme de chocolate e coloquei ao redor do bolo. Ele chegou da escola, olhou para aquele bolo e disse: mãe, esse bolo não vai dar para todo mundo. E esse bola está horrível com esse negócio preto ao redor. Aí eu perguntei. Mas Jean, para quem todo mundo meu filho? E ele respondeu: mãe você esqueceu que vem meu vô, minha vó, meu nono, minha nona, os tios, vem todos no meu aniversário! Esse bolo não dá! Você lembra no ano passado que bolo grande você fez e nem deu para todo mundo? Aí eu disse para ele: filho, não vai vir ninguém. Foi a coisa mais triste que eu já tive de dizer para o meu filho. Filho, não vai vir ninguém. É só eu, você e o seu pai. Essa criança chorou tanto, daí é que caiu a ficha dele que não tinha mais ninguém. $E$ ele não esquece disso até hoje. Hoje ele mora na fazenda e a minha neta adora fazenda.
\end{abstract}

Alguns fatos mudaram com o tempo, como é o caso da Sra. Luciane, mas tem alguns pontos que insistem em não contribuir com o ritmo desenvolvimentista que as cidades pretendem manter. Tanto para o Deputado Mauro Savi em sua entrevista concedida em 21.06.2011 quanto para a fazendeira Janete Zerwes que concedeu entrevista em 04.07.2011, comentam que o governo está pecando seriamente em não apoiar mais os pequenos agricultores, responsáveis pela cultura de hortifrutigranjeiros. Para o Deputado, o Projeto Casulo, que ocupa áreas de 2 a 3 hectares por agricultor próximo de cidades de maior porte, está dando certo. A ideia do projeto, associada ao incentivo aos pequenos produtores, como sugere a Sra. Janete, incluem um cuidado maior, por parte do governo, para viabilizar a produção 
de hortifrutigranjeiros, monitorada por técnicos do Estado, que podem atender à demanda de cestas básicas regionalizadas.

Sobre este mesmo tipo de produção, o Deputado Mauro Savi comenta que,

Lamentavelmente, o governo tem procurado adquirir terras para este fim, mas tem encontrado dificuldade; quando o proprietário sabe que as terras são para aquisição do Estado, o preço triplica. O vendedor sabe que precisa dar para este um pouco, para aquele, outro pouco e irá receber em precatórios daqui uns dois anos.

Como lembra o Sr. Emiliano Preima em sua entrevista de 19.09.2012, no início, houve muita dificuldade a vencer:

Além de ter a dificuldade com o plantio, a gente tinha a dificuldade na logística. Por exemplo, você sair daqui com o caminhão carregado de soja para Ponta Grossa ou para Paranaguá além do preço absurdo no frete, perde muito grão pelo caminho por causa dos caminhões que são mal feitos e as carrocerias são ruins. Hoje nós perdemos entre $3 \%$ e $5 \%$ de grão só no frete. [...] Então, a grande dificuldade era a logística, para você sair daqui para vender soja para as empresas que estava aqui na época, e trazer o adubo do porto de Paranaguá, pelo custo do frete que era muito alto. Óleo diesel. Vamos dizer que no período era relativamente barato. O mais difícil era abrir a terra, dar as condições à terra.

Como uma das regras da Colonizadora Feliz era a de que cada agricultor recebia um terreno na cidade e precisava construir sobre ele uma casa (de moradia ou de comércio), para o Sr. Preima, isto se tornou complicado. De qualquer maneira, a maior dificuldade continuava sendo a negociação da produção porque, a pouca lisura de alguns acabou prejudicando muitos.

A maior dificuldade era dentro da cidade, porque a gente tinha de construir
casa. Mas a fazenda em si, tinha de abrir, leirar ${ }^{97}$, no primeiro ano se
plantava arroz, colhia $25 \mathrm{sacos}$ de arroz por hectare, que não dá pra pagar
nem a despesa, e era um arroz de péssima qualidade, tinha o 25 e o 47 ,
que eu lembro assim mais ou menos que era o arroz que se usava, arroz de
grão ruim, de terceira pra quinta qualidade, mas era o que se tinha na
região. $\mathrm{E}$ aí vinha de novo o velho problema: a CONAB (Companhia
Nacional de Abastecimento) ${ }^{98}$ tinha os classificadores de arroz, então para o
cara que colhia 50 mil sacas de arroz, o cara ia lá, classificava o arroz dele
o cara dava $60 / 65$ de inteiro e o meu dava 40 de inteiro. Então, para o meu
dar 60 de inteiro, eu tinha que dar um cheque para o cara. Continuava da
mesma forma, então... o arroz do cidadão mais rico era melhor que o meu.
E aí teve algumas situações aqui em Sorriso, que o arroz era empilhado a
céu aberto naquela BR lá, o arroz era colocado em blocos coberto com uma
lona preta. Se era arroz ninguém sabe; tinha muita palha de arroz ensacado
lá. Daí dava um vento com a chuva, descobria, molhava tudo, vinha o fiscal
da CONAB e constatava: o arroz se perdeu. Daí fazia um buraco e
enterrava tudo. Se tinha um milhão de sacos, ninguém sabe e se era arroz,

${ }^{97}$ Criar covas deixando o monte de terra ao lado de cada sulco num campo arado

98 Companhia Nacional de Abastecimento, empresa pública, vinculada ao Ministério da Agricultura, Pecuária e Abastecimento - Figura, criada por Decreto Presidencial e autorizada pela Lei $n^{\circ} 8.029$, de 12 de abril de 1990, tendo iniciado suas atividades em 01 de janeirod e 1991. 
também ninguém sabe. Mas era assim que funcionava. Tanto que hoje lá naquela área não dá para fazer poço para tirar água para tomar porque aquela região está cheia de palha de arroz podre e contaminou o solo. [...] Apesar de todos estes problemas, Sorriso foi uma cidade abençoada.

O que os imigrantes pioneiros construíram, ainda está presente no inconsciente coletivo da maioria dos habitantes da área de abrangência de BR-163, do bom e do ruim, só sobraram os que tinham força e capacidade de trabalho, as mesmas forças motrizes que movem o desenvolvimento das cidades hoje. O diretor comercial da Colonizadora Sinop, Jose Barbaro Neto, que está na cidade há um ano, traduziu esta força assim:

Como gerente comercial, eu lido com muitas pessoas. Aqui tem uma coisa interessante. Os clientes de grande poder aquisitivo aqui, quando a gente cumprimenta, é totalmente diferente de São Paulo. Ao cumprimentar, mão deles é calejada. É difícil ver alguma pessoa rica ou milionária, que não tenha a mão calejada. Mesmo os mais jovens que trabalham com os pais nas fazendas, todos eles têm a mão calejada. Isso é dificílimo você encontrar em outros estados. Porque é o pessoal que põe a mão na massa.

Maria Inez Ferlin, contadora da Prefeitura de Sorriso, quando fala da cidade em sua entrevista concedida em 19.09.2012, revela uma opinião muito peculiar a respeito dos vínculos que estes grupos de imigrantes pioneiros criaram em função da distância onde permaneceram por muito tempo:

No nosso caso mudou, porque cresceu e a gente não tem mais vínculo com todo mundo como tinha. Já não dá mais para colocar a cadeira na calçada nos fins de tarde para conversar. Até porque nós viciamos em trabalho. A gente venceu por causa disso, mas a gente viciou em trabalho. Mas a turma antiga se encontra sempre: em festas, na igreja. A cidade cresceu, mas aqueles mais antigos continuam sendo os nossos amigos, a nossa família. Quando me perguntam se eu não vou visitar minha mãe, eu vou, de vez em quando porque a minha família está aqui. Eu convivi mais com este grupo que com a minha mãe. Eu um dia disse a ela: mãe você não sabe o que a gente passou aqui, pra chegar onde nós estamos hoje. Vocês não sabem. Quando vocês vêm aqui, está tudo bem. Quando eu vou lá, está melhor ainda. Quantas vezes eu fiquei calada, e para vocês não se preocuparem, a gente falava que estava melhor do que era. [...] O nosso maior problema em Sorriso continua sendo o lazer. Uma das razões é o nosso vício em trabalho, que virou nossa rotina.

\section{Já para o professor Edison Antonio de Souza,}

Aí você pergunta para ele: você quer voltar para o Rio Grande? Não; a não ser que eu esteja quebrado. Não, por que? Porque eu estou ganhando dinheiro aqui. Gente, isso tem uma significação tão importante, porque é aquilo que o Max Weber fala da ética protestante e o espírito do capitalismo. Ou seja, você não quer voltar para o Rio Grande do Sul? Não. Eu estou ganhando dinheiro aqui; eu estou bem. Ah! Mas como é que é o seu dia aqui? Eu trabalho feito louco, de segunda a sexta ou a sábado e no final de semana eu durmo. E aí cria-se um relacionamento um tanto frio porque as pessoas se encontram pouco. E onde está estourando isso, que é um 
fenômeno nacional ou internacional mas aqui na fronteira isso também daria outro estudo? Na espiritualidade. Nessa balança existencial, está se criando um vazio existencial e de consciência pelo que fez para chegar onde está. Onde pisou, onde matou, quem matou, e isso está levando para as igrejas, principalmente as igrejas evangélicas.

Destas opiniões, o que se pode deduzir é que o caminho iniciado por estes imigrantes pioneiros continua a ser trilhado, rumo a um perfil específico para cada município, à proporção que as cidades vão se desenvolvendo e encontrando suas principais vocações. Para organizar estas escolhas, é preciso programar as ações futuras e traçar metas de sustentabilidade.

\title{
3.5 - PENSANDO NO FUTURO
}

Na opinião do Deputado Estadual Mauro Savi (PR) expressada em entrevista gravada na Assembleia Legislativa em 21.06.2011, a BR-163 se tornou muito perigosa, em função do número de veículos que nela trafegam principalmente em período de safra.

\begin{abstract}
A BR-163 foi planejada para um tráfego de 27 toneladas e hoje trafegam, em média, 70 toneladas. Só recentemente o poder público passou a respeitar a estrada porque ela tem trazido praticamente tudo para a região. Eu atribuo a falta de interesse na conclusão da pavimentação da BR-163 a questões políticas. Existem poucos detentores de mandato ou grandes nomes no país que olhem para um Estado que tem hoje dois milhões e pouco de eleitores, mas que tinha na época dessa bandeira entre 800 a 1 milhão de eleitores, sabendo que qualquer cidade importante deste país tem 2 a 3 milhões de habitantes. Então não justifica um investimento tão grande, de 300, 400, 500 milhões, numa produção que hoje é grande, mas que na época era inexpressiva para devolução eleitoral. [...] O governo sempre pensou em assentamentos como massa de manobra. Não é interessante o assentado ou parceleiro ter vida própria. O governo prefere que ele fique refém do governo para ser usado politicamente. [...] o assentado é parceleiro do governo, mas ele tem que ter vida própria para sustentar a família. Nos anos setenta foi feito um acordo entre o INCRA e o INTERMAT (Instituto de Terras de Mato Grosso), para geoprocessamento dos assentamentos e não se tem mais notícia disso. Então, infelizmente, eu volto ao que disse antes: é mais fácil dar um caminhão de feijão ou de arroz, duas passarelas da rocinha ou dar uma BR-163, onde só uma ponte como a que atravessa o rio Teles Pires custa mais de 3 milhões? É uma questão de custo $\mathrm{x}$ benefício.
\end{abstract}

Já Ary Junior, em entrevista concedida em 19.09.2012, na Secretaria de Ação Social da Prefeitura de Sorriso, sugere que o município, daqui a 20 anos terá outras atividades que atuarão tanto ou até com mais ênfase na economia.

Se você fizer uma conta rápida: eu trabalho com planejamento e estou vivendo uma Sorriso daqui a 20 anos. Sorriso não vai se transformar num 
polo do primeiro setor. A vocação de Sorriso é se transformar num polo industrial do segundo ou do terceiro setor. Esmagar soja, transformar a proteína vegetal em proteína animal não vai ser mais o mote de Sorriso. O mote de Sorriso vai ser fazer lecitina de soja, trazer os farmacêuticos para cá, fazer a carne de soja.

O Sr. Leonildo Bares foi taxativo em sua declaração durante a entrevista concedida na sede do Sindicato Rural de Sinop em 17.09.2012, quando disse que "Mato Grosso, hoje, é o único lugar do mundo que consegue fazer três safras numa mesma terra. Planta-se o soja, tira o soja planta o milho com capim no meio, colhe o milho e faz o confinamento do boi de julho até outubro".

Mas também colocou uma frase que, no contexto dos municípios da área de abrangência da BR-163 é muito importante: "A água é um bem considerável que tem de ser usado com muita diplomacia, com muita tecnologia e com muito conhecimento. Tem que ser estudada a possibilidade de como usar esta água". (Leonildo Bares, 2012)

Para José Barbaro Neto, da Colonizadora Sinop, independente do cuidado com os novos loteamentos, com as questões de saneamento e fornecimento de água, existe a questão ambiental, de arborização, que precisa ser pensada com cuidado. Em entrevista concedida na sede da Colonizadora Sinop em 18.09.2012, sugeriu:

Tem as grandes reservas nos parques, lindas, mas a cidade poderia ser hoje muito melhor arborizada. Essas avenidas, os redondos ${ }^{99}$, as praças, a cidade ficaria linda! Independente disso refrescaria o ambiente e protegeria do sol forte do meio dia.

Em Lucas do Rio Verde, o fornecimento de água, luz e saneamento básico que deve ser fornecido pelas imobiliárias, a Prefeitura disponibiliza o serviço de coleta de lixo imediatamente após a entrega das chaves aos moradores.

Para Emiliano Preima, a questão imobiliária de Sorriso se resume a um quadro social bastante importante para o futuro da cidade. Em sua entrevista concedida em 19.09.2012, externou sua opinião:

Acho que mudou muito, porque hoje não existe uma Colonizadora (Feliz) mais. Existem várias imobiliárias, existem condomínios fechados, nós temos aí 3 condomínios fechados em processo bem avançado de construção. Se nós não tivéssemos criado outras imobiliárias, nós estaríamos pagando um terreno hoje que ainda custa $\mathrm{R} \$ 100$ mil, $R \$ 80$ mil, você pagaria uns $R \$$ 200 mil; um terreno na avenida Natalino, 1 milhão e meio. Hoje tem Imobiliária Independência, tem um pessoal do Bemterra. Uma das maiores

\footnotetext{
${ }^{99}$ Áreas com junções de avenidas que possuem uma praça redonda ao centro
} 
brigas de governo que nós tivemos aqui, foi exatamente pelo motivo de evitar o cartel, direcionamento. A separação da cidade hoje, em grande São Domingos e BR-163 é exatamente por isto. Porque para se colocar pessoa com renda inferior, não se conseguia comprar terra do lado de cá. Então o que é que o prefeito fez, o Zé Domingos, em 1989/1990: foi lá, desapropriou uma área onde é o São Domingos hoje e criou um loteamento lá de uns 200 lotezinhos pequenos, de 10×15, e a gente loteou e entregou para as famílias que vieram na época que catava raiz aqui e que não tinha onde morar. Então se criou um loteamento lá. Então estas são algumas situações que levaram a cidade para este caminho.

Luciane Bertinatto Copetti, representante da TNC (The Nature Conservancy) Instituto de Conservação Ambiental, entrevistada na Prefeitura de Lucas do Rio Verde em 21.09.2012, descreveu alguns pontos do projeto que está desenvolvendo no município, voltado para a preservação e sustentabilidade urbana e rural:

Todo este trabalho do projeto Lucas do Rio Verde Legal foi baseado em procurar fazer com que o produtor rural tivesse o suporte junto a prefeitura para que ele enquadrasse a sua propriedade dentro das normas ambientais, sanitárias e trabalhistas brasileiras e que então o mercado lá fora estaria perguntando: você cumpre a legislação do seu país? Se você cumpre nós compramos o seu produto. O mercado trabalha desta forma. Então no final de 2005 nós começamos a trabalhar nisso e foi quando a gente conheceu a TNC - Instituto de Conservação Ambiental, que veio com a proposta de nos ajudar a montar esse projeto e de fazer com que a prefeitura tivesse o suporte técnico e científico necessário para que nós desenvolvêssemos um projeto e que se tornasse um programa municipal depois, para auxiliar estes produtores rurais. Aí nos começamos a angariar quem seriam estes parceiros. Então o intuito principal do projeto foi fazer com que a produção econômica de Lucas do Rio Verde tivesse, com o decorrer do tempo, cumprindo as exigências das normas brasileiras. Só que a gente foi encontrando várias dificuldades no meio do caminho e uma delas é justamente a falta de informação que o produtor rural tem.

\section{A Sra. Luciane explicou como estão sendo solucionados os problemas:}

Ele (o produtor) conhece muito de mercado, ele conhece muito de produzir, de como fazer o plantio de como fazer a colheita, de como consertar seus equipamentos; ele conhece muito de comercialização, mas da legislação ambiental, ele tinha pouco conhecimento. Muitos proprietários rurais de Lucas do Rio Verde, na época, já antes de 2005, aí por 2003, antes disso ainda, se fala muito na questão do trabalho escravo, tudo mais, as pessoas foram adequando esta mão de obra às normas trabalhistas. Mas na parte ambiental faltava muita informação. Porque aqui nós tínhamos uma parte do município que pega bioma Floresta, uma parte que pega bioma Cerrado, enfim, é uma confusão bastante grande. Para a gente que trabalhava com isso é difícil, imagina para um produtor que não lê, que não estuda sobre legislação ambiental. Ele ficava à mercê dos profissionais que faziam os projetos. E aí a gente tem os bons profissionais e os profissionais mais ou menos. Aquele que faz as coisas de acordo com o que é preciso e aquele que só contrata e ele protocola o projeto e acabou. Nós encontramos coisas assim que o produtor estava à mercê realmente de autos de infração, de embargos da propriedade, enfim tudo isso. O que é que acontece, como a gente começou a trabalhar isso tudo, a primeira coisa que a gente mostrou para os produtores rurais é que a parte do Cerrado brasileiro, que Lucas estava com boa parte no Cerrado e uma parte na floresta. 
Mas, havia uma parte do projeto que precisava ser desenvolvida e que foi tratada com o apoio incondicional do poder público, como explica a Sra. Luciane:

\begin{abstract}
A mudança da concepção da monocultura da soja e do milho para outras atividades como a diversificação através de suínos, de aves, enfim de outras atividades que poderiam ser empregadas ali, este projeto acabou buscando outros parceiros em outros municípios, pessoas que moravam em Lucas e que foram para outros municípios plantar e tudo mais, e o projeto de integração de diversificação econômica e verticalização da produção, também vinha com este escopo de cumprimento da legislação ambiental, sanitária e trabalhista. E isto foi migrando para todos os municípios do entorno de Lucas do Rio Verde, porque o projeto das empresas se instalando em Lucas do Rio Verde iria abranger mais municípios aqui do entorno, numa faixa de oito municípios.
\end{abstract}

O que se percebe é que o trabalho das administrações públicas e da maioria dos empresários de todos os setores, agropecuária, saúde e serviços em geral, é buscar uma solução para a sustentabilidade, sem perder de vista o lucro, a sobrevivência que cada município ou empresa precisa para equilibrar econômica e socialmente estes munícipes. O projeto de Lucas do Rio Verde Legal atende boa parte desta proposta como detalha Luciane Copetti.

O projeto foi pensado só para o produtor rural e quando a gente percebeu ele tinha tomado uma amplitude muito grande porque ele deixou de ser só na área rural. Era o projeto Lucas do Rio Verde Legal no urbano e no rural. Baseado nisso era a questão sanitária na área urbana em questão de saneamento básico era a questão do descarte correto de produtos altamente perigosos como óleo, filtros e coisarada de empresas que trabalhavam com mecânica, o próprio combustível e tudo isso. Na área rural era a adequação da propriedade rural e depois a adequação da atividade rural. São duas coisas bem distintas. Em 2007 nós começamos este levantamento todo e a TNC foi quem trouxe toda esta informação para a gente através de imagem de satélite de alta resolução. Naquela época nós detectamos que Lucas tinha $68,7 \%$ da sua área aberta, dos 363 mil hectares, tinha $31 \%$ de remanescente de vegetação em pé e tínhamos também $2.077 \mathrm{~km}$ de rios. Depois do diagnóstico por imagem todo realizado, nós cadastramos todas as propriedades rurais, uma por uma, e começamos a trabalhar com o produtor rural no sentido de que eles seriam orientados através da imagem de sua propriedade. Hoje são 670 propriedades de 544 produtores rurais em Lucas do Rio Verde. Mas lá em 2007, eram menos de 670 propriedades e só 360 produtores. Então em 2007 eram 360 produtores e em 2011, 544.

O trabalho continuou no sentido de organizar e dar maior credibilidade aos dados coletados e, conforme a Sra. Luciane,

Nós tivemos então uma distribuição fundiária por conta do projeto de diversificação e verticalização da economia. Ou seja, estes produtores rurais começaram a passar para os seus filhos primeiro um pedaço para colocar uns suínos ou umas aves, então houve uma distribuição fundiária muito bacana. E a gente cadastrou $100 \%$ das propriedades rurais. A gente sabe quem está em cada propriedade e o que tem em cada uma. Quanto que é o uso do solo do município de Lucas do Rio Verde, hoje 242 mil hectares de 
área plantada. Quantos rios nós temos. Nós temos cadastrados e georeferenciados todos os cursos d'água e todas as nascentes de Lucas do Rio Verde. Hoje, ou seja, em 2011, nós temos 703 nascentes. A TNG continua investindo em Lucas do Rio Verde, porque a gente precisa fazer o monitoramento de áreas degradadas que estão em recuperação. Nós temos um cadastro específico por propriedade com todos os dados importantes para o meio ambiente. Com este diagnóstico, nós informamos um por um dos produtores rurais. Nós passamos para cada proprietário todos os pontos importantes para serem observados em termos de meio ambiente.

Houve ainda outras iniciativas para aperfeiçoar o projeto e a Sra. Luciane mostra alguns parceiros que foram se agregando ao longo do caminho:

Nós chegamos a discutir com o BNDS que criou uma linha de crédito específica para financiar a aquisição de reserva legal e conseguimos prorrogar esta Linha este ano, para mais dois anos porque esta discussão do Código Florestal colocou todo mundo de stand by. Cada um está esperando o que vai dar para resolver o seu problema. O mais bacana do projeto é que ele gerou uma discussão com os vizinhos, ou seja, o rio começa num ponto e passa em várias propriedades. Então quando este vizinho não tem beira de rio degradada, o outro tem. Um começa a exigir do outro que trate da sua parte para que ele não seja prejudicado. Isso foi criando uma concepção de que a área de preservação de beira de rio é muito importante. Eles sabem que estão cuidando da água de Lucas do Rio Verde. Então a gente não tem resistência nenhuma com estes proprietários de imóveis rurais. Em Lucas para as nascentes se exige 100 metros de preservação e para os rios 50 metros. Em 2008 a gente já percebeu uma recuperação. Agora em 2011 foram adquiridas novas imagens e serão gerados novos relatórios para saber quais as propriedades que isolaram, quais estão cumprindo os termos de conduta, enfim, para saber realmente como está.

Esta visão de sustentabilidade que se busca em Lucas do Rio Verde através do Projeto Lucas Legal, é ratificada pelo Projeto da Cooperativa que nasceu em Sinop, capitaneada pelo presidente do Sindicato Rural, Sr. Leonildo Bares, como ele mesmo explica em sua entrevista concedida em 17.09.2012:

Eu não estou falando em destruir, não. Eu estou falando em usar com tecnologia. Tanto é que hoje nós temos uma cooperativa que nasceu aqui, junto com a Goretti e um pessoal nosso aí com os quais nós fizemos parceria e agora a EMBRAPA vai estar trabalhando junto com a gente, com a qual nós pretendemos criar um serviço social. Por exemplo, você tem uma terra e chega ali na cooperativa e diz: eu tenho uma terra de 100 hectares; eu queria ver o que é que eu posso fazer naquela terra. Nós queremos fazer um estudo de viabilidade daquela terra. Então nós vamos na sua terra e dizemos: olha, para soja, esquece. Sua terra é muito arenosa ela não vai produzir o equivalente. Então é melhor você usa-la como reflorestamento, mas você tem uma água boa, você pode fazer uma piscicultura, você pode criar uma apicultura aqui dentro, você poder querer outras coisas que vão dar muito mais resultado e será prazeroso para você, ou você pode vender depois o seu crédito de carbono. Estas são as coisas que você pode fazer. Tudo isto para não destruir a natureza e sim usá-la com conhecimento tecnológico, de retorno, sem prejudicá-la. Isto se chama sustentabilidade ou consciência ambiental. Isto se chama gestão empresarial; eu quero fazer do que eu tenho, um bom negócio. Nós temos que falar no econômico, no 
ecológico e no social. Antes de derrubar uma área o sujeito precisa perguntar se ela não estará valendo mais em pé.

Uma das questões sociais mais preocupantes, como informaram o professor Edison Antonio de Souza e a Sra. Luciene Francio, em entrevistas gravadas em 16.09.2012 e 20.09.2012, respectivamente, é a criação de políticas específicas para manter a qualidade de vida dos munícipes, enquanto se aumenta a quantidade de defensivos agrícolas. Na opinião da Sra. Luciene Francio, este é um dos principais focos de pesquisas no momento, porque as consequências do veneno utilizado na lavoura é, muitas vezes, irreversível, como coloca o professor Edison Antonio de Souza em sua entrevista:

E nesta questão social é a questão da saúde pública. A quantidade de veneno que estão jogando milhões de litros, e as implicações disso naquilo que chama-se água. Os grandes desafios do mundo, do Brasil, enfim são energia, água e alimento. [...] Existe um plano, o $M T+20^{100}$, que dá uma certa diretriz para os caminhos futuros de Mato Grosso. Foi lançado no final do ano passado (2011) o atlas de Mato Grosso que traz dados interessantes sobre os novos caminhos do Estado no futuro (indústria de transformação, qualificação de mão de obra local etc.)

De acordo com o artigo veiculado por Onofre Ribeiro no jornal A Gazeta, de Cuiabá, em 02 de dezembro de 2012,

\begin{abstract}
A notícia animadora de que empresários chineses estão interessados em construir a ferrovia ligando Rondonópolis (no sul do estado de Mato Grosso) a Santarém (a oeste do estado do Pará), de alguma forma rejuvenesce a economia do Estado que cresce apesar de lutar contra todas as adversidades burocráticas e o escoamento inadequado da produção de commodities. Mato Grosso tem o porte de um país, mas como província, luta contra o óbvio. Os contatos para investimentos e negócios que se complementam e desdobram em grandes oportunidades, têm passado em branco, porque o governo do estado não tem preparo para lidar com essas perspectivas.
\end{abstract}

No mesmo artigo, o jornalista relata que outros negócios já foram propostos e não passaram de conversas privadas sem consequências, e continua:

Falta ao governo do estado uma secretaria ou outro órgão de articulação para o desenvolvimento, com foco nos cenários de investimentos de curto, médio e longo prazos. Só para ilustrar: as universidades, mal e mal dão conta de graduar estudantes, o poder legislativo mal e mal cuida de leis de pouca utilidade, as federações da indústria e da agricultura vem ocupando alguns destes espaços, embora não possam adiantar muito, porque depende do governo estadual os encaminhamentos. Tudo isto é muito ruim,

\footnotetext{
${ }^{100}$ A preocupação com um planejamento de longo prazo para Mato Grosso, como forma de alavancar o seu desenvolvimento, já vem de longa data e é uma reivindicação de diferentes segmentos que compõe o Estado. Esta preocupação foi inserida nos instrumentos legais de planejamento já em sua primeira revisão como o Projeto de Elaboração do Planejamento Estratégico do Estado de Mato Grosso. (Fonte: SEPLAN - Secretaria de Estado de Planejamento de Mato Grosso).
} 
porque os cenários mundiais apontam para o Centro-Oeste brasileiro investimentos em áreas de mineração, atividades florestais, atividades agroambientais, atividades de educação superqualificada, atividades de pesquisas avançadas em meio ambiente, atividades florestais, águas, biodiversidade, climatologia, experiências tecnológicas com a produção diversificada. Isso, sem contar com as expansões no agronegócio e em tecnologia, a transformação de grãos em proteínas e em química fina. Sem contar com a pecuária, a carne e sua transformação, a engenharia genética e a diversificação animal. Nem falaremos da indústria, dos serviços, da logística. Cito apenas estes, para dar uma pálida ideia das potencialidades.

Onofre Ribeiro analisa ainda no artigo alguns perigos para o futuro.

Como lidar com estes cenários, com um ou dois burocratas, que nem a língua pátria dominam direito? Como se sentirá um investidor estrangeiro diante desse potencial e do amadorismo estatal para recebê-lo e para conversar? [...] O pior de tudo isso, é o risco de que Mato Grosso abra a guarda e entregue a sua noiva em mãos inapropriadas, do tipo, não compreender e negociar as adequadas proteções às suas riquezas e à sua sociedade, com os experientes e predatórios chineses, por exemplo. Para esse tipo de situação, a História costuma cobrar mais tarde ou rapidamente. O preço é sempre muito caro, fora a excomunhão política para quem se omitir frente à História e arriscar esse fantástico patrimônio chamado Mato Grosso. (A GAZETA, 2012)

Um dos projetos mais importantes que estão sendo montados para entrar em funcionamento até 2014, é o projeto de viabilização do transporte das commodities produzidas nos municípios da área de abrangência da BR-163 até o porto graneleiro no distrito de Mirituba, no município de Itaituba-PA, utilizando um processo multimodal. Como pertence a União, estão sendo montados os projetos para regularizar a área e o município de Sorriso está requerendo.

Para isto estão fazendo projetos de urbanização, para atender a lei federal para preencher os requisitos necessários à titularização rapidamente o município e o município que está titularizando por ser uma área portuária. No projeto está também a Bunge, a Cargill, a Docas do Pará, e estão montando um porto em Macapá-AP.

Este planejamento envolve desde o porto de Mirituba, onde as commodities serão embarcadas em barcaças para serem transportadas pelo rio Tapajós, até o porto de Santana, no Amapá, de onde partirão para o exterior. Entre Mirituba e Santana circularão barcaças para atender uma movimentação média diária de 6 mil caminhões carregados com commodities.

Encurta uma média de 5 mil km por água, se for tomado por base o porto de Amsterdam, na Holanda. Isto vai agregar um valor considerável. Afinal o Brasil está de costas para o Oceano Pacífico e as rotas pelo Atlântico tendem a diminuir, graças 
à situação econômica na Europa. A CIANPORT é a empresa responsável por este planejamento $^{101}$.

A importância deste dado está no fato do agronegócio ter tomado uma atitude, diante da morosidade do governo federal em concluir a BR-163, fator que está majorando o preço final das commodities no mercado externo. Neste futuro que está presente o agronegócio que não só participa das decisões do governo federal, como se antecipa quando estas favorecem o seu negócio.

\footnotetext{
${ }^{101}$ A Cianport foi criada há apenas um ano com o único objetivo de explorar as oportunidades do corredor logístico BR-163-Rio Tapajós. A companhia é uma joint-venture entre Fiagril e a Agrosoja, duas comercializadoras de grãos de Mato Grosso. As duas empresas possuíam terrenos vizinhos em Miritituba desde o ano 2000 e, no ano passado, resolveram integrar seus projetos. Juntas, Agrosoja e Fiagril movimentam cerca de 2 milhões de toneladas de soja e milho por meio das chamadas operações de barter - troca de insumos por produção agrícola. Além de uma estação de transbordo, em Miritituba, a Cianport prevê construir um terminal privativo na ilha de Santana (AP) para receber e exportar essa produção. Por enquanto, a companhia possui um contrato de uso temporário no Porto de Santana, que é público. O novo corredor deve proporcionar uma economia de pelo menos $10 \%$ a $15 \%$ nos custos de frete dos produtores mato-grossenses e, além disso, prevê, o eixo deve viabilizar a expansão da fronteira agrícola para os municípios localizados entre o norte de Mato Grosso e o sul do Pará. Fonte: Valor Econômico veiculado em 24.01.2013. Acessado em 10.03.2013.
} 


\section{CONSIDERAÇÕES FINAIS}

Esta pesquisa se propôs a fazer um trabalho baseado nas questões sociais, imbricadas nos processos recentes de urbanidade e modernização ocorridas desde entre a década de 1960 e o ano 2012, na área de abrangência da BR-163, importante artéria que liga as regiões Sul, Sudeste, Centro-Oeste e Norte do Brasil. A rodovia que, cada vez mais, assume o papel de principal vetor do sucesso agropecuário na área da Amazônia Legal Mato-grossense, é um importante marco histórico para os imigrantes que escolheram Mato Grosso para construir suas vidas, confiando num futuro que dependia, basicamente, da força empreendedora que sempre esteve por trás do grande desenvolvimento conseguido ao longo das últimas três décadas.

Como disse a Sra. Luciene Francio, "se não fosse a soja, seria qualquer outra coisa, porque eles sabiam que tinha de dar certo". E este pensamento foi completado pelo Sr. José Barbaro Neto, diretor comercial da Colonizadora Sinop, quando afirmou que "a cidade nunca viveu de agronegócio; agora é que está vivendo e ele só se estabeleceu por conta da necessidade do Brasil e do mundo".

O jornalista Onofre Ribeiro lembra bem que o presidente Juscelino Kubitscheck tinha a clara noção de que o Brasil precisava ocupar o seu interior. De Brasília partiram algumas rodovias essenciais: a Belém-Brasília (BR-153), a Belo Horizonte - Brasília (BR-040), a Brasília-Uberlândia (BR-050), a Brasília-Cuiabá (BR070), e a Brasília-Salvador (BR-242). Todas tinham ou teriam ramificações que integrariam região Centro Oeste com as outras regiões do país.

Quando o presidente Ernesto Geisel, em 1977, justificou ao governador José Garcia Neto que Mato Grosso seria dividido porque tem tantas potencialidades que no futuro poderia ameaçar a soberania nacional, ele se apoiava em estudos da Escola Superior de Guerra, a academia doutrinária e filosófica do regime militar, que seriam colocados em prática para expandir a antropização daquela área, então considerada anecúmena.

Sobre este assunto, em conversa com o professor doutor André Roberto Martin, do departamento de Geografia da Universidade de São Paulo (USP), chegou-se à conclusão que os estudos sobre a região amazônica, onde se pretendia implantar a Amazônia Legal, se baseavam em estratégias militares, de guerra, ou 
seja, lançaram os paraquedistas lá na frente porque, isolados, "tinham de dar certo", já que nem mesmo tinham condições geográficas ou financeiras para voltar.

Sob a ótica humanística, a estratégia pode ser considerada cruel; mas, numa visão geopolítica, que era a visão de Golbery do Couto e Silva, estava corretíssima. A fronteira precisava ser rapidamente expandida e esta seria a estratégia com menos vulnerabilidades. As estradas viriam depois para que a expansão se completasse, numa segunda etapa.

Portanto, é possível afirmar que a criação da Amazônia Legal obedeceu muito mais a razões políticas que regionais, na medida em que sua distribuição geográfica sequer respeitou os biomas dos estados que dela fazem parte.

É importante frisar que os projetos federais que trataram e tratam do ordenamento do território da Amazônia Legal subentendem uma política pública aplicada a um bloco de nove estados (Acre, Amapá, Amazonas, Maranhão, Mato Grosso, Pará, Rondônia, Roraima e Tocantins), com interesses comuns, isto é, como partes de um mesmo território. Isto pode satisfazer a uma política de Estado, mas deixa a desejar geograficamente. São conjunturas geopolíticas ${ }^{102}$ diferentes, com prioridades regionais muito distintas.

Esta talvez seja a principal razão dos impasses para os estudos e projetos federais na área, pois todos são direcionados e manejados de forma globalizada, como uma questão hegemônica e em águas de um empirismo que não identifica soluções práticas para os problemas locais, que acontecem numa velocidade acima da média.

Paulatinamente, vem sendo implantado pelas imobiliárias, com o apoio do poder público municipal, uma ampliação dos núcleos urbanos, que transforma as áreas cultiváveis menos importantes do seu entorno em condomínios que favorecem a modernização da franja urbana ${ }^{103}$. Cidades como Sinop, Sorriso e Lucas do Rio Verde já pensam em programas específicos para ampliar suas áreas urbanas. A

\footnotetext{
${ }^{102}$ A geopolítica sempre se caracterizou pela presença de pressões de todo tipo, intervenções no cenário internacional desde as mais brandas até guerras e conquistas de territórios. Inicialmente, essas ações tinham como sujeito fundamental o Estado, pois ele era entendido como a única fonte de poder, a única representação da política, e as disputas eram analisadas apenas entre os Estados. Hoje, esta geopolítica atua, sobretudo, por meio do poder de influir na tomada de decisão dos Estados sobre o uso do território, uma vez que a conquista de territórios e as colônias tornaram-se muito caras. BECKER, Bertha K. (2005). "Geopolítica da Amazônia". Estudos Avançados.Vol.19, n.53, p. 71-86. http://www.scielo.br/pdf/ea/v19n53/24081.pdf.

${ }^{103}$ Espacialmente, em redor do núcleo central, mais ou menos saturado de atividades e despovoado de residências, desenha-se uma enorme franja periférica, mais ou menos estruturada e equipada, que se dilui por vezes muito longe, no campo (BEAUJEU-GARNIER, 1997:455).
} 
consequência lógica deste movimento é a majoração dos preços por metro quadrado nas áreas que circundam as cidades, antes ocupadas por fazendas.

É importante acrescentar que esta movimentação tem privilegiado o mercado imobiliário em detrimento de áreas agricultáveis de menor porte, até bem pouco tempo ocupadas pela agricultura familiar, responsável por boa parte do abastecimento de leguminosas e frutas para as cidades da região. Paralelamente, não se percebe qualquer tipo de política agrícola municipal, visando a relocação destes pequenos agricultores para áreas próximas dos núcleos urbanos, exceto em Lucas do Rio Verde onde existe um sindicato articulado para criar estas políticas.

A ausência de uma política regional que poderia ser identificada como uma geopolítica amazônica, muito próxima daquela elaborada por Golbery do Couto e Silva, entre as décadas de 1950 e 1970, diminui as possibilidades de integração com a geografia inter-regional, responsável pela verticalização das prioridades para horizontalizar soluções. Como exemplo, existe o caso do projeto idealizado para a utilização de diferentes modais até chegar aos portos de Matupá (PA) e Santana $(\mathrm{AP})$, desenvolvido por empresários de Sorriso e Lucas do Rio Verde para solucionar uma demanda de melhores condições para o escoamento da produção de commodities, reivindicada pelo agronegócio e pelas populações da área de abrangência da BR-163, há quase trinta anos.

Não é possível valorizar os planejamentos locais que se moldam às necessidades de cada município ou de seus empresários, conforme seus perfis socioeconômicos. Diante disso, as comunidades vão expandindo suas propostas e, quando outros municípios percebem que seus interesses similares podem ser atendidos, incorporam e reforçam as ideias, para transformá-las em programas regionais. Um bom exemplo disso foi o projeto Lucas Legal que hoje já se expandiu para mais oito cidades da região, cujos propósitos de educação ambiental atendem a interesses regionais de atingir mais qualidade na finalização dos produtos produzidos em cada município e, com isto, mais credibilidade no mercado internacional, tido como consumidor final.

No caso específico da Amazônia Legal, não houve sequer um espaço para que acontecesse o entendimento e a relação entre tecnologia e sociedade, como menciona Castells (2007), porque o Estado atropelou o processo como um todo, em lugar de organizar as forças sociais dominantes. Houve, por parte do governo do estado, um interesse específico por posse de terras para apadrinhados. Para 
beneficiá-los, não poupou a burla, razão dos maiores problemas fundiários com os quais o estado lida hoje, por conta da sobreposição de áreas. Este é um dos grandes problemas que ainda está muito distante de uma solução, considerando estar nele imbricado o poder do capital em jogo, capital este que aumenta a cada ano, na mesma proporção em que as terras valorizam.

Pelos estudos realizados por Eliseu Alves, pesquisador da EMBRAPA, a tecnologia é o aspecto mais importante para explicar o aumento da produção de grãos no país. O relatório apresentado em 2012 ao ministro da Agricultura, Pecuária e Abastecimento, Mendes Ribeiro Filho, aponta que aproximadamente 500 mil estabelecimentos com acesso a tecnologias modernas são responsáveis por $86,65 \%$ de toda a renda agrícola de 2006, com base no último censo agropecuário do IBGE.

Daí a mobilização do agronegócio no sentido de se posicionar à frente das questões tecnocráticas, elegendo seus representantes junto ao poder público e influindo em políticas específicas para defender seus interesses. No fundo, é o agronegócio quem está criando as políticas públicas, assim como é o capitalismo agropecuário quem determina as tomadas de decisões futuras na área de abrangência da BR-163 e no estado de Mato Grosso.

A tecnologia avançou em seu processo de desenvolvimento e o Estado, estrategicamente, entregou aos "representantes" da área de abrangência a BR-163 as decisões e políticas para, em conivência com as novas regras estabelecidas pelo mercado, usufruir das melhores oportunidades políticas e dos resultados nos negócios privados, enquanto as comunidades foram sendo acomodadas sob o comando do poder instituído em cada município. A busca por novas tecnologias que contribuam para a inserção de suas atividades no mercado internacional com mais rentabilidade, demanda uma indústria de transformação que agregue valores à produção e transformação das commodities até então vendidas in natura.

Aqui existem duas vertentes: uma é a possibilidade de agregar ao produto in natura e, com isto, atingir mais rentabilidade com o produto final; outra é qualificar mão de obra para esta nova fase de produção, resolvendo, paralelamente, o problema de contingente técnico exigido pelo mercado sofisticado no qual atuam.

A escolha deste caminho apoiado em duas vertentes implica não só na aquisição de know how para executar a transformação dos produtos in natura, como na contratação de instrutores altamente preparados para qualificar mão de obra. $O$ que se tem visto, não só naquela região, mas em todo o Brasil são adestramentos, 
confundidos com qualificação. O adestramento trata do fazer seguindo ordens, comandos; a qualificação trata da identificação do que precisa ser feito, com a consciência de que aquela forma, até que se descubra algo inédito, é a forma mais adequada de executar aquela tarefa. A diferença está na orientação para a próatividade, para o empreendedorismo, para compreensão do papel de cada qualificado no contexto produtivo em qualquer área.

Numa pesquisa feita pela professora doutora Tereza Cristina Cardoso de Souza Higa, da Universidade Federal de Mato Grosso, ela ouviu de um engenheiro da mesma região, responsável por uma pocilga de grande porte, que a dificuldade em contratar pessoas sem qualificação está no fato deles não praticarem o que aprendem, por mais qualificados que sejam.

No caso, os empregados precisavam passar, com botas de borracha, por dentro de um tanque com água misturada a bactericidas para proteger o plantel. Bastava o chefe do setor se afastar, para que a grande maioria dos empregados pulasse o tanque, demonstrando que não dava a menor importância ao fato da atitude colocar em risco a saúde do plantel.

O que isto significa? Que estes empregados foram adestrados a cumprir uma ordem. É muito provável que o adestrador não tenha conseguido fazê-los entender o que é uma bactéria. Todos sabem o que é um rato, uma barata, uma mosca ou qualquer outro animal que possa ser morto com um chinelo ou uma vassoura. Já bactéria é algo amorfo, inodoro e incolor, a respeito da qual sequer têm noção da existência. Está fora da realidade deles e a tendência é não levar a sério esta história de passar por dentro da água com bactericidas!

Ao optar por uma forma menos vulnerável para vencer os problemas sociais que estão se avolumando através da qualificação de mão de obra, é importante que haja uma mudança de paradigma para que o grande número de imigrantes que continua a chegar a estas cidades possa efetivamente ser preparado para a demanda dos mercados da região.

Apesar da opinião contrária do consultor de planejamento da prefeitura de Sorriso, Sr. Ary Junior, quando afirma durante a entrevista concedida em 19.09.2012 que acredita em Sorriso como "uma cidade que cresce e não tem conflito social", os problemas sociais estão surgindo e crescendo na mesma proporção em que cresce a cidade e aumenta o volume de arrecadação do município, por conta do sucesso do 
agronegócio e das atividades na área de prestação de serviços, em franco desenvolvimento.

Entre as classes menos favorecidas, cresce uma realidade que se contrapõe ao movimento do sucesso, provocando grandes frustrações por não conseguir uma qualificação adequada e, consequentemente, não "enricar" ${ }^{104}$, para voltar à terra natal depois de uns dois anos dirigindo uma "caminhonetona". Daí para os desvios de conduta e consumo ou tráfico de drogas ilícitas, a distância é curta.

O fato das pessoas terem donos, sugerida por Marins, como citou o Sr. Ary Junior na mesma entrevista, é interessante; quando analisada a estrutura social dos estados que adotaram o capitalismo tardiamente no Brasil, como é o caso dos estados do Nordeste e do Centro-Oeste, se constatará que o voto de cabresto, o coronelismo e todas as questões ligadas às grandes propriedades e ao patronato, de uma forma ou de outra, se mantêm até hoje em várias instâncias sociais e no poder público.

Os conflitos sociais já existem nas camadas menos favorecidas, apesar do baixo índice de desemprego encontrado nas cidades pesquisadas, graças à capacidade de absorção de mão de obra menos qualificada do setor de prestação de serviços e setores sem vínculo direto com a produção das commodities. Enquanto a produção agropecuária está diminuindo a capacidade de absorção de mão de obra em função da ampliação do uso de maquinário cada vez mais sofisticado, o crescimento expressivo dos mercados indiretamente ligados ao agronegócio ou sem vínculo exclusivo com ele tem aumentado a demanda por mão de obra menos qualificada.

Em Lucas do Rio Verde, por exemplo, é perceptível a preocupação do poder público com o aumento de imigrantes em situação social menos favorecida e sem qualificação profissional, cuja rotatividade na indústria de alimentos tem causado sérios problemas de segurança. A situação é preocupante, como comentou em sua entrevista o Sr. Lira, imigrante pioneiro do município onde aportaram quase seis mil pessoas entre 2005 e 2007, em busca de uma oportunidade de trabalho que não exigia grande qualificação profissional. A mesma preocupação se percebeu na entrevista concedida em 20.09.2012 pelo professor Rodrigo de Vargas Hahn, diretor da escola do bairro São Domingos, em Sorriso, onde a imigração maranhense

\footnotetext{
${ }^{104}$ Expressão locar que traduz enriquecimento rápido.
} 
cresce acima da média porque continua chegando muita gente, praticamente para o mesmo bairro, na esperança de encontrar um emprego "com carteira assinada".

Por outro lado, as pessoas que aprenderam a conviver com as dificuldades e com os "desgovernos" dos tempos iniciais, ainda não conseguiram superar o preconceito, antes uma questão vivida apenas por Lucas do Rio Verde que, como relatou o professor José Dario Munhak durante sua entrevista em 21.09.2012, "durante muito tempo, o pessoal aqui era tratado com preconceito por parte dos outros imigrantes, por conta dos assentados que chegaram do Rio Grande do Sul".

Hoje, na opinião da Secretária de Educação e Cultura de Sorriso, Avanice Lourenço Zanatta e do professor Edison Antonio de Souza, de Sinop, conforme entrevistas concedidas em 19.09.2012 e 16.09.2012, o preconceito é uma realidade em toda a região e, por mais que as escolas procurem trabalhar as diferenças, ainda existe um preconceito bastante nítido entre sulistas, nordestinos e novos imigrantes de classes menos favorecidas.

Com esta constatação, é possível afirmar que os pioneiros imigrantes vão, cada vez mais, se sentindo autóctones, a ponto de agora criarem preconceitos em relação aos imigrantes mais recentes (ou menos favorecidos).

Estas questões somadas à escassez de moradia, serviços de saúde ainda muito dependentes da capital, além da falta constante de escolas, causada pelo aumento semestral de crianças que chegam aos municípios, vai se desenhando uma situação de vulnerabilidade social com forte tendência a comprometer a qualidade de vida e a segurança até então praticamente inexistentes.

Os serviços de saúde de média e alta complexidade que, teoricamente, deveriam ser resolvidos na capital, estão sendo gradativamente transferidos para os municípios não só pela escassez de vagas e serviços nos hospitais, como também pelo custo do traslado dos doentes e a estadia durante dois dias, no mínimo, que implica em diárias, pernoites e refeições para o motorista, além de pernoites e refeições para o paciente mais um acompanhante.

Como neste cálculo também se inclui o perigo constante para quem trafega pela BR-163, atualmente são enviados para Cuiabá apenas os casos graves sem condições de serem resolvidos no interior.

Além destes existe a questão do débito do governo do estado para com os municípios que, nos últimos meses, tem deixado de repassar as verbas para as secretarias municipais de saúde, dificultando ainda mais o atendimento ao público. 
A decisão de Sinop de desenvolver um polo de saúde no município vem ao encontro desta necessidade, considerando sua posição geográfica e a importância de poder atender não só os municípios do norte de Mato Grosso como os do sul do Pará, onde as condições de atendimento são ainda mais precárias.

A força do jogo político imbricado nas decisões que têm como pano de fundo o poder do capital movido pelo agronegócio, mexe com a geografia e com a demografia, como peças em um jogo de xadrez. Desde o direcionamento do tipo de público que ocupará determinado loteamento, até quem ocupará os cargos públicos para dar continuidade às políticas em jogo.

Em Sinop, por exemplo, estão sendo vendidos terrenos para a classe média alta, na região próxima ao aeroporto. O terreno onde serão edificadas as casas está num estágio próximo à desertificação do solo. O que se pode deduzir? Que a área era ocupada anteriormente pelo agronegócio e que agora está sendo administrada por alguma imobiliária para capitalizá-lo com outra função.

Por um lado, existe o fator localização; com o tempo, as terras agricultáveis acabaram muito próximas do núcleo urbano; por outro lado foi uma solução para o proprietário do agronegócio, cuja baixa qualidade do solo já não lhe auferia bons resultados e lucros.

Conforme pesquisa do Instituto Mato-grossense de Economia Agropecuária (Imea), o preço da terra em Sinop aumentou 75\% entre 2010 e 2012. Em 2010 o hectare valia entre $R \$ 12$ mil e $R \$ 13$ mil. Em 2011, subiu para $R \$ 15$ mil e, em março de 2012, atingiu R\$ 21 mil. Daí se deduz também que o agricultor escolheu vender a terra via loteamento imobiliário, porque lhe traria grandes vantagens.

A urbanização, a modernização e a reestruturação do ciclo produtivo que vem acontecendo nestes municípios, obedecem a um planejamento do setor produtivo, o mesmo que montou as propostas do programa MT+20, programa este desenvolvido para acompanhar o crescimento das cidades, independente do agronegócio que, depois da mecanização praticamente total das fazendas, só tem lugar para os grandes produtores.

O espírito empreendedor do Sr. Enio Pipino abriu o espaço para o futuro em Sinop, considerada hoje um importante polo na Amazônia, onde empresas de grande porte resolveram instalar seus entrepostos para atender uma vasta região que cresce à razão de 6 a 7\% ao ano. 
Em Sorriso, o empreendedorismo do Sr. Claudino Francio ainda reverbera através das lideranças que se arrojam em novas investidas para ampliar a infraestrutura de transporte da produção de commodities. Já Lucas do Rio Verde, embora participe direta e indiretamente dos processos de Sinop e Sorriso, vem sendo traçado um caminho paralelo ao da produção de commodities com investimentos em mudanças na concepção da monocultura da soja e do milho, para outras atividades como a diversificação através de suínos, de aves.

Cada município, a seu modo, vai encontrando o seu perfil que, de alguma forma, está muito próximo ao idealizado por seus colonizadores e imigrantes pioneiros.

A migração e modernização das cidades médias da Amazônia Legal da área de abrangência da BR-163, aqui representadas pelos municípios de Lucas do Rio Verde, Sorriso e Sinop tornaram realidade o sonho e abriram o futuro para a tecnologia de ponta que ampliou as fronteiras ao norte do Estado de Mato Grosso.

Durante a pesquisa, houve momentos em que era perceptível o pulsar do dinamismo que a BR-163 permitiu para aqueles imigrantes pioneiros, e o quanto eles trabalharam para transformar um sonho em realidade; do trabalho duro de desmatamento, destoca, limpeza, gradeação, enleiramento, correção e adubação do início, à criação de políticas imbricadas às questões geopolíticas de terras e produção de commodities que hoje contribuem enormemente para o PIB (Produto Interno Bruto) do país.

Também ficou muito claro que não foi a divisão do estado, em 1979, a responsável pelo desenvolvimento do agronegócio, hoje tão importante para o estado e para o país. A principal alavanca foi a construção da BR-163, principal artéria da complexa regionalização gerada pela malha viária construída posteriormente, que levou no seu rastro o sucesso do agronegócio.

É compreensível que muitos pioneiros imigrantes tenham voltado, porque a falta de alimento, de meios de comunicação, de infraestrutura causavam muita insegurança e medo. Mas os que permaneceram, uns por sentirem vergonha de voltar como perdedores, outros por acreditarem que esta empreitada teria de dar certo, transformaram o Nortão em uma das áreas com a maior renda per capita do Brasil. 
Uma das grandes lições desta pesquisa é que a esperança jamais deve ser abandonada à beira do caminho enquanto houver força para empreender, uma vez que:

Além da curva, existe, deve existir, tem de existir uma terra hospitaleira em que se fixar, mas depois de cada curva surgem novas curvas, com novas frustrações e novas esperanças ainda não destroçadas. (BAUMAN, 1998:92).

E os imigrantes da área de abrangência da BR-163 entenderam isto de maneira singular.

\section{REFERÊNCIAS}

ALBERTI, Verena. Manual de História Oral. $2^{\mathrm{a}}$ ed. rev. e atual. Rio de Janeiro: FGV, 2004

ALMEIDA, Paulo Roberto de. Os primeiros anos do século XXI: O Brasil e as relações internacionais contemporâneas. São Paulo: Paz e Terra, 2002.

ANTAS JÚNIOR, Ricardo M. Território e regulação: espaço geográfico, fonte material e não-formal do direito. São Paulo: Associação Editorial Humanitas: Fapesp, 2005.

ARRUZZO, Roberta Carvalho. Modernização agrícola, trabalho e organização espacial na BR-163. In: BERNARDES, Julia Adão e FREIRE LUNA FILHO, Osni de (Orgs). Geografias da soja BR-163, fronteiras em mutação. Rio de Janeiro: Arquimedes, 2006, p.99 a 113.

BARBIER, René. A pesquisa-ação. Brasília: Líber Livro Editora Ltda, 2002.

BARROZO, João Carlos (org.). Mato Grosso: a (re)ocupação da terra na fronteira amazônica (século XX). São Leopoldo: Oikos; Unisinos; Cuiabá, MT: EdUFMT, 2010.

BAUMAN, Zygmunt. Modernidade líquida. Trad. Plinio Dentzien. Rio de Janeiro: Jorge Zahar Ed., 2001. Ed., 2000.

. Em busca da política. Trad. Marcus Penchel. Rio de Janeiro: Jorge Zahar

. O mal-estar da pós-modernidade. Trad. Mauro Gama e Claudia Martinelli Gama. Rio de Janeiro: Jorge Zahar Ed., 1998.

BEAUJEU-GARNIER, Jacqueline. Geografia Urbana. 2a Ed. Lisboa: Ed. Fundação Calouste Gulbenkian, 1997 
BECHARA, Evanildo. Minidicionário da língua portuguesa Evanildo Bechara. Rio de Janeiro: Nova Fronteira, 2009

BECKER, Bertha K. Amazônia: geopolítica na virada do III milênio. Rio de Janeiro: Garamond, 2004.

Migração e mudança ocupacional na fronteira amazônica brasileira:estratégia, trajetória, conflitos e alternativas. In: BECKER, Bertha $\mathrm{K}$. et al. Fronteira Amazônica: questões sobre a gestão do território. Brasília:UNB; Rio de Janeiro:UFRJ, 1990.

BERNARDES, Júlia Adão; FREIRE FILHO, Osni de Luna (Org.). Geografias da soja: BR-163: Fronteiras em Mutação. Rio de Janeiro: Arquimedes, 2005.

BERNARDES, Júlia Adão. BR 163: Uma nova fronteira do Capital; in MAITELLI, Gilda Tomasini e ZAMPARONI, Cleusa Aparecida Gonçalves Pereira (Orgs). Expansão da soja na pré-amazônia mato-grossense. Impactos sócio-ambientais. Cuiabá: EdUFMT: Entrelinhas, 2007.

BERNARDES, Júlia Adão. Modernização agrícola e trabalho no Cerrado brasileiro - IX Colóquio Internacional de Geocrítica. Porto Alegre, 2007.

BOBBIO, Norberto. As ideologias e o poder em crise: pluralismo, democracia, socialismo, comunismo, terceira via e terceira força. Trad. João Ferreira; rev. téc. Gilson César Cardoso; $1^{\mathrm{a}}$ reimpressão. Brasília: Ed. UnB; São Paulo: Polis, 1990

BOURDIEU, Pierre. Razões práticas: sobre a teoria da ação. $8^{a}$ ed. Trad. Mariza Corrêa. Campinas: Papirus, (1996) 2007.

BRANCO, Samuel Murgel. Ecossistêmica: Uma abordagem integrada dos problemas do Meio Ambiente. São Paulo: Ed.EdgardBlücherLtda, 1999.

BRANDÃO, Carlos Antonio Leite (organizador). As cidades da cidade. Belo Horizonte: Editora UFMG, 2006.

BRASIL. Constituição Federal. Decreto $\mathrm{n}^{\circ} 1318$ datado em 30.01 .1854 que manda executar a Lei $n^{0}$ 601, de 18 de Setembro de 1850, que dispõe sobre as terras devolutas do Império.

. IBGE - Instituto Brasileiro de Geografia e Estatística. Recenseamento de $\overline{2010}$ e outros dados estatísticos. www.ibge.gov.br/cidades/limk.php?uf=mt. Acessado em março de 2012

. MEC - Ministério da Educação. Ideb 2011: Brasil continua a avançar. www.mec.gov.br Acessado em 13.10.2012

CAMPOS, Regina Helena de Freitas; GUARESCHI, Pedrinho A. (orgs.). Paradigmas em psicologia social: a perspectiva latino-americana. $4^{\mathrm{a}}$ ed. Petrópolis: Vozes, 2009. 
CASTELLS, Manuel. A sociedade em rede. Trad. Roneide Venancio Majer e Klauss Brandini Gerhardt. São Paulo: Paz e terra, 2007.

O poder da identidade. vol 2. Trad. Klauss Brandini Gerhardt. São Paulo: Paz e Terra, 2008.

CASTILLO, R., TOLEDO, R.Jr e ANDRADE, J. Três dimensões da solidariedade em Geografia. Autonomia político-territorial e tributação. São Paulo: Humanitas Publicações, FFLCH/USP, 1997.

CASTRO, S. P.; BARROZO, J.C.; COVEZZI, M.; PRETI, O. A colonização oficial em Mato Grosso "a nata e a borra da sociedade". Cuiabá: EduUFMT/Neru, 1994.

CASTRO, I. E. de. Geografia e política: Território, escalas de ação e instituições. Rio de Janeiro: Bertrand Brasil, 2005.

CASTRO, I. E.; GOMES, P. C. C; CORREAA, R. L. (orgs.). Geografia: conceitos e temas. Rio de Janeiro: Bertrand Brasil, 1995.

Questões atuais da reorganização do território. $3^{a}$ ed. Rio de Janeiro: Bertrand Brasil, 2005.

CAVALCANTE, Else Dias de Araújo; COSTA, Maurim Rodrigues. Mato Grosso e sua história. Cuiabá, 1999.

CERTEAU, Michel de. A Invenção do cotidiano: 1. artes de fazer. 13 ${ }^{a}$ ed. Trad. Ephraim Ferreira Alves. Petrópolis: Vozes, 2007.

CHAUI. Marilena. Brasil: mito fundador e sociedade autoritária. $7^{a}$ reimpr. São Paulo: Fundação PersuAbramo, 2007.

CHESNAIS, François. A mundialização do capital. Trad. Silvana FinziFoá. São Paulo: Xamã, 1996.

CONDORCET Jean Antoine-Nicolas de Caritat, Marquis, 1743-1749. Ensaio de um quadro histórico do espírito humano; trad. Carlos Alberto Ribeiro de Moura. Campinas: Editora Unicamp,1993

CORREAA, Roberto Lobato. O Espaço urbano. São Paulo: Ática, 2005. (Série Princípios).

Região e organização espacial. São Paulo: Ática, 2003. (Série Princípios).

A periodização da rede urbana da Amazônia. Revista Brasileira de Geografia. Rio de Janeiro. n.3, jul./set.1987.

CORTI, Ana Paula. Artigo A ditadura de Getúlio Vargas veiculado na Revista Página 3 Pedagogia \& Comunicação - 2009 
COSTA, Lucia Cortes da. os impasses do estado capitalista: uma análise sobre a reforma do Estado no Brasil. Ponta Grossa: UEPG. São Paulo: Cortez, 2006.

COSTA, Wanderley Messias da. Ordenamento territorial e Amazônia: vinte anos de experiências de Zoneamento Ecológico e Econômico. Artigo contendo ideias discutidas em seminário promovido pelo Ministério da Integração Nacional. Brasília, 2005.

Geografia política e geopolítica: discursos sobre o território e o poder. $2^{\mathrm{a}}$ ed. $1^{\mathrm{a}}$ reimpr. São Paulo: EdUSP, 2010.

CUTTI, Dirceu. As coisa escureceu pra mim: os imigrantes de ontem e de hoje. Barretos, 26 out.1994. Palestra proferida no V Encontro Regional sobre Migração, realizada em Riberão Preto, no ano de 1995.

DAMIANI, A.L.; CARLOS, A.F.A.; SEABRA, O.C.L.(Orgs). O espaço no fim de século: a nova raridade. São Paulo: Contexto,1999.

DIÁRIO DE CUIABÁ. O Código Florestal poderá dar ao zoneamento de Mato Grosso autonomia de alterar o porcentual da Reserva Legal do Cerrado. Edição n.12758 11/07/2010. Acessado em: 27/02/2012.

DICIONÁRIO HOUASSIS: Sinônimos e antônimos. Instituto Antônio Houassis; diretor de projeto Mauro de Salles Villar. 3ª ed.São Paulo: Publifolha, 2011.

DIONNE, Hugues. A pesquisa-ação para o desenvolvimento local. Trad. Michel Thiollent. Brasília, 2007.

ELIAS, Norbert. A sociedade dos indivíduos. Org. Michael Schröter; Trad. Vera Ribeiro; Revisão Técnica e notas, Renato Janine Ribeiro. Rio de Janeiro: Jorge Zahar, 1994.

ESCOLAR, Marcelo. Crítica do discurso geográfico. São Paulo: Hucitec, 1996.

ESPING-ANDERSEN, Gosta. Um estado de bem-estar social para o séculoXXI. in GIDDENS, Anthony (Org.) $\mathbf{O}$ debate global sobre a terceira via. Trad. Roger Maioli dos Santos. São Paulo:Unesp, 2007, p.193-224.

FARIA, José Eduardo. Direitos humanos e globalização econômica: notas para uma discussão. Revista Estudos Avançados/USP 11(30), 1997.

FERNANDES, Florestan. A Revolução burguesa no Brasil: ensaio de interpretação sociológica. 5a ed. $2^{\mathrm{a}}$ reimpr. São Paulo: Globo, 2006.

FEYERBAND, Paul. Contra o método - Rio de Janeiro: Francisco Alves, 1977.

FOUCAULT Michel. A verdade e as formas jurídicas. Rio de Janeiro: Nau; PUCRJ, 1996. 
Microfísica do poder. $25^{a}$ ed. Organização, Introdução e Revisão Técnica de Roberto Machado. Rio de Janeiro: Graal, 2008.

FOWERAKER, Joe. A luta pela terra: a economia política da fronteira no Brasil de 1930aos dias atuais. Trad. Maria Júlia Goldwasser. Rio de Janeiro: Zahar, 1982.

FRIEDMANN, John. Repensando a pobreza: delegação de poderes e direitos de cidadania.Paris: Unesco, 1996

GIDDENS, Anthony (Org.) O debate global sobre a terceira via. Trad. Roger Maioli dos Santos. São Paulo:Unesp, 2007

A constituição da sociedade. Trad. Álvaro Cabral. $2^{\mathrm{a}}$ ed. São Paulo: Martins Fontes, 2003.

1991.

As consequências da modernidade. Trad. Raul Fiker. São Paulo: Unesp,

GOFFMAN, Erving. A representação do eu na vida cotidiana. 14a ed. Trad. Maria Célia Santos Raposo. Petrópolis: Vozes, 2007.

GOTTDIENER, Mark. A produção social do espaço urbano. $2^{\mathrm{a}}$ ed. $1^{\mathrm{a}}$ reimpr. São Paulo: EdUSP, 2010.

GARCÍA, J.L. Antropologia delterritorio. Madri: Taller de Ediciones, 1976

GUERRA, Isabel Carvalho. Pesquisa qualitativa e análise de conteúdo - sentidos e formas de uso. Estoril, Portugal: Principia, 2006.

HABERMAS, Jürgen. A inclusão do outro: estudos de teoria política. Trad. George Sperber; Paulo AstorSoethe; Milton Camargo Mota. 3a ed. São Paulo: Loyola, 2007.

HAGUETTE, Teresa Maria Frota. Metodologias qualitativas na sociologia. $11^{\mathrm{a}}$ ed. Petrópolis: Vozes, 2007.

HAESBAERT, Rogério. Territórios alternativos. Niterói: EdUFF 2002.

O mito da desterriorialização: do "fim dos territórios" à multiterritorialidade. 6a ed. Rio de Janeiro: Bertrand Brasil, 2011.

HALL, Stuart. A identidade cultural na pós-modernidade. Trad. Tomaz Tadeu da

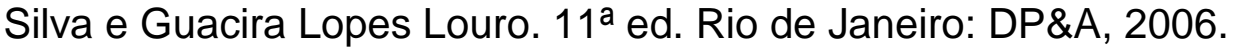

HARVEY, David. A produção capitalista do espaço. Trad. Carlos Szlak. $2^{\mathrm{a}}$ ed. São Paulo: Annablume, 2006.

HARRES, Marluza Marques; JOANONI NETO, Vitale. História, terra e trabalho em mato grosso: ensaios teóricos e resultados de pesquisas. São Leopoldo, RS: Olkos; Unisinos; Cuiabá: EdUFMT, 2009. 
HIRST, Paul e THOMPSON, Grahame. Globalização em questão: a economia internacional e as possibilidades de governabilidade. 4ª ed., Petrópolis: Vozes, 2002.

HOBBES, Thomas. Leviatã ou matéria, forma e poder de uma república eclesiástica e civil. Organizado por Richard Tuck; edição brasileira supervisionada por Eunice Ostrensky; tradução João Paulo Monteiro, Maria Beatriz Nizza da Silva; tradução do aparelho crítico Claudia Berliner; revisão da tradução Eunice Ostrensky. $2^{\mathrm{a}}$ ed. São Paulo: Martins Fontes, 2008.

HUBER, Anton. Tempestade no Cerrado. Cuiabá: Carlini\&Caniato, 2010.

HUNTINGTON, Samuel P. O Choque de Civilizações: e a Recomposição da Ordem Mundial. Trad. De M. H. C. Côrtes. Rio de Janeiro: Objetiva, 2010.

IANNI, Octavio. Origens agrárias do estado brasileiro. São Paulo: Brasiliense, 2004.

ISNARD, H.. O espaço do geógrafo. In Annales de Géographie, Mars-Avril, 1975 LXXXIV année - Paris, França. Trad. Bol. Geogr. Rio de Janeiro, 36 (258-259); 5-16, jul./dez., 1978.

JOANONI NETO, Vitale. Fronteiras da Crença: Ocupação do Norte de Mato Grosso após 1970. Cuiabá: Carlini\&Caniato; EdUFMT, 2007.

JOANONI NETO, Vitale (org.). Política, Ambiente e Diversidade Cultural (VI Seminário do ICHS). Cuiabá: EdUFMT, 2007.

JORNAL A GAZETA, CUIABÁ. Artigos do Caderno de Economia sobre o agronegócio em Mato Grosso, veiculados entre 2010 e 2012.

KINOSHITA, Alberto K. Sinop + Desenvolvimento $=+$ Saúde. Revista Notícia do Estado de Mato Grosso, ed.108, ano XVIII, março 2012.

KOSIK, Karel. Dialética do Concreto. São Paulo: Paz e Terra, 1995.

LATOUR, Bruno. Jamais fomos modernos: ensaio de antropologia simétrica. $2^{\mathrm{a}}$ ed. Rio de Janeiro: Editora 34, 2009.

LEFEBVRE, Henri. La production de l'espace. Paris: Ed Anthropos, 1974.

LEFEBVRE, Henri. A revolução urbana. Trad. Sérgio Martins. Belo Horizonte: Ed UFMG, 2004.

LEMKOW, A.F. O Princípio da Totalidade: a dinâmica da unidade na religião, ciência e sociedade. São Paulo: Aquariana, 1992.

LEMOS, Amália Inês Geraiges de (Org.). Turismo: Impactos Socioambientais. São Paulo: Hucitec, 2001. 
Gentrification ou moradia social: estudo comparativo do consumo no Centro Antigo de São Paulo in CARLOS, Ana Fani Alessandri; Carreras, Carles (orgs.). Urbanização e mundialização: estudos sobre a metrópole. São Paulo: Contexto, 2005.

LENCIONI, Sandra. Região e geografia. São Paulo: EdUSP,1999.

LÉVI-STRAUSS, C. La pensée sauvage. Paris:Plon. 1962.

LOPES, José Reinaldo Lima. O direito na história: lições introdutórias. São Paulo: Max Limonad, $2^{\mathrm{a}}$ ed. 2000.

LÖWY, Michael. As aventuras de Karl Marx contra o barão de Münchhausen: marxismo e positivismo na sociologia do conhecimento. São Paulo: Cortez Editora, 2007.

LUXEMBURGO, Rosa. Reforma social ou revolução? Prólogo à ed. brasileira de Emir Sader. Rio de Janeiro: Global, 1986.

MAITELLI, Gilda Tomasini; ZAMPARONI, Cleusa Aparecida Gonçalves Pereira. (Orgs.) Expansão da soja na pré-amazônia mato-grossense: impactos socioambientais. Cuiabá: Entrelinhas; EdUFMT, 2007.

MARCIANO, Max Rodrigues Vieira; SIMÕES, Tânia Regina. Da Esperança do EI Dorado à Degradação do Humano: mapeamento das redes de resistência e conivência em polos irradiadores de trabalho escravo de Mato Grosso. Cuiabá: EdUFMT, 2008.

MARICATO, Ermínia. Brasil, cidades: alternativas para a crise urbana. Petrópolis: Vozes, 2002.

MARX, K. e ENGELS, F. A Ideologia Alemã (Feuerbach). Trad. José Carlos Bruni e Marco Aurélio Nogueira. São Paulo: Hucitec, 1986.

MEIHY, José Carlos Sebe B.; HOLANDA, Fabíola. História Oral: como fazer, como pensar. São Paulo: Contexto, 2007.

MENDONÇA, Sonia Regina de. Estado e Historiografia no Brasil. Niterói: EdUFF, 2006.

MERLAU-PONTY, Maurice. Fenomenologia da percepção. São Paulo: Martins Fontes, 1996.

MICHAELIS. Moderno dicionário da língua portuguesa. São Paulo: Melhoramentos, 1998.

MILÉSKI, Jamerson. Boom Imobiliário: 15 novos bairros sendo abertos, Sinop emplaca 18,5 veículos por dia e Sinop terá o maior hospital do estado. Revista Notícia do Estado de Mato Grosso, ed.110, ano XVIII, julho 2012. 
. Uma cidade jovem e rica. Revista Notícia do Estado de Mato Grosso, ed.108, ano XVIII, março 2012.

MOORE, Barrington. As origens sociais da ditadura e da democracia. Trad. Maria Ludovina F. Couto. São Paulo: Martins Fontes, 1983.

MORENO, Gislaene. Terra e poder em Mato Grosso: política e mecanismos de burla | 1892-1992. Cuiabá: Entrelinhas; EdUFMT, 2007.

MORENO, Gislaene e HIGA, Tereza Cristina (Orgs). Geografia de Mato Grosso: território - sociedade - ambiente. Cuiabá: Entrelinhas, 2005.

MORIN, Edgar. Saberes globais e saberes locais: o olhar disciplinar. Rio de Janeiro: Garamond, 2008.

MÜLLER, Frederico Guilherme Moura. Rodovia Cuiabá - Santarém, Br - 163, desmatamento atual e futuro: uma questão de monitoramento e controle. Dissertação de Mestrado Dissertação (mestrado) - Universidade Federal de Mato Grosso, Instituto de Ciências Humanas e Sociais, Pós-Graduação em Geografia, 2006.

MÜLLER, Geraldo. Complexo agroindustrial e modernização agrária. São Paulo: Hucitec; Educ, 1989.

NYE, Joseph S. Compreender os conflitos internacionais: uma introdução à teoria e à história. Trad. Tiago Araújo; Rev.Científica: Henrique Lages Ribeiro. Lisboa: Gradiva, 2002.

OLIVEIRA, Ariovaldo Umbelino de. BR-163 Cuiabá-Santarém: geopolítica, grilagem violência e mundialização. In: TORRES, Mauricio (Org.) Amazônia revelada. Brasilia:CNPQ, 2005.

OLIVEIRA, Cristiane (org). A saga dos guardiões da floresta: uma viagem emocionante à história do setor de base florestal de Mato Grosso. Sinop: Sindusmat/Print, 2011.

OLIVEIRA, João Mariano. A esperança vem na frente: contribuição ao estudo da pequena produção em Mato Grosso - O caso de Sinop. Dissertação de mestrado. São Paulo: USP, 1983.

PEREIRA, Rafael Henrique Moraes; FURTADO, Bernardo Alves. Dinâmica urbanoregional: rede urbana e suas interfaces. Brasília: Ipea, 2011.

PIZZORNO, Alessandro; GALLINO, Luciano; BOBBIO, Norberto; DEBRAY, Régis e GRAMSCI, Antonio. Gramsci y las ciências sociales. $5^{\mathrm{a}}$ ed. Trad. José Aricó, Celina Manzoni e Isidoro Flambaum. Mexico: EdicionesPasado y Presente, (1970) 1978.

PÓVOAS, Lenine C. História da cultura mato-grossense. Cuiabá: 1994. 
. História geral de Mato Grosso: dos primórdios à queda do império, vols.1e 2. Cuiabá: L.C. Povoas, 1995.

RAFFESTIN, Claude. Por uma geografia do poder. São Paulo: Atica, 1993.

RANGEL, Ignácio. Obras reunidas. Rio de Janeiro: Contraponto, 2005. (2 v.).

RAVACHE, R. L. e SOUZA Daniel B. de. Estruturação do espaço urbano regional do centro-norte mato-grossense: Sinop, Sorriso e Lucas do Rio Verde;in:Novas territorialidades nas cidades mato-grossenses, ROMANCINI, S. (Org). Cuiabá: EdUFMT, 2009, p.199 a 220.

RÉMY, Jean; VOYÉ, Liliane. A cidade: rumo a uma nova definição? Porto, Portugal: Afrontamento, 2004.

REVISTA MATO-GROSSENSE DE GEOGRAFIA, ano 07/08 Número 07/08 Dezembro 2002/2003, Cuiabá: Editora Universitária/UFMT, 2002-2003.

REVISTA MATO-GROSSENSE DE GEOGRAFIA, ano 12 Número 10 Jan/ Jun 2007. Cuiabá: FAPEMAT/EdUFMT.

REVISTA MATO-GROSSENSE DE GEOGRAFIA, ano 13 Número 12 Jan/ Jun 2008. Cuiabá: FAPEMAT/EdUFMT.

RIBEIRO, Onofre. Mato Grosso e o século 20: migrações. Cuiabá: Jornal A Gazeta, 2000.

RIGOL, Sergi Martinez. A gentrification: conceito e método; in CARLOS, Ana Fani Alessandri; Carreras, Carles (orgs.). Urbanização e mundialização: estudos sobre a metrópole. São Paulo: Contexto, 2005.

RODRIGUES, Arlete M. Produção e consumo do e no espaço: problemática ambiental urbana. Campinas: CreativeCommons, 1997.

ROMANCINI, Sonia Regina e RODRIGUES, Cleire Oliveira. Urbanização matogrossense: o exemplo de Sinop. Revista Acta Geográfica, Universidade Federal de Roraima, Instituto de Geociências, Ano I - № 2. Julho/Dezembro de 2007, p.43-45.

ROSSETTO, Ornélia Carmem - Dinâmica agrária e resiliência camponesa: estudo comparativo entre o lócus do agronegócio e o pantanal mato-grossense. Revista do Instituto Histórico e Geográfico de no 68-69. Cuiabá: IHGMT, 2011, p.49-64.

SACHS, Ignacy. Caminhos para o desenvolvimento sustentável. $3^{\mathrm{a}}$ ed. Organização: Paula Yone Stroh. Rio de Janeiro: Garamond, 2008.

SANTOS, Luiz Erardi F. Raízes da história de Sinop. Sinop, MT: Midiograf, 2011

SANTOS, Milton. A natureza do espaço: técnica e tempo, razão e emoção. $4^{\mathrm{a}} \mathrm{ed}$. $5^{\mathrm{a}}$ impr. São Paulo: EDUSP 2009. 
. Por uma economia política da cidade. $2^{\mathrm{a}}$ ed. São Paulo: EdUSP, 2009.

. Pensando o espaço do homem. São Paulo: Hucitec, 2007.

. Por uma outra globalização: do pensamento único à consciência universal. Rio de Janeiro: Record, 2006.

A urbanização brasileira. São Paulo: EdUSP, 2005.

. Metamorfoses do espaço habitado: fundamentos teórico e metodológico da Geografia. São Paulo: Hucitec, 1988.

. Espaço e método. São Paulo: Nobel, 1997.

Técnica, espaço, tempo: globalização e meio técnico-científico informacional. São Paulo: Editora Hucitec, 1994.

. Da política dos estados à política das empresas. Belo Horizonte: Cadernos da Escola do Legislativo 3191,1992.

. O espaço geográfico como categoria filosófica. São Paulo, Terra Livre 5.

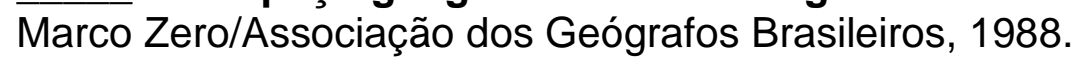

SANTOS, Milton e SILVEIRA, María Laura. O Brasil: território e sociedade no início do século XXI. $7^{\text {a }}$ ed. Rio de Janeiro: Record, 2005.

SILVA, Aldo A.Dantas da; GALENO, Alex (Orgs.). Geografia: ciência do complexus: ensaios transdisciplinares. Porto Alegre: Sulina, 2004.

SILVA, Golbery do Couto e. Conjuntura política nacional: O Poder Executivo \& Geopolítica do Brasil. 2ª ed. Rio de Janeiro: José Olympio, 1981.

SILVA, Ligia Osorio. Terras devolutas e latifúndio: efeitos da lei de 1850. $2^{\mathrm{a}}$ ed.. Campinas : Ed.UNICAMP, 2008.

SILVEIRA, M.L. Concretitude territorial, regulação e densidade normativa. São Paulo: Experimental n.2, p.37, Humanitas Publicações FFLCH/USP, 1997.

SINGER, Paul Israel. Economia política da urbanização. São Paulo: Brasiliense, 1973.

SIQUEIRA, Elizabeth Madureira. História de Mato Grosso: a ancestralidade aos dias atuais. Cuiabá: Entrelinhas, 2002.

SMITH, Adam. A Riqueza das Nações: investigação sobre sua natureza e suas causas. Trad. LuizJoãoBaraúna; vol 1-2. São Paulo: Abril Cultural, 1983.

SOJA, Edward W. Geografias Pós-modernas: a reafirmação do espaço na teoria social. Rio de Janeiro: Jorge Zahar Editor, 1993. 
SOUZA, Ana Maria de. Relatos da cidade: nomadismo, territorialidades urbanas e imprensa: segunda metade do século XX. Cuiabá: Entrelinhas; EdUFMT, 2007.

SOUZA, Edison Antonio de. Questão Agrária: uma reflexão sobre a fronteira amazônica mato-grossense. Revista mato-grossense de Geografia. Ano 11 número 09. Dezembro, 2006. Depto de Geografia do Instituto de Ciências Humanas e Sociais da UFMT. Cuiabá: Fapemat/EdUFMT, 2006.

. Estado e Sociedade na BR-163: uma reflexão social política e econômica. In STRAUB, Ilário, PICOLI, Fiorelo e SANTOS, Josivaldo Constantino (Orgs). Sinop: CEACD/UNEMAT, 2011.

SOUZA, Edison Antônio de (Org). Desenvolvimento Regional: história, economia e meio ambiente. Cuiabá: EdUFMT, 2010.

SPOSITO, Eliseu Savério. Geografia e filosofia: contribuição para o ensino do pensamento geográfico. São Paulo: Editora UNESP, 2004.

SPOSITO, Maria Encarnação Beltrão. Urbanização difusa e cidades dispersas: perspectivas espaço-temporais contemporâneas. Artigo vinculado ao projeto temático apoiado pela Fundação Amparo à Pesquisa do Estado de São Paulo (FAPESP) coordenado pelo professor Nestor Goulart Reis Filho (FAU/USP). São Paulo, 2008.

Cidades médias: reestruturação das cidades e reestruturação urbana. In: SPOSITO, Maria Encarnação Beltrão (Org.). In: Cidades Médias: espaços em transição. São Paulo: Expressão Popular, 2007

TABORELLI, Valeria Nassarden; JOANONI NETO, Vitale. Enganado pelo gato: pistas de exploração da mão-de-obra do migrante atendido pelo Centro Pastoral para migrantes e Cuiabá, na década de 1980. In: Joanoni Neto, Vitale (Org). Da Esperança do El Dorado à degradação do Humano. Cuiabá: EdUFMT, 2008.

TEIXEIRA, Ana Carolina Wanderley. Região metropolitana: instituição e gestão contemporânea; dimensão participativa. São Paulo: Fórum, 2005.

TUAN, Yi-Fu. Espaço e lugar: a perspectiva da experiência. São Paulo: Difel, 1983.

ZART, Laudemir Luiz. Desencanto na Nova Terra: Assentamento no Município de Lucas do Rio Verde-MT na década de 80. Dissertação de Mestrado em Sociologia Política, Universidade Federal de Santa Catariana. Florianópolis, junho de 1998.

\section{Sites}

ADA. Superintendência de Desenvolvimento da Amazônia. http://www.ada.gov.br. Acessado em: 15/12/2010. 
ALTAMIROBORGES.BLOGSPOT.COM.BR. Major Curió. Postado em 15/03/2012 e Acessado em: 16/05/2012.

BRASIL. Casa Civil. A Lei $\mathrm{n}^{0}$ 601, de 18 de setembro de 1850, dispõe sobre as terras devolutas no Império. Fonte: www.planalto.gov.br/ccivil. Acessado em 27.12.2011.

BRASIL. Instituto Brasileiro de Estatística - IBGE. Artigo Geoestatísticas de recursos naturais da Amazônia Legal. <http://www.ibge.gov.br/ home/geociencias/ recursos naturais/diagnósticos_levantamentos/default.shtm>. Acessado em: 15/12/2010, 26/12/2011, 12/01/2012 e 25/02/2012.

BRASIL. Ministério da Saúde; Fundação Nacional. Estrutura de formação da SUCAM. www.funasa.gov.br. Acessado em 12.10.2012

ECOAGÊNCIA. Artigo sob o título MT: lei de zoneamento joga no lixo 20 anos de estudos e US\$ 30 milhões. Repórteres: Fernanda Bellei e Julio Cezar Garcia.<www.ecoagencia.com.br>. Acessado em: 3/11/2010 e 26/02/2012

ISA. Instituto Socioambiental - www. socioambiental.org. Acessado em: 03/12/2010 e 14/03/2012.

JUS BRASIL NOTICIAS. DECISAO (www.stj.jus.br). Extraído de: Rede de Ensino Luiz Flávio Gomes. 05 de Janeiro de 2010. www. Ifg.jusbrasil.com.br/noticias. Acessado em: 27.02.2013

MATO GROSSO. Assembleia Legislativa de Mato Grosso. <www.al.mt.gov.br>. Acessado em: 03/12/2010.

MATO GROSSO. FAMATO. Federação da Agricultura e Pecuária de Mato Grosso. Dados sobre a produção de commodities em Mato Grosso<www.famato.org.br>. Acessado em: 03/12/2010.

MATO GROSSO. Instituto Mato-grossense de Economia Agropecuária IMEA.<www.imea.com.br>. Acessado em: 21/01/2012.

MATO GROSSO. Secretaria de Estado de Planejamento e Coordenação Geral (Seplan). Dados da década de 1980. <www.seplan.mt.gov.br>. Acessado em: 15/12/2010, 12/02/2011, 20/02/2012.

PAPPE Ilan. Mitos e propaganda israelenses. Entrevista em vídeo gravado pela blogconvergencia.org/blogconvergencia/?p=188. Acessado em 13.06.2012

REVISTA ESTUDOS AVANÇADOS. BECKER, Bertha. Geopolítica da Amazônia Vol.19, n.53, http://www.scielo.br/pdf/ea/v19n53/24081.pdf. Acessado em: 03.03.2012.

SONOTICIAS. Safra de soja deve atingir novo recorde em MT. www.sonoticias. com.br/agronoticias/mostra.php?id=54631. Acessado: 27.08.2012. 
VERMELHO.ORG.BR. Major Curió. Postado em 14/03/2012 e Acessado em: $16 / 05 / 2012$.

UNESCO, Organização das Nações Unidas para a Educação, a Ciência e a Cultura. Texto da $32^{\mathrm{a}}$ Sessão que focou a Declaração da Convenção para a Salvaguarda do Patrimônio Cultural Imaterial realizada em Paris, 2003. http://unesdoc.unesco.org/. Acessado em 12.01.2013

UNIDADES DE CONSERVAÇÃO NO BRASIL. Dados sobre a área da Amazônia Legal. http://uc.socioambiental.org.br. Acessado em: 12.10.2012

WIKIPEDIA. Agricultura de subsistência; PIN (Plano de Integração Nacional). www. wikipedia.org/wiki/. Acessado em: 24.06.2011.

Y IKATU XINGU. Artigo sob o título - ZSEE de Mato Grosso: Proposta prevê exclusão de áreas indígenas não homologadas para dar lugar à expansão do agronegócio.<www.yikatuxingu.org.br/. Acessado em: 17/12/2010 e 27/2/2012. 